GOETHE AND ZELTER: MUSICAL DIALOGUES 
For Seóirse 


\title{
Goethe and Zelter: Musical Dialogues
}

\author{
LORRAINE BYRNE BODLEY
}

National University of Ireland Maynooth 
All rights reserved. No part of this publication may be reproduced, stored in a retrieval system or transmitted in any form or by any means, electronic, mechanical, photocopying, recording or otherwise without the prior permission of the publisher.

Lorraine Byrne Bodley has asserted her right under the Copyright, Designs and Patents Act, 1988 , to be identified as the author of this work.

Published by

Ashgate Publishing Limited

Wey Court East

Ashgate Publishing Company

Union Road

Farnham Suite 420

Surrey, GU9 7PT

101 Cherry Street

England

www.ashgate.com

\section{British Library Cataloguing in Publication Data}

Bodley, Lorraine Byrne, 1968-

Goethe and Zelter : musical dialogues

1. Goethe, Johann Wolfgang von, 1749-1832-Correspondence 2. Zelter, Carl Friedrich, 1758-1832 - Correspondence 3. Authors, German - 19th century - Correspondence 4. Composers - Germany - Correspondence 5. Music - Germany - 19th century - History and criticism

I. Title

831.6

\section{Library of Congress Cataloging-in-Publication Data}

Bodley, Lorraine Byrne, 1968-

Goethe and Zelter : musical dialogues / Lorraine Byrne Bodley. p. cm.

Includes bibliographical references and index.

ISBN 978-0-7546-5520-6 (hardcover : alk. paper)

1. Goethe, Johann Wolfgang von, 1749-1832-Correspondence. 2. Zelter, Carl Friedrich, 1758-1832-Correspondence. 3.

ML423.G65B63 2008

$780.92 ’ 243-\mathrm{dc} 22$

[B]

2008050802

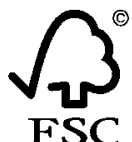

Printed and bound in Great Britain by

MPG Books Group, UK 


\section{Contents}

Preface vii

Acknowledgements ix

List of Abbreviations xiii

List of Music Examples xvii

A Musical Odyssey: Thirty-Five Years of Correspondence between Goethe and Zelter

Section I Early Years' Correspondence 1796-1814 29

Section II Middle Years’ Correspondence 1815-1825 179

Section III Later Years' Correspondence 1826-1832 343

Appendix $\quad 555$

Bibliography $\quad 557$

Index $\quad 569$ 


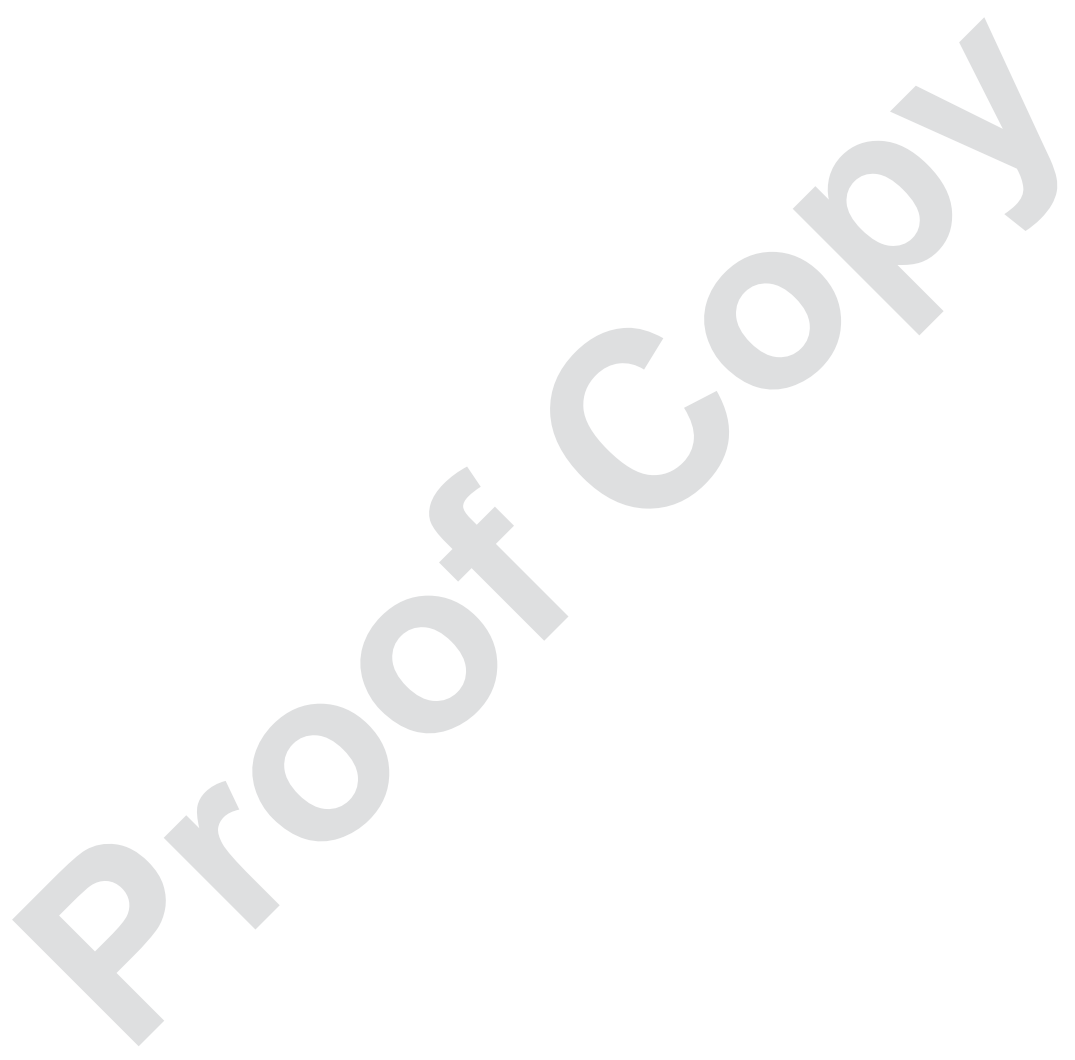


7 Cold print can be a harsh medium in which to bare all the faults of subjective 7 8 letters written in the midst of busy active lives. Nuances in the handwriting or in 8 9 the positioning of postscripts are all lost in the printing; irregularities in Zelter's 9 10 punctuation, abbreviations and colloquial phrases are to some extent ironed out. 10 11 Zelter used his literary abilities to further his cause but never laid claim to be a writer. 11

12 The immediacy and urgency of his letters sometimes did not allow for constructional 12

13 considerations: he dashed them off and in excitement or annoyance would sometimes 13 14 make hasty judgements and criticisms that were reconsidered later. Goethe was a 14 15 professional and disciplined writer whose letters show his ease with and command of 15 16 words. Being able to consider his reactions and emotions allowed him a greater ease 16 17 of expression. The character of both letter-writers and their varied sense of style were 17 18 among the considerations which I had to take account in making this translation. 18

19 Anyone engaged in translation, and who has thought about it, knows that a 19 20 grammatically correct or almost literal translation of any interesting text could well 20 21 be unfaithful to it. Every good translation is an interpretation of the original text and 21 22 will thereby contain critical commentary. A good translation must be, at the same 22 23 time, close and free. The quest for precision is analogous to the quest for certainty and 23 24 both should be viewed with caution by the translator. I do not suggest that linguistic 24 25 precision in writing and translation is not something to strive for, but rather that it 25 26 should not be placed higher than the advancement of the subject.

27 One may relatively easily find lexical meanings for the words, but it is overridingly 27

28 important to find the tuning fork that can give the note and pitch of the overall music 28

29 of the letters. Without some sense of the tenor of the voices, it is impossible to 29 30 establish the translator's right-of-way into the letters. I was therefore lucky to hear this 30 31 enabling note straight away, a familiar voice, one that has accompanied me since my 31 32 years as a doctoral student at University College Dublin, where I developed not only 32 33 an understanding of Goethe's language, but a fondness for the music and fortitude 33 34 that characterizes his poetry. Consequently when I came to the task of translating 34 35 these letters, I found the voice of these letters attractively direct even though the 35 36 narrative method of letters can, at times, be oblique. Similarly Zelter's deep sense 36 37 of irony and colloquial German was on my ear from conversations with German 37 38 friends in Berlin. What I loved in translating this correspondence was a feeling of 38 39 living in the presence of an understanding that assumes you share an awareness of the 39 40 perilous nature of life and are yet capable of seeing it steadily and, when necessary, 40 41 sternly. There is an undeluded quality about Goethe and Zelter's sense of the world 41 42 which gives these letters immense emotional credibility and allows both men to make 42 43 general observations about musical life which are grounded in experience. These 43 44 letters have the cadence and force of earned wisdom, and their cogency and verity is 44 
1 marked, too, by the self-consciousness of two artists convinced that they must labour 1

2 in their endeavours to produce work of lasting value.

3 Goethe and Zelter's lives embraced an extraordinary period in music history. In 3

4 Goethe's first year of life Bach dictated on his deathbed the chorale prelude for organ, 4

5 Vor deinen Thron tret ich hiermit (Before thy throne I now appear, BWV 668a), a 5

6 work often played after the unfinished fourteenth fugue to conclude performances 6

7 of the Art of Fugue and in the final year of Goethe's life, Berlioz was busy revising 7

8 the Symphonie Fantastique in Italy. In order to translate the complete musical 8

9 correspondence that these lives embraced, omissions had to be made: with reluctance 9

10 I passed over engaging philosophical and literary debates, which show Zelter as a 10

11 man of gusto and quick apprehensions, and omitted closing salutations which capture 11

12 the tenor of an extraordinary friendship. Such sacrifices had to be omitted in order to 12

13 unveil through music solidarities that are democratic and a discipline that is traditional 13

14 and solitary - as many an artistic discipline sooner or later becomes, once it has been 14

15 seriously embraced.

Goethe's engagement with music as a discipline has been called into question not 16 17 only by scholars but also by the poet himself. Continually in the letters he bemoans 17 18 the limitations of his musical experience in Weimar, the silence of his piano after 18

19 his beloved Mendelssohn leaves. In the summer of 1807 (after the death of Anna 19 20 Amalia) he laments: 'I am, unfortunately, so cut off from music and although we 20 21 sometimes have really good voices, the little bits of operetta here and there are not 21 22 enough. And so it seems as if all sound, all song in me has disappeared, and with it 22 23 all my musical imagination.' For too long scholars have taken such statements at face 23 24 value without contextualizing them against the broad backdrop of musical experience 24 25 in Goethe's life: the amelioration of music at the Weimar theatre, whose programme 25 26 was a macrocosm of contemporary operatic developments, during Goethe's years as 26 27 artistic director (1791-1817); his delighted reconnaissance of local excellence: Carl 27 28 Friedrich Abel, Johann Friedrich Armand von Uffenbach and Johann Adam Hiller in 28 29 Goethe's early years to musicians in Zelter's circle, most notably Felix Mendelssohn, 29 30 but also Spontini.

31 Lea Mendelssohn, when she visited the poet in 1822, recognized the potency 31 32 of Goethe's engagement with music: an opinion Zelter reinforced when he read the 32 33 preface to Goethe's translation of Diderot's Neveu de Rameau and declared 'it really 33 34 hurt to realize that you know more about the art of music than I do'. While one 34 35 could write this off as Zelter's veneration of the poet, the truth of Zelter's judgment 35 36 became evident to me in the translation of the theoretical discussions about music 36 37 where Zelter's languages buckles as he endeavours to hold in his own in the famous 37 38 Molldebatte, the debate about the nature of the minor mode. Here Goethe shows 38 39 himself as a writer of unparalleled scope, one who possessed a commanding sense 39 40 of music in outline and a delicate capacity for eliciting fully-fledged meaning by 40 41 brooding upon details. By contrast Zelter writes as a practical musician, and though 41 42 his words buckle and break, there is a definite, unapologetic drive in his letters, a 42 43 rallying cry that celebrates music for being on the side of life, continuity of effort and 43 44 enlargement of the spirit. 
7 During the writing of this book there were times when I felt my role as editor was 7 8 to be the intermediary through whom the suggestions and ideas of many people 8 9 were channelled; whatever richness or insights this book contains is evidence of 9 10 the generosity of so many scholars, librarians and friends on both sides of the 10 11 Atlantic. My thanks are due to Professor Timothy Watkins at the Department 11 12 of Music, Rhodes College, who invited me to give a lecture at the international 12 13 Sing-Akademie conference in November 2003 and to Professor Christoph Wolff 13 14 for his encouragement and warm reception of my paper on that occasion. I was 14 15 very honoured to be offered the opportunity by Professor Jeremy Adler and 15 16 Professor Martin Swales of the English Goethe Society to give a guest lecture 16 17 on this correspondence in King's College London in 2002. I owe both scholars a 17 18 great deal for their interest in my work and graciousness in publishing my paper 18 19 in the Publications of the English Goethe Society. The substance of these pages 19 20 was constantly illuminated and invigorated by the example of many fine scholars 20 21 and dear friends: my greatest debt is to the eminent Schubertian, Professor Susan 21 22 Youens (J.W. Van Gorkom Professor of Music, University of Notre Dame), whose 22 23 seminal books continue to shape our understanding of Schubert and nineteenth- 23 24 century song. For her encouraging belief in the need for this translation and generous 24 25 endorsement of my work, I am profoundly grateful. Professor Nicholas Boyle 25 26 (Schroeder Professor of German and President of Magdalene College, Cambridge) 26 27 occupies a unique place in Goethe scholarship and without his work no one can 27 28 venture into the study of Goethe, even less into writing about him. My decision to 28 29 undertake a translation of these letters had his support for which I am immensely 29 30 grateful. I remember with special pleasure my time as postdoctoral fellow at Trinity 30 31 College Dublin where I was lucky to enjoy discussions with Professor Moray Mc 31 32 Gowan (Chair of Germanic Studies and Head of School of Modern Languages) 32 33 and time worrying about word choices with Professor Jürgen Barkhoff (Registrar 33 34 of Trinity College Dublin): I warmly salute both men and thank them for their 34 35 solidarity and example. I am sincerely grateful to a triumvirate of dear friends: Dr 35 36 Claus Canisius, for his penetrating suggestion of the word 'dialogues' in the title and 36 37 for his ongoing personal interest - as unfailing as it is unobtrusive - which acts as an 37 38 inspiration and a stimulus; Professor Harry White (Professor of Music, University 38 39 College Dublin) who has long been a premier guiding voice in musicology, and to 39 40 whom I am profoundly grateful for his unwavering support of my research; and 40 41 the eminent Graham Johnson, whose fine recordings of Zelter's Lieder serve the 41 42 composer's legacy quite marvellously. Last but by no means least, my warmest 42 43 thanks to Professor Gerard Gillen: during his time as Professor of Music at the 43 44 
1 National University of Ireland Maynooth most of this book was written. Qualities 1

2 I greatly admire in Zelter - a noble integrity, warmth of personality and lasting 2

3 contribution to musical life - I find embodied in Gerard two centuries later. 3

4 This book required extensive archival research which was facilitated by 4

5 many helpful librarians. Thanks to the perseverance of the Interlibrary loan staff 5

6 at Trinity College Dublin and the National University of Ireland, Maynooth, I 6

7 was able to conduct much of my preliminary research from Dublin and prepare 7

8 thoroughly for my research trips to Germany. Dr Helmut Hell at the Preußischer 8

9 Staatsbibliothek in Berlin was always ready to share the holdings of the rich 9

10 collection of Zelter's manuscripts. Likewise the kindness of the curators at the 10

11 Goethe and Schiller Archive in Weimar and Klassik Stiftung Weimar (Weimar 11

12 Cultural Foundation) made exploring the extensive correspondence of Goethe 12

13 and Zelter one of the most pleasurable research experiences I have had. It is a 13

14 pleasure to record a depth of thanks to Olaf Molansky at Klassik Siftung Weimar 14

15 who helped me to track down the cover image of Zelter, and to Karin Ellermann 15

16 (Goethe- und Schiller Archiv, Weimar) who located and supplied the images for 16

17 Zelter's musical citations. In addition to such research I must pay tribute to former 17

18 scholars who have produced editions of these letters, most notably the seminal 18

19 work of Hans-Günter Ottenberg, Sabine Schäfer and Edith Zehm, whose three 19

20 volumes Briefwechsel mit Zelter in Goethe Sämtliche Werke nach Epochen seines 20

21 Schaffens (Munich: Hanser Verlag, 1985-98) were of invaluable importance. My 21

22 translation is made always in the knowledge of a considerable debt to these fine 22

23 scholars for their sterling scholarship and inspiring example.

24 I warmly acknowledge a deep depth of gratitude to the Irish Research Council 24

25 for Humanities and Social Sciences, the organization that provided financial 25

26 support for this project through a Government of Ireland Post-Doctoral Scholarship. 26

27 This award allowed me to complete three books while beginning work on this 27

28 research project. I am especially grateful to the National University of Ireland and 28

29 to the Publications Committee at the National University of Ireland Maynooth 29

30 whose support and encouragement of this book proved crucial to its preparation 30

31 and progress: without their generous publication grants a critical edition of the 31

32 complete musical correspondence would not have been possible.

33 Via Ashgate, I benefited greatly from Lorraine Slipper's editorial pencil on the 33

34 first draft and Emily Ruskell's tact and intelligence in editing the second draft. I 34

35 am most grateful to them and to Tom Norton, whose generosity with his time and 35

36 meticulous attention to detail produced a fine index. Particular thanks are due to 36

37 Ashgate's Music Editor, Heidi Bishop, who graciously guided me through the 37

38 editorial process on a project that she cordially accepted as taking far longer than 38

39 anticipated. My third book with Ashgate has given me the same joy as the previous 39

40 two.

41 One person in particular has gone out of his way to make this endeavour a 41

42 pleasure and has greatly enriched my knowledge and my life by his generosity; 42

43 without his help, the quality of this translation would be greatly diminished. To 43

44 him, Dr Dan Farrelly, my deepest thanks. Heartfelt thanks to my husband, Seóirse 44 
1 Bodley, for his advice and help stretching back over many books. He shared 1 2 every thought, hope and dilemma as I wrote, countered my uncertainties, and was 2 3 always there for me: l'amor che move il sole e l'altre stelle. My final thanks are 3 4 reserved for my lovely daughter, Bláthnaid, whose affection and receptiveness to 4 5 everything around her brings immense joy. 6 Dublin, September $2008 \quad 8$ 


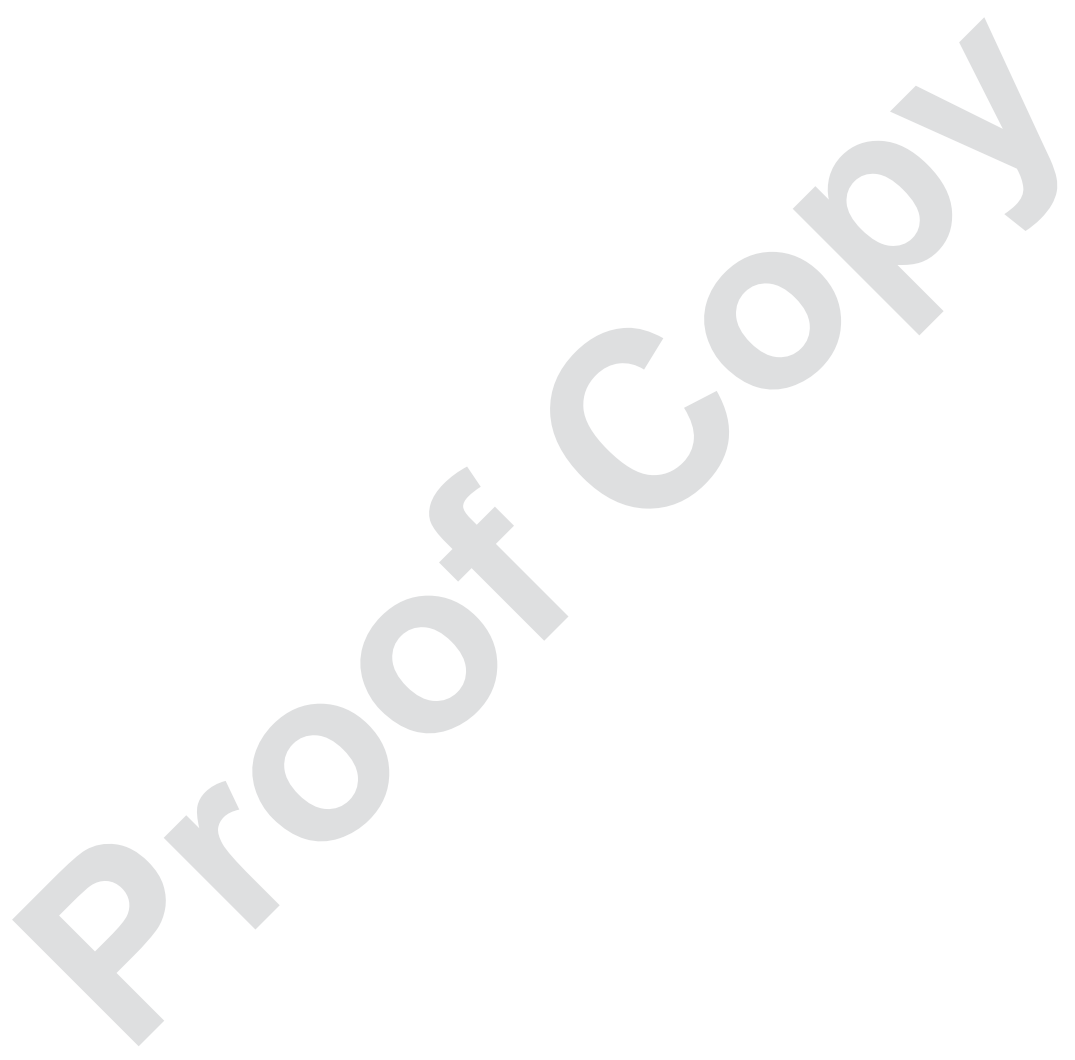




\section{List of Abbreviations 1}

Jenaische Allgemeine Literatur-Zeitung 13 Jahrbuch der Sammlung Kippenberg $\quad 14$ Jahrbuch der Deutschen Schillergesellschaft 15 Music and Letters 16 The Music Quarterly 17 The Music Review 18 Nineteenth Century Music 19 Publications of the English Goethe Society 20 Journal of the Modern Language Association of America 21 Schriften der Goethe-Gesellschaft 22

Allgemeine Deutsche Bibliographie (56 vols, Leipzig: 27 Duncker and Humblot, 1875-1912). Dietrich Dahnke, Regine Otto and Peter Schmidt (4 vols, 30 Stuttgart and Weimar: Metzler Verlag, 1996-99). Goethes Gespräche. Eine Sammlung zeitgenössischer 32 Berichte aus seinem Umgang. Auf Grund der Ausgabe 33 und des Nachlasses von F. Freiherrn von Biedermann. 34 Completed and edited by Wolfgang Herwig (4 vols, Zürich 35 and Stuttgart: Artemis Verlag, 1965). Goethe's Letters to Zelter. In J.W. von Goethe. Sämtliche 37 Werke nach Epochen seines Schaffens. Münchner Ausgabe, 38 vols 20.1, 20.2 and 20.3 (Briefwechsel zwischen Goethe 39 und Zelter in den Jahren 1799 bis 1832), (eds) Hans- 40 Günter Ottenberg and Edith Zehm in collaboration with 41 Anita Golz, Jürgen Gruß, Wolfgang Ritschel and Sabine 42 Schäfer. 
7 Reisebriefe (1862)

8

9

10 SNA

11

12

13

14

15

16

17

$18 \mathrm{ZG}$

19

20

21

22

23

24

25

26 III Texts

27

28 Blumner

29

30 Bohnenkamp

31

33 Eckermann

34

$35 G M$

36

37 Keudell

38

39

$40 \mathrm{KuA}$

41

42 Mendelssohn Briefe 43

44
Goethes Werke. Hamburger Ausgabe, (ed.) Erich Trunz 1 (14 vols, Hamburg: C.H.Beck, reprint 1994). 2 J.W. von Goethe. Sämtliche Werke nach Epochen seines 3 Schaffens. Münchner Ausgabe, (eds) Karl Richter, Herbert 4 G. Göpfert, Norbert Miller, Gerhard Sauder, Edith Zehm et 5 al. (21 vols, Munich: Carl Hanser Verlag, 1985-98). 6 Reisebriefe von Felix Mendelssohn Bartholdy aus den 7 Jahren 180 bis 1832, (ed.) Paul Mendelssohn Bartholdy, 8 3rd edn (Leipzig, 1862, reprint Bonn, 1947). 9 Schillers Werke. Nationalausgabe, edited in collaboration 10 with the Goethe and Schiller Archive, Weimar, and the 11 Schiller National Museum, Marbach (Weimar, 1943ff). 12 Goethes Werke. Weimarer Ausgabe, (eds) Gustav von 13 Loeper, Erich Schmidt, Hermann Grimm et al. on the 14 instructions of the Grand Duchess Sophie von Sachsen- 15 Weimar-Eisenach (143 vols, Weimar: Hermann Böhlau, 16 1887-1919; reprint Munich, 1987). 17 Zelter's Letters to Goethe. In J.W. von Goethe. Sämtliche 18 Werke nach Epochen seines Schaffens. Münchner Ausgabe, 19 vols 20.1, 20.2 and 20.3 (Briefwechsel zwischen Goethe 20 und Zelter in den Jahren 1799 bis 1832), (eds Hans-Günter 21 Ottenberg and Edith Zehm in collaboration with Anita Golz, 22 Jürgen Gruß, Wolfgang Ritschel and Sabine Schäfer. $\quad 23$

Martin Blumner, Geschichte der Sing-Akademie zu Berlin 28 (Berlin: Horn \& Raasch, 1891).

Anne Bohnenkamp, '... das Hauptgeschäft nicht außer 30 Augen lassend'. Die Paralipomena zu Goethes 'Faust' 31 (Frankfurt am Main and Leipzig: Insel Verlag, 1994). 32 Johann Peter Eckermann, Gespräche mit Goethe (Leipzig: 33 Brockhaus, 1836-48; Stuttgart: Reclam, reprint 1998). 34 Karl Mendelssohn Bartholdy, Goethe und Mendelssohn 35 (Leipzig: Hirzel Verlag, 1872).

Elise von Keudell, Goethe als Benutzer der Weimarer 37 Bibliothek. Ein Verzeichnis der von ihm entliehenen Werke 38 (Weimar: H. Böhlau, 1931, reprint 1982). 39 Goethe, Über Kunst und Altertum, vol. 1 (Stuttgart, 1812- 40 32; reprint Bern, 1970).

Rudolf Elvers (ed.), Felix Mendelssohn Bartholdy. Briefe 42 (Frankfurt am Main: Fischer, 1984). 43 
$1 M G G$

2

3

4

5

$6 R A$

7

8 Ruppert

9

10

11 Schünemann

12

13 Zelters Königsberger

14 Briefe

15

16

17

18 IV Archives

19

20 GMD

21

22 GSA

23 SBB PK

24

25

26

27

28

29

30

31

32

33

34

35

36

37

38

39

40

41

42

43

44
Die Musik in Geschichte und Gegenwart. Allgemeine 1 Enzyklopaedie der Musik. Unter Mitarbeit zahlreicher 2 Musikforscher (...), (ed.) Friedrich Blume vols 1-17 3 (Kassel, Basel: Bärenreiter Verlag, 1949-86; reprint 4 Munich: Deutscher Taschenbuch Verlag, 1989). 5 Briefe an Goethe. Gesamtausgabe in Regestform, (ed.) 6 Karl-Heinz Hahn (Weimar: Regestausgabe, 1980ff). 7 Goethes Bibliothek. Katalog, (ed.) Hans Ruppert 8 (Weimar: Goethe Sammlung der Kunst, Literatur und 9 Naturwissenschaft, 1958, reprint Leipzig 1978) 10 Georg Schünemann, Carl Friedrich Zelter der Begründer 11 der Preußischen Musikpflege (Berlin: Hesse, 1932). 12

Joseph Müller-Blattau, 'Karl Friedrich Zelters Königsberger 13 Briefe 1809' in Altpreußischen Forschungen 12 (1935): 14 256-76.

Goethe-Museum Düsseldorf. Anton-und-Katharina 20 Kippenberg-Stiftung. $\quad 21$

Goethe-und Schiller-Archiv Weimar. 22

Staatsbibliothek zu Berlin. Preussischer Kulturbesitz. 23 


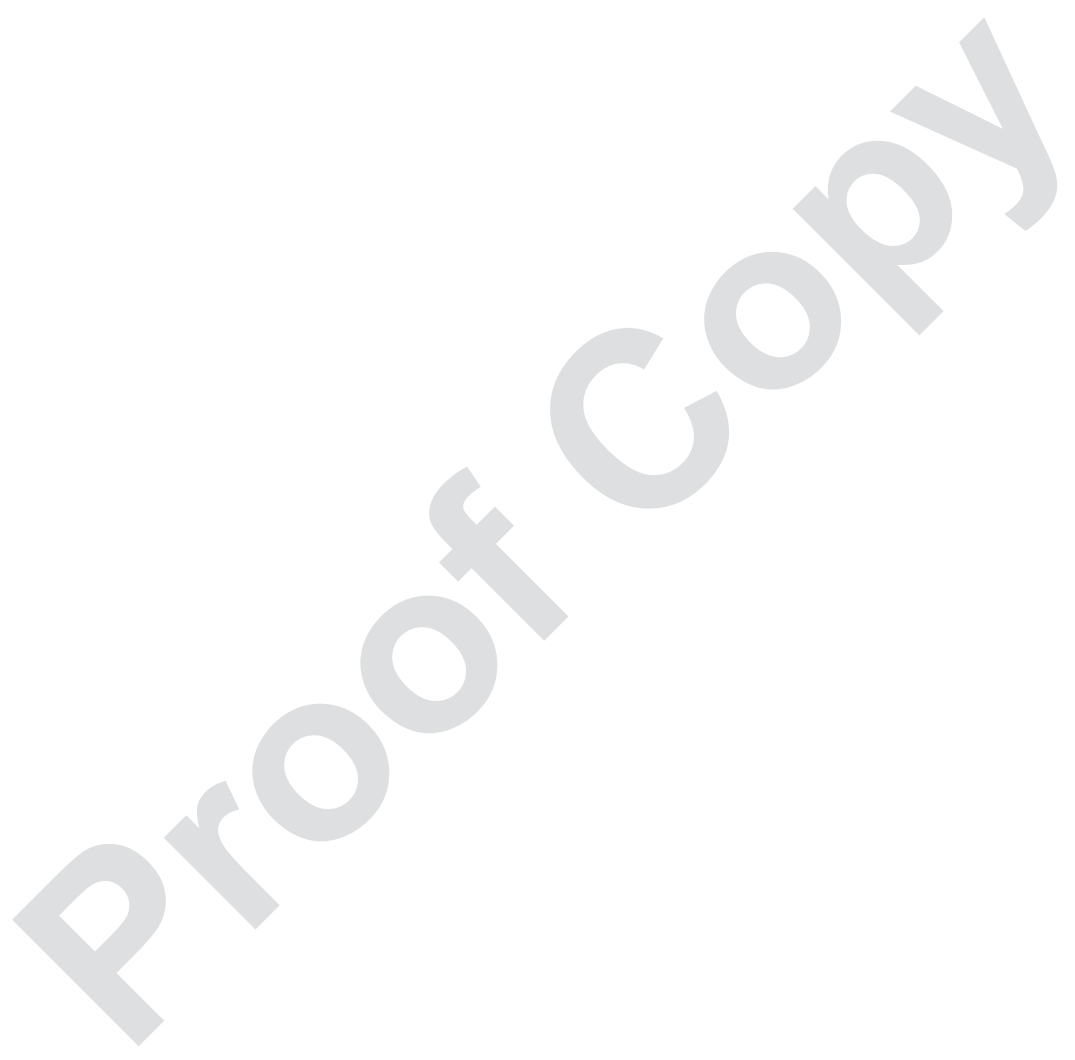




\section{List of Music Examples}

1 Letter no. 95, ZG, Berlin, 6 April to 7 May 1808, Scottish hornpipe, GSA 28/1015, s.62.

2 Letter no. 252, ZG, Berlin, 11 January 1819, 'Klaggesang', GSA 28/1017, s.172.

3a Letter no. 258, ZG, Vienna, 20 July to 9 August 1819.

Waiter's call, GSA 28/1017, s.178.

3b Letter no. 258, ZG, Vienna, 20 July to 9 August 1819.

Waiter's response, GSA 28/1017, s.178.

4 Letter no. 333, ZG, Berlin, 12 April 1825,

Zelter's sketch of the orchestral pit, GSA 28/1020, s.249.

5a Letter no. 460, ZG, Berlin, 14 May 1829,

Zelter's sketch for the formation of triads,

GSA 28/1024, s.381.

5b Letter no. 460, ZG, Berlin, 14 May 1829,

Zelter's example of perfect and imperfect cadences,

GSA 28/1024, s.381.

5c Letter no. 460, ZG, Berlin, 14 May 1829,

Zelter's example of consecutive fifths in ascending triads,

GSA 28/1024, s.381.

5d Letter no. 460, ZG, Berlin, 14 May 1829,

Zelter's sequence of dominant-tonic chords

(leading to a full close in $\mathrm{F}$ major),

GSA 28/1024, s.381.

6 Letter no. 559, Berlin, 28 to 30 August 1831, Canon by Zelter,

GSA 28/1026, s.481. 


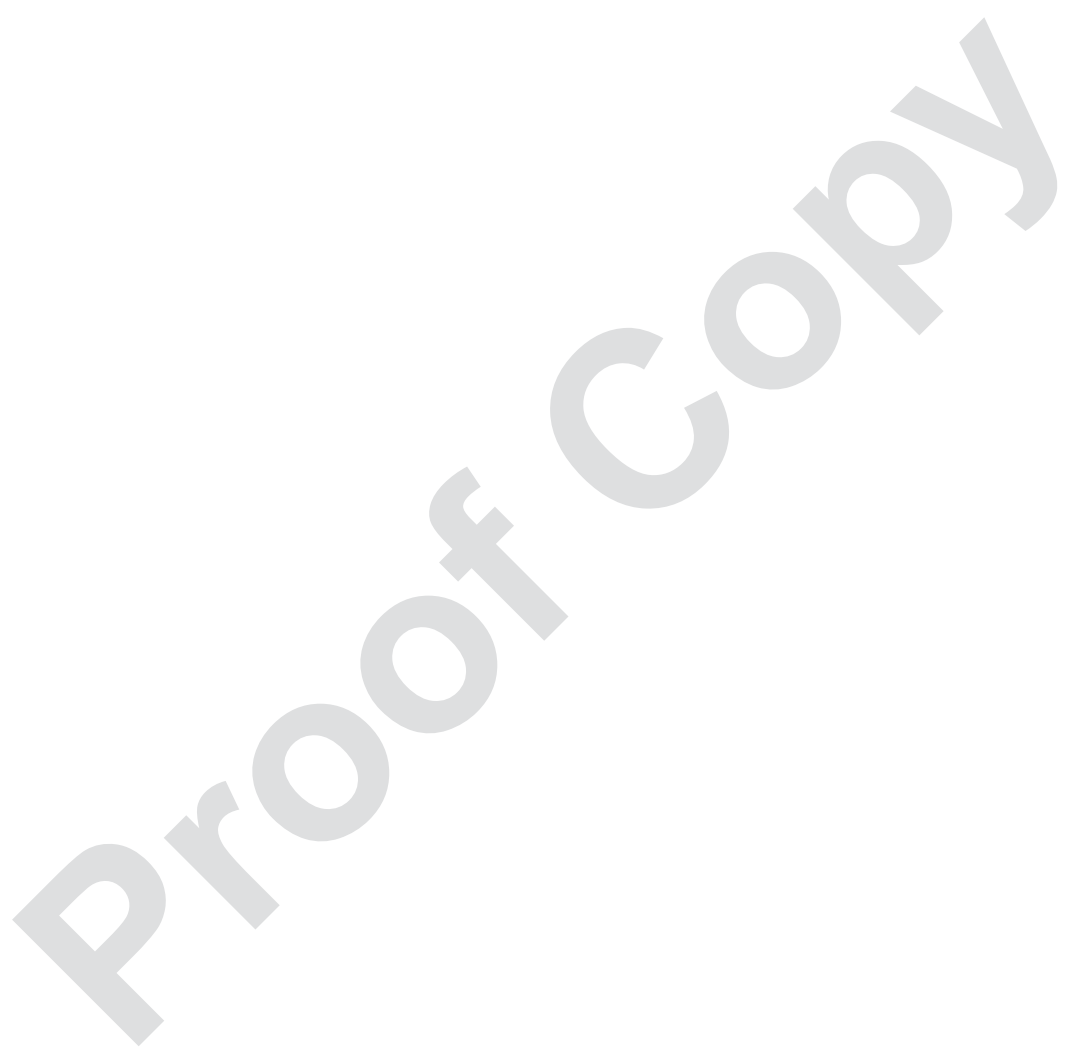




\section{A Musical Odyssey:- \\ A Musical Odyssey:

Lorraine Byrne Bodley

15 Goethe's letters to Zelter provide us with an almost embarrassingly rich testimonial 15 16 to the intensity and variety of his intellectual life. Yet his critics have not made 16 17 use of them. His biographers cite them only to illustrate his state of mind at a 17 18 given moment, or to make an incidental point about his thinking on one or another 18 19 matter. His exegetes have for the most part ignored the letters, arguing that one 19 20 should either develop a working relationship with the whole body of letters or 20 21 leave them alone. The first editor of these letters, Goethe's secretary, Friedrich 21 22 Wilhelm Riemer, was of this opinion when he published the complete edition of 22 23 the letters just two years after Goethe's death. ${ }^{1}$ When this first edition of the letters 23 24 appeared between 1833 and 1834 several of the artists' contemporaries were, for 24 25 better or worse, against the boldness and buoyancy of Zelter's words, ${ }^{2}$ and the 25 26 musical conservatism of both its writers has since been criticized. ${ }^{3} \quad 26$

281 Johann Wolfgang von Goethe, Briefwechsel zwischen Goethe und Zelter in den 28

29 Jahren 1796 bis 1832, ed. Friedrich Wilhelm Riemer (6 vols, Berlin, Hermann Böhlau, 29

30 1833-34).

312 See, for example the private letters of Henriette (Hinni) Mendelssohn (née Meyer) to 31

32 her daughter-in-law, Rosamund Mendelssohn, Berlin, 9 November 1833; Fanny Hensel (née 32

33 Mendelssohn) to her brother, Felix Mendelssohn Bartholdy, 1 December 1833; Charlotte 33

34 Stieglitz to Baron Stieglitz, Berlin 20 December 1833; Fanny Hensel to her brother, Felix 34

35 Mendelssohn Bartholdy, Berlin, 27 November 1834. For positive reception see the private 35

36 letters of Wilhelm Neumann to Karl August Varnhagen von Ense, Berlin 31 December 1833; 36

37 Karl Ludwig von Knebel to Friedrich Wilhelm Riemer, Jena, 25 January 1834; Carl Gustav 37

38 Carus to August Carl Graf von Bose, Dresden, 9 April 1834 and, on balance, Friedrich von 38
39 Müller to Carl August Böttinger, Weimar, 23 September 1834. All letters are contained in
39

39 the Münchner Ausgabe, 20.2, pp. 1673-80. Hereafter referred to as $M A$.

$40 \quad 3$ See, for example: W.J. Wasiliewski, Goethes Verhältnis zur Musik (Leipzig: 40

41 Sammlung musikalischer Vorträge, 1880); Wilhelm Bode, Goethe und die Tonkunst, 41

42 (2 vols, Berlin: E.S. Mittler und Sohn, 1912); Hermann J Abert, Goethe und die Musik 42

43 (Stuttgart: J. Engelhorns Nachf., 1922); Edgar Istel, 'Goethe and Music', $M Q, 14$ (1928): 43

44 216-54; Romain Rolland, 'Goethe's Interest in Music', $M Q, 17$ (1931): 157-94 and also 44 
When considering the reception of the Goethe-Zelter letters in recent years, 1

2 two publications stand out: Bettina Hey'l's study of literature discussed in the 2

3 Goethe-Zelter letters ${ }^{4}$ and the Münchner Ausgabe edition of the letters ${ }^{5}$ alongside 3

4 the correspondence of Goethe and Schiller. The editorial team for this edition, led 4

5 by Hans-Günter Ottenberg, Sabine Schäfer and Edith Zehm, took for granted the 5

6 letters' integrity and distinction as a correspondence and gathered together related 6

7 documents in a detailed lengthy postlude to show the basis of this integrity and 7

8 distinction. While Zehm assumed that these letters preserved the historical and 8

9 imaginative world of both writers, this treatment has still not changed the way 9

10 in which the correspondence is viewed, nor has it initiated a new era - or new 10

11 terms - of appreciation. One reason for this neglect in musicology is that these 11

12 letters have never been published in English. A.D. Coleridge's nineteenth-century 12

13 translation Goethe's Letters to Zelter presents a selection of excerpts from 250 of 13

14 the 900 letters; ${ }^{6}$ Jeffrey Pulver's article 'Beethoven in the Goethe-Zelter letters'7 14

'Goethe the Musician' in Dagobert D. Runes (ed.), Goethe Symposium (New York: Roerich 16 Museum Press, 1932): 3-17; Emil Voigt, 'War Goethe musikalisch?', Musik, 23 (1931): 17 321-7; Ferdinand Küchler, Goethes Musikverständnis (Leipzig, 1935); Friedrich Blume, 18 Goethe und die Musik (Kassel: Bärenreiter Verlag, 1948); M. Heller, 'Goethe and Music', 19 GQ, 22 (1949): 205-208; Louise Levin, 'Goethe and Music', Contemporary Review, 17620 (1949): 225-30; M.H. Nathan, 'Goethe was musical', Musical Opinion (London, Nov. 21 1949); John Greenhill, 'Goethe's attitude towards music and contemporary composers', 22 Australian Goethe Society Proceedings (1950); Guido Kisch, 'Music in Goethe's Life', 23 Monatshefte für deutschen Unterricht, 42 (1950): 243-51; Hans Ple $\beta$, 'Goethe und die 24 Musik', Musikerziehung, 3 (1950): 70-76; Anne-Marie M. Sauerlander, 'Goethe's Relation 24 to Music' in J. Alan Pfeffer (ed.), Essays on German Language and Literature in Honour 25 of Theodore B. Hewitt (Buffalo: The University of Buffalo Studies, 1952), pp. 39-55; 26 W.C.R. Hicks, 'Was Goethe Musical?', PEGS, 27 (1958): 73-139; Susan Sonnet, 'Goethe 27 and Music' in Soundings: Collections of the University Library (California: University 28 of Santa Barbara, 1970), pp. 30-33; John L. Miller, 'Goethe and Music' in Seminar: 29 A Journal of Germanic Studies, 8 (1972): 42-54; David Dalton, 'Goethe and the 30 Composers of his Time', MR, 34 (1973):157-74; Meredith McClain, 'Goethe and Music: 31 Nur wer die Sehnsucht kennt' (Texas: Texas Tech. Press, 1984), pp. 201-77; Ernst-Jürgen 32 Dreyer, Goethes Tonwissenschaft (Berlin, Frankfurt am Main \& Vienna: Ullstein, 1985); 33 H. Zeman, 'Goethe und die Musik, Prologomena zu einem großen Thema' in Wort und Ton 34 im europäischen Raum. Gedenkschrift für Robert Schollum (Vienna: Böhlau Verlag, 1989), 35 pp. 109-14; Elmar Budde, 'Goethe und die Musik' in Goethe Spuren. Ein Lese-Buch zum 35 Konzertprojekt (Göttingen: Wallstein Verlag, 1998), pp. 15-35.

4 Bettina Hey'l, Der Briefwechsel zwischen Goethe und Zelter. Lebenskunst und 37 literarisches Projekt (Tübingen: Niemayer Verlag, 1996). 5 Hans-Günter Ottenberg, Sabine Schäfer and Edith Zehm (eds), Briefwechsel mit 39 Zelter vols 20.1; 20.2 and 20.3 in Karl Richter (ed.) Goethe Sämtliche Werke nach Epochen 40 seines Schaffens. Münchner Ausgabe (20 vols, München: Hanser Verlag, 1985-98). 41 6 A.D. Coleridge, Goethe's Letters to Zelter (London: George Bell \& Sons, 1887). 42 7 Jeffrey Pulver, 'Beethoven in the Goethe-Zelter Correspondence', ML 17 (1936): 43 124-30. 
1 is the only secondary source available in English, and there has never been a book 1

2 published in English - or in German - which concentrates solely on the musical 2

3 dialogues of these letters.

4 The three volumes of this correspondence do essentially rest upon this 4

5 musical foundation. Flouted as this foundation has been and continues to be, it 5

6 is this critical reception which will, ironically enough, make them attractive to 6

7 cultural historians. This book is not intended as a panacea for musicological ills 7

8 but is geared to effect what Seamus Heaney once called 'The Redress of Poetry' ${ }^{8} 8$

9 Heaney's idea of redress finds its roots in Simone Weil's book, Gravity and Grace, ${ }^{9} \quad 9$

10 which observes that if we know how something is unbalanced, we add weight to 10

11 the lighter side of the scale. So what are the roots of this lack of equilibrium in 11

12 critics' response to the Goethe-Zelter letters? And what counterweights need to be 12

13 hung in the scale of their reception? 13

14

15

16 Goethe and Musical Modernity

18 The pervasive image of Goethe as a musically conservative poet ${ }^{10}$ has, without 18

19 question, engendered the scholarly neglect of Goethe's correspondence with Zelter, 19

20 which is one of the few areas in Goethe philology that has been left unexplored. It 20

21 has also influenced the portrayal of Goethe's musical historicism as an excessive 21

22 veneration of past musical styles, rather than the desire to challenge contemporary 22

23 norms in art by asserting the validity of the art of a plurality of peoples and 23

24 periods. The new perceptions of historical processes which emphasized modernity 24

25 and granted little role to any reference to the past, and thereby engendered an 25

26 increasingly teleological perspective on music history, portrayed Schubertian song 26

27 as an evolutionary development, an improvement on Goethe's aesthetic theories 27

28

298 Seamus Heaney, The Redress of Poetry, Oxford Lectures (London: Faber and Faber, 29

30 1995).

319 Simone Weil, Gravity and Grace (Oxford and New York: Routledge Classics, 31

32 1992).

3310 See, for example: Wasiliewski, Goethes Verhältnis zur Musik; Bode, Goethe und 33

34 die Tonkunst; Abert, Goethe und die Musik; Istel, 'Goethe and Music': 216-54; Rolland, 34

35 'Goethe's Interest in Music': 157-94 and also 'Goethe the Musician', pp. 3-17; Voigt, 'War 35

36 Goethe musikalisch?’: 321-7; Küchler, Goethes Musikverständnis; Blume, Goethe und die 36

37 Musik; Heller, 'Goethe and Music': 205-208; Levin, 'Goethe and Music': 225-30; Nathan,

38 'Goethe was musical'; Greenhill, 'Goethe's attitude towards music and contemporary

39 composers': 18-26; Kisch, 'Music in Goethe's Life': 243-51; Pleß, 'Goethe und die

39 Musik': 70-76; Sauerlander, 'Goethe's Relation to Music', pp. 39-55; Hicks, 'Was Goethe

40 Musical?': 73-139; Sonnet, 'Goethe and Music', pp. 30-33; Miller, 'Goethe and Music':

41 42-54; Dalton, 'Goethe and the Composers of his Time': 157-74; McClain, 'Goethe and

42 Music: Nur wer die Sehnsucht kennt', pp. 201-77; Dreyer, Goethes Tonwissenschaft;

43 Zeman, 'Goethe und die Musik, Prologomena zu einem großen Thema', pp. 109-14;

44 Budde, 'Goethe und die Musik', pp. 15-35. 
1 of song. And it is only in recent years that scholars have begun to chart the more 1

2 complex contours of pre-Schubertian song. ${ }^{11} \quad 2$

5 Reconsidering Goethe's 'rejection' of Schubert

7 The neglect of the Goethe-Zelter letters in musicology has been influenced by the 7

8 impression of a hapless relationship between Schubert and Goethe. The image of 8

9 'Poor Schubert', partly born of the Romantic idea of the 'unrecognized artistic 9

10 genius, the artist who valiantly struggles for acceptance and yet is explicitly 10

11 ignored by the world until after his death', ${ }^{12}$ thus set in antithesis with the canonical 11

12 artist and titanic personality of Goethe, has contributed to misconceptions about 12

13 the relationship between Goethe and Schubert. ${ }^{13}$ Goethe's 'rejection' of Schubert's 13

14 first book of songs was claimed to have been influenced by Zelter, to whom Goethe 14

15 supposedly sent the songs for advice. Such arguments are clearly unfounded: in the 15

16891 letters exchanged between these artists there is no mention of Schubert Lieder; 16

17 on the contrary, the letters prove the dispatch was never sent to Zelter, nor was he 17

18 in Weimar during the period in which Schubert's first songbook arrived. In their 18

11 See, for example, the seminal work of Otto Biba, 'Goethe in the Vienna Music 22

Scene of his Era' in Lorraine Byrne (ed.), Goethe: Musical Poet, Musical Catalyst (Dublin: 24 Carysfort Press, 2004), pp. 7-40 or the pioneering recording by Graham Johnson, Songs by 25 Schubert's Friends and Contemporaries (London: The Hyperion Schubert Edition, 2004), 26 CDJ33051/3.

${ }_{12}$ Christopher Gibbs, “Poor Schubert”: images and legends of the composer' in 27 Christopher Gibbs (ed.) The Cambridge Companion to Schubert (Cambridge, 1997), 28 pp. 36-55.

13 See, for example: O. Linke in 'Schubert und Goethe', Neue MusikZeitung, 12 (1891); 30

R. Boehmer-Aachen, 'Goethe und Schubert' in Rheinische Musik-und Theaterzeitung, 1431 (1913): 486-89; Konrad Volker, 'Schubert und Goethe', Die Musik, 14 (1915): 129; M. v. 32 Leinburg, 'Schubert und Goethe' (Munich: Propyläen Ausgabe, 1928); M. Zeiner, 'Goethe 33 und Schubert', Die Quelle, 79 (1929): 105; Romain Rolland, 'Goethe's Interest in Music': 34 177 and 190; P. Riesenfeld, 'Goethe und Schubert', Signale für die musikalische Welt, 9035 (1932): 267; Konrad Huschke, 'Schubert und Goethe', Musica, 7 (1953): 580-81; Alexander 36 Witeschnik, 'Goethe und Schubert: Die Geschichte einer einseitigen Liebe', Jahrbuch des 37 Wiener-Goethe Vereins, 67 (1963): 78-85; Joseph Müller-Blattau, 'Franz Schubert, der 38 Sänger Goethes' in Joseph Müller-Blattau, Goethe und die Meister der Musik (Stuttgart: 39 Klett, 1969), pp. 62-80; Dalton, 'Goethe and the Composers of his Time': 157-74; Ronald 40 Taylor, Goethe-Schubert and the Art of Song' in Volker Dürr and Géza v. Molnãr (eds), 40 Versuche zu Goethe: Festschrift für Erich Heller (Heidelberg: Lothar Stiehm Verlag, 1976), 41 pp. 141-9; Frederick W. Sternfield, Goethe and Music: A List of Parodies and Goethe's 42 Relationship to Music: A List of References (New York: The New York Public Library, 43 1979), introduction, p. vii. 
1 portrayal of a 'neglected Schubert', ${ }^{14}$ scholars have overlooked the significance of 1

2 Goethe's acknowledgement of Schubert's second dedication in his diary as early 2

3 as 1825: 'Sendung von Schubert aus Wien, von meinen Liedern Kompositionen' 3

4 (A parcel of my song compositions from Schubert of Vienna). ${ }^{15}$ Johann Nepomuk 4

5 Hummel, Weimar's most eminent musician at the time, and Felix Mendelssohn, 5

6 friend and musical advisor to Goethe, did not discover Schubert until 1827. ${ }^{16} 6$

7 Whether Goethe's failure to respond to Schubert in a personal letter of thanks was 7

8 linked to his reticence in encouraging the younger generation of Romantic literary 8

9 artists $^{17}$ or coloured by the sad reality that Goethe and Schubert never met, ${ }^{18}$ one 9

10 will never know. What is clear, however, from Metternich's new censorship laws, 10

11 which were tightened up as a result of the Congress of Vienna, is that Schubert 11

12 could not have published his op. 19 Lieder in Vienna - with the dedication to 12

13 Goethe on the title page of this volume - without the poet's written permission. ${ }^{19} 13$

14 At some point - perhaps the same day as Goethe acknowledged receipt of these 14

15 songs in his diary - a written missive must have been sent to Vienna to allow 15

16 these songs to be published with a dedication to the poet. The presumed loss of 16

17 this letter ${ }^{20}$ coupled with the legend of Schubert's neglect and Goethe's 'Olympian 17

18 aloofness [and] blindness to new writers of talent ${ }^{\prime 21}$ have fuelled misconceptions 18

19 surrounding Goethe's 'neglect' of 'Poor Schubert'. 19

21 Gibbs traces this image of Schubert in musicology in: "Poor Schubert": images and

22 legends of the composer', pp. 46-8. A good example is the review of Newman Flower's book,

23 Franz Schubert: The Man and his Circle, in New York Times, 25 November 1928, cited in

24 Robert Winter, 'Whose Schubert?', NCM, vol. 17/1 (1993), p. 97.

2515 Goethes Werke. Weimarer Ausgabe, (eds) Gustav von Loeper, Erich Schmidt,

26 Hermann Grimm et al. (Weimar: Hermann Böhlau, 1887-1912), III/10, 16 June 1825,

27 pp. 68-9. Hereafter referred to as $W A$.

2816 R. Larry Todd, Mendelssohn: A Life in Music (Oxford: Oxford University Press, 28

29 2003), p. 72.

3017 Examples include the works of Wachenroder (Herzensergießungen), E.T.A. 30

31 Hoffmann, Bretano and Kleist (Das Kätchen von Heilbronn). For an example of Goethe's 31

32 polemical broadsides against Romanticism, see Johann Peter Eckermann, Gespräche mit

33 Goethe (Stuttgart: Reclam, reprint 1998), 2 April 1829, p. 343. Hereafter referred to as 34 Eckermann.

3518 On 16 June 1825, the same day as Franz Schubert's letter and manuscript containing

36 the op. 19 settings arrived, Lea Mendelssohn sent an exemplar of Mendelssohn's newly

36 published Piano Quartet no. 3 in B minor from Berlin, for which she had already requested

37 permission to dedicate to Goethe. Goethe wrote to Mendelssohn, thanking him for the

38 dedication of the Quartet, which Mendelssohn had played for him on his third visit to the

39 poet in Weimar. See Karl Mendelssohn Bartholdy (ed.), Goethe und Mendelssohn (Leipzig:

40 Hirzel Verlag, 1872), p. 50. Hereafter referred to as GM.

4119 Biba, 'Goethe in the Vienna Music Scene of his Era', p. 27.

4220 Ibid. 42

4321 Lesley Sharpe (ed.), The Cambridge Companion to Goethe (Cambridge: Cambridge 43

44 University Press, 2002), introduction, p. $2 . \quad 44$ 
1 Like Breath on Glass: Reception of Goethe's Music Theatre

3 A third reason for the musicological neglect of this correspondence is encountered 3

4 in Germanistik which has wilfully ignored Goethe's works of music theatre. The 4

5 value Goethe placed on his musico-dramatic writings and the positive reception of 5

6 these works during his lifetime challenges Hugo von Hofmannsthal's designation 6

7 of Goethe's music theatre as 'Nebenwerke', works of secondary importance in 7

8 the poet's creative canon. Yet the ripples from the stone which Hofmannsthal cast 8

9 in 1913 spread through Goethe scholarship in Germany and beyond, where the 9

10 works have been outside the canon of research almost up to the present day, as 10

11 a cursory glance at the commentary on these works in the Münchner Ausgabe 11

12 will affirm. In recent years this lacuna in Goethe reception has been addressed in 12

13 the seminal work of such scholars as Benedikt Holtbernd, ${ }^{22}$ Markus Waldura, ${ }^{23} 13$

14 Thomas Frantzke, ${ }^{24}$ and by the publication of Goethe's musico-dramatic works by 14

15 Metzler Verlag in 2004. In the context of this scholarly tableau Tina Hartmann's 15

16 mighty argosy of scholarship, Goethes Musiktheater, ${ }^{25}$ is an important milestone 16

17 in understanding Goethe's contribution to the rise of German national theatre. 17

This current revision of Goethe's musicality in contemporary musicological 22

23 discourse is fettered by the mythologization of Goethe. Although the image of 23

24 Goethe in the popular imagination is a matter quite different from the scholarly 24

25 reception of Goethe's musical and literary works, the two worlds do cross over 25

26 since any seriously revised perception of the poet is difficult to establish when 26

27 the spectre of an unmusical poet keeps re-emerging in contemporary Goethean 27

28 culture. $^{26}$ Twenty years before the Goethe-Zelter correspondence began, Goethe 28

29 had already become an icon of German cultural gravitas, the founding figure of a 29 30 national cultural heritage, and the enterprise of marketing and merchandising this 30

22. Benedikt Holtbernd, Die dramaturgischen Funktionen der Musik in den 32 Schauspielen Goethes (Frankfurt am Main: Lang, 1992). musikalischen und sozielen Formen', Archiv für Musikwissenschaft, 50 (1993): 259-90; 36 'Die Singpsiele', in Bernd Witte, Theo Buck, Hans-Dietrich Dahnke, Regine Otto and Peter 36 Schmidt (eds), Goethe Handbuch, (4 vols, Stuttgart and Weimar: Metzler Verlag, 1996-99), 37
vol. 2, pp. 192-3; hereafter referred to as Goethe HB.

${ }_{24}$ Thomas Frantzke, Goethes Schauspiele mit Gesang und Singspiele 1773-1782 39 (Frankfurt a.M., Berlin, Bern, New York, Paris, Vienna: Lang, 1998). 40

25 Tina Hartmann, Goethes Musiktheater (Tübingen: Max Niemeyer Verlag, 2004). 41

26 See, for example, Knut-Olaf Haustein, 'Da schwebt hervor Musik mit 42 Engelsschwingen': Goethes Dichtungen in der Musik (Weimar: quartus-Verlag, 2005), 43 Chapter 1, 'Wie musikalisch war Goethe', p. 24f. 
1 great national poet had already been ushered in, in the Intelligenz Blatt of Bertuch's 1

2 Journal des Luxus und der Moden (Journal of Luxury and Fashion, which ran from 2

31786 to 1827). ${ }^{27}$ Yet the complexities of Goethe, his life's work and reception, are 3

4 reduced the moment he is transformed into the signifier of a myth. Bottled up in 4

5 this way he becomes a lifeless icon and the message in the bottle is a profoundly 5

6 conservative one, more akin to the nationalistic tradition of Wilhelmine Germany 6

7 than to Weimar in the early 1800 s or the serious scholarship of the cultural 7

8 foundation, Stiftung Klassik Weimar (Weimar Classics Foundation), which has 8

9 recently begun to unwrap Goethe's Weimar and consider the process involved 9

10 in producing various myths surrounding the poet, Goethe. While Henke, Kord 10

11 and Richter's valuable study, Unwrapping Goethe's Weimar, ${ }^{28}$ does not unravel 11

12 the mystery of Weimar's musical past, an earlier voluminous lexicon, Goethes 12

13 Weimar, by Effi Biedrzynksi ${ }^{29}$ places countless evocative details into the hands of 13

14 prospective cultural studies scholars and allows the reader to infer the crucial role 14

15 that music played in the life of Weimar - a position recently acknowledged by the 15

16 Weimar Classics Foundation and Institute for Musicology at the Liszt Hochschule 16

17 which have begun to unveil the music of Weimar Classicism. ${ }^{30} \quad 17$

$18-18$

$19-19$

20 Unfolding Goethe's Engagement with Music 20

$21 \quad 21$

22 This quest for what was forgotten, concealed, revised or transformed lies behind 22

23 my translation of Goethe and Zelter: Musical Dialogues. In this correspondence 23

24

2527 Friedrich Justin Bertuch and Georg Melchior Kraus (eds), Journal der Moden, vol. 1

26 (Gotha: Ettingersche Buchhandlung, 1786); Friedrich Justin Bertuch and Georg Melchior

27 Kraus (eds) (ed. Carl Bertruch from 1807-12), Journal des Luxus und der Moden, vols

28 2-27 (Weimar: Industrie-Comptoir, 1787-1812); Carl Bertuch (ed.) (ed. Heinrich Döring

29 from 1815), Journal für Luxus, Mode und Gegenstände der Kunst, vols 28-30 (Weimar:

30 Industrie-Comptoir, 1813-15); Heinrich Döring (ed.) (ed. Stephan Schütz from 1825),

31 Journal für Literatur, Kunst, Luxus und Mode vols 31-41 (Weimar: Industrie-Comptoir, 31

32 1816-1826); Stephan Schütz (ed.), Journal für Literatur, Kunst und geselliges Leben 32

33 vol. 42 (Weimar: Industrie-Comptoir, 1827); Friedrich Justin Bertuch and Georg Melchior 33

34 Kraus (eds), Journal des Luxus und der Moden. Abridged Edition (ed.) Werner Schmidt.

354 vols Rpt. (Hanau: Müller and Kiepenheuer, 1967-70).

$36 \quad 28$ Burkhard Henke, Susanne Kord and Simon Richter (eds), Unwrapping Goethe's

37 Weimar: Essays in Cultural Studies and Local Knowledge (Rochester, NY: Camden House, 37 2000).

3829 Effi Biedrzynski, Goethes Weimar: Das Lexikon der Personen und Schauplätze, 39 3rd edn (Zurich: Artemis and Winkler, 1994).

$40 \quad 30$ Detlef Altenburg (General Editor), Musik und Theater, 5 vols. to date (Weimar:

41 Studio Verlag, 2005-). See especially: Detlef Altenburg and Beate Schmidt, Musik und

42 Theater um 1800 (Musikund Theater, vol. 1); Thomas Radecke, Theatermusik-Musiktheater.

43 Shakespeare-Dramen aud deutschen Bühnen um 1800 (Musik und Theater, vol. 2) and

44 Beate Schmidt, Musik in Goethes Faust (Musik und Theater, vol. 5).

西


1 Goethe's critical facility in contemplating music contradicts the common 1

2 perception that the poet blindly accepted Zelter's musical opinions - a conjecture 2

3 even contradicted by Zelter who admits to Goethe in the correspondence, 'you 3

4 are the only person I know, whose musical judgment offers unique insight 4

5 and value.' Although Goethe had been seeking a musical advisor early in the 5

6 correspondence, Zelter swiftly recognized how the high voltage of Goethe's early 6

7 talent embraced a rich array of musical experience including a detailed practical 7

8 knowledge of contemporary music theatre. The only dependency which arises 8

9 in the letters, therefore, is not a musical dependency, but a human dependency 9

10 which first manifests itself after Schiller's death in 1805, where Goethe begins to 10

11 write more frequently to Zelter, who forms an audience for the poet to whom he 11

12 can speak comfortably and at length. So, too, Zelter's need for Goethe is evident 12

13 upon the death of Zelter's second wife, intensified by the loss of three children 13

14 and augmented by his abiding recognition that his friendship with Goethe greatly 14

15 enhances his intellectual and musical life. While it may lie beyond the scope of 15

16 this introduction to detail exhaustively the intensity and intimacy of Goethe's 16

17 engagement with the musical life of his times, a brief glance at some of the main 17

18 musical themes of this correspondence might countervail the critical reception of 18

19 these letters.

24 Although questions of music theory had preoccupied Goethe from an early age, ${ }^{31}$ it 24

25 was not until his early years of correspondence with Zelter that Goethe's first formal 25

26 papers on music began with a critical translation of Diderot's Neveu de Rameau. ${ }^{32} 26$

27 What is most significant about Goethe's translation is that its annotations, which 27

28 make up almost a third of the text, contain some important comments on music 28

29 and music history and allow us to consider the poet's understanding of the art of 29

30 music in the light of the eighteenth-century French debates between Rameau and 30

31 Rousseau. In contrast to the concept espoused by the French Enlightenment, where 31

32 music acquires intellectual responsibility by painting concrete images, Goethe 32

33 argued that music reached beyond the senses to the intellect and imagination. 33

34 Goethe had first criticized Diderot's concept of musical mimesis in a translation 34

35 and discussion of the philosopher's Essai sur la peinture (1795). This belief is 35

36 evident in Goethe's letters to Zelter where the poet's preference for suggestion 36

37 rather than naturalism in programme music is apparent. ${ }^{33} \mathrm{In}$ his response to Zelter's 37

3931 In his diary, Ephemerides, Goethe had transcribed an excerpt from Hiller's journal, 39

40 Wöchentlich Nachtrichten, die Musik betreffend, on the art of musical declamation and in 40

41 the Italian Journal there are passages on the aesthetics of musical tempi WA I/32, p. 287. 41

$42{ }^{32}$ GZ 19 June 1805. Rameaus Neffe: Ein Dialog von Denis Diderot trans. J.W 42

43 v Goethe (Frankfurt a.M.: Insel Verlag, reprint 1996). 
1 Cantata, 'Johanna Sebus', Goethe draws a comparison between the musical and 1

2 visual arts, yet in music he departs from the principles of imitation: 'It is a kind 2

3 of symbolism for the ear, where the subject, in so far as it is in motion, or not in 3

4 motion, is neither imitated nor painted, but produced in the imagination, in a way 4

5 that is quite peculiar, and impossible to grasp, in so far as the thing described and 5

6 the describer appear to stand in scarcely any relation to one another.' ${ }^{34}$ For Goethe 6

7 the visual symbol is at once effective and elusive; the musical symbol, by contrast, 7

8 is emancipated from its original source and merely triggers the imagination. ${ }^{35} 8$

9 The central purpose of art lies in the creation of Stimmung, an individual artistic 9

10 voice, yet the domain of music hovers between thought and phenomena, spirit 10

11 and matter. It is not representative of the particular, but expresses objects and 11

12 emotions in the abstract, in their essential nature, and enables us to share them in 12

13 this quintessence. 13

14 Although Goethe's letters to Zelter make no further reference to Rameau, his 14

15 research on the French composer awakened his interest in such other theorists as 15

16 the acoustician Ernst Chladni and the scientist Ernst Meyer, ${ }^{36}$ and he was versed in 16

17 the main musicological writings of his day. While reading Chladni's 1802 Theory 17

18 of Acoustics, ${ }^{37}$ Goethe made extensive notes, Über die Nachteile der Stimmung in 18

19 ganz reinen Quinten und Quarten nach Chladni, on the problem of tuning and equal 19

20 temperament. ${ }^{38} \mathrm{He}$ owned copies of and read Johann Mattheson's monumental folio 20

21 Der Vollkommene Capellmeister, ${ }^{39}$ Johann Josef Fux's 1725 counterpoint treatise, 21

22 Gradus ad Parnassum, ${ }^{40}$ and also Marpurg's Abhandlung von der Fuge, ${ }^{41}$ which is 22

23 largely based on The Art of Fugue, Bach's practical 'treatise'; so, too, Kirnberger's 23

24 Die Kunst des reinen Satzes in der Musik (1771) ${ }^{42}$ appealed to Goethe because the 24

25 theoretician focuses on both principles and practical examples. Goethe's interest in 25

26 Kirnberger's theoretical writing reveals his alliance with the progressive musical 26

27 ideas which developed in Berlin scholarship. The breadth of Goethe's knowledge 27

28 of and intimate familiarity with the music literature both of his day and of the past 28

29

$3 0 \longdiv { 3 4 \mathrm { GZ } 6 \mathrm { March } } 1 8 1 0$

$3135 \quad$ GZ 6 March 1810. 31

$32 \quad 35$ GZ 2 May $1820 . \quad 32$

$33 \quad 36 \quad$ GZ 31 January 1803.

34 Ernst Florens Friedrich Chladni, Die Akustik (Leipzig: Breitkopf und Härtel,

35 1803).

$36{ }_{38}$ Über die Nachteile der Stimmung in ganz reinen Quinten und Quarten nach 36

37 Chladni, WA II/13, p. 461.

38 1739); GZ 4 January 1819. See Zelter's response on 2 June 1819.

3940 Johann Josef Fux, Gradus ad Parnassum (Vienna: Joannis Petri van Ghelen, 1725), 39

40 Steps to Parnassus, translated by Alfred Mann (New York: Norton, 1943). 40

$41 \quad 41$ Friedrich Wilhelm Marpurg, Abhandlung von der Fuge (Berlin, A. Haude and J.C. 41

42 Spener, 1753; facsimile, Hildesheim. and New York: Georg Olms, 1970). 42

$43 \quad 42$ Johann Philipp Kirnberger, Die Kunst des reinen Satzes in der Musik (Berlin: C.F. 43

44 Voss, 1771-79; Facs. Rpr. Hildesheim: Georg Olms, 1968). 44 
1 reveals his willingness to absorb new insights in his reception of music, as elements 1

2 of enrichment and reorientation. The overall development of Goethe's theoretical 2

3 knowledge reflects his immense curiosity and openness toward change; his power 3

4 of integration is evident in his treatise on acoustics, which reveals the influence 4

5 of Rameau's harmonic theory and counters contemporary idealist interpretations. 5

6 Goethe's desire to collaborate on a theory of acoustics was partly realized in the 6

7 daily conversations he had with Zelter in Carlsbad, July 1810. These discussions 7

8 on music theory, music history and the human ear, which he carefully recorded in 8

9 his diary, ${ }^{43}$ informed the synoptical table of his Tonlehre. Goethe sketched the first 9

10 draft of his musical mosaic on 28 July 1810. Following further discussions with 10

11 Zelter in Teplitz in August 1810 he revised this fragmentary table and then set it 11

12 aside until 1826, where he encloses it in the correspondence for the composer's 12

13 consideration. ${ }^{44}$ Goethe's enclosure of this table in his correspondence with Zelter 13

14 is significant, for the Tonlehre addresses the artist and not the theoretician. ${ }^{45} \quad 14$

15 The fragmentary table which Goethe sent to Zelter summarizes the poet's belief 15

16 in the primacy of the ear in musical perception, and the primacy of the human voice 16

17 in performance. Countering the idealist and Romantic interpretations of Schlosser, 17

18 who saw a confrontation rather than a harmony between man and nature and 18

19 believed the minor mode expressed an ethical will to emancipate man from nature, 19

20 Goethe ingeniously reinterpreted Schlosser's notion of a Tonmonade to suit his 20

21 own theory of polarities. In his Theory of Sound he reaffirms his conviction of the 21

22 equality of the minor and major modes as poles of a fundamental duality in human 22

23 nature. $^{46} \mathrm{He}$ questions the Empfindsamkeit association of the minor mode with 23

24 melancholy, and instead relates musical polarity to the duality in human nature. 24

25 For Goethe, the major mode was an expression of all that is objective and connects 25

26 the soul to the outer world, and the minor tonality is the mode of introspection and 26

27 concentration. The instinct that leads Goethe from naturalism to abstraction in the 27

28 Tonlehre is countered by an equally powerful aversion to Romantic subjectivity, 28

29 which he recognized as being fundamentally akin to pure mathematics: both were 29

30 human constructs without natural bases. In contrast to the works of Descartes, 30

31 Leibniz, Rameau and Euler, where mathematics becomes fused with the emerging 31 Heinrich Schlosser, 6 February 1815, WA IV/25, p. 187. A very engaging comparative 38 analysis of Goethe's Tonlehre with medieval music classifications of musica mundane, 39 musica humana and musica instrumentalis is found in Claus Canisius, Goethe und die 39 Musik (Munich: Piper-Verlag, 1998) and Claus Canisius, 'Goethes Tonlehre. Ergebnis 40 seines lebenslangen Nachdenkens über Musik und Wissenschaft' in Andreas Ballstaedt, 41 Ulrike Kienzle and Adolf Nowak (eds), Musik in Goethes Werk. Goethes Werk in der Musik 42 (Schliengen: Edition Argus, 2003), pp. 114-21. 
1 science of physical acoustics, in the Tonlehre music is not perceived as being 1

2 imitative of a mathematical or verbal paradigm. Goethe's metaphor for music was 2

3 different: of all the arts, music was the furthest removed from nature and most 3

4 highly structured according to abstract principles.

5

6

7 An Eye for Innovation: Goethe's Engagement with Contemporary Music 8 Theory

9

10 One of the most interesting aspects of Goethe's communication with Zelter is 10

11 his interest in music as an acoustic phenomenon and his discussion of major and 11

12 minor tonalities. The status of the minor chords and keys was a central issue 12

13 between Rameau, Rousseau and the encyclopedists, and their debate is developed 13

14 in the Goethe-Zelter letters. That Goethe was the leader in this discussion, and 14

15 not reliant on Zelter's opinion, is evident as early as 1808 . When Goethe asked 15

16 Zelter why composers were inclined towards the minor mode, Zelter revealed his 16

17 knowledge of Rameau's music theory, outlining the natural origin of the major 17

18 triad in the overtone series and showing the minor chord as being derivative. ${ }^{47} 18$

19 Goethe, who was working on the Farbenlehre at that time, replied with a line- 19

20 by-line refutation of the derivation of the minor from the major. ${ }^{48}$ If the minor 20

21 chord could not be derived by dividing a vibrating string, Goethe deduced 21

22 that this disqualified the argument. If the historical practice of music showed a 22

23 development which culminated, as he thought, in the parity of major and minor 23

24 modes, the modes had to be rooted in the sound-producing body (corps sonore), 24

25 not in the accidental auditory mechanism of man. Goethe agreed that the evolution 25

26 of compositional practice was not accidental: if composers had treated the minor 26

27 chord as a consonance, though it is not contained in the overtones or the vibrating 27

28 string, it must be naturally harmonious and cannot be a dissonance. ${ }^{49}$ While similar 28

29 convictions sent Rameau out to nature, Goethe referred back to man himself and he 29

30 concluded the 1808 debate with the famous postscript, where he characteristically 30

31 referred back to the musician's ear to clinch his argument: 'For what is a string and 31

32 all mechanical division of it in comparison with the ear of the musician?'50 Zelter's 32

33 conciliatory response brought the debate to a halt. When Goethe reopened the 33

34 discussion a year before his death, ${ }^{51}$ this time it is Zelter who agrees with Goethe's 34

35 musical opinion. ${ }^{52}$ Goethe's creative thinking is evident in his combination of 35

36 intense interest in the debate with highly critical thinking; a readiness to question 36

37 established suppositions. Out of these theories Goethe created a musical world: 37

38

$39 \quad 47$ GZ 20 April 1808; ZG 6 April to 7 May 1808.

$40 \quad 48$ GZ 22 June 1808. 40

$41 \quad 49$ ZG 15 May $1808 . \quad 41$

$42 \quad 50 \quad$ GZ 22 June 1808. $\quad 42$

$43 \quad 51 \quad$ GZ 31 March 1831. 43

$44 \quad 52 \quad$ ZG 14 April 1831. 
1 not the real world in which Zelter practised as a musician, but his own nets in 1

2 which he tried to catch the real world. 2

7 Goethe's independent reflections upon music, as exemplified by the major- 7

$8 \mathrm{key} /$ minor-key controversy with Zelter or by his draft of a system of acoustics, 8

9 derive not least from his opinion that the sensual effect which music exercised 9

10 upon his imaginative faculty was more important than preconceived aesthetic 10

11 dogma. For Goethe, theory was the critical penetration of sensual perception, of 11

12 what is audible as music. The primary encounter was of paramount importance 12

13 to Goethe, followed by knowledge through reflection. Thus Goethe gave priority 13

14 to listening to music. To Friederike Helene Unger Goethe named three qualities 14

15 which characterized his listening to music: his conviction regarding the unique 15

16 affective power of music, the frame of mind in which he listened to music, and 16

17 listening, as far as possible, 'unreservedly' and 'repeatedly'. ${ }^{53}$ Goethe placed 17

18 great emphasis on repeated listening, not merely because of the importance of 18

19 increased familiarization, but rather because, in the phase of actually coming to 19

20 grips with the music - described by Goethe as a reflective process (nachdenken) - 20

21 repeated critical listening provided him with several chances to check his first 21

22 impressions and deepen them. Goethe's personal experience of this phenomenon 22

23 is evident in his attendance at three performances of Il Seraglio before forming 23

24 a critical impression of the work. ${ }^{54}$ And in conversation with Johann Christian 24

25 Lobe about developments in contemporary song, Goethe did not blindly accept 25

26 the theoretical explanations Lobe offered, but asked the Weimar court musician to 26

27 demonstrate his ideas on the piano before Goethe would accept them. ${ }^{55}$ In a similar 27

28 fashion he urged the 22-year-old Mendelssohn to play him pieces in chronological 28

29 order and explain what each composer had done in order to further the art. ${ }^{56}$ And 29

30 in a letter to Zelter on 4 January 1819 Goethe records a series of instructional 30

31 recitals in Berka where Schütz played to him every day for three to four hours at 31

32 his request 'in historical sequence selections from Sebastian Bach to Beethoven, 32

33 including C.P.E. Bach, Handel, Mozart, Haydn, Dussek too, and other similar 33

34 composers'. ${ }^{57} \quad 34$

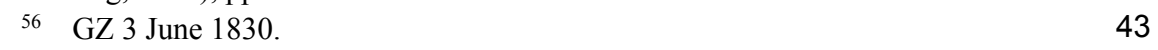

$44 \quad 57 \quad$ GZ 4 January 1819. 
1 In his accounts of these recitals, Goethe's response to the music of J.S. Bach

2 stands in complete contrast to the sociable aspect of music-making and performance.

3 Lying down with his eyes shut in the Juno room of his Frauenplan house - in a state

4 of heightened experience - Goethe listened attentively to Schütz's interpretations

5 of Bach's preludes and fugues. This took place in November $1818 .{ }^{58}$ Even before

6 this significant encounter he acclaimed Fräulein Hügel's performance of Bach in

7 1815, many years before Mendelssohn's Berlin performance of the St Matthew

8 Passion in 1829 heralded the revival which brought Bach's music to the attention

9 of the public at large. The significance of Goethe's encounter with the music of

10 Bach is apparent in a letter to Zelter in 1827, where he again records the private 10

11 recitals in Berka. He recalls how he felt lifted out of the world: and experienced 11

12 the moral power of music, its benediction, and describes how his entire attention 12

13 was directed at the transacoustic background of the music. ${ }^{59}$ Listening to Schütz's 13

14 performance, Goethe experienced the very essence of Bach's music, its inner 14

15 coherence and timelessness. When Goethe speaks of eternal harmony, he is, of 15

16 course, alluding to the classical idea of a numerically structured cosmic harmony, 16

17 which he believed to have witnessed upon hearing Bach's music. He describes 17

18 Bach's instrumental music as resounding metaphysics, as the revelation of musica 18

19 mundana, which gave him a sense of inwardly participating in the cosmic order. 19

20 Within the framework of Goethe's Tonlehre, enclosed in a letter to Zelter on 620

21 September $1826,{ }^{60}$ the music of Bach would be classified in terms of numerical 21

22 laws. In this way it contrasts with the anthropocentric, organic dimension of 22

23 music, whose medium is the human voice, and with which Goethe ultimately had 23

24 greater affinity. $\quad 24$

25

27 A New Mimesis: Goethe's Representation of Musical Reality 27

$28 \quad 28$

29 As with his scientific studies, Goethe's portrayal as an Augenmensch is 29 30 complementary to his musicality, for he often translated the effect music had upon 30 $31 \mathrm{him}$ into pictorial terms. Various pictorial interpretations show how Goethe sought 31 32 to capture the gestures of music pictorially, in a way which altogether matched 32 33 the basic nature of music. During his visit in 1830, Mendelssohn reports that 33 34 upon hearing the beginning of Bach's Overture in D Major, Goethe visualized 34 35 a Baroque feast in tableau form. ${ }^{61}$ While scholars have interpreted this form of 35 36 criticism as a lack of technical ability, Goethe's method of approach is embedded 36 37 in the universality of interdisciplinary thinking. His form of musical appreciation 37 38 revealed relationships which a more narrow subject-specific approach might 38 39

$40 \quad 58 \quad$ GZ 4 January 1819.

4159 GZ 17 July 1827, enclosure MA 20.1, p. 1021; see also ZG 9 June 1827.

$42 \quad 60$ Walwei-Wiegelmann, Goethes Gedanken über Musik, pp. 214-20. 42

4361 Felix Mendelssohn to Zelter, 22 June 1830, Walwei-Wiegelmann, Goethes 43

44 Gedanken über Musik, p. 183. 
1 possibly have left unexamined. An example of this is his manner of thinking in 1

2 analogies, which he drew between music, architecture and colour, and which 2

3 transcended the limits of the individual arts. Goethe considered Leonardo's Last 3

4 Supper to be the first fugue in the visual arts ${ }^{62}$ and it is reasonable to assume 4

5 Goethe was predisposed to synaesthesia. In his letters to Zelter Goethe openly 5

6 acknowledged this visual orientation and he took cognizance of this when 6

7 listening to music. Unlike Carl Philipp Emanuel Bach, who saw the gestures of 7

8 music-making as a positive contribution to the communication process, Goethe 8

9 held them to be a disturbing secondary phenomenon, which could divert attention 9

10 from the unreserved reception of music if they were not in harmony with the music 10

11 performed. With chamber music the communication between players enhanced 11

12 the performance, but in opera the orchestral players should be hidden, for their 12

13 gestures interfered with the musical drama. ${ }^{63}$

14 Goethe regarded not the eye but rather the ear as the sense organ, which 14

15 permits the most direct access to the individual's innermost being. When Goethe 15

16 found himself incapable of making more than a partial pictorial transformation 16

17 of a quartet by Mendelssohn, whom he greatly esteemed, he described how it 17

18 remained 'in den Ohren hängen' ${ }^{64}$ It remained on his ear until he had time to 18

19 assimilate it. Conversely, when Mendelssohn played through the first movement of 19

20 Beethoven's Fifth Symphony during his 1830 visit, Goethe remarked, 'That does 20

21 not move one at all, it only causes astonishment. ${ }^{95}$ Goethe's verbal inadequacy in 21

22 the face of Beethoven's Fifth is not an example of the poet's musical conservatism, 22

23 as is usually claimed. Like Zelter, Goethe recognized Beethoven's brilliance as a 23

24 composer and admired him with awe ${ }^{66}$ Beethoven's music had a diffuse emotional 24

25 effect upon Goethe: some of it remained beyond rational grasp and was therefore 25

26 incomprehensible. Interestingly, for Zelter, such incomprehensibility was part of 26

27 its appeal and in his letter to Goethe on 6 April 1831, he considers, 'This is the 27

28 advantage we derive from genius: it offends and reconciles, it wounds and heals; 28

29 one must go along with it. ${ }^{97}$ Yet musical enjoyment, which Goethe described to 29

30 Zelter as a balanced relationship between 'Sinnlichkeit und Verstand' (sensuality 30

31 and intellect), was, for him, tantamount to 'Faßlichkeit' (intelligibility). By not 31

32

33

34

35

36

37

38

39

40

41

42

43

44

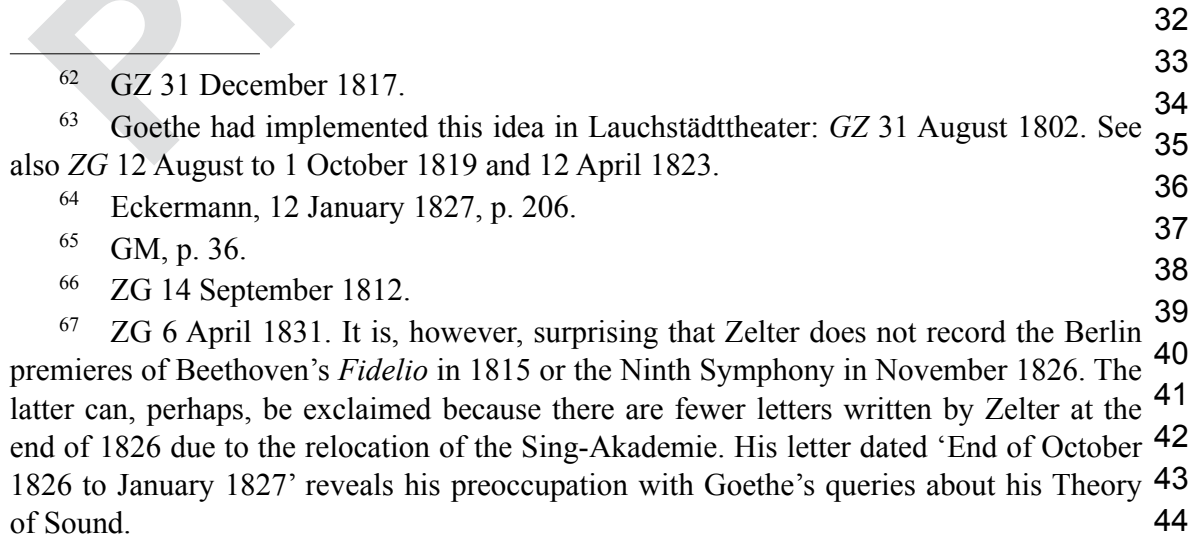


1 being accessible to the intellect, Beethoven's instrumental music embodied the 1

2 Daemonic for Goethe, the amoral world force which he had always inwardly 2

3 rejected and once defined for Eckermann as that 'which cannot be accounted for 3

4 by understanding and reason' ${ }^{68}$ While Goethe clearly recognized the emotional 4

5 significance of music, he was deeply critical of the Romantic perception of music 5

6 as self-expression, or the expression of the artist's emotions. While Beethoven 6

7 was far removed from such doctrines of self-expression, and continually revised 7

8 and clarified his musical ideas, Goethe believed the indirect influence of his 8

9 tempestuous personality and the attempts to emulate him led to a decline in music 9

10 brought about by expressionist theories of music. 10

13 Goethe's Musicality Reclaimed 13

$14 \quad 14$

15 To borrow Emerson's words, Goethe 'lived more fully and consciously on several 15

16 levels than most other men' ${ }^{69}$ and his catholic taste embraced music from early 16

17 Byzantine chant to the motets of Palestrina, Morales and Allegri ${ }^{70}$ from the music 17

$18{\text { of } \mathrm{Bach}^{71} \text { and Handel }}^{72}$ to contemporary works by Mozart, ${ }^{73}$ Hummel, Beethoven, 18

19 Schubert and Mendelssohn. Nowhere in these letters can you hear the drumbeats 19

20 of obsession associated with Goethe's celebration of strophic song. Instead his 20

21 susceptibility to the music of poetry, the physicality of his aural response as well 21

22 as the fastidiousness of its discriminations, his poet's intelligence exercising itself 22

23 in the activity of listening are evident in his discussions on song setting. While 23

24 this compulsive Goethean music is clearly heard in Zelter's settings and there is 24

25 a rightness in the pulse and movement of the best of these settings, a drumbeat 25

26 that will not be denied, Goethe did not demand a rigid adherence to the musical 26

27 metrics of poetry. 'I feel at once that your compositions are identical with my 27

28 songs; the music, like the gas which is pumped into the balloon, merely raises 28

$30 \longrightarrow 30$

3168 Eckermann, 2 March 1831, (Stuttgart 1998), p. 486.

3269 Ralph Waldo Emerson, 'Goethe, or the Writer' (1850). In Representative Men: 32

33 Seven Lectures (New York and Toronto: Random House Publishing Group, reprint 2004), 33

34 p. 244.

$35 \quad 70$ Goethe, Italienische Reise, 1 March 1788, HA 11, p. 542; 14 March 1788, p. 528; 35

3622 March 1788, p. 530.

$37 \quad 71 \quad$ GZ 4 January 1819 and GZ April 1827.

3872 GZ 24 April 1824, GZ 28 April 1824; Goethe to Friedrich Rochlitz, 2 April 1824, 38

39 WA IV/38, pp. 100-101. Eckermann, 14 April 1824 (Stuttgart, 1998), p. 118.

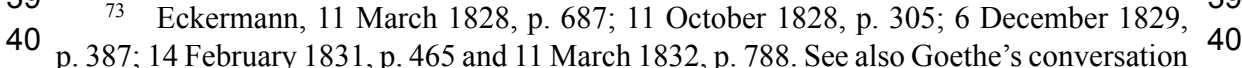

41 with Johann Christian Lobe in November 1821, Goethes Gespräche. Eine Sammlung 41

42 zeitgenössischer Berichte aus seinem Umgang auf Grund der Ausgabe und des Nachlasses 42

43 von F. Freiherrn von Biedermann. Completed and edited by Wolfgang Herwig (4 vols, 43

44 Zürich and Stuttgart: Artemis Verlag, 1965), p. 190. Hereafter referred to as Gespräche. 44 
1 them up,' he writes to Zelter in 1820. 'With other composers I must first see how 1

2 they have understood the song and what they have made out of it. ${ }^{94}$ Although he 2

3 was glad on one hand to identify in Weimar - rather than Berlin - the origins of 3

4 Zelter's song tradition, Goethe was open to shaking that tradition up, reviving it 4

5 and retuning it to other musical registers. Perhaps one of the most extraordinary 5

6 examples of his willingness to learn is evident in his private audiences with the 6

7 22-year-old Mendelssohn ${ }^{75}$ who most likely introduced him to Schubert's Erlkönig 7

8 and unquestionably opened him to contemporary musical developments. 'Who 8

9 can understand any kind of occurrence if he is not thoroughly acquainted with its 9

10 development down to the present time?', ${ }^{76}$ the octogenarian writes to Zelter, and 10

11 he describes himself as 'passionately active, aspiring and keen to learn' from the 11

12 musicians Zelter sends him. ${ }^{77} \quad 12$

17 In a letter to Zelter in 1801, Goethe criticized the 'poor picture' of a person 17

18 bequeathed to us by those necrologists:

26 In Zelter's case the opposite has been enacted by musicologists who have 26 27 bequeathed to us the portrait of a blunt Zelter, who is falsely blamed for Goethe's 27 28 persistence in espousing eighteenth-century concepts of musical aesthetics and 28 29 ignoring such composers as Schubert and Berlioz. This image of the composer can 29 30 obviously be linked to canon formation and to former detractors of pre-Schubertian 30 31 song, as also to the complex trajectory of Mendelssohn reception, but it fails to 31 32 recognize the self-divisions in Zelter. A stonemason who strove to study music, a 32 33 born activist who was also a silence-seeking lyric composer, a self-made musician 33 34 whose inability to produce anything of lasting value caused him much private 34 35 pain, a cultural administrator and committeeman who did not really believe in 35 36 democracy in the arts, Zelter embodied many contradictions. Lea Mendelssohn 36

77 Ibid. Goethe's willingness to learn from Felix - even as a small boy - is echoed in 42

43 the Mendelssohn documents. See GM, p. 36. 
1 recognized these self-divisions in Zelter just months after her children commenced 1

2 lessons with the composer:

$4 \quad[\ldots]$ he weaves so much spirit, taste, meaning, humour, even genius into his 4

5 discourses everywhere, that I often regret not having jotted down the best of it. 5

6 In his case the belief of the ancients, that man has two souls, seems to be true, for 6

7 I cannot deny that the same man who charms us with the inspiration of an artist, 7

8 touching seriousness of thought, and jokes à la Jean Paul, can also be downright 8

9 insipid and prosaic. ${ }^{79} 9$

$10 \quad 10$

11 A mixture of Polonius and Tiresias, of bore and of bard, Zelter was more prepared 11

12 than most to admit his contradictions. Enjoined by his calling to live fully and 12

13 truly, Zelter gave full rein to what was passionate in his sensibility and sceptical 13

14 in his intelligence; he could be majestic in public and mocking in private, tactical 14

15 and obstinate, down-to-earth and elevated. Yet these were symptoms not of an 15

16 absence of coherence but of an appetite for abundance; in fact, the coherence lay 16

17 in his determination to live fully, and the honesty of perception and expression that 17

18 this determination compelled turned him not only into the first Professor of Music 18

19 in Germany but also into a great observer and reporter of his musical world and 19

20 its inhabitants. 20

$21+21$

$22 \quad 22$

23 Zelter and the Shape of Early nineteenth-century Music History 23

$24 \quad 24$

25 Zelter's active engagement in the musical life of Berlin and his discussion of 25

26 concerts attended provides an important chronicle of concert life in Berlin at 26

27 the beginning of the nineteenth century. ${ }^{80}$ Zelter's descriptions of performances 27

28 by the Berlin court opera reveal the court's choice of carnival for the main 28

29 performance season; its penchant for mythological subjects; ${ }^{81}$ its tendency towards 29

30 action-packed scenes with emphasis on the visual spectacle rather than on the 30

31 psychological impact of the drama; ${ }^{82}$ as well as its inclusion of ballet. ${ }^{83}$ While 31

32 Zelter's letters record Gaspare Spontini's popularity and opposition in Berlin, 32

33 they also mark the directorship at the Königliches Opernhaus of Count von Brühl 33

34 and Wilhelm von Redern, who expanded the repertory to include the works of 34

3679 Letter of 14 July 1819, Lea to Henriette von Pereira Anstein. Quoted in Todd, 36

37 Mendelssohn: A Life in Music, p. 44.

$38 \quad 80$ See for example: ZG 27 August 1818; ZG 7 June 1820; ZG 21 July 1820; ZG 38

3916 December 1825; ZG 26 January 1830; ZG 11-12 April 1830; ZG 26 October 1830; 39

401 November 1830; ZG 27 October 1831.

$41 \quad 81$ Reichardt's setting of Tod des Herkules: ZG 13 April 1802.

$42 \quad 82$ Winter's setting of Die Zauberflöte II: ZG 10 August 1803. See also ZG 29 October 42

43 to 2 November 1830.

$44 \quad 83 \quad$ ZG 14 April 1831. 
1 more German composers including the world premiere of Weber's Der Freischütz 1

2 (1821), successful performances of Weber's Euryanthe $\left(1825^{84}\right.$ and $\left.1827^{85}\right)$ and 2

3 the Berlin premiere of Spohr's Faust (1829). ${ }^{86}$ As Zelter shared Goethe's love 3

4 of the human voice, his letters celebrate performances by the most popular and 4

5 successful divas of his day: ${ }^{87}$ the attractive voice and technical skill of Henriette 5

6 Sontag; ${ }^{88}$ the imposing presence and rich flawless voice of Berlin's prima donna 6

7 assoluta, Anna Milder-Hauptmann; ${ }^{89}$ and the vocal prowess of Wilhelmine 7

8 Schröder-Devrient which was matched by an innate dramatic skill. ${ }^{90}$ In addition to 8

9 marking the meteoric ascent of the diva in nineteenth-century concert life, Zelter's 9

10 letters record such extraordinary performances as the first performance of Bach's 10

11 St Matthew Passion for over a hundred years, conducted by Felix Mendelssohn in 11

12 the Sing-Akademie, attended by the king and his retinue and counting the leading 12

13 Prussian theologian Schleiermacher, the German philosopher Georg Wilhlem 13

14 Friedrich Hegel, Heinrich Heine, Rahel von Varnhagen and Spontini among its 14

15 audience. ${ }^{91}$ An equally colourful record of the first setting of Goethe's Faust, 15

16 composed by a crown prince and rehearsed by a royal cast, is contained within 16

17 this correspondence. ${ }^{92}$ In addition, Zelter's letters to Goethe highlight the cultural 17

18 and musical problems of his age from the rise of a German national music theatre 18

19 to the introduction of metronome markings, ${ }^{93}$ from the question of authorship 19

20 in Mozart's Requiem ${ }^{94}$ to the beginnings of musical biography ${ }^{95}$ and the rising 20

21 debates about the nature of musical virtuosity. ${ }^{96}$

22 Like Goethe, Zelter criticized the virtuoso cult of individualism, which 22

23 degrades the musical work to a mere vehicle for the demonstration of technical 23

24 and artistic dexterity and so works against the listener's purely musically-oriented 24

25 interest. At first Zelter complains bitterly about the general acclaim of Paganini's 25

26 concerts of his violin concerti, his empty showmanship and the eccentricity of his 26

27 playing, yet his openness to change is evident when he hears him perform publicly 27

28 and acclaims in his performance and compositions a balance of musical content 28

29

30

31

32

85 ZG 5 September to 13 October 1827.

ZG 13 to 16 November 1829 .

$87 \quad$ ZG 14 April 1831.

88 ZG 28 October 1827; ZG 11 April 1830; ZG 10 May 1830.

89 ZG 13 September 1812.

$90 \quad$ ZG 2 February 1831.

91 ZG 9 March 1829. See also ZG 17 April 1829.

$92 \quad$ ZG 31 March 1816.

93 ZG 10 May 1831.

94 ZG 16 June 1827.

95 ZG 1 to 9 July 1803; GZ 28 July 1803; ZG 12 to 22(?) March 1829; ZG 21 to 41

23 February 1830.

96 ZG Good Friday, 1829; ZG 1 May 1829; ZG 14 May 1829; GZ 17 May 1829; GZ 43 
1 and profound knowledge of violin technique. ${ }^{97}$ In a similar fashion he praises the 1

2 clarity and precision of Moscheles's piano playing and the Classical balance of his 2

3 compositional style, ${ }^{98}$ and acclaims the clarity, evenness and delicacy of tone in 3

4 performances by the Weimar Kapellmeister Hummel. ${ }^{99}$ When Goethe envies the 4

5 musical experience of Moeser's Quartet evenings in Berlin, ${ }^{100}$ Zelter - aware of 5

6 the poet's musical isolation - imagines Goethe in his audience ${ }^{101}$ and gives many 6

7 musicians letters of introduction to him.

828

9 9 9

10 Imagining Mendelssohn's Childhood and Artistic Identity 10

$11 \quad 11$

12 One of the most important introductions was to his pupil Felix Mendelssohn, 12

13 whose early development is recorded in these letters. From the beginning Zelter 13

14 was very conscious of Felix's extraordinary ability. His first mention of his young 14

15 protégé to Goethe on 20 August 1821 acclaims Felix's talent and already augurs his 15

16 departure. ${ }^{102} \mathrm{He}$ introduces Felix to Goethe in the winter of $1821 / 22$ and after the 16

17 visithis letters chronicle Mendelssohn's development. He describes 'his astounding 17

18 piano playing'; ${ }^{103}$ and he recounts Mendelssohn's 'admirable industry' ${ }^{104}$ without 18

19 any trace of jealousy, admitting, 'Even if I fail to produce anything much myself, 19

20 I keep my students focused.' ${ }^{105}$ Zelter's praise may also have been augmented 20

21 in the light of the publication and international reception of Felix's op. 1, where 21

22 he was acclaimed as a second Mozart in Leipzig ${ }^{106}$ and as a composer of genius 22

23 in Paris. ${ }^{107}$ It may also have been influenced by the composition of the second 23

24 Piano Quartet op. 2, written in 1823, published and dedicated to Zelter the 24

25 following year. It is no coincidence that the most substantial chamber work of 25

26 1823, revealing the formal and expressive influence of Beethoven, was dedicated 26

27 to Zelter, whose relationship to the composer is generally misunderstood. In a 27

28 letter to Goethe on 11 March 1823, Zelter acclaims the modernity of the work and 28

$30 \quad 97$ See, for example, ZG 17 April 1829; 1 to 5 May 1829; 14 May 1829. See also GZ

17 May 1829; 9 November 1829; 9 to 13 June 1831.

98 ZG 27 November 1824 . 32

33 - 29 G 30 April $1821 ; 22$ to 23 May 1826; 25 to 27 May 1826; 5 to 8 March 1828; 33

3416 to 17 January 1832.

$35 \quad 100$ GZ 9 November 1829; ZG 17 November 1829.

$36 \quad 101 \quad$ ZG 14 April 1831.

$37 \quad 102$ ZG 9 March 1829. See also ZG 10 May 1830 and ZG 2 November 1830.

$38 \quad 103$ ZG 11 March 1823.

$39 \quad 104 \quad$ ZG 10 December 1824.

$40 \quad 105 \quad$ ZG 17 March 1822. 40

$41 \quad 106$ AMZ 26 (1824), columns181-4. 41

42107 Henriette Mendelssohn to Lea Mendelssohn, 11 February 1824; see Peter Ward 42

43 Jones, Catalogue of the Mendelssohn Papers in the Bodleian Library, Oxford, III (Tutzing: 43

44 Hans Schneider, 1989), pp. 269-70. 44 
1 considered it 'even better than the one he performed in Weimar' ${ }^{108}$ His generosity 1

2 as a teacher again comes through in his appraisal of Felix's fourth opera, Die 2

3 beiden Neffen, or Der Onkel aus Boston (The Two Nephews, or The Uncle from 3

4 Boston), as that of a master. ${ }^{109}$ He recognizes the sterling quality of his writing ${ }^{110} \quad 4$

5 and when he hears Felix's double piano concerto, he recognizes his individuality 5

6 becoming more and more apparent ${ }^{111}$ and avows to Goethe, 'I do everything I can 6

7 to encourage him, as he drives himself on to experiment in the various new and 7

8 more conventional forms.' 112

9 Although the evidence of these letters verify Zelter's continual encouragement, 9

10 and Larry Todd's brilliant book, Mendelssohn's Musical Education: A Study and 10

11 Edition of his Exercises in Composition, generously extols Zelter's merit as a 11

12 teacher of composition, it was difficult, at first, to dispel doubts as to what Zelter 12

13 could have given Mendelssohn during these formative years. What could Zelter 13

14 have given a student capable of composing the Sextet in D for piano and strings 14

15 (op. 110) at the age of 15, or the Octet in E flat Major (op. 20) written a year later? 15

16 A clue to the answer is found in the compositional notebooks in the Preussischer 16

17 Staatsbibliothek in Berlin. While the fugal subjects in these early notebooks lack 17

18 the musical impetus immediately visible in a fugal subject by Bach - and were 18

19 most likely given by Zelter - it is clear that Zelter aimed to nurture Felix's musical 19

20 intuition. The conversations recorded on Felix's first visit to Goethe confirm 20

21 Zelter's understanding that this is something an individual has to find within 21

22 himself. From Mendelssohn's early works, completed under Zelter's guidance, it 22

23 is clear this Felix pursued composition with the idea of conquest, not of territory 23

24 perhaps but of imagination - an awakening which would allow him to repossess 24

25 his musical territory with new conviction.

26 Negative reception histories of Mendelssohn and Zelter go together hand 26

27 in glove and when considering Mendelssohn's early development, we must 27

28 re-evaluate the musicological image of his venerable teacher, Zelter, whose 28

29 fidelity to his vocation and fulfilment of its public demands were steady and 29

30 characteristically vigorous. There has been a sustained effort to criticize Zelter's 30

31 compositional oeuvre when we should have honoured much else: his acuity as a 31

32 critic and writer on music; his record as an active witness and committed participant 32

33 in those times of important musical change; his wisdom and acuity as a teacher. 33

34 While it lies beyond the scope of this preface to re-evaluate Zelter's relationship 34

35 with Mendelssohn, let us briefly consider one aspect, namely contemporary reports 35

36 of Zelter's possessiveness regarding his student, of which there is no evidence in 36

37 these letters.

$38 \quad 38$

$39-39$

$40 \quad 108 \quad$ ZG 11 March $1823 . \quad 40$

$41 \quad 109$ ZG 8 February $1824 . \quad 41$

$42 \quad 110 \quad$ ZG 11 March 1823. $\quad 42$

$43 \quad 111 \quad$ ZG 26 December 1824.

$44 \quad 112 \quad$ ZG 6 June $1826 . \quad 44$ 
1 Felix's lessons with Zelter commenced in 1819 and continued for approximately 2 eight years. For A.B. Marx, who only completed a few figured bass exercises 3 with him, Zelter was an uninspiring teacher, and he compared Zelter's teaching 4 of Mendelssohn to observing a fish swim and then imagining he had somehow 5 instructed the fish to swim. Marx's opinion contrasts with Abraham's appraisal, 6 where he claimed that Felix's 'musical existence and direction would have been 7 entirely different without Zelter'; an opinion which was shared by Felix, who 8 praised his teacher for raising him 'not according to rigid, constructing theorems, 9 but in true freedom, that is in the knowledge of proper boundaries'. ${ }^{113}$ When Felix's 10 formal lessons with Zelter were discontinued in 1827, Eduard Devrient's portrayal 10 11 of an angry Zelter, who believed that Felix had 'learned everything from him and 11 12 not yet outgrown his guidance' ${ }^{114}$ does not hold any weight in these letters. From 12 13 his first mention of Felix to Goethe, Zelter recognizes Felix would outgrow him, 13 14 and throughout the correspondence we find Zelter mirroring Abraham's reasons 14 15 that 'Felix's genius was [...] self-existent'. Moscheles believed that few, other than 15 16 Zelter and Berger, truly recognized the youth's genius. A good example of Zelter's 16 17 ability to pave Mendelssohn's path is found in the musical forms and dedications 17 18 of his first publication. While the piano quartet played to Mendelssohn's strengths 18 19 as a pianist and violinist, it also ingeniously avoided immediate comparisons with 19 20 his musical forefathers. So, too, the dedication of op. 1 to Prince Radziwill, an 20 21 important patron of the arts, and to Goethe (op. 3) announced Mendelssohn's 21 22 significance as a composer. But beyond such sound musical guidance and 22 23 unwavering encouragement, Zelter's greatest gift to his young protégé was, 23 24 undoubtedly, the introduction he gave him to Goethe, who was one of the most 24 25 generous presences of Mendelsohn's early years. 25

26 Between the ages of 12 and 21, Mendelssohn stayed in Goethe's home on four 26 27 separate occasions, three of which are recorded in these letters. ${ }^{115}$ According to 27 28 Abraham, Goethe's warm reception of his son 'ennobled' Felix's youth. ${ }^{116}$ More 28 29 than this, Zelter's introduction of Felix to Goethe in November 1821 acted as 29 30 a catalyst, channelling Mendelssohn's energies and talents in new directions. 30 31 Buoyed by Goethe's comparisons with Mozart on the first Weimar visit from 31 322 to 19 November 1821, Mendelssohn was inspired to work in larger instrumental 32

114 Eduard Devrient, Meine Erinnerungen an Felix Mendelssohn-Bartholdy und seine Briefe an mich (Leipzig: J.J. Weber, 1869); Eng. trans., Natalia MacFarren, My Recollections

38 of Felix-Mendelssohn-Bartholdy and his Letters to Me (London: Richard Bentley: 1869; 39 repr. New York: Vienna House, 1972), pp. 32-3.

39115 All four visits are recounted in GM. For a detailed reading of these visits and

40 of Mendelssohn's relationship with Goethe in general, see Lorraine Byrne Bodley,

41 'Mendelssohn as portrayed in the Goethe-Zelter Correspondence'. In Mendelssohn in the

42 Long Nineteenth Century (Aldershot: Ashgate, forthcoming).

43116 Abraham to Goethe, 26 November 1821 in Max Friedländer, 'Briefe an Goethe 44 von Felix Mendelssohn', GJb 12 (1891): 111. 2 3 4 5 6 7 8 9 10 11 2 .

.

.

.

8

政


1 forms, and the subsequent publication of his piano quartet op. 1 in 1823 marked his 1

2 entrance as a composer into the public domain. Felix's dedication of the B minor 2

3 Piano Quartet on his third visit to Goethe in May 1825 is also highly significant, 3

4 for it heralds a new phase in Mendelssohn's compositional development. The 4

5 dedication of the Piano Quartet no. 3 to Goethe may have been inspired by the 5

6 poet's comparison of the composer with Mozart, one of the few composers to 6

7 have written in this genre. ${ }^{117}$ Goethe's enthusiastic response to this dedication is 7

8 evident in the letter he wrote to Felix, thanking him and praising the quartet as 'the 8

9 graceful embodiment of that beautiful rich, energetic soul which so astonished me 9

10 when you first made me acquainted with it'. ${ }^{118} 10$

11 As accounts of these early visits show, Goethe knew that Felix needed a 11

12 tremendous amount of support to flourish: good teachers, attentive parents, ample 12

13 opportunities for performance and display, access to avenues for publicity provided 13

14 by the poet, who had set up a sequence of hurdles, acknowledged in the musical 14

15 sphere, over which Felix had the opportunity to bound. All these steps are in place 15

16 on the very first visit to Goethe, whose immediate identification with Felix was 16

17 anchored in the high voltage of his early talent. Like Mendelssohn, Goethe had 17

18 surpassed his local masters by early adolescence; and at an early age had moved 18

19 to the European centres of artistry where he accomplished his art with obvious 19

20 supremacy. The extraordinary friendship, which subsequently developed between 20

21 the 12-year-old Mendelssohn and 72year-old Goethe, emerged from this intensity, 21

22 a root, a common emotional ground.

23 During the first three visits we find Mendelssohn intent on pleasing Goethe and 23

24 it is interesting to consider the development that had taken place in Mendelssohn 24

25 prior to his final visit, which took place between 21 May to 3 June 1830 on the 25

26 threshold of Mendelssohn's Italian journey. Buoyed by the success of the St 26

27 Matthew Passion, his publications and English tour, Mendelssohn now greeted 27

28 the poet as an established artist, asked for and was granted the familiar 'du' - 28

29 a form of address which Goethe rarely granted after 1800. (Even Schiller and 29

30 Goethe had always remained on 'Sie' terms, though their correspondence shares 30

31 an intimacy different from that of the Goethe-Zelter letters.) 31

32 For Goethe, Mendelssohn's visit was a welcome interruption to the naturally 32

33 increasing solitude of old age. The gratitude Goethe expressed, and the willingness 33

34 of the 80 -year-old poet to learn from the 22 -year-old composer, ${ }^{119}$ provides a 34

35 counter-image to the portrayal of a conservative poet in musical literature. For 35

36 Mendelssohn, Goethe was an important figure in the question of artistic identity. 36

37 In his writing and in person Goethe offered Mendelssohn important lessons on 37

38 how an artist ought to conduct himself. The high standards he set were the usual 38

$40 \quad 117$ Mozart's C minor Piano Sonata K457 (1784) has also been sourced as a model by 40

41 Todd. Felix was familiar with Mozart's two piano quartets (K478 and K493) whose imprint 41

42 is on Felix's score. 
1 basis for the attainment of durable distinction in any life or art: openness, courage 1 2 and complete commitment to one's art. Goethe's courage was evident not only in 2 3 his embrace of solitude, both personal and intellectual, in his later years, in order 3 4 to produce Faust II, but also in the writing of Werther, the novel that made his 4 5 name at 22 - the same age as Mendelssohn on this final encounter. Such accidental 5 6 resemblances between Goethe's formative years and Mendelssohn's own 6

7 experiences added intimacy to this final encounter with the Olympian patriarch, 7 8 whose wisdom, abundance and acuity were made available to the composer. ${ }^{120} \quad 8$

9 For Mendelssohn, Goethe was a rara avis, an artist whose note was uniquely 9

10 beyond the common scale. ${ }^{121}$ Mendelssohn could grant this inimitable status to his 10 11 art and, on his final visit, still recognize the process that produced it as the usual, 11 12 uncertain, hopeful, needy, half self-surrendering, half self-priming process that 12 13 he, like every artist, had also experienced. Perhaps the final thing to be learned 13 14 from this extraordinary relationship is that in the realm of art, as in the realm of 14 15 consciousness, there is no end to the possible learning that can take place. When 15 16 Goethe embraced his friend, knowing it might be the last time they would meet, 16 17 Mendelssohn took with him an image of an exemplary poet who showed him 17 18 how the artistic vocation entails the disciplining of a habit of expression until it 18 19 becomes fundamental to the whole conduct of a life. 19

22 Zelter's Nobility of Spirit: A Forgotten Ideal 22

24 One of the incidental pleasures of the pages is the constant stimulation of the 24 25 wily remarks and upfront judgements that Zelter made with such relish. In 1827, 25 26 for example, he refers to Couperin's ornamentation as 'French froth', ${ }^{122}$ a remark 26 27 which is understandably levelled against him when cited without reference to the 27 28 following letter where he explains to Goethe how Couperin's style of ornamentation 28 29 became ingrained in J.S. Bach's compositional style. ${ }^{123}$

30 In a similar fashion, Zelter's rejection of Berlioz's 1828 setting of Huit scènes de 30 31 Faust (Eight Scenes from [Goethe's] Faust) is cited out of context. First, Goethe's 31 32 request is usually cited as an example of his inability to judge a musical work, 32 33 yet the poet's openness to the composer is evident in these letters: 'A Frenchman 33 34 has set eight passages of my Faust to music, and sends me the score which is 34 35 very beautifully typeset; I should much like to forward it to you and hear your 35

$38 \quad 120$ An important reference on the reciprocity of Goethe and Mendelssohn's relationship

39 is found in Claus Canisius, 'Stranger in a Foreign Land: Goethe as a scholar in music', in 38

40 Goethe and Schubert: Across the Divide (Dublin: Carysfort Press, 2003), p. 36.

41121 Albert Bielschowsky, Goethe, sein Leben und sein Werke (2 vols, Munich: Beck, 41

42 1922), vol. 2, p. $683 . \quad 42$

$43 \quad 122 \quad$ ZG 5 to 14 April 1827.

$44 \quad 123$ GZ 21 to 22 April 1827; ZG 8 to 9 June 1827. 
1 favourable opinion.' ${ }^{124}$ Goethe's receptiveness to Berlioz's musical realization in 1

2 this passage is indicative of his openness to French interpretations of his Faust in 2

3 general. Through the translations of Faust I (1828) and parts of Faust II (1840), 3

4 which inspired Delacroix (paintings and etchings) and Berlioz (La Damnation 4

5 de Faust, 1846), Gerard de Nerval (1808-55) succeeded in presenting a 'French 5

6 Faust' which Goethe preferred to his own: 'I don't like reading Faust in German 6

7 any more; yet in this French translation everything makes a refreshing, novel, and 7

8 spirited impression.' ${ }^{125}$ Zelter's reply to Goethe's request and subsequent diatribe 8

9 against Berlioz's Huit scènes de Faust ${ }^{126}$ should also be placed in context, for his 9

10 remarks tell us as much about Berlioz as about Zelter's prejudices. Berlioz's first 10

11 pieces submitted for the Prix de Rome met with a similar reaction from the judges; 11

12 Paganini rejected Berlioz's ideas for a violin concerto including a programme based 12

13 on the sad fate of Mary Stuart, and the Paris Opéra, which paid extraordinarily 13

14 high royalties to composers, consistently rejected his works. Berlioz was a caustic, 14

15 provocative writer who disagreed with the musical standards of his time: in every 15

16 sense, he fought an uphill battle, not just with Goethe and Zelter but also with his 16

17 most of his contemporaries.

18 In Goethe's letters to Zelter, by comparison, one is aware of the strictness of 18

19 his mind of his scrupulousness in respect to what he withholds. In Zelter's letters 19

20 to Goethe he gave free reign to his prejudices, and such passages parade Zelter in 20

21 full flight. But as attractive as this off-the-cuffness may be, the real attraction of 21

22 Zelter lies in the nobility of his mind, the way he combined ardour with rigour, the 22

23 ideal of service behind and beneath the attitudizing. 'Could I but achieve something 23

24 great! My life is passing and nothing comes of it', ${ }^{127}$ he writes to Goethe after he 24

25 administers a rebuke to himself for failing to produce work of lasting substance. ${ }^{128} 25$

26 At the same time he was well able to discover and acclaim musical ability in those 26

27 around him. In a letter to Goethe on 11 June 1826 he compares his own setting of 27

28 a poem by Voss to a setting by his student, Fanny Mendelssohn, and admits, 'She 28

29 has really caught the spirit of it better than I have.' ${ }^{129}$ It was this crystalline purity of 29

30 motive and conduct that redeemed much of the egotism and common clowning. $\quad 30$

35 The happy entertainer in Zelter got wonderfully into his stride in Weimar and 35

36 besides earning the respect of Goethe and Schiller, he also won the love of a 36

37 great number of men and women who encountered him during these years. What 37 
1 gratified Zelter most was the feeling of being privy to an atmosphere of artistic 1

2 and intellectual endeavour, a cultural climate generated by an art so boldly and

3 unpredictably written. Goethe was a rara avis, one whose note was uniquely

4 beyond the common scale, and his friendship with Zelter elevated the composer's

5 sense of personal and poetic destiny. In such settings as Rastlose Liebe and Um

6 Mitternacht, ${ }^{130}$ Zelter was true to the impact of Goethe's poetry and sensitive to

7 the inner laws of his composer's being. At the same time Zelter perceived song as

8 irreducibly an event of language, and he was invariably true to Goethe's muse, if

9 not to himself. In Wandrers Nachtlied, ${ }^{131}$ for example, the sense of evanescence,

10 of the transitoriness of things, of the stillness behind things into which they 10

11 eventually pass, resounds in the music. In the composition of this lyric there is a 11

12 deep, emphatic appreciation of the ephemeral beauty manifested in nature, human 12

13 life or a song. A different economy of means, a sense of a huge encircling stillness, 13

14 a strong sense of another world within worldly surroundings, are evident in 14

15 Schubert's setting of this poem. Both Schubert and Zelter felt a need to extend the 15

16 alphabet of expressiveness in setting Goethe's poetry. Yet in contrast to Schubert's 16

17 Gretchen am Spinnrade, which has come to represent the kind of untrammelled, 17

18 radically unaligned work we associate with music of high artistic purpose, Zelter's 18

19 Goethe settings unveil a natural inclination to make himself an echo chamber for 19

20 the poem's sounds. At the same time he knew what the creative demands entailed 20

21 and it was this essential knowledge that punished him when his compositional 21

22 work began to lose its sense of inevitability, and he had to labour towards a power 22

23 rather than ride upon it. 23

24 As a figure of his times, Zelter may have lived out a certain cliché: the 24

25 self-educated musician who studied music against his father's wishes. And in 25

26 biographies of his early years we are confronted with an artistic isolation that is 26

27 painful and resistant, a figure painfully displaced within himself and yet familiar. 27

28 In these letters to Goethe we witness the way in which he envisaged and conducted 28

29 his life. The exchange of poems to be set and their musical reply verifies song as 29

30 a domestic art, where Zelter has drifted into a certain vein of musical thought. 30

31 The songs exchanged in these letters corroborate the creative purpose of early 31

32 German song and it was Zelter's historic good fortune to have not only his own 32

33 compositional talent but also the genius of his good friend Goethe to sponsor it. 33

34 During these years, Goethe's poetry was both the ship and anchor of Zelter's talent - 34

35 a buoyancy and a steadying. Through Goethe, Zelter extended the idiom of his art 35

36 and left behind no ignominious legacy. 36

$37 \quad 37$

$38-130$ Carl Friedrich Zelter, Fünfzig Lieder fur eine Singstimme mit Klavier (Mainz, 38

39 London, New York, Paris, Tokyo: Schott, 1932, 'Rastlose Liebe', pp. 5-8 and 'Um 39

40 Mitternacht', pp. 34-35. Hereafter referred to as Zelter, Fünfzig Lieder. A exemplary 40

41 performance of Zelter's 'Um Mitternacht' by Ann Murray (soprano) and Graham Johnson 41

42 (piano) is can be found (along with other songs by Zelter) on Songs by Schubert's friends 42

43 and contemporaries (London: Hyperion Edition, 2006), CD1, CDJ33051/3. 43

$44 \quad 131$ Zelter, Fünfzig Lieder, 'Wandrers Nachtlied', pp. 1-2. 44 
1 The Lure of the Poet: Zelter's Relationship with Goethe 1

2

3 The original object of Goethe's correspondence with Zelter was correctly 3

4 recognized by Kayser and Reichardt, who believed Goethe found in Zelter the 4

5 musical correspondent he had been seeking. In Zelter Goethe found an intelligent 5

6 and reflective musician whose natural outspokenness, sharp wit, and ironic sense 6

7 of humour engaged the poet. Zelter provided Goethe with the sounding board 7

8 and support he lacked after his return from Italy, in ample measure and in various 8

9 forms - a sympathetic understanding and musical realization of his poetry, an 9

10 engagement with musical life outside Weimar. Far from becoming dependent on 10

11 Zelter's musical opinions, in the early years of the correspondence Goethe clearly 11

12 recognized Zelter's contradictions and limitations: in the very first letter he wrote 12

13 to Zelter, Goethe requested Zelter to set 'Die erste Walpurgisnacht', a task Zelter 13

14 was unable to fulfil; similarly, plans to write a cantata for the Reformation Jubilee 14

15 together ${ }^{132}$ or provide music for a commemorative performance of Schiller's 15

16 Lied von der Glocke ${ }^{133}$ were impeded by Zelter's inability to realize a large-scale 16

17 commission.

18 Despite such failings Goethe found his belief in man's essential goodness and 18

19 continual progress embodied in Zelter, a recognition symbolized in the coat of arms 19

20 he designed for Zelter: 'Zum Werk und Kunst treu'. As W.B. Yeats later wrote, 20

21 'The intellect of man is forced to choose/Perfection of the life, or of the work', ${ }^{134} 21$

22 Zelter chose the latter and his letters to Goethe envelop us in a musical life that 22

23 is honour-bound and assiduous. In 1804, when Zelter was in the full summer of 23

24 his power, he established the Ordentliche Singschule: ${ }^{135}$ the first state-supported 24

25 programme of music education in Prussia. Four years later, in December 1808, 25

26 he founded the Berlin Liedertafel, a choral society of 25 men, who composed and 26

27 performed works for each other, and which became a model for the formation 27

28 of other such societies throughout Germany. Zelter was also responsible for the 28

29 foundation of the Musikalische Bildungsanstalt, which became the Institut für die 29

30 Ausbildung von Organisten und Musiklehrern in 1822, ${ }^{136}$ and he also established 30

31 various institutes for teaching church and school music in Königsberg (1814), 31

32 Breslau (1815), and Berlin (1822). As founder of the Royal Academy of Religious 32

33 Music in Berlin (1822) and director of the Sing-Akademie (1823), Zelter was 33

34 responsible for introducing significant works to the general public, ${ }^{137}$ thereby 34

132 GZ 14 November 1816.

133 GZ 22 July 1805; ZG 30 July 1805; GZ 4 August 1805; ZG 25 August to 37

8 September 1805; GZ 12 October 1805; ZG 26 October 1805; GZ 18 November 1805; ZG 38

40134 W.B. Yeats, 'The Choice' in Collected Poems (Dublin: Macmillan, 1933), p. 278. 40

$41 \quad 135$ ZG 8 December 1824.

42136 This in turn became the Königliches Akademisches Institut für Kirchenmusik in 42

431875.

137 See for example the performance of Bach's B Minor mass, ZG 19 February 1831. 44 
1 earning the composer a reputation as an authority on early sacred music. Under his 1

2 guidance, the Sing-Akademie became a model for the performance of early sacred 2

3 choral works with instrumental accompaniment provided by the Orchester-Schule 3

4 or Ripienschule, which he founded in 1809 to supply string players for his concerts 4

5 in the Sing-Akademie. ${ }^{138}$ In recognition of this musical distinction, Zelter received 5

6 an honorary doctorate from the University of Berlin in 1808. At the suggestion 6

7 of Wilhelm von Humboldt, the first chair of music was created at the Akademie 7

8 der Künste in 1809 and Zelter was made responsible for the city's sacred and 8

9 secular music education. ${ }^{139}$ Zelter held the first academic music position in Berlin 9

10 in 1815, when appointed director of music at the Friedrich-Wilhelm University, 10

11 founded five years before. In 1830 this position was changed to that of a university 11

12 lectureship; only the second of its kind in Germany. Zelter was appointed Professor 12

13 of Music and two years later Marx became his successor. 13

14 Inexorably Zelter was driven to raise musical standards across Germany. It was 14

15 this unceasing energy, his activism and passionate devotion to music, his horse- 15

16 sense and perspicacity which drew Goethe to him. Goethe also admired Zelter's 16

17 ability to encounter the harsh realities of life without jeopardizing traditional 17

18 order. Following the suicide of Zelter's stepson, Carl Flöricke, when Zelter 18

19 writes under the shadow of death, his letter to Goethe is a nightmare glimpse into 19

20 the mind of a man who has survived traumatic events and is now exposed to a 20

21 comfortless future. ${ }^{140}$ We immediately recognize his predicament and the pitch 21

22 of his grief and find ourselves the better for having them expressed with such 22

23 dignity and unforgiving truth. So, too, Goethe's letter marking the sudden death 23

24 of his only living child, 'In Memoriam (August von Goethe) - In Friendship and 24

25 Sympathy', ${ }^{141}$ may be read as a projection of his wisdom, refined, as it was, in the 25

26 crucible of experience. $\quad 26$

$27 \quad 27$

$28 \quad 28$

29 Epilogue: Numbered Days 29

$30 \quad 30$

31 In an age such as ours, when 'the instability of the human subject' is constantly 31

32 argued for if not presumed, there should be no problem with a correspondence 32

33 which is woven from two such different psychic fabrics. In fact the Goethe-Zelter 33

34 letters perfectly answer the modern conception of a work of creative imagination 34

35 as one in which conflicting realities find accommodation within a new order; 35

36 and this reconciliation comes most poignantly and most profoundly in the final 36

37 years of the correspondence when the poet in old age gathers in his harvest and 37

38 begins to plan the posthumous publication of their letters. The final five years 38

39

$40 \quad 138$ This gave rise to the Spontini's Königliche Theater-Instrumental-Schule (1822) 40

41 which trained musicians for the royal theatres. 41

$42 \quad 139$ ZG 19 June 1825; ZG 19 May 1831.

$43 \quad 140$ ZG 14 to 17 November 1812; GZ 3 December 1812.

$44 \quad 141 \quad$ GZ 23 February 1831. 
1 of the correspondence are imbued with a strong sense of death hovering close, 1

2 unknowable but certain, and yet, because it is imagined within a consciousness 2

3 which has learned to expect that the correspondence will find an ultimate home 3

4 among the poet's published papers, this primal human emotion is transmuted into 4

5 something less shadow-line, more metaphysically tempered. As Goethe prepares 5

6 the letters for publication, he looks beyond the grave, resolved to immortalize a 6

7 composer who lived a singularly individual life. Goethe's correspondence with 7

8 Zelter commemorates the composer not as an Orphean musical voice but as an 8

9 exemplary practitioner, one whose history was the musical history of his times. 9

10 Yet these late letters are not just a narrative full of musicological interest; they 10

11 are also literature of a high order, in which such letters of great intensity - such as 11

12 'In Memoriam (August von Goethe) - In Friendship and Sympathy' 142 - rise like 12

13 emanations from some fissure in the bedrock of the human capacity to endure. 13

14 This 35-year correspondence with Zelter endorses the perception of Goethe 14

15 as a toiling intelligence, a Dantesque spirit pushing toward ever higher levels of 15

16 understanding and mastery. Yet it also bequeaths an enduring profile of Zelter as 16

17 a noble musician working towards high national purposes, a profile which, will, 17

18 I hope, persuade readers to suspend their disbelief in Zelter, and will be part of 18

19 the redress that the composer deserves. But is not enough for musicologists to be 19

20 what Osip Mandelstam once called 'purveyors of the paraphrasable meaning', 20

21 not enough to have the will doing the work of the imagination. Some shift in the 21

22 mindset or reception has to occur, some startle of insight or originality that may 22

23 prompt an exegesis of Zelter's life and work and the reinvention of Goethe and 23

24 Zelter's musical world. My aim in writing this translation is, therefore, to rebalance 24

25 truth that has been regarded for two centuries as self-evident by garnering together 25

26 a critical record that might be hung in the scale as a counterweight to the current 26

27 musicological reception of their lives. 


\section{Section I 1 \\ Early Years' Correspondence 1796-1814 $\quad 2$ \\ 1. Goethe to Madame Unger 10

14 Your letter, dear lady, ${ }^{1}$ and the enclosed songs gave me very great pleasure. Herr 14 15 Zelter's admirable compositions reached me while I was with people who first 15 16 made me acquainted with his work. His melody to the Lied 'Ich denke Dein'² had 16 17 an unbelievable charm for me, and I could not help writing that text for it, which 17 18 stands in Schiller's Musenalmanach.

19 I am no judge of music, since I don't have a grasp of the means it uses to achieve 19 20 its ends; I can only speak of the effect it produces upon me, when I give myself over 20 21 to it fully and repeatedly; and so I can say of Herr Zelter's settings of my poems: 21 22 that I could scarcely have believed music capable of such heartfelt tones.

23 Thank him very much for me, and tell him that I should very much like to get 23 24 to know him personally with a view to mutual discussion. Although it is true that 24 25 in the eighth volume of my novel there will not be any room for [new] settings; 25 26 still, the legacy of Mignon and the old Harper is not yet exhausted, and all of it that 26 27 can be allowed to see the light I should most gladly entrust to Herr Zelter.

28 Meantime, I may, perhaps, send some other poems soon, with the request that 28 29 they be set to music for Schiller's Musenalmanach; I had hoped to enclose them 29 30 in this letter, which, as a result, has been longer in coming than it ought to have 30 31 been.

32 Accept my thanks, dear Madam, for the trouble you have taken, and believe 32 33 that I appreciate the interest which kind and enlightened minds take in me and in 33 34 my works, through which I can also bring a part of my existence near to persons 34 35 far from and unknown to me.

38 The wife of Goethe's publisher in Berlin. Goethe had written his 'Nähe des 38 39 Geliebten' as a musical parody to Zelter's setting of Frederike Brun's 'Ich denke Dein', 39 40 and incorporated the new song into a production of Claudine von Villa Bella in Weimar 40 41 in May 1796. Hearing of this through a mutual friend, J.F. Latrobe (1769-1845), Zelter 41 42 was encouraged to send Goethe (through Unger) some of his compositions, including his 42 43 Wilhelm Meisters Lehrhjahre settings. 
6 My good friend, Herr Unger, brought me ineffable joy through something you 6

7 wrote in your letter to him. The favour which my [compositional] endeavours have 7

8 received from you is a great joy to me, something I had hoped for but without any 8

9 confidence, although I have no doubt about the quality of some of my work; the 9

10 unsolicited approbation of a man whose works are held sacred in my home has 10

11 given me reassurance such as I have never felt so purely and as strongly as now. 11

It would be a great boon to me if you would entrust the composition of more of 12

13 your poems to me, for I don't know how to commend them more than through my 13

14 own pure inner response; and I may say that with great dedication I have worked 14

15 on your poems according to the measure of my talent.

Apart from the settings which were published in the Schiller Almanach, 16

17 I have also composed: 'Der Zauberlehrling'; 'Die Braut von Corinth'; 'Die 17

18 Erinnerung'; 'Das Blümlein Wunderschön'; 'Der Junggesell und der Mühlbach' 18

19 and 'Bundeslied', which I would gladly send you if it were agreeable to you. I 19

20 have thought about sending them for a long time and never dared. As soon as you 20

21 give me the nod, they will be in your hands as quickly as possible.

30 It is with deep gratitude that I reply to your friendly letter, by which you express 30

31 in words that of which your compositions themselves have long convinced me: 31

32 namely that you take a lively interest in my works, and show that you respond 32

33 with genuine empathy. The beauty of an active participation is that it is itself in 33

34 turn productive, for if my poems called forth your melodies, I can say that your 34

35 melodies have stirred me to many a song, and doubtless if we lived nearer to one 35

36 another, I should more frequently than at present feel myself inspired by a lyric 36

37 mood. Every kind of communication with you will give me great pleasure. $\quad 37$

38 I enclose a work ${ }^{3}$ that has rather a strange appearance. It was suggested by the 38 39 question: whether dramatic ballads might not be worked out in such a manner, as to 39 
1 furnish a composer with material for a large-scale choral work. Unfortunately this 1

2 particular ballad is too insignificant to deserve being treated on so large a scale. 2

Warmest greetings to Herr Unger. 3

11 It is against my wishes to have delayed this consignment, and even for these few 11 12 settings I had to push the copyist. I am holding several settings back and console 12 13 myself with the pleasant hope of being able to write to your Excellency more 13 14 often.

15 The manner in which 'Der Zauberlehrling' is performed is essentially how I 15

16 like to read the poem: namely, I begin not too quickly, here and there the tempo 16 17 accelerates so that a powerful rendition of incantation remains possible and flows 17 18 from the singer until the sorcerer appears, at which point I underscore the setting 18 19 with a higher, commanding tone. The musical climaxes lie mainly in the power of 19 20 the singers, who must remain serious and take great care not to labour the words. 20 21 I took the Lied 'Thekla'4 from the Musenalmanach. It is performed by a 'harp- 21 22 strummer', who sometimes narrates and sometimes is moved to use gesture. If 22 $23 \mathrm{I}$ had in those days already known the Piccolomini,${ }^{5}$ then it is very likely that it 23 24 would have turned out differently, although the weight and depth of the lament 24 25 should be effective even without the context. 'Die Erinnerung' ${ }^{6}$ ought to have 25 26 a secretive, uneasy, tender character and that should be conveyed by the music 26 27 alone, without the singer having to demonstrate any special agitation. For that 27 28 reason it is indicated comodetto.

29 The sonnet is a daring venture. I am ill-versed in the theory of poetry and 29 30 thought that the sonnet, with its architectonic structure as Sulzer ${ }^{7}$ sees it, is 30 31 especially suitable to be set to music. However, although this setting is the best 31 32 of several attempts, I cannot consider it successful. The melismatic phrases which 32 33 occur here and there in the melody are most suited to the expression and at the 33 34 same time misplace the outer proportions of the poem, which I strove to maintain. 34 35 There are perhaps still metrical rules for the sonnet which I did not discover in 35 36 theories known to me: the poet must have observed the enjambments, for example, 36 37

384 Zelter's setting of Schiller's poem 'Des Mädchens Klage' from Schiller's 38

39 Wallenstein. 39

405 Part Two of Schiller's Wallenstein Trilogy; first performed on Anna Amalia's 40

41 birthday on 30 January 1799. The Berlin premiere took place on 18 February 1799.

426 ZG 11 August 1799.

437 Johann Georg Sulzer, Allgemeine Theorie der Schönen Kunste (Leipzig, 1774), 43 44 'Sonnet', p. 1095. 
1 in the first quatrain and Schlegel's sonnet 'Gesang und Kuß', which I have also 1

2 composed, closes with a question.

3 I received your most precious letter of 26 August on 30 August. 'Die erste 3

4 Walpurgisnacht' is a very suitable poem. ${ }^{8}$ The verses are musical and singable. 4

5 I wanted to set it to music which I could send to you here and have worked on a 5

6 good portion of it, but I cannot quite capture the tone of the entire poem and so 6

7 it is best to let it lie for a while. Herr Unger sends his best wishes and I have the 7

8 honour of being your respectful

16 I haven't forgotten to send your Excellency a few of my compositions again, and 16 17 even if, apart from the serenade, ${ }^{9}$ nothing among them is entirely new, neither 17 18 are they known through publication. Nearly all of them observe the metrical 18 19 patterns and verse forms and I would like to be in a position to acquire a thorough 19 20 grounding in this area of the art. The short verses in the middle of long strophes 20 21 are the most difficult to set to music, if one strives to preserve the [correct] tone 21 22 and poetic disposition.

23 'Das Herbstlied' ${ }^{10}$ calls for a lively tempo. 'Der Jungesell und der Mühlbach'"11 23 24 works well especially when it is sung antiphonally. 'Das Blümlein Wunderschön'12 24 25 could also be sung as a duet. Of 'Die Braut von Corinth'13 I don't quite know 25 26 what to say. Friends of mine who have performed it really like it and I don't 26 27 have anything to say against it. It could be that this poem can only be performed 27 28 in this way. I sing it almost in a quasi speech-like manner, and if it is sung in a 28 29 hollow voice, as if one is bound to tell something dreadfully mysterious, then 29 30 the essence of the poem really comes forward. I strove to observe the short lines 30 31 among the long sentences and because of this a rather adventurous musical metre 31 32 has evolved. ${ }^{14}$ The most difficult thing for the singer is to handle all the verses 32 in Zwölf Lieder am Clavier zu singen in 1801; the composition is not in Goethe's music 36 collection. 
1 in such a way that the poem remains animated though the melody is repeated so 1

2 often. When all is said and done it is not a poem for everyone: so not everybody 2

3 can sing it. "Bundeslied" 15 I have heard sung by 112 voices at the Liedertafel and 3

4 [through it] have experienced how powerful a German poem can be. A serenade is 4

5 not the best poetic form: so I was more interested in the actual form of a serenade 5

6 which, when strummed outside a beloved girl's window, is the most important 6

7 aspect of it.

8 I don't know whether I should fear that my scribblings will be too tedious for 8

9 your Excellency. I have long enough repressed a desire, which I will still finally 9

10 dare to utter. For a long time rumour has it that you have written the libretto for 10

11 a serious opera. ${ }^{16}$ Perhaps I am ill-informed; but how it would delight me alone 11

12 if I could assist you to produce such a meritorious work! And what an agreeable 12

13 task would the composition of such an opera be for me! I don't want to give the 13

14 impression of being a braggart, but I know what I can accomplish and under such 14

15 guidance I would not produce anything mediocre. Through your Iphigenie I have 15

16 been almost convinced that we would find each other through such a collaboration, 16

17 perhaps never to be parted again. Through my own affinity for dramatic music, 17

18 which is being developed generally but without good fortune, it was inevitable 18

19 that a number of dramatic attempts came to me spontaneously. Several of them 19

20 confirm to me that I am capable of producing a large scale work. ${ }^{17}$ Through this I 20

21 haven't composed anything well-known, but I will send you samples of my work 21

22 and would really value your opinion. I have edited more operas because the libretti 22

23 only partly met my own inclinations. It is very likely that we will be granted a 23

24 new, large theatre here ${ }^{18}$ very soon which allows one to imagine that this great 24

25 event will give rise to even greater things. I would not use this information lightly 25

26 because I don't want to stand with empty hands among the children of Parnassus 26

27 and bemoan the common taste of our time!

28 Herr Unger told me of late that your Excellency had some questions he wished 28

29 to discuss with me. ${ }^{19}$ As far as it goes my knowledge is at your service and what 29

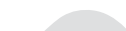

15 ZG 11 August 1799. A copy is contained in Goethe's music collection.

16 Goethe's fragment, Der Zauberflöte zweiter Teil. Goethe listened to Schiller's words of caution about writing a sequel to Mozart's Die Zauberflöte and did not complete the libretto.

17 Zelter's settings of Gellert's Das Orakel (operatic fragment); scenes from Metastasio's libretti by and scenes from the opera Olympia: 'Misero me! Ah! Che veggo?'

39 and 'Oh Dio, se in questo istante'.

$40 \quad 18$ In 1801 the Königliches Nationaltheater replaced the Französiches Komödienhaus

41 (founded in 1786) on Gendarmenmarkt. A new 2,000-seat theatre was opened on 1 January 421802 .

4319 In his letter to Johann Friedrich Unger on 4 November 1799, Goethe had expressed 43

44 the desire to discuss some theoretical issues with Zelter. 
1 I don't know, my fatherly friend, Fasch, ${ }^{20}$ a very thorough and fine theorist, will 1

2 supplement with pleasure. I recommend myself best through my songs, because I 2

3 don't know a better way to serve you as when I follow your own judgement and 3

4 remain with the most sincere esteem yours sincerely

When you compare how lovingly the individual is here restored to us, what a 18 poor picture is given by those necrologists, who, immediately after one's death, 19

20 carefully balance the good and bad as perceived and applauded by the majority. 20

21 They touch up his so-called virtues and vices with hypocritical righteousness, and 21

22 thereby are worse than death in destroying a personality, which can be imagined 22

23 only in the living union of those opposing qualities.

24 I was particularly delighted with your account of the creation of the Mass in 1624

25 parts, ${ }^{22}$ and of the Sing-Akademie to which it gave rise; how pleased I was that the 25

26 good Fasch should be so fortunate as to have lived to see such an idea realized. 26

27 In an earlier letter - for which I regret I still owe you an answer - you ask 27

28 whether there is anything resembling an opera among my papers? In the next edition 28 Frederick the Great in 1756), composer, teacher, founder of the Sing-Akademie (1791), was 35 an important figure in the revival of choral singing in Germany. He performed numerous 36 choral works by J.S Bach with the Sing-Akademie, the first of which was the motet, Komm, 37 Jesu, komm; this practice reached its pinnacle in Mendelssohn's revival of the St Matthew 37
Passion.

${ }_{21}$ Zelter's biography, Karl Friedrich Christian Fasch (Berlin: Unger, 1801); Unger 39 had sent a copy of the book to Goethe on 5 May 1801.

22 In his biography Zelter reports how Fasch, inspired by a mass by Orazio Benevoli 41

43 (a mass for four choirs (16 vocal parts)) in a few weeks. Zelter, Karl Friedrich Christian 43

44 Fasch, p. 25. 
1 of Wilman's Taschenbuch ${ }^{23}$ you will find the first scenes of Die Zauberflöte II. ${ }^{24} 1$

2 Some years ago I sketched a plan for a serious cantata, Die Danaiden, in which, in 2

3 the manner of the ancient Greek tragedy, the chorus was to appear as the principal 3

4 subject; but neither of the two pieces will, I expect, ever be finished. One would 4

5 have to live with the composer, and work for some particular theatre; otherwise 5

6 not much can come of such an undertaking. $\quad 6$

7 From time to time be sure to send me some of your compositions. They give 7

8 me great pleasure. Besides, I do not live in a musical atmosphere; throughout the 8

9 year we reproduce first one, then another piece of music, but where nothing new is 9

10 actually produced, an art cannot make itself vividly felt. 10

12

17 [...] Of your poems, I have only set to music the ones I have enclosed. In 17

18 'Frühzeitiger Frühling'25 the three strophes automatically became one, since with 18

19 all your songs the composer rarely acts on his own volition, if at all, because 19

20 they always determine themselves. Whoever wants to sing it well, must know it 20

21 by heart. I have a copy of 'Schäfers Klagelied'26 from Frau Hufeland ${ }^{27}$ and have 21

22 already composed it in Leipzig. ${ }^{28}$ It should not be performed too loudly but as 22

23 lightly as possible. I have also composed a song for her friend de Mappes, ${ }^{29}$ but 23

2623 Taschenbuch auf das Jahr 1802. Der Liebe und Freundschaft gewidmet (Bremen:

27 G.F. Williams), pp. 15-36: 'Zer Zauberflöte zweiter Teil von Goethe. Entwurf zu einem

28 dramatischen Märchen'.

2924 For discussion on Goethe's unfinished sequel to Die Zauberflöte, see Eckermann, 29

3013 April 1823, p. 546.

3125 Zelter's setting of Goethe's poem 'Frühzeitiger Frühling' ('Tage der Wonne ...'); 31

32 Zelter had received the poem from Goethe on his first visit to Weimar in February 1802. The

33 setting is not in Goethe's music collection.

3426 Zelter's setting of Goethe's 'Schäfers Klagelied' ('Da droben auf jenem Berge'); 34

35 the song is no longer in Goethe's music collection.

$36 \quad 27$ Conradine Louise Wilhelmine Hufeland (1776-1823), wife of Privy Councillor 37 Gottlieb Hufeland (1788-1803).

$38 \quad 28$ Zelter composed it on his return journey from Weimar, on 28 February or 1 March 381802 .

$39 \begin{array}{lr}1802 . \\ 40\end{array}$

40 Walter Map (Gualterus Mapes) (1140-1209), English poet. 'Das Schenklied' ('Mihi 41 est propositum in taberna mori ...') was, at this time, attributed to him; later Jacob Grimm 41 traced it back to the work of the medieval poet 'Archpoet': Carmina Burana 191 'Estuans

42 intrinsecus ira vehementi'. Goethe was familiar with the text through Bürger's adaptation

43 'Zechlied', written in 1777 and published in his Gedichte of 1780. The song which Zelter 43

44 has composed is an early setting of Goethe's 'Tischlied', which was written as a parody of 44 
1 he is not too happy with it. Schulz's melody ${ }^{30}$ is as good as it gets, but she didn't 1

2 perform her German Lied with enough dignity and worse than Schulz would have 2

3 wanted; I, too, was unhappy with it. I had more luck with Schiller's 'Die vier 3

4 Weltalter'; $; 1$ at least I achieved what I can make of it. I have also set Schiller's 4

5 romances to music once again: 'Der Kampf mit dem Drachen', ${ }^{32}$ which I must be 5

6 happy with because the 12-line verses are infinitely difficult to vary. If only the 6

7 poem were not so long that the singer nearly collapses, then I would rate it in my 7

8 works alongside 'Der Taucher'. ${ }^{33} \quad 8$

9 As a result of all the sunshine and glory that I enjoyed in your home, I left the 9

10 five strophes of your new romance ${ }^{34}$ behind me, which pleased me infinitely and 10

11 I would be immensely grateful if you could forward them on to me. Perhaps the 11

12 composition will encourage you to complete the work if it hasn't happened already. 12

13 I thank God hourly on bended knee that I have finally met you. The memory 13

14 of those days is imprinted on my mind. Through the encounter a new spirit has 14

15 awakened in me and if I brought or if I bring something forward which is worthy 15

16 of the muses, I know it is a gift and recognize from where it comes. 16

1713 April: [...] I enclose a copy of a little song for your noble honourable 17

18 princess, ${ }^{35}$ which, in my name, you will be so kind as to lay at her feet in my name. 18

19 I would have sent it myself had I not thought that this little thing would appear 19

20 better and more valuable if delivered by more worthy hands than mine. 20

21 Last Saturday Reichardt's setting of Der Tod des Herkules ${ }^{36}$ was performed 21

22 at the Nationaltheater. The libretto is treated à la Sophocles by the composer, 22

23 like Gotter's Medea, ${ }^{37}$ except that there are choruses interspersed which, by 23

24 their grouping, give an uncommonly clear and advantageous coherence. The 24

26 Schulz's setting. Zelter's manuscript is dated 19 October 1823 (Ms. autograph 10); there is 26

27 no copy in Goethe's music collection.

2830 Johann Abraham Peter Schulz (1747-1800), composer, Kapellmeister in Berlin, 28

29 Rheinsberg and Copenhagen. His setting of the Map/Bürger text was published in his 29

30 Lieder im Volkston (1st edn, Berlin, 1782; 2nd edn, Berlin, 1785).

31 Zelter's setting of Schiller's 'Die vier Weltalter' ('Wohl perlet im Glase der 31 purpurne Wein ...') from Cotta's Taschenbuch für Damen auf das Jahr 1803, pp. 205-08, 32 was published in Zelter, Sammlung kleiner Balladen und Lieder (Hamburg: Böhme, 1803). 33 Zelter's composition is no longer contained in Goethe's music collection.

32 Zelter's setting of Schiller's ballad 'Der Kampf mit dem Drachen' ('Was rennt 34 das Volk ...') from Schiller's Musen-Almanach für das Jahr 1799, pp. 151-64, was also 35 published in the Sammlung kleiner Balladen und Lieder (1803).

33 Zelter's setting of Schiller's 'Der Taucher' ('Wer wagt es, Rittersmann oder Knapp') 37 was first published in 1803 .

36 Melodrama by Johann Friedrich Reichardt (1752-1814) premiered on 10 April 41 1802 , with a second performance on 12 April. 
1 music is stamped with Reichardt's genius, which is always announced through 1

2 great courageous strides; it appears at its best in the quiet moments, which are 2

3 exceptionally moving and very resolute. Iffland ${ }^{38}$ plays the part of Hercules so well 3

4 and so nobly and he is able to make the gradual transitions to the pinnacle of agony 4

5 to which only the body succumbs, so that everywhere an advantageous mixture of 5

6 suffering humanity and divine power develops. The finale is particularly beautiful: 6

7 Hercules climbs the [funeral] pyre which is kindled by a bolt of lightning; his 7

8 head is lit from above and his death is a visible crossing of the transfiguration into 8

9 Olympus. 9

16 [...] Now I have something on my mind that you will easily guess from the 16 17 enclosure. Hercules has had a very cold reception. The reasons for this [reception] 17 18 lie partly in the subject, which is not easy for the general public to digest, and in the 18 19 current prejudice against the composer, who years ago was praised to the heavens 19 20 at the expense of other good composers. It would be all right to leave both sides to 20 21 their opinions, if art were not to suffer thereby, which, with its moderate progress 21 22 to perfection, has to survive the war against whims, arrogance and ignorance. I 22 23 myself can no longer bear it that an industrious, skilful well-intentioned work 23 24 which is staged with unspeakable efforts and much expense should be thrown 24 25 away in such a disdainful, capricious manner, and be dismissed as worthless. 25

26 Therefore I have a request: that you read my description of Hercules. ${ }^{39}$ I would 26

27 be very proud if you could give even one word of recommendation; then I would 27

28 feel I had the right to speak, where others, who ought to speak, remain silent. 28

29 Would you be so kind as to deliver the single page of manuscript to Schiller? 29

30 If you have both of these Tafellieder transcribed, ${ }^{40}$ you could try them out some 30

31 morning at the theatre rehearsals; the soloist must do his best thereby. 31

$38 \quad 38$ August Wilhlem Iffland (1759-1814), actor and (from 1795) director at the

39 Mannheim Nationaltheater; Artistic Director and General Manager of the Königliches

40 Theater from 1811 until his death in 1814.

4139 Zelter's essay on Reichardt's melodrama, Der Tod des Herkules; the manuscript has

42 not been preserved with these letters.

$43 \quad 40$ Zelter's settings of Schiller's poems: 'Punschlied. Im Norden zu singen' and 43 44 'Punschlied'. 
5 During the time you heard nothing from me, dear Zelter, while I have not travelled 5

6 very far, I have mostly been away from home. I had to oversee the building of a 6

7 new theatre in Lauchstädt ${ }^{41}$ and direct the inauguration, whereby, as is usual in 7

8 such cases, one caters for the enjoyment of others at the expense of one's own 8

9 pleasure. Then I stayed in Jena for a while, in literary seclusion in the library; 9

10 this time neither noise nor silence inspired anything in which a composer could 10

11 take pleasure. Let us hope that the friendly social life of the winter will put us in a 11

12 lyrical frame of mind, which would most certainly be secured if you put your good 12

13 intentions into practice and came to stay with us once again. Give me your kind 13

14 reassurance in due course.

15 You will soon see in print the prelude ${ }^{42}$ that I wrote for the inauguration of 15

16 the Lauchstädt theatre. At the beginning I had no desire to publish it, because 16

17 everything was inspired by the occasion, the moment, the individual members 17

18 of the company, the power of the music, ${ }^{43}$ and all that is connected with external 18

19 production; now, may all that remains on paper be published and have whatever 19

20 effect it can.

Let me know soon that I am in your thoughts. 21

29 [.. ] I very much look forward to the appearance of your prelude and repeat my 29

30 request that you send me the romance ${ }^{44}$ from which you read five strophes to me. 30

31 This winter I am unable to make plans for a short trip because almost everyone at 31

32 home has been sick during the summer. God knows how much I like to be with 32

33 you; I have never felt the sun shine so warmly as in Weimar. I am greatly indebted 33

${ }_{41}$ Goethe travelled to Lauchstädt on 21 June 1802, where Joseph Bellomo had 35 founded a provisional summer theatre in the new theatre designed by the architect, Johann 36 Heinrich Gentz (1766-1811). Goethe had opened the theatre with his prologue, Was wir 37 bringen, and a performance of Mozart's Titus given by the ensemble of the Weimar Court 38 Theatre. The ensemble remained in Lauchstädt until the middle of August. 39

4243 Mozart's Titus, libretto by Caterino Mazzolà after Pietro Metastasio, La clemenza 42

43 di Tito; German translation by August Vulpius. 
1 to you for your response to Hercules ${ }^{45}$ for me, it is the seal of your affection which 1

2 I know how to treasure. $\quad 2$

$3+3$

4 5 4

5 11. Goethe 5

$6 \quad 6$

$7 \quad$ Weimar, 6 December 18027

$8 \quad 8$

9 When, during these dark days, I thought of happy circumstances, I often looked 9

10 back to the time of your delightful presence amongst us last year. I have but slender 10

11 hope of seeing you again soon; yet it is my wish that a thread should continue to 11

12 be spun between us. $\quad 12$

13 Therefore give a friendly welcome to the count and the dwarfs, ${ }^{46}$ who arrive 13

14 with this letter; for the first time, I think, they show style and ingenuity. Cherish 14

15 these merry imps in your true musical sense, and prepare for yourself and us some 15

16 diversion for the winter evenings. But do not let the poem out of your hands; if 16

17 possible, keep it secret. 17

My whole household thinks of you with affection and love 18

19

Goethe 19

Berlin, 12 December 180224

26 A group of Sing-Akademie members organized a pleasant surprise in celebration 26 27 of my birthday. A little play with many of my songs woven into its fabric was 27 28 staged very nicely; all of my children were given parts. The finale was a little 28 29 Lustspiel, ${ }^{47}$ at which you yourself would have been quite amused to come across 29 30 our carpenter, Steffani, dressed up in the most outrageous costume - a low-cut 30 31 dress - as a lady-in-waiting to the Queen of Bathsheba. This had the whole house 31 32 in hysterics. Among the many lovely presents of the day was your dear letter, 32 33 which I recognized from the address and which I guessed was from you by the 33 34 exceptional size of its contents. I will not leave your lovely wedding song out of 34 35 my hands and as soon as it is composed, you shall have a copy. [...] 35

$3 8 \longdiv { 4 5 \quad \text { ZG } 9 \text { May } 1 8 0 2 \text { . } } 3 8$

3946 A copy of Goethe's 'Hochzeitslied' which Zelter had left behind on his visit to 39

40 Weimar in February 1802.

$41 \quad 47$ Lieder und Gesänge aus dem Liederspiele: die Mühle, in einem Akt. Aufgeführt zur 41

42 frohen Geburtstagsfeier am 11. Dezember 1802. The play contains settings by Zelter which 42

43 were performed by members of the Sing-Akademie. A copy of the first publication is held 43

44 in the Preußischer Staatsbibliothek, Berlin (SBB PK: Mus.Ms 1164). 44 
The pleasant news that you are going to share your treasures with the world has 1

2 inspired me again, and since then I have set to work on your poems again. What 2

3 you once wrote to me about the dramatic form of the romance in relation to ' $\mathrm{Die} 3$

4 erste Walpurgisnacht', confirmed to me a direction which I had already sought to 4

5 develop in 'Der Zauberlehrling'. 'Walpurgisnacht' remains unfinished because it 5

6 always imposed on me the old worn-out cantata form. ${ }^{48}$ Now I have attempted 6

7 [to set] 'Der Müllerin Reue' and I wonder what you would think of it. ${ }^{49}$ As it must 7

8 be sung by two people, it would be good if one of them were a tenor. Unfortunately 8

9 the piece is difficult to produce and must be learnt well, so that neither breathing 9

10 nor diction fails. The tenor must declaim his rumbling lines very boisterously and 10

11 the [soprano] descant [should be sung] gently but coherently and full of feeling. 11

12 I have thought of setting Cupid's song as a little intermezzo in the Italian 12

13 style: $:^{50}$ if three young girls, lightly dressed with net cages on their backs, appear 13

14 on stage friendly and blithe in a circle, cry out, 'Wer kauft Liebesgötter!' and 14

15 then sing the poem to a light and playful melody, then it cannot fail to work. The 15

16 fortepiano, which at the very least requires the lightest accompaniment (without 16

17 any passionate expression), could be placed behind a screen or even in the same 17

18 room.

19 And so accept what I so willingly give. I would like to send the peace of the 19

20 blessed to you, for where there are no gods, there is no heaven. Remember me 20

21 warmly to Schiller. I would like to surprise myself with the joy of going to my 21

22 dear Weimar. I can't yet fix a date, especially with the carnival approaching, when 22

23 the royal family is in Berlin. I must be mindful of my duty, to which I naturally 23

24 apply myself when it concerns the Sing-Akademie. This institute enjoys a special 24

25 hospitality in a king's household ${ }^{51}$ and it would be very painful to me if a request 25

26 came from a higher source in my absence and there was no one there who knew 26

27 what to say on behalf of 200 members, no one who knew how to say the correct 27

28 thing about an unfamiliar project and so would give a very confused impression 28

29 by mixing up ends and means. For who will know, in this day and age, how to 29

48 Berlin composers and theoreticians - among them Reichardt and Zelter - 33 recommended a cantata-like form, when there were heterogeneous emotions in the text and 34 when a change in emotions was dominant because it would be unreasonable to expect a poet 35 to write an ode which maintains the same feeling through many verses.

49 Zelter's setting of 'Der Müllerin Reue' first appeared in Schiller's Musenalmanach 36 in 1799 and subsequently in Goethes Schriften, vol. 7, pp. 77-81. An original copy of 37 the setting is neither in Goethe's music collection nor housed with Zelter's manuscripts in 38 Berlin.

50 'Wer kauft Liebesgötter' from Goethe's sequel to Die Zauberflöte. Zelter's setting 40 is in Goethe's music collection (GSA, 32/32).

51 From the end of 1793 the choir was granted use of the round room in the building 42

43 of the Königliche Akademie der Künste, and from this point on they called themselves the 43

44 Sing-Akademie. 
1 bring together bright young people and dignified men and organize them to sing a 1

2 devout Kyrie together. [...] 2

3

4 Enclosure: Zelter's settings of Goethe's poems, 'Der Müllerin Reue' and 'Wer 4

5 kauft Liebesgötter?'

$6 \quad 6$

$\begin{array}{ll}7 & 7 \\ 8 & \end{array}$

$8 \quad 13$. Zelter 8

929

10 Berlin, 18 December 180210

$11 \quad 11$

12 I haven't forgotten to send you the setting of the 'Hochzeitlied' ${ }^{52}$ It was finished 12

13 before I sent my last letter, but I wanted to wait until I was happy with it. You will 13

14 find that the strophes in which there is a full stop after verse seven are the clearest 14

15 and the three rhymes of verses five, six and seven appear to establish the intention 15

16 of this metre which is new to me, ${ }^{53}$ so I have developed the modulation of the 16

17 entire setting not on the first but on the second strophe. 17

18 'Der neue Amadis' ${ }^{54}$ can now go back to you with 'Hochzeitlied'. I have set it 18

19 as an exercise because of its fifth unrhymed verse. 19

20 I have not let any of your unpublished poems out of my hands. I did not receive 20

21 'Schäfers Klagelied' from you and when Frau Privy Councillor Herz ${ }^{55}$ requested a 21

22 copy of my setting and already had a copy of the poem, I gladly acquiesced. In a 22

23 new song collection by Reichardt, the manuscript of which I saw through Sanders, 23

24 I caught sight of 'Frühzeitiger Frühling', which Reichardt probably received from 24

25 you. ${ }^{56} \quad 25$

26 They say the king is coming to Berlin on the 21 st of this month and so the 26

27 carnival can end towards the end of January. The queen's close delivery [date] 27

28

29

$30 \quad 52$ Zelter's setting of Goethe's 'Hochzeitlied', published in Zelter's Sämtliche Lieder, 30

31 Balladen und Romanzen, vol. 2. The enclosed composition is no longer part of Goethe's 31

32 music collection. 32

33 53 Zelter's setting of 'Hochzeitlied' for solo voice and piano is composed in 6/8 time; 33

34 the choice of metre is rare among his settings.

$35 \quad 54$ An autograph of Zelter's unpublished setting of Goethe's poem 'Der neue Amadis', 35

36 dated 18 December 1802, is housed in Berlin (SBB PK: Mus. ms. Autogr. Zelter 22, no. 2). 36

37 The enclosed copy is no longer contained in Goethe's music collection. As Zelter's previous

38 letter suggests, the setting was notated on the same manuscript page as 'Hochzeitlied' (GSA

38 95/I, 9).

$39{ }_{55}$ Henriette Julie Herz, née de Lemos (1764-1847); the setting was presumably

40 composed for her salon.

4156 Goethe's poem 'Frühzeitiger Frühling', set to music by Johann Friedrich Reichardt

42 in 1802, was first published in Le Troubadour italien, français et allemand (Berlin: Heinrich

43 Fröhlich, 1805/06). The publication of Reichardt's setting by the Berlin publishers, Johann 43

44 Daniel Sanders, which Zelter mentions, cannot be sourced; MA 20.3, p. 136. 
1 confirms my suspicions,${ }^{57}$ which means I could be in Weimar in early February, 1

2 if this pleasant calculation is not by chance proven wrong. You have opened your 2

3 house to me with such a warm welcome and I will accept in so far as I do not 3

4 inconvenience you in any way. [...] Like a child I look forward to being with you 4

5 and have nothing else on my mind. 5

6

7 Enclosure: Zelter's settings of Goethe's 'Hochzeitlied' and 'Der neue Amadis'. 7

14. Goethe

14 I cannot contemplate the hope of your visit with such silence, ${ }^{58}$ especially as there 14

15 are some things for which I have to thank you.

Weimar, 24 January 180312

The songs you sent gave me, and others, much joy and have already been 16

17 carefully performed in little concerts, which I arranged in anticipation of your 17

18 visit. Naturally their performance awaits your own finishing touches.

Would it be possible to bring with you some SATB settings which are not too 19

20 difficult? That way your presence will have an effect on us in many ways. 20

21 I will close here for now, so that this page, which has already missed the post, 21

22 will not be delayed any further. Your room, which you know, has been arranged 22

23 beside a little bedroom, so you can come and go as you please. I myself am in a 23

24 good position to be able to relax and enjoy your visit next month in peace [...] In 24

25 the hope of looking forward to some interesting talks with you soon, I wish you 25

26 good health and a good journey.

33 Only one line to tell you briefly that good Dr Chladni is here ${ }^{59}$ and will remain in 33

34 the area until about 9 or 10 February. Perhaps this may have some bearing on your 34

57 Queen Luise Augusta Wilhelmine Amalie of Prussia (1808-77) bore a daughter, 37

Princess Friederike Wilhelmine Alexandrine Maria Helene, on 23 February 1803.

58 Goethe's diary on 24 January 1803 mentions Zelter's visit: 'To Herrn Zelter, ${ }^{39}$

59 Ernst Florens Friedrich Chladni (1756-1827), physicist and music theorist. Author 41

42 of the theoretical work Die Acoustik, 1802. Goethe's diary on 31 January 1803 mentions his 42

43 visit: 'To Herrn Zelter regarding Chladni', WA III/3, p. 70. See also the section, 'Chladnis 43

44 Tonfiguren' in Goethe's essay Entoptische Farben, vol. 12, p. $501 f$. 
1 journey. If you could meet him while he is still here, we would have some lively 1 2 discussions about music. $\quad 2$

3 Only this much to confirm once more my eager wish to see you under my 3 4 roof.

\section{Zelter}

11 I must relinquish any hope I had of spending some days in Weimar this winter; 11

12 so I will take the opportunity of sending you what I would have brought myself. 12

13 For years I have been dissatisfied with my setting of the enclosed 'Reiterlied' ${ }^{60} 13$

14 Therefore you receive it in score, in order to be able to make use of it perhaps for 14

15 the theatre. If you want it, would you be so kind as to return the score to me when 15

16 you have it copied for the various voices, ${ }^{61}$ for I haven't kept back a copy. You 16

17 will probably decide that the performance of this piece should be free, lively and 17

18 light rather than heavy and dragging - this goes for the orchestra as well as for the 18

19 singers - and I have nothing else to add than that it would be very nice if it were to 19

20 appeal to Schiller as it stands, ${ }^{62}$ because all of the settings of this song, with which 20

$21 \mathrm{I}$ am familiar, ${ }^{63}$ are unsuccessful. 21

22 Madame Mara has arrived here, ${ }^{64}$ and, after so many years, I long to hear the 22

23 divine singing of this artist. In all that time I have heard no other singer who can do 23

24 everything with her glorious voice, never delivering anything less than perfect. 24

25

$26 \quad 60$ Zelter's setting of Schiller's 'Reiterlied' from Wallenstein. Schiller had sent the

27 poem to Zelter on 6 July 1797 and asked him to compose a setting for the play, SNA 29,

28 p. 96.

2961 In Goethe's music collection there is a five-page copy of this song, with the choral 29

30 voices indicated by the names of the actual singers: H. Spitzeder, Ehlers, Brandt, Benda, 30

31 Eilenstein (GSA 32/34). 31

3262 On 28 February 1803 Schiller wrote to Zelter: 'Goethe has been telling about a 32

33 number of lovely melodies you have sent him; he is having them rehearsed and promises 33

34 us a real feast of them this week. I will hear 'Der Kampf mit den Drachen' as well as 34

35 'Reiterlied' this week', SNA 32, p. 17.

$36 \quad{ }^{63}$ Settings by Christian Jakob Zahn (1797), Christian Gottfried Körner (1797), 36

37 Johann Rudolf Zumsteeg (1802), Bernhard Anselm Weber (1803): see Max Friedländer,

38 Das deutsche Lied im 18. Jahrhundert. Quellen und Studien, 2 vols (Stuttgart and Berlin:

39 Cotta, 1902), vol. 2, p. 397f.

40 this diva's performance in Leipzig in 1767 and later recalled it in the poem 'Sangreich 41 war dein Ehrenweg' for her, GZ 19 February 1831. Mara arrived in Berlin on 1 February

42 1803. During this visit she gave two concerts with the Königliche Kapelle in the opera

43 house on 13 February and 6 March, which were reviewed by Zelter in the Spenersche

44 Zeitung, 8 March 1803. She was also soloist for Zelter's performance of Graun's Passion

1

33

5


Your dear kind letter of 24 January saddened me. I was unwilling to come 1

2 empty-handed to Weimar and therefore I have not been idle. I hoped that several 2

3 quite new settings of your poems would win your favour. 'Sehnsucht' ('Was zieht 3

4 mir das Herz so?' $)^{65}$ and 'Der Sänger' ${ }^{\prime 66}$ are quite new and, in my opinion, are even 4

5 better than Reichardt's settings. Since Part I of Wilhelm Meisters Lehrjahre was 5

6 published, I have had 'Der Sänger' constantly on my mind, and finally here it is 6

7 on paper. Reichardt's setting ${ }^{67}$ is like a march, and starting rather imperiously, 7

8 should at all events end as it began; I have restored the ballad form. After that I 8

9 finished several of your songs and have added four new strophes to 'Das Blümlein 9

10 Wunderschön'. 'Der Junggesell und der Mühlbach' has, at the suggestion of a 10

11 critic in the Apollon, ${ }^{68}$ been given more musical substance. Schiller's 'Hero und 11

12 Leander', 'Worte des Glaubens', 69 'Der Kampf mit dem Drachen', 'Die Sänger der 12

13 Vorwelt ${ }^{\prime 70}$ have received the final touches; I have reset some new sonnets, including 13

14 one by Herder, ${ }^{71}$ as well as several old German songs from the seventeenth century 14

17 in the Nicholaikirche, Berlin on 11 March; see AMZ 5 (1802/3). Rochlitz's Für Freunde 17

18 der Tonkunst (4 vols, Leipzig: Carl Cnobloch, 1824-32) contains an interesting memoir of 18

19 her.

65 Zelter's setting of Goethe's 'Sehnsucht', MA 61, p. 76. As the poem was first 19 published in 1804, these verses belong to an unpublished edition given to Zelter on his 2 visit to Goethe in February 1802. Zelter's setting is in Goethe's music collection. A Berlin 21 autograph (SBB: PK: Mus. ms. autogr. Zelter 22, no. 1), dated 18 December 1802, is 22 unpublished.

66 Zelter's setting of the Harper's first song in Wilhelm Meisters Lehrjahre. Zelter's 24 setting is not in Goethe's music collection; the Berlin autograph (SBB PK: Mus. ms. autogr. 25 Zelter 22, no. 1), dated 18 December 1802, is still unpublished.

67 Reichardt's 'Sehnsucht' was published in the Romantischen Gesängen (1805) 27 and in Goethe, Wilhelm Meisters Lehrjahre (Berlin: Unger, 1795) where all the settings 28 appeared as inserts in the book.

68 'For a fuller definition of the latter we would like to add that it is, what music in 30 a genuine Romanze always is and has to be, namely genuinely romantic', Apollon. Eine 31 Zeitschrift, (ed.) Julius Werden (pseudonym for Johann Gottlieb Winzer), Adolph Werden 32

69 Zelter's settings of Schiller's ballad 'Hero und Leander' (SNA 2/I, p. 298) and his 35 poem 'Die Worte des Glaubens' (SNA 2/I, p. 329) are not in Goethe's music collection and 36 remain unpublished.

70 Zelter's setting of Schiller's poem 'Die Sänger der Vorwelt' (SNA 2/I, p. 298) is 37
38
not contained in Goethe's music collection. It was published in Zelter's collection Sechs Deutsche Lieder für die Baß-Stimme (1826).

71 Zelter's setting of Herder's sonnet 'Ach könnt ich, könnte vergessen Sie', which he 40 discovered through Wilhelm Schneider's setting published in the Apollon, is no longer in 41

43 . 44 in 1821 . 
1 by Abschatz, ${ }^{72}$ Zinkgref, ${ }^{73}$ Paul Gerhardt. ${ }^{74}$ I recount my small glories to you like 1 2 a child who has had Christmas presents from the Muses, and when all is said 2 3 and done, does not know what to do with all his treasures. Could I but achieve 3 4 something great! My life is passing and nothing comes of it. Could you possibly 4 5 suggest something by Herder, whom I esteem most highly? ${ }^{75}$ I read so little, and 5 6 re-read my old favourites so often, that poetic gems often escape me. And now, 6 7 'Enough, ye Muses!' But pray be on your guard, that your house is not haunted! 7 $8 \mathrm{It}$ is my spirit which has taken up his quarters with you, and is settling down and 8 9 making its nest by degrees.

10 Of the settings I have sent you there is one, 'Die Erinnerung', of which I have 10 11 given away all the copies I had. Could I possibly ask you to have a copy made and 11 12 dispatched to me, as I would like to have it published? As far as I remember it is 12 13 in B flat major or E major. ${ }^{76}$

20 I can understand very well that it requires some resolution to leave one's own 20 21 circle, and to look up distant friends at this time of the year; yet I am troubled in 21 22 more ways than one by your letter of refusal. Apart from what we should have 22 23 gained for the general and higher aims of art by personal communication, it so 23 24 happens that this winter I am preoccupied with the organization of the opera and 24 25 orchestra $^{77}$ more with a view to the future than the present; and I thought your help 25 26 would be absolutely indispensable in this matter.

27 The significance of the old proverb, 'Go straight to the right smithy', was clear 27

28 enough to me long ago; but what use is this knowledge if the smithy is so far off 28

29 that one cannot reach him with one's harness? 29

30

72 Zelter's setting of 'Mut', written by Baron Hans von Aßmann (really Johann Erasmus) von Abschatz, is not in Goethe's music collection. The Berlin autograph, dated Berlin 3413 January 1803, is unpublished (SBB PK: Mus. ms. autogr. Zelter 22, no. 4).

73 Zelter's setting of Julius Wilhelm Zinkgref's 'Klage' is not in Goethe's music

36 collection. The Berlin autograph (SBB PK: Mus. ms. autogr. Zelter 22, no. 6), was first 36 published by Landshoff in 1932.

$37 \quad 74$ Zelter's setting of the poem 'Sonnet' (Berlin autograph (SBB PK: Mus. ms. autogr. 38 Zelter 22, no. 7) is not in Goethe's music collection. It was first published in Zelter's

39 Sämtliche Lieder, Balladen und Romanzen. Here and in the published version Zelter names 32 33

40 the poet as Gerhardt; on the manuscript copy he attributes it to Paul Fleming. The poem 40

41 could not be traced to either author. $\quad 41$

$42 \quad 75$ See Goethe's letter to Amalie von Imhoff, WA IV/51, p. 171.

$43 \quad 76$ The setting in B flat was first published in Zelter's Neue Liedersammlung in 1821. 43

4477 Goethe was Director of the Weimar Court Theatre from 1791 to 1817. 
So as I cannot give up the hope of seeing you, I make a proposal that I trust you 1

2 will welcome. If you could possibly find the time to make the trip to us, I would 2

3 feel obliged in my present position, and in view of the benefit I expect for the plans 3

4 to which I am committed, to cover your travelling expenses here and back, and to 4

5 provide for you during your stay. Now, if you were to weigh the inconveniences of 5

6 the journey, and the loss of your valuable time against the enjoyment you would 6

7 have through a visit here, we would not remain too much in debt to you, and 7

8 perhaps we could arrange to meet more often in the future; this might not be of any 8

9 great advantage to you, but at least you would not suffer any monetary loss. 9

10 Think it over and tell me what you think of the proposal to which I hope you will 10

11 give a favourable answer; and all the more so since you are in no way restricted as 11

12 to the time of your visit, and we should be ready to welcome you any day between 12

13 this and Whitsuntide. Your room is still unoccupied and ready to receive you. 13

14 All your friends think of you with enthusiasm, which was rekindled by your 14

15 new compositions - 'Reiterlied' and 'Der Zwerg' - which were performed again 15

16 only yesterday. ${ }^{78}$ Schiller thanks you most sincerely.

17 A new tenor has come here, ${ }^{79}$ he has a very beautiful voice, but is in every 17

18 sense a novice. What a thing it would be for him and for us if you could advise on 18

19 his future development! I mention but this one link in the chain of obligations we 19

20 should gladly owe you.

21 I need not tell you how seriously we are taking the improvement of our theatre, 21

22 and particularly of the music, for the wedding of our crown prince, ${ }^{80}$ and the 22

23 celebrations which have to be given in the last quarter of the present year, and 23

24 so on. Nor is there any need to repeat the proposals and requests I have already 24

25 made.

26 I enclose the delightful composition you asked for. ${ }^{81}$

27 If you look through Herder's early publications of Volkslieder, ${ }^{82}$ as well as his 27

28 miscellaneous poems, you are certain to find much that will interest you. When my 28

29 small concerts are given, I am very anxious that every one of my friends should be 29

30 astonished at himself, when he hears his works reproduced in your music. $\quad 30$

Can you give me your considered opinion of Madame Mara?

78 Zelter's settings of Schiller's 'Reiterlied' and Goethe's 'Hochzeitlied'; ZG 35 3 February 1803.

79 Franz Brand, tenor and actor, made his first appearance on the Weimar stage on $\begin{aligned} & 37 \\ & 38\end{aligned}$ 26 February 1803; he remained in Weimar until 1807.

80 Carl Friedrich von Sachsen-Weimar-Eisenach (1783-1853) married the Tzar's 39 daughter, Maria Pawlowna (1786-1859) in St Petersburg on 3 August 1804.

81 Zelter's setting of 'Die Erinnerung'. Goethe sent back the original manuscript; a 41

copy remains in his music collection (GSA 32/14).

82 Collections of folk songs translated into German by Herder, published in 1774, 43 1778 and 1779. 
5 I will definitely come to Weimar, at the very latest in June, and I look forward to 5

6 it like a child. For six weeks I have been watching my mother dying, suffering

7 appallingly day and night, whereby my whole house has been in disarray. ${ }^{83} \quad 7$

8 On 21 March my son ${ }^{84}$ left here for Dresden. From there he will travel on to 8

9 Weimar. I haven't given him a letter of introduction; he will announce himself in 9

10 person and ask your blessing. ${ }^{85}$

11 The enclosed reviews about Madame Mara were written by me; more about 11

12 that again. ${ }^{86} \quad 12$

$13+13$

\section{Goethe}

19 Accept with affection, dear friend, a little present, which Privy Councillor von 19 20 Wolzogen $^{87}$ will bring you from me. You enjoyed von Knebel's Spanish snuff, and 20 21 a further supply was found. Where? You shall find out when it is safely in your 21 22 hands. Fill your box with it, and sometimes when you take a pinch, whether you 22 23 are alone or in good company, think of my affection and esteem for you. That is 23 24 always an enjoyable moment.

25 The sower, when he has sown his seed, goes away and lets it sprout; ${ }^{88}$ what 25

26 a pity you cannot see how much good is springing up from what you have sown 26

27 among us. ${ }^{89}$ 1803.

$36 \quad{ }^{84}$ Zelter's stepson, Carl Flöricke (1784-1812).

$37 \quad 85$ See Goethe's diary entry on 14 May 1803, WA III/3, p. 73.

$38 \quad 86$ Zelter's reviews of two concerts given by Gertrud Elizabeth Mara in Berlin

38 appeared in the Spenersche Zeitung, no. 21, 17 February 1803 and no. 29, 8 March 1803

39 (GSA 28/1014); MA 20.3, p. 143.

$40 \quad 87$ Baron Wilhelm Ernst Friedrich Franz August von Wolzogen (1762-1809), architect,

41 diplomat and minister in the service of the Duke of Sachsen-Weimar-Eisenach. 41

4288 Reference to the biblical parable of the sower (Matthew 13, 18-23; Mark 4, 42

43 26-29).

$44 \quad 89$ Zelter stayed with Goethe from the end of May until 11 June 1803. 
5 [...] In Dresden I met Madame Mara, who was overjoyed to see me. ${ }^{90}$ She was 5

6 just about to give a concert that I attended. There, as everywhere, she has admirers 6

7 and enemies. The thing she liked best was the unexpectedly good reception which 7

8 appears to be her main priority just now.

The first thing that caught my attention in Berlin was a short biography of the 9 late Mozart, half dedicated to you, ${ }^{11}$ to which is appended an anything but short, 10

11 aesthetic description of his works, together with a poor portrait of him. Could you 11

12 possibly find out for me who is the Neudietendorfer author of this educational 12

13 work for young composers? ${ }^{92}$ The Neudietendorfers may benefit by it [...] 13

144 July: Yesterday, I saw a performance here of Schiller's Die Braut von 14

15 Messina for the first time. ${ }^{93}$ It was the third performance of the work. Madame 15

16 Meyer $^{94}$ did everything that was possible for her as Donna Isabelle; Madame Fleck 16

17 was somewhat better as Beatrice. Manuel H. Beschort sometimes showed noble 17

18 attitude; Iffland played Bohemund suitably and Bethman gave the best performance 18

19 as Cesar. The entire production was a highly polished and glorious spectacle and 19

20 the entire cast, apart from the choruses, displayed knowledge of the theatre and 20

21 attention to detail. Almost every grouping of the two brothers, the mother and the 21

22 sister betrayed a special artistic touch and the costumes were beautiful, as were the 22

23 sets, four of which were new. The final scene with the sarcophagus and its newly 23

24 composed incidental music were both superb.

The play itself is distinguished here by its length rather than by its breadth. 25

26 Long speeches in verse rhythm are not Madame Meyer's thing. She has neither 26

27 breath nor tone to carry the modulation of Schiller's lines and consequently a 27

90 Zelter travelled from Weimar to Dresden on 11 June 1803. Mara was away for 30 several months on a concert tour throughout Germany which brought her to Frankfurt am 31 Main, Gotha, Weimar, Leipzig and Dresden; there are no accounts of any concerts given by 32 her in the Dresden newspapers. She arrived in Berlin in August where she gave a concert 33 with Giovanni Carol Concialini (1742/45-1812), Italian singer at the court opera, Berlin; 34 see $A M Z 5$ (1802/03), no. 19, 2 February, column 322-4 and no. 50, 7 September, column 35 850.

42 Königliches Nationaltheater on 14 June 1803; further performances were given on 16 and 42

4320 June, and 3 July 1803 . Zelter had, in fact, attended the fourth performance. 
1 substantial part of the first and final acts were drawn out and very unclear. From 1

2 time to time she tried to pull herself together and aim at the sublime, but she had no 2

3 idea how to achieve this. With great confidence in the author, audiences here take 3

4 every opportunity, through loud and sustained applause, to encourage the artists in 4

5 their quest and seem unable to hide their thirst for what is better and higher. There 5

6 was a full house and it didn't hold back.

$7 \quad$ I would prefer not to say anything about the choruses because everything is

8 unclear and rather vague. I bet Schiller was justified and that there is something

9 behind it which we don't yet recognize. Perhaps I will write more about it to you

10 again when the play is published and I have it before me in black and white. ${ }^{95}$

11 Several choral passages were really effective, which many of my friends in 11

12 Berlin had already told me. When I think that, year in year out, day in day out, 12

13 our company must play around with so-called domestic pieces, with the study 13

14 of frivolous, ordinary, everyday material and a lot of the most common local 14

15 pedestrian events, I must admit I am amazed that they can act so expertly. Schiller 15

16 himself would not be dissatisfied with the individual performances. 16

17 The positioning of the chorus was not to my liking. I thought the chorus 17

18 should be tightly grouped on both sides of the stage and, as far as possible, in 18

19 the background, thereby separated from the main groups by the greatest distance 19

20 possible. In this way the chorus would have, as it were, the main part of the entire 20

21 play and bring the whole play to life. Metre controls delivery of the text - at 21

22 least that's the way it seems to have been rehearsed, and through his movements 22

23 Iffland indicates the rhythm. The passages which are true to the metre are the most 23

24 effective. It would be worth investigating whether the metre would not be better 24

25 maintained and the entire play would benefit if a damped beat was marked on the 25

26 drums. The chorus should be divided into two, placed on both sides. They would 26

27 alternate like the strophes and antistrophes of the ancients, and could also consist 27

28 of questions and answers. ${ }^{96}$ In any case a composer should be brought in who 28

29 would know what needs to be done. Also there should be some attempt to raise the 29

30 chorus up on a platform to make it immobile; because the mobility they have here 30

31 is neither to their advantage nor to that of the work. They could set the tone, create 31

32 the general mood to contrast with the action. I don't know how to make my feeling 32

33 clearer here; rehearsals are needed using real singers to make things easier and the 33

34 whole of it needs to be invented anew. 34

35 I would like to be instructed about the role of the Greek chorus by you. ${ }^{97}$ I never 35

36 imagined it as anything else but a living backdrop and believed, therefore, that the 36

37 chorus must be immobile. One could, of course, think of another interpretation 37

38 of the chorus, if it is not too fine or speculative: in the earliest stages of theatre, 38

39 there cannot have been an audience capable of understanding the poet. Therefore, 39

$40 \quad 40$

$41 \quad 95$ Schiller's play was published in four episodes (Tübingen: Cotta, 1803). 41

4296 Antiphonal song for two singers or two choirs (or a divided choir) following the 42

43 practice of ancient Greek music, later developed in settings of early Christian Psalms. 43

4497 Goethe's reply is given in an enclosure to GZ 28 July 1803; MA 20.1, p. 44. 
1 the poet was compelled to create everything himself: the language, the play, the 1

2 characters and also the public, and the latter could have been represented by the 2

3 chorus. At the very least the chorus has to have been of ancient origin, predating 3

4 the Greeks. They gladly took on the chorus to place it in front of their audience to 4

5 teach them how to feel and to think as the poet wishes them to and not to demand 5

6 what the poet is not prepared to give. [...] 6

7 The glorious snuff, redolent of the fragrance of all muses, is real refreshment 7

8 to me; it will be no surprise now if I write something good. 8

15 So often have I followed you in thought that I have unfortunately neglected to do 15

16 so in writing; today only a few words to accompany the enclosed sheet. I shall 16

17 continue my reflections and only touch the main points as briefly as possible; you 17

18 yourself will, of course, supply the details.

Of Mozart's biography I have heard nothing further as yet, but shall inquire 19

20 about it and about the author too..$^{98}$

21 Could you outline for me the duties of a Kapellmeister, at least in so far as it is 21

22 necessary for one like me to know, so that I may to some extent be able to judge a 22

23 man in this position, and in any case give him direction. ${ }^{99}$

24 Madame Mara sang last Tuesday in Lauchstädt; I have not yet heard how it 24 25 went. ${ }^{100}$

26 Thank you sincerely from myself and my friends, for the songs I received 26

98 The book appears to have arrived in Goethe's library only at a later stage; Goethes 32 Bibliothek. Katalog, (ed.) Hans Ruppert (Weimar: Goethe Sammlung zur Kunst, Literatur 33 und Naturwissenschaft, 1958, reprint Leipzig 1978), no. 176. Hereafter referred to as 34 Ruppert.

99 On 7 August 1803 Zelter sent Goethe a manuscript with his remarks on the nature 36 of an orchestra, for which Goethe thanked him on 29 August. Six months later, on 28 March 36 1804, Goethe asked Zelter's permission to publish it in the Jenaische Allgemeine Literatur- 38 Zeitung, hereafter referred to as JALZ. Zelter consented, though with some hesitation. At 38 first nothing happened; only when Reichardt took up the manuscript to have it printed in 39 the Berliner Allgemeine Musikalische Zeitung, which he edited, did Goethe realize that 'he 40 could not withhold the essay from an intellectual literary journal'; in June and July the essay 41 $\begin{array}{ll}\text { appeared in the } J A L Z . & 42\end{array}$ 100 The performance took place on 26 July 1803.

101 Presumably in Zelter, Sammlung kleiner Balladen und Lieder (1803). 44 
1 There was no time to think of producing anything new. Soon I hope to send 2 you the proof sheets of my poems, with the request that you will keep them secret 3 until they are published. ${ }^{102}$

5 Enclosure: In Greek tragedy the Chorus is seen in four Epochs. In the first Epoch 6 a few characters calling up the past into the present are introduced between the 7 singing, in which divinities and heroes are exalted and genealogies, mighty deeds, 8 portentous destinies, are brought before the fancy. Of this we have a proximate 9 example of the Seven against Thebes by Aeschylus. This was the beginning of 10 dramatic art - ancient style.

11 The second Epoch shows us the whole Chorus as the mystic leading character 11 12 of the piece as in the Eumenides and Supplices; I am inclined to think these 12 13 represent the lofty style. The Chorus is independent, the interest rests upon it; it 13 14 is, one might say, the republican period of dramatic art; the rulers and the gods are 14 15 mere supplementary personages.

16 In the third Epoch, the Chorus becomes supplementary; the interest is projected 16 17 upon the families, their respective members and chiefs, with whose destinies the 17 18 destiny of the surrounding people is slightly connected. The Chorus is subordinate, 18 19 and the figures of Princes and Heroes step forth in their isolated majesty. I am 19 20 inclined to think of this as the grand style. The tragedies of Sophocles stand on this 20 21 level. Inasmuch as the multitude has only to watch the hero and Fate, and cannot 21 22 influence Nature either in special circumstances or generally, it falls back upon 22 23 reflection and undertakes the office of an appointed and welcome spectator.

24 In the fourth Epoch, the action continues increasingly to confine itself to 24 25 private interests; the Chorus appears often as a wearisome tradition, as an inherited 25 26 piece of the dramatic inventory. It becomes unnecessary, and therefore is equally 26 27 useless, tiresome and disturbing in a living, poetical whole - as, for example, when 27 28 it is called upon to keep secrets in which it has no interest, and so on. Several 28 29 examples of this are to be found in the plays of Euripedes, of which I might name 29 30 Helena and Iphigenie in Tauris.

31 In order to return again to the musical thread, you will see from the above that 31 32 any attempts must be made in connection with the first two Epochs and this could 32 33 be realized in very short oratorios.

$43 \quad 102$ Goethe's 'Der Geselligkeit gewidmeten Liedern' which appeared in Goethe and 43 
5 Privy Councillor von Wolzogen has very obligingly, through an acquaintance, sent 5

6 off six copies of my songs for you. One of them is for Schiller and one is intended 6

7 for Ehlers. ${ }^{103}[\ldots]$

8 When I received your kind letter of 28 July, I had just been reading at my 8

9 leisure Schiller's preface to Die Braut von Messina, and had already begun to try 9

10 a musical arrangement of the choruses. This much I have divined: that to come to 10

11 grips properly with the new genre, I should need a quiet year. As soon as I have 11

12 completed enough for it to be recognizable, I will write to you about my discovery. 12

13 What you wrote to me about the choruses has been extremely useful, for I am more 13

14 concerned with an accurate view of the ancient Greek chorus than with one of my 14

15 own invention. The musician is so horribly subordinate to the poet, and besides 15

16 that he needs the whole strength of his art. Your idea of attempting a small oratorio 16

17 is excellent and, for more than one reason, I should like to see it carried out. It is a 17

18 new way to [access] the heart and I constantly think about it.

19 That someone could dedicate a book to you without sending you a copy ${ }^{104}$ is 19

20 totally inconceivable to me. It is dedicated to you and to Müller (probably Cantor 20

21 of the Thomasschule in Leipzig). ${ }^{105}[\ldots]$

22 Your songs should be highly welcome to me especially as I cannot compose 22

23 because there is too much work to do. I have had a painful wait for the publication 23

24 of Die natürliche Tochter, but it is not yet available. ${ }^{106}$

25 What I have written down about the orchestra, I have enclosed for you here. ${ }^{107} 25$

26 Something more complete could only be accomplished if one worked continually 26

27 with an orchestra. I would like to know whether this small piece is of any interest 27

28 to you and whether, from time to time, I might write to you on the subject; if so, I 28

29 would need to get the pages back from you as I haven't made a copy. There is much 29

30 to say on the subject and if you require information, I would gladly accommodate 30

31 you. I believe I know the essentials as well as anyone does and would be able to 31

32 speak about it just as well as others. A completely new discipline would have to be 32

33 introduced if anything is to be achieved.

103 Johann Wilhelm Ehlers (1774-1845), actor, singer, guitarist, composer; in Weimar from January 1801 to Easter 1805 . Goethe valued him as an interpreter of his Gesellige 36 Lieder, Tag-und Jahres-Hefte, 1801, MA 14, p. 65.

104 Ignaz Ferdinand Arnold, Mozarts Geist (Erfuhrt: Henning, 1803). 38

105 August Eberhard Müller (1767-1817), organist at the Nicholaikirche in Leipzig 39 from 1794; Director of Music at the Thomaskirche from 1800; appointment as choirmaster 40 and organist at the Thomaskirche in August 1804.

106 Goethe's tragedy was first published by Cotta in the Taschenbuch auf das Jahr 42 1804. 
$5[\ldots]$ You ask me about the music to the second part of Die Zauberflöte. I take you 6 to mean by that our new representation of Winter's music. ${ }^{108}$ It is being staged with 7 great pomp and will be a huge theatrical undertaking. ${ }^{109}$ An immeasurable amount

8 of new scenery, air and earth apparitions which follow one another almost from

9 minute to minute - so that the cast can barely fit their arias in - dominates the

10 piece and keeps the machine operators busy, so that they are seen here and there 11 and heard before they are meant to be. The music suits the play about as much as 12 Die Zauberflöte II fits with Part I. The score is very full and crammed with effects 13 that startle and overwhelm one's ears and senses. There is a full house every time, 13 14 though I see no signs of real satisfaction from that part of the audience for which 14 15 the piece seems to have been written; I suppose it will come in time [...] 15

16 The amount of expensive props for this opera as well as the noisy and 16 17 disturbing machinery are so mindlessly and unprofessionally put together and so 17 18 badly painted that one would turn away one's face with annoyance if one were 18 19 not attracted and drawn in at the same time. In a disturbingly dangerous way the 19 20 figures of three beautiful young women are suspended over 20 feet in the air on 20 21 thin ropes for more than half an hour and sing with such fear and trepidation, that 21 22 one's heart would skip a beat. The end of these four hours of childish pranks, 22 23 which are protracted through the insertion of three long musical scenes, consists 23 24 of the fall of the empire of the Queen of the Night: a King of Paphos, named 24 25 Tipheus, to whom the Queen of the Night wants to marry off her daughter, Pamina, 25 26 is eventually killed by Tamino and thrown into the jaws of a fire-spitting mountain, 26 27 from which the flames shoot high into the sky [and] join with a rain of fire from 27 28 above. Amid horrific crashes and bangs which completely drown out the music, 28 29 the Queen of the Night is flung down from her high perch.

30 One part of the libretto is not without humorous appeal: Papageno, who is 30 31 again bereft of his new-found Papagena, searches for her, among other places, 31 32 in a rural region where he encounters, by chance, his father, his mother and an 32 33 innumerable multitude of younger and older siblings, aged from 2 to 20 , who are 33 34 all his father's children, which gives rise to much farce and comical situations. 34 35 Apart from that the libretto is incredibly bad. [...] 35

41 Der Zauberflöte Zweiter Teil which appeared in Willman's Taschenbuch (1802), MA 6.1, 42 p. 101.

$43 \quad 109$ The performance was reviewed in the Spenersche Zeitung, 21 July 1803, MA 20.3, 43 44 p. 152. 
Regarding the composition of the chorus [from Die natürliche Tochter] I have 1

2 now made a definite decision. Namely, all the chorus lines must be sung. It is bad 2

3 luck for me that I have to do without you. When I flick through it, thousands of 3

4 ideas occur to me and the [real] question is whether I should give a singer the 4

5 bride's part at the end, not whether she should sing everything - but here and 5

6 there she will have to sing. Let me know what you think of this. In addition, I 6

7 am thinking that something has to happen with the libretto, which I can't explain 7

8 clearly because I have to handle the music in a fragmentary way. Schiller would 8

9 not be in favour of any alterations. But, to my mind, towards the end the libretto 9

10 becomes very diffuse rather than compressed; and so I would suggest that, instead 10

11 of what is in Act Four of the manuscript, you include a kind of epilogue where the 11

12 chorus, noble and detached, appears as the main character, and finds itself at home 12

13 in the highest regions that the musician can create. I would also like to know what 13

14 you think of this.

15 Madame Mara is due to arrive today or tomorrow, 14 August. ${ }^{110}$ They say 15

16 that she experienced terrible aggravation at Lauchstädt, even though - thanks to 16

17 Reichardt - her concert went off well. She had announced in Dresden that she 17

18 wanted to entertain the Electoral Prince with her talent, but when she was told 18

19 His Royal Highness was pleased to hear music during dinner, she was forced to 19

20 confess that she could not sing at a banquet. This decision cost her a hundred 20

21 ducats, and the Electoral Prince an aria. $\quad 21$

28 First, let me thank you for your songs, ${ }^{111}$ which are distributed according to your 28

29 instructions and otherwise are well-housed; thanks also for the pages on musical 29

30 direction. ${ }^{112}$ As soon as our musical exercises are taken up again, I will put them 30

31 into practice and hopefully come to the point where I can ask you for more 31

32 guidance. [...]

33 What do you think of the plans to transplant the Jenaische Allgemeine 33

34 Literatur-Zeitung to Halle? We others, who are behind the scenes, never cease to 34

35 be amazed that a Royal Prussian Cabinet, just like any other public body, should 35

36 allow itself to be fooled by names, shams, charlatanism and importunity. As if 36

37 such an institution could be taken over and transported like the Laocoon or any 37

38 other movable work of art! [...]

110 The concert is reviewed in the $A M Z 5(1802 / 3)$, no. 51, 14 September 1803, MA, 41

20.3, p. 152.

111 Zelter's Sammlung kleiner Balladen und Lieder (1803). 43

$44 \quad 112$ Zelter's essay on the orchestra sent to Goethe on 7 August 1803. 
1 For the moment things continue as usual in Jena, and as we still have Court 1

2 Councillor Eichstädt, ${ }^{113}$ the most active editor, everything will go on in its own 2

3 course. [...] 3

4 If you care to join us, you are very welcome. How good it would be if you 4

5 could use your role as reviewer to tell the public, in an orderly way, what at present 5

6 so badly needs to be said about music. $\quad 6$

7 I shall share in the undertaking, giving advice, and actively participating. 7

$8-8$

929

10 25. Zelter 10

11

12 Berlin, 7 September 180312

13

14 [...] I am inclined to recommend young Mendelssohn ${ }^{114}$ as a thoroughly useful 14

15 correspondent in Paris. He was fortunate enough, a few years ago, to have been 15

16 speaking with you at Frankfurt am Main. He is a fine young man, well read, with 16

17 good taste. He is now in Berlin, and hopes to pass through Weimar on his return 17

18 journey to Paris. If you approve, I might give him a letter [of introduction] to you. 18

19 Whatever else I can do in the interests of the Jenaische Allgemeine Literatur- 19

20 Zeitung I will do gladly in the course of time. 20

$21 \quad 21$

$22-22$

23 26. Zelter 23

$24+24$

$25 \quad$ Berlin, 1 October 180325

$26 \quad 26$

27 It is true that our theatre is in danger of being split up. The singer, Ambrosche, is 27

28 dead; Beschort should be dead; Madame Fleck is getting married and will leave 28

29 the theatre; Madame Meyer is married already but is still leaving; Madamoiselle 29

30 Eigensatz is moving to Vienna, and Eunicke and his wife have found work 30

31 elsewhere. What truth there is in all of that, time will tell! 31

$32 \quad 32$

$33-33$

$34-34$

$35-35$

$36 \quad 36$

$\begin{array}{ll}37 & 37\end{array}$

$38 \quad 38$

$39 \quad 113$ Heinrich Karl Abraham Eichstädt (1772-1848), editor of the Jenaische Allgemeine 39

40 Literatur-Zeitung. $\quad 40$

41114 Abraham Ernst Mendelssohn (1776-1835), second son of the philosopher, Moses 41

42 Mendelssohn, and father of Felix Mendelssohn and Fanny Hensel. Goethe had met him in 42

43 August 1797 in Frankfurt; see Abraham Mendeslssohn's letter to Zelter, 1 September 1797, 43

44 Jahrbuch der Sammlung Kippenberg 4, 1924, pp. 72-6. Hereafter referred to as JbSK. 44 
5 My theatre school, founded on Unzelmann's advice, has now grown to 125

6 members. ${ }^{115}$ The first fully staged performance will be given next Thursday but 6

7 it will not be open to the general public. I hope much good will come from this 7

8 venture.

9 Could you enquire after young Lauchery, the choreographer's son? ${ }^{116} \mathrm{He}$ is 9

10 employed at the cadet's house in Berlin. In our circumstances we need a man who 10

11 understands dance more than one who dances, one who has good teaching methods 11

12 and a feeling for theatrical arrangements and divertissements. He is recommended 12

13 here and I would like to get to know more about him through you. [...]

14 Would you not like to take on this year's edition of the musical journal, which 14

15 is now finished, in line with what has gone before? ${ }^{117}$ It seemed to me a good 15

16 opportunity to say something in general about the nature of music and introduce 16

17 aesthetic judgements.

24 [...] I will gladly take up the opportunity to write something for the music column 24

25 in the Jenaische Allgemeine Literatur-Zeitung. ${ }^{118} \mathrm{I}$ am working on something, 25

26 which it would be important for me to discuss with you in person. ${ }^{119}$ When I have 26

27 finished it, I will forward it to you to get your opinion; it involves some important 27

28 issues in the art [of music] and for me personally. 28

115 Goethe had started to give acting lessons the actor Friedrich Unzelmann's son, Carl 33 Wolfgang Unzelmann (1786-1843), on 14 March 1803. In July 1803 two further students 34 emerged in Bad Lauchstädt: Karl Franz d'Akácz and Pius Alexander Wolff (1782-1828), 35 Tag- und Jahres-Hefte (1803), MA 14, p. 102. See also Goethe's Regeln für Schauspieler, 36 MA 6.2, p. 703. 116 Albert Lauchery (1779-1853), dancer and choreographer in the êcole militaire in 38 Berlin; son of the court choreographer, Etienne Lauchery. $(1802 / 03)$ on 28 October and several times remembered the promise, but the idea was never 41 
1 Would Schiller be willing to compose some hymn-like verses which I could 1 2 set to music to welcome my King when he visits the Sing-Akademie? ${ }^{120}$ The King, 2 3 who has expressed his wish and desire to subsidize us, has never visited the Sing- 3

4 Akademie before. It is possible that he will visit soon and I would like to receive 4

5 him worthily. It is up to the poet; four or five verses would be sufficient and a fairly 5

6 strong choir of at least 150 voices could sing like one person producing the whole. 6

7 I want to keep it a secret; you can imagine how things are here. 7

8

929

10 29. Goethe 10

11

12 Weimar, 27 February 180412

13

14 How long have I been silent to you, dear friend, and how often have I wished to be 14

15 with you on Mondays and Tuesdays. ${ }^{121} \mathrm{I}$ have hardly heard any music this winter 15

16 and through it I feel I am missing out on one of life's great pleasures. [...] 16

17 Our newspaper is going exceptionally well. ${ }^{122}$ If you would like to take the 17

18 opportunity to write something really fundamental about music, we would gladly 18

19 publish it. Do it this winter before you get caught up with work in the spring and 19

20 the summer. [...] 20

21

22

23

30. Zelter 23

24

Berlin, 5 March 180425

25

Berlin, 5 March 180425

26

27 I should have written to you a long time ago, even before I received your second 27

28 letter, and so your apologies for not being in touch are doubly embarrassing. [...] 28

29 Heartfelt thanks for the seal. I heartily hoped for this little thing which will 29

30 soon be indispensable to me because my Sing-Akademie is now thriving more 30

31 than ever. Our Queen was with us on 3 January and on 14 February the King paid 31

32 a visit with his whole court, which gave me tremendous joy. I entertained the King 32

33 with an eight-part Te Deum for double choir, which I composed for his birthday 33

34 two years ago. ${ }^{123}$ He was obviously very pleased and paid me many personal 34

35 compliments, which I lapped up from him. $\quad 35$

$36 \quad 36$

$37 \quad 37$

$38 \quad 120$ Friedrich Wilhelm II of Prussia (1770-1840) visited the Sing-Akademie on 38

3914 February 1804. It is not known whether Schiller received Zelter's request. 39

40121 The weekly rehearsals took place on Mondays and Tuesdays in the Sing- 40

41 Akademie. $\quad 41$

$42 \quad 122 \quad J A L Z . \quad 42$

$43 \quad{ }^{123}$ Zelter's Te Deum for two choirs and soloists in D major; the manuscript is now 43

44 lost. $\quad 44$ 
[...] The minister has actually written to me [...] In the enclosed I have 1

2 recommended my beloved Sing-Akademie to the minister ${ }^{124}$ and expressed my 2

3 wish that he sanction it and place it under the curatorium of the fine arts. This same 3

4 Sing-Akademie has 200 members and consequently is a constant heavy workload, 4

5 because I have to work day and night for it. I have brought it on so much that it 5

6 will be able to sustain itself in future times if the King can house it in the academy 6

7 as happened before; and this was not exactly easy, because the mere upkeep costs 7

81,000 thaler per annum and I perform my service free of charge. [...] 8

15 Many a traveller testifies to your works and deeds, in so far as they are in the public 15 16 forum and have a public impact; your refreshing letter gives me a glimpse into 16 17 your inner life, worked by no steel spring but animated by a living spirit. I think 17 18 you are lucky to be exerting a growing, formative influence on that environment 18 19 which you have yourself created, and to have the hope that you have also achieved 19 20 something that will last. [...]

21 What our little company is able to accomplish was shown in the production of 21

22 Schiller's Wilhelm Tell, which was very fittingly performed. However, our opera is 22

23 not as satisfactory. Yesterday I recognized your remarks about so many orchestral 23

24 points, which I could make no use of because I had to abandon the chaos. May I 24

25 perhaps publish the little essay in the cultural column of the Jenaische Allgemeine 25

26 Literatur-Zeitung in the section at the end, where you will have discovered many 26

27 insightful observations about art and language? May I put 'Weimar Arts Circle' at 27

28 the end, whereby we designate the essay as ours or at least link it with our way of 28

29 thinking? If possible could you also soon write a review for us?

30 I just found your letter in which you enclosed your remarks about the orchestra. 30

31 Certainly if you saw it in print you would be encouraged to go further along this 31

32 track and to discuss it further. I would love it if you agreed. It would benefit us all 32

33 if a thing like that were brought to the attention of the general public.

34 Bye for now. I am wondering how it may be possible somehow to see you this 34

124 Zelter's second memorandum to Minister Hardenberg. Both memoranda 38 published in: Georg Schünemann, Carl Friedrich Zelter der Begründer der Preußischen 39 Musikpflege (Berlin: Hesse, 1932), hereafter referred to as Schünemann; subsequently 40 in extracts and with the pertinent correspondence in: Cornelia Schröder, Carl Friedrich 41

42 Zelter und die Akademie. Dokumente und Briefe zur Entstehung der Musik-Sektion in der 42

43 Preußischen Akademie der Künste (Berlin: Akademie der Künste. Monographien und 43

44 Biographien 1959). Hereafter referred to as Carl Friedrich Zelter und die Akademie. 
5 My essay to Minister von Hardenberg ${ }^{125}$ would soon be in your hands if I could 6 have taken the time to write a fair copy and so I send you a copy my wife made 7 from the original draft, which I have handed in and for which I ask to have back

8 in case I might need it. As yet there has been no response and perhaps there never 9 will be. However, it is necessary to know that this essay was prefaced by a letter to 10 the minister, in which two of the minister's questions were addressed: how an arts 11 academy can have influence on manufacture and industry, and how the academy 11 12 can be perfected in its own right. My proposal to the minister implied that the latter 12 13 must be a priority if the first objective is to be realized and also that the artists must 13 14 be masters of their art if they are to have any influence at all; that all the arts in 14 15 an academy must be developed simultaneously and that in our academy one art 15 16 (music) is completely wanting in that it is not scientifically grounded; that I could 16 17 make many useful proposals if permitted and so on. The minister answered very 17 18 graciously and asked me to outline my ideas and so that was how the following 18 19 essay came to be written. [...]

20 The greatest joy that my little piece of writing could give me is this: if you 20 21 should find it of value, the whole article or just in places, and would read it yourself 21 22 to Anna Amalia, because only you could convey my feeling and intent. ${ }^{126}[\ldots] \quad 22$

23 The difficulties you experience with your opera are the same as here, where the 23

24 situation also leaves much to be desired; however, despite that we still enjoy it. We 24 25 have a right to discuss something which costs us money and we have to swallow 25 26 it down whether it tastes good or not. 26

27 I did not write the comments about the orchestra with a view to publication. 27

28 What you consider practical or beneficial could be included, if you don't find the 28

29 corrections too tedious. I am happy for you to publish in the Jenaische Allgemeine 29

30 Literatur-Zeitung whatever you find useful among my report and artistic views (in 30

31 so far as they do not directly concern the Sing-Akademie about which I don't want 31

32 to say anything publicly) and reports; I will also be looking for any interesting 32

33 artistic reviews. The article in the Jenaische Allgemeine Literatur-Zeitung is a 33

34 good idea: alternation between art and science is in any case advantageous, while 34

35 it has to be said that the public is currently more concerned with art. [...] 35

36 My plan to create something of lasting value for music and in general occupies 36

37 me day and night and is increasingly aimed at establishing principles. One cannot 37

38 hope for much from a public that is still in the making. It has to be made and 38

39 created and that can only ever be done by one person, and he has to be able to 39

40

$41 \quad$ Zelter's first memorandum to Minister Hardenberg on 28 September 1803.

42126 Anna Amalia (1739-1807) thanked Goethe on 13 May 1804 for 'passing on Zelter's

43 essay on music' (Briefe an Goethe. Gesamtausgabe in Regestform, (ed.) Karl-Heinz Hahn 43

44 (Weimar: Regestausgabe, 1980ff), 4, no. 1526). Hereafter referred to as $R A$. 44 
hold his own against the crowd. I would really like to discuss the matter with you 1

2 further.

4 Enclosed: Copy of Zelter's second memorandum to Minister Hardenberg in Julie 4

5 Zelter's hand.

6

33. Zelter $\quad \begin{array}{r}7 \\ 8\end{array}$

12 Has Reichardt shown you his attempt at setting your Iphigenie to music? ${ }^{127}$ If so, 12

13 I would like to hear a word from you about it. It seems to me like an operation 13

14 carried out on a healthy developed body and the body is like a patch applied where 14

15 there is no hole. But your opinion is dearer to me than my own.

Everyone in Berlin is going on holidays and I remain here. If only I could 16 17 spend once more just six hours with you sometime, it would keep me going the 17 18 entire year. ${ }^{128}[\ldots]$

I have composed Schiller's 'Berglied' and enclosed it with this letter with the 19 20 request that you pass it on to him. ${ }^{129}$ If only I could sing it for him as well, because 20 21 it would be hard for someone to get it right. 21

30 Your essay, my honourable friend, has given me and a few of the initiated to whom 30

31 I showed it much pleasure; ${ }^{130}$ even more it has enlightened and strengthened us 31

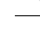

127 Zelter's en Behandlung jenes Meiserwerkes (Leipzig, 1798).

36

128 Goethe and Zelter did not meet until August 1805 in Bad Lauchstädt.

129 Zelter had received the poem from Schiller during his visit to Berlin (1 to 17 May 38 1804). In Schiller's diary he notes meeting Zelter twice: on 3 and 15 May. Zelter's autograph 38 manuscript is in Goethe's music collection, dated 21 May 1804. It was first published in 39 Zelter's Sämtliche Lieder, Balladen und Romanzen (1812).

130 Zelter's second memorandum to Minister Hardenberg which Goethe had shown to 41

Schiller and Anna Amalia on 1 May 1804. Schiller responded to Zelter directly in a detailed 42

43 letter on 16 July 1804 (SNA 32, pp. 153-55) which Goethe enclosed with his own. In Anna 43 8

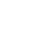
11 
1 in our convictions of what is good and right. It has come from the depth of your 1

2 character and talent and must make the most vivid impression on those who are 2

3 in any way receptive. But what will the world think of it and make out of it? - the 3

4 world which does not care to listen when complaints are formally made against 4

5 it, and which, of course, cannot dream of finding a worthy enjoyment which it 5

6 does not know, but rather snatches at some fleeting joy, which is created out of the 6

7 world itself and therefore conforms with it.

8 It is a great pity in our times that every art, which after all is surely meant first 8

9 and foremost for living, should, in so far as it is excellent and worthy of eternity, 9

10 find itself in conflict with the time, and that the true artist frequently lives alone 10

11 and in despair, in the conviction that he possesses and could impart to men what 11

12 they are seeking. $\quad 12$

13 We agree with you that first and foremost music must be improved through 13

14 hymns, and that even for a government nothing could be more desirable in every 14

15 sense than to foster an art and suitable higher feelings, and to purify the sources 15

16 of a religion which is suitable for the cultivated and uncultivated alike. You have 16

17 expressed yourself so admirably and concisely on this point that nothing can be 17

18 added to it. But what we now wish you to take to heart, for practical purposes, is 18

19 that you should, if possible, conceal your opposition to the time, and generally that 19

20 you should dwell more upon the advantages that religion and morals would derive 20

21 from such an institution, and less upon those that art has to expect from it. We 21

22 should not use our arguments to move men to the good of which we are convinced, 22

23 but we should consider what their [arguments] might be. [...] 23

24 If you have composed any poems of mine or my friends, I would ask you to 24

25 send them to me at your leisure. There is no music around here at the moment, but 25

26 I would make sure I heard anything which comes from you and would again feel 26

27 renewed by for a long time. [...] 27

2828

29 Enclosed: Copy of Zelter's second memorandum to Minister Hardenberg; 29

30 Schiller's letter to Zelter, 16 July 1804; Schiller's poem 'Der Alpenjäger'. $\quad 30$

$31 \quad 31$

$32 \quad 32$

$33-33$

$34-34$

$35-35$

$36 \quad 36$

$37 \quad 37$

$38+38$

$39-39$

$40 \quad 40$

$41 \quad 41$

42 musical essay, she agreed with the author's opinion and passed on her good wishes for 42

43 the 'implementation of his humanistic ideas'. Later Goethe showed the essay to Friedrich 43

44 August Wolf; see Goethe's diary, 10 September 1804, WA III/3, p. 107. 
35. Zelter 1

$5[\ldots]$ As your letter has been lying around for another day, I will send you a song 5

6 which I have just composed. ${ }^{131}$ Reichardt has set the Italian poem to music so 6

7 successfully, that I wouldn't consider composing it; ${ }^{132}$ instead of which I found 7

8 your parody ${ }^{133}$ and set about composing it and I will be really happy if my melody 8

9 ranks with Reichardt's setting as your parody does with the original. 9

11 Enclosure: Zelter's setting of Goethe's 'Nachtgesang'; Letter from Zelter to 11

12 Schiller, 24 July 1804.

Thank you very much for the programmes you sent me through Mademoiselle 19

20 Amelung. I look forward with pleasure to your Schiller setting, ${ }^{134}$ which we will 20

21 perform as well as possible [...]

In a month's time I hope to have a reading of my Götz von Berlichingen. ${ }^{135} \mathrm{I}$ am 22

23 entirely indebted to you that it is so far advanced. I could not understand why, over 23

24 a year past, I had dealt with my work like Penelope, forever unravelling again what 24 dolce fuoco', presumably from the first edition: 6 Canzonette con accompagnamento de 34 piano o arpa (December 1803, no. 1). collection. It is contained in the songbook which Zelter put together for his wife (SBB PK: 29 Mus. ms. autogr. Zelter 22, no. 17), dated 29 July 1804, originally only with Goethe's text, 30 Presumably in Goethe/Wieland, Taschenbuch auf das Jahr 1804 (Hagen, 36 no. 486), which appeared in October 1803. Reichardt's setting of Goethe's text, a parody 37 of the Italian folksong 'Tu sei quel dolce fuoco', first published in Gesänge mit Begleitung der Chitarra, (ed.) Wilhelm Ehlers (Tübingen, 1804), where it appeared under the title 'Notturno', though only the first stanza was published and without identifying the author 39 (because the songs were intended as a supplement to the Taschenbuch); obviously Zelter 40

41 did not know this publication.

$42 \quad 134$ Zelter's setting of Schiller's 'Berglied'. $\quad 42$

43135 From mid-February Goethe was reshaping this play; see Goethe's draft letter to 43

44 Wilhelm von Humboldt, 30 July 1804, WA IV/17, pp. 171-75. 
1 I had woven. Then in your essay I found the words, ${ }^{136}$ 'What one does not love, 1

2 one cannot do'. ${ }^{137}$ My eyes were opened, and I saw clearly how up to that point 2

3 I had treated the work as a piece of business, which, along with everything else, 3

4 had to be got rid of; this explained how I approached it, and why it had no lasting 4

5 value. From then on I devoted more attention, sympathy and concentration to this 5

6 subject; so that the work is now - I will not say good - but at least finished. 6

7 Now I would like to ask you for a couple of small pieces of music, first, for 7

8 George's song, 'Es fing ein Knab' ein Vögelein', ${ }^{138}$ which I believe you have 8

9 already set. Secondly, I want a quiet, devotional and elevating four-part hymn - 9

10 with Latin words - that would take around eight minutes to perform; it may be a 10

11 piece from a mass, or anything else of the kind. ${ }^{139}$

12 How I wish we lived nearer one another, or that we were both more mobile; 12

13 the benefit of a continual exchange of ideas is incalculable. Anyhow, let us write 13

14 to one another from time to time.

23 The song from Götz is not among my early compositions, but I have already 23

24 composed it in the joy of this morning. I would like to know whether the song 24

25 can be accompanied by orchestra or whether the boy should sing it alone without 25

26 accompaniment? And another question: would the following passage be suitable 26

27 for what you want: 'Domine Deus rex coelestis, pater omnipotens; Domine fili 27

28 Jesu Christe, qui tollis peccata muni, Miserere nostri! ${ }^{140}$ I will try to keep within 28

29 eight minutes. The Latin words are from the Catholic mass and if you are not 29

30 happy with them, I could also choose words from a Latin Psalm. ${ }^{141}$

31 Now I will ask you for a reply by return of post so that you should receive at 31

32 least one of the pieces in the next mail. [...] 32

$35 \quad 136$ Zelter's second memorandum to Minister Hardenberg which he had sent to Goethe 36 on 1 May 1804.

37 137 This citation is not in the editions of Zelter's memoranda edited by either 37

38 Schönemann or Schröder. 38

$39 \quad 138$ Goethe, Götz von Berlichingen, Act 4, scene 16.

$40 \quad 139$ In response to Goethe's request, Zelter set Psalm 111. 40

$41 \quad 140$ Domine Deus, from the Gloria of the Ordinary of the Roman Catholic Mass, was 41

42 set to music by Zelter in 1804; it was not used for the stage music to Götz. 42

$43 \quad 141$ Goethe decided upon this option and in the next letter Zelter sent him his setting of 43

44 the words 'Beatus vir' from Psalm $111 . \quad 44$ 
It will be best if I enclose the little song here. If it needs to be altered or 1

2 composed differently, I will follow your instructions; I will compose it as you 2

3 would like it. One more observation: eight minutes' devotional music is quite a 3

4 long time on the stage. Obviously it depends on the circumstances and so I will 4

5 leave it to your judgement.

The King's birthday was celebrated yesterday. ${ }^{142}$ We gathered together a group 6

7 with Hufeland, Müller, Tralles, Woltmann, the Fichtes, ${ }^{143}$ a few strangers and a 7

8 few members, myself and family and toasted the occasion well. This Tuesday I 8

9 will hold a birthday celebration in the Sing-Akademie and give a speech which is 9

10 still not written down. ${ }^{144} 10$

11 Bye for now. I will expect your instructions by return of post. 11

14 Enclosure: Zelter's setting of 'Georgs Lied' from Goethe's Götz von Berlichingen 14

38. Goethe

21 I thank you most heartily for sending me the little song so promptly, and will now 21

22 go more into detail about the chorus in Götz. It is really meant to be sung at the 22

23 nuptials of Maria and Sickingen. The simple church procession moves across the 23

24 stage to the sound of a hymn, an organ can be clearly heard in the distance, and as 24

25 the chapel is close by, the chanting may continue to be heard while a scene is being 25

26 played outside. Be so kind as to choose some words from a psalm. The character 26

27 of it, as you will observe, is gentle and solemn, inclined to sadness on account 27

28 of the circumstances; a prelude to the following scene, where those who are just 28

29 married are, so to speak, chased away by Götz. All things considered, I think you 29

30 are perfectly right in saying that eight minutes is too long; we will be content with 30

31 four. It lies within my power to fill out the rest. [...]

I am very pleased with the melody to my serenade ${ }^{145}$ and it is certainly better 32 suited to my poem than my poem is to Reichardt's very praiseworthy melody. 
1 The little song for Georg is quite deliberately without accompaniment; we will 1

2 see how the little fellow handles it!

3 I am very anxious to get this new version of Götz out of me. I should have

4 finished it long ago had its length not delayed me; for in trying to make the play

5 more theatrical, it became longer rather than shorter; what was diffuse has certainly

6 been condensed, but what was transitory has become fixed; it will still take nearly

7 four hours to play. If it is performed in Berlin, let me know your first impressions

8 and what you make of it; for with the exception of the exposition in the first one

9 and a half acts, which have been left almost entirely as they were, the piece has

10 been altogether dismantled and recomposed [...]

Farewell and forgive my rambling letter. 11

19 I am taking the liberty of sending you another copy of 'Georgs Lied'. ${ }^{146}$ It is 19 20 transposed down a semitone and is tighter and more polished, and so I think it 20 21 should be sung in a more carefree manner. In the event that it is not sung by 21 22 a young boy, the song would work if transposed into a lower key again, which 22 23 would be suitable for the voice in question. If you don't agree with the freedom I 23 24 have taken with 'So! So! Hm! Hm!', ${ }^{147}$ it could be composed strictly following the 24 25 words, although it would lose some of the feeling of ease. 25

26 In relation to the Latin church song, ${ }^{148}$ I would like to have as exact information 26 27 as possible regarding the situation and occasion. My work is, in fact, finished; but 27 28 since I don't have the right viewpoint, I don't know myself what to make of my 28 29 work and in short I am not too happy with it. I could recommend better pieces by 29 30 other composers to you, who do what they do quite well but who would not be 30 31 suitable for a new occasion [...] If you haven't fully planned the scene yourself, 31 32 then perhaps the composition of this section could wait until everything is finished 32 33 and then I promise to deliver the composition into your hands from one post-day 33 34 to the next.

$38 \quad 146$ Zelter's revised setting is not in Goethe's music collection. A copy, entitled

39 'Georg', dated 5 August 1804, is in Zelter's collection: Lieder für eine Mutter und ihre elf

40 Kinder (SBB PK: Mus. ms. autogr. Zelter 22, no. 18).

41147 Goethe's refrain; in his setting Zelter abandoned this plan and inserted further 41

42 repeats, in part omitting this interjection.

$43 \quad 148$ Zelter's setting of the Latin text 'Domine Deus rex coelestis'; Goethe decided on 43

44 the composer's second suggestion of a Latin psalm. 44 
18 August: I am to blame for not having written the review, since I promised 1

2 to; ${ }^{149}$ but the fact that it hasn't happened is also not entirely my fault. Things 2

3 continually crop up here which are not more important but are more pressing at 3

4 the moment. I am much more preoccupied with myself than ever before. I have 4

5 written to the King ${ }^{150}$ and have received a very promising reply. ${ }^{151} \quad 5$

6 If, my dear friend, you could arrange for my little piece on Fasch to be published 6

7 in the Jenaische Allgemeine Literatur-Zeitung, it would be very advantageous for 7

8 me because the paper is highly regarded. ${ }^{152}$ There has been no notice about it in the 8

9 Hallische Allgemeine Literatur-Zeitung, ${ }^{153}$ at least not that I am aware of. Perhaps 9

10 I could find out through the editors at Jena. 10

12 Enclosed: Zelter's revised setting of 'Georgs Lied'

My feeling has not deceived me. In the same moment as I read your letter of 19 208 August, I realized that my complete choral piece was worth nothing. ${ }^{54}$ What I 20 21 wrote to you about the sound of an organ appears to me to be no longer relevant, 21 22 even confusing, because the sound of the organ can't come from the same place 22 23 as the church procession, but should come from where it is going. The current 23 24 arrangement is simpler ${ }^{155}$ and will hopefully perform its function by not saying 24 25 more than it should. The orchestra begins to play as the procession approaches. 25 26 The chorus enter at bar 5; the choral procession must be arranged so that at least 26 27 the singers are all visible by the time they sing their first note, even if the largest 27 28 part of the procession is still off stage. Their entrance must be arranged so that 28 29 four steps are taken to a bar: a step to every crotchet. The bigger the chorus is, 29 30 the better; it must contain at least 12 singers: 3 sopranos, 3 altos, 3 tenors and 30 313 basses. They must articulate all the words very clearly and the orchestra must 31 32 interject powerfully, not sluggishly and not aggressively. The music takes exactly 32

33 four minutes to perform; should it happen in this performance that the moment is 33

150 Zelter's fourth memorandum, dated 1 August 1804 and sent directly to the Prussian 36

King Friedich Wilhelm III, is a very personal letter, in which Zelter describes his career 37

and his work for the Sing-Akademie, with a view to obtaining a fixed salary; excerpts are 38

4015111 August 1804; Schröder, p. 108.40

$41 \quad 152$ There is no mention of Zelter's Fasch biography in JALZ (1804) or JALZ (1805). 41

$42 \quad 153$ Allgemeine Literatur-Zeitung (ed.) Christian Gottfried Schütz in Halle. 42

$43 \quad 154$ Zelter's setting of the words 'Domine Deus rex coelestis'.

$44 \quad 155 \quad$ Zelter's setting of Psalm 111. 
1 too short or over-hasty, a reprise is marked in the score where ten bars could be 2 repeated, but only if it is necessary. The choral entries must be very secure, not 3 tailing each other, as is often the case here, but they should appear as one voice.

4 Wind instruments are not woven into the piece because the singing would suffer;

5 only at the very end do two bassoons enter one after the other. As the chorus 6 withdraws at the end, the orchestra becomes quieter, just as at the beginning it

7 became louder. The words are taken from Psalm 111 as it appears in the 1554

8 Vulgate. ${ }^{156} \mathrm{I}$ have, therefore, included the Gloria because it is used in all religious

9 ceremonies of the Catholic Church. The audience - assuming they are probably

10 situated on the stage - could speak a few appropriate words in between the Gloria 10

11 and the Psalm; I have marked a fermata on the score at this point and expect it will 11

12 work well. That's my sermon, which is longer than my music, though I hope the 12

13 latter is better and the former would be unnecessary.

14 Let me know whether the revised version of Götz also begins with the inn 14

15 scene as in the old one; when I can find enough time and peace, I would like to 15

16 write a new overture to it. Perhaps it would earn me a free ticket to the Iffland 16

17 production at our theatre. If you find you have a feeling, preparatory to Act One, 17

18 which is not closely identifiable with the first scene, I would like you to tell me, 18

19 because the overture should be attached to the hostel scene. Although it will take 19

20 care not to paint the first scene, it should try to capture much more the spirit, life, 20

21 moral weight and strength of the hero.

2224 August: Tonight I have drawn up a plan for setting Götz to music. ${ }^{157}$ The 22

23 new piece will be set in acts or large masses of material, with artistic punctuation 23

24 added not for its own sake but to enhance understanding. The overture is as good 24

25 as finished and in order to finish it, I just need a response to the questions I asked 25

26 you; I have also thought of a musical epilogue which would really add closure to 26

27 the piece, in case old Götz were to be the last person on the stage, who in your 27

28 play appears like a setting sun. To finish it I must have a copy of the complete 28

29 manuscript, which you probably won't want to let out of your hands until you 29

30 send it off. Meanwhile I would only need to have it for a few days and I could 30

31 send it back to you by return of post. Admittedly I could wait until Iffland had a 31

32 copy $^{158}$ but then Reichardt or Weber would fall on it ${ }^{159}$ and I would end up with 32

33 nothing once more. This epilogue is only 25 bars long and gains its meaning 33

34

156 Beatus vir qui timet Dominum: in mandatis eius volet nimis: the opening words of

Psalm 111. The composition, listed in Kruse's catalogue, is now lost.

157 As with many of Zelter's plans for large-scale works, this remained unrealized.

38 Zelter's only settings for this play are: 'Georgs Lied'; incidental music for the Wedding ceremony scene of Maria and Sicklingen (Psalm 111); a Gloria and the overture.

$40 \quad 158$ Zelter is referring to Iffland's production of the play in Berlin.

$41 \quad 159$ Reichardt had already published an overture and some songs from Goethe's Götz

42 von Berlichingen in the Musikalisches Kunstmagazin 2 (1791): 124, as volume five of

43 his Music zu Göthes Werken series, but never expanded his incidental music beyond this 44 publication. Bernhard Anselm Weber never composed incidental music for this play. 
1 (for the unskilled especially) only through repeated performance of the entire 1

2 piece. For this epilogue is at the same time the prologue and precedes the overture, 2

3 immediately suggesting what type of character one can expect in the course of the 3

4 play. It would also be a pleasure to find the prophecy fulfilled at the end. What do 4

5 you think of all this?

6

7

41. Goethe 8

Weimar, 10 September 180410

12 Just to let you know that your overture should work very well. The piece begins 12

13 with the hostel scene. I am caught up in rehearsals. All would be well except that 13

14 I am worried about the length. You will hear as soon as it is finished and then we 14

15 can discuss the intermezzo. A thousand greetings and thanks for your heartening 15

16 and encouraging letter.

24 Once again through Levin ${ }^{160} \mathrm{I}$ am sending you a packet of snuff, which our dear 24

25 Duchess Amalia gave me for you with best wishes. [...]

26 Levin will tell you that your choral hymn came across as very charming 26

27 and beautiful, and gave prominence to the important moment. ${ }^{161}$ I enclose an 27

28 advertisement for our art exhibition this year. I shall write again in a few days. Let 28

29 me hear from you soon.

160 Liepmann Levin, later Ernst Friedrich Ludwig Robert, and from 1814: Robert- 41 Tornow (1778-1832), brother of Rahel Levin, later Varnhagen von Ense (1771-1833). 42

161 Zelter's setting of Psalm 111 and Gloria, premiered in Goethe's revised version of 43 
5 Egmont was due to be performed on the 13th of this month but nothing came of 5

6 it. ${ }^{162}$ Madame Unzelmann told me that Schiller was not happy with Reichardt's

7 composition of the song in Egmont, ${ }^{163}$ so I took it on and my music is included

8 here. ${ }^{164} \mathrm{I}$ had to repeat the first word, 'Freudvoll', which has a dipthong and cannot

9 be treated melismatically. The two words which directly follow one after the other,

10 'Freudvoll und Leidvoll', are musically difficult to set; it depends on how you 10

11 see it. The little introduction is nothing more than a single chord: then the voice 11

12 enters vehemently, and at the word, 'Leidvoll', changes to melancholy. It becomes 12

13 livelier towards the end and the words 'Glücklich allein ist die Seele die liebt' must 13

14 be sung with increased animation. You will see how the song is received in the 14

15 theatre, where it has the failing that it does not fit in with Reichardt's intermezzo, 15

16 because for the following intermezzo Reichardt has written variations on this 16

17 theme for the orchestra which are even more beautiful than his song. ${ }^{165} \quad 17$

18 Your Court Chamber Councillor Kirms ${ }^{166}$ has written to me to ask my opinion 18

19 on the Silbermann grand piano which I saw at your ducal palace. I would advice 19

$20 \mathrm{him}$ to hold onto this instrument. You would get very little for it and the instrument 20

21 is good, even if it is out of fashion. In a palace where the good and the beautiful 21

22 have so much room, there is bound to be a remote room somewhere where this 22

23 old instrument, which is not lacking in taste, could find a modest home underneath 23

24 portraits of some old heroes of the dynasty until there comes a time when a 24

25 connoisseur takes it away and replaces it with a beaten-up fortepiano. 25

$28 \quad 162$ There is no mention of a performance (or its cancellation) in the Berlin newspapers

29 in 1804.

30163 Reichardt's setting of 'Clärchens Lied' ('Freudvoll und Leidvoll') from Goethe's 30

31 Egmont, Act 3; first published in Reichardt's Lieder der Liebe und der Einsamkeit, zur 31

32 Harfe und zum Klavier zu singen (Leipzig: Fleischer, 1798).

33164 Zelter's setting of 'Clärchens Lied' is no longer in Goethe's music collection. An 33

34 autograph in Berlin (SBB PK: Mus. ms. autogr. Zelter 22, no. 19) is dated 5 September 34

35 1804. The song was published in Zelter's Sämtliche Lieder, Balladen und Romanzen (1810), 36 vol. 1 .

$37 \quad 165$ The publication was planned in Reichardt's Musik zu Göthes Werken, vol. 5

38 (Berlin: Verlag der neuen berlinischen Musikhandlung, 1793). The $A M Z$ reported Reichardt

38 'is also working on music for Goethe's Egmont, which will be performed this winter'; $A M Z$

39 (1801), no. 11, 7 January, column 255. The performance took place on 25 February 1801 in

40 the Berlin Nationaltheater; Reichardt's music was not reviewed in the AMZ.

41166 Franz Kirms (1750-1826), court official in Weimar, 1791-1824: member of the

42 board of management for the Weimar Court Theatre, finally theatre manager and artistic

43 director. Zelter's reply to Kirms is in the Weimar Archives (GSA 95/N 10); MA 20.3, 44 p. 173. 
1 I have indeed completed a sketch to your Götz overture, but I have been out 1 2 and about so much and have had so many distractions that I won't have it for you 2 3 before the performance of the play (which apparently is just around the corner). ${ }^{167} 3$

4 If you could let me know when the premiere of Götz will be, perhaps I could find 4 5 a time where I would be in the mood to complete the work I have begun. I am on 5 6 tenterhooks and a word from you would be a great boon and comfort. There is no 6 7 word from Schiller. There was news in the papers yesterday that recently he is 7 8 seriously ill again. ${ }^{168} \mathrm{I}$ had so hoped that we would welcome him here without your 8 9 losing him, and in the end perhaps we will all lose him. 9

11 Enclosed: Zelter's setting of 'Clärchens Lied'

18 Levi, a young man whom I got to know in Lauchstädt, departed immediately after 18

19 the first performance of Götz von Berlichingen. I gave him a sealed box of the 19

20 famous Spanish snuff and he promised to give you as detailed an account of the 20

21 performance as is possible. As I haven't heard from you for a while, I fear that the 21

22 journey has taken him longer than he planned and he has not yet arrived in Berlin. 22

23 [...]

24 One more thing. Would you send me the score of your 'Wohl auf Kameraden';169 24

25 I don't have a copy to hand and it is to be rehearsed for performance in the winter 25

26 and is to replace the old popular song.

Warmest greetings from Schiller and myself. 27

Your Götz von Berlichingen is now a reality. ${ }^{170} \mathrm{I}$ was especially pleased that our 35 choir gave a good performance because it is the first piece of theatrical music 36

169 Through lack of time, Zelter could not, at first, accede to Goethe's request for the 42 score of Schiller's 'Reuterlied'; in the end Goethe had the score copied from the parts. 43 170 The premiere took place on 22 September 1804. 
1 which I have composed. ${ }^{171}$ I heard from Levi and from other quarters that Götz was 1

2 given a good performance in Weimar. The grand length of it, by the way, should 2

3 not be burdensome to us. It is the container for the whole and if it is too big for 3

4 anyone, he can drink out of bottles. The rest of us are ready to drink in one draught 4

5 what is prescribed for us! [...]

6 I will put the 'Reuterlied' score in the next post for you. [...] 6

46. Zelter 9

13 The reasons you have still not received the 'Reuterlied', even with this letter, is 13

14 because of unpleasant work which I myself, of course, have imposed on myself. 14

$15 \mathrm{I}$ had let it be known among friends that I would be willing to give a type of 15

16 workshop on the art of singing. ${ }^{172}$ Soon there were many participants and for the 16

17 last two weeks I have needed nine hours a week in which I had to prepare with 17

18 great diligence to fulfil the expectations which, without my intending it, have been 18

19 roused. Meantime I got into my stride more quickly than I would have imagined 19

20 possible and I have no doubt of a successful outcome. Well, it would have given 20

21 me much more enjoyment if I were now not forced, because of this venture, to 21

22 read a pile of terrible books on singing. More later; the post is going now! 22

\section{Goethe}

29 I have created the score of 'Reuterlied' from the parts: don't worry yourself about 29

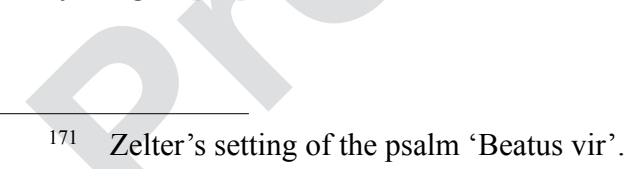

172 While his teacher, Fasch, was still alive, Zelter had begun to hold additional singing classes in 1792 with members of the choir founded by Fasch, and 'with those who wanted it, to do solfege and other useful exercises'; see 'Fragen die Sing-Akademie betreffend', namely

38 Reichardt's questions about the origins of the Sing-Akademie, answered by Zelter (GSA 95/ii, 7, 5). See also Zelter's report regarding musical and singing institutions, 'Über den Zustand des allgemeinen Gesangswesen', 11 February 1811, Akten des Kultusministeriums,

40 Berlin 158 I-III, in Alfred Morgenroth, Carl Friedrich Zelter: Eine musikgeschichte Studie

41 (Berlin: Unpublished Doctoral Dissertation Friedrich-Wilhelms-Universität, 1922), vol. 1,

42 p. 62 . See also Zelter's letter to Goethe, ZG 8 May 1816. Zelter's student Emil Fischer pays

43 homage to Zelter as singing and composition teacher in his Rede beim Wohltätigkeitsfeste

44 des Berlinischen Gymnasiums am 20 Dezember 1834 (Berlin, 1836), pp. 7-29.

\section{5} 36 
116 December: I am really sorry that I am unable to take part in your lectures. ${ }^{173} 1$

2 It is according to my nature to live in a small place; but the worst thing about it 2

3 is that one has hardly anything to enjoy apart from what one dishes up oneself, 3

4 whereas in a bigger place one can easily and often be entertained by others. [...] 4

5

6

7

48. Zelter $\quad 7$

8

Berlin, 22 December 18049 introduce me to things in art and science that I don't yet know and then I will have 15

16 fulfilled more than one aim.

Today I am trying to digest an incredible operatic mêlée, Die Sternenkönigen, ${ }^{174} 11$ which I saw for the first time yesterday and which is so immeasurably bad that we 12 are all at war with it while playing and seeing it.

My [singing] course progresses nicely. The best I can hope for it is that it will 14

17 If you were to have a free hour then I would recommend a little task for you: 17

18 to think up a plan for a little roguish Singspiel of one or two acts which is also 18

19 quite frisky.[...]

Just before my arrival home, Ehlers was here ${ }^{175}$ and brought greetings from you 26

27 and from Schiller. He didn't want to delay so I don't know whether I will get to 27

28 speak to him. He has arrangements made for today and tomorrow and didn't leave 28

29 any indication as to how I might see him.

30 Recently I have composed a new song by Schiller, 'Die Gunst des 30

31 Augenblicks', ${ }^{176}$ in which an increasingly larger musical form is attempted; I will 31

32 send it with Ehlers if I see him. [...]

175 In January 1805 Wilhelm Ehlers travelled to Berlin to give concerts with a letter 41 of recommendation from Goethe. 
5 A few words to accompany the enclosed documents which I ask you kindly to pass 5 6 onto young Voß. ${ }^{177}$

7 I have now set the song to music three times. ${ }^{178} \mathrm{I}$ am sending you the final 7 8 product, since it is probably needed. If I come up with something better, I will send 8 9 it on. The singer will do her best with it and she must see to the insertion of the 9 10 melody into the spoken dialogue with a natural, quiet expression. I will write to 10 11 Voß as soon as I can free myself from all diversions and all the running around. ${ }^{179} 11$

18 Since I last wrote to you, ${ }^{180} \mathrm{I}$ have had very few good days. I thought I was losing 18 19 myself, and now I lose a friend, ${ }^{181}$ and in him one half of my existence. ${ }^{182}$ In truth, I 19 20 ought to begin a new way of life, but at my age there is no longer a way. Therefore 20 21 each day I can only look straight ahead of me and address immediate concerns 21 22 without worrying about the future.

23 As people try to turn every loss and misfortune into some diversion for 23

24 themselves, I am being urged by our theatre company, and many others, to honour 24

25 our departed friend's memory by a stage performance. ${ }^{183}$ I shall say nothing further 25

26 about this, except that I am not against it and all I should like to ask you just 26

27 now is, whether you would be willing to assist me in this, and first of all - if you 27 enquiring whether he had received the manuscript of his setting from Othello.

$37 \quad 180 \quad$ GZ 29 January 1805.

38 Johann Christoph Friedrich Schiller (1759-1805) died in Weimar on 9 May 381805.

39182 Quotation from Horace's Carmina I, 3/8, where Virgil is described as 'animae 40 dimidium meae' (the half of my soul).

41183 Goethe's original plan was to complete and stage Schiller's Demetrius, Tag- und

42 Jahres-Hefte 1805. The memorial performance for Schiller was, in fact, staged in Bad

43 Lauchstädt on 10 August opening with a scenic performance of Schiller's 'Das Lied von 44 der Glocke', to which Goethe had written an Epilog zu Schillers Glocke. 
1 would be so kind as to let us have your motet, Der Mensch lebt und bestehet ${ }^{184}$ for 1

2 which I see a notice in the twenty-seventh edition of the Berlinische Musikalische 2

3 Zeitung. ${ }^{185}$ Would you also either compose something else in a solemn style, or 3

4 search out and forward to me some compositions, whose character I will specify 4

5 to you, in order that suitable words may be added? As soon as I hear your response 5

6 to this, you shall have further details. 6

7 Your admirable series of short essays on the arrangements of the orchestra I 7

8 have kept by me up to now, ${ }^{186}$ not least because they contained a sort of satire upon 8

9 the state of affairs here. Reichardt now wishes to have them for the [Berlinische] 9

10 Musikalische Zeitung. ${ }^{187} \mathrm{I}$ am going back to them, looking at them, and I cannot 10

11 possibly withhold them from the review section of our [Jenaische Allgemeine] 11

12 Literatur-Zeitung. Some of our circumstances have changed somewhat and in the 12

13 end we are allowed to criticize even what we ourselves have brought about. 13

14 Privy Councillor Wolf of Halle is here at present. ${ }^{188}$ If only I could hope to see 14

15 you too this year. Is there no possibility that you would come to Lauchstädt at the 15

16 end of July, to assist preparing and carrying out the work mentioned above? ${ }^{189} 16$

17 Think it over, and tell me whether it is possible; the means we can think about 17

18 afterwards. [...] 18

19

184 The opening words of Matthias Claudius's poem, composed as a motet for double 25 choir (both SATB) by Zelter in 1803.

185 Founded by J.F. Reichardt, Berlin's first notable journalist. The journal was 27 short-lived (1805-06). In this journal Reichardt and others had reported a celebration in 28 memory of the deceased Academy director, Johann Wilhelm Meil, on 12 February 1805, at 29 which Zelter's Requiem, a Haydn motet and Zelter's eight-part motet Der Mensch lebt und 30 bestehet were performed. The latter was analysed in detail by Reichardt.

186 Zelter's Bemerkungen über das Orchesterwesen were enclosed in a letter to 32 Goethe on 7 August 1803. They were, in fact, published - issued in separate articles - in 33 June and July 1805: 'Planiform des Orchesters', JALZ 66 (1805), 17 June, column 567f; 34 'Direktion des Orchesters', JALZ 67 (1805), 19 June, column 575; 'Der erste Violinist', 35 JALZ 68 (1805), 22 June, column 583f and JALZ 69 (1805), 24 June, column 591f; 'Stärke 36 des Orchesters', JALZ 70 (1805), 26 June, column 599f and JALZ 71 (1805), 29 June, 37 column 607f; 'Stimmung des Orchesters', JALZ 72 (1805), 1 July, column 615; 'Proben', 37 JALZ 73 (1805), 3 July column 623f; 'Tempo', JALZ 74 (1805), 6 July, p. 631; 'Stellung 38 der Instrumente', JALZ 75 (1805), 8 July, p. $639 \mathrm{f}$.

188 Christian Wilhelm Friedrich August Wolf (1759-1824) arrived in Weimar on 41

30 May and remained there until 14 June.

189 Goethe's request is reissued on 22 July; Zelter declined on 30 July due to an 43 overload of work and also financial commitments. 
5 I have not written to you, dear friend, for so long that it is a source of anxiety to 6 me. Although I have written many a letter in that time, it would have been perhaps

7 impossible for me to write you a proper letter without some special reason. Your

8 dear letter of 1 June woke me up. I have just received it and am answering it

9 straight away, even though it can only be posted from here next Wednesday the

1012 th.

11 My motet is enclosed, ${ }^{190}$ but I doubt that it will suit your present purpose ${ }^{191} 11$

12 because it is in eight parts and needs a choir of at least 32 good choral singers if 12

13 it is to be effective. As a result I did it mainly to try my hand at a type of music 13

14 which is rarely used or looked for today. It would also work well if the vocal parts 14

15 were doubled by an orchestra (however, without wind instruments). By the way, 15

16 I also enclose the opening movement of my Requiem, ${ }^{192}$ which perhaps might 16

17 also be useful in so far as it only requires a choir of 16 to 20 singers and four 17

18 soloists; the choir could also be supported by the orchestra. But why do we want to 18

19 make do with borrowings? I should think it would not be difficult for you to make 19

20 something special or arrange for it, and I could send you the music as soon as it is 20

21 possible. ${ }^{193}$ The pieces mentioned above are really intended for the church and I 21

22 am afraid they won't be suitable outside this context. [...] 22

23 I read Rameaus Neffe $e^{194}$ for the first time yesterday and really enjoyed it and it 23

24 really hurt to realize that you know more about the art of music than I do. I have 24

25 never read anything that had my eyes so out on springs as this book. One can be 25

26 astonished at oneself in understanding this book and I think to myself: you could 26

27 not resist translating it, if translating it you did. Your remarks about the people in 27

28 the book are so admirable that I would have to admire you, even if you had written 28

29 nothing else.

30 The unexpected death of our beloved Schiller has caused a general sensation 30

31 here in Berlin [...] for just now, when Schiller is played, the house is always full - 31

32 a rare thing for this time of year.

33 Then let us too do something in this matter, something which shall be a lasting 33

34 connection with a lasting subject. (Natural for us.) If you are not under too much 34

$37 \quad 190 \quad$ Zelter's setting of Matthias Claudius's Der Mensch lebt und bestehet, motet for

38 mixed double-choir; the score is not in Goethe's music collection.

39191 A memorial performance for Schiller.

$40 \quad 192$ Presumably Zelter's Requiem composed in memory of Fasch and first performed

41 on 3 August 1802; the manuscript is now lost.

42193 Zelter's promise was not realized.

43194 Rameaus Neffe. Ein Dialog von Diderot aus dem Manuskript übersetzt und mit 
1 pressure, it might be a soothing, healing employment for you, and I will pull 1

2 myself together and do what I can. 2

3 I would love to pay a visit to Lauchstädt. Just finding you there would be 3

4 reason enough; however, I will not be able to manage it. My wife has been so sick 4

5 this winter, that she has to drink pyrophosphate at the spa itself; as a result I am 5

6 alone with all my children and work and have no help. 6

7 The Requiem that I enclose is the one we performed in Schiller's memory at 7

8 the Sing-Akademie on 21 May, at which our good friend Jacobi attended. 8

9 Farewell and give me the happiness of hearing reassuring news of you. 9

17 Many thanks for your prompt dispatch of the music I requested. ${ }^{195}$ As soon as 17

18 possible I will try to find an opportunity to hear it. Furthermore, I share your 18

19 conviction, that we should have no patchwork on this occasion but should create 19

20 something out of the whole piece. Unfortunately, I have never been so lucky as 20

21 to have a first-rate musician by me to collaborate with, so in cases like this I have 21

22 always been obliged to keep to cobbling and patching, and on this occasion I had 22

23 expected it to be the same again.

24 You shall now at least hear about my plan ${ }^{196}$ as soon as possible and do let me 24

25 know what you think of it. But our intention, as well as our work, must be kept a 25

26 secret until we are ready and can proceed to performance with an easy mind.

While working on Rameaus Neffe, and things related, I often thought of you, and 27

28 wished for only a few hours conversation with you. I know music more by reflection 28

29 than by enjoyment and therefore only in the general sense. I am glad you found this 29

30 little volume entertaining; the dialogue is also a genuine masterpiece. [...] 30

31 Privy Councillor Wolf of Halle was with me for a fortnight. ${ }^{197}$ The presence of 31

32 this highly capable man has supported me in every sense. I am expecting Jacobi to 32

33 arrive any day. ${ }^{198}$ Why can I still not hope to see you this year?

Farewell, and write to me again soon so that such long pauses may not arise. 34

195 Zelter's motet Der Mensch lebt und bestehet and the opening movement of his 36

196 Goethe's notes for an oratorio libretto for a memorial celebration for Schiller on 1038

39 November 1805 , Schillers Totenfeier, WA I/16, pp. 561-9. Although in principle he agrees 39

40 with Zelter about the creation of a new work, Goethe eventually considered the project 40

41 unrealistic from a practical perspective. 41

$42 \quad 197$ Friedrich August Wolf was in Weimar from 30 May to 14 June 1805.

43198 Friedrich Heinrich Jacobi (1743-1819) was with Goethe from 23 June to 1 July 43

441805. 
5 I am perfectly prepared for your plan and await its arrival. As soon as I know your 5 6 thoughts, you will have my response by return of post. I will put all other work 6 7 aside in order to perform what I can with diligence and at leisure. I am rushing to 7 8 get this letter into today's post.

15 At the moment I have in mind to do a dramatic production of Schiller's Glocke; 15

16 what might come of it if I had your help! Do come! 16

23 My desire to be with you and your recent invitation to join you at Lauchstädt, 23

24 brings me almost to the point of despair. I am up to my neck in so much work and 24

25 drudgery that I cannot leave the place and must stay at home. Apart from that, a 25

26 week from today the King's birthday will be celebrated at the Sing-Akademie, ${ }^{199} 26$

27 for which I have made all kinds of preparations and am not quite finished yet. 27

28 [...]

\section{Goethe}

$35 \mathrm{Up}$ to today I have been flattering myself, though with only a faint hope, that I 35 36 would see you here. It is one of the saddest conditions under which we suffer, that 36 37 not only death, but even life separates us from those we most esteem and love, and 37 38 whose assistance could be most beneficial to us. ${ }^{200} 38$

$40 \quad 199$ The birthday of King Friedrich Wilhelm III on 3 August was officially marked by 40

41 the Sing-Akademie on 6 August. 41

$42 \quad 200$ After the celebration of the king's birthday, Zelter made a rash decision to travel 42

43 down to Goethe and he arrived in Bad Lauchstädt on 9 August 1805, a day before Goethe's 43

44 memorial celebration for Schiller. Carl August wrote to Goethe on the same day: 'As I am 44 
So that this letter may be dispatched at once, I will move immediately from 1

2 such sorrowful reflections to a request. I am going to give a dramatic representation 2

3 of Schiller's Glocke, ${ }^{201}$ and beg you to help me with it. Read the poem through, 3

4 and send me an appropriate overture for it, by any master. ${ }^{202}$ Then, in the middle of 4

5 the fifth verse, declaimed by the master, after the line, 'Say a holy word', I should 5

6 like a short chorale, for which the words, 'In all we strive to do Thy grace, O Lord, 6

7 be near' might form the text. Then the following four lines, as far as 'With waves 7

8 of fiery brown' would be spoken again. The chorus would then be repeated, or, if 8

9 you like, musically developed.

10 In the final chorus, I should like to hear the words 'Vivos voco. Mortuos plango. 10

11 Fulgura frango' 203 in a fugue, which, as far as possible, should imitate the pealing 11

12 of bells, and, as suits the occasion, lose itself in 'Mortuos plango'.

If a good idea should occur to you, do me the favour of elaborating it, and send 13

14 me the scores direct to Weimar where I shall soon return.

If it were possible for this gift to reach me by 19 or 20 August, its arrival 15

16 would be very timely; for I should like to open the season in Weimar with this 16

17 performance.

I hope then to send you the other poem, or at all events a sketch of it, ${ }^{204}$ which 18

19 20 could be given on 10 November, in honour of our friend's birthday.

More in the next few days, 20

writing this, Zelter walks in [arriving] from Berlin. My joy at seeing this superb man and 23 to have him for several days is immense.' Zelter's visit was very short, as the next letter he 24 wrote was from Berlin on 13 August.

201 The memorial performance took place in Bad Lauchstädt on 10 August. The 26 evening included performances of Maria Stuart by the Weimar Court Theatre, Schiller's 27 'Das Lied von der Glocke' and Goethe's Epilog zu Schillers Glocke. Zelter's music was 28 not ready in time. When the performance was repeated on 19 August, Zelter's choral finale 29 was performed for the first time. The first Weimar performance of Schiller's Glocke with 30 Goethe's Epilog took place on 10 May 1806. Goethe's Epilog was later composed by 31 Bernhard Heinrich Romberg (1767-1841) and Max Bruch (1838-1920).

202 Zelter could not deliver an original composition or another suitable piece on time. 33 On 25 August he informs Goethe of his completion of the overture for Schiller's Glocke. 34 After many attempts to finish the music, he seems to have finally given up the project 35 around the beginning of 1806 .

203 'I call on the living. I mourn the dead (lit) I break the flashes of lightning', 36 468). (1468).

204 The planned libretto with music by Zelter for Schiller's memorial celebration. 39 Goethe's sketch is not published. In Goethe's view, 'this was mainly due to his musical 40 friend', as he wrote to Friedrich August Wolf on 5 January 1805. For his part Zelter justified 41 himself by saying, 'I had already started the work. I don't know what Goethe had completed - 42 he was seriously ill' (Zelter to David Friedlaender, 27 October 1808, on the occasion of 43 sending a schematic plan - written in Goethe's own hand - for Schillers Totenfeier). 
5 I have arrived back in Lauchstädt, and am dictating this in the rooms where your 5 6 presence made me so happy.

7 I have been to Magdeburg with Privy Councillor Wolf and from there went on

8 to Helmstadt, where I found many interesting people and things. Afterwards we 9 went via Halberstadt, past the Harz and returned to Halle via Aschersleben. ${ }^{205}$

10 Here I am quite alone again, after sending my son August, who has accompanied 10

11 me so far, back to Weimar, ${ }^{206}$ and I am looking back on all the good that has 11

12 happened to me during the last eight weeks and trying by degrees to remember 12

13 what we agreed upon.

14 An ancient work that fell into my hands, ${ }^{207}$ almost accidentally, will be useful 14

15 for this purpose; you will receive with this letter my translation of a translation. ${ }^{208} 15$

16 As soon as I can revise it according to the original, the wording will, of course, 16

17 sound quite different, but I dare say you will find no more food for thought in it 17

18 then than you do now, since the expressions are still a bit halting. 18

19 Do write, and send your letter soon to Weimar. Before I leave these parts you 19

20 shall hear more from me. In particular, I am now dictating something about the 20

21 underlined passage of the old mystic. ${ }^{209}$ A thousand farewells and thanks for your 21

22 visit, which made me glad to be alive again and increased my happiness. 22

30205 This journey took place between 14 and 27 August and is recounted in unusual 30

31 detail in his Tag- und Jahreshefte (1805).

32206 Goethe's secretary, Friedrich Wilhelm Riemer (1774-1845), Goethe's wife (from 32

3319 October 1806), Christiane Goethe, née Vulpius (1765-1816), and Goethe's 16-year old 34 son, August (1789-1830), had accompanied Goethe to Lauchstädt. Christiane and Riemer 35 went back on 12 August; August travelled to Halle and Helmstedt, returning home on 3629 August.

$36 \quad 207$ An unknown Latin edition of Plotinus's works, most likely Plotini, Platonicorum coryphaei, opera quae extant omnia trans. Marcellus Ficinus (Basel, 1515), which Goethe had borrowed from the Weimar Library on his return from Lauchstädt on 18 September 1805.

40208 Goethe's translation of Plotinus, Ennead, V, Book 8, chapter 1, (ed.) Marcellus 41 Ficinus, (Basel, 1515).

$42 \quad 209$ What Goethe dictated was his critical response to the content of this passage: three 43 aphorisms which he later integrated in the collection of aphorisms, 'Aus Makariens Archiv' 44 in Goethe's Wanderjahre. 
59. Zelter 1

5 In your letter dated 4th of this month, which arrived here while I was still in 5

6 Lauchstädt, you wished to have the music to [Schiller's] Glocke by 19th or 20th 6

7 of this month. Today is already 25 [August] and I have just finished the overture. 7

8 But I did arrive back here on the 13th and needed a week to settle myself back into 8

9 my regime as well as to tie up the many loose ends in my affairs, which had got 9

10 quite out of hand.

11 I am continuing to work on it every day and so the thing will be ready in time; 11

12 when exactly I really can't say. Work is very slow when one is not able to stay with 12

13 it and is disturbed by many external matters.

20 Above all, I need from you an indication as to how far the music for [Schiller's] 20

21 Glocke has progressed. I don't want to produce it in the old way because you 21

22 always establish a work through its first performance and afterwards the public, 22

23 even the more educated [public], is no longer receptive. Meanwhile time has 23

24 moved on and the prologue will probably be published before I have it performed. 24

25 At the same time that doesn't matter very much as long as we are not too late. So 25

26 please tell me soon what the prospects are. [...] 26

[...] Meanwhile I have finished the music to Schiller's Glocke as far as the finale, 35

36 but I will need some quiet days before I can be back on track, something which is 36

37 difficult in my present circumstances. Today is already 26 October and the question 37

38 is whether late November will be time enough? Whatever happens I will start on it 38

39 again next week and try to get into it. I will keep you informed of my progress. 39 
5 On 9 November, the same day we wished to commemorate Schiller in our theatre, 6 the Royal Russian Emperor was happy with our performance of Wallensteins 7 Lager. As soon as you kindly send us your work we will make up for lost time.

8 How are your music classes going? I, too, have set aside one morning in every

9 week, where I lecture to a small circle on my experiences and convictions, relative 10 to natural history. ${ }^{210}$ This opportunity will enable me to realize for the first time 10 11 what I possess and what I do not possess.

12 Madame Jagemann has also finally arrived back. The programmes had arrived 12

13 earlier and they, too, as a sign that you are thinking of me, brought me happiness. 13

14 Let me hear from you again soon. Before long, the results of my own quiet activities 14

15 will give you some pleasure.

22 With this letter you will receive a packet of fresh morsels, given to me on the 22

23 occasion of my birthday, so lovingly celebrated last Wednesday by all the members 23

24 and friends of the Sing-Akademie, amounting to 250 in total. ${ }^{211}[\ldots]$

25 My building projects are continuing into the winter and for almost three 25

26 months I have felt so unwell that a persistent feverish tension has rendered me 26

27 incapable of attending to matters of the spirit; as a result the music for Glocke is 27

28 not yet finished. ${ }^{212}$ Not that I can say that I feel any better. Instead, everything is 28

$30 \quad 210$ The so-called Mittwochgesellschaft, consisting of Duchess Luise Augusta (1757- 30

31 1830) and her daughter, Caroline (1786-1816), Maria Pawlowna (1786-1859), Charlotte 31

32 von Stein (1742-1827), [Luise Antoinette] Charlotte von Schiller (1766-1826), Frau 32

33 Friederike Sophie von Schardt (1755-1819), [Magdalena] Henriette von Knebel (1755- 33

34 1813), Luise von Göchhausen (1752-1807), sometimes also in the presence of the Duke, 34

35 Carl August (1757-1828), Karl Ludwig von Knebel (1744-1834) and Christoph Martin 35

36 Wieland (1733-1813). The lectures on his research and experiments in natural science

37 took place on Wednesdays from 10 a.m. to 1 p.m.; see Goethe's Physikalische Vorträge

38 schematisiert, MA 6.2, p. 1271 .

39 of the Englishes Haus, the celebratory speech was published by Dieterici: Rede bei der

40 Geburtstags-Feier des Herrn Zelter, im Kreise der Sing-Akademie gehalten von August

41 Hartung (GSA 143/22).

$42 \quad 212$ Up to 1810 Zelter's work for the Sing-Akademie was unpaid. In order to earn a

43 living for himself and his family, he continued his building business. As a result of the war 44 in 1806, building work in Berlin had almost come to a standstill and in December 1808 
1 immeasurably sour for me, because a wretched sluggishness in my bones makes 1

2 me tired every time I move. 2

3 But that doesn't mean that my part in this work has lapsed, and as soon as I am 3

4 up on my feet again it will be finished with all haste. 4

5

6

64. Goethe 7

8

11 It belongs to the perverse ways of the world, that you, whose birthday I ought to be 11

12 celebrating, should celebrate your birthday with me by sending me precious foods 12

13 to savour. You have our thanks daily as we eat them. If only we were not separated 13

14 by such a great distance, that we could hope to see you among us sometimes. 14

15 The good effects of your Lauchstädt visit ${ }^{213}$ have lasted well and within the first 15

16 six months of the year you will get to see things which I can recommend to you in 16

17 advance. Since I hadn't heard from you for a long time, and the work you promised 17

18 hadn't arrived, ${ }^{214}$ I regretfully assumed that you must be unwell this winter, for I 18

19 know that you do much out of love for me even when it inconveniences you. Don't 19

20 leave the good work aside; surprise me with it later on. 20

21 You have a copy of Wunderhorn at home. ${ }^{215}$ Does it stir up any strong feelings? 21

22 Share with me the melodies which it must certainly have inspired. That's enough 22

23 for today; it is just to show that I am thinking of you and to break the silence. 23

\section{Goethe}

30 I haven't heard from you for so long, my dear, excellent friend, and I understand 30

31 that things are for you much the same as they are for us. Everybody has so much 31

32 to do in his own circle that there is hardly any time to look around outside. 32

Zelter realized that for 26 months he had earned virtually nothing professionally and had 34 as good as resigned from the building trade; the appointment to Professor of Music at the 36 Akademie der Künste in July 1809 finally put him in a position to give up his practice as 37 a builder; however, it was only in 1815 that Zelter officially resigned from the builder's 37
guild.

43 Des Knaben Wunderhorn. Alte deutsche Lieder gesammelt von Achim von Arnim 42

43 und Clemens Brentano (2 vols, Heidelberg, 
1 Meanwhile I have been busy in various ways ${ }^{216}$ and before too long I hope what I 1

2 have in progress will bring you some joy. You, too, are, no doubt, busy tending to 2

3 the pleasure and edification of many people, which unfortunately I am not able to 3

4 partake in so easily. $\quad 4$

5 The idea of visiting you and Berlin has often attracted me; but so many things 5

6 detain me here and of course I cannot see when it will all come to a merciful end. 6

7 As I feel a pressing need not merely to see you but also to get a clear picture of 7

8 your surroundings and to give you a clearer picture of mine, the thought occurred 8

9 to me that I might send my son to you. ${ }^{217} \mathrm{He}$ could bring you my greetings and in 9

10 the full bloom of youth, at which time worldly matters make a strong impression, 10

11 could take in the image of such a great city and also bring it back fresh for my 11

12 pleasure. $\quad 12$

13 Although he is already a steady and self-contained boy, I still wouldn't like to 13

14 send him alone and think of him in an urban whirlpool. I was wondering whether 14

15 you might find accommodation for him near you and look after his needs in 15

16 the beginning. I will send you a letter of credit so that all the money he needs 16

17 won't be in his pocket. I won't say any more, because everything else depends 17

18 on the circumstances. The main question is: whether such a visit would be too 18

19 inconvenient for you. I would give him letters of introduction to my other friends 19

20 in Berlin and the rest would work itself out. But above all, I would like to know 20

21 that he is set up in a safe place. The visit would not last more than a fortnight or 21

22 three weeks. He could arrive in Holy Week. A thousand greetings and please let 22

23 me have an answer soon. 23

24

Goethe 24

25

26

31 It is bad when in the dispersive confusion of the world, the excitement from outside 31

32 interferes with artistic production. Under such circumstances there are times when 32

33 one forgets his capital when no creditor appears to remind him of it. So it has 33

34 happened to me, more or less. I am everywhere in debt and since the summer I 34

35 have hardly - or not even - thought of composing. 35

36 In recent days I have got rid of a very uncomfortable sore throat which my 36

37 illness of over three months appears to have developed into. I feel freer now and 37

38 my old cheerfulness seems about to be restored. Your letter, which I have just 38

39 received, will hopefully reinforce what my own sturdy constitution has begun, and 39

40 so work will start again on our Glocke, so that it can soon be performed. $\quad 40$

41

$42 \quad 216$ Goethe's Farbenlehre and Faust I.

$43 \quad 217$ The visit was always postponed and plans for August von Goethe's visit were 43

44 finally relinquished in June 1806. 
Our court enjoys the illustrious presence of your heir to the throne and the 1

2 grand duchess. ${ }^{218}$ Today, for the first time, I spoke to von Wolzogen ${ }^{219}$ in Professor 2

3 Fichte's Sunday colloquium. ${ }^{220}$ He told me that the heir to the throne had asked 3

4 for me, but since he is staying in the King's palace, I didn't want to visit him 4

5 unannounced. There is no end to the comings and goings there. Next Tuesday or 5

6 the Tuesday after, I am thinking of entertaining him at the Sing-Akademie and 6

7 then I will definitely get a chance to speak to him.

8 My Sing-Akademie is flourishing and awaits your arrival. Come soon and 8

9 come before my summer is over.

... and so here I take up this letter on 11 March, two months later, which even 10

11 today perhaps would not happen if I didn't have to answer your dear letter of 11

125 March. Everything is taken care of for your son's arrival. If he doesn't come 12

13 earlier than Holy Week I will take him into my home, and, whatever things are 13

14 like here, he will be with me where I can look after him well. If he were to come 14

15 earlier everything is still taken care of and you can be fully confident sending him 15

16 off. My wife is about to give birth and is due any moment. All the signs are good. 16

17 I would love your son to be here at the latest by Holy Thursday so that he could 17

18 hear Graun's Passion Music, ${ }^{221}$ which he won't hear anywhere else and will never 18

19 again hear performed with such perfection. Everything else will be looked after 19

20 when he arrives and you can count on it that you won't be under obligations to 20

21 anyone in Berlin as a result of your son's visit. In any case, as soon as he arrives 21

22 he must come to my address, no.1 Münzstraße, so as not to be wandering around 22

23 unnecessarily. and his wife, Maria Pawlowna, née grand Duchess of Russia.

219 Baron Wilhelm Ernst Friedrich Franz August von Wolzogen (1762-1809), 27 architect, diplomat, resident in Weimar from 1801.

220 Fichte had advertised his Sunday lecture series in the Berlin newspapers on 29 7 January 1806. The first lecture took place on 7 January, 12-1 p.m. in the round hall of 30 the Akademie buildings; a second lecture took place on 26 January 1806; no further dates 31 are known.

221 Carl Heinrich Graun (1703/4-59), Kapellmeister to the court of Friedrich II, 33

34 best-known for his Passion Music. Princess Anna Amalia commissioned the libretto from 34

35 Carl Wilhelm Ramler and suggested to Graun that he compose it. The first performance, 35 which was given by J.P. Sack's Musikübende Gesellschaft in the Berlin Cathedral on 2636 March 1755, marked the beginning of performances in the main churches of Berlin on 37 Good Friday which lasted until the end of the nineteenth century. The first performance 38 of the work by the Sing-Akademie, which took place on 12 April 1796, was also the first 39 official performance of a large-scale work with orchestral accompaniment presented by 40 the singing society, founded in 1791. From 1801 performances took place in the hall of 40

42 Zelter's death the work was part of the standard repertoire of the Sing-Akademie. The 42

43 performance mentioned in this letter took place on 4 April 1806: AMZ 8 (1805/06), no. 30, 43

4423 April, column 478; MA 20.3, p. 193. 
1 I had made a wonderful plan. The music for Glocke is finished to the point 1

2 where it can, as it were, be tried out by and made suitable for a particular orchestra. 2

3 With that in mind I wanted to come to Weimar and perfect it there; this has all been 3

4 thwarted by this mild, crazy winter, for I have had to work almost every hour so 4

5 that my family would not go hungry. Finally, I confess that for the sake of your 5

6 Prince and Grand Duchess I didn't want to leave here, for I hoped they would want 6

7 to hear some proper music done very professionally. [...] Yesterday evening I 7

8 finished a very good piece of church music, which, in memory of a worthy preacher 8

9 who passed away five weeks ago, will be performed next Sunday. ${ }^{222}[\ldots] \quad 9$

10 Now I will make a suggestion: when you son is here, collect him from Berlin. 10

11 Naturally I can't offer you my house, but think about it. I don't think it is such a 11

12 bad idea. $\quad 12$

$13+13$

$14+14$

$15 \quad$ 67. Zelter $\quad 15$

$16-16$

$17 \quad$ Berlin, 18 March 180617

$18 \quad 18$

19 Instead of being able to report something joyful, something pleasant to you, I 19

20 lift myself out of the depths of sorrow to tell you that yesterday, without any 20

21 warning and contrary to all expectations, I lost my lovely, beloved wife just before 21

22 childbirth. ${ }^{223}$ The child was brought into the world after her death and was also 22

23 dead. 23

24 I don't know yet what I am going to do or how I will bear it. I am alone again 24

25 now. $\quad 25$

26 If I say that in the ten years of our marriage we were always of one mind and 26

27 felt the same about everything, whether it was within us or external to us; that 27

28 there was no fibre of her that did not love me, I am able to say that she really 28

29 deserved to be known by you, for that was one of her wishes. 29

30 She will be buried tomorrow morning. I am alone and have plenty of room. 30

31 Send me your son as soon as you can; he should be nowhere else but with me. My 31

32 address is: 1 Neue Münzstraße.

$33 \quad 33$

$34-34$

$35-35$

$36 \quad 36$

$37 \quad 37$

$38 \quad 38$

$39-39$

$40 \quad 40$

41222 Zelter's cantanta, Der Fromme geht dahin, composed in memory of Theodor Karl 41

42 George Woltersdorf (1727-1806). 42

43223 Zelter's second wife, Juliane Karoline Auguste (1767-1806), died on 16 March 43

44 1806. Their son, Felix, was stillborn. 
68. Zelter 1

$5[\ldots]$ I am using my new solitary state and the need to keep busy to write to you and 5

6 gather my thoughts bit by bit, which have been scattered as a result of my tragic 6

7 circumstances. I am healthy and will regain my strength, once the next difficult 7

8 days are over in which every new sight reminds me of my deepest sorrow, which 8

9 I treasure as if it were healing me.

10 In Lauchstädt it was said to me, your Farbenlehre would appear in the Easter 10 11 exhibition. ${ }^{224}$ You don't seem opposed to the idea of sending the director of our 11

12 Kunstakademie, the court painter Frisch, ${ }^{225}$ a signed copy through me. Without 12

13 this fine fellow the Sing-Akademie would perhaps have gone under this year, and 13

14 I would like to do something to delight him. He is very old. As I am certain that 14

15 he holds you in very high regard, I am sure I can be very nice to him in this way, 15

16 which is the reason why I am taking the liberty of reminding you. 16

23 I had hardly sent off my letter announcing the postponement of August's journey, 23

24 when yours arrived with this unexpected and traumatic news which has really 24

25 dismayed me. At the very time when Berlin is on my mind more than ever, when 25

26 we were planning a visit in the new Münzstrasse ${ }^{226}$ and I am hoping to get a clearer 26

27 picture of yourself and your surroundings from my boy just as he brought me 27

28 back the picture of my mother last year, ${ }^{227}$ you are experiencing a violent wrench 28

29 which I feel with you in every sense. I must now think of you as lonely in a 29

30 large household with many demanding tasks to attend to, or else my thoughts turn 30

31 to myself and I imagine this happening to me. Unfortunately the obstacle which 31

32 delays my deputy cannot be cast aside, ${ }^{228}$ otherwise I should send him at once, for 32

33 the presence of a new, friendly and loving person, would perhaps be a comfort to 33

224 Although Goe did not appear until 1810

225 Johann Christoph Frisch (1738-1815), Court Painter under Friedrich II, Director 37 of the Akademie der Künste, Berlin. 
1 you, and the good to which it would give rise, would probably counterbalance any 1

2 inconvenience it might occasion. It would also be a comfort to me to know that a 2

3 representative of my sympathy and of my heartfelt concern was with you; but even 3

4 this is not to be, and all this happens at a time when I, too, have many burdens to 4

5 bear. No more! Let me hear from you soon. 5

6

Goethe 6

7

8

70. Zelter

13 I have resumed work but cannot get back on track; above all, it won't come; no 13 14 matter what.

15 I am like a split tree. The lovely half, that of summer, is separated from me and 15

16 this half is beset by everything that causes pain.

17 My friends want to get me out of the house, to bring me out of myself, but I 17 18 won't do it. Only I can make myself whole again and I will overcome [my loss]. 18 19 I feel my strength and hope to retain some of it, but I want the full experience of 19 20 my present condition.

21 Five days ago I had no premonition of my misfortune and I can honestly say it 21 22 made me happy to be having another child and to make up the dozen again. ${ }^{229}$ My 22 23 youngest son was born on Good Friday and as a result she called him Raphael. ${ }^{230} 23$

24 She believed she was carrying another boy, which was to be called Felix, and now 24

25 it has come to this. $\quad 25$

26 On Saturday, the day before she died, she went into the church to hear the 26

27 rehearsal of my music. ${ }^{231}$ I was not meant to know, and how overjoyed I was to see 27

28 her there. She said so many pleasant and intelligent things about it afterwards, that 28

29 it was only then that I knew what I had achieved. She said she had felt the weight 29 30 of her body for the first time, which was the reason she couldn't sing along. $\quad 30$

31 O my friend, why have you not heard this sweet, powerful voice [...] which 31 32 she has now taken with her to the grave. Her pure heart poured forth from her 32 33 mouth like a fresh, enlivening zephyr; it was touching, bringing ease. When she 33 34 sang in the choir of the Sing-Akademie, I could recognize her voice in a choir of 34 35150 without her having to project. The sound was light and flowed easily when 35 36 she opened her mouth. Two years ago even when her voice was affected by nerves, 36 37 she sang with Madame Mara in a local church. ${ }^{232}$ Friends of Mara's contested and 37

39229 Zelter's family consisted of three stepchildren: Henriette, Caroline and Carl 39

40 Flöricke; six children from his first marriage: Adelheid, Georg, Julie, Doris, Rosamunde 40

41 und Auguste; two children from the second marriage: Adolph Raphael and Clara. $\quad 41$

$42 \quad 230 \quad$ Adolph Raphael was born in Berlin on 22 March 1799.

43231 Zelter's cantata Der Fromme geht dahin. 43

$44 \quad 232$ AMZ 5 (1802/03), no. 27, 30 March 1803, column 453f; MA 20.3, p. 195. 
1 believed the heavenly voice belonged to their favourite. One of our connoisseurs 1

2 had said: now you see ...

3 You know, my noble friend, my opinion of Mara, whom in terms of ability, 3

4 basic virtuosity, and taste, no other German singer has matched, but her voice had 4

5 two dangerous breaks, which sometimes like an evil fate, even when she is well- 5

6 prepared to sing, come between what she intends and what she produces and cause 6

7 embarrassment even to her great talent. My wife's voice, in a range of two and a 7

8 half octaves, was like a series of equally polished [notes] which flowed into one 8

9 another and at the same time were distinct, resulting in a cantilena, which didn't 9

10 surprise you but always enraptured you the more you heard her sing. [...] 10

11 It is Saturday and I will say farewell; the letter must go in the post. 11

18 [...] Many thanks for your letter. Write to me from time to time. I will let you hear 18

19 from me from time to time, even though I can, at present, be quite withdrawn. I 19

20 have not been in great form lately. I must seek out time to make progress with 20

21 editing works of mine that are to be published. ${ }^{233}[\ldots] \quad 21$

28 As I haven't heard from you at all, I cannot stop thinking about you without 28 29 anxiety. I imagine you afflicted by your old complaint, alone, brooding, turned 29 30 in on yourself. I am now as frightened as a child; the slightest unsuspected thing 30 31 frightens me. On the 13th of this month, my wife's mother arrived in time for 31 32 lunch. We had a friendly happy meal together; the following morning she was 32 33 dead. ${ }^{234}$ She was 82 years old, and with that, lively, sociable, active, and I can also 33 34 say beautiful - and so she was taken from us. Two months ago my sister died ${ }^{235}-34$ 35 I don't know what I am to do. I ask you earnestly to let me hear from you. Also 35 36 your son is not coming. I had forgotten that if your son came in the company of 36 which was originally planned by Cotta as volume 4 of Goethe's collected works, though it, 39 in fact, appeared as volume 8.

234 Dorothea Luise Pappritz, née Hildebrandt (1725-1806) died on 14 April 1806 in 41

Berlin.

43235 Marie Charlotte Syring, née Zelter (1754-1806), Zelter's second sister, died in 43

44 Calbe on 16 January 1806. 
1 a guide or an attendant, that I would be perfectly equipped to put up both, since 1

2 a bright, healthy, warm room, two beds and whatever else my house provides, is 2

3 ready to receive dear guests.

423 April, evening: I have just received your dear letter of the 19th of this 4

5 month, which has calmed and comforted me now that I know you were occupied 5

6 with such pleasant work. [...]

7 We have a new magic opera. Levi, who calls himself Robert on the book,

8 created the text and our Kapellmeister Himmel a really nice score. ${ }^{236}$ The public

9 are still not too sure how to receive the work, in so far as they are embarrassed to

10 consider such magical works as good [...] If only this opera were not so long for 10

11 what it is (it plays for four hours) and the music were not always impossible to 11

12 play, I would consider it the best of its kind, although I have only seen it once. The 12

13 whole production has a truly modern tendency in that it represents the theatrical 13

14 character of our time in a nutshell. The beautiful, the good, the high, the low, 14

15 the fluctuating, the charming, the complex, the intoxicating, the grotesque, the 15

16 glorious, the rollicking, the dark, the adventurous, the unbridled - in short, the 16

17 individual externalities of contemporary art that must always resort to old marvels 17

18 to relight its torch which will not burn because it has no new oil - speaks very 18

19 clearly to him who will listen. The author is a Jew, so you can imagine what he 19

20 must put up with because in addition to this he is one of the poetic poets. The 20

21 Berlin state and learned newspaper critics will not forgive him for this, even if they 21

22 wanted to show mercy to a Jew.

29 [...] My loneliness has its good moments in that I get a rest from life, so to speak. I 29

30 gathered everything around me that belongs to my wife and so I keep myself busy 30

31 in my own way and to me it is as if she was still alive. Sometimes it hits me really 31

32 hard when I must recall the past and yet I must move on, bear the loss and be silent. 32

$33 \mathrm{I}$ am healthy. In two months I expect to marry my daughter to my sister's son; ${ }^{237} 33$

236 Die Sylphen by Friedrich Heinrich Himmel (1765-1814), pianist and composer

for the Berlin Court. The libretto, after Gozzi's Zobeis, was written by the Berlin writer

Ernst Friedrich Ludwig Robert (formerly Liepmann Levin and from 1814 known as Robert-

40 Tornow). The premiere was on 14 April 1806 at the Königliches Nationaltheater, Berlin.

41 Zelter had attended either the premiere or the performance on 20 April. The opera was

42 performed five times in Berlin (between 14 April and 30 May 1806).

43237 Zelter's eldest step-daughter, Henriette Flöricke (1780-1849), married Johann 43

44 Ferdinand Syring, a son of Zelter's sister Luise, on 14 September 1806. 
1 then I will have more room. My eldest $\operatorname{son}^{238}$ works as a foreman, the second ${ }^{239}$ is 1

2 learning to be a bricklayer, the third, ${ }^{240}$ who goes to school, is not without talent, 2

3 wild, learns with difficulty, is physically strong and teases his sisters. The girls, 3

4 of whom there will be six when the bride has gone, all go to school and are all 4

5 healthy. I dare not think what it will be like when our bride is gone. I have a very 5

6 hard life ahead of me, but let it come and I will not be afraid of anything transitory. 6

7 [...]

8 Saturday evening, 21 June: On 12 June the Academy of Arts and Mechanical 8

9 Sciences appointed me as an honorary member and assessor ${ }^{241}$ and has given me 9

10 an official certificate. You can imagine how dear this is to me because of the Sing- 10

11 Akademie and I ask you to draw attention to it in the [Jenaische Allgemeine] 11

12 Literatur-Zeitung.

I'll close so this letter doesn't miss the post again 13

$21[\ldots]$ The most recent news I can give you is that everything is as it was in the past, 21

22 that I'm healthy and I that I think about you every hour, every day.

23 Tomorrow evening after the Sing-Akademie I think I will go to Potsdam for 23

24 a few days to have a look at the musical treasures of the deceased king. ${ }^{242}$ I have 24

25 something in mind which I will let you know about if it transpires. [...] 25 
5 My Sing-Akademie has been suspended since 14 August. ${ }^{243}$ I have left the thread 5

6 lying so that when it is possible I can take it up again where I left it, but there is no 6

7 prospect of this to date. [...]

8 Let me know whether your art treasures were spared. In the local academy 8

9 where I had left my lovely scores, I found the cabinet broken into, but I haven't 9

10 missed anything yet. The main works and monographs are there and because the 10

11 collection is very large, I would need a few weeks to go through it and I have 11

12 neither sufficient time nor sufficient light because the days are so short and dark. 12

$13[\ldots]$

14 Apparently, Schmidt wants to enlist actors and singers for the Viennese 14

15 Theatre, though he has not said anything to me about it yet, nor have I asked him 15

16 about it. ${ }^{244}$

Bye for now. If only I had the chance to speak to you again. 17

19

Zelter 18

33 the Sing-Akademie: 'In recent times the general concern of patriotic people is affected 33

34 by external circumstances, which are important enough to hinder our artistic endeavours. 34

35 For that reason we are cancelling our usual rehearsals in order to continue them in more

36 favourable circumstances. I, myself, will attend for my usual hours and will personally look after the welfare of the institute, since it is so close to my heart.' In Martin Blumner, Geschichte der Sing-Akademie zu Berlin (Berlin: Horn \& Raasch, 1891), p. 37. Hereafter referred to as Blumner. The society reassembled for the first time on 10 February the 39 following year in the usual venue.

40244 As a result of Schmidt's conversation in Weimar, in January 1807 offers were 41 made from Viennese theatres to the Weimar actors and singers Henriette Beck, Friedrich

42 Haide, Karl Unzelmann, Heinrich Stromeyer and Friederike Vohs. It led to an engagement

43 for Henriette Beck and Friedrich Haide; the former did not take up the post and the latter 44 resigned after a few months. 
5 A thousand thanks dear friend, for having finally broken this painful silence. ${ }^{245}$

6 I have been thinking of you every day since 14 October, ${ }^{246}$ and even as I write to

7 you, a sealed letter, addressed to you, is lying on my desk, which I didn't have 7

8 the courage to send off. For what can we say to one another? On 12 December I 8

9 celebrated your birthday in silence ${ }^{247}$ and so too in the future we shall only be able 9

10 to celebrate what is dear to us in silence.

11 Anyhow I have got through these bad days without much damage. It was not 11

12 necessary for me to take part in public affairs, as they were sufficiently well- 12

13 attended to by excellent men; ${ }^{248}$ and so I was able to stay in my cell and brood over 13

14 my inmost thoughts.

15 During the worst hours, when one could not but be anxious about everything, 15

16 my greatest fear was losing my papers, and since then I have been sending 16

17 everything I can to the printers. My Farbenlehre is making big strides. [....] 17

18 Some proof sheets of my works, published by Cotta, have arrived. Some of the 18

19 poems of the first volume will, I hope, call forth melodies from you, which will 19

20 make us feel we are the same as ever. It is wonderful that you found your musical 20

21 treasures unharmed. I am sorry that you are so bogged down by administration and 21

22 so many other things Schmidt tells me of. However, in the current situation, it is 22

23 not in our power to say how we would like to be active. Your good spirit will never 23

24 leave you; likewise may your good courage never fail you. Let me hear something 24

25 from you occasionally; I will write too. $\quad 25$

245 The exchange of letters between Goethe and Zelter was interrupted from the end 31

32 of August to mid-December on account of military events surrounding Napoleon's invasion 32 of Sachsen-Weimar and Prussia. Zelter broke this silence in the previous letter, recounting 33 affairs in Berlin.

246 The date of the battle of Jena and Auerstedt. On 15 October Napoleon entered 35 Weimar, on 16 October he ordered that the plundering should cease and on 17 October he 36

departed. On 26 December, the day he wrote to Zelter, Goethe reopened the theatre.
247 Zelter's birthday is 11 December; Goethe's diary for 1806 observes his friend's 37
38 birthday, WA III/3, p. 182.

42 illness), had an audience with Napoleon in the Weimar Palace on 16 October in which they 42

43 asked the emperor that the plundering be stopped for the sake of protecting the State of 43

44 Sachsen-Weimar. 
5 I have a good opportunity to send you here the first delivery of my [collected]

6 works. ${ }^{249} \mathrm{I}$ had hoped that they would reach you in peaceful times, but since even

9 Let me hear from you soon. I don't know what to write about myself, other 9

10 than I use the quiet times, which are granted to us at present, as best I can, in order 10

11 to protect from oblivion and transitoriness what I have thought and what I have 11

12 achieved. $\quad 12$

13 If you could be inspired by some of my songs to compose them, it would be a 13

14 very welcome sign of your existence and your empathy 14

15 Enough for now, with heartfelt greetings from my family 15

$16 \quad$ G 16

$17-17$

18

19

78. Zelter

23 When I read the first edition of the [Jenaische Allgemeine] Literatur-Zeitung 23

24 in January, ${ }^{250}$ my old determination rose up powerfully in me and I decided to 24

25 compose music for which the lovely long nights would have to yield up the time. 25

26 I composed the enclosed poem ${ }^{251}$ for want of a better one, and I have done with it 26

27 what I can.

28 On Easter Sunday I performed the work in public. ${ }^{252}$ It was received favourably 28

29 even by our guests and I earned nearly 800 thaler for the work, with which I will 29

30 pay my debts and establish new credit.

249 The first four volumes of Goethe's collected works published by Cotta containing

36 poetry (vol. 1), Wilhelm Meisters Lehrjahre (vols 2 and 3) and theatrical works (vol. 4).

$37 \quad 250$ Zelter is referring to the article by Johann Heinrich Meyer and Goethe,

38 'Unterhaltungen über Gegenstände der bildenden Kunst als Folge der Nachrichten von den

38 Weimarischen Kunstaustellungen', JALZ 4 (1807): pp. i-xii.

39251 Presumably the libretto to Die Auferstehung und Himmelfahrt Jesu, eine geistliche

40 Kantate von Carl Wilhelm Ramler, komponiert von Carl Friedrich Zelter (Berlin: Unger,

41 1807). The work is neither in Goethe's music collection nor in his library; a copy is held in

42 the Goethe Museum in Dusseldorf (KK 1774).

43252 The oratorio was performed for the first time on 29 March 1807; AMZ 9 (1807), 43

44 no. 29, 15 April, column 464; MA 20.3, pp. 208-09. 44 
What would I have given for you to have been able to hear the music! I tried to 1

2 realize our idea of a chorus in my own way, and despite the poem, have not been 2

3 unsuccessful [...] Perhaps it has even enhanced it in the most meaningful parts. 3

4 The choir performed the whole resurrection episode as well as the ascension 4

5 into heaven, and the whole thing came across forcefully and with clarity. By the 5

6 way, this chorus is a permanent presence throughout the work and is interposed at 6

7 crucial points to make its presence felt - and without it nothing can happen. 7

8 The desire to write a choral work has awoken in me but I cannot find a [suitable] 8

9 subject. If only I could find someone here who would write me the verses. Think 9

10 of a [suitable] subject and tell me. Among my local acquaintances, there is a man 10

11 who can write quite nice verses and who could be useful to me and I could send 11

12 you what he produces before I set it to music. It doesn't have to be spiritual in 12

13 nature, as long as it is heroic. Since it will be a while before any proper building 13

14 can be done, for the time being I will have to write music to earn a living. 14

15 I have repeatedly received proposals from Vienna, which I have, admittedly, 15

16 not even declined, but I cannot leave here yet, nor do I want to - even if the 16

17 conditions offered were favourable. I have been sent a melodrama from there 17

18 containing choral sections (Hypermestra, the noble Danaide) but it is so modern, 18

19 so shallow and so empty that I will take care not to waste my efforts on such a 19

20 libretto. . $^{25}$

21 I am waiting impatiently for the first volumes of the new edition of your works. 21

22 Make sure I get a copy straight away. Since the invasion ${ }^{254}$ I haven't read anything 22

23 other than Die Propyläen, ${ }^{255}$ which have helped me in the composition of my 23

24 music; if perhaps a genuinely musical book might have seduced me into wanting 24

25 to write something better than I am capable of.

While I was thinking this morning that you could well have received my last letter 32 by now, Privy Councillor von Müller sent me your delightful package with the 33 lovely books and your letter of 27 March. The enclosed setting ${ }^{256}$ composed itself 34

253 The text sent to Zelter could not be established. A work of the same title by 36 Heinrich Schmidt was later published in the Wiener Hof-Theater Taschenbuch auf das Jahr 37 1814 (Vienna, 1813), pp. 109-31; neither a setting nor a performance could be traced. See 38 Wolfgang Schimpf, Lyrisches Theater. Das Melodrama des 18. Jahrhunderts (Göttingen: 39 Palasetra, 1988), vol. 2, p. 239.

44 collected works published by Cotta, vol 1, p. 98 . The copy in Goethe's music collection is 44 
1 on the spot as I was reading the poem. When I was reading sorrow fell like a dead 1

2 weight from my heart, and if the melody is suitable then it is hardly surprising and 2

3 no thanks to me.

4 After I sent my last letter off in the post I heard the news about the Grand 4

5 Duchess Amalia's death. ${ }^{257}$ I will never come across another like her. Who will 5

6 our dear songs appeal to from now on when everything worth loving is no more? 6

$7 \mathrm{I}$ knew well that she was old and was full of dread for a time that could not be 7

8 averted, but still I must mourn at a distance.

925 April: Since yesterday I have set to music another five of your poems ${ }^{258}$ and 9

10 am working on another: 'Stirbt der Fuchs, so gilt der Balg' ${ }^{259} \mathrm{I}$ have, as you might 10

11 say, through-composed this but am not exactly unhappy with it. The title suggests 11

12 to me a party game with which I am not familiar. Let me know the nature of this 12

13 game. Something is missing from my setting and I guess it is the knowledge of 13

14 this game. I need to know soon while the idea of the composition is still fresh and 14

15 new. $\quad 15$

16 Of the poems in volume one, I have now set 36 and several more will follow 16

17 later. There are some I will not set since Reichardt has done them unsurpassably, 17

18 for example: 'Das Veilchen'; 'Heidenröslein'; 'Der untreue Knabe'. ${ }^{260}[\ldots]$

19 I am impatiently waiting the approaching spring, and God only knows what it 19

20 will bring. But we live in hope: pacem te poscimus omnes. ${ }^{261} 20$

21

22

27 Warmest thanks for setting my song. ${ }^{262}$ Just now it is most refreshing to be able to 27

28 take refuge, if only for a short time, in a light and easy mood. [...] 28

dated 23 April 1807 (GSA 32/16). The song was published in vol. 2 of Zelter's Sämtliche Lieder, Balladen und Romanzen.

$40 \quad 259$ Zelter's manuscript is dated Berlin, 24 April 1807.

41260 J.F. Reichardt, Goethes Lieder, Oden, Balladen und Romanzen mit Musik, I-IV, (4 41

42 vols, Leipzig: Walter Salmen, 1809-11), nos 104, 10 and 110 respectively. 42

43261 'We all ask peace of you.'

44262 Zelter's setting of Goethe's poem 'Vanitas! Vanitatum vanitas'. 44 
Our Grand Duchess [Anna Amalia] is a great loss, ${ }^{263}$ at a time when so much is 1

2 turned upside down and chaotic. We must reflect no further on this subject, nor on 2

3 anything else at the present time. We must live on from one day to another, and do 3

4 and accomplish what is still possible. [...]

57 May: Your letters, which arrived one after the other, really delighted me and I 5

6 will continue to reply to some points. How I would have loved to have been able to 6

7 hear your oratorio: ${ }^{264}$ but I am, unfortunately, so cut off from music and although 7

8 we sometimes have really good voices, the little bits of operetta here and there 8

9 are not enough. And so it seems as if all sound, all song in me has disappeared, 9

10 and with it all my musical imagination. Perhaps good fortune and a reasonable 10

11 project will bring us together again and we will be in a position to collaborate on 11

12 something.

13 That you liked my Elpenor ${ }^{265}$ gives me the greatest pleasure and the object of 13

14 those pages has now been achieved. [...] I am looking forward to the enjoyment 14

15 you will get from the continuation of my Faust; ${ }^{266}$ it contains things that will also 15

16 interest you from a musical point of view. [...]

17 Farewell, and write again before Whitsuntide, and then send me news of 17

18 yourself to Carlsbad.

26 It is a long time, my very dear friend, since you heard from me. [...] Write and tell 26

27 me how you are getting on. I have thought of you a thousand times, and of what 27

28 you have accomplished as a private person, without the support of the wealthy and 28

29 powerful, and without any special encouragement. Perhaps what we have most to 29

30 regret from political change is mainly this: that under its old constitution Germany, 30

31 and especially the Northern part, allowed the individual to cultivate himself as far 31

32 as possible, and it allowed everyone to do what was right in his own way, without, 32

33 however, there ever being any special interest shown in him by the community at 33

34 large.

35 To these general and certainly inadequate reflections, which I should like 35

36 to discuss further with you in person some day, I wish to add a special request, 36

37 which I beg you will kindly comply with soon. Although we have both voices and 37

39263 See Goethe's obituary, Zum feierlichen Andenken der Durchlauchigsten Fürstin 39

40 und Frau Anna Amalia, MA 9, p. 929.

41264 Zelter's cantata Die Auferstehung und Himmelfahrt Jesu.

$42 \quad 265$ Goethe's tragedy Elpenor. 42

43266 Faust: Ein Fragment was published in 1790; Faust I was first published by Cotta 43

44 in Goethe's collected works (1808). 
1 orchestra in Weimar, in addition to which I am the person in charge, ${ }^{267} \mathrm{I}$ could 1

2 never secure musical enjoyment with any definite regularity, because the terrible 2

3 relation between life and the theatre invariably destroys the higher purpose for 3

4 which alone they exist or ought to exist. Schleswig has sent us two new people 4

5 again: a very good tenor ${ }^{268}$ and a kind of répétiteur. ${ }^{269}$ I have not yet made their 5

6 acquaintance, but they seem to be good, intelligent people. 6

7 I do not care to concern myself with opera as it exists here at the moment, 7

8 particularly as I do not have a complete knowledge of such musical matters. 8

9 I should therefore prefer leaving the secular age to itself and withdrawing into the 9

10 spiritual. ${ }^{270}$ I should like now once a week to have sacred part songs performed at 10

11 my house, in the same way as at your Sing-Akademie, though it would be a pale 11

12 reflection of it. ${ }^{271}$ Help me to achieve this, and send me some part songs for four 12

13 voices, ${ }^{272}$ not too difficult, and with the parts already written out. I will gratefully 13

14 reimburse you for any expense involved. Let me know whether such scores are 14

15 available in print or engraved. Canons, too, and whatever you may think useful 15

16 for the purpose. You will always be in our midst in spirit, and heartily welcome 16

17 whenever you care to appear in person. Write me a few lines here, for I shall 17

18 remain here another month, and send me a parcel to Weimar, that I may begin at 18

19 once when I get home. Farewell, and rest assured of my lasting friendship. 19

Goethe 20

21

22

23

$28 \quad 267$ Goethe occupied the position of Senior Director of the newly-founded Weimar

29 Court Theatre, where plays as well as operas and Singspiele were staged.

30268 Otto Morhardt (d.1813/14), singer in Weimar from 1807-09.

31269 The opera singer Rudolf Karl Heß (b.1769), singer and actor; in Weimar 1807-8/9.

32 See Goethe's Tagebuch, 14, 20, 21 and 27 September 1807, WA III/3, pp. 275, 277 and 33279.

270 Goethe pointedly compares the opera-loving century and its secular music to the

271 On his return from Carlsbad, Goethe immediately implemented this plan; see the time being Rudolf Karl $\mathrm{He} \beta$ arranged rehearsals, took on the role of music director and performances took place on Sunday at lunchtime; see Goethe's diary: 4, 11 and

3918 November 1807 WA III/3, pp. 292, 294 and 297. The first Sunday concert (for an invited 40 audience) took place on 20 December 1807 in Goethe's home; see Tag- und Jahres-Hefte 41 1807, where Goethe mistakenly dates the concert 30 December 1807, MA 14, p. 196.

$42 \quad 272$ Zelter, who had nothing suitable to hand at that time, at first recommended songs by

43 Josef Haydn which were available in publication and which Goethe immediately ordered.

44 Zelter in fact sent Goethe the promised setting for a small choir in the following letter. 
82. Zelter 1

5 [...] I set up a ripieno school ${ }^{273}$ in March, which gave me a lot of work without too 5

6 much to show for it. Finally I am continuing the Sing-Akademie two days a week. 6

7 I am doing it so quietly that the members I don't want there won't notice, and this 7

8 is what I am working on from week to week. [...]

9 And to turn to what you requested again: I don't have many spiritual works 9

10 which you could perform at your home with less than four or six people because the 10

11 majority of what I possess are for a large, well-established choir, and they are also 11

12 old works, which contemporary singers are not very favourable towards, because 12

13 they never learn to sing them well without wanting to, without perseverance and 13

14 thorough direction. But I will send you what is appropriate. For the time being I 14

15 would recommend a collection of four-part choral works by Haydn, which are, 15

16 in their own way, very good and which were published by Härtel in Leipzig ${ }^{274} 16$

17 about two years ago and which you could probably buy in Weimar. Then I will 17

18 also send you some short songs from here, the majority of which, however, have 18

19 bad German texts. As I don't possess copies of them myself, I will have to search 19

20 them out and send them to you from time to time. But if you would like to spend 20

21 the autumn in Berlin, then you would hear something which is not too bad. After 21

22 that I will leave for Italy; that means the Sing-Akademie is as good as lost for it 22

23 can't survive. I can see that and it makes me sad. It is now 250 strong and I cannot 23

24 see who will keep this ship afloat. It is one thing to maintain a paid orchestra and 24

25 another to keep a group of so many amateurs together. Do come! You should find 25

26 a good excuse. Privy Councillor Wolf is here. ${ }^{275}$ He swallows down a piece of 26

28 To counter the difficulties of performing old music with instrumental 28 29 accompaniment, Zelter had formed the Sing-Akademie's own Collegium Musicum, which 29

30 had commenced with his seminars on 10 April 1807 and met every Friday (additional 30

31 rehearsals on Thursday at midday for older music works connected with the Sing- 31

32 Akademie). In his diary, kept from the beginning of the rehearsals, Zelter names the players: 32

3310 first and 10 second violins; 8 violas; 8 cellos; 4 double bass; 3 flutes; 2 oboes; 2 horns; 33

343 bassoons; 3 trumpets and timpani. Instrumental works by Handel, Johann Sebastian Bach, 34 Hasse, Albinoni, Geminiani, Quantz and others were studied. The accompaniment of arias 35 performed by members of the Sing-Akademie was part of the programme. In accordance 36 with its original remit, the ripieno school played for the Sing-Akademie performances, 37
for example, the performance of Handel's Alexanderfest. See Georg Schünemann, Die Singakademie zu Berlin 1791-1941 (Regensburg: G. Bosse, 1941), pp. 27-9; Schünemann 38 published the diary with Zelter's entries, the manuscript of which is still missing today.

40274 Joseph Haydn, Drei- und vierstimmigen Gesänge mit Begleitung des Pianoforte 40

41 (Leipzig: Breitkopf und Härtel, 1803).

43 Eloquence in Halle to Berlin in 1807, where he was soon named a member of the Academy 43

44 of Science and was invited to play a role in establishing the future university. 
1 work that history has worked at for a thousand years as if it were a cup of tea. That 1

2 can't be healthy. For the rest, he feels at home in Berlin and whether we keep him 2

3 [here], time will tell. 3

$4 \quad 4$

525

6 83. Zelter 6

$7 \quad 7$

$8 \quad$ Berlin, 23 to 24 August $1807 \quad 8$

929

10 Enclosed is a package of choral works of all kinds. ${ }^{276}$ They are all short and therefore 10

11 it won't be too difficult to use them in a small and narrow circle. Admittedly one 11

12 should have for a small sociable group pieces which are other than spiritual -12

13 really cheerful and also easier ones than this package contains. Meanwhile a start 13

14 must be made somewhere; all is well where music is. 14

15 Here in Berlin there are perhaps more than 50 such family circles, who enjoy 15

16 singing together and which are called 'singing teas'. I myself am not able to 16

17 take part in any of them, because they are the most lethal enemies of the Sing- 17

18 Akademie. As a result I am not familiar with their repertoire. I have, however, 18

19 already been given a commission for a second consignment. Admittedly the Sing- 19

20 Akademie came into existence through one such circle; but extreme care must be 20

21 taken not to see it dissolved into a Singtee once again, where for everyone there is 21

22 total freedom and no law. As a result the Sing-Akademie is only concerned with 22

23 large-scale works for many voices and if, my friend, you should need anything of 23

24 this nature, I can serve you with a rich and excellent repertoire. 24

25 If only you could be here this October, you would hear something of real value. 25

26 The Sing-Akademie has had a white marble bust of my wife sculpted. ${ }^{277}$ It will be 26

27 ceremonially unveiled in the Sing-Akademie and on this occasion I will perform 27

28 a work $^{278}$ which Handel has written for the feast of Saint Cecilia. ${ }^{279}$ What happens 28

29

30276 In Goethe's music collection there are two bundles of papers with four sets of 30

31 choral parts, whose inscriptions (SATB) are in Zelter's hand (everything else is by a 31

32 copyist). One of these (GSA 32/19) contains 12 settings of religious texts by Fasch, Gluck, 32

33 Haydn and Reichardt, among others; no. 13 is a copy (by a different copyist) of Pertis's 33

34 Adoramus te Christe. The second package (GSA 32/183), written by the same copyist as 34

35 the first dispatch, contains 15 songs by Haydn, Himmel, Mozart, Reichardt, Righini and 35

36 Zumsteeg among others. Of the two collections mentioned here, the second was presumably 36

37 the dispatch sent in January 1808.

38277 The bust of Julie Zelter, who had died on 12 March 1806, was commission by the

38 Sing-Akademie from Gottfried Schadow. He modelled it on her death mask by Beyer and

39 the work was completed by the beginning of March 1807. A marble copy, undertaken by

40 Schadow's son Rudolph, was unveiled in the Sing-Akademie on 13 October 1807; AMZ 10

41 (1807/08), no. 6. 4 November 1807; MA 20.3, p. 219.

$42 \quad 278$ George Friedrich Handel, Alexanderfest; text by John Dryden, German trans. Carl 42

43 Wilhelm Ramler. $\quad 43$

$44 \quad 279 \quad 22$ November. $\quad 44$ 
1 otherwise in this world, I will leave to others; for my part I will carry on from 1

2 where I left off. No one can stop me, even if no one thanks me; in the end you will 2

3 do the same and if everyone does what he must do, according to where the spirit 3

4 drives him, then I imagine things will only become better rather than worse. [...] 4

524 August: I must tell you, whenever you sing though these pieces, you must go 5

6 back to the beginning each time; otherwise the singers, according to new practice, 6

7 will sing the piece through to the end, have their opinions about it, swallow one 7

8 piece after the other, and then they are finished and look around for something 8

9 else, for they are generally convinced that art is only there to justify their opinion, 9

10 whereas the good and the best cannot be discerned until one knows the work by 10

11 heart and is possessed by it. As it doesn't require much to get four voices together, 11

12 people soon become familiar with this and bored with it the more appealing and 12

13 the simpler it is; in such a circle there has to be something else to change the 13

14 singers around and to give them a breather. Finally, the room cannot be too small 14

15 where music in several parts is being sung. One can begin by singing in a room, 15

16 but then where possible change to a bigger space so that the voices can reverberate. 16

17 Automatically they limit themselves, or expand, according to the space. 17

18 In a future dispatch you shall receive a Stabat Mater, which consists entirely 18

19 of canons: 22 in total. ${ }^{280} \quad 19$

26 Let me thank you from the heart, my dearest friend, that you let me look so deeply 26 27 into yourself and how you really are. There is really something Promethean in 27 28 your nature, ${ }^{281}$ which I can only be amazed at and admire. While you were calmly 28 29 and patiently bearing that which can hardly be endured, and making future plans 29

30 for a happy and creative activity, I have been acting like one who has already 30

31 crossed Cocytus, and has at least tasted the waters of Lethe. ${ }^{282}$ Otherwise, in as far 31

32 as I still consider myself an inhabitant of this world, I, too, have done what I can 32

33 do, in my own way, taking in many experiences, doing some reading, learning, 33

34 making notes, working things out and taking things as they come. 34

$40 \quad 280$ A motet, Stabat Mater Dolorosa, by Zelter is unknown. 40

41281 A reflection of Goethe's preoccupation with the Pandora myth, already mentioned 41

42 in his diary in July 1807 and which lead to the Festspiel Pandoras Wiederkunft later that 42

43 year. 
5 You really are a good friend! When I returned home, I found the songs, and we 6 have already started our little singing school. ${ }^{283}$ We shall by degrees attract our 7 stage singers and chorus, besides people from the town; then we shall see how far 8 we have got. We have a good [rehearsal] venue in our theatre.

9 Your renewed invitation makes my heart heavy. It is unpardonable that I should

10 still be unacquainted with your institution, but for several years past I have felt a 10 11 certain attachment to the place I live in. This has mainly arisen from the way so 11 12 much has been aroused in me but not developed. So throughout the year I am 12 13 busy merely trying to get things cleared up here and there, quite apart from the 13 14 circumstances of my health and the time we live in. The latter, however, would be 14 15 less likely to prevent my coming were it not for the former. But if the truth were 15 16 known, I feel a dread of new influences and excitements, and therefore, of my own 16 17 free will, deny myself many a pleasure.

18 The reception our theatre received in Leipzig ${ }^{284}$ inspires me with energy and 18 19 inclination to devote myself eagerly to the business this winter once more. We have, 19 20 in this instance, been rewarded for our perseverance, and shall go on in the old way 20 21 with confidence and hope; and thus, even the worst slander and opposition, such 21 22 as we once had to experience from Berlin, will have no effect. Your perseverance, 22 23 too, my worthy friend, is ever before my eyes. I am only afraid, that if you do go 23 24 to Italy, the glorious bond of so many years will be dissolved. It is pleasant and 24 25 natural that some of the grains of seed scattered abroad by you should have fallen 25 26 upon the tea tables. ${ }^{285}$ Please get me some such songs; they might be the very thing 26 27 we need!

28 I shall not tell you anything about my other activities, but hope soon to be able 28

29 to send you some of the fruits of my quiet industry. ${ }^{286}$ Farewell, and let me also 29 30 have a song now and then. I could enjoy such little things more readily now if you 30 from 14 May to 5 July and 4 to 31 August 1807 . Goethe was informed of its great success

$42 \quad 286$ Around mid September Goethe was working on the Vorspiel zu Eröffnung des

43 Weimarischen Theaters which was published on 22 and 22 October 1807 in the Morgenblatt 44 für gebildete Stände, MA 9, p. 235. 
1 would set them to an easy accompaniment for guitar, ${ }^{287}$ as I have several guitarists 1

2 at hand.

9 A longer, not unpleasant visit detained me from sending this letter yesterday 9

10 evening. My foot is still not completely healed, but I was still able to go into the 10

11 Academy and hold the rehearsals, from where I have now returned. If only you 11

12 could have heard Handel's choruses in Alexanderfest! I am certain that the glory, 12

13 the power, the life and the peace would have shown you another aspect of the 13

14 music, as very few people see it - and then only very seldom. The text, which is 14

15 by Dryden and originally in English, recounts how Timotheus moves Alexander ${ }^{288} 15$

16 through his art and has won a victory over this violent war-like character. If only 16

17 I, too, could also relate what always makes me rather sheepish and speechless: the 17

18 naivety, the clarity, joy and the life! I cannot possibly conceive how one can exist 18

19 without these qualities and yet one lives - but that's the way it is. [...]

20 Our theatre begins to hoist itself up after a very sad summer, where one almost 20

21 feared we would see it closed. The house is full at every performance; above all 21

22 the ballet and opera are popular, which overall and in their own way are also better 22

23 than the rest, especially as we now do without our best female leads, because 23

24 Madame Bethmann is away and Madame Fleck heavily pregnant.

25 I can no longer remember whether I have sent you the composition of the 25

26 'Generalbeichte', ${ }^{289}$ so I am sending it to you now. You might be in need of it for 26

27 your choir. I have handled the poem in a very dramatic way, and you will find that 27

28 it has achieved our usual standard. Because it is so easily written out, I will just 28

29 send you the score, so as not to send such a large letter again. I have marked it up 29

30 very exactly, and you yourself can see to it that it is sung with the correct dignity 30

31 and will not be raced through.

32 I look forward eagerly to the next volumes of your works, ${ }^{290}$ and I hope that 32

33 they will appear at the next fair.

289 Zelter's setting of Goethe's 'Generalbeichte', for solo voice, choir and 41 accompaniment is in Goethe's music collection (GSA 32/6). The setting was not sent in an 42 earlier letter. 
$5[\ldots]$ We have diligently studied the four-part choral works which you have sent. 5

6 Every Sunday morning people gather here. I have had the Haydn pieces you 6

7 recommended sent from Leipzig. Send me more from time to time and you will do 7

8 me a special favour, and let me know what I owe you, so I don't add to the debt for 8

9 accommodation. Next time, news about other matters. 9

16 Some more music for your new choir, if I have not sent it already! More will 16

17 follow as soon as my messenger has returned from Leipzig.

24 First of all, dear friend, I could not ask enough of you; first it was one thing, then 24

25 another; I plagued you with my commissions, ${ }^{291}$ though you have enough to do 25

26 without them, and now that everything has come - songs, price list, turnips - I am 26

27 like those whose prayers have been answered, and with no more thanks turn from 27

28 the giver to the gifts.

29 I will not excuse this, for there is always time to send a few lines to a friend, 29

30 but since my return home from the baths I have felt strangely oppressed by the 30

31 present, as if I had to pay another penalty for those four months which I spent upon 31

32 the unclouded mountain heights like a retired gymnosophist. It is true nothing 32

33 disagreeable has happened to me, but yet so much that I like and disliked forced 33

34 itself upon me that neither my physical nor my moral powers were quite sufficient 34

35 to the task.

36 My small choir, which, of course, consists of hardly more than four voices, is 36

37 shaping up quite nicely and already shows its influence upon the theatre. Shortly 37

38 before I left home, ${ }^{292}$ it was greatly improved by the acquisition of a young female 38

41291 Goethe refers to his repeated requests for music for his newly-founded choir, 41

42 as well as his requests for the Berlin theatre programmes, and for a price list for Berlin 42

43 porcelain. $\quad 43$

$44 \quad 292$ Goethe was in Jena from 11 November to 18 December 1807. 
1 voice, ${ }^{293}$ which might almost pass for a countertenor. Might I ask you, at your 1 2 convenience, to let me have Schiller's 'Punschlied'? ${ }^{294}$ Unfortunately I have but 2

3 one voice part left; the others have been removed. [...] 3

4 So much, my dearest friend, for the moment. I am packing up to return to 4

5 Weimar. I have been very happy here, and you would never guess it: I have been 5

6 drawn into sonneteering. ${ }^{295}$ I shall send you a dozen some day soon, ${ }^{296}$ on the one 6

7 condition that no one sees them, and that they are not copied. But should you care 7

8 to set one of them to music, I should be very much pleased; I am only too glad to 8

9 see my productions floating in your element. Write to me again, if only a line or 9

10 two. A word from a friend is doubly enjoyable in these gloomy, short days. 10

11 Privy Councillor Wolf has given us an excellent book on the study of antiquity, 11

12 which is very rich and reminds us of everything we know, and gently points out to 12

13 us what we should know and how we should deal with it all. 13

20 A second parcel of songs has been ready for a good while and awaits dispatch. Of 20

21 Schiller settings, I enclose two 'Punschlieder' which I composed. You will find 21

22 your way into it and be able to write the following strophes. [...]

23 I received your kind letter from 16 December last year on 23 December. I am 23

24 overjoyed about the sonnets and please send me them soon. The conditions shall 24

25 be fulfilled. No one is to see them or write them out, and what will lend itself to 25

26 composition by me you will have immediately.

293 Regina Henriette Häßler (1790-1849), daughter of the pianist, composer and music 33 dealer Johann Wilhelm Häßler in Erfurt; in Weimar from 1807; wife of Carl Eberwein from 34 1812.

294 As Zelter was not clear which of Schiller's Punschlieder Goethe meant - 36 'Punschlied. Im Norden zu singen' ('Auf der Berge freien Höhen') or 'Punschlied' ('Vier 36 Elemente, innig gesellt') which he had already sent the poet on 9 May 1802 - he enclosed 38 both compositions in the following letter.

295 Around the end of his time in Jena, Goethe attended August Wilhelm Schlegel's 39 lecture on the sonnet and had become preoccupied with the form; the origin of his sonnet 40

43. Goethe eventually kept his promise (after Zelter reminded him several times); on 42

44 in the winter of $1807 / 08$. 
5 [... The music has already been handed over to our little [singing] school; your 5 6 first consignment is still the best thing we have had for some time past. The greater 6 7 part of it was performed yesterday before our princesses, ${ }^{297}$ who really enjoyed it. 7

8 You once spoke about a Stabat Mater; pardon me for reminding you of it. My 8

9 little institution is getting on well; but the young people, as you well know, are 9

10 very fond of stepping out of line, and each one imagines himself to be better off 10 11 when he is singing some pitiful or mournful lament of unrequited love as a solo. 11 12 I allow such things towards the end of each session and yet, at the same time, 12 13 execrate men like Matthisson, Salis, Tiedge ${ }^{298}$ and the clerical body who show us 13 14 heavy Germans - even in songs - a path beyond the world, which we leave quickly 14 15 enough as it is. Add to this that musicians themselves are often hypochondriacal, 15 16 and that even joyous music may descend into melancholy. I praise what you 16 17 produce, dear friend. Again yesterday, during the 'Niemals erscheinen die Götter 17 18 allein' ${ }^{299}$ and in the 'Liebe Freunde, es gab beßre Zeiten', ${ }^{300}$ it almost seemed as if 18 19 everyone was shaking from his head the dust and ashes of the century. 19 20 I owe so much to you; perhaps I shall be able to repay you some day. 20

27 [...] But where are the sonnets that my heart longs for? Don't let me languish 27

28 after them any longer and send me no fewer than the promised dozen; otherwise I 28

29 compose elegies and hymns by Tiedge, and send you them to you as a plague on 29

30 the land.

(1762-1834) and Christoph August Tiedge (1752-1842): representative of a generation

40 of lyric poets between Sentimentality and Romanticism. Their poetry was very popular,

40 especially in almanacs, and was often set by Reichardt, Zelter and Zumsteeg.

41299 Zelter's setting of Schiller's 'Dithyrambe', which appeared under an earlier title

42 'Der Besuch', in Schiller's Musenalmanch für das Jahr 1797.

297 Louise Augusta (1757-1830), wife of Duke Carl August, and Maria Pawlowna

$43 \quad 300$ Zelter's setting of Schiller's 'An die Freude'; there are numerous handwritten 44 copies of Zelter's song in Goethe's music collection. 
1 In actual fact I have composed a hymn to the sun by Tiedge, ${ }^{301}$ because he is 1

2 here at the moment with his patroness, Frau von der Recke, whose favour I also 2

3 have to boast. I have also composed a spiritual poem by Frau von der Recke ${ }^{302}$ and 3

4 let her hear it in the Sing-Akademie. 4

5 It is said here that Reichardt is performing his operas in Weimar all through 5

6 the winter. ${ }^{303}$ Here there are nothing but translations from the French, which also 6

7 have their good points, all the more so because, in general, they are always still the 7

8 pick of the crop. In addition we mostly enjoy ballet, where one can take pleasure 8

9 in beholding physical prowess. 9

\section{Goethe}

22 Since, instead of communicating something to you or offering you something 22

23 pleasant in my letters, I am always wanting and expecting something new from 23

24 you, so I look around to see if I can find something to give you pleasure, and that's 24

25 when the delay with my new volumes is irksome. I suspect Cotta will publish the 25

26 eight remaining volumes together. As soon as they are in my hand, your copy will 26

27 be in the post. There are some things in it that will certainly give you pleasure. 27

301 Zelter's setting of Christoph August Tiedge's 'Hymnus an die Sonne', for two 32 choirs, bass solo and piano accompaniment, was performed on 16 February 1808 by the 33 Sing-Akademie.

302 The poes 34 The poem has not been identified; it is not the poem ascribed to von Kubik/Meier 35 Elisa von der Recke which was reviewed in the Berlinische Musikalische Zeitung, 15 June 36 (it 37 303 Rolf Pröper, Die Bühnenwerke Johann Friedrich Reichardts: 1752-1814 (Bonn: 38 H. Bouvier, 1965) does not refer to any performances of Reichardt's operas in Weimar. 39 Zelter is most likely referring to Reichardt's Singspiel Jery und Bätely, which was in 40 the Weimar repertoire from 9 June 1804 and appears once in the theatre programmes of 41 1807/08, on 21 December 1807.

304 The cycle of 17 sonnets written between December 1807 and early 1808.

305 Franz Carl Adalbert Eberwein (1786-1868). 
1 Reichardt, as you know, has employment in Cassel. ${ }^{306}$ Nothing has become of 1

2 the performance of his operas here, about which there was a great deal spoken. I 2

3 hear Himmel died in Rome. ${ }^{307}$ It is truly a pity for such a fine talent! [...] 3

4

5

6 94. Goethe 6

7 - 7

$8 \quad$ Weimar, 20 April 18088

9 9

10 Here are the songs, ${ }^{308}$ dearest friend. Cast an eye over them! Perhaps you will 10 11 make some remarks in red ink, and say generally what you think of the young 11 12 man's talent, and in particular let me know how far he seems to have progressed 12

13 in this difficult art. I shall perhaps send him to you for Michaelmas, as next winter 13

14 he would like to become the conductor of my little musical choir. As I was not 14

15 fated to revel at ease at the rich table of a great city, I must cultivate and plant on 15

16 a small scale, and produce and accomplish what is possible at the time, under the 16

17 given circumstances. 17

18 Please tell me, when you have time, something about early Church music in 18

19 Constantinople, which, with the Greek Church, seems to have spread in the East, 19

20 and to have influenced the Slavonic people. 20

21 Where do you think the universal tendency towards minor tones originates, 21

22 which can be traced even in the Polonaise? $\quad 22$

23 This Easter, eight Choristers passed through here on their way from 23

24 St Petersburg to Paris and the Chapel of the Russian Ambassador. They sang in 24

25 the Greek Church ${ }^{309}$ here on both feast days, when - as her Royal Highness ${ }^{310} 25$

26 told me - they performed nothing but genuine, ancient church compositions. The 26

27 nearest thing that I have heard to it is the canto firmo of the Italians and the way 27

28

31306 Reichardt was employed as court composer by King Jérôme in 1808; he soon left 31

32 Kassel for Vienna and from there travelled back to Giebichenstein.

$33 \quad 307$ Friedrich Heinrich Himmel died on 8 June 1814; the rumour stemmed from a 33 34 death notice in the $A M Z 10$ (1808), no. 27, 30 March announcing the death of a Leipzig 34

35 Kapellmeister Himmel, who was employed in Rome, $M A$ 20.3, p. 227.

$36 \quad 308$ Settings by Carl Eberwein, mentioned in the previous letter. Zelter returned them 37 in his letter of 6 April to 7 May, in which he writes a critical report on them.

$37 \quad 309$ The Russian orthodox church of the Grand Duchess, Maria Pawlowna, was on the

38 ground floor of Ackerwand 25, the property in which Charlotte von Stein lived. After Maria

39 Pawlowna's move to Weimar, a magnificent private chapel was founded in November 1804

40 by the family and by the Russian community in Weimar. This small Russian group, which

41 consisted of four choristers and a conductor, was directed by the father confessor of the

42 Grand Duchess, Proto-Presbyter Nikita Jasnwskij, for whom lodging was also prepared in

43 the same house.

44310 Maria Pawlowna von Sachsen-Weimar-Eisenach. $\quad 44$ 
1 in which the Passion is performed in the Papal Chapel, namely to the actual text 1

2 of the Evangelists.

3 I still haven't any [volumes] of my published works to send. I attach the first 3

4 section of Faust; no more of it has been sent to me. I ask you not to let anyone see 4

5 it and to send it back to me with the music, because otherwise something will be 5

6 missing from a copy.

[...] Telemann (a composer from Hamburg of the last century) said, 'A good 13 Berlin, 6 April to 7 May 180811

composer must be able to sing a public notice. ${ }^{311}$ That I should disgrace my 14 5 Emperor $^{312}$ by not being able to sing a sonnet? God forbid! And so bring on the 15

19 develop.] I am told he has left Rome for Munich; perhaps you will meet him in 19

21 I am waiting to see the work of your young composer ${ }^{314}$ and he himself will be 21

22 welcome if he visits us.

23 At the moment I am busy with [the] preparations for two concerts, ${ }^{315}$ through 23

24 which I intend to coax a few thaler out of my dear fellow citizens. If only the path 24

25 to Carlsbad was via Berlin. [...]

26 1 May: Of Eberwein's songs, which I return with the first section of Faust, 26

27 'Am Neujahrstage' 316 pleases me most. One recognizes a definite sentiment in 27

28 it and, more to the point, this sentiment is homogeneous throughout. The piece 28

29 begins, it develops, it reaches a pinnacle through the climax at bars 36 and 37, and 29

311 This saying can be sourced back to Johann Friedrich Reichardt's essay 'An junge 32 Künstler', which appeared in the Musikalisches Kunstmagazin (Berlin 1782), p. 4. Goethe 33 adopts this expression in a letter to Zelter on 15 January 1814 without realizing that he had 34 received this anecdote from Zelter.

312 Napoleon I. By 'my' emperor Zelter is referring to his membership of the 35 
1 ends quietly. The five-part passage in it follows logically and is at least studiously 1

2 developed.

3 The composition is pure but meagre. I say meagre because here one is dealing 3

4 with a developing composer, although I must state again that the middle voices 4

5 move naturally enough. All that is missing is freedom and assurance which only a 5

6 good schooling can give - and at present this is nowhere to be had. 6

7 The main criticism would be directed against the modulations or the cadences. 7

8 But this is such a broad subject that it cannot be dealt with by letter. Let me attempt 8

9 some comments: 9

10 The beginning of the poem consists of an invocation, which I feel is incorrectly 10

11 handled here [...] the first bar is rather unmelodic, disjointed, so that the opening 11

12 appears incomprehensible. In order to make myself clearer, I have sketched it in, 12

13 in my own way, in red notation. The second line of the poem I have altered, not 13

14 to improve upon the poem, but to show the composer how he should punctuate 14

15 musically. As mentioned, it is difficult or impossible to write about this. Eberwein 15

16 must think it over until he has grasped it; therefore, I have mapped out the first 16

17 four bars. $\quad 17$

18 I have marked some unacceptable harmonic progressions with red crosses. They 18

19 appear hidden from the eye, but a practiced ear finds them offensive, although one 19

20 is constrained to hear them often enough today. They are more disagreeable to me 20

21 than obvious mistakes because there is something wretched about them, against 21

22 which I warn my students daily. The faults of a master are always the outcome of 22

23 mastery, and therefore do no harm, whereas disjoined work is only a cover-up for 23

24 incompetence. [...] 24

25 One must also avoid repeating words unnecessarily - especially in works for a 25

26 number of voices - because the cantilena suffers through it. 26

27 The other pieces appear to me less suitable to part settings; on the other hand 27

28 one could still have an infinite number of parts; I also sing along even where I 28

29 would have to supply the sixth voice by myself alone. 29

30 One must accustom oneself early to consider art not as an essential luxury, but 30

31 the result of cause and effect; otherwise a false taste develops, on which what is 31

32 false continues to build until the whole construction collapses. 32

33 The song 'Ich denke dein' ${ }^{317}$ has something rather church-like about it and 33

34 thereby is rather like a lament. I would imagine it could be hopeful instead. I 34

35 don't see any justification for the minor key; besides I generally don't like to 35

36 permit a sad tone unless it is based on the deepest sorrow. Above all, one can let 36

37 art partake of nature's overwhelming and shattering emotions, for its purpose is 37

38 to edify, not to overwhelm and destroy. In such circumstances art appears to me 38

39 misplaced, like the best wine to someone who is drunk. Admittedly, this depends 39

40 much on the individual character of the artist; but that is what art is for; otherwise 40

41 the artist wouldn't need it and also could not be an artist. By the same token an 41

42

$43+43$

$44 \quad 317$ Eberwein's setting of Goethe's 'Nähe des Geliebten'. 
1 actor cannot be allowed to play a comic role sadly or to play a moderate character 1

2 as an exaggerated one; the composer is no less constrained in his own way. 2

32 May: You ask where the universal tendency towards minor tones originates, 3

4 which is traceable even in the Polonaise?

5 I have had the same experience, but musicologists give no satisfactory answers 5

6 on the subject. The minor key is distinguished from the major tonality through the 6

7 minor third, which takes the place of the major third. Our present diatonic (natural) 7

8 scale originates in the way a string is divided. If it is divided in half one gets an 8

9 octave; if one divides it into three, a perfect fifth results; if one divides it into five, 9

10 one finds the major third. The string may, however, be divided into as many parts 10

11 as one likes, yet this will never produce a minor third, although by so doing one 11

12 can always get nearer to it. Accordingly this minor third is no immediate given of 12

13 nature but a work of more recent art, and it must be regarded as a diminished major 13

14 third, just as - even by the strictest composers - it has been treated as a consonant 14

15 interval. Namely, it may, like the major third, be introduced everywhere, freely and 15

16 without preparation, which, in a pure style, is not permissible for a dissonance. 16

17 I think I first met with the almost universal bias towards minor keys in the 17

18 songs of northern nations, especially among island dwellers and along the coasts. 18

19 The history of the art of music says next to nothing about the songs of the far 19

20 north; travellers, who may have had some musical knowledge, have written them 20

21 down so unsatisfactorily that we can conclude more about the limitations of their 21

22 knowledge than about the true spirit of the songs, for only good musicians can 22

23 record such things correctly. The hunting and fishing songs of Russia, Livonia, 23

24 Norway and Scotland are the first that lead us to draw some conclusion about 24

25 character; even more so the dances, which are capable of more outward expression 25

26 than the songs, which demand inner feeling. This is why the Scottish, Russian, and 26

27 Polish dances are so beautiful, and so truly national, that they are imitated, though 27

28 awkwardly enough, among all cultivated nations. But even these dances, as far 28

29 as I thought them to be genuine, were always set to minor keys, the best of them 29

30 anyhow. It is well known that the Russians and Poles love dancing, and that they 30

31 dance beautifully, with grace, agility and expression, showing much more dignity 31

32 and life than one would ever suppose from their ordinary habits. The Russian 32

33 songs and dances that I have heard were, without exception, in minor keys, though 33

34 at the same time very lively, consisting of many quick notes and short metres. 34

35 Had these dances been in major keys, I should have thought them extravagant 35

36 and wild in their elation, whereas in the minor key they become serious, tender, 36

37 more yearning, as if they are in search of the cheerfulness which is hindered by the 37

38 damp, cold air and spicy food.

39 The genuine Polonaise inclines already to the south; an easier passion seems 39

40 to awake in it. The uneven or triple time, which is already more an artificial than 40

41 a natural metre, gives it a special character and the many melodic stresses that 41

42 dominate the polonaise and always cut across the middle of the measure seem to 42

43 even out this uneven metre, which betrays a tendency towards the more northern 43 
1 style, or derives from it. This will also be the case with the minor keys which can 1

2 be found here, but not so commonly. 2

3 Now, if we leap from the north to Italy, minor keys are found - especially 3

4 in the best musical epochs - only in temples and churches, where they were 4

5 indispensable on account of the so-called Greek or Ecclesiastical modes. In songs, 5

6 dances and theatrical pieces, a light, flexible melody is most common, even in 6

7 the expression of the fiercest passion (with few exceptions), and in more recent 7

8 times the Italians have gone so far that even an air such as 'Tu mi da me dividi' 8

9 is set to the brightest melodies, to prevent the slightest suggestion of anything 9

10 melancholic. These airs are then the most popular of all. On the whole, opera buffa 10

11 enjoys far greater perfection than opera seria, for which no greater texts exist than 11

12 those of Metastasio, ${ }^{318}$ Apostolo Zeno ${ }^{319}$ and others of the same ilk. Yet in opera 12

13 buffa minor keys are used to heighten the comic and resist the serious. 13

14 To judge by this, one might look for a minor key tendency in relation to climate. 14

15 Now, the North Germans stand in the centre, eagerly reaching out to every point of 15

16 the compass in order to enrich their flat territory. Since they learn to do everything, 16

17 ultimately they are just looking for spices to free up the blood, and then they 17

18 call that passion. It is another matter with shepherd folk and mountaineers. These 18

19 seem to take their scales from their horns, for they know no other instrument, 19

20 so their songs and dances are either major or minor, according to what the horn 20

21 can produce. A good example of this is the Scottish hornpipe, as is found in the 21

22 following melody: $\quad 22$

24

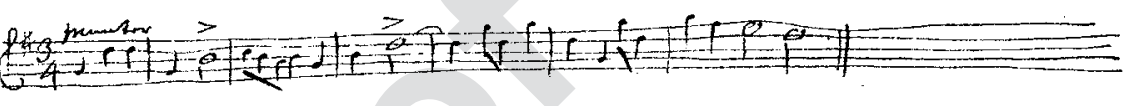

28 This dance is in a major key, but I have met with Swiss songs, also in minor keys, 28

29 which presently escape my memory.

30 As for music in Constantinople, I know as much as my historians, namely 30

31 nothing at all. An Oriental Emperor, Constantine IX, surnamed Porphyrogenitus, 31

32 who made emperor when he was seven years old and was poisoned in the year 32

33 959, is said to have been a great musician. Then Nicolai tells me, a Greek Emperor, 33

318 Metastasio's libretti are quintessential examples of eighteenth-century Italian subordinate to the text. Mythological and allegorical figures were replaced by historical heroic figures. Independently of their geographical origins, they act according to the eighteenth-century courtly ceremonial, in crassly distinguished, contrasting emotional

42 qualities, determined by conflicts that arise from the demands of duty and love.

43319 Zeno had endeavoured to bring the libretto back to the classical norms for drama, 44 especially the literary norms of French tragedy. 
1 Constantinus, ${ }^{320}$ wrote a work in the tenth century on the court ceremonies at 1

2 Constantinople, which was printed at Leipzig in 1751 in two folio volumes of 2

3 Greek and Latin and, according to him, must certainly be in the Weimar Library. 3

4 Perhaps this book might contain something about music in Constantinople. You 4

5 may possibly get further information in the Abbot Gerbert's Latin work, De cantu 5

6 et musica sacra, ${ }^{321}$ which, unfortunately I do not possess. The same author also 6

7 published a work called Scriptores ecclesiastici de Musica sacra potissimum. Ex 7

8 variis Italiae, Galliae, et Germaniae, codicibus manuscriptis collecti. ${ }^{322}[\ldots] \quad 8$

15 Your dear letter of 6 April did not reach me until I arrived here. I immediately sent 15

16 back Eberwein's songs, and afterwards a copy of your favourable criticism. What 16

17 a good thing it would be for that young man to study under you for a good while! 17

18 Just now, however, he is experiencing the fate of all beginners: they go astray like 18

19 sheep, and each takes his own line.

20 My warmest thanks for what you have said, to my comfort and instruction, 20

21 in reply to my questions. It is only with regard to your theoretical statements, 21

22 which, as I well know, square with the convictions of the physical and musical 22

23 world, that, as is usual with me, I have something (in my own way) to remind 23

24 you of. How dearly I should like to converse with you on this subject, which is so 24

25 closely connected with others I am pondering; then some of the chief knots would 25

26 surely be unravelled for me. I enclose a sheet of paper on which your statement is 26

27 repeated, followed by my doubts, objections and questions, in so far as I was able 27

28 to summarize my thoughts upon so complicated a subject. As I have numbered the 28

29 points of argument and kept a copy of them, you might be so kind as to answer 29

30 them one by one. That way I should be able to keep your explanations together 30

31 with my draft. [...]

If you find Voß's sonnet objectionable, we are completely agreed upon that 32

33 point as well. In Germany we have had several instances of very gifted men who 33

34 end up losing themselves in pedantry, and it is the same in his case. Through sheer 34

35 prosody his poetry has entirely vanished. And what is the point of pursuing with 35

36 hatred and rage an individual rhythmic form - the sonnet, for example - when after 36

37 all it is only a vessel into which anyone can put whatever substance he likes? $\quad 37$

320 They are both the same person: the Kaiser von Byranz, Konstantin VII. 39

40 Porphyrogennetos, who was also known as a writer of hymn texts; his treatise Libri duo de 40

41 ceremoniis aulae Byzantinae appeared in a two-volume edition in the eighteenth century. 41

$42 \quad 321$ Martin Gerbert, De Cantu [About Song] (2 vols, St Blasien, 1774). 42

$43 \quad 322$ Ecclesiastical writers on sacred music, collected from various handwritten codices 43

44 from Italy, France and Germany (3 vols, St Blasien, 1774). 
1 How ridiculous it is to be forever returning to that sonnet of mine, ${ }^{323}$ in which 1

2 I spoke rather unfavourably of sonnets, to take sides on an aesthetic subject, and 2

3 to see me as taking sides, without considering that one may quite well jest and 3

4 joke about a thing, without at the same time despising or denouncing it on that 4

5 account.

6 I hope, therefore, that the accompanying sonnets will meet with a warmer

7 reception from you; only I urgently beseech you not to let them out of your

8 hands. ${ }^{324}$

\section{2 4}

9 I have nothing further to write to you from here, except that I am in good health 9

10 and as industrious as I can be. [...] 10

12 First Enclosure $\quad 12$

$13 \quad 13$

14 1. 'The minor key is distinguished from the major, by the minor third.' Is it not 14

15 also distinguished by diminishing or narrowing the other intervals? 15

162 . 'Which takes the place of the major third'. This expression can only work if 16

17 we start from the major key. A theorist of northern nationality, when speaking 17

18 of the minor tones, could just as well say that the major third takes the place 18

19 of the minor third. 19

20 3. 'Our present diatonic (natural) scale'. That the diatonic scale should be the 20

21 only natural one - my opposition is really directed against this opinion. 21

22 4. 'Originates in the way the string is divided. If it were divided in half and so 22

23 on.' That the division of the string into different parts should produce sounds 23

24 harmonious to the ear is a nice experiment which might even be made the 24

25 foundation of a certain scale; but if it cannot be accomplished in this way, 25

26 might it not be possible in some other manner? 26

27 5. 'The string may, however, be divided into as many parts as you like and yet 27

28 this will never produce a minor third, although by so doing, you can always 28

29 get nearer to it.' You ask too much of an experiment when you require it to 29

30 do everything. Electricity was at first only produced by friction, whereas its 30

31 greatest manifestations are now produced by mere touch. Our aim should be an 31

32 experiment by which one could also represent the minor tones as original. 32

33 6. 'Accordingly, this minor third is no immediate given of nature, but a work of 33

34 more recent art.' I deny the conclusion as I do not admit the premises. 34

35 7. 'And it must be regarded as a diminished major third'. This is a subterfuge 35

36 to which theorists usually resort when they have established something that 36

38 'Das Sonnet', written in 1800 in response to Voß's programmatic sonnet. It first

39 appeared in the Morgenblatt für gebildete Stände in 1807. Later Goethe revised his opinion,

40 composing a cycle of sonnets, one of which, 'Die Liebende schreibt', was set to music by

41 Schubert and Mendelssohn.

$42 \quad 324$ Six sonnets by Goethe from a group of 17 sonnets which he later completed in Jena

43 in 1817; the six enclosed sonnets are 'Mächtiges Überraschen'; 'Freundliches Begegnen'; 43

44 'Wachsende Neigung'; 'Gewöhnung'; 'Entsagung'; 'Jähe Trennung'. 44 
restricts nature: for they are then obliged to retract and annihilate what they 1 formerly maintained in a very paradoxical fashion. If a major third is an interval 2 that nature gives us, how can we diminish it without destroying it? How much 3 and how little can it be diminished and not be a major third and still be a third? 4 And, ultimately, at what point would it cease to be still a third? My imaginary 5 northern theorist might with equal justification affirm that the major third is an 6 augmented minor third.

8 8. 'And so - even by the strictest composers - it has been treated as a consonant interval.' We have a clear instance here of what happens so often both in art 9 and technique: that the practical sense knows very well how to dispense with 10 theoretical limitations without making too much fuss about it.

. 'That is: it may, like the major third, be introduced everywhere, freely and 12 without preparation - which, in a pure style, is not granted any dissonance.' 'If 13 it is treated as a consonant interval, it is consonant, for such things cannot be 14 established primarily by convention. If it occurs freely and without preparation, 15 then it is not dissonant: it is by nature harmonious as is everything which 16 springs from it.'

Here a very remarkable consideration comes into play in respect of all physical 19 20 inquiry - one which has been already touched upon before. When he is in full 20 21 command of his senses, man is the greatest and most perfect physical apparatus 21 22 that there can be. And it is, in fact, the greatest failing of modern physics that the 22 23 experiments are, as it were, separated from human beings and only acknowledge 23 24 as nature what artificial instruments demonstrate - and thereby want to limit and 24 25 prove what nature is capable of. It is exactly the same with calculations. Much 25 26 that is true cannot be calculated, just as there is much that cannot be clinched by 26 27 experiment. On the other hand, man stands so high, that what otherwise defies 27 28 representation finds its representation in him. What then is a string and all its 28 29 mechanical divisions compared with the ear of the musician? It may even be asked, 29 30 what are the elementary manifestations of nature herself compared to man, who 30 31 must first control and modify them in order to be able to assimilate them to some 31 32 extent? However, I do not intend to lose myself in these considerations just now. 32 33 I would prefer to discuss them in detail first and to ask you for more information 33 34 on a few other points.

38 All the arts, seeing that they could only work themselves upwards by exercise 38 39 and thought, practice and theory, seem to me like towns where the ground and 39 40 soil on which they are built can no longer be detected. Rocks have been blasted 40 41 away, and these same stones carved into shape and made into houses. Caves were 41 42 found very convenient and converted into cellars. Where the earth gave way, it 42 43 was entrenched and walled up; perhaps right beside the original rock a bottomless 43 44 piece of swamp was encountered where stakes and piles had to be driven in. When 44 
1 at last all is completed and made habitable, what part of it can be called nature, 1

2 and what art? Where is the foundation and where are the accessories? Where is 2

3 the substance, where is the form? How difficult it is, then, to give reasons, if we 3

4 would assert that in the earliest times, if one had had an overview of the whole, 4

5 everything could have been done more in accordance with nature and art, and with 5

6 more purpose. If you consider the piano or the organ, you might imagine you had 6

7 the simile of my town before you. I wish to God that I could live beside you some 7

8 day and attain true enjoyment of life; I should then be heartily glad to forget all 8

9 questions about nature and art, theory and practice. 9

16 My ripieno school, about which I wrote to you last year, has had to be shelved for a 16 17 long time, because the Academy of Fine Arts is planning an exhibition, which is to 17 18 open already this month. Needless to say this interruption is not agreeable to me. I 18 19 have spent a whole year teaching the basics of musical practice and have achieved 19 20 hardly anything. [...]

2115 May: Meanwhile I continued work I had begun earlier, especially the 21 22 attempt to handle special artistic verse metres musically and to lay them in the 22 23 mouths of the choir. I thought I would make good use of the time Privy Councillor 23

24 Wolf is here. [...]

25 I found the repercussions of your observations on music theory electric because 25

26 so many of these objections have also been stirring in me for a long time. I can 26

27 only state what we already know. I lack the mathematical patience to investigate 27

28 further, and when I am striving for clarity, it suits my own purposes, since in my 28

29 compositions there is a certain striving towards the classical. 29

30 Our theory [of music] has become a system that one should learn and be able to 30

31 teach. That thereby violence is done to nature cannot be doubted. True, it is a rich 31

32 web of modification which one can hardly contemplate without admiration, so that 32

33 the musicians are led to believe that what is not achievable through this system 33

34 cannot be achieved at all. This much is certain: if one moves individual pillars of 34

35 this theory away from their foundation, then one runs the danger of damaging the 35

36 building. Now to your questions: 36

$37 \quad 37$

38 1. The minor key is distinguished from the major 'only by the minor third'. The 38

39 fifth and octave remain unchanged in both tonalities, hence both of these form 39

40 perfect consonances, whereas the third, because of its variability, is called an 40

41 imperfect consonance, because it can be great or small (major or minor). 41

42 2. The experiment of the division of a string, from which the intervals of our 42

43 scales originate, includes yet another a physical phenomenon: the appearance 43

44 of overtones. If one sets a deep string vibrating, one doesn't just hear the sound 44 
of the string but at the same time several tones automatically resounding above 1 it. If one looks for these overtones, the numbers $2,3,4,5,6,7$ and so on are 2 found, which the human ear can still distinguish. The same experiment can be 3 performed on the Aeolian harp since, especially with stronger and prolonged 4 air movement, the higher numbers $8,9,10,12,13$ and so on also become audible and resound discordantly. The wonderful effect of the Aeolian harp is that these sounds appear essential and arbitrary at the same time. All of these resounding sounds share a common tonic (to which the harp is tuned) and in this tonic the third never appears other than great (major), so never small 9 (minor). Therefore, I have called the minor third a work of art, a diminished 10 major third, because of the way it is handled by musicians as consonant (like 11 the major).

3. That our diatonic scales are the only natural ones, I have at least not wanted to 13 maintain, because it cannot be proven. True we possess right now two different 14 temperaments for scales of which one is called equal temperament and the 15 other is called unequal temperament. Neither is completely natural and we 16 don't know whether the Greeks had a natural scale, because we know so little 17 about the past.

4. Should it not be possible by other means? - By all means! The minor third is 19 there, but not as a product of the tonic, so it cannot automatically resound. The 20 minor third develops much more from the relationship: 6/6:5/6 $=\mathrm{I}: 5 / 6=6: 5 ; 21$ otherwise one could not tune it at all. The perfect fourth also exists in this way: 22 4/5:3/4 or I: $3 / 4=4: 3$; and so it also does not resound automatically and yet it 23 is truly consonant.

5. and 6. If an experiment provides everything to achieve a complete picture, 25 one can ask what more is required? The minor third is not among the natural 26 overtone series. It is a composite relationship and I doubt any external cause 27 could make this interval appear naturally of itself. If it were possible, however, 28 all remaining intervals would alter themselves at the same time and we would 29 then indeed have a completely new and completely different system for 30 minor tonalities, which most likely would not tolerate being within the major 31 tonality, whereas our present system combines both in an unlimited wealth of 32 modifications. 37 only be significant for the major third, for the ear can accept all dissonances a step 37 38 apart: the tonic beside the second, the second beside the third, the third beside 38 39 the fourth, the fourth beside the fifth and so on. But the minor third is intolerable 39 40 beside the major third because it cannot be resolved, which is the reason why I had 40 41 considered the minor third as an indirect given of nature.

42 The following three points arise from the previous one. All intervals that lie 42 43 between the usual ones are possible; but if we are to use them and teach them with 43 44 proper respect for order and art, then we must have a new system. However, what 44 
1 our accepted - though imperfect - theory dictates is exactly what you yourself 1

2 add. For the above phenomena are not only not separate from man in his physical 2

3 and spiritual make-up, but rather they marry him to those elements of nature which 3

4 are outside him. His nerves, the most secret powers of his mind resound with 4

5 kindred tones and attract him, they lead him forward; they would really torture, 5

6 depress and destroy if they were not what they are and have remained that way 6

7 for so long.

8 The horn and the trumpet are among the instruments that do not freely produce

9 all the natural overtones of our scale. The major third is freely sounded on horn as

10 on the trumpet. But the minor third can only be acquired through stops with the 10

11 hand, and so since it does not freely appear, it is also never completely pure: the 11

12 ear misses something. Finally, I recall a bell that is situated here in the city. This 12

13 bell, which must have disparate parts, lets a third be heard that is smaller than the 13

14 major and therefore is closer to the minor than the major, yet every time the bell is 14

15 struck, this third purifies itself while swinging in the air and gradually approaches 15

16 the major third until it is pure. I have often observed this experiment myself for 16

17 a quarter of an hour at a time. Now, since this resounding tone is nearer to the 17

18 minor third than to the major, then why does the lingering sound not merge into 18

19 the minor third? 19

2013 July: The last eight volumes of your works arrived on the 5th of this month. 20

21 [...] The sight of the unfortunate Gretchen made me disconsolate. It is so subtly 21

22 implied and yet has a tremendous effect. Will you clarify for me so much that is 22

23 new in Faust, which I have read so often, for example the intermezzo? But first I 23

24 will read the whole poem once again. 24

25 I have read your Pandora ${ }^{325}$ and am agitated because since then I cannot sleep 25

26 until I know the entire play. In order to calm myself, I have already composed 26

27 these scenes and committed them to paper. ${ }^{326}$ I hope to present the two brothers 27

28 alongside one another so they should be recognizable, but I don't know the children 28

29 yet and to guess at the mother is so dangerous; for once the wrong character is 29

30 given melodic forms, nothing can be done to set it right. 30

$31 \quad 31$

$32 \quad 32$

$33-33$

$34-34$

$35-35$

$36-325-36$

$37 \quad 325$ Goethe's Festspiel Pandoras Wiederkunft was in the first edition of the journal 37

38 Prometheus (1808). Goethe had referred Zelter to the publication on 22 June. 38

39326 Zelter's setting of Pandora was left lying for the time being because of the problems

39 referred to but also because Zelter did not have the continuation of the text. Work on this

40 setting was resumed when Zelter received the complete text during their time together in

41 Bohemia in July and August 1810, but, once again, Zelter's compositional work came to a

42 halt under the pressure of everyday life. The work was taken up again in May 1811, at which

43 point Zelter discarded everything he had composed to date. Even Goethe's encouragement

44 to continue composing the work could not prevent it from being unfinished in the end. 44 
5 The young Eberwein arrived on the 19th of last month, and the next day we began 5

6 our scholarly discussions, which in the last few days have taken an easier path, 6

7 after having gone rather astray into a general wilderness. As he has only a short 7

8 holiday, it will be difficult to fit in some of the preconditions of art which should 8

9 get into the blood from one's youth; and so he wants me to ask you, my friend, for 9

10 a longer period of leave. I do this gladly, all the more as I hope that, on his return, 10

11 he will compensate for the extra time. So I ask that you leave him at least next 11

12 winter in Berlin, which will bring some musical benefit. ${ }^{327}$ Even his participation 12

13 in the Sing-Akademie can only be of use to him as an artist if he attends a series 13

14 of lectures, whose product he sees develop and grow, but especially if he hears 14

15 solid and masterly compositions in the plain German style, which will either make 15

16 him aware of his shortcomings or spur him on to compete. It has taken hold of 16

$17 \mathrm{him}$, that I can see, but he is not finding it because he is looking from the outside. 17

$18 \mathrm{He}$ has already made many friends. Yesterday, for the first time, he performed 18

19 publicly on the violin, not without applause. ${ }^{328}$ His tone is good and pure, but he 19

20 has, God knows from whose example, acquired the habit of a tearful, retarding 20

21 cantilena, the drawbacks of which I will suitably explain to him. To his question 21

22 of how much he has to pay me for the lessons I have explained that I am thinking 22

23 of arranging this matter with you: to you I will say to begin with that the more he 23

24 learns, the less he has to pay, and his longer stay with me in Berlin will not cost 24

25 more if he is not well off.

2611 September: Since this letter was left behind yesterday and can only be sent 26

27 next Wednesday, I must ask you for an answer by return of post with regard to 27

28 young Eberwein. I have said to him I had a letter from you in which you requested 28

29 we set up a diary recording his progress.

30 It is necessary that the young man stays on course; to this purpose I myself am 30

31 giving him the opportunity and for that reason he has been accepted [in the Sing- 31

32 Akademie]. However, as his time is also limited, I have also made it clear to him 32

33 not to lose himself; apart from that he can enjoy applause and friendship in great 33

34 company every day, about which nothing should get back to Weimar. 34

328 Eberwein performed 'with real skill and precision', Vossische Zeitung, 41 10 September 1808, at a summer concert entitled 'Musikalische Divertissement' arranged 42 by the court chamber musician Georg Abraham Schneider. The performance took place in 43 
5 You make me your debtor yet again, dearest friend, through the good reception 5 6 you have given Eberwein. When I granted him the short holiday in Berlin, ${ }^{329}$ I 6

7 could only do it with the intention of making him aware that art has a height and 7

8 a depth of which he seemed to have only a remote understanding, and a law of 8

9 which, if one comes from the outside and like the young people only scratches the 9

10 surface, one can have only the faintest notion. Unfortunately I cannot extend his 10

11 holiday this time and I will be satisfied if he, in the language of Pietism, comes 11

12 back as a sinner, if he feels that much is to be discarded which he had considered 12

13 good, if he notices that what the world considers roads to success are often wrong 13

14 paths, if an insatiable desire is activated in him to see you again and to be educated 14

15 by you. If I find him so disposed, I will provide for him in the future what he must 15

16 for the time being do without. 16

17 I am back safely from Carlsbad and accomplished a great deal there, which 17

18 sooner or later I will confide to you. [...] As soon as I am easier in my mind you 18

19 will hear more from me. When Eberwein's leave is over, send him on his way. 19

27 So I am sending Eberwein back to you a little better than when he arrived. He has 27

28 only seen the entrance; whether he will find even the inner courts, time will tell. I 28

29 have diligently given him work which appears dry to beginners in order to isolate 29

$30 \mathrm{him}$ first and to cut him off from the age, for if he doesn't learn to do anything 30

31 better than what the crowd has always wanted to hear, then it doesn't matter much 31

32 how he wastes his time. I have given him the task of sending me something of 32

33 this kind at least every month; then I will answer him promptly. I rely on your 33

34 encouragement, since he has to keep up the work [...] 34

35 Your letter of the 19th of this month arrived here on the 27 th. I considered it 35

36 appropriate to let young Eberwein read it himself, partly so as not to be the bearer 36

37 of sad news and partly to show him how you yourself think about art. [...] 37

3815 October: This letter, which awaits the departure of Eberwein, is still lying 38

39 here in front of me as he is also still here because a letter and money from Weimar 39

40

$43 \quad 329$ From 19 August to 16 October 1808, during which time Eberwein studied 43 44 compositional techniques and performance with Zelter. 
1 are outstanding. As he is becoming more and more anxious, I have advanced him 1

2 six Friedrichs d' ${ }^{330}$, which will enable him to depart from here tomorrow. 2

3

4

5

9 Accept my best thanks, dear friend, for all that you are able to do and for all that 9

10 you mean to do for young Eberwein. The world of art has certainly gone too much 10

11 towards the bad for a young man to see easily what is crucial. They always look 11

12 for it anywhere but where the real source is; and even if they once catch a glimpse 12

13 of the source, they are unable to find their way to it.

14 For this reason, some half-dozen of our younger poets put me into a state of 14 15 despair; in spite of their extraordinary natural gifts, they hardly manage to write 15 16 anything that I can admire. Werner, Oehlenschläger, Arnim, Brentano ${ }^{331}$ and others 16 17 work and toil away; but everything they produce is completely lacking in form 17 18 and character. No one will understand that the highest and sole operation of nature 18 19 and of art is form and in form, specification, so that each thing may be and remain 19 20 something special, something significant. It is not art to allow one's talent to act 20 21 capriciously, according to one's individual whim; something should always arise 21 22 out of it, as from the scattered seed of Vulcan, there arose a marvellous serpent- 22 23 boy. [...]

24 Have the kindness, dear friend, whenever you have a quarter of an hour to 24 25 spare, to give me a brief sketch of the errors of young musicians; I should like to 25 26 compare them with the blunders made by painters, for one must, once and for all, 26 27 calm oneself about these matters, denounce the whole system, not think about the 27 28 education of others and devote the short time that remains to one's own works. 28 29 But while expressing myself in so ungracious a manner upon these points, I 29 30 must nevertheless, as good-natured grumblers are wont to do, at once recall my 30 31 words and beg of you to continue devoting your attention to Eberwein, at all events 31 32 until Easter when I shall send him back to you again. He feels great confidence 32 33 in you, and great respect for your institute; but even this, unfortunately, does not 33 34 mean very much for young men because secretly they still think that something 34 35 outstanding can be equally well produced in their own silly way. A good many 35 36 men have an idea of the goal, only they would like to reach it by sauntering along 36 37 the labyrinthine ways.

330 The contemporary currency, namely gold coins; one Friedrichs d'or was worth five 41 
5 Yesterday we feasted on some of your gifts, on your compositions, as on your

6 turnips. I was also so grateful to you in that Eberwein appears to have brought

7 back with him something of your gravity. He seems to me like Moses when he

8 came down from the mountain with his face shining ${ }^{332}$. If that is only an outer

9 manifestation, we can suspect that something is also likely to have happened

10 inside. I thank you for your kind help towards his progress because his return here 10

11 is advantageous for him and for us. Our little choral singing would be completely 11

12 gone to ruin during the winter. Now he can take stock and make his pilgrimage to 12

13 you around Palm Sunday.

14 Reichardt from Cassel was here yesterday: ${ }^{333}$ he is visiting the theatres of 14

15 southern Germany to get personnel for Cassel Theatre, which of course must be 15

16 very strangely organized. He wants people who can perform two functions [as 16

17 actor and singer].

24 [...] Eberwein departed from here on 16 October and I also received a letter 24

25 from him on the 7th of this month. He must remain very focused if he is to have 25

26 any success. The technical aspects of an art really must be properly learnt in the 26

27 early years. If it is true that the spirit only stirs from within, concern for the outer 27

28 presentation must be eliminated. He who knows the trade will admit that it is a 28

29 help to the writer because it nourishes his joy and liberates the inner drive. 29

30 What you say in your letter in relation to specification in the shaping and in 30

31 form and character is perhaps more true of music (at least in music it is more 31

32 difficult to achieve) than of the plastic arts. For each of the poetic spirits named 32

33 by you, I could name a musical counterpart, and so confirm your judgement that 33

34 one sees with admiration and terror, will-of-the-wisps, and signs of blood on the 34

35 horizon of Mount Parnassus. Men so brilliantly gifted as Cherubini, Beethoven, 35

36 and several others steal the club of Hercules to smash flies with; at first one marvels 36

37 and then directly afterwards one shrugs one's shoulders at the amount of talent 37

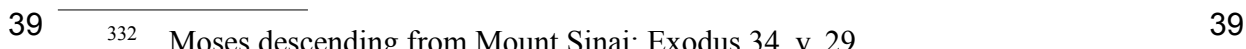

$40 \quad 333$ Reichardt had found a position as Directeur général des théâtres et de son orchestre

41 and music teacher to the queen in Westfalen at the beginning of 1808 , but the position

42 was not artistically satisfying. By the end of October 1808 he was sent to Vienna with the

43 task of engaging singers for Italian opera buffa. En route he passed through Weimar on 6

44 November; his visit is not recorded in Goethe's diary. 
1 wasted in making minutiae important and exalted ways common. I really could 1

2 despair when it occurs to me that new music must perish if art is to come out of 2

3 [new] music.

$4 \quad$ No art can exercise a positive influence, which wanders about in endless space, 4

5 shameless and shapeless like the more modern music, exposing its highest and 5

6 most secret charms, out of context, to the public gaze of the common and vulgar, 6

7 like an anatomical cabinet or a collection of anecdotes about illicit affairs which 7

8 oversatiate common curiosity. Let people object as they will to the composers of 8

9 earlier centuries (for who is not obliged to learn more than he knows?); they never 9

10 threw art away nor surrendered the inner sanctuary. Whoever appreciates this side 10

11 of them also learns to respect them. This much is certain: had we built on their 11

12 foundation, we would have an art and we would be very different people from the 12

13 way we must view ourselves now. 13

20 You receive here, dear friend, the requested manuscript. It contains a couple of 20

21 my songs which I looked for and found at your prompting. ${ }^{334}$ By the way, I myself 21

22 possess a very fine collection of original manuscripts and sometimes double 22

23 copies, especially in the case of German writers. [...]

24 With the next post you will receive a vellum copy of my works, ${ }^{335}$ which has 24

25 finally arrived here. [...] 25

32 [...] In honour of the King's return, I have established a Liedertafel: a society of 32

3325 men, the twenty-fifth of whom is the appointed master, gathers once a month 33

34 for a supper of two courses and entertains itself with jovial German songs. ${ }^{336}$ The 34

336 Zelter reports here a few days after a gathering of the founder members in Voitus, 38 house on 21 December 1808, but before the official formation, on 24 January 1809, of a 39 new Liedertafel, an assembly of 25 men from the Sing-Akademie who came together once 40 a month to sing and eat a light meal: "the idea a forming a male-voice choir combined with 41

44 Zelterschen Gründungen' in Carl Dahlhaus (ed.) Studien zur Musikgeschichte Berlins im 44 
1 members must either be poets, singers or composers. The writer or composer of 1

2 a new song reads or sings, or has it sung at table. If it is well received, a box is 2

3 passed round the table, into which everyone (if he likes the song) puts a groschen 3

4 or two, as he wishes. The money is counted on the table; if it is enough to purchase 4

5 a silver medal to the value of a good thaler, the conductor awards the winner the 5

6 medal; in the name of the Liedertafel they drink the health of the poet or composer 6

7 and discuss the beauty of the song. If a member can show 12 silver medals, he has 7

8 a supper at the expense of the group, he is crowned with a garland, can ask for 8

9 any wine of his choice, and is presented with a gold medal worth 25 thalers. All 9

10 other arrangements are mentioned in the plan, which right now is being circulated. 10

11 Anyone blurting out words that are dishonourable or offensive to any member or 11

12 to the society pays a fine. Satirical verses about individuals are not performed; 12

13 everyone has complete freedom to be himself provided that he is liberal. The 13

14 maximum number of rules is 12 ; there can be less, not more. Now draw me a 14

15 sketch for an attractive scroll, rather a big one, containing the word 'welcome' - 15

16 and one for a small medal and one for a gold medal; I ask you urgently because we 16

17 must strike when the iron is hot. All the members are enthusiastic and can hardly 17

18 wait for the King's arrival.

27 Dear friend, you will receive only this short note of greeting through Eberwein, 27

28 who is leaving now. ${ }^{337}$ Having put it off long enough, he has reminded me about 28

29 a letter to you exactly at a time when I don't have my thoughts together. Give 29

$30 \mathrm{him}$ a warm reception and help him to develop further through advice, teaching 30

31 and example. If what we wish for is not produced in our students, we still won't 31

32 be rid of them, so we have no other recourse but, with resignation, to reproduce 32

33 ourselves in this imperfect way. I am working on something that will also give you 33

frühen 19. Jahrhundert (Regensburg: Bosse, 1980), pp. 11-26, here p. 15). According to their statutes, the first meeting was scheduled to take place the day after the king's return, which was long anticipated; the meeting was, however, postponed, and the first proper 40 assembly took place on 2 May 1809 - more than seven months after the king's arrival on

4123 December 1808. See also Hermann Kuhlo, Geschichte der Zelterschen Liedertafel von

421809 bis 1909 (Berlin: Horn \& Raasch, 1909).

$43 \quad 337$ Eberwein's second study trip to Berlin, to take composition classes with Zelter 43 
1 joy some day. ${ }^{338}$ Therefore, forgive my silence and in your own time let me hear 1

2 something from you once again. 2

9 My dear friend, you have sent me quite a fine young man in Eberwein, for whose 9 10 acquaintance I remain newly obliged to you and you shall receive him back more 10 11 competent than when he arrived. I must praise not only his diligence and his 11

12 perseverance, but also for six weeks his eye is beginning to search for the kernel of 12

13 art, and his desire is being transformed into a sense that what is right and beautiful 13

14 has to be found for each individual thing. We have taken a serious path which 14

15 initially does not exactly go smoothly, yet we have made considerable progress 15

16 in a short time and we hope to settle comfortably into our routine. Already we 16

17 understand that the rule does not stand alone and itself has a rule we can intimately 17

18 approach by finding its foundation in the depths of our heart. In this way a feeling 18

19 for art develops, which recognizes that the cycles of everyday life cannot be 19

20 directly translated in art. The wonder at artistic craft merges into deep admiration 20

21 and love of truth and so we hope to arrive on a path where perception is clearer 21

22 and the goal more certain.

23 I must confess now that I myself am beginning to feel more and more affinity 23

24 with the young Eberwein, and since he is working so well, I would like to be able 24

25 to extend his visit. Now the question is whether he could stay here for another four, 25

26 five, six months? If he remains as diligent, I can vouch that the time will be put to 26

27 good use; if he doesn't, I would rather write and tell you. It is really terrible to be 27

28 pressed by time in such circumstances, because it is also true that all days cannot 28

29 be called good days. 29

36 I consider Eberwein fortunate; I even envy him that he lives near you and can 36 37 be enlightened by you on life and art. As our opera company is not going to 37 38 Lauchstädt this summer, he is not needed and may stay away, but only until his 38 39 presence is required here again. I enclose a short poem, which you might like to 39 40 accompany with the necessary musical declamation; ${ }^{339}$ or perhaps you will give it 40

$43 \quad 339$ 'Johanna Sebus', published by Frommann in Jena in 1809; Zelter's setting of 43

44 Goethe's ballad as a cantata for soprano, baritone and bass solo with SATB choir was 44 
1 to Eberwein to try his hand at it. I was induced to write it by good people of that 1

2 district, who, in an all-devouring age, wished to preserve the memory of a pure act 2

3 of humanity. [...]

4 Since Eberwein left and I have been occupied with all kinds of theatrical 4

5 matters, I am rather cut off from music. I hope in future to have all the more 5

6 enjoyment of it through him - echoes from your heaven, which alas! I am destined 6

7 never to enter, a thought that sometimes annoys me. In times of war we see for the 7

8 first time how clumsily and awkwardly we behaved in times of peace. When you 8

9 have set it to music, let the little ballad be as widely known as you like, and do not 9

10 leave me too long without a word of encouragement.[...] 10

17 Eberwein is just as delighted with his extended leave as am I. He is making 18 progress and this time you might find it harder to get him back. He is more familiar 18 19 with things which used to amaze him and he now sees in art, which seemed to 19 20 confine him, an open sea in which one can fish to one's heart's content. His violin 20 21 playing has also improved and ascends gradually from the dreary moaning and 21 22 whining to a brighter expression of life. He attends all my singing lessons daily at 22 23 the academy ${ }^{340}$ and will educate good students for you if he stays with it and does 23 24 not move away from the fundamentals. So as not to distract him with sensibility, I 24 25 have set the ballad to music myself. [...]

2610 July: You will have seen from the papers that I have been made Professor 26 27 of Music at the Akademie der Künste. ${ }^{341}$ I had as good as resigned from industry ${ }^{342} 27$ 28 and I am now in my element and want to see what success is possible at our time of 28

32 enclosed in a letter to the poet on 17 February 1810 and published by Ambrosius Kühnel 33 in Leipzig in 1810.

$34 \quad 340$ The vocal group established by Zelter, about which he wrote in his sixth 35 memorandum: 'For five years I have a held a proper Singschule like those of Italian 36 conservatories, in order to be able to teach the individual members of the Sing-Akademie'

37 (Schröder, p. 120).

$38 \quad 341$ The Spenersche Zeitung (also read by Goethe) had reported on 8 July 1809:

38 'Persuaded by the unmistakable influence which public music has on the nation's [cultural]

39 education, his Majesty the King has, following an application from the Head of the

40 Department of Culture, set up a Professorship of Music at the Akademie der Künste, and this

41 Professorship has been granted to the well-established composer, Herr Zelter [whom] his

42 Majesty has also deigned to appoint an official member of the Academy.' The appointment

43 was made on the recommendation of Goethe and Wilhelm von Humboldt.

$44 \quad 342$ Zelter's practice as an [architect and] master builder. $\quad 44$ 
1 life and in our [present] times. Hopefully our misfortune will bring us the benefit 1

2 of banishing the costly foreign parasites and their tastes. 2

314 July: I am just about to travel to Königsberg ${ }^{343}$ and you will not yet receive 3

4 the ballad ${ }^{344}$ but only this letter. The composition is in fact finished, but I want 4

5 to send it to you only after my return, because I intend to make all kinds of 5

6 improvements in it. I haven't forgotten what you wrote to me once about dramatic 6

7 ballads; ${ }^{345}$ in some ways this idea has formed the basis here, and since I employed 7

8 it, the realization has thereby become more mature. Good work also requires 8

9 good hands and only since I have it in front of me do I see exactly what is to be 9

10 done. There is nothing for it but to busy myself with architecture; ${ }^{346}$ if only I were 10

1130 years younger! 11

12

18 Accept my warmest thanks for the good care you are taking of Eberwein. I will 18 be very happy if he brings us back something really fruitful in his subject. [...] 19 I am very grateful that you have taken on poor Najada; ${ }^{347}$ I am really eager to hear 20 your composition.

343 Zelter combined many tasks on this journey to Königsberg, to where the Prussian 27

28 king had escaped before Napoleon's arrival in Berlin. The need for his journey arose through 28

29 the conflict with the Royal Kapellmeister, who wanted to refuse Zelter the use of the opera 29

30 house for his Good Friday and Easter Sunday performances; a decision by the cabinet to allow 30

31 Zelter the use of the room was the first outcome of the journey. The next issue was the long- 31 overdue payment of Zelter's salary, which was due to him after his appointment as Professor 32 of Music; this, too, was agreed with Minister Altenstein to Zelter's satisfaction. The most 33 difficult task concerned his own business, namely the collection of long-outstanding rental 34 debts from General Scharnhorst and the royal physician, Hufeland. Zelter's experiences 35 on this journey, from which he returned on 24 September, are documented in detail in his 35 daily letters to his sister Luise Syring. See Joseph Müller-Blattau, 'Karl Friedrich Zelters 36
Königsberger Briefe 1809' in Altpreußische Forschungen 12 (1935): 256-76. Hereafter 37 referred to as 'Zelters Königsberger Briefe'.

43 Sebus', which commemorates a young girl who loses her own life in a storm tide through 43 
5 If Professor Zelter has returned to Berlin, I cordially beseech him to send news of 5 6 himself and our Eberwein. ${ }^{348}$ If he has not returned, then I will ask his family. [... 6

7 It would be very nice if Eberwein would let me know how he is and what are his 7 8 current wishes and prospects. ${ }^{349} \quad 8$

15 And so gladly yet reluctantly I am sending Eberwein back to you: gladly because 15

16 I hope that what he now has and knows will have an effect, develop and do him 16 17 justice, which best happens away from the school and in freedom; reluctantly, 17 18 however, because I would still prefer to keep him here. He takes with him all 18 19 kinds of knowledge about the nature of his art, of which he has not yet fully taken 19 20 possession, because as yet he hasn't felt the need for it. It will awaken after a time 20 21 and come to fruition in him and perhaps appear to him in the form of completely 21 22 new ideas. If he is actively engaged as soon as possible, he will generally be able 22 23 to cope, especially if he has to, and what he finds lacking I will then supply. I 23 24 therefore advise that he be employed in an official post. If the directors were to 24 25 give him the task of creating the intermezzos of a comedy in three acts together 25 26 with a proper overture (yet in a set time frame which is not too long), he would 26 27 be suitably encouraged; and if he has some success, one could reward him with 27 28 a small gratuity. It takes a great fountain of genius for an artist to occupy himself 28 29 completely and to find his own way. Eberwein's talent is not so rich, but he appears 29 30 to me to be the man who does what one needs and there have to be such people, 30 31 especially with a standing orchestra. [...]

32 In Königsberg von Humboldt told me you put in a good word for me with 32 33 someone influential. ${ }^{350}$ I have been made Professor of Music; however, because of 33 34 the disruption of the whole system I still don't know how to measure my situation. 34 35 Plans for the university are in hand except for their execution, which, as it appears, 35 36 is dependent on the King's return. I shall be salaried - that goes without saying; 36 37 how and whether I am to earn my bread on the side and do most of it without being 37

$41 \quad 348 \quad$ Zelter returned from Königsberg at midnight on 24 September 1809.

$42 \quad 349$ There is no record of the letter Goethe requests from Eberwein. 42

$43 \quad 350$ Zelter had met Wilhelm von Humboldt many times in Königsberg, mostly over 43 
1 paid, time will tell. ${ }^{351} \mathrm{I}$ know the way it is and I am in no way capable of being 1

2 importunate. There is enough to do, but, knowing the situation and the people as 2

3 I do, I doubt whether the right things will happen. Meanwhile I go on in my old 3

4 way, come what may. Quite apart from what we didn't know or didn't have, we 4

5 have lost too much for me to be able to entertain great hopes; for as you say in your 5

6 letter, they are only despairing that they are no longer to lead the old sinful life; 6

7 and everyone only thinks that the right thing is what is right for him. 7

823 October: I have had to make a necessary journey which is why this letter 8

9 was left lying here and Eberwein departed without saying goodbye. [...] 9

10 A musician from the Königliche Kapelle called Schneider, ${ }^{352}$ who can no longer 10

11 get work here, is setting out on a musical tour with his wife and will pass through 11

12 Weimar. He asked me for a letter to you, that he might see you. I didn't give it to 12

13 him, because I knew that you are not in Weimar. He is a skilled horn player and 13

14 he has composed an enormous amount of good music, including a short German 14

15 opera. He was very accommodating to Eberwein, as he is generally a true phoenix 15

16 among his peers. As he has no letter of introduction, he will announce himself in 16

17 person to you. If you would like to see him and at all events give your consent that 17

18 the Weimar orchestra facilitate him in case he wanted to give a concert, or help 18

19 him to have his little opera be heard in your theatre, you would certainly give him 19

20 great pleasure. His pretty little wife ${ }^{353}$ is one of my students and has a nice voice, 20

21 but she is really timid and lacks experience. $\quad 21$

28 [...] On Thursdays and Sundays Eberwein plays for us much of the music he has 28

29 brought back with him, and whatever he can communicate to us by virtue of your 29

351 On 23 August 1809 Zelter discussed his salary with Minister von Altenstein: 35 'Yesterday Minister von Altenstein spoke favourably and in very friendly terms about my 36 academic existence. I can be happy about this, since I can see that they cannot do what they 37 would like to do' ('Zelters Königsberger Briefe', p. 273). In a further letter to his sister it 38 emerges that he is promised 600 thalers in addition to the 400 thalers he had received from 38 the Sing-Akademie since Easter 1809.

352 Georg Abraham Schneider (1770-1839), cellist, conductor and composer, 40 horn player in the Königliche Kapelle in Berlin, and his wife were Goethe's guests on 41 17 November and gave a concert in Weimar on 21 November; see Goethe's diary entry on 42 17 November 'Die Berliner Musici' and 21 November, WA III/3 pp. 400-401. 
1 input and blessing. ${ }^{354}$ Schiller's poems have been most admirably composed. ${ }^{355} 1$

2 The music supplements them, for really no song is perfect until it has been set to 2

3 music. Here, however, is something quite peculiar. Thinking or enthusiasm is now 3

4 for the first time dissolved, or, I should rather say, melted into the free and lovely 4

5 element of sensuousness. One thinks and feels, and is carried away by it. 5

6 You can also imagine that the light-hearted songs ${ }^{356}$ do not fail to produce their 6

7 effect, as I am much more fond of such things, and in fact everybody is glad to be 7

8 happy or to be put in good humour. $\quad 8$

9 Eberwein is doing really well. Through your help he has come further in 9

10 everything than those he has to conduct in the small school, and he is making 10

11 good progress, in so far as I can judge in a subject which I don't understand. The 11

12 supply of music in our small musical archive is for our purposes already quite 12

13 considerable, and as slight as everything is, compared to what you have done and 13

$14 \mathrm{do}$, it is still something. How we treasure a copperplate engraving of a painting we 14

15 cannot see. [...] 15

16 Write and tell me something about yourself when you have the opportunity, and 16

17 send me something to enjoy. It is true, we have plenty of the old and unexplored; 17

18 however, the newest and most immediate has the greatest attraction. 18

19

114. Goethe

25 Don't forget 'Johanna Sebus' and don't let it be submerged again, ${ }^{357}$ now that you 25

26 have passed her a helping hand.

$33 \mathrm{I}$ am in complete agreement with you with regard to the tone and spirit of social 33 34 songs. I, too, prefer cheerful, light songs and Privy Councillor Wolf claimed 34

36354 Rehearsals were on Thursdays with concerts at Sunday lunchtimes in Goethe's

37 home; on Eberwein's return from Berlin he took over the role of Director of Music of

38 Goethe's Hauskapelle.

39355 Most likely, Zelter's setting of Schiller's 'Die Gunst des Augenblicks' and the two

40 Punschlieder (first sent to Goethe on 2 April 1805 and again on 9 January 1808).

41356 'Urians Reise um die Welt' and 'Die Gunst des Augenblicks' mentioned in the

42 following letter.

$43 \quad 357$ Zelter had mentioned his completion of this setting on 12 June 1809 , but failed to

44 send it; it is enclosed in his letter to Goethe on 21 February 1810. 
1 recently that he had only fully recovered from his terrible illness ${ }^{358}$ through the 1

2 cheerful songs of the Liedertafel. I, too, would be inclined to complain to you 2

3 about the German poets, who are too serious in their poems, and I imagine you 3

4 could talk to these good people cheerfully and tell them not to express themselves 4

5 too pensively and gloomily. One should get one's fill of moaning and groaning in 5

6 everyday life.

7 I am delighted that Eberwein is getting on well because he must be very 7

8 industrious, especially if his stay in Berlin is to be useful to him. A talent must 8

9 become fully developed and that can only happen through constant activity. 9

10 Macbeth is being performed here in Schiller's translation as well as the cast 10

11 will allow. ${ }^{359}[\ldots]$ Then finally, after a long wait, we are going to have Iphigenie 11

12 with Gluck's music at the theatre. ${ }^{360}$ The general public show no great enthusiasm 12

13 because we are not so lucky as to be able to cast the two female roles suitably. 13

1424 January: [Wilhelm] von Humboldt has sent me by post your letter dated 14

154 th of this month as a sign that he will be absent longer than he wanted. I was 15

16 really delighted to see my songs praised by you. 'Herr Urian' is well received 16

17 here and is sung at almost every gathering. The song included here belongs to the 17

18 melodramatic $^{361}$ and will not scare off singers if it is performed perfectly. Eberwein 18

19 will see to it that it is performed in the correct way $[\ldots]$.

20 Eight years ago I left a composition, 'Der Müllerin Reue', with you in Weimar 20

21 without retaining a copy. I remember this composition only in so far as it appeared 21

22 to be successful and you liked it. Could you look for this piece and send me a 22

23 copy? I want to look for and have [in my keeping] what I would wish to retain. 23

24 When you are in full health and feel inspired, you think only of [creative] work 24

25 and form. What you liked I will preserve in love, even if it is the smallest thing: 25

$\begin{array}{lll}358 & \text { Wolf had been seriously ill with malaria. } \\ 359 & \text { Following Burger's translation of Macbeth in 1806, Schiller's adaptation of the } 33\end{array}$ translation was first staged in Berlin on 11 December 1809, with an overture and incidental 34 music by the music director Friedrich Ludwig Seidl (1765-1831). Further performances 35 were given on 18 and 31 December 1809.

360 Christoph Willibald Gluck's Iphigenie in Aulis was first performed in the 36 Königliches Opernhaus in Berlin with ballet music composed by Bernhard Anselm Weber 37 (1764-1821). The festive occasion (not mentioned by Zelter) marked the return of the royal 38 couple from East Prussia, where they had stayed during Napoleon's invasion of Berlin. 39

40 The reviewer in the Vossiche Zeitung (28 December 1809) only devoted a few lines to the 40 41 performance, noting the full house. A longer report appeared in the AMZ 12 (1810), no. 16, 41

4217 January, column 253.

43361 Zelter's setting of Goethe's poem 'Weltseele', which bears the performance 43

44 direction 'melodramatic (pathetisch) and spiritual (spirituos)'. 
2 He whom the poet lauds is given a forum; the individual 2

3 Allies himself to the choir of heroes. ${ }^{362} 3$

4

5 In 'Johanna Sebus' I have tried to do what you once wrote to me about the 5

6 dramatic form of romances. ${ }^{363}$ The composition is sketched and finished but not 6

7 in an accomplished manner, and since my journey to Königsberg I have not been 7

8 able to find a quiet hour to devote to it. If one goes out from oneself every time, out 8

9 from the same point, then life and art will always lead onto new radii, new forms, 9

10 and it is hard, so to speak, to enter in again from the beginning. [...]

17 Here, my divine friend, is my - our - 'Johanna [Sebus]'364 to whom, at all costs, 17 18 I wanted to do no harm [...]

19 Apart from the fortepiano I am asking Eberwein not to rehearse the other 19 20 instruments $^{365}$ until the choir (which should not be more than nine members) 20 21 perform really well. The singers must vocalize uniformly: that means if two or 21 22 more people sing the vowel 'o' together and one sings 'a' and the others sing 'o', 22 23 the expression is unclear; therefore, they must accentuate all the same vowels 23

24 together.

25 The dam bursts $[\ldots]$ melts $[\ldots]$ disappears $[\ldots]$ disappeared $[\ldots]^{366}$ If this is 25 26 performed properly, the composition will be effective. It is written that way. 26

27 I ask you then not to let the music out of your hands as I have already sent it 27

28 for publication in Leipzig. ${ }^{367}$ It should come out at Easter. It can, of course, be 28

29 transcribed in your home.

$34 \quad 364$ The autograph, dated 30 January 1810, is in Goethe's music collection (GSA

$36 \quad 365$ In contrast to Zelter's published version, this manuscript is scored with additional

36 instruments in the coda ('Bedeckt ist alles mit Wasserschwall ...'): flute, violin, viola,

37 cello, drums and timpani. An arrangement for orchestra, scored by Zelter's friend Johann

38 Christoph Schultz and published by Johann-Wolfgang Schottländer, makes the false

39 assumption that it is the first orchestral setting of the cantata; see Zelter, 'Johanna Sebus',

$40 \mathrm{JbSK} 9$ (1931), pp. 291-94. The manuscript sent to Goethe in this version is, in fact, the first 41 orchestration of the cantata.

$42 \quad 366$ Here Zelter indicates the slight variations made with each refrain. 42

$43 \quad 367$ Contrary to his original desire to have the cantata published by Cotta, Zelter sent 43 44 the manuscript to the publishers Ambrosius Kühnel in Leipzig on 17 February 1810. The 44 
1 I cannot express in words the joy you gave me on the 14th of this month with

2 the poem ${ }^{368}$ received for my Liedertafel. I have set it to music already. It shall be 2

3 performed next time, on 10 March on the birthday of our Queen and than you will 3

4 receive it directly. [...] 4

5 We usually print the words of songs which we sing during festivities at the 5

6 Liedertafel. As I look upon your song as our property, I shall have it printed with 6

7 the rest, unless you expressly forbid it; so, if you do not wish it to be printed, let 7

8 me know in the course of the month. ${ }^{369} \quad 8$

9 I don't know whether Eberwein brought you 'Trommellied' by Voß $\beta^{370}$ and 9

10 whether you already know it? It is completely cheerful, but there is a fatal 10

11 transcription mistake in the score: the last note of the melody should be in all 11

12 voices, not a minim with a fermata, but a short staccato crotchet and the final drum 12

13 beat must fall on this crotchet. I will ask Eberwein to correct this detail in his 13

14 manuscript and the singers must practice to catch this final beat exactly. 14

1521 February: While we are on the subject I am sending you the music to your 15

16 poem $^{371}$ with this [letter] before I have heard it. Should I find something to improve 16

17 in it, it can be inserted later. Would you like to give it a title? ${ }^{372}$ It must have a 17

18 name. The post is leaving. God be with you! 18

26 work appeared in 1810 with a commemorative title, 'Johanna Sebus' by Goethe. In memory 26 of the 17-year-old beautiful girl from Brienen, who, on 13 January 1809, perished in drift 27

28 ice on the Rhine, while saving others. For voice and piano, set to music by Zelter.' The first 28

29 edition was published by A. Kühnel in Leipzig in March 1810, the second was published by 29

30 Kühnel's successor, C. F. Peters.

369 Zelter's through-composed choral setting, 'Rechenschaft', was published by 32

33 C. Salfeld in Berlin in 1810.

370 'Tafellied für die Freimauerer'. Zelter's setting is entitled 'Tafellied' (GSA 32/44). 34

371 Zelter's through-composed setting of Goethe's poem 'Frisch! der Wein soll 37
38
reichlich fließen' for mixed choir and soloists; the autograph is in Goethe's music collection (GSA 32/13).

40

372 The poem, of which there is no manuscript copy in Goethe's hand, is written 40

42 title 'Pflicht und Frohsinn'; Zelter referred to it as 'Ächzlied' on 4 April; eventually it was 42 without a title in Zelter's handwritten copy. In the following letter, Goethe suggests the 41 
5 In the manuscript of 'Johanna Sebus', which should be in your hands by now, 5

6 I have just discovered all kinds of mistakes which I entrust to Eberwein for 6 7 correction: ${ }^{373}$

8 In all four piano repeats of the first choir 'Der Damm ...' in the tenor part, 8 9 eighth bar, the fifth note should not be G but a minor third lower: E.

10 In the third choral repetition, 'Der Damm verschwindet! Die Welle braust!', 10 11 in the soprano line, second bar, third note, the word 'braust' should not be B but a 11 12 fifth higher: F sharp. $\quad 12$

13 In the timpani part some notes are missing, therefore I enclose the page. 13

14 When you have heard the music sung through a few times, I would like to 14

15 know from you: whether your idea is fulfilled and whether anything has got lost 15

16 and doesn't come through. [...] 16

17 There is no lack of successful passages. You should make your judgement 17

18 about the whole piece. Perhaps the plastic arts are a more advantageous field, as 18

19 they place all the elements before the eye and can give it a complementary effect. 19

20 I hear Bury has painted the scene but I haven't seen it. Let it be what it will; we 20

21 have done our best. $\quad 21$

22 'But enough, you Muses! In vain I strove to portray what does not sing in the 22

23 song; what you haven't granted to the song; so you gave me the writer friend, the 23

24 friendly poet. Just as everything comes from you, I have everything from him.' ${ }^{374} 24$

31 Your music to 'Johanna Sebus' I have as yet only heard imperfectly, but enough for 31

32 me to assure you that I think it is excellent. I would have to write at some length, if 32

33 I were to try and tell you everything that went through my mind on this occasion. 33

34 I will only say one thing: that you have made very important use of something for 34

373 In the manuscript bequeathed to us (GSA 32/74) Zelter's corrections are all carefully inserted (in pencil, with the original entries recognizable in ink), and the timpani

41374 Zelter's poetic thanks to Goethe in the form of a parody of the last four lines 41 of Goethe's elegy from Alexis und Dora: 'But enough, O Muses! In vain you attempt to 42 portray how misery and happiness succeed one another in a lover's heart. When love has 43 inflicted its wounds, you cannot heal them; but they can be soothed, dear Muses, only by 44 you.' 
1 which I have no name, but which is called imitation, word painting, among other 1

2 things - something which with other composers leads to error and goes astray. 2

3 It is a kind of symbolism for the ear, where the subject, in so far as it is in motion 3

4 or not in motion, is neither imitated nor painted, but produced in the imagination, 4

5 in a way that is quite peculiar and impossible to grasp, so that the thing described 5

6 and the describer appear to stand in scarcely any relation to one another. 6

7 It is a matter of course that in music thunder can roll and waves roar quite 7

8 naturally. But it is surprising how you have expressed the negation, 'Kein Damm, 8

9 kein Feld' by a disjointed, interrupted passage ${ }^{375}$ and also the anticipation of 9

10 pleasure before the passage 'Doch Suschens Bild' ${ }^{376}$ Let me stop here, as I should 10

11 have to discuss the whole [setting] as well as the details. I hope to hear it again 11

12 several times soon and to enjoy it completely - which is better than reflection and 12

13 criticism. Your corrections arrived safely and have been inserted. ${ }^{377} \quad 13$

14 As for the song, ${ }^{378}$ it could be called 'Pflicht und Frohsinn'. Continue as you 14

15 are doing, and as often as it is sung, let some genial fellow add a new verse or sing 15

16 it instead of some other one. I have not yet heard the melody; lately things have 16

17 been too unsettled around here.

18 Now goodbye, and let me have Voß's 'Trommelied', for Eberwein did not 18

19 bring it with him. Our little society arranged a musical performance the other 19

20 day in the theatre, ${ }^{379}$ when your 'In Flammen nähet Gott' ${ }^{380}$ and 'Die Gunst des 20

21 Augenblicks', among other things, were most effective. 21

375 Before the choir sing the words 'Kein Damm! Kein Feld!', the choir and soloists 29

30 have five bars rest as the piano accompaniment leads into the final passage.

376 The music for the verse, 'Doch Suschens Bild schwebt überall', is a variation of 31 what has gone before, which is next heard in the solo setting of the verse 'Bedeckt ist alles 32 mit Wasserschwall' before being taken up by the piano and finally voiced by solo voice 33 accompanied by piano.

377 See Goethe's letter to Eberwein, 3 March 1810, WA IV/51, p. 282.

378 -Zelter's setting of Goethe's poen 'Fisch! der Wein soll reichlo 35

378 Zelter's setting of Goethe's poem 'Frisch! der Wein soll reichlich fließen'. $\quad 36$

379 On 22 February 1810 Goethe's domestic chamber choir mounted a concert under 37 Eberwein's direction in the Weimar theatre. Goethe's diary records 'an evening of musical 38 entertainment' in the theatre. In addition to the two songs mentioned in the letter, the 38 programme included further compositions by Zelter ('Das Vaterland'; 'Generalbeichte' 39 and 'Herr Urian'); Mozart ('Liebes Mädchen wir sind hier'; 'Ich armes welsches Teufel' 40 and 'Bandel-Terzett') and Carl Eberwein ('Lasset eure Lieder hören'; 'Willkommen Dir, 41 des neuen Jahres Sonne!' and 'Holder Genius des Landes') as well as music by Jommelli, 42 
5 Our little song ${ }^{381}$ made quite a sensation in that some are secretly delighted with it 5

6 and at the same time also get annoyed by it. Actually we are not so bad: we only 6

7 act that way now and again. It was sung at the birthday of Queen [Luise] ${ }^{382}$ at the

8 Liedertafel and already I hear it sung again here and there and cannot prevent it.

9 Most of all it pleased Prince Radziwill, ${ }^{383}$ who was among my guests on the day.

10 This man takes great pains in setting your verses to music and for a foreigner he 10

11 has hit the right tone happily enough.

12 Your letter dated the 6th of this month has just arrived, which I read with 12

13 great edification. It is really satisfying to be in agreement with the poet about the 13

14 fundamental meaning of the poem. If the poet understands the composer, then the 14

15 latter has also understood the poet and everything else is the ordinary material that 15

16 everyone is capable of who understands his trade. 16

17 Your thoughts about the composition of 'Johanna Sebus' are very informative 17

18 for me in so far as they highlight the points in the piece which the composition 18

19 has to separate before achieving a totality. If I have not failed here, then I will not 19

20 worry about the rest, which has its own direction.

21 Since the beginning and the end of the poem are of different sentiments, 21

22 but such that the latter follows from the first, filling in the not too considerable 22

23 space between both ends always remains a challenge, if the stages of change and 23

24 intensification are not to appear disconnected or feeble, to which end the chorus is 24

25 industriously employed as you will probably notice at the passage: 'verloren sein - 25

26 sind alle fern'. 26

27 If you would only be inclined to entrust a larger work to me where one would 27

28 be able to really let go. It would be a real shame if we would some day have to 28

34383 Prince Antoni Heinrich Radziwill (1775-1833), Polish cellist and composer, 34

35 important patron of music. Radziwill was one of seven people who responded to Beethoven's

36 request to act as patron to the publication of his Mass in D; Beethoven dedicated his

37 Namensfeier overture to him, op. 115, and he was also an important patron to Chopin. As a

38 composer he is best known for his music to Goethe's Faust. Scenes from Radizwill's Faust -

which is the first setting of Goethe's Faust - were performed at a private performance in

39 Berlin in 1816; they were performed again at Monbijou, near Berlin, on 10 June 1819 and

40 the entire performance was repeated on 24 May 1820. Radziwill worked on the score until

41 his death in 1833 . The complete work was performed by the Sing-Akademie on 25 October

421835 and the score was published the same year. It was performed by the Sing-Akademie

4325 times between 1835 and 1888. It was also used as incidental music for the first official 44 performance of Faust in Berlin in 1888. 
1 part without producing such a work for the world, which we had set about together 1

2 with proper collaboration.

3 You will show little interest in an opera or suchlike, given the frenzy of musical 3

4 production. [...] In any event a German subject would be the most appropriate: a 4

5 Hercules would not be scoffed at and ultimately I would put up with Orpheus, who 5

6 could still be presented as he has not been seen before.

7 'Trommellied' is enclosed. ${ }^{384} \mathrm{I}$ have not written out the words so that the letter 7

8 will not be too large. The poem is in the new edition of Voß's collected works 8

9 published in 1802, second volume, page $132 .{ }^{385}$

1019 March: [Wilhelm] von Humboldt ${ }^{386}$ sent me your verses of 30 January, 10

11 in which I take the greatest pleasure. I cannot comprehend how you clothe such 11

12 marvellous ideas in such a calm style of writing. When I have your verses in front 12

13 of me, it always seems to me as if they themselves are nestled in melodic forms 13

14 and need to be sung. [...] 14

1520 March: As you have to forgive so much, perhaps you will forgive your 15

16 verses when you find them planted on my territory. For I can only enjoy the 16

17 beautiful if I myself assimilate it. What function has beauty in the world, if not to 17

18 make it more lovely? 18

19

25 For some weeks past I have not been myself; perhaps it was the withering March 25

26 wind, or some other outside influence, that made me, not exactly ill, but rather 26

27 depressed and out of sorts. I eat without relish and life, which I value, holds no 27

29 So yesterday afternoon I took no wine; I did not want it and went to sleep 29

30 after dinner on the couch. Meanwhile my understanding postman laid your blue 30

31 envelope on my chest and I joyfully recognized it on awaking. Before I opened it, I 31

32 called for a glass of wine to complete my good cheer. As my daughter was pouring 32

33 it out, I broke open the letter and shouted: 'Ergo bibamus'. ${ }^{387}$ She was so startled 33

34 that she let the bottle fall; I caught it, once more I was blithe and cheerful, and the 34

35 wine, probably from gratitude for its salvation, did its job. 35

37384 Zelter's four-part setting of Johann Heinrich Voß's 'Tafellieds für Freimauer'. The 37 autograph is contained in Goethe's music collection (GSA 32/44).

40 Nicolovius, 1802). The poem is in vol. 4, Oden und Lieder, pp. 132-7. The first five volumes 40

41 of this edition are in Zelter's library.

42386 Goethe, Die romantische Poesie, MA 9, p. 245.

$43 \quad 387$ Title and refrain from Goethe's poem, 'Hier sind wir versammlet zu löblichem 43

44 Tun ...' (MA 9, p. 35) which he sent to Zelter on 27 March 1810. 
1 So that the first impression might not ebb away, I sent for pen and ink and set 2 your poem to music there and then. Looking at the clock, I found it was time to go 3 to the Sing-Akademie and after that there was a meeting of the Liedertafel. Forty 4 members were present. I read the poem aloud; at the end of each strophe, they all 5 shouted of their own accord in unison, as though in a double chorus, 'Bibamus!', 6 laying such a significant stress on the long vowel, that the floors resonated, and the 7 vault of the great hall seemed to lift off. This gave me the melody at once, and here 8 you have it, exactly as it composed itself. ${ }^{388}$ If it is all right the way it is, I claim no 9 part in it; it is all yours, and yours alone.

10 Your interest in the Liedertafel will inevitably bear fruit. The powerful German 10 11 songs increasingly have the desired effect. Instead of a weary, tired life, a lively 11 12 reinforced sense emerges, which no one before dared to show. One can stand up 12 13 straight: the path becomes more certain through sheer joy. [...] There is nothing 13 14 but good prospects here.

15 The delight that you thought of us so soon again enlivened everyone. Your health 15

16 was toasted like no one else's. The groaning song was called for and they sang it as 16

17 animatedly as the last time. They understood it much more today. Between every 17

18 verse they tippled and shouted, 'Long live duty!' and the last stanza was repeated 18

19 with hearty determination. 19

20 Amid the hustle and bustle that holds us back and makes us weary of work, 20

21 I have thought up a secret aspiration, which I now nurture every day. For a 21

22 considerable time I have already been plagued by gout in my wrist, which has 22

23 got so out of hand that I can hardly grip anything without pain. Apart from the 23

24 piano I cannot play a single instrument any longer and must live in fear of losing 24

25 that one. I have always heard the baths at Teplitz praised and I would like to visit 25

26 them. [...] 26

275 April: Yesterday my work was interrupted by Reichardt, who had just 27

28 arrived. We would have four Kapellmeister together here again. ${ }^{389}$ If the senior 28

29 Kapellmeister in the south ${ }^{390}$ wanted to accept their rotation, he would be helpful 29

30 to us. I'd be surprised if he is not looking for something we don't have. I am more 30

31 sorry for him than for many others. I have become accustomed to his peculiarities. 31

32 I would not want him to be other than he is. But not everyone thinks the same and 32

33 he will have to see where he stands. [...] 33

$34+34$

$35-35$

$36 \quad 36$

$37-388$ Although enclosed with this letter, Zelter's setting is not in Goethe's music 37

38 Although enclosed with this letter, Zelter's setting is not in Goethe's music 38

39 Johann Friedrich Reichardt (1752-1814), Vincenzo Righini (1756-1812), 39

40 Bernhard Anselm Weber (1764-1821), Friedrich Heinrich Himmel (1765-1814). 40

41390 Zelter is alluding to Reichardt, who, from 1810, no longer held a position as 41

42 Kapellmeister in Berlin. Two years previously (November 1808 to April 1809) he had 42

43 travelled to Vienna and had tried in vain to find a new position as Kapellmeister in one of 43

44 the opera houses. The reference to the south refers to this Viennese visit. 44 
I am busy with my Easter concerts at present, ${ }^{391}$ which I don't have the heart 1

2 for this time. If I knew you were among my audience, then the rest could go 2

3 wherever they liked.

121. Goethe

The warmest thanks for your practical reply. Unfortunately I am separated from my 10 little choir and so I can only celebrate 'Ergo Bibamus' with the eyes and with the 11 throat. Tell me first of all what songs are repeated most often at your Liedertafel, 12 so that I can get a feeling for your guests and discover what type of poetry pleases 13 their ear. When one knows that, one can give all kinds of fun to one's friends. 14

Follow up your idea of going to Teplitz. I am convinced that this spa would be 15 very beneficial for me, after Carlsbad. [...]

Berlin, 24 to 30 April 181021

As our Liedertafel is officially concerned with song, everything performed by the 23 members of the table must be sung.

Every time the newest pieces form the beginning as a rule and the poet and 25 composer are able to demand that anything that doesn't succeed immediately 26 or isn't understood is repeated as often as they find necessary. Until now I have 27 been very concerned that something new came to the table every time; we have 28 certainly had much that is new.

Song has the capacity to bind entertainment together and to maintain focus 30 on a subject. From it the memory of a passage from a lovely popular poem often 31 arises which is then called for and immediately sung. [...] The songs which 32

automatically come up in this way most often are: 'Bundeslied'; 'Generalbeichte'; 33 'Herr Urian'; 'Freude schöner Götterfunken'; Voß's ‘Trommellied'; 'Ein Musikant 34 wollt' fröhlich sein' from the second part of Des Knaben Wunderhorns, ${ }^{392}$ an old 35 Sunday he conducted a performance of his oratorio Die Auferstehung und Himmelfahrt 39 Jesu.

392 Zelter's settings of 'Bundeslied' ('In allen guten Stunden'); 'Generalbeichte' 41

43 Claudius); 'An die Freude' ('Freude schöner Götterf 
1 Gallias Caesar subegit 1

2 Nicomedes Caesarem. 2

3 Ecce Caesar nunc triumphat 3

$4 \quad$ Qui subegit Gallias. 4

$5 \quad$ Nicomedes non triumphat 5

6 Qui subegit Caesarem. ${ }^{393} \quad 6$

$7 \quad 7$

8 And lots more! The last work is sung splendidly by two choirs and Privy Councillor 8

9 Wolf, who wrote the poem, appeared happy with the metrical treatment. It was 9

10 repeated many times - six to eight times - because everyone really felt like doing 10

11 it as the metre catches on wonderfully.

12 If I am looking forward to something, it is this: finally to embrace you again 12

13 after five years. ${ }^{394}$ Everything must be done to bring this about. My Easter concerts 13

14 are over ${ }^{395}$ and I am happier with my income than with what has been achieved. 14

15 I could say I was rich if I didn't have to pay debts. [...] 15

22 [...] Kaufmann is the inventor of an instrument which he calls a harmonichord. ${ }^{396} 22$

23 This instrument has many similarities with the common-place harmonica and at 23

24 the same time [has] something of the organ. It seems to me, however, much more 24

25 perfect than the harmonica because it plays lighter and more purely. At the right 25

26 distance - especially in the evening in the open air - it must be an unbelievably 26

27 beautiful effect and so I have not wanted to delay directing this fine young man 27

28 to you. One cannot hear anything purer than the beautiful tones of this instrument 28

31393 Zelter's setting of 'Cantus martialis Romanus' from Gaius Suetonius Tranquillus's 31

32 biography on Caesar (chapter 49): 'Caesar subjugated the Gauls/ Nicomedes subjugated 32

33 Caesar./ Behold, Caesar now triumphs/ who subjugated the Gauls./ Nicomedes does not 33

34 triumph/who subjugated Caesar.'

$35 \quad 394$ The last time Goethe and Zelter met was in Lauchstädt in August 1805.

$36 \quad 395$ Zelter was unhappy with both performances, as were the critics. Unfavourable 36

37 reviews - especially of Zelter's oratorio - were published in the Spenersche Zeitung and the

38 Vossische Zeitung on 24 and 26 April. Friedrich Rellstab's review in the Vossische Zeitung

38 was publicly answered on 1 May 1810 , signed by 37 members of the Sing-Akademie and

39 published in: AMZ 12 (1810), no. 33, 16 May 1810, column 527; MA 20.3, p. 262.

40396 In 1808 Johann Gottfried and Johann Friedrich Kaufmann (father and son)

41 invented the harmonichord, a kind of upright (giraffe) piano, in which the strings are set in

42 vibration not by the blow of the hammer but by indirectly transmitted friction. Carl Maria

43 von Weber explored the possibilities of the harmonichord, which in tone resembled the

44 glass harmonica, in his Adagio and Rondo for harmonichord and orchestra.

.

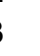

15


1 and the harmonica, which is unpleasant to play and hardly ever so well tempered, 1

2 will very likely be supplanted through it. 2

[...] I intend to visit the master of the harmonichord at his invitation, and introduce 9

$10 \mathrm{him}$ to other music lovers.[...]

17 With regard to a social life, it is very impoverished here, especially since Privy 17

18 Councillor Wolf departed. Still, yesterday I made the acquaintance of the poet 18

19 Carpani, who, from now on, will compensate me through his operas and spiritual 19 20 poems. $^{397}$

21 Will you be so kind as to send the enclosed letter to Körner, ${ }^{398}$ as it contains 21

22 something musical? [...] I am now thinking seriously of the trip to Vienna because 22

23 I don't see how I can arrange it if it doesn't happen now. ${ }^{399} \quad 23$

30 I arrived here on Sunday 22nd, just in time to go to the theatre. To my delight 30

31 I suddenly saw before me my former student, little Minna Unzelmann, ${ }^{400}$ who 31 contributed to a collection of arias edited by the writer: In questa tomba oscura. Arietta con 35 accompagnamento di Piano-Forte composta in diverse maniere da molti Autori (Vienna, 36 1808). Later, in July 1819, Zelter met Carpani again in Vienna; in his account of his travels 36 he mentions Le Haydine, the well-known Haydn biography in epistolary form. 398 The letter has not been handed down.

400 Wilhelmine Unzelmann (1802-71), actress in Berlin and Prague; daughter of the 41

42 actress Friederike Bethmann. Of the performance Zelter wrote to his sister, Luise Syring: 42

43 'She recognized me immediately in the stalls and from then on she performed so that her 43

44 body was always turned to me' (GSA 95/I, 8. 16, no. 27). 
1 happily played the pleasant role of the cobbler's wife (in the opera Die verwandelten 1

2 Weiber $^{401}$ to applause. She has really come on in a short time. She sang purely 2

3 and performed with ease. After the finale she was called for and applauded. On 3

4 Monday Kotzebue's Intermezzo was performed; I was not exactly impressed 4

5 by it; and on Tuesday Die Schweizerfamilie ${ }^{402}$ [was performed], which I found 5

6 delightful. The music for this opera is exceptionally charming and entertaining 6

7 and I would say, for the most part, with the most excellent forces. Mademoiselle 7

8 Müller, ${ }^{403}$ daughter of the famous composer Wenzel Müller, ${ }^{404}$ makes a great Frau 8

9 von Heygendorff. ${ }^{405}$ Attractive figure, light movements, ease in speaking, control 9

10 of the voice are natural to her. Just as she doesn't do anything that is too much with 10

11 these rare resources, neither does she do anything wrong. Yesterday she played 11

12 Sargin. $^{406}$ I cannot stand this work or the laboriously rich music. I listened through 12

13 it yesterday purely because of this girl. One cannot see anything more noble, more 13

14 agreeable than this young girl in traditional male costume. Feet and hands, thighs 14

15 and upper body are in perfect proportion and move with unbelievable daintiness. 15

16 Only the youth and sweetness of the voice betrayed the woman. I will make an 16

17 effort to speak to her and especially to congratulate her. At the same time I was sad 17

18 that her voice will not hold out. [...] 18

19 Yesterday lunchtime I was invited to a Lenten supper by the prelate of the 19

20 Strahofer convent, ${ }^{407}$ by the name of Milo Griem. ${ }^{408}$ That's the way one likes to 20

21 fast! For a private library, the collection of books appears very significant and 21

22 contains interesting manuscripts of Bohemian history. The church is splendidly 22

23 laid out and has the best organ gallery I have ever seen. In the librarian, Father 23

24 Gottfried [Dlabacz], and an approximately 60-year-old Father Octavian [Joseph 24

25 Prutky], I found a couple of people I can identify with. 25

Paer (libretto from the Italian, Poche, ma buone, ossia le Donne cambiate of Giuseppe Maria Foppa).

402 Joseph Weigl, Die Schweizerfamilie, Singspiel (libretto from the French, La 32

404 Wenzel Müller (1767-1835), composer and Kapellmeister in Vienna and for a 36

37 brief period in Prague (1807-1813).

38405 Henriette Caroline Friederike von Heygendorff née Jagemann (1777-1848),

39 singer and actress in Weimar (1797-1828), Carl August's lover, ennobled with the name

40 'von Heygendorff' from 1809.

41406 The title role in Ferdinando Paer's opera, Sargines, oder Der Zögling der Liebe 41

42 (libretto from the Italian, Sargino ossia l'Allievo dell'amore by Giuseppe Maria Foppa). 42

43407 Premonstratensian monastery in Strahov, Prague. 43

$44 \quad 408$ Johann Nepomuk Grün (1751-1816). 44 
Monday, 30 July: I have already had some fun with our canon. ${ }^{409}$ I wrote it 1

2 in the family album of a [female] singer, who didn't know what I meant by it. 2

3 Apropos it occurred to me that I wrote it out in four parts on your manuscript 3

4 paper, at least that's how I remember it. However, it is in fact for six voices and a 4

5 voice can enter on the second crotchet of every bar. The canon can also be sung 5

6 solo or in two, three, four, five and six parts. [...] 6

7

8

\section{Zelter}

Along with the new composition which I enclose, you will receive 13 'Schneidercourage', ${ }^{410}$ once again, because I think I made some alterations; you 14 can destroy the old copy.

[...] And to add on immediately now, how much joy you have given us through the 22 last consignment of compositions ${ }^{411}$ as well as through 'Diogenes', ${ }^{412}$ which has 23 become a favourite of our small audience. ${ }^{413}$ I hope your Liedertafel will have had 24 no less pleasure in the same [pieces].

The weekly musical meeting, as small as the institution may be, provides me 26 the invaluable pleasure, which I otherwise would have to forgo, of hearing your 27

409 Zelter's canonic setting of Goethe's verse 'O, wie lallt das Kind so faul', first 29 published in WA (1893) under the title 'Singschule'; $M A$ 9, p. 49. Zelter's manuscript, 30 entitled Canone perpetuo a 4 Voci (GSA 32/23), is corrected in Goethe's hand to: Canone 31 perpetuo a 6 Voci.

411 Zelter's settings of Goethe's poems 'Es ist ein Schuß gefallen' and 'Zwischen 35 Weizen und Korn'.

412 Zelter's three-part canonic setting of Goethe's poem 'So wälz' ich Unterlaß, 36 (published in 1815 under the title 'Genialisch Treiben' in Goethe's collected works). The 37 composition is not in Goethe's music collection; the enclosed manuscript is possibly the 38 Düsseldorf autograph which is dated 'Teplitz, 22 August 1810', but incorrectly dated ' 1820 ', 39 in the catalogue (GMD: Katalog der Musikalien, Nr. 1544a). 40

413 Riemer later wrote of Zelter's 'superb as well as humorous canon' which was 41 'premiered by Goethe's Hauskapelle on the 4 November 1810 and from then on performed 42 repeatedly as one of their favourite pieces', Mittelungen über Goethe, vol. 2 (Berlin, 1841), 43 p. $542 f$. 
1 superb works repeatedly and becoming acquainted with them. 'Johanna Sebus' and

2 'Die Gunst des Augenblicks' will be performed today and I am already looking

3 forward to it. Let me know soon how Pandora is going ${ }^{414}$ or whatever else you

4 have taken up to work on. The writer of this letter ${ }^{415}$ has dug out some songs and

5 jokes again, ${ }^{416}$ which will reach you in good time and are likely to give pleasure

6 both to you and to others. 'Der Schneider' ${ }^{317}$ is really excellent and always gives

7 great satisfaction.

8 At the end of this week we are to hear Paer's Achilles in Italian; ${ }^{418}$ Brizzi has

9 arrived, ${ }^{419}$ and will sing the part of the hero for us. Our other singers are either

10 polishing their Italian, or beginning to learn the language; whatever happens, we

11 shall have a nice performance [...]

12 In conclusion, let me tell you about a curious plan we have, that is, a 12

13 performance of Faust just as it is - insofar as it can be done. ${ }^{420}$ Perhaps you could 13

14 help us with some music, more especially for the Easter song ${ }^{421}$ and the slumber 14

15 song, 'Schwindet ihr dunklen Wölbungen droben'.

414 Goethe is enquiring about Zelter's setting of Pandora, which the composer had

20 taken up in Teplitz once more; on his return to Berlin the work was put aside again due to a

415 Goethe's amanuensis, Friedrich Wilhelm Riemer, who later prepared these letters

$24 \quad{ }^{416}$ Perhaps Goethe's poem 'Problem' (MA 9, p. 50) which Zelter set on 22 November

241810.

27 representatives of the Italian operatic school at the close of the last century. He settled in

28 France and became Maitre-de-chapelle to Napoleon, whom he accompanied to Warsaw

29 and Posen in 1806. His most famous operas include the sequel to Mozart's Marriage of

30 Figaro (1797) and Leonora, which has the same plot as Beethoven's Fidelio (pre-dating

31 it by a year). Paer's opera, Achilles (libretto by Giovanni De Gamerra), was performed on

3228 November 1810 in Weimar, with further performances on 1, 15 and 19 December.

34 in Munich. Carl August had got to know him in Eisenberg through Prince Lobkowitz and 35 asked Goethe to engage him as a guest performer in November. Difficulties in rehearsals 36 of the Italian opera Achilles, proposed by Brizzi, caused Goethe to reject, or to be precise,

37 'postpone' Brizzi's appearance until the following year; since Brizzi did not consent and 38 demanded full salary, he was engaged nonetheless. Brizzi arrived on 16 November. In

38 November and December 1810 he appeared many times in Paer's Achilles. See Goethe's

39 correspondence with Carl August between September and December 1810 and also Goethe's

40 letter to Brizzi on 4 and 22 October 1810, WA IV/30, pp. 155-7.

41420 Goethe noted down ideas for a performance of Faust in his diary on 13 November.

42 The idea was put aside at first and then abandoned. The first performance of Faust $I$ in

43 Weimar took place on 29 August 1829. 
5 At last I have had enough time to myself to be able to consider my debt to you. I 5

6 have to observe, report and make arrangements and can neither find the beginning 6

7 nor the purpose in the accursed music world, in which everyone is so self-satisfied 7

8 that my flesh creeps. Everything would go well if we could do everything in peace 8

9 and move forward step by step; but everything has to be reported and we have to 9

10 fill up reams of paper. This is at the cost of joy and courage. [...] 10

11 As to Pandora, as good as nothing has happened the whole time, although I 11

12 have, at the same time, finished a fine number of little songs, which come [to me] 12

13 short but complete and instantaneous outpourings. I will send you what is finished 13

14 of Pandora, when I get to it. [...]

15 But the real reason why I have not written for so long is that I wanted to send 15

16 you straight away what you wanted for Faust ${ }^{422}$ and had just started to do so when 16

17 I received your letter; then irksome things occurred and the thing had to remain 17

18 lying and is still there. So you will have to get music from elsewhere; I cannot do 18

19 it now because it needs an uninterrupted stretch of time; also I would have to speak 19

20 with you about it in person, because the thing is no trifle in so far as it has to fit into 20

21 the whole: one must do that; all the rest comes from the gods. Your undertaking 21

22 is as beautiful as it is audacious. Prince Radziwill will arrive with you around the 22

23 time of the performance. ${ }^{423}$

30 [...] I cannot quarrel with you for declining to compose the music to Faust. ${ }^{424}$ My 30

31 proposal was rather whimsical like the project itself. [...] Now farewell, dear sun, 31

32 and continue to give forth warmth and light.

422 The incidental music for Faust, including settings of 'Ostergesang' ('Christ ist 37 erstanden') and 'Einschläferungslied'.

423 As with the planned performance, Radziwill's meeting with Goethe was postponed; 39 his first visit to the poet was not until 25 November 1813.

424 Zelter had relinquished Goethe's request for incidental music for Faust I on 41

43 scheduled performances, namely Brizzi's appearance in Achilles and Der standhafte 43

44 Prinz. 
5 [...] Everyone here is talking about your performance of Der standhafte Prinz, 6 Don Fernando von Portugal; 425 it must have been excellent. I have a similar work 7 in front of me: I will perform an old, very fine piece of music, which the members 8 have brought to my attention. But they want their old licentious way, which I will 9 not endure and that causes quarrels and is very painful. [...]

10 At last I have also seen and heard the recently acclaimed Parisian Opera, Die 10 11 Vestalin. ${ }^{426}$ It is a real joke and the gentlemen of the Paris Conservatoire - who 11 12 would not make up their minds as to which of two excellent people they should 12 13 award the prize because they really have no critical standard and trilling and 13 14 chirping is all they are interested in - were forced to see the Emperor put his finger 14 15 into the pie and award the prize to a young artist, who, if he is past 25 , will never 15 16 do anything much. The libretto is flexible enough for an opera and there is room 16 17 for music. Spontini ${ }^{427}$ has used it like a boy, whose hands have just been set free 17 18 from swaddling bands for the first time, and he lays about him with both fists so 18 19 violently that the pieces fly about one's ears.

20 Bettina wanted to be married last Sunday week. ${ }^{428}$ However, both parties had 20 21 forgotten a few trifles, such as the calling of the banns, the hiring of lodgings, the 21 22 procuring of a bed and similar preparations. I imagine, therefore, that things must 22

23 remain as they are until after Lent.

34 von Portugal (in August Wilhelm Schlegel's translation) was first performed on 30 January 35 1811, with a second performance on 6 February.

426 La Vestale (1807) and Ferdinand Cortez (1809), two of Spontini's best-known

38 Napoleonic era for operas with sumptuous production and plots with historical and political

38 significance. The Berlin premiere of Die Vestalin (libretto by Etienne de Jouy, translated

39 by Carl Herklots) took place on 18 January 1811 in the royal opera house. See AMZ 113

40 (1811), no. 7, 13 February, column 132 and no. 11, 13 March, column 195. Zelter went to

41 the fourth performance on 27 February.

$42 \quad 427$ The Italian theatrical composer Gaspare Luigi Pacifico Spontini (1774-1851). 42

43428 Elizabeth Bettine Brentano (1785-1859) married Achim von Arnim (1781-1831) 44 on 11 March 1811. 
$5[\ldots]$ May you succeed in every way, in all you do, and in all you write. I imagine 5

6 how you manage in your Sing-Akademie. Just educate a certain number of pupils 6

7 and you will be cultivating almost as many adversaries. Every genuine artist must 7

8 be regarded as one who is protecting something acknowledged as sacred, which he 8

9 intends to propagate with thoughtfulness and with care. But every age, in its own 9

10 way, tends towards what is secular, striving to make what is sacred common, what 10

11 is difficult easy, what is serious amusing: and nothing could be said against this, 11

12 were it not for the fact that sincerity and humour are thereby utterly destroyed. So 12

13 much for today! Let me hear from you frequently. 'Johanna Sebus' is often enough 13

14 asked for at our musical gatherings on a Sunday, ${ }^{429}$ and is delightfully performed; 14

15 I might almost hope that you yourself would be satisfied. We have not yet had it 15

16 performed with instruments. Eberwein is doing admirably; I wish he could have 16

17 the good fortune to enjoy another six months of your company and teaching. Our 17

18 Kapellmeister Müller ${ }^{430}$ has a good grip on his orchestra and chorus, as well as the 18

19 soloists; and with regard to musical enjoyment we certainly have been well off this 19

20 winter. And for now, from my heart, farewell! I am busy in various ways, and am 20

21 quietly easing myself away from things, so that I may soon be able to set out again 21

22 on my summer tour. ${ }^{431}$

Thanks for the beautiful poems. The Swiss one has been written in a good Swiss; 29

I will just let it ferment, then you will have it. 
5 This winter our theatre has been very lively. Many new pieces and a number 6 of foreign actors have enlivened it. Reichardt had a new opera performed, Der

7 Taucher ${ }^{432}$ which will not appear again. The libretto is too mediocre ${ }^{433}$ and the

8 composer, who thinks less of the witchcraft than of the pace, would have done well

9 to have taken more time and fill it in somewhat better, instead of which he runs

10 from one thing to another and collects or spreads political anecdotes.

11 Madame Schütz (formerly Madame Hendel, before that Madame Meyer and 11

12 before that Madame Eunike, née Schüler) ${ }^{434}$ is here now and her performance is all 12

13 storm and bluster. I have seen Benda's Medea $^{435}$ and Kotzebue's Oktavia. ${ }^{436}$ For 13

14 a woman who is already sleeping with her fourth husband, something so natural 14

15 would not be too much. She makes enough effort and screeches and runs and 15

16 wrenches; I don't like it when context and melody are missing. Essentially it is 16

17 like a disjointed work soldered together from a hundred fragments which clash 17

18 horribly. 18

2523 May: On 19 May Ariadne auf $\operatorname{Naxos}^{437}$ was performed very proficiently by 25

26 Madame Wolff. The dialogue in this so-called Duodrama is just too deplorable 26

27 and our Theseus ${ }^{438}$ was like a commercial attendant in disguise. It says much for 27 roles as well as in two pantomimes. In contrast to Zelter's harsh criticism, she was very 36 favourably received by the press: Vossische Zeitung, 6 November 1811, MA 20.3, p. 280.

37435 Georg Benda's melodramatic setting of Friedrich Wilhelm Gotter's tragedy Medea,

38 performed at the Königliches National Theater on 28 March 1811 with Henriette Schütz in 39 the title role.

40436 Kotzebue's Oktavia was performed on 30 March with Henriette Schütz as Octavia 40

41 and Iffland as Antonio.

42437 Georg Benda's melodrama Ariadne auf Naxos; libretto by Johann Christian 42

43 Brandes.

$44 \quad 438 \quad$ The role was played by Franz Mattausch (1767-1833). 44 
1 Madame Wolff that she could hold herself in her position without bursting into 1 2 loud laughter over her beloved Theseus. Straight after this Madame Wolff played 2

3 alongside her husband in the confessions, which ran smoothly and went well and 3

4 made a suitable impression.

$5 \quad$ [...] I have resumed work on Pandora ${ }^{439}$ and a good section from pages 50 to 5

657 inclusive is almost finished. And what's best is that it appears it will be all of 6

7 a piece. You will remember that I had already written the opening to this section 7

8 in Teplitz: 'Mühend versenkt' ${ }^{440}$ On the other hand, I can use nothing at all that I 8

9 composed two years ago and I would prefer to set it again and relate it to the whole 9

10 than to patch it up. I must leave pages 58 to 64 (where Eos appears) ${ }^{441}$ until the 10

11 whole is ready in order to set off the light side of the work against the dark. What's 11

12 really important to know is how Eos' apparition will take place in the theatre, for 12

13 it should not work like copper: impetuously, in spurts. 13

14

15

16

17

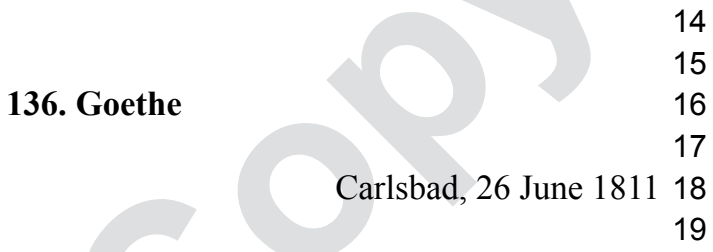

May you also in some way be rewarded for what you are doing for Pandora. 20 Could I have foreseen your interest in this work, I should have treated the subject 21 differently, and tried to free it from the difficulties for both music and performance 22 which it now has. But now that's the way it is. Continue with it, as it pleases you, 23 and I will see if I can undertake the completion of Part Two. ${ }^{442}$ I have planned 24 and sketched out everything, but the figures themselves have become rather 25 distant from me, and I am somewhat astonished at their titanic shapes, when - as 26 yesterday, by chance - I happen to declaim something from it.

May good fortune accompany you on your journey to Silesia, and may your 28 active perseverance be rewarded by proper results - for truly, when one reflects 29 how little the world has responded to your fair and noble achievements, one might 30 well say that the response has not been appropriate. [...]

[...] Himmel has been here for some days ${ }^{443}$ and, though suffering, is still the 32 same as ever: cheerful and communicative, and by his playing improving even 33 the roughest instruments. All along I have heard and seen too little of him, and 34 we do not meet very often, owing to his convivial way of life; yet it has occurred 35

439 Zelter had begun work on this composition during the days spent with Goethe in 37

Teplitz: 7 to 23 August 1810.

440 'Mühend versenkt ängstlich der Sinn/ Sich in die Nacht', Pandora, v. 949f. 39

441 Pandora, v. 749f. $\quad 40$

442 In time Goethe believed he had planned Pandora, Part One, on too large a scale for 41

continuation and, as a result, Part Two was never written.

443 In his diary, Goethe records a visit from the Kapellmeister Friedrich Heinrich 43

Himmel on 23 and 24 June 1811, WA III/4, p. 214. 
1 to me recently whether I might not be able to publish the maxims, convictions 1

2 or passions, or whatever you wish to call them, around which he centres his 2

3 musical settings of lyric poems or by which he is guided. This does not seem to 3

4 me impossible, and I think I am well on the way; still I have too many deficiencies 4

5 to be able quit my task so easily. If, at your leisure, you can help me occasionally, 5

6 you would be doing me a kindness. 6

$8-8$

9 137. Zelter 9

10 10

$11 \quad$ Breslau, 12 August 181111

$12 \quad 12$

13 [...] It is generally believed that Himmel has been dead for three weeks. ${ }^{444} \mathrm{He} 13$

14 must have died just after your letter of 26 June, yet the papers would have reported 14

15 it. His death would have hit me very badly because I have never experienced 15

16 a better, more comfortable handling of the fortepiano. Nature and opportunity 16

17 proved themselves very loving in this happy youth and it would be no wonder if 17

18 the world were to lose the best musician in him. 18

19 To go through life supported by the remains of a king, schools and universities, 19

20 in artistic lands, the castles and chapels of princes is a lot which can support an 20

21 artist's cheerfulness and humour. In the process he attempted much and could have 21

22 even been luckier therein, if he had not started where art breaks off. I considered 22

23 his lyrical talent crucial. If only his boldness and brazenness were quiet and certain, 23

24 his works would lack nothing. In recent times he would have learned much, if only 24

25 he had not despised schooling, without which mastery cannot occur. Therefore, 25

26 like Reichardt he venerates what he could have improved. Ultimately what every 26

27 artist needs must be learnt first and you yourself have said it clearly enough in 27

28 'Künstlers Apotheose': namely that art remains art and natural talent and instinct 28

29 are not enough without it. 29

$30 \quad 30$

$31 \quad 31$

$32 \quad$ 138. Zelter 32

$33-33$

$34 \quad$ Berlin, 25 October 181134

$35 \quad 35$

36 [...] Since the end of last month I have been in Berlin again, after I had almost 36

37 spent three months in the Silesian mountains in order to dig up old musical 37

38 treasures from the dust. ${ }^{445}$ The business was not altogether thankless [...] I 38

39 had only one volume of your works with me on my journey and from this I set 39

$40 \quad 40$

41444 This was the second rumour to circulate claiming that the piano virtuoso was dead; 41

42 he died three years later, on 8 June 1811.

43445 Zelter's journey was recorded in the $A M Z 13$ (1811), no. 34, 21 August, column 43

$44580 f . \quad 44$ 
1 'Die Geheimnisse'. ${ }^{446}$ I should be surprised if you will recognize your octaves 1

2 again; if only I could sing them to you. Some friends didn't find the composition 2

3 too bad.

$4 \quad[\ldots]$ I always invite a couple of guests to the Liedertafel; 'Ergo bibamus' is sung 4

5 so that the hall resounds. This little piece is not bad, so that even Reichardt had 5

6 to praise it, though he is envious of my songs and he will not gladly acknowledge 6

7 them. He gets annoyed that you waste your time with all kinds of vermin: I know 7

8 who he means by that and laugh about it. He pinches your poems from me, shits 8

9 them onto a piece of manuscript and sends them warm to the press in order to 9

10 be the first. Or else they are composed afterwards: since he treated 'Der junge 10

11 Jäger' ${ }^{\prime 47}$ and many others in a very careless manner. He likes to make every good- 11

12 natured fool his obedient servant, as I was for a long time, and then he thinks one 12

13 is ungrateful.

[...] Brizzi is here again and tonight we listen to 'Ginevra, Queen of Scotland' ${ }^{448} 20$

21 I wish that you were here with us, partly to enjoy this festival with us, partly to 21

22 give me explanation of the composition, whereby my enjoyment would be at the 22

23 same time judicious and intelligent. [...]

If there were to have been some talk about the composition of one of my works, 24

25 I would not have easily guessed 'Die Geheimnisse'. This news of yours makes me 25

26 very curious.

446 Zelter's setting of Goethe's epic fragment 'Die Geheimnisse'; the Berlin 34 manuscript (SBB PK: Mus. Ms. Autogr. Zelter 21/3) is dated Breslau, 19 August 1811. 35 There is a second copy in Goethe's music collection (GSA 32/30) scored by a music copyist 36 on a double page which contains two compositions: Prolog zu den Geheimnissen and Die 37 Geheimnisse. When Zelter sent this manuscript to Weimar is unknown.

447 Reichardt's setting of Goethe's poem 'Es ist ein Schuß gefallen' (first published 38 in Zelter's setting in the 1810 edition of his Sämtliche Lieder, Balladen und Romanzen). 39

40 Reichardt's setting was published in his Oden und Lieder von Goethe vol. 4 (1811). It later 40 appeared under the title 'Schneider-Courage' in vol. 1 of Goethe's collected works (1815). 41

448 In his second appearance as guest artist, the Munich singer Antonio Brizzi played 42

43 the part of Polineso in Simon Mayr's Ginevra on 11, 16 and 27 November, followed by a 43

44 single performance in the title role of Ferdinando Paer's opera Achilles on 30 November. 44 
$5[\ldots]$ As the work of my little musical institute ${ }^{449}$ has been interrupted this winter, 5

6 I have been able to enjoy the usual exchange of ideas with you less than usual. $7[\ldots]$

8 At Easter our friend Riemer was appointed Professor at the Gymnasium 8

9 here ${ }^{450}$ and although I am sorry to lose him, I am happy in the knowledge that he 9

10 is active, and, what's more, in a way which is suited to his powers and talents. His 10

11 abilities surpass what is demanded of him here, so he cannot but feel at home in 11

12 his appointment. $\quad 12$

19 [...] Dr Sibbern from Copenhagen ${ }^{451}$ is asking me to deliver something to Weimar 19 20 for him and so I am taking this opportunity to send our songbook, ${ }^{452}$ which, as a 20 21 favour to me, the gentlemen have had published during my absence in Silesia. 21 $22 \mathrm{I}$ am almost ashamed to send it to you because it is teeming with misprints, which 22 23 upset me every time I look at it. One would almost have to be everything and do 23 24 everything oneself; no one is any good. That's how it is with the new edition of my 24 25 collected songs. ${ }^{453}$ In two years three volumes have been brought out and it should 25 26 have been eight issues. I had ordered copies for you on holland paper and I have 26 27 still not received them; on top of that, the publisher has gone to Leipzig ${ }^{454}$ without 27 28 paying me and so the whole saga continues.

450 Friedrich Wilhelm Riemer, linguist and tutor to Goethe's son until 1805; editor of the Goethe-Zelter letters. each poem); a copy is in Goethe's library (Ruppert, Nr. 917).

$39{ }_{453}$ Zelter's Sämtliche Lieder, Balladen und Romanzen für das Piano-Forte 3 vols

40 (Berlin: Kunst und Industrie Comptoir: 1810, 1811, 1812), in Goethe's music collection 41 (GSA 32/42).

$42 \quad 454$ August Friedrich Kuhn was proprietor of the music publishers, Kunst und Industrie

43 Comptoir, established 1807. A branch was opened in Leipzig in 1811, but shortly after the 44 company's relocation to Leipzig in 1815 it went bankrupt. 
5 I have given Dr Sibbern a copy of the first three volumes of my songs to take 5

6 with him for you. I ordered an express copy for you on holland paper, but my 6

7 publisher ${ }^{455}$ is not a man of his word. You can't work with him. I'd like to be rid of 7

$8 \mathrm{him}$ and have a better publisher. [...]

Madame Simonin-Pollet has arrived and has brought me your card. ${ }^{456}$ She will 9

10 give a concert on the 29th of this month and will probably have a good audience. 10

11 I will show her around the Sing-Akademie next Tuesday. 11

[...] I have made up my mind to send you a something small I wrote last year, ${ }^{457} 18$

19 so that we may have a new subject for regular discussion. I wrote this cantata, or 19 20 scene if you prefer to call it that, for Prince Friedrich von Gotha, ${ }^{458}$ who wanted 20 21 something of the kind to show off his fine, well-trained tenor voice.

Kapellmeister Winter of Munich has set it to music very successfully ${ }^{459}$ - with 22 23 ability, taste and fluency, so that the Prince's talent is displayed in its best light. 23 $24 \mathrm{He}$ is now, however, keeping the score for himself, for which I do not blame him. 24

456 The harpist Marie Nicole Simonin-Pollet, to whom Goethe had given a letter 28 of recommendation on 27 February 1812. On 30 April 1812 she gave a concert in the 29 Königliches Theater with the Königliche Kapelle, in which she performed: Nattermann's 30 harp concerto Les Papillons, a rondo by Steibelt, variations on the popular duet from the 31 play Der Weihe der Kraft, a fantasy and (together with her six-year old son) a Gavotte by 32

458 See Goethe's letter to Prince Friedrich von Sachsen-Gotha on 6 March 1811, WA 35 
1 But why should I not show the poem to you and with it bring some new life into 1

2 our communications? 2

9 Yes, yes, my friend, you are certainly correct. Straight after your letter of 8 April 9

10 my conscience was awakened and I swiftly took my letter and set three of your 10

11 poems to music, which up to now I had never wanted to risk: 'Rastlose Liebe';460 11

12 'Neue Liebe, Neues Leben'; 461 'Mailied'. ${ }^{462} 12$

13 Unfortunately I am coming to these lovely things so late, as always, when 13

14 others have already composed them incompetently and if these [settings] don't 14

15 please you, I won't have done any better. What should come of restless love, new 15

16 love, new life, at my time of life? And true: I'd like to see someone who loves you 16

17 as I.

18 Your Rinaldo will not be an easy task, ${ }^{463}$ if the full meaning hidden in it is to be 18

19 brought out - [in particular] its enchanting delicacy, grace and charming rhythmic 19

20 flow. One would have to take a lesson from the Italian school if one were not too 20

21 old, but when the time is right let us try our hand at it. 21

22 The poem is suitable for the composer who knows what is to be done and 22

23 protects himself from the danger of doing too much. Everything is light and freely 23

24 intimated. The words are not pre-emptive and the musician has much input into 24

25 the subject, $\quad 25$

26 Far too often some supply the musician with words which, though they are 26

27 intended to help, add superfluous, emphatic words which are sometimes negative 27

28 and induce the poor devil, with the same expenditure of artistic means, to do the 28

29 opposite of what is required. [...]

30 Finally the musician doesn't have it easy in collaboration with the poet or 30

31 when he is subservient to him. He should be a man of genius, a poet himself, and 31

32 be extremely dependent thereby. If the poet can carry on, as long as it is goes well, 32

33 piano. An autograph has not been handed down. It was published in volume four of Zelter's Sämtliche Lieder, Balladen und Romanzen (1813).

38 An autograph has not been handed down. It was published in Zelter's Sämtliche Lieder,

39 Balladen und Romanzen (1813).

$40 \quad 462$ Zelter's setting of Goethe's 'Mailied' ('Wie herrlich leutet'), first published under

41 the title 'Maifest' and later renamed 'Mailied'. It should not be confused with Zelter's

42 setting of Goethe's 'Mailied' ('Zwischen Weizen und Korn'), published in 1811.

43463 As with many settings of Goethe's large-scale poetic works, nothing came of 43

44 Zelter's setting of Goethe's cantanta, Rinaldo. 
1 the number of words is prescribed for the composer whether he can use them or 1

2 not. In short, if the most difficult aspects go easily for him, then he has the greatest 2

3 pains with minutiae. Often the trained musician himself is often unaware what 3

4 artistry goes into them. 4

58 May 1812: A while ago, I found in Voltaire's works (the Gotha edition of 5

61785 , volume nine) ${ }^{464}$ a musical opera, Samson, which Rameau actually set to 6

7 music, ${ }^{465}$ though it has not yet been performed. I quite liked Voltaire's treatment, 7

8 and the subject, assuming some necessary alterations, would be thoroughly suitable 8

9 for an opera. 9

10 An opera, in my judgement, should not have more than three acts; two long and 10 11 one short, or better still, one long act between two short ones. Here is my plan: 11

12
Act One: The Chorus of Israelites lament their defeat but, encouraged by 12 Samson, conquer the Philistines.

Act Two: Triumphal entry of the Israelites. Reconciliation of Samson with 15 Delilah. Recognition of the son. Treachery practised on Samson. 16

Act Three: Imprisonment and death of Samson, the known story; very brilliant.

Now what do you think of this? Would there not be enough scope there for plot 20 and dramatic action? I thought you might set to work on it and at least amend this 21 plan; at all events I will have verses made for me here. ${ }^{466}$

[...] Your kind words about Rinaldo are not only very pleasant to me but will, I 29 hope, prove fruitful, for they have made me aware of that which by nature and 30 inclination I have done, and should like to do, particularly for music on the stage. 31 When you say, 'Everything is freely and lightly alluded to; the words are not 32 encroaching, and the musician has to deal with the subject itself', this awards me 33 the greatest praise I could wish for; for in my opinion, a poet ought to draw his 34 sketch, upon a very widely woven canvas, so that the musician may have enough 35 space to work out his embroidery with greater freedom and with coarse or fine 36 threads as he thinks fit. The libretto for an opera should be a vessel, not a finished 37 picture. This is certainly our opinion, but most of our good Germans have no 38 comprehension of the matter, yet hundreds try their hand at it. On the contrary, 39 how great our admiration of many of the Italian works must be, where poets, 40

464 Ceuvres complètes de Voltaire (Gotha 1784-90) in Zelter's library (no. 756-825). 42

465 Rameau's lyric tragedy Samson (1733). 43

466 Zelter's plan was never realized. 
1 composers, singers and stage directors can all agree about a certain adequate 1

2 technique. One new German opera after another fails for want of a good text, and 2

3 the good Viennese, ${ }^{467}$ who do not in the least know where the shoe pinches, offer 3

4 a hundred ducats for the best opera which anyone in Germany could produce; 4

5 however, they would be better off doubling the amount at the right smithy, and 5

6 would then come out the winners.

7 The matter is, in fact, more difficult than people suppose; one would have

8 to enjoy working in the theatre among all those who are contributing to the

9 performance, and then, year after year, one should produce something new. One

10 thing would lead to another and perfection might spring even from a failure. 10

11 Just now I should have no faith in Samson; it is one of the most monstrous 11

12 of the old myths. A perfectly bestial passion of a supernaturally strong, divinely 12

13 gifted hero for the most accursed wretch that the world has ever seen - the mad 13

14 desire that always leads him back to her, though each time, owing to repeated acts 14

15 of treachery, he is conscious of the danger of this lustfulness, which itself springs 15

16 from danger - the mighty conception one must form of the supreme brilliance of 16

17 this gigantic woman, who is capable of shackling such a bull! Considering all this, 17

18 dear friend, it will at once become clear to you that we would have to destroy it, if 18

19 only to choose names in accordance with the conventions of our time and stage. It 19

20 would be much more advisable to choose a subject with less specific substance, if 20

21 not indeed one of more immediate appeal to contemporary audiences. Look at Die 21

22 Schweizerfamilie 468 and things of that ilk.

23 I must mention one other consideration. Subjects from the Old Testament 23

24 produce a very strange effect here; I had occasion to reflect on this when Robert's 24

25 Jephth $^{469}$ and Alfieri's Saul ${ }^{470}$ were given. They do not excite any disfavour, but 25

26 still it is not popular; not disinclination, but lack of inclination. Those myths, truly 26

27 grand as they are, present a respectable appearance in the solemn distance, and our 27

28 youthful devotion remains attached to them. But when these heroes step forward 28

29 into the present, it occurs to us that they are Jews, and we feel a contrast between 29

30 the ancestors and the descendants that confuses and jolts us. This is the way I 30

31 quickly explain it to myself after closely watching the effect of both pieces. This 31

35 Residence from 8 to 12 September 1810, and the singer Brizzi, whom Goethe had engaged

36 as guest artist, had set up a competition 'to contribute to the furthering of dramatic art' (see

36 Lobkowitz's letter to Goethe, 2 September 1812). Goethe had agreed to chair the panel of

37 judges but afterwards showed very little enthusiasm; the project itself did not have much

38 success.

39468 Joseph Weigl's Singspiel was performed in Weimar on 21 September and 4026 October 1811.

41469 Ludwig Robert's tragedy Die Tochter Jephthas, performed in Weimar on 41

4221 September and 26 October 1811.

$43 \quad 470$ Vittorio Alfieri's tragedy Saul, performed (in Knebel's translation) in Weimar on 43

446 April 1811 and 8 April 1812. 
1 last consideration would be set aside, were the myths transferred to other nations. 1

2 But other difficulties would then arise; I shall think further about this. 2

3 In conclusion, I must ask of you not to withhold those compositions, and at the 3

4 same time, for our old love's sake, to give our correspondence new life. 4

5

6

7

8

And I beg you, no such long pause again! $!^{471}$

\section{(n)} 5

Carlsbad, 2 September 181211

In recent weeks, dear friend, I have longed for you very often and warmly. Through 13 the performance on your songs and many other riches which he remembered, 14 through the account of the delightful Sing-Akademie and the refreshing Liedertafel, 15 and all the other things which are written about you and experienced, our good 16 and highly esteemed Langermann ${ }^{472}$ let me feel very acutely what I really lose 17 as a result of living far away from you and as a result of the gulf between us, 18 which the longer it lasts, the more it seems to widen. If I did not particularly avoid 19 despair, these observations would make me very unhappy. Thank you for your 20 lovely letter. ${ }^{473}$ Next time write to me in Weimar, where I hope to come close to 21 music again through your songs and other earlier gifts, from which, to my great 22 dissatisfaction, the hustle and bustle of the world has driven me away. Admittedly, 23 on my return I will find the old theatre and a new organ. However, I fear neither 24 Belial nor Christ will have anything to blame me for with regard to either. ${ }^{474} \quad 25$

If you could and would like to send me your composition of the memorial 26 verse 'Invocavit', you would really make me happy. Langermann gave me a little 27 taste of it. It was meant to celebrate your memory. [...] 28

I met Beethoven in Teplitz. ${ }^{475}$ His talent astounded me; but unfortunately his 29 natural temperament is completely uncontrolled, and although, indeed, not at all 30 wrong in thinking the world detestable, still, in so doing, he does not make it more 31 pleasant, either for himself or for others. However, he is to be greatly excused 32 32
3

471 Between 7 December 1811 and 8 April 1812 the correspondence ceased; Zelter 34 only received Goethe's greeting from 27 February in mid. April. 472 Johann Gottfried Langermann (1768-1832), doctor, appointed State Councillor in 36 Berlin in 1812 and subsequently a member of Zelter's Liedertafel. Goethe became acquainted 37 with him in 1810; his diary for these weeks in Carlsbad record daily conversations with 38 Langermann. 39 473 Zelter's letter of 9-10 April delivered by Sibbern or possibly Zelter's letter from 40 14 to 19 April. $\quad 41$ 474 Reference to 2 Corinthians, 6, v. 15 . 42

475 Goethe met Beethoven on 19, 20, 21 and 23 July 1812. His diary entry on 21 July 43 4 reads: 'An evening with Beethoven. He played superbly', WA III/4, p. 305. 
1 and much pitied for he is losing his hearing, which perhaps affects the musical 1

2 less than the social part of his being. As it is, he is reserved by nature and is now 2

3 becoming doubly so through this loss. 3

147. Zelter 6

10 The objections you raise against my opera plans are enlightening. As historical 10 11 personae Samson and Delilah are offensive, even repulsive. One would have to 11 12 alter much, which would be more difficult than it seems. Also, what you remember 12 13 in general about Old Testament subjects we experience here with Joseph $^{476}$ and 13 14 with Solomon. ${ }^{477}$ One is only accustomed to seeing Jewish heroes ill-treated. 14 15 If the words 'No matter. The Jew will be burnt!' ${ }^{478}$ were spoken, the effect would be 15 16 obvious. However, I would not be inclined to write an opera without a tragic subject. 16 17 In any case the libretto would have to be written with an eye to the future. [...] 17

18 'Invocavit' is enclosed. ${ }^{479}$ Unfortunately it is so tailored to our Liedertafel that I 18 19 almost fear elsewhere it will have far too weak an effect. [...] I gladly send you the 19 20 setting of 'Die heiligen drei Könige' ${ }^{480}$ with it, which is of a somewhat lighter style 20 21 and is enjoyed at nearly every table. However, you must excuse my brazenness, 21 22 for I have botched up your words, ${ }^{481}$ and tell me what corrections you want. 22

2313 September: We have just had Siboni from Vienna here, who endeavoured 23 24 to sing Paer's Achilles in German. ${ }^{482}$ Last winter Tombolini sang an Italian aria 24

27476 Etienne Nicolas Méhul's musical drama Joseph in Ägypten, (libretto from 27

28 the French, Joseph by Alexandre Duval, presumably in the version by Franz Joseph 28

29 Hassauruk).

$30 \quad 477$ Adrian Quaisin's musical drama Salomons Urteil (libretto from the French, 30 31 Le Jugement de Salomon by Louis-Charles Caigniez, in a version by Matthäus 31 32 Stegmayer).

33478 Quote from Lessing's Nathan der Weise, Act 4, scene 2. 33

$34 \quad 479$ Zelter's setting of Goethe's 'Versus memorials'; a copy is in Goethe's music 34

35 collection (GSA 32/11). 35

$36 \quad 480$ Zelter's setting of Goethe's 'Ephiphaniasfest' ('Die heil'gen drei König'), first 36

37 published under the title 'Ephiphanias' in Zelter's Gesänge der Liedertafel (1811); Zelter

38 composed a second setting in 1812 with the title 'Die heiligen drei Könige'; a copy of the 38 score is in Goethe's music collection (GSA 32/10).

39481 Zelter altered the second stanza of 'Versus memorials'; in lieu of the line of text

40 'O wär ich Braut', in Gesänge der Liedertafel Zelter wrote 'mir juckt die Haut' in his 41 setting.

$42{ }_{482}$ Giuseppe Siboni (1785-1839), first tenor in the royal court theatre in Vienna, 43 performed the title role in Paer's Achilles on 1 September 1812 in the Berlin opera house; 43 44 see Vossische Zeitung, 5 September 1812.

\section{3
4}

5

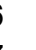

2

.

.

.

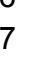

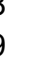

2


1 in German translation. ${ }^{483}$ You see how we advance in art and in nature. What we 1

2 might have been able to learn from this would be how the Germans fare when they 2

3 sing Italian.

4 Milder-Hauptmann is with us at present. ${ }^{484} \mathrm{I}$ have heard her in Gluck's 4

5 Iphigenie, ${ }^{485}$ the Schweizerfamilie ${ }^{486}$ and the Zauberflöte, in which she sings the 5

6 part of Tamino $[$ sic $] .{ }^{487}$ The voice, figure and style of this young artist are so free, 6

7 powerful and graceful, especially in the part of Emelina, ${ }^{488}$ that we have seen 7

8 nothing like it here for a long time. They criticize her vocalization as inartistic ${ }^{48} \quad 8$

9 and that kind of thing, but I find much to praise - warmth, truth, secure and 9

10 appropriate singing and a kind of Swiss solidity most naively expressed - in any 10

11 case I have never seen passions represented with such control and so effectively. 11

12 I am looking forward to your second volume and only wish to enjoy it soon. 12

13 Have you also received our little book of songs? I hope it was delivered safely. 13

14 I thought it might stimulate you to do something for our table once again. Come 14

15 yourself and hear how your songs sound. I always imagine you don't yet know 15

16 your songs well.

We have lost our very clever Italian conductor, Righini, ${ }^{490}$ who died in his home 23

town of Bologna on 19 August. He was to us much what Salieri was to Vienna; 24

483 The programme for Raffaele Tombolini's concert in the Königliches Nationaltheater 27 classical operas and was largely responsible for the Gluck revival in Vienna and Berlin. Her 32 greatest triumph was in this production of Gluck's Iphigénie in Tauris. Goethe wrote a short 33 poem in her honour after hearing her in Iphigénie in Tauris and presented her with a copy 34 of his drama on the same subject.

485 Christoph Willibald Gluck, Iphigénie in Tauris. For reviews of Milder-Hauptmann's 35 performance, see $A M Z 14$ (1812), no. 41, 7 October, column 670; MA 20.3, p. 295. 486 Zelter went to the performance on either 6 or 9 September 1812; further 37 performances were given on 15 and 22 September. 487 Mozart's opera was performed with Anna Milder-Hauptmann in the role of Tamino 39 [sic] in the Berlin opera house on 11, 13 and 18 September. 
1 fresher than Salieri perhaps, but pretty equal in breadth and depth. For the moment 1

2 I don't know any Italian composer whom we would want to see in Righini's 2

3 position; but who knows what we will have to settle for? I have learnt much from 3

$4 \mathrm{him}$, although indirectly, especially through the present opposition with other 4

5 conductors. The difference [of opinion] between excellent people often gives the 5

6 best result.

7 What you say of Beethoven is quite natural; I, too, admire him with awe. His 7

8 own works seem to cause him a secret shudder - a feeling which, in this day 8

9 and age, is set aside much too lightly. His works seem to me like children whose 9

10 father might be a woman or whose mother a man. The last work of his that I 10

11 became acquainted with (Christus am Ölberge) ${ }^{491}$ seems to me an unchaste thing, 11

12 the foundation and aim of which is an eternal death. The music critics, who seem 12

13 to be more at home in anything other than in what is natural and individual, have, 13

14 in the oddest fashion, poured themselves out in praise and blame of this composer. 14

15 I know musical people who formerly, on hearing his works, were alarmed, even 15

16 indignant, and are now seized with a passion for them, like the devotees of Grecian 16

17 love. How thoroughly one can enjoy them is conceivable, and what may come of it 17

18 you have shown clearly enough in Die Wahlverwandtschaften. [...] 18

19

25 My eldest son, ${ }^{492}$ who must have been well known to you since you were so good to 25

26 him in Weimar, ${ }^{493}$ shot himself tonight. Why? I still don't really know because his 26

27 debts can be covered and his accounts are in order. He had just begun to be helpful 27

28 to me, just as, in comparison with his relatives, he could be called competent. And 28

29 now he leaves me when I wanted to draw him really close.

30 Sunday, 15 November: He wrote two letters on the day before his death: ${ }^{494}$ one 30

31 to his brother, ${ }^{495}$ in whose presence he took his life. In it he recommended to the 31

32 care of his brother his natural daughter, ${ }^{496}$ a child of two-and-a-half years, and a 32

33 beloved widow to whom he was engaged and who had already lost two husbands. 33

34 The second letter is addressed to this widow. He gave his ring back in it, regretted 34

36491 Beethoven's oratorio Christus am Ölberge (1803); Zelter is referring to the Berlin 36

37 performance on 2 September 1812, under the direction of Bernhard Anselm Weber, AMZ 14

38 (1812), no. 23, 3 June, column 378.

$39{ }^{492}$ Zelter's stepson, Carl Flöricke (1784-1812), son of Zelter's first wife, Eleonora, 39

40 widow of August Wilhelm Flöricke.

41493 Carl Flöricke had been Goethe's guest in Weimar on 14 May 1803.

$42 \quad 494$ The letters have not been handed down. 42

$43 \quad 495$ Zelter's eldest son, Georg (1789-1827), from his first marriage. 43

44496 Louise Flöricke (1811-84); her mother's name is unknown. 44 
1 that he had paid no heed to her loving admonition and bade farewell. Don Carlos 1

2 lay open on his writing desk. On the pages was written: 'So is there no salvation? 2

3 Even through transgression? - No!' ${ }^{497} \quad 3$

$4 \quad$ At times I have had the unpleasant feeling: whether through my strictness I did 4

5 him wrong. His many passionate, sensual relationships were acceptable. Although 5

6 he lived completely with me and off me, he was completely free, had his good 6

7 income and his own financial arrangements. In the letter to his brother he wrote 7

8 that he had often tried to write to me, but in vain. 8

9 In pressing times, when he became of age, I paid him his father's inheritance 9

10 which was in my care (because he is my stepson). His account was empty. 10

11 Sitting on his bed, beside his sleeping brother, he killed himself. He still sits 11

12 there now in this position because I don't dare disturb the corpse before the post- 12

13 mortem, but so lovely and noble as an experienced actor would like to appear to 13

14 contented connoisseurs. The widow remarked to me that she had once wanted to 14

15 release him, since just then she had the opportunity to get married properly. At that 15

16 he pressed his pistol to his breast and said: then this is to be his beloved. 16

17 He shot himself in the mouth but lost little blood where the bullet went through. 17

18 The mouth is intact and only marked by the gun smoke. His face is friendly. The 18

19 other pistol is also loaded and the pan equipped with gunpowder. The letters were 19

20 written a day before, but illegibly and covered by great big drops of tears. He has 20

21 also made a form of will for his bequest. His acquaintances had not heard from 21

22 him for weeks. I had not seen him for a week. My accounts which he kept for me 22

23 were in the best order.

24 Now I must start to organize myself all over again. He had become indispensable 24

25 to me. For his sake I had maintained all business projects from which he shared the 25

26 profits. The day before yesterday he had received his tasks to qualify as a master, 26

27 which he would have passed with honours before many others. So he leaves me 27

28 in releasing himself. I would not have believed that I would be capable of the 28

29 bitterest envy with which I looked at his lovely corpse after he passed away and 29

30 would have thought of the other gun which lay in the desk in reserve. It is hard, 30

31 cruel. If he had known how I love him, he could rest in peace.

Say something to ease this. I must pull myself together, but I am no longer 32

33 what I was years ago. I have strength but for other things. Here I will be steady. In 33

34 the last nine months I have lost my only dearly loved sister, ${ }^{498}$ her son (who was 34

35 also my son-in-law) and now this beloved offender. [...]

36 Monday Evening: Finally today, on the third day after the death, the official 36

37 post-mortem took place. The pistol was not loaded with one bullet but with eight 37

38 small ones [...] With them he was certain of hitting the brain through the mouth. A 38

39 third pistol, mine, which he had taken with him, is also still loaded. Inwardly and 39

40

43498 Luise Syring died on 17 April 1812. Her son, Ferdinand Syring (married to Zelter's 43

44 eldest step-daughter, Henriette), died on 23 January 1812. 
1 outwardly the body was sound and healthy except for the bowels, which had signs 1

2 of hypochondria. The stomach was empty. Tomorrow he will be buried. 2

3 Tuesday morning: Now he is being brought to rest. I am tormented and can 3

4 only think I could have prevented it.

518 November. [...] Scold me that I write so often, when things are going so 5

6 badly. I don't like to be on my own and I only feel at home with you. 6

721 November: Could you provide some historical information on 'Die erste 7

8 Walpurgisnacht'? I began to set the poem to music some time ago and I am clear 8

9 about the form of the poem, but I would like to learn something quite detailed 9

10 about it. [...] 10

11 11

12 12

13 150. Goethe 13

$14 \quad 14$

15 Weimar, 3 December 181215

$16 \quad 16$

17 Your letter, my beloved friend, announcing the great misfortune which has befallen 17

18 your house, ${ }^{499}$ has greatly afflicted me and left me bowed down, for it came to me 18

19 when I was in the middle of very serious meditations on life, and it was only 19

20 through you yourself that I was enabled to rise again. In the face of death you have 20

21 proven yourself genuine, refined gold. How glorious a character appears when it 21

22 is penetrated with mind and soul, and how beautiful must that talent be that rests 22

23 on such a basis. 23

24 As to the deed or misdeed itself, I can say nothing. When weariness of life 24

25 seizes a man, he is only to be pitied, not blamed. Anyone who reads Werther ${ }^{500} 25$

26 will not doubt that all the symptoms of this strange disease, as natural as it is 26

27 unnatural, at one time raged furiously through my innermost self. I know full well 27

28 what determination and effort it cost me in those days to escape from the waves 28

29 of death just as, with difficulty, I saved myself to recover painfully from many 29

30 a later shipwreck. And so it is with all sailors' and fishermen's stories. After the 30

31 storm at night, the shore is reached again, the drenched man dries himself, and 31

32 the following morning, when the glorious sun once more breaks forth over the 32

33 glittering waves, the sea has once more an appetite for figs. ${ }^{501} 33$

34 When one sees how the world in general, and young people in particular, are 34

35 not only given over to their desires and passions, but how, at the same time, what 35

36 is nobler and better in them is dislodged and distorted by the serious follies of 36

37 the time, so that everything which should lead to its happiness becomes its curse, 37

38

39499 The suicide of Zelter's son described in ZG 14 to 17 November 1812. Here, for the 39

40 first time in this letter, Goethe uses the familiar $D u$, instead of the formal Sie. 40

41500 Goethe's epistolary novel Die Leiden des jungen Werthers. 41

42501 Reference to the Greek anecdote, whereby a merchant from Sicily dealing in figs 42

43 suffers shipwreck. Looking from a rock over the peaceful sea, he says 'I know what it wants - 43

44 it wants figs' (see Goethe's diary 21 May 1797, WA III/2, p. 22). 44 
1 not taking into account the inexpressible external pressure, one is not astonished at 1

2 the misdeeds by which man rages against himself and others. I would be capable 2

3 of writing a new Werther that would make people's hair stand more on end than 3

4 the first one did. Let me add one further remark. Most young persons, conscious 4

5 of some merit in themselves, make more demands upon themselves than is fair. To 5

6 this, however, they are urged and driven by their monstrous surroundings. I know 6

7 half a dozen such persons who are certainly being ruined, and whom it would be 7

8 impossible to help, even if one could enlighten them as to their real advantages. 8

9 No one easily arrives at the conclusion that reason and a strong will are given to us 9

10 that we may not only hold back from evil, but also from an excess of good. 10

11 Now let us pass on to other things in your letters, which have done me good 11

12 [...] If some day or other you could send me Rinaldo unexpectedly, it would be a 12

13 grand thing. I have no connection with music, except through you; for that reason 13

14 let me thank you sincerely for the 'Invocavit' and 'Die drei Könige', though I 14

15 have, as yet, only enjoyed reading through them.

Living here we spend quite disproportionately on music and yet we are really 16 17 quite deprived of music. The opera, with its old repertoire and the novelties that 17 18 are tailored to the needs of a small theatre and produced slowly enough, cannot 18

19 be compensation to anyone. Meanwhile, I rejoice that both court and town are led 19 20 to believe that there is some kind of enjoyment to be gained. The inhabitant of a 20 21 great city must be deemed fortunate in this respect; for after all, it attracts many 21 22 remarkable foreign artists. I would like to have heard Madame Milder. [...] 22 23 And now I still have to reply to your query about 'Die erste Walpurgisnacht'. 23 24 The matter rests like this. Among historians there are some men, and more to the 24 25 point, men whom we cannot but respect, who look for a real foundation for every 25 26 fable, every tradition, however fantastic and absurd it may be, and always expect 26 27 to find a kernel of fact within the fairy-tale husk.

28 A great deal of good has come of treating the matter this way, for the subject 28 29 demands great knowledge; it is even necessary to have mind, wit and imagination 29 30 to convert poetry into prose in this way. In this manner one of our German 30 31 antiquarians has endeavoured to rescue and to give historical foundation to the 31 32 story of the witches and devils on the Brocken, a legend which has been topical 32 33 in Germany from time immemorial. His explanation is that the heathen priests 33 34 and patriarchs of Germany, when they were driven from their sacred groves, and 34 35 when Christianity was forced upon the people, used to retire at the beginning of 35 36 spring with their faithful followers to the wild, inaccessible heights of the Harz 36 37 mountains in order, according to the ancient custom, to offer prayer and fire there 37 38 to the immaterial god of heaven and earth. And furthermore, in order to be safe 38 39 from the armed spies and converters, he thinks, they found it necessary to disguise 39 40 a number of their own people so as to keep their superstitious enemies at a distance, 40 41 and that in this way, protected by the antics of devils, they carried out the purest 41 42 of services. 
1 I found this explanation somewhere, ${ }^{502}$ a few years ago, but cannot remember 1

2 the name of the author. The idea pleased me and I have turned this fabulous story 2

3 back again into a poetical fable. 3

10 With the outgoing post you will receive a wonderful work ${ }^{503}$ which will certainly 10 11 give you some entertainment. It is by a remarkable though admittedly a somewhat 11 12 strange man and contains a new system of music notation. Instead of the lines, 12 13 intervals, little note heads and tails to date, he sets out numerical signs and maintains 13 14 that this system is much more accessible. I cannot assess it because firstly I am used 14 15 to the traditional notation from my youth and secondly no one could be more shy 15 16 of numbers than myself. I have avoided and flown from all numerical symbolism - 16 17 from those of Pythagoras to the recent mathematical mystics - as something 17 18 formless and depressing. [...] Let me know what you think of this little book as 18 19 you will easily assess what is favourable and unfavourable about it. [...] 19

20 I want to thank you now for the theatre programmes which you sent. They are 20 21 bound now and I can follow the theatrical and musical delights of Berlin for the 21 22 entire year.

29 [...] So my deep sorrow, which has turned me away from everybody, has doubled 29 30 your support for me by openly showing you a dear brother to me; so I have gained 30 31 though I suffered loss and scarcely thought I would get over it; so life stirs in me 31 32 again - violent and human - and I will confess: I have felt happy again. [...] 32

33 Many thanks for your instruction regarding 'Die erste Walpurgisnacht'. I have 33 34 taken the thing really according to your description, namely poetically, and the 34 35 historical looks after itself. From much experience I have noticed that factual 35

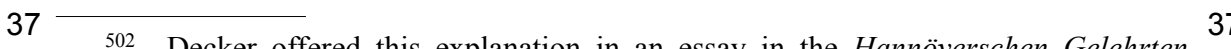
38502 Decker offered this explanation in an essay in the Hannöverschen Gelehrten 38 39 Anzeigen (1752).

$40 \quad 503$ Johann Friedrich Werneburg, Allgemeine neue, viel einfachere MusikSchule für 40 jeden Dilettanten und Musiker. Mit einer Vorrede von. J. J. Rousseau (Gotha, 1812). The 41 book was not sent by post but delivered by Emil Osann to Zelter on 22 February 1813 .

42 Goethe's diary entry on 27 January 1813 reads: 'Werneburg's new system of notation 43 brought to Prof. Zelter in Berlin by Dr Osann', WA III/5, p. 10. See Zelter's letter of thanks, 43 4426 February 1813.

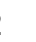

1

2

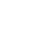

5

6

8

9


1 notes at times cause reverberations through which a type of clarity and truth enter 1

2 into a melody. This excites understanding to such an extent that part of the work 2

3 presents itself to me automatically, especially as I am so badly in need of external 3

4 stimulation.

513 December: As I leaf through Part I of your memoirs, I wonder whether 5

6 some of your sacred music texts written at that time still exist? I cannot conceal my 6

7 curiosity to see some of them, because the period in which you occupy yourself with 7

8 biblical subjects is very close to me, because I, too, was caught up with such things 8

9 for a good part of my youth, although I neither knew what I was looking for nor 9

10 found what I needed. It mainly interested me because it was ancient and dark. [...] 10

11 We will soon have to send home our French-Italian German Nationaltheater, 11

12 which became our royal theatre [company] for quite a number of years [...] Opera 12

13 must carry everything and for this [reason] plays are so badly supported that the 13

14 few people who still go leave again because of the cold. 14

21 [...] Musicians have frequently been upbraided for liking bad librettos, and it 21

22 has been said in jest that one of them offered to set a poster to music; ${ }^{504}$ if the 22

23 song were not independent of the words, how could the Good Friday music in the 23

24 Sistine Chapel possibly have ended with the word 'vitulos'? ${ }^{505}$ And there may be 24

25 other instances. Many a programme, properly arranged, would make a better opera 25

26 than the libretto itself. 1808.

40505 The last verse of Psalm 51 reads: 'Tunc acceptis sacrificium justitiae, oblationes 40

41 et holocausta, tunc imponunt super altare tuum vitulos' (Now you accept the sacrifice of 41

42 justice, offerings of holocaust, then they lay heffers on your altar). Goethe had heard the 42

43 Good Friday liturgy in the Sistine chapel at the end of his visit to Rome; see Goethe's letter 43

44 to Christian Friedrich Schnauß of 24 March 1788, WA IV/30, p. 41. 
5 [...] Recently I bought an original picture by Denner, a portrait of the composer 5

6 Hasse, ${ }^{506}$ whom I highly esteem. He died in Italy in the year 1783 aged 78, after 6

7 a very fruitful artistic life. The picture was painted in 1740; it is two-and-a-half 7

8 feet high and two feet broad, painted in oil and well preserved; it represents the 8

9 artist as a handsome man, in the fullness of his strength and the zenith of his 9

10 fame in Germany, but especially in Italy, where he was famous under the name of 10

11 Il Sassone. ${ }^{507}$ Eyes, mouth, chin and nose are beautifully chiselled and rounded, 11

12 and the bearing of the man, with his expression and colour, confirms his character 12

13 as an artist, who could feel quite happy only in Italy; for in Italy he learnt, loved, 13

14 pleased, married and died, and he also adopted the religion of that country. His 14

15 wife was the famous singer, Faustina. ${ }^{508}[\ldots] \quad 15$

16 I knew Dr Werneburg ${ }^{509}$ when he was in Berlin before the war. At that time he 16

17 submitted his work (if I am not mistaken in manuscript) to the local academy, ${ }^{510} 17$

18 through which it was brought to my attention and for which my opinion was sought 18

19 (by Nicolai, I think). ${ }^{511}$ The thing has its own value and it has never been denied 19

20 that theory of musical notation is very extensive. But we possess it, we need it, we 20

21 are used to it; our instruments sound as we have wished and even most accurate 21

22 notation demands performers who achieve the best results of themselves. [...] 22

23 The work by Werneberg has still not arrived with the post, and although I know 23

24 it from the manuscript, nevertheless it would be important enough for me to see it 24

25 published after many years. [...]

Johann Adolph Hasse (1699-1793), pupil of A Scarlatti in Italy, and the mos popular composer of Italian opera in Neapolitan style of his time. Such a painting exists today in the Staatsoper (Semperoper) Dresden and was presumably passed down from the electoral estate. Zelter obviously possessed a replica.

507 Hasse had acquired the epithet 'the Saxon' because he had mainly lived in Dresden from 1733 to 1763. It even appears in the title of Franz Sales Kandler's biography of the

37 composer, Cenni storico-critici intorno alla vita ed alle opere del celebre compositore di 38 musica Gio. A. Hasse detto il Sassone (Venice, 1820).

39508 Faustina Hasse née Bordoni (1700-81), Italian singer, married to Hasse from

40 1730; her success in Dresden and Italy and an invitation to perform for the French court in

41 Paris made her internationally famous.

42509 Johann Friedrich Christian Werneburg (1777-1851), mathematician and physicist.

$43 \quad 510 \quad$ Akademie der Künste und mechanischen Wissenschaften.

$44511 \quad$ The writer and publisher Christoph Friedrich Nicolai (1733-1811). 44 
526 February: I have also now read Werneburg's music tutor. Dr Ossan sent it to me 5

6 on the 22 nd of this month. ${ }^{512}$ The enthusiasm and painful seriousness with which

7 he goes to work would amuse musicians if they were to read the book. It is like

8 our deceased preacher, Bierdemann, ${ }^{513}$ who always scolded the absentees from the

9 pulpit, so that the innocent had to listen to it.

10 If his new music theory were used and he wanted to introduce our current 10 11 students to it, they would think he was mad. The world is as it is and it will be hard 11

12 to influence it in his way. Now I don't know whether it is possible to advise him. 12

13 Because if he had the desire to take an extract or form a catechism from the work -13

14 which is too wordy - and give it to this person or that person in order to apply it in 14

15 schools, I think the thing could be lighter and I also would offer a hand.

27 February: The day before yesterday I heard a first-rate performance of 16 17 Beethoven's overture to Egmont. ${ }^{514}$ Every important theatrical work on the German 17 18 stage should, by rights, have its own music. The benefit which would then accrue 18 19 to poet, composer and public is immeasurable. The poet has the composer on his 19 20 own territory, can guide him, teach him to understand, and learn to understand 20 $21 \mathrm{him}$; the composer works with an understanding of the whole and can know with 21 22 certainty what he must avoid, without being limited, and it would be delightful for 22 23 each to recognize himself through the other.

24 This time the overture was heard without the play, ${ }^{515}$ just as the deceased 24 25 Gleim always presented the hat of Friedrich the Great. ${ }^{516}$ The overture in F minor 25

29 p. 10; presumably it was Dr Emil Osann (1787-1842) in Berlin, who had delivered the 29 in a subscription concert in theatre hall; a review is published in the $A M Z 15$ (1813), no. 19, 34 12 May, column 318.

515 In his review in the Vossische Zeitung 36 on 2 March 1813, Friedrich Rellstab 36 raised some interesting ideas on the meaning and function of overtures in general and 37 performance than performed as an overture to the play.

40 After his audience with the Prussian King Frederick II, Gleim expressed to Duke 39

40 Friedrich August his wish to have the old hat which the monarch wore during his audience
with him. After King Frederick's death the Duke sent the hat of the deceased Prussian King
41

42 to Gleim with the words, 'My dear, here is the hat which the deceased king was wearing the 42

43 morning before his death.' Zelter's reference is comparing the overture without the play to 43

44 the hat without the king. 
1 announces a tragedy in a series of dark chords, turns into a republican character 1

2 with war-like overtones, becomes calm and wistfully nostalgic, dreamy, turbulent 2

3 and finally victorious. One more merit in the music is the length: it is exactly as 3

4 long as I would have wanted it and the first scene connects really well to the end 4

5 of the overture. Now, I would like to persuade him to set the entr'acte to music, 5

6 which must all come from the overture. ${ }^{517}[\ldots] \quad 6$

7 Reichardt's intermezzo, between Acts 3 and 4 of the tragedy, is first-rate - in 7

8 spite of the slack performance. He has composed variations on the melody of the 8

9 song 'Freudvoll und Leidvoll', which the orchestra play between Acts 3 and 4, at 9

10 whose first hearing I was spellbound. [...] 10

17 In Dresden Dr Sibbern told me he had seen you, that you had wished to give him 17 18 something for me, but that you refrained from so doing as he would probably not 18

19 go to Weimar. He certainly will not get there, but I should have been delighted 19

20 to hear something of yours in Dresden. I enclose a short poem, a parody of one 20

21 of the worst German songs, 'Ich habe geliebt, nun lieb' ich nicht mehr'. ${ }^{518}$ If 21

22 writing poetry were not an inward and necessary operation, independent of any 22

23 external circumstances, these verses, of course, could not have arisen now; but as 23

24 I imagine that one day or other you will be eating and singing again, I dedicate this 24

25 unseasonable joke to you. 25

$35 \quad 517$ Zelter obviously did not know at the time that Beethoven had composed incidental

36 music for Egmont for the court theatre in Vienna, which was first performed on 15 June

37 1810. In addition to the overture, the music contains nine parts, among them the intermezzi,

38 Acts One to Four. The orchestral parts for the overture were published in December 1810;

38 the parts for the intermezzi appeared in January 1812. For Zelter's relationship with

39 Beethoven, see Theodor Frimmel (ed.), Beethoven Handbuch (2 vols, Leipzig: Breitkopf \&

40 Härtel, 1926) vol. 1, pp. 470-73.

41518 A copy (in Carl John's hand) of the poem 'Ich habe geliebet, nun lieb' ich erst

42 recht ...', later with the title 'Gewohnt, getan' (MA 9, p. 80); it is a parody of Christian

43 Gottfried Solbrig's poem 'Ich habe gelacht', which Goethe had heard in Herr Solbrig's

44 'Deklamatorium' on 18 April 1813 in Leipzig. 


$$
7
$$

[...] Tell me something pleasant about yourself. In the midst of so much trouble, ${ }^{519}$

it is a great consolation not to be completely cut off from those we love. Blessings 6 be yours - inwardly, if not outwardly!

At last, my old reliable friend, I see your dear handwriting again! [...] 14

First of all, if you will very much oblige me by setting the words 'In te, Domine 15 speravi; et non confundar in aeternum ${ }^{520}$ as a vocal quartet with your usual great 16 charm, your name shall be highly praised. When you have refreshed me through 17 this, I will send you some quodlibets for your Liedertafel. [...]

Towards Christmas, I shall probably send you volume three of the thousand 19 and one nights of my foolish life, ${ }^{521}$ which looks almost more indiscreet in the 20 telling than it actually was.

You will be amused when you see that I have been plagiarizing you. Were your 22 profession not so utterly different from mine, it would happen more often.

This note was written some time ago [...] Lieutenant Mendelssohn ${ }^{522}$ wants to 24 take a few words to you from me. Here, therefore, is what I have written, with my 25 best wishes and hopes. [...]

Let me hear from you soon. I have some lively songs to hand. ${ }^{523}$ We have also 27 been singing your 'Drei Könige' lately. This is the way we have to drive away the 28 bitterness of death. ${ }^{524}$

519 Following the Battle of Nations at Leipzig from 16-19 October 1813, in which the 34 allied Prussian, Russian and Austrian armies had defeated Napoleon and forced his retreat, 35 Weimar was again shaken by the wars surrounding the French and Cossack invasion on 2036 and 21 October. 37 520 The final verse of the Te Deum, the Ambrosian Hymn of Praise, based on Psalm 38 $71,1$. 521 Dichtung und Wahrheit, Part 3, Books 11-15. 40 522 Nathan Mendelssohn (1782-1852), youngest son of Moses Mendelssohn. 41

523 'Die wackelnde Glöcke'; 'Die Lustigen von Weimar'; 'Viele Gäste wünsch' ich 42 3 heut'...'; 'Meine Wahl'. 
5 So that no post day will be lost, I am immediately sending you something 5 6 singable ${ }^{525}$ and something toneless; ${ }^{526}$ let one please your artistic sense and the 7 other your understanding. To say how infinitely your consignment has delighted 8 and refreshed me, I would have to tell you stories; today, however, only heartfelt 9 thanks.

1621 February: Your golden poems arrived early today. I spread them out like a 16 17 Christmas gift in front of me at the round table by the oven. I am sending back a 17 18 setting of one of them immediately. ${ }^{527}$ [...] I don't know whether I told you that 18 19 from time to time I have worked on something from your Zauberflöte Zweiter Teil. 19 20 In the last few days I have also almost finished the overture. ${ }^{528}$ It occurs to me now 20 21 that in the gaps in the libretto some bright and cheerful text could be inserted and 21 22 one could finally celebrate the peace when it comes about. But you would have to 22

23 insert all that yourself. Other poets would not want to get it wrong and we can be 23

24 grateful for that. How it would be if you were to take up the work once again and 24 25 complete it. Let me know your thoughts on this suggestion. 25

525 Songs for the Liedertafel mentioned in GZ 26 December 1813. The exact contents

35 of this dispatch cannot be determined. Possible songs include the following: 'Offne

36 Tafel'; 'Die Lustigen von Weimar'; 'Meine Wahl'; 'Eigentum'; 'Kriegsglück'; 'Wandrers

36 Nachtlied' ('Über allen Gipfeln ist Ruh'); 'Gefunden'. 
5 Are you not becoming worried, old friend, once again to receive a note from me 5 6 and a composition ${ }^{529}$ with it? For I cannot refrain from giving you one of the happy 6 7 moments back which your lovely poems give.

825 February: I have just set the chorale again for three voices. ${ }^{530}$ If the poem 8

9 had another strophe, one would have had time to establish the [right] feeling, 9

10 where it is not possible to repeat any words. On the other hand it can be done if 10

11 the melody is sung twice. Three male voices rehearsed to sing perfectly with one 11

12 another will, in the clear stillness of the evening, have the best effect. 12

First of all, I must tell you that our little singing society has been feasting upon 19 you and living off you alone, and after an unhappy break, has risen through you 20 again. ${ }^{531}$ We offered the transfiguration of 'Johanna Sebus' ${ }^{532}$ as a sacrament of our 21 rescue from the endlessly broad floods. ${ }^{533}$

I could also tell you a long story about the 'In te, Domine, speravi', 534 how I 23 composed those words ${ }^{535}$ in my Bohemian solitude, ${ }^{536}$ among peculiar pressures 24 angehört'). Zelter's manuscript, entitled Hauschoral, is dated 'Berlin, 23 February 1814'. 28 An autograph copy in Berlin bears the same date (SBB PK: Mus. Ms. Autogr. Zelter 20). 29

530 On the reverse side of Zelter's four-part composition, Hauschoral, is a three-part 30 setting (TTB) of the same poem.

531 Rehearsals had resumed at the end of November after an interruption caused by 32 the war; see Goethe's diary, 21 and 28 November, 5 and 19 December 1813, WA III/5, 33 pp. 84-6 and 88 .

532 Zelter's setting of Goethe's ballad 'Johanna Sebus'.

533 As a metaphor for the French occupation and military manoeuvres during the Wa 35 of Liberation.

534 Goethe had requested a four-part setting of the first verse of Psalm 71; he received 37 the composition at the beginning of February 1814 .

$40 \quad 535$ Clearly Goethe's composition attempt was merely a question of a rhythmic sketch. 39

41 There seems to be no extant written record. Riemer reports in his diary on 11 February: 'In 40

41 the evening visited Goethe, who showed me letters from Sartorius und Zelter. Discussed his 41

42 composition. His setting of 'Domine in te speravi'. Goethe's composition of it for himself 42

43 in Teplitz' JbSK 3, p. 59. 
1 from within and without; they had rhythm but no sound, were meant for four 1

2 persons - not to say four voices - and I had no dearer wish than to hear these 2

3 beautiful words musically realized by you. I was tempted into drawing four lines, 3

4 one below the other, in order to illustrate the way I understood it. Now that I hear 4

5 your composition, all is clear to me and it is a pleasant experience. The dilettante 5

6 is only touched by that which is easily comprehensible and by that which has an 6

7 immediate effect; this is also characteristic of his own productions, wherever he 7

8 ventures into any one of the arts. My composition, which is fairly rounded and 8

9 definite, resembles one of Jomelli's, ${ }^{537}$ and it is wonderful and rather funny to 9

10 catch oneself accidentally upon such paths, and to become aware of one's own 10

11 somnambulism. In order to become clear about this in another form of art to 11

12 which I have devoted myself more seriously, I am examining some old landscape 12

13 sketches and perceive that it is much the same here. 13

14 Surely there must be some magic sounds in 'Die wandelnde Glocke' 538 for I 14

15 really did write it in Teplitz, to where it seemed to call you. [...] Can you inform 15

16 me about my little song concert so that it is a great success? 16

23 [...] Your observations about the composition of the words 'In te Domine [speravi]' 23

24 excited many ideas in me: the melody came to me the moment I read the words in your 24

25 letter and the fugal character of the words 'non confundar in aeternum' also work ${ }^{539}-25$

26 more because one is so accustomed to them in music from early times than that it 26

27 simply is so and cannot be any other way. Whoever could do it, it is always daring 27

28 to think up and use new forms in place of the accepted ones; and the listener, be 28

29 he dilettante or artist, will want something of his own in it. Therefore, I think, like 29

30 your own attempts, I always had to resemble a fine work of this type in order for it 30

31 to be good itself and for it to address the feeling. 31

32 'Die wandelnde Glocke' ${ }^{540}$ should, I think, be sung by a good contralto, such 32

33 as I have often heard among elderly Bohemian women. In Bohemia the mountains 33

34 are shaped like bells and when you drive past them at a certain distance, they 34

35 seem, to a fantastic eye, to wander after you. Well, once a child, always a child. 35

$37 \quad 537$ Goethe knew Niccolò Jommelli's composition of the psalm since 1808 from the

38 motet Confirma hoc dues performed by Goethe's house choir; see Goethe's diary 6 March

391808 .

$40 \quad 538$ Goethe had enclosed this poem in a letter to Zelter on 29 December 1813.

41539 In Zelter's composition of the Psalm 'In te Domine speravi' the opening words are

42 composed homophonically, with the words 'non confundar in aeternum' composed in fugal

43 style, with the vocal entries rising from bass to tenor to alto to soprano.

$44 \quad 540 \quad$ Zelter's setting sent to Goethe on 5 February 1814. 
I enclose now a composition ${ }^{541}$ which you will like even if it should appear 1

2 somewhat confused. However, if you could sing the song of Sebus so beautifully, 2

3 you may take this reflection to heart. [...] 3

4 In the future you will receive several things: 'Das Gastmahl'; ${ }^{542}$ 'Die Lustigen 4

5 von Weimar' ${ }^{543}$ and 'Wer sich nicht selbst zum besten haben kann' ${ }^{544}$ are already 5

6 composed; they should just be left to settle awhile. 6

7 Your suggestion that we see each other this summer is splendid. I had already 7

8 thought of Teplitz because of my health, as I had hoped to relax my sinews. You 8

9 will let me know a suitable time. I really long to chat with you about a hundred 9

10 thousand things.

11 Regarding the canon, it is worth pointing out that the art is formed out of 11

12 the dominant order of our Liedertafel, in that the rectangular table divides itself 12

13 into two halves which sing at times as choir and counter-choir. From this, the 13

14 most delightful animosities result, which would have given, especially you, the 14

15 opportunity for really sound fun. As a rule, a canon is sung through three times. 15

16 While re-reading your letter, I am just reminded again of what I really wanted 16

17 to say before, namely that I should like to see your composition for four voices, ${ }^{545} 17$

18 or your plan, be it what it may. We are such slaves to the current forms, the subject 18

19 or image of which our fathers had before them, that we cannot go beyond them 19

20 without being unnoticed. If the occasion or the image which dictated and defined 20

21 the form were before our eyes again, no one would have to strain every nerve to 21

22 seem original. If we only lived nearer each other, no doubt many difficulties on this 22

23 point would be cleared up, as certain things cannot be illustrated by words and are 23

24 only made clear through the medium of art. I remember well that the music of the 24

25 Leipzig Bach, ${ }^{546}$ and his son the Hamburg Bach, ${ }^{547}$ who were both quite new and 25

${ }^{541}$ Zelter's four-part setting of Goethe's 'Beherzigung', handed down in Zelter's 27

28 collection for the Liedertafel (SBB PK: Mus. ms. autogr. Zelter II, 2, IV) as well as an 28

29 autograph copy in an album by Edward Grell (Staatliches Institut für Musikforschung PK 29

30 Berlin: RE 4 C.F. Zelter I). No copy exists in Goethe's music collection.

542 Goethe's poem 'Das Gastmahl', later published under the title 'Offne Tafel'. The 31 page with Goethe and Zelter's handwriting (SBB PK: Mus. ms. autogr. Zelter 15) was 32 music collection. and choir; an autograph copy exists in Hamburg (SUB: CS 15, Zelter). A copy exists in 35 Goethe's music collection (GSA 32/33).

544 The opening line of verse three in Zelter's four-part setting of Goethe's poem, 37 'Ich liebe mir den heiteren Mann ...' which was enclosed in the dispatch of 14 February; 38 it was published with the title 'Meine Wahl' by Cotta; the composition is in Zelter's 181339 collection for the Liedertafel (SBB PK: Mus. ms. autogr. Zelter II, 2 V). 
1 original in their time, seemed to me almost unintelligible, though I was attracted 1

2 by a dim recognition of their value. Then came Haydn, whose style was blamed 2

3 because it, so to speak, travestied the extreme seriousness of his predecessors, 3

4 so that good opinion reverted back again to them. At last Mozart appeared, who 4

5 enabled us to understand each of the three men whom he had for his masters. 5

6 I enclose now the music to an ode by Horace, ${ }^{548}$ over which I would be almost 6

7 at odds with Wolf. The piece was written on the death of Dr Friedrich Ferdinand 7

8 Flemming, ${ }^{549}$ who was a loveable member of the Sing-Akademie and Liedertafel. 8

9 All of Berlin grieves the loss of an eye doctor. 9

10 Our singers carry this piece softly to the end and the appoggiaturas indicated 10

11 above notes are tiny stresses which moderate the strong beats, just as in a painting 11

12 the colour contrasts with the contour. It must be sustained and flowing. That is 12

13 not exactly easy in this piece; we have had to keep rehearsing it. In it lies, in my 13

14 opinion, what some theorists consider a lack of a regular metre which could be 14

15 called free time, because absence of measure is quite unphilosophical. 15

16 Now I want to admit that I have dabbled in your profession: I have attempted a 16

17 transcription of the Latin ${ }^{550}$ to give those of the academy who have even less Latin 17

18 than I - but still have to sing it - a guide to its pronunciation. It would be nice if 18

19 our friend Riemer could, without too much trouble, give a helping hand. I would 19

20 not have been able to compose the Latin without thinking of it in German. Perhaps 20

21 Riemer would like to give me a better word for 'Chorule', which I have put in the 21

22 third stanza instead of Virgil. 22

23 I enclose the piece by Perti ${ }^{551}$ as a remnant of a fine style from the late eighteenth 23

24 century. Unfortunately I don't have more from this fine composer. 24

2516 March: Professor Kiesewetter ${ }^{552}$ wanted to take a letter with him and I 25

26 wanted to give him last year's theatre programmes. He is still here now and today 26

27 I set to music the last two poems you sent to give our Singtees ${ }^{553}$ the opportunity 27

28 to grumble about me with a full heart. This little joke would also like to go to you 28

29 and when you have heard it, let me know whether the form is correct, especially as 29

30 I have stitched both poems together.

31

32 - 32

33548 Zelter' setting of the verse 'Quis desiderio ...' from Horace's Carmina (I, 24) 33

34 for four solo voices and choir; the music is lost. The Ode is a lament for Virgil's friend, 34

35 Quintilius Varus.

35 Friedrich Ferdinand Flemming (1778-1813), amateur composer, died 27 May 1813.

36550 Enclosed with this letter; Goethe filed it in his archive under the title

37 Fremdliteratur.

38551 Presumably the four-part setting of Giacomo Antonio Perti's Adoramus te Christe.

39 The original could not be identified in Goethe's music collection. The setting is, however,

40 handed down as an appendix to the choral setting, Canzonette, which was presumably sent

41 by Zelter (GSA 32/179).

$42 \quad 552 \quad$ Johann Gottfried Karl Christian Kiesewetter (1766-1819). 42

$43 \quad 553$ Zelter's settings of Goethe's poems 'Die Jahre sind allerliebste Leute' and 'Das 43

44 Alter is ein höflich Mann'; neither are in Goethe's music collection. 44 
23 March: When I came home yesterday evening around 11[p.m.] I found your 1

2 little letter and in the lovely stillness of the evening I immediately set to work on 2

3 'Der Totentanz'. The character had me terribly frightened, because just as I was 3

4 about to write out the last notes, my loudmouth living room clock struck $12-4$

5 one after the other - so I went to bed and had to write the last notes out this 5

6 morning. I enclose the little song. The singer must perfect the words as well as the 6

7 music, read without emphasis and let one follow the other smoothly. Otherwise it 7

8 is nothing. Admittedly, no one gladly gets involved in such conditions; I would 8

9 think, however, one can pretend to be able to read well. 9

164. Goethe

24 Through Professor Kiesewetter, who is going from here in the morning via 24

25 Weimar to the army, you will receive some remaining things, including Fasch's 25

26 Quintet for five singers which I had long laid aside for your collection of signature 26

27 manuscripts. ${ }^{555}$ As Fasch himself has not signed his name on the work, I have 27

28 enclosed a report about the origin and intention of the piece ${ }^{556}$ and I am already 28

29 pleased that you will on occasion take delight in it. [...] 29 Zweiter Teil. The idea, which had formed in conversations with Iffland who wanted to 32 perform it in Berlin, was discussed in correspondence with Schiller in May 1798 and gained 33 new life upon publication of the fragment in Wilmann's Taschenbuch auf das Jahr 1802. 34 Despite this and also Zelter's interest, Goethe heeded Schiller's caution and it remained 35 unfinished. hanget Dir an (in Fasch's hand and dated 4 November 96). The composition is no 37 longer in Goethe's collection of autographs; see Hans-Joachim Schreckenbach, Goethes 38 collection (GSA 32/46). 40 Autographensammlung. Katalog (Weimar: Arion, 1961); it is now held in the poet's music 39

556 The following notes, written in Zelter's hand, are enclosed with the composition: 41

43 'The five-part choral work, in the composer's hand and written by Fasch, is an attempt to 42

43 apply the seventh degree of the scale, discovered by the mathematician Euler, which is 43

44 not completely contained in the [tempered] scale. It is also remarkable that it was written 44 
1 The day before yesterday I entertained their Majesties of Saxony ${ }^{557}$ at the Sing- 1

2 Akademie in our own way. The King and Queen openly showed satisfaction as 2

3 experts and as I cannot be happier than when I do something good for fine people, 3

4 you can imagine my own satisfaction. On this day the choir consisted of 1524

5 singers not counting myself and the pieces went off well. What I liked so much 5

6 about the King was that he didn't speak about the large number [of singers] but 6

7 about the purity, the unity and the general impression. 7

8

929

10 166. Goethe 10

$11-11$

12 Weimar, 22 April 181412

$13 \quad 13$

14 Today just a word or two, dear friend, to tell you that, to my great delight, your last 14

15 consignment reached me safely; the parts are copied out and are so far prepared 15

16 that my household choir, with its adequate resources, will soon be able to give me 16

17 a treat. Undoubtedly a special art is required to keep alive this mixed group from 17

18 which now this, now that member drops off. The 'Ruhelied' is admirable; ${ }^{558}$ our 18

19 tenor $^{559}$ sings it very well, and in these times of unrest, it is all the happiness we 19

20 get.

21

22 Enclosed: 'Gleich ist Gleich'

23

29 The most laughable scenes in Wilhelm Meister are serious in comparison with the 29

30 tricks I have to resort to in arranging that your music should no longer only be 30

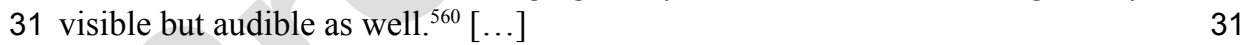

35 when the composer came down with serious illness and was notated in the early days of his recovery. The words are written out in the music and after the setting.'

37557 Friedrich August I (1750-1827), King of Saxony and his wife, Marie Amalie

39558 'Wanderers Nachtlied' ('Über allen Gipfeln ist Ruh').

40559 Carl Melchior Jakob Moltke (1783-1831); in Weimar from 1809; see Goethe's

41 diary 22 April 1809: 'An evening in the theatre: Zauberflöte; debut of the new tenor,

42 Moltke', WA III/4, p. 23; his performances with Goethe's house choir are often mentioned

43 in Goethe's diary.

44560 Zelter's settings written for performance by Goethe's house choir. 44 
1 When an opportunity offers, I shall send you a full score by Christoph Kaiser, ${ }^{561} 1$

2 some of whose music you know - in particular the Christmas cantata. ${ }^{562} \mathrm{He}$ was 2

3 with me in Italy, and is still leading a secluded life in Zurich; I should like to hear 3

4 in detail what you think of his style. I shall send you the Overture, and Act One of 4

5 Scherz, List und Rache, the whole of which he has set to music. He is on my mind 5

6 just now, as I am working at my ltalienische Reise, and should like to be as clear 6

7 about his art as I am about his studies and his character. $\quad 7$

8 Briefly and hastily, let me thank you for the great pleasure which your parcel 8

9 gave me. I succeeded this time in getting the ever-changing choir that meets at my 9

10 house very well organized. 10

168. Zelter

17 Your last letter of 4 May, from Weimar, arrived safely. Please let me have Christoph 17

18 Kaiser's score as soon as possible, as I am already busy preparing for my journey 18

19 to the spa, though for the rest of this month, at least, I am staying where I am. 19

20 As yet I do not know a note of Kaiser's music, and if you happen to have his 20

21 Christmas cantata at hand, please send that also. Reichardt wrote to me the day 21

22 before yesterday, that he expects a complete recovery from his painful condition. ${ }^{563} 22$

23 Abbé Vogler died suddenly in Darmstadt on 6 May. ${ }^{564}$ Art would lose an excellent 23

24 man by his death, had he not wasted the best time of his life in ploughing foreign 24

25 acres, dissecting organs ${ }^{565}$ and polishing up old trash. [...] 25

561 Presumably the second edition of the autograph score of the overture and Act 1 of 31 Philipp Christoph Kayser's music to Goethe's Singspiel Scherz, List und Rache.

562 Kayser's Weihnachstkantate for two solo voices and strings (Zurich, 1810); the 33 work was rehearsed by Goethe's house choir (see Goethe's diary, 1 and 4 November 1810, 34 WA III/4, p. 146).

563 Reichardt's letter has not been handed down; it was one of the last letters written 36 before his death. 
5 Cologne, 9 September: Yesterday I spent the whole day in the cathedral [...] The 6 space in the church between the columns is very majestic and large. I have never 7 seen anything so finely shaped; the sound is soft like the light and as clear as 8 an unclouded starry sky. The effect of music without castrati would always be 9 moderate in such spaces if the forces are not too large. Reichardt doesn't know 10 what he is talking about when he speaks out against castrati. ${ }^{566}$ There may be one 10 11 castrato among a thousand men and the rock on which this church is built will not 11 12 be the smaller for it. [...]

13 Early on Saturday: Music here is as quiet as the trade. Since I have been here I 13

14 have hardly heard a note, not even on a barrel organ. [...]

21 [...] On my nocturnal journey there was no time to piece together all kinds of 21 22 reminiscences on Epimenides ${ }^{567}$ The little song, 'Vorwärts! Hinan!'568 crystallized 22 23 and took melodic shape in my mind, as I have had your manuscript often enough 23 24 before my eyes. I wanted to surprise you with this song: your choristers in Weimar 24 25 should serenade you with it. On 11 October last Prince Blücher paid our Sing- 25 26 Akademie a visit, and I thought I could not do better than greet him with the little 26 27 song 'Vorwarts! Hinan!' ${ }^{569}$ They sang it with such truth and delicacy of feeling that 27 28 he was delighted. The 181 voices sounded so fresh and spirited that the old fellow 28 29 could not help crying. Our friend $\mathrm{Weber}^{570}$ was upset about it and I will have my 29

34 Musikfreunde (Berlin: Berlinische Musikhandlung, 1793), p. 21; Reichardt, Vertraue

35 Briefe aus Paris (Hamburg: B.G. Hoffmann, 1804), vol. 1, p. 191. See also Reichardt's

40569 A manuscript of Zelter's setting bears the title 'Vorwärts. Blüchers Ehre' (SBB PK: 40

41 Mus. ms. autogr. Zelter 10, no. 21). 41

$42 \quad 570$ Bernhard Anselm Weber, composer and Kapellmeister of the Nationaltheater from 42

431792 until his death in 1821, during which time he keenly promoted operas by Mozart and 43

44 Gluck. $\quad 44$ 
1 work cut out to placate him. Perhaps he will complain to you himself because 1

2 he has lent me his manuscript ${ }^{571}$ in order to show it to Schulz ${ }^{572}$ and believes I 2

3 transcribed the verses from his score [...]. 3

412 November: Please do not forget 'Gastmahl der Weisen'573 and what you 4

5 encounter on your travels, as next year I would also like to go through this 5

6 district.

7

8

9

$40 \quad 571$ Bernhard Anselm Weber's manuscript of the incidental music to Goethe's Des 40

41 Epimenides Erwachen.

8

$\begin{array}{ll}8 & 9\end{array}$

$\begin{array}{ll}9 & 10 \\ 11 & 10\end{array}$

12

13

14

16

17

18

19

20

$\begin{array}{ll}21 & 22\end{array}$

23

24
24

25
26

$\begin{array}{ll}27 & 27\end{array}$

28

$(-2)-30$

31

32

34
34

35

36

37

38

42572 Presumably Christoph Ludwig Friedrich Schultz (1781-1834), Chairman and 42

43 financial manager of the Sing-Akademie. 43

44573 Zelter's setting of Goethe's poem 'Die Weisen und die Leute'. 44 


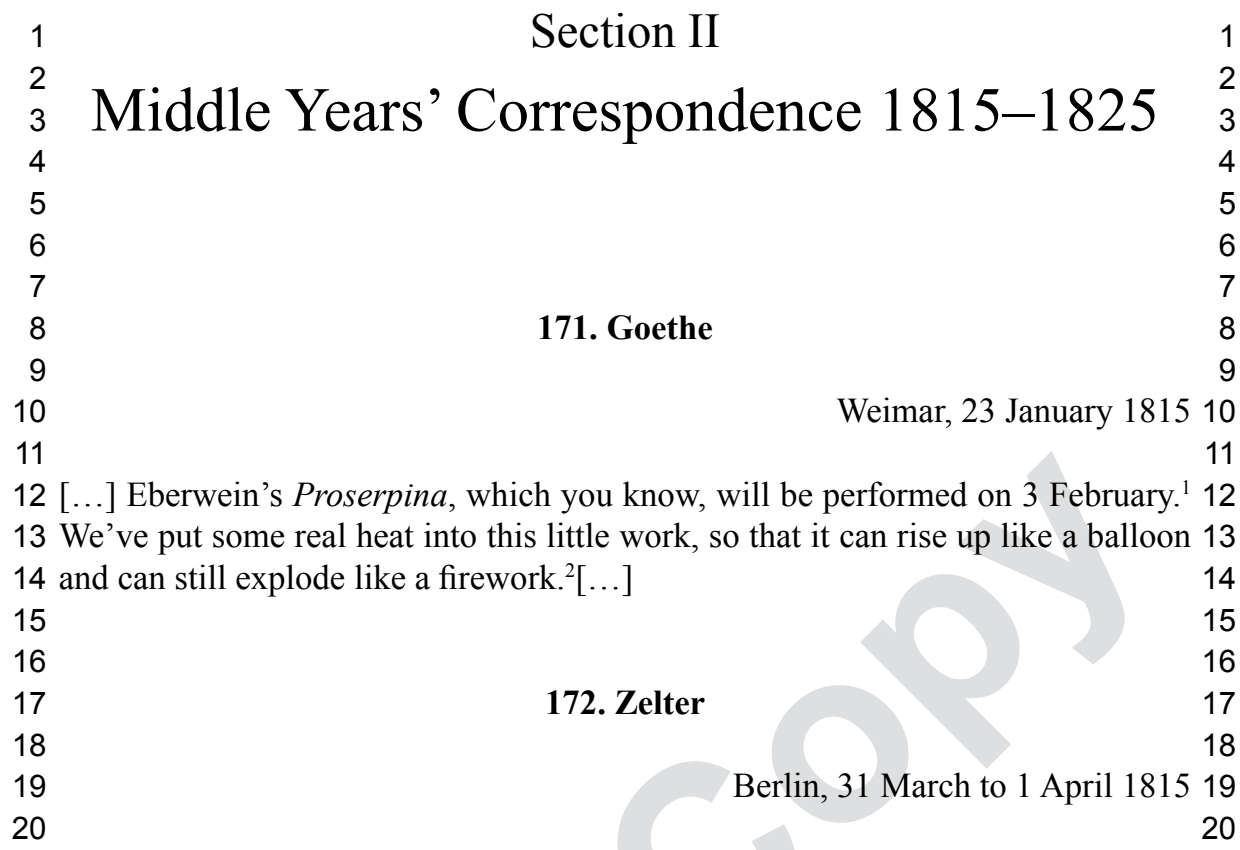

21 Finally yesterday Epimenides was successfully launched. ${ }^{3}$ The effect was significant 21

22 and it hit [the right tone], despite our spoilt audience, the delay in the work ${ }^{4}$ and 22

23 many minor details, which the poet himself would have wanted addressed. Yes, 23

24 it appeared like a prophetic vision and, at the same time, like a test case. One 24

25

261 Carl Eberwein's setting of Goethe's melodrama Proserpina composed in the Spring 26

27 of 1814 (GSA 32/61). On the origins of the music and the rehearsals in Goethe's house; see 27

28 'Eberweins Erinnerungen' in Wolfgang Herwig (ed.) Goethes Gespräche. Eine Sammlung 28

29 zeitgenössischer Berichte aus seinem Umgang. Auf Grund der Ausgabe und des Nachlasses 29

30 von F. Freiherrn von Biedermann (4 vols, Zurich and Stuttgart: Artemis Verlag, 1965-87), 30

31 vol. 2, pp. 901-903, and p. 991. Hereafter referred to as Gespräche. The performance took 31

32 place in the Weimar Court Theatre on 4 February 1815, repeated on 6 February and 6 March 32

331815 .

342 See Goethe's recollections in the Tag- und Jahres-Heften (1814): 'The monodrama, 34

35 Proserpina, in Eberwein's setting, was rehearsed with Madame Wolff, and a short, but 35

36 highly significant performance was prepared which involved recitation, declamation, mime, 36

37 and noble, dignified movement, and a large tableau portraying Pluto's Kingdom crowned 37

38 the performance and left a strong impression [on the audience].' 38

39 Goethe's one-act festival piece Des Epimenides Erwachen, set to music by B.A. 39

40 Weber. Performances took place on 30 and 31 March in the Königliches Oper, Berlin, 40

414 A performance had been planned to celebrate the king's return from France on 41

42 20-14 July 1814 but was postponed because the score was not finished; Herklots's Festspiel 42

43 Asträas Wiederkehr was performed instead of Des Epimenides Erwachen at the king's 43

44 reception on 7 August 1814. 
1 had believed (as the unbeliever is the most faithful) that the work would have no 1

2 appeal to modern audiences anywhere. From the outset a good reception was not 2

3 to be expected. I myself was embarrassed and had crept into the orchestra pit in 3

4 order to be in the empty space between the stage and the audience. The opening 4

5 was delayed, the full house became restless and I was worried. 5

6 The overture began: either Weber didn't have the time or he had considered 6

7 that the muse itself voices the overture. In short he composed a modest, suitable, 7

8 although somewhat lugubrious introduction to the work, which sounded very well. 8

9 Even the first stanza, spoken rather broadly but well, caused quiet emotion, and 9

10 with the departure of the muse ${ }^{5}$ I noticed a better mood within myself and in the 10

11 house which was perfected by the cheerful song of the spirits. ${ }^{6}$

12 The Daemon of Oppression ${ }^{7}$ was spoken with emotion, clearly and steadily. 12

13 His corruption of Love ${ }^{8}$ and Belief, ${ }^{9}$ as well as the wretched condition of lost 13

14 freedom and innocence and the eventual emancipation through Hope, ${ }^{10}$ make a 14

15 deeply impressive scene. Both virtues cowered like trodden-on chickens and, as 15

16 I said, the scene moved me tremendously and everyone felt it, thank God, even if 16

17 they didn't recognize it. [...]

18 Saturday, 1 April: The second performance of Epimenides took place yesterday 18

19 evening. If yesterday the piece received the usual applause for a good work, today 19

20 the court, which was missing yesterday, was present. A significant section of the 20

21 general public saw it for the second time today and the reception was warmer from 21

22 the outset, more prepared, and yesterday's performance was to be considered a 22

23 general rehearsal. Weber is delighted beyond words. He had to make every effort 23

24 because Count Brühl pressed him ${ }^{11}$ and one expected music that was arduous, cold 24

25 and cobbled together. If he missed out sometimes and sometimes tried too hard, 25

26 most of it succeeded admirably. The scene with the appearance of fire on the stage 26

27 is perfect. He has composed much in the so-called melodramatic style and [it is] 27

28 really first-rate; he is particularly skilled in this genre. With Cunning he has made 28

29 much thankless effort and as a result this character is too lyrical. The licking and 29

30 crawling which he wanted to express turns into sentimentality because he spends 30

31 too long on it and stops the flow of the piece. Incidentally this character, Cunning, 31

32

33

34

44 General Director of the Königliches Theater, Berlin (1815-28).

.

.

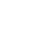

.

列

.

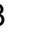
11 . 
1 is a problem for every composer. The choruses, equipped here in the way they can 1

2 be only in large theatres, made a very imposing impression, especially a visual 2

3 one, through the entrance of the various ethnic tribes. Weber gave our leading 3

4 lady a big magnificent aria with supporting choir, which ultimately is a work in 4

5 itself. The piece lasts two and a half hours - but on both days it was held up as an 5

6 endless amount of powerful phrases and sentences were clapped and called back, 6

7 which was why the actors must pause so long. Sometimes it appeared as if the 7

8 crowd formed themselves into two choirs in order to applaud this and that, here or 8

9 there; then they all reunited briefly again and, in short, I really enjoyed it. On the 9

10 first day the actors left out anything that referred to the King because the King had 10

11 refused to tolerate - had even forbidden - all such connections: however, yesterday 11

12 these had to be spoken and the cheering was furious. What's more is, where the 12

13 group is formed for the finale, the triumphal chariot of the Brandenburg Gate is 13

14 raised and displayed above the facade of the temple. Of all the speaking characters 14

15 Epimenides made his mark through coherence, clarity, composure and dignity. 15

16 Love was beautifully sung [though] spoken less well. Cunning, a slim, beautiful, 16

17 smooth, tallish, humble courtesan, was exceptionally well and clearly sung. The 17

18 chap has a tongue like a strip of tagliatelle. The performance was much more 18

19 together than yesterday. The cast played more freely, fuller, with more eagerness. 19

20 The appearance of Hope is really powerful. This scene really gripped me again, 20

21 although it wasn't perfectly performed. It is the secret body to which all parts are 21

22 fixed - it is calm but monstrous. 22

23 To me Epimenides was a good plaster on the wounds which struck me like 23

24 cleavers before the despicable 24 February. ${ }^{12}$ The man $^{13}$ looks at fate like a cargo 24

25 carriage onto which one can pack what one will, or as a charnel house for old 25

26 bones. God preserve mankind from such poets! The clergy have laid a really good 26

27 catch for themselves: he brings them all to the gallows. ${ }^{14}$

28 Now I have to I won't say 'apologize' that I have not replied to two of your 28

29 letters. ${ }^{15}$ The truth is I was out of sorts all the time and in pain, and have waited 29

30 for the good weather which has now appeared. Could I go to a spa this summer? ${ }^{16} 30$

31 God knows how badly I need it. I organized a really good Easter concert ${ }^{17}$ and 31

12 Der vier und zwanzigste Februar, tragedy by Zacharias Werner; the premiere took

34 place on 23 March 1815; Zelter attended the performance on 29 March 1815.

13 Friedrich Ludwig Zacharias Werner (1768-1823).

14 Following his conversion to the Catholic Church in 1810, Werner was ordained in 1814

3815 Goethe's letters on 21 November and 27 December 1814; whether Goethe's third 39 letter of 23 January had reached Zelter at this stage is uncertain.

$40 \quad 16$ Zelter was unable to accept Goethe's proposal of a visit to Wiesbaden; he spent a

41 fortnight in Dresden in August 1815 and afterwards spent five weeks in Teplitz.

$42 \quad 17$ On 24 August 1815 the annual performance of Graun's Der Tod Jesu was given by

43 the Sing-Akademie under Zelter's direction; a report in the Vossische Zeitung on 20 March 43

44 mentions 'the packed hall'. 
1 made over 800 thaler pure profit from it. Also the department ${ }^{18}$ has proven itself 1

2 well disposed towards me. The extension of the State Chancellor's absence ${ }^{19}$ is 2

3 awkward for me because he must confirm my expected additional allowance. ${ }^{20}$ It's 3

4 no joke because it already involves 700 thaler. [...]

5 Send me some songs. I have dressed your 'Hans Adam"21 [in a way] in which 5

6 he is fit to be seen. 6 on 9 June 1815.

The young Mendelssohn, ${ }^{22}$ a student doctor, asked me for a letter of introduction to 13 you so he could meet you in person. He has already taken part in the last war, and 14 despite his indifferent health, he has decided to return to the army. 15

We are expecting our King here in Berlin and Epimenides will rest until then, ${ }^{23} 16$ with whose interpretation I am occupied in all kinds of ways. [...]

I avail myself of the opportunity to send you some original manuscripts of 18 remarkable people. And even if you should already have something of theirs in 19 your collection, from a historical point of view the compositions are important in 20

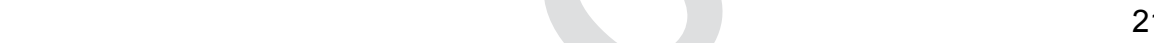

18 The section for culture and public education in the Ministry of the Interior. 26

19 Prince Carl August of Hardenburg was at the Congress of Vienna, which concluded 27 20 An annual payment of 600 thaler for Zelter's position as Professor of Music at the 29 Berlin Akademie der Schönen Künste had already been agreed, but the first payment was 30 made the following year. Already in his letter of 26 June 1811 Schuckmann, as director of 31 the relevant Department for Culture and Education, had put in a request to State Chancellor 32 Hardenberg for an increase in salary; see Cornelia Schröder (ed.), Carl Friedrich Zelter und 33 die Akademie. Dokumente und Briefe zur Entstehung der Musik-Sektion in der Preußischen 34 Akademie der Künste. (Berlin: Akademie der Künste Monographien und Biographien 3, 35 1959), p. 128f. Only in December 1816 could Zelter report to Weimar that he had received 36 'an additional annual allowance of 400 thaler'.

21 The poem ('Hans Adam war ein Erdenkloß') from Goethe's West-östlicher Divan 37 written in Berka an der Ilm; originally entitled 'Buchstabe Dal. 18te Gasele'. It was later 38 published in the Divan as 'Erschaffen und Beleben'. Zelter's setting, which bears the title 39 'Der erste Mensch' (1815), was first published in his Liedertafel anthology of 1818.40

22 Georg Benjamin Mendelssohn (1794-1874), son of Joseph Mendelssohn and his 41 wife, Henriette (Hinni) Mendelssohn, née Meyer. 
1 themselves; particularly those of Sebastian Bach, ${ }^{24}$ and Kirnberger. ${ }^{25}$ In the life of 1

2 Fasch $^{26}$ you will find an explanation of the piece headed $\mathrm{La} \mathrm{Coorl.}{ }^{27}[\ldots]$

12 Everything depends on a play of this kind being given a dozen times in 12

13 succession. If you realize the elements that go to make up such a representation, 13

14 you will almost despair of a happy result:

15 The work of the poet, whose basic position will always occupy the external 15

16 senses and at the same time will stimulate the inner [senses] and demand from the 16

17 audience that at every moment it look, notice and interpret. 17

18 The composer, who should accompany, carry, enhance and support and more 18

19 or less fulfils this duty of his. 19

20 The orchestra, who should perform the intentions of the conductor perfectly. 20

21 Actors and singers, who, using the thread put into their hands, have to weave 21

22 their way through so many perils. Everyone should do his duty and keep an eye 22

23 on the rest. 23

24 Costumes, which are not just passable and are comfortable. 24

25 Many miscellaneous props, on which so much depends. 25

26 Scenery, whose invention must complement the whole and which must be 26

27 changed without delays.

28 And then there is the audience who are assembled from so many classes and 28

29 cultures, who, even with good will, come cold and unprepared. One can't take 29

30 it amiss if in the present case they come together unconvinced and in the worst 30

31 possible frame of mind. 31

$32[\ldots]$ When the play is frequently repeated, it is quite a different matter [... 32

33 with more light-hearted nations; when any piece has once taken hold of them, it 33

34 can be repeated endlessly because the actors, the play and the general public come 34

3624 No longer identifiable either in Goethe's music collection or his collection of 36

37 manuscripts; Zelter describes the work in ZG 16 to 22 April 1815 . 37

3825 Josef Philipp Kirnberger (1721-83) pupil of Johann Sebastian Bach, composer

39 and violinist in Berlin; teacher to Fasch, Zelter and Anna Amalia von Preußen; music

40 theoretician; author of Die Kunst des reinen Satzes.

$41 \quad 26$ Zelter's Fasch biography. $\quad 41$

$42 \quad 27$ C.P.E. Bach, Sonata in A minor, third movement (GSA 33/33). 42

$43 \quad 28$ Goethe had received letters about the performance of Des Epimenides Erwachen 43

44 from B.A. Weber (1 April), Konrad Levezow (3 April) and Count Brühl (12 April). 44 
1 to understand each other better and better; and then, too, one neighbour in the town 1

2 stirs up another to go to the theatre until finally the common conversation of the 2

3 day makes it necessary for everyone to see such a novelty. I saw an example of 3

4 this in Rome, when an opera, Don Juan (not Mozart's), ${ }^{29}$ was given every evening 4

5 for a month, an event which so stirred the city that the humblest shopkeepers with 5

6 the family all dressed up booked seats in the pit and boxes, and no one could exist 6

7 without having seen Don Juan roasting in Hades and the governor rising towards 7

8 heaven as a blessed spirit [...] That you should have held so firmly to the pivot 8

9 upon which my play turns (but, as I hope, without grinding and creaking) and that 9

10 you felt it so deeply pleased me greatly, although it is quite in accordance with 10

11 your nature. Without these fearful chains the whole thing would be a failure. The 11

12 fact that this example is proven in women makes the thing more pardonable and 12

13 draws it into the domain of emotion; however, we will say nothing further about 13

14 the matter, and leave its fortune to the gods. [...] 14

15 I do not doubt that you have succeeded in clothing Hans Adam's body in an 15

16 excellent jacket; and I look forward to seeing him parade about in it. I will search 16

17 out a later poem for you. I find orientalizing very dangerous work because before 17

18 one is aware of it, the most solid poem slips out of one's hands [and] vanishes into 18

19 air like a balloon filled with rational and spiritual gas. [...]

20 Just as I was wondering with what to fill up my remaining space, Mendelssohn ${ }^{30} 20$

21 came in, bringing with him your kind greeting and gift, ${ }^{31}$ both of them most 21

22 welcome; I received him cheerfully, but distractedly, for when he first called I 22

23 was more than a hundred miles away from the house. The music manuscripts 23

24 are fantastic! I had no specimen of any of the three masters ${ }^{32}$ in my collection. 24

25 My very best thanks! As we have brought the Berliners to reflect and to make 25

26 puns, let us stick to it for a time. Remember me very kindly to State Councillor 26

27 Schultz. I have studied his treatises ${ }^{33}$ again lately; both they and he have become 27

28 so much dearer to me. Now adieu! May this letter be the happy beginning of new 28

29 communication between us. 29

29 Goethe had presumably seen Vincenzo Fabrizi's Opera Il convitato di pietra in the 36 Teatro Valle, Rome, in 1787; Giuseppe Gazzaniga's opera Don Giovanni Tenorio o sia Il 37 convitato di pietra was performed much later in Rome.

31 Zelter's letter from 11 April and the autograph manuscripts. $\quad 40$

32 J.S. Bach; C.P.E. Bach and Johann Philipp Kirnberger. 41

33 Christoph Ludwig Friedrich Schultz, 'Über physiologe Gesichts- und Farben- 42

Erscheinungen'. Schultz sent this essay to Goethe on 27 November 1814, and Goethe had 43 it published in Schweiggers Journal in 1816. 
5 How was the performance of your Proserpina staged and did it have a repeat 5 6 performance? ${ }^{34}$ Because such a piece, if it has also been rehearsed in the best 6 7 possible way, will have something for the eye and the ear, as long as eye and ear 7 8 are practised. One must help the best pieces to be well performed. [...]

9 I will hear 'Hans Adam' for the first time next Tuesday. It was ready quick 9 10 enough though I went over it for a long time and now we want to hear whether it 10 11 has not become only too much of a mosaic. As we must give a song a title, I have 11 12 written 'Der erste Mensch' at the top. If you prefer another title, let me know. We 12 13 will also sing the song 'Aus wie vielen Elementen soll', ${ }^{35}$ which should stand 13 14 out as more intellectual in so far as it was an exercise in bringing the different 14 15 elements together under one melody. I have given the Lied the title 'Liederstoff'. 15 16 I would have called it 'Die vier Elemente's6 if Schiller had not written one with 16 17 this title.

18 Next Tuesday we will perform Mozart's Requiem in the Sing-Akademie in 18 19 memory of our deceased director, Frisch. ${ }^{37}$ Why could I not be so fortunate as 19 20 to expect you and Mozart among my audience? All that carping and toiling at 20 21 minutiae (which are self-explanatory because they are lost in the whole) makes 21 22 your body tired, if you are not listened to from time to time. Fortunately this is 22 23 one of those pieces of music which, without opportunity, one takes into oneself 23 24 like a beautiful artistic fragment, and when the opportunity is there, one can very 24 25 innocently forget about it. There is just enough peace in the piece as is necessary 25 26 to dismiss the memory of a pleasant, noble departed [person] in the shortest 26 27 possible time. On the other hand, it is the same with the performance of Der Tod 27 $28 \mathrm{Jesu}:{ }^{38}$ through performing it for many years the piece is firmly fixed in our choral 28 29 repertoire and so I have little or nothing to do. What's more, the holy day arrives 29 30 to which the people are accustomed and for which the theatre is closed. If the 30 31 performance does happen to be praised, that just means that no one is disturbed 31 32 and then I can be quietly satisfied [...] 32

3534 Goethe's monodrama Proserpina, with music by Carl Eberwein, performed 36 on 4 February 1815 in the Weimar Court Theatre; a repeat performance was staged on 376 February.

$38 \quad 35$ Goethe's Divan poem, 'Aus wie vielen Elementen', written on 22 July 1814;

39 published under the title 'Elemente' (1819); Zelter's setting entitled 'Liederstoff' dates

40 from 1814 and was published in the Liedertafel (1819). 40

4136 Schiller, Vier Elemente, SNA 2/I, p. 215.

4237 Johann Christoph Frisch (1738-1815), painter, since 1805 Director of the Akademie 42

43 der Künste, died in Berlin on 28 February 1815.

4438 Passion Oratorio by Carl Heinrich Graun. 44 
1 I am extremely delighted that you received young Benjamin Mendelssohn, as

2 his disposition needs every encouragement if he is not to go under when he is not 2

3 with others of his kind. His mother, an old friend and the loveliest female creature 3

4 I have ever encountered, asked me for an address for you and as I had just laid 4

5 out the fine autograph manuscripts for you, I was glad to save a few groschen on 5

6 postage. The piece by Sebastian $[\mathrm{Bach}]^{39}$ is actually the Sunday recreation of its 6

7 writer and considered by me like a drawing carried out by a great artist. If you 7

8 should hear it said so often how I enjoy your Epimenides, you should praise me. It 8

9 must be played vigorously and not be thrown away, because it is exactly as long as 9

10 it should be and is completely united. 10

11 Now your obedient servant asks for something poetic. I have started many 11

12 sketches of pieces I have to hand and sketched what, given a calm atmosphere, 12

13 must work itself out. If the new [poems] arrive, the old will be made whole and 13

14 the work is halved. I have still not finished 'Das Gastmahl der Weisen': ${ }^{40}$ Riemer ${ }^{41} 14$

15 is so good as to have it written out by his excellent lady, ${ }^{42}$ for whom I will again 15

16 send some of my eau de cologne.

Yesterday our Requiem went like clockwork. ${ }^{43}$ The Crown Prince, our entire court 23

24 at present and the Ministry of Culture, and all the members of both the Academy 24

25 of Fine Arts and the Academy of Science were present. Before the music for such a 25

26 celebration can be thought about, there has to be a church, altar, catafalque, mourners 26

27 and the office of the mass itself. There was no talk of all of these things because we 27

28 enjoyed our music like good bread without meat. Our academy hall ${ }^{44}$ which, by a 28

29 long way, is not big or high enough to hold 500 people comfortably, was doubled 29

30 in the absence of these things. That means with the mixture of daylight and light 30

31 from 300 wax candles the resulting semi-light was very effective. The position 31

32 of the catafalque was taken by the bust of the composer and that of the mourners 32

33 was taken by friendship and gratitude. The mass was held; that means Schadow 33

34 spoke of the merits of the artists and then I added the enclosed words. ${ }^{45}$ As a result 34

$36 \quad 39$ The piece cannot be identified as it is in neither Goethe's music collection nor in his 36

$\begin{array}{ll}37 \text { collection of autograph manuscripts. } & 37\end{array}$

3840 Goethe's poem 'Die Weisen und die Leute'. 38

$39 \quad 41 \quad$ Friedrich Wilhelm Riemer, Goethe's secretary and amanuensis. 39

4042 Caroline Riemer née Ulrich (1790-1855). 40

$41 \quad 43$ The performance in honour of J.C. Frisch; see Vossische Zeitung 29 April 1815.41

4244 The round room of the Akademie der Künste, in which the Sing-Akademie 42

43 rehearsed until $1827 . \quad 43$

$44 \quad 45 \quad$ Zelter's speech is enclosed with this letter, MA 20.3, p. 351. 
1 the mass was divided into three sections, which made a pleasant change. I was 1

2 certain enough of the progress of my music and of my cheerful assistants to direct

3 my attention to the audience. My enjoyment consisted in this: to take deep delight

4 in the devotion and salutary atmosphere which lasted long after the music. Our

5 Crown Prince, a cheerful, open, friendly youth, delighted me by his applause in

6 so far as he had said to me earlier that he didn't think much of Mozart's Requiem.

$7 \mathrm{He}$ came up to me full of joy and said: one should often hear good music, but one

8 also has to hear it [performed] well, otherwise one learns not to listen. I ventured

9 to give my applause to these good words, in that I replied: the good lies neither too

10 deep nor concealed and a worthy investigation always reveals it. He praised the

11 brevity of my speech and that I had mentioned Frederick the Great. - 'Had he not

12 lived like us?' - 'Better!', I added and he bounded off happily.

19 I shall send you a few words at once, in return for your dear letter, so that you 19 20 may be kept in the humour to write again and again. First of all, please let me 20

21 have some news of the theatre from time to time; for as I am on good terms with 21

22 Count Brühl, whom I knew as a boy, and as the success of Epimenides was due to 22

23 his exertions, I should like to do him a favour, and in a general way, to remain on 23

24 good terms with the Berlin Theatre. If there were only some incitement, it is very 24

25 likely that I should write plays once more, and then Berlin is, after all, the only 25

26 place in Germany where one has the courage to undertake anything. Owing to the 26

27 numerous journals and daily papers, all the German theatres lie bare before our 27

28 eyes, and when you think of it, which one can you turn to with any confidence? 28

29 Only speak out like a good blunt German, as you were always inclined to, that 29

30 I may not stumble about in the dark and squander my good intentions on false 30

31 undertakings. $\quad 31$

32 I have made my Proserpina ${ }^{46}$ the carrier for everything which modern criticism 32

33 finds and favours in works of art: (i) the heroic and decorative landscape; (ii) 33

34 heightened recitation and declamation; (iii) Hamiltonian-Hendelian gestures; ${ }^{47} 34$

46 A lyric monodrama, initially intended as a collaboration with Gluck in memory

38 of his niece, and later initially introduced into Der Triumph der Empfindsamkeit. Goethe

39 Nicholas Boyle's preface to Lorraine Byrne Bodley, Proserpina: Goethes Melodrama with

40 Music by Carl Eberwein (Dublin: Carysfort Press, 2007), pp. xvii-xx. See also my own 41 introduction to this score, pp. xxi-xl.

$42 \quad 47$ Gestures and expressions imitating Lady Hamilton (née Emily Lyons, known

43 as Emily Hart), whose performance Goethe had witnessed in March 1787 in Caserta

44 (Italienische Reise, MA 15, p. 258) and the actress Henriette Hendel-Schütz, who had made 
1 (iv) change of costume; ${ }^{48}$ (v) change of scenery; and (vi) even a tableau for a 1

2 finale that represents the realm of Pluto - all this, accompanied by the music you 2

3 know, which serves as welcome spice for this immoderate feast of the eyes. It was 3

4 received with great applause, and when foreigners come to us, it will be a tiny 4

5 useful example of what we can do.

6 For some time past I have had just enough inclination to contribute articles to

7 the Morgenblatt; ${ }^{49}$ and that I may save you from wasting time looking for them, 7

8 I will mark the numbers should like you to look them up. [...] nos. 75 and 76: 8

9 Account of Epimenides Erwachen ${ }^{50}$ [...] I shall also give an account of Proserpina 9

10 and explain in more detail what I briefly touched upon above, ${ }^{51}$ so that a similar, 10

11 though more elevated representation of this little play may be given in several 11

12 different theatres.

13 I have been glancing through my West-östlicher Divan in order to send you a 13

14 new poem, but I now see clearly for the first time how this kind of poetry drives 14

15 one to reflection; for I did not find anything singable in it, especially for the 15

16 Liedertafel, for which, after all, it is our main business to provide. For what cannot 16

17 be sung in company is in reality no song, just as a monologue is no drama. 17

$18[\ldots]$ Meanwhile I am reading Winckelmann in the new edition by Meyer and 18

19 Schulze, ${ }^{52}$ who have immensely enhanced the value of his works, inasmuch as we 19

20 see here what the author has actually accomplished and also what exactly is found 20

21 to need correction and supplementation after so many years. [...] His own History 21

22 of Ancient Art, ${ }^{53}$ from the earliest down to the most recent times, has already been 22

23 sketched from beginning to end, and some sections have been worked out in a 23

24 masterly style. The merits of such men as Rubens [and] Rembrandt have never yet 24

25 been expressed by anyone with so much truth and energy. One imagines oneself 25

27 her name through pantomime and Hamiltonian attitudes; see Tag-und Jahres-Heften (1810), 27

28 MA 14, p. 218.

2948 In an essay on the performance of Proserpina, on which this sketch is based, Goethe 29

30 wrote: 'Proserpina appears as Queen of the Underworld; she is characterized by glorious 30

31 cloaks folded one over another and a veil and a diadem.'

49 In 1815 and 1816 Goethe wrote 19 articles for the Morgenblatt für gebildete Stände, 32 presumably out of a certain commitment to the
the Morgenblatt was also published by Cotta.

51 'Proserpina, Melodram von Goethe, Musik von Eberwein', Morgenblatt, no 136, 36

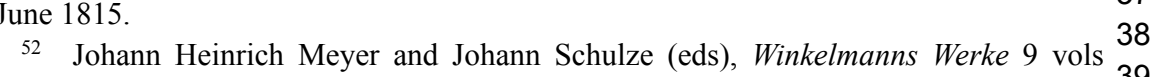


1 in a gallery of their works: the effects of light and shade and colouring in these 1

2 admirable artists speak to us from the black letters.

3 Now do make up your mind to write a History of Music in the same vein! You

4 would hardly be able to resist doing so, were I to read out Meyer's work to you

5 for only a quarter of an hour. From your letters and conversation I have already

6 become acquainted with many of your first-rate masters. With the same idea and

7 with the same energy, you would have to begin with an important period and

8 work forwards and backwards, for the true can be raised and preserved only by its

9 history, and the false can be lowered and destroyed only by its history [...]

10 Before I close this, I am again looking through my Divan and find a second 10

11 reason why I cannot send you a single poem from it; this, however, speaks in 11

12 favour of the collection. For every individual member is so inspired with the spirit 12

13 of the whole, is so thoroughly oriental, referring to eastern customs, usages, and 13

14 religion, and it requires explanation by one of the preceding poems, before it can 14

15 produce any effect upon the imagination or upon feelings. I myself did not know 15

16 in what a strange way I had made the anthology hang together. I have almost 16

17 completed the first hundred poems; when I have finished the second, the collection 17

18 will look more serious $[\ldots]$

19

25 [...] What you write about a history of music has lived in me for many years 25

26 and what I have revealed to Johann Müller about it was also not rejected by him. 26

27 Actually the purpose of describing my humble life was that I should be given the 27

28 opportunity to present what I know from practical experience and history; as for 28

29 writing a history of music which I have never seen, it would hardly be fitting for 29

30 me as I have read little.

311 June: Epimenides has just been performed for the third time yesterday to 31

32 celebrate the arrival of our King.

33 Each time the music, which is frequently rich in felicitous sections, is realized 33

34 better. The overture is appropriately very serious and the song of the spirits moves 34

35 along simply and cheerfully just as the first three scenes flow naturally from one to 35

36 the other. Epimenides spoke with composure, clarity and grace. ${ }^{54} \quad 36$

37 The fire episode in scene five, which was already effective, has improved 37

38 further, although the Good Spirit of War almost does too much: a fine, brilliant 38

39 actor $^{55}$ who plays Wallenstein and Götz to much applause took on slightly too 39

40

41

$42 \quad 54$ The title role was played by Friedrich Jonas Beschort (1767-1846), actor and singer 42

43 at the Königliches Theater, Berlin, 1796-1838. 43

$44 \quad 55$ Franz Mattausch (1767-1833), actor employed by the Berlin Court Theatres. $\quad 44$ 
1 much. The music for this scene is really first rate and links very well with the 1

2 warriors' song.

3 If only the three Daemons, which admittedly do not appear together, were 3

4 grouped together through the music, then I would say it was perfect. Cunning has 4

5 lovely music: the actor is a natural, ${ }^{56}$ of beautiful form and voice, smooth speech 5

6 and holds his line well; only it is too long. Fischer ${ }^{57}$ has a really oriental character 6

7 and plays the part of an arrogant, contrary, despondent, spoilt, secure, courageous 7

8 tyrant really well. 8

9 Something which has got tighter is [the performance of] the three virtues. 9

10 There is still much to be desired and the freedom which should arise out of the 10

11 redemption doesn't have any really brilliant music; otherwise the scene would be 11

12 really effective.

13 From the nineteenth scene onwards, where the resolution of previous mysteries 13

14 is meant to happen, it dawdles and seems as if it will never end. 14

15 I would prefer if Epimenides's song ${ }^{58}$ were spoken, because he doesn't sing 15

16 again through the entire piece. How would it be if it were sung offstage by some 16

17 alto voices and only heard by Epimenides? It seems to me that it would be a good 17

18 counterpart to the corresponding visual image and Epimenides could quickly join 18

19 in and continue speaking.

20 To me the comet scene is also not right yet. It doesn't give any impression of 20

21 the universe and doesn't correspond with the earth. I thought the scene should 21

22 have a similar effect to the fire scenery. The naked light shaft on the horizon is 22

23 not sufficient and would hardly be noticed if Epimenides hadn't announced its 23

24 presence.

25 The twenty-first scene could be improved, although the different groups on 25

26 foot and on horseback make an imposing impression. As the on-stage music is 26

27 very strong, alternating with the music on stage and from time to time freshening 27

28 the effect which is otherwise deafening, thereby becoming irksome.. 28

29 The brilliant aria is really a concert aria ${ }^{59}$ and as such belongs here really well. 29

30 But it is cut off and stands apart and at the very least would have to be sung by a 30

31 perfect, beautiful voice.

Miss Unity ${ }^{60}$ doesn't know what she says and forces and pronounces in her old 32

57 Joseph Fischer (1780-1862), singer at the court theatres in Berlin from 1814 to 39

(1816), later Act 2, scene 6, v. 759f. 
14 July: Madame Milder from Vienna is here and will appear in 12 [different] 1 2 roles. ${ }^{61}$ She will perform for the first time on Thursday. ${ }^{62} \mathrm{I}$ am looking forward to 2 3 her superb golden voice, which obviously belongs to those rarities that you will 3 4 always be happy with. Admittedly we have a similar soprano, perhaps even as 4 5 beautiful, in our Tombolini, ${ }^{63}$ but the chap is Italian and has become so shallow, 5 6 unfocused and cold that he is no longer to be enjoyed. Hasse may well have been 6 7 justified in saying: a German artist would have to live from one year to the next in 7 8 Italy if he wants to die blessed. ${ }^{64} \quad 8$

15 I am indebted to you for the repeated reviews of Epimenides. This is how I 15 16 would like to express the result that emerges from it: on the whole it is lacking in 16 17 imagination and feeling; exaggeration must occur, then absence. This would also 17 18 happen with frequent repetitions now and then; because what the people cannot 18 19 invent, they will surely discover. There's a great deal to be gained if you can see 19 20 that Epimenides's song is sung behind the scenes if it is not recited by Epimenides. 20 21 They will produce the piece again occasionally ${ }^{65}$ and perhaps in the future it could 21 22 be given an independent form.

29 Imagine a calm, really feminine form, fully formed, about 30 years old; with 29 30 beautiful arms, white, gentle, German, reliable, unspoilt; whose lips are open so 30 31 wide that a lightly expressive, rich, full voice can comfortably flow through: then 31 32 you will see Madame Milder, who performed in Gluck's Armida yesterday. 32

61 Anna Milder appeared in the title roles of Gluck's Armide and Iphigénie en Tauride;

36 as Emmeline in Weigl's Die Schweizerfamilie; Antigone in Sacchini's Oedip zu Colonos;

36 Susanne in Mozart's Die Hochzeit des Figaro; for reviews of her performances see AMZ

3717 (1815), no. 29, 19 July and no. 46, 15 November, columns 772 and 490; MA 20.3, 38 pp. 356-7.

3962 Anna Milder's first appearance was in Gluck's Armide, on 9 June 1815.

4063 The Italian castrato Raffaele Tombolini (1766-1839). 40

4164 The anecdote can be traced to either Hasse's writing or Kandler's biography of the 41

42 composer.

4365 In addition to the Berlin performances, performances took place in Leipzig on 43

4419 October 1815 and 5 April 1816. 
If in your mind you add to such a figure an inner life of pure naivety that, in its 1

2 innocence, reminds you of Pallas von Velletri (if I have the correct name), ${ }^{66}$ then 2

3 you will have Armida.

4 That such a creature, who is inhibited by no rules or acquired knowledge of 4

5 the art, flows along like a fine stream, who doesn't come and go and stand as if 5

6 an audience were present, but is rather like a blacksmith [who stands] before a 6

7 forge in order to pull out hot what was placed in cold; that such a creature causes 7

8 confusion and conflict for the connoisseurs of our art will become very evident 8

9 perhaps because one says: a pretty woman - but colossal; a beautiful voice - but 9

10 not what one calls singing; gentle and feminine - but cold and so on - and yet such 10

11 sensational applause, as if they were really enthralled, moved and touched. 11

12 So one sees with joy how the appearance of sheer talent turns to water the ideas 12

13 of an entire generation, who had become so accustomed to suspending the natural 13

14 until there are enough words, notes about it and even attempts at travesty of it. 14

15 I did not have to change my old impression about the music and the libretto 15

16 and understood even more that a true work is clearly recognized by a true 16

17 performance.

18 This honest Pallas drops what does not impose itself and rises to the heavens 18

19 with that which suits her. Gluck has clearly paid too much attention to minutiae 19

20 and he would have been none too pleased if a woman had treated him like that. 20

21 What he has done well is certainly good and he is to be excused on the grounds 21

22 that he did not write the libretto.

23 The German translation ${ }^{67}$ is so sluggish that it remains stuck in the singer's 23

24 mouth. Milder knows how to free herself even from this.

25 Every week we have two, sometimes three, guest roles, which is not a bad 25

26 thing because our [opera] house, which is too small in the winter, is often too big 26

27 in the summer, and the general public are more interested in attending [the theatre] 27

28 in the summer and getting to know the artists it wants, through which the directors 28

29 have a better box office and other advantages. Incidentally if things go on like this 29

30 for a year, we would take off by getting rid of debts and, given the technical set up 30

31 which is there really for both theatres, great and noble objectives could be aimed 31

32 at. Perhaps it will be possible to think that in time opera, operetta, comedy and 32

33 tragedy will be kept separate from one another, for which purpose another house 33

34 would have to be built, and then it would be possible to train the general public. 34

35 If the Queen were still alive, ${ }^{68}$ we could certainly think about it, especially 35

36 in a time of peace, because a court theatre is important where there is a court 36

37 and when an audience do not show enough enthusiasm for their best poets. Such 37

38 enthusiasm is completely absent. The oldest and best works are always new to the 38

39 general public, in addition to which unity is missing on the stage and also in the 39

66 Statue of Athena (c.430 BC) from ancient Velletri, south of the Albanian mountains; 41

it is housed in the Louvre, Paris.

67 Translation by Julius Voß. 
1 relationship between performance and audience. The general public is certainly 1

2 better than the judges, who always only rebuke the mistakes and have nothing to 2

3 say about the genuine, the fine, the lofty and the excellent. It is pathetic how these 3

4 people must grapple with things they do not understand and by actual disposition 4

5 can do nothing for an artist with natural flair except correct him, when he himself 5

6 is already annoyed over what he hasn't managed to bring off. On the other hand, 6

7 they make concessions to mediocrity and youth which they intend to encourage 7

8 and out of which nothing will come. Likewise, they confuse both public and actors 8

9 with their judgement of the plays, for what is the artist to do if there is no resonance 9

10 of what he intended to do? 10

11 But why do I tell you about such things which you yourself know a thousand 11

12 times better? 12

13 Yesterday (on 15 June) Oedip zu Colonus $^{69}$ was very successfully performed. 13

14 One seldom sees such a slick production. The opera has never appealed to me and 14

15 I listen to it repeatedly only because I have the judgement of France and Germany 15

16 against me. ${ }^{70}$ Yesterday I liked it and one sees what is possible for an excellent 16

17 voice. The subject is obviously too large and mysterious for an Italian composer 17

18 and the music contains little of the tragic. Everything is bright, cheerful, lively, 18

19 without depths and will not grip [the audience]. And yet Gluck influenced this 19

20 Italian because there are, however, faint Gluckean echoes in Sacchini. The effect 20

21 of these is all the more pleasant in so far as they occur spontaneously and spice 21

22 up the Italian cantilena, through which it is in fact enhanced. Although I am not 22

23 like those who would wish for the mixture of talent and want to make one man out 23

24 of Gluck, Mozart and Haydn, I don't want to have what God can't do and have 24

25 enough in what is there. $\quad 25$

32 [...] Imagination and feeling cannot be pushed or pressed into a work and, given

33 the little attention to detail which artists and scholars of art pay to it, it cannot be 33

34 otherwise, as long as musicians quibble with words and concepts over harmony 34

35 and melody, and philosophers quibble over allegories and superstition. [...] 35

69 The comic opera Oedipe à Colone by the Italian composer Antonio Sacchini

39 (libretto by Nicholas François Guillard) was staged in Herklots's German translation on

4016 October 1797 in the Königliches Opernhaus, Berlin; for a review of the performance; see

41 AMZ 17 (1815), no. 29, 19 July, column 491f. Anna Milder sang Antigone.

4270 Sacchini's opera, which was premiered on 1 February 1787 in the Paris Opera

43 House and hailed as the composer's masterpiece, remained in the repertoire until 1830,

44 enjoying 583 performances, as well as countless sequels on European stages. 
With regard to our friend Weber, I will try to come to an agreement with him 1

2 about the inscription in question ${ }^{71}$ (since I suspect that he continues to work at 2

3 perfecting his work) and will give you information from time to time. I am pleased 3

4 that you have taken up the idea which came to me, though so much depends 4

5 on the performance. The ritornello to these words would have to commence as 5

6 Epimenides still concerns himself with the contemplation of the family portrait 6

7 [...]. Three good alto voices (supported intermittently by instrumental backing) 7

8 would perform the eight verses briefly and audibly and, above all, like an old wise 8

9 saying. The action remains flowing, which is particularly important. 9

10 Madame Milder continues to be applauded. I have never seen the theatre so 10

11 full during the summer. She earned new friends even as Susanne in Figaro, and as 11

12 Emeline in Die Schweizerfamilie she is thought to be unsurpassable. What pleases 12

13 me most is that the crowd recognizes the talent as talent and exalts it. 13

I have not returned empty-handed from my crusade, and before long you will 20 receive my printed observations upon art and antiquity in the districts around the 21 Rhine and Maine, ${ }^{72}$ with incidental remarks on science. [...]

I heard no public musical performances on my journey that gave me any 23 pleasure. I met with some sympathetic voices that sounded very agreeable when 24 accompanied by piano and guitar. I heard 'Der Gott und die Bajadere' given with 25

27 songs no longer available? ${ }^{74}$ I could not get it in Frankfurt, though the later ones 27

28 were there. They know nothing about you on the Main, and the Rhine is not 28

29 acquainted with you, so we have been preaching your gospel in these districts. In 29

71 Zelter's suggested change to the Berlin production, of which Goethe approved.

${ }^{72}$ Goethe, Über Kunst und Altertum in den Rhein und Mayn Gegenden (Stuttgart: 34 Cotta, 1816).

73 Zelter's setting of Goethe's ballad, published in Schiller's Musen-Almanach für 36 das Jahr 1798, was performed on 16 and 17 September by Marianne von Willemar (1784- 37 1860). Her rendition of the aria 'Gib mir die Hand' from Mozart's Don Giovanni enchanted 38 Goethe and he described her as a little Don Juan. A muse for Goethe's West-östlicher Divan, 39

43 August Friedrich Kuhn, had gone bankrupt and was taken over by the publishers Adolph 43

44 Martin Schlesinger, who brought out a complete edition of Zelter's songs. 
1 Heidelberg, on the other hand, you are fresh in people's memory. ${ }^{75}$ You will, no 1

2 doubt, allow me to send some of your canons and part songs there: ${ }^{76}$ I should also

3 like to forward the score of 'Johanna Sebus'. ${ }^{77}$ They have a society of amateurs

4 under [the direction of] a clever and able conductor. ${ }^{78} \mathrm{~A}$ well-disposed young man

5 has started a singing academy in Frankfurt, ${ }^{79}$ which I hope to be able to assist and

6 I wish you would test how good they are. These musicians suffer from the same

7 misfortune as poets, for each one only brings forward his own work: that which is

8 like him and within his reach. Fräulein Hügel ${ }^{80}$ plays Handel's and Bach's Sonatas

9 most admirably, and unfortunately, neither in that province of art, nor in any other,

10 is there any central point after which everybody is sighing, since people are only 10

11 accustomed to revolve around themselves. [...] And now a kind farewell, and do 11

12 send me a little song or canon!

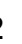

Berlin, 8 to 11 November 181517

19 [...] In Giebichenstein I visited Reichardt's grave and his garden ${ }^{81}$ and recalled the 19 20 image of him when he was fresh and active. To turn to the living [...] from time 20 21 to time I receive letters from around the place, [asking me] to send them some of 21 22 my people to found and equip singing academies for them, with conditions which 22 23 would not be too bad for myself. If I knew everything which is desired by these 23

2675 Goethe is referring to the Heidelberg lawyer and university professor Anton

27 Friedrich Justus Thibaut (1772-1840), who as amateur musician and leader of a singing 27

28 circle was known to Zelter, who later composed Tenebrae factae sunt for Thibaut's choir 28

29 book (1816).

3076 On 16 December 1815 Goethe sent the following compositions by Zelter to 30 31 Thibaut: (i) 'Wer kauft Liebesgötter' (Goethe), score and parts; (ii) 'Nimmer, das 31 32 glaubt mir' (Schiller), score and parts; (iii) 'Lieben Freunde' (Schiller), score and parts; 33 (iv) 'Berglied' (Schiller) score; (v) Two 'Punschlieder' (Schiller), (GSA/32/1509b). 33

79 Johann Georg Heinrich Düring (1778-1858), organist, flautist, composer and music teacher in Frankfurt am Main, founder of the Frankfurt choral society in 1809; see Goethe's Kunst und Altertum am Rhein und Mayn, MA 11.2, p. 40.

80 Anna von Hügel (b.1789), daughter of Baron Johann Aloys Joseph von Hügel, an

39 Austrian diplomat at the Nassau Court. Of her piano playing Goethe wrote to his wife,

40 Christiane: ‘At Baron Hügel's whose daughter played sonatas by Handel, which reminded 41 me of the Bach sonatas [performed by Badeinspektor Schutz]'.

4281 Giebichenstein in Halle was Reichardt's place of residence from 1791; in 1804

43 he bought a manor house there on extensive grounds which he developed into a famous 44 national park. 
1 pretenders, then I could feel I was somebody. You are expected to be able to do all 1

2 that they want, but nobody requests what you can do - either there or here. 2

3 I will send you Part One of my songs [...] when it can be obtained because I 3

4 no longer have any more copies myself and my publisher is bankrupt. You need 4

5 not be too secretive about my settings; they are intended to be brought to light and 5

6 there is an engraving of 'Johanna Sebus' in Leipzig, so you can give your copy 6

7 away.

8 I will send several Tafellieder at the next opportunity. ${ }^{82}$ It is impossible to find 8

9 good copyists, otherwise they would be in your hands already. 9

184. Zelter

Dr Chladni has also arrived ${ }^{83}$ and I hope that we will keep this clever, good man. 16 [...] In the meantime I have read Rameaus Neffe ${ }^{84}$ with admiration.

24 Our royal princes have made the heroic decision to stage and portray among 24

25 themselves a full version of your Faust. ${ }^{85}$ The preparations are projected so grandly 25

26 that I almost fear it will come to nothing, as we have no venue where we would 26

27 want to stage it.

28 I have also been given the role of director, which I intend to play with as much 28

83 Ernst Chladni arrived to give lectures at the University in Berlin. 36 $\begin{array}{ll}84 & \text { Goethe's translation of Diderot's dialogues, } M A \text { 7, p. } 567 . \\ \end{array}$ absence - arising through his appointment as Prussian governor in Posen in 1815 - put a 40 halt to these rehearsals. Four years later two scenes were performed in Berlin on 24 May 41 1819, with a second performance in Schloss Monbijou on 7 June 1820. 
1 Everyone is delighted with the additional passages you sent in manuscript to 2 Prince Radziwill. ${ }^{87} \mathrm{I}$ hear the Crown Prince ${ }^{88}$ is completely absorbed in Faust, [the 3 title role of] which, according to what I know of him, he will like very well. [The 4 role of] Mephistopheles will be played by Carl von Mecklenburg. ${ }^{89}[\ldots]$

5 In the meantime they have newly cast Die Zauberflöte $e^{90}$ and provided it with 5 612 new sets, four of which are already on view. [...]

7 Dr Chladni is here and has concluded his second seminar on acoustics. [...] 7

8 Write to me about Epimenides: I am really keen. I can imagine what Müller ${ }^{91} 8$ 9 will say about it. 7

16 The presence of Messrs Schadow and Weber has brought me into closer rapport 16 17 with Berlin; ${ }^{92}$ for through personal conversation and friendly chat, even distant 17 18 conditions can be brought nearer to us. A thousand times have I thought of you, 18 19 and how you sail, swim, plunge in and plough through such a sea! [...] 19

20 My Divan has grown in bulk and in strength..$^{93}$ The style of poetry, which, 20 21 without further reflection, I have adopted and made use of, has this peculiarity: 21 22 that, like the sonnet, it almost resists being sung; it is also notable enough, that 22 23 the Orientals distinguish themselves by writing not by singing. However, it is a 23 24 kind of poetry that suits my time of life, way of thinking, experience, and view of 24 25 things, while it allows one to be as foolish in love matters as one can only be in 25 26 one's youth. 26 $27 \quad 27$

$28 \longrightarrow 28$

$29 \quad 87$ Radziwill had visited Goethe on 1 April 1814 and performed excerpts from his 29 30 Faust composition for the poet. Impressed by his 'strong talent' (Goethe to Knebel, 30 312 April 1814, WA IV/24, p. 213) Goethe gladly accommodated Radziwill's wish for 32 additional verses, suitable for musical treatment. On 4 April Goethe was preoccupied with 33 'Paralipomena to Faust' (see Goethe's diary, WA III/5, p. 102) and on the 11 April 1814 33 he sent an additional scene and a newly revised scene to Radziwill ('Zwei Teufelchen und Amor', and a revised version of the 'Gartenhäuschen' scene; Anne Bohnenkamp,

5 '...das Hauptgeschäft nicht außer Augen lassend'. Die Paralipomena zu Goethes 'Faust'

36 (Frankfurt am Main and Leipzig: Insel Verlag, 1994), pp. 250-53 and pp. 257-9), hereafter 37 referred to as Bohnenkamp.

$38 \quad 88$ Friedrich Wilhelm von Preußen (1797-1888), later King Friedrich Wilhelm IV. 38

3989 Prince Carl Friedrich August von Mecklenburg-Strelitz (1785-1837), stepbrother 39

40 to Queen Luise of Prussia. $\quad 40$

4190 See $A M Z 18$ (1816), no. 7, 14 February, column 105; MA 20.3, p. 366.

4291 Presumably the Weimar Court Kapellmeister August Eberhard Müller. $\quad 42$

$43 \quad 92$ The recent visit of Gottfried Schadow and B.A. Weber to Goethe in Weimar. 43

$44 \quad 93$ From the beginning of the year Goethe had added 25 poems to the Divan. 44 
To close: a song that can be sung: 'Dir zu eroffnen/ Mein Herz verlangt 1 2 mich'.

\author{
187. Zelter \\ Berlin, 9 March 18167
}

5

6

7

8

9 Once again I have received bad news. My youngest son ${ }^{94}$ died of fever on 179

10 February in St Michel on the Aisne, after he had fought in the bloodiest battles 10

11 without being wounded. He was captured in the last affair at Versailles. Two 11

12 Prussian cavalry regiments fought against seven French cavalry regiments and 12

13 four infantry regiments. He lost his horse and remained healthy. [He was only] 13

14 sixteen. The beautiful boy. How will I get over it? 14

15 In the week since I received the news from his cavalry captain, I have thrown 15

16 myself into my work and am copying out scores. In the evening I go to the theatre 16

17 as writing in [poor] light makes my eyes tired. [...] 17

18 Chladni leaves here frustrated. I regret that we cannot keep this man here. 18 $19[\ldots]$

26 Indeed you have had another hard task put upon you; unfortunately it is always the 26 27 same old story, that to live long means to outlive many, and in the end, what is the 27 28 meaning of it all? A few days ago, the first edition of my Werther ${ }^{95}$ accidentally 28 29 came into my hands and its song, long since forgotten, began to resound in me 29 30 once again. And then one cannot understand how a man could bear to live another 30 3140 years in a world, which in his early youth already appeared so absurd to him. 31 32 One part of the riddle explains itself in the way everyone has something peculiar 32 33 to himself which he proposes to develop by giving it free reign. Now nature makes 33 34 fools of us day by day and so we grow old without knowing why or for what reason. 34 35 When I consider the matter carefully [I realize] it is only the talent in me that helps 35 36 me through all the unsuitable conditions in which I find myself entangled by false 36 37 tendencies, accident and the adoption of foreign elements. 37

4294 Adolph Raphael Zelter (1799-1816), Zelter's second son from his (second) 42

43 marriage to Julianne Zelter.

4495 Die Leiden des jungen Werthers (Leipzig: Weygand, 1774). 
5 Your little song ${ }^{96}$ made a big impression on me as I understand it and apply it to

6 myself. It immediately inspired a musical form, for without this medium I would

7 not have come to terms with it. As soon as it is written out and tidied up, you shall

8 have it and then you can tell me gently whether my experiment matches your text 9 or not! [...]

10 Chladni, who is leaving tomorrow, will take this letter with him. As a result 10 11 I have finished the song ${ }^{97}$ and send a little sample from the Divan. ${ }^{98}$ One of your 11 12 singers will easily be able to perform it for you, if he doesn't cause trouble for 12 13 himself. I have not yet heard Hafis myself and still don't know how it will be in 13 14 performance because it was set to music very recently. Pieces that are outside 14 15 the spirit of our time I must carry around with me for a long time before I find 15 16 a modern form in which they can be composed. And afterwards who should say 16 17 whether one has succeeded because the others also cannot grasp it and prefer to 17 18 pass over it? As a result a word from you about it should be very helpful because 18 19 you live in it.

26 After several rehearsals with orchestra and chorus, there was also a reading 26 27 rehearsal with music, yesterday evening. Prince Carl of Mecklenburg read the 27 28 part of Mephistopheles, and the actor Lemm stood in for Faust; ${ }^{99}$ the rehearsal 28 29 was at Prince Radziwill's [palace] among his family circle. The Princess and her 29 30 children were present, ${ }^{100}$ the Crown Prince with his brothers and sisters, Prince 30

97 Zelter's setting of 'Dir zu eröffnen' for bass and piano accompaniment is in Goethe's

38 autogr. Zelter 26). Goethe mentions the setting in a letter to Jacob von Willemar on 5 April

38 1816, WA IV/26, pp. 324-5. The song was first published under the title 'Aus der Ferne' in 37

39 Sechs Deutsche Lieder für die Bass-Stimme mit Begleitung des Pianoforte (1826). 39

4098 Zelter's setting of Goethe's poem 'So lang man nüchtern ist' for male-voice choir, 40

41 written on the reverse side of the manuscript of 'Dir zu eröffnen'. 41

$42 \quad 99$ In later performances the role was played by Pius Alexander Wolff. 42

$43 \quad 100$ Princess Friederike Dorothea Luise Radziwill (1770-1836) with her daughter Elisa 43

44 (1803-34) and her son Friedrich Wilhelm Ferdinand (1811-31). 44 
1 George of Mecklenburg, ${ }^{101}$ Frau von der Recke with her friend Tiedge, Frau von 1

2 Humboldt, ${ }^{102}$ and several artists who are to take part in the production. 2

3 For a start only those scenes were read in which Faust appears alone with 3

4 Mephistopheles. Prince Carl reads this character in a way that leaves little to be 4

5 desired - voice, tone, rhythm, figure and appearance - all is congruous, apart from 5

6 the cloven foot. What is lacking in modulation and tempo will, I hope, be sorted 6

7 out. His delivery, too, won universal applause, and the music jogged by his side 7

8 like a donkey beside a horse.

9 The effect of the poem upon an almost entirely youthful audience, to whom 9

10 everything was new and strange, is quite remarkable. They are amazed that it is all 10

11 in print. They go and look at the book to see if that's what it really says. They all 11

12 feel it is true; it is as if they were inquiring whether the truth is true.

13 Some of it the composer has brought off astonishingly well; where he goes 13

14 astray is that he, like all artists at the beginning of their career, emphasizes what 14

15 should be secondary.

16 'Christ ist erstanden': ${ }^{103}$ performed well and with impetus, although not religious 16

17 enough. Organ, choir and bells can still be produced, however. As [Radziwill] has 17

18 no concept of the inner form of art, he searches in the distance for what lies at 18

19 his feet. They offered him a bell which he also wants to use. However, he is not 19

20 lacking in taste. I will let him try this and I am certain he will leave it out. 20

21 'Spaziergänger vor dem Tore': ${ }^{104}$ In general, good, but it occasionally gets stuck 21

22 in minor details. The beggar sings like a beggar and the orchestra play lavishly. 22

23 With the soldiers he really let go: it never occurred to him that these soldiers are 23

24 walking, not marching, soldiers but nothing is boring and good taste always has 24

25 the upper hand.

26 The shepherd dressed himself up to dance: very popular and pastoral but not 26

27 ephemeral enough.

28 'Drinnen gefangen ist Einer': ${ }^{105}$ perfect! But the entire incantation needed 28 29 music, although it was effective with just a mere reading. The swelling up of the 29

30 monster, the mist, the sulphur, leading to the emergence of the fully grown form 30

31 lends itself very well to music - and that with very ordinary means. Mephisto's 31

32 explanation of who he really was had a great impact. Everyone was dumbfounded. 32

33 It was grasped without, perhaps, being understood.

34 'Schwindet, ihr dunkeln': truly artistic. I would not know how it could be 34

35 improved. The rat incantation, however, has to be described as excellent. It was 35

36 rehearsed six times and was first rounded off in rehearsals. I found it appropriate 36

37 that Faust, through the departure of Mephisto, did not simply wake but was awoken 37

101 Grand Duke Georg Friedrich Carl Joseph von Mecklenburg-Strelitz (1779-1860). 39

103 'Chor der Engel', Faust I, Nacht, v. 757ff.

42104 The scene 'Vor dem Tor'.

43105 The spirit's words ('There is something captive in there') in Studienzimmer, 43 
1 as if by an electric shock. The bassoons, through a deep, short sound, made the 1

2 thing natural to the amusement of all, and only the smell was missing. 2

3 'Weh! Weh! Du hast sie zerstört': ${ }^{106}$ initially somewhat too heavy. The land of 3

4 milk and honey presented from the words 'New life begins ${ }^{107}$ was really well and 4

5 very originally realized. $\quad 5$

6 The play is to be performed in three parts. The second section, which we are to 6

7 rehearse soon, begins with 'Auerbachs Keller'; I shall keep you informed! 7

8

929

10 191. Zelter 10

11

$12 \quad$ Berlin, 4 April 181612

$13 \quad 13$

14 [...] In Paris our King bought the so-called 'Justina' picture collection, ${ }^{108}$ which 14

15 is really valuable. According to these happy circumstances we hope that the 15

16 Kunstakademie, in which horses and stable lads had the upper hand up to now, 16

17 will be converted into a museum, and also that a decent room will be granted to 17

18 the Sing-Akademie, which is now in its twenty-sixth year. 18

19 Evening: I have come directly from Clavigo. ${ }^{109}$ A foreign actor, Julius von 19

20 Breßlau, ${ }^{110}$ dedicated himself to Beaumarchais, but not convincingly. A rescuer- 20

21 avenger must have a resounding voice. The work was neither really different nor 21

22 really together and is a straightforward piece which should be tossed off easily. 22

23 I fear it was not well directed in rehearsals. Not one person occurred to me who 23

24 should direct it. The Wolffs ${ }^{111}$ were expected, but they are not yet here. Madame 24

25 Catalani $^{112}$ should also come and Milder should sing, yet we still never can be sure 25

26 of having her because she has those against her who would wish for Italian opera. 26

27 Admittedly German opera is very touch-and-go. The majority are translations and 27

28 the majority of operas by Mozart are Italian. It can come to nothing here. There 28

29 are too many cooks and not all who carry long knives are cooks. Epimenides is on 29

30 tomorrow. 30

$31 \quad 31$

$32 \quad 32$

$33-33$

$34-34$

$35 \quad 106 \quad$ The spirit's chorus, v. 1606ff.

$36 \quad 107$ Ibid., v. 1622.

$37 \quad 108$ In November 1815 the Prussian king purchased 157 works of old masters from the 37

38 Galerie Giustiniani, founded by Vincenzo and Benedetto Giustiniani. 38

39109 Performance of Goethe's tragedy Clavigo on 4 April 1816, Berlin. 39

$40 \quad 110 \quad$ Friedrich Julius (1776-1860). 40

$41 \quad 111$ Pius Alexander and Amalia Wolff. $\quad 41$

42112 Angelica Catalani (1780-1849), Italian singer, enjoyed an international reputation 42

43 in Italy, Lisbon, Paris and London. She began a European tour in 1816 and gave her first 43

44 concert in Berlin on 24 June 1816. 
1 The bearer of this letter is the banker Abraham Mendelssohn. ${ }^{113} \mathrm{He}$ is the second 1

2 son of the philosopher, and from the first years of his youth, after his father's 2

3 death, ${ }^{114}$ he has been attached to my house and its inmates. He is one of the right 3

4 sort, and as such you will receive him. He has lovely children, and his eldest little 4

5 daughter ${ }^{115}$ could let you hear a thing or two of Sebastian Bach. This child was 5

6 somewhat precocious, which she still is, and all of them are early developers. [His 6

7 wife, Lea] is a most excellent mother and housewife; though unfortunately she is 7

8 not very strong. The husband is very well disposed towards me, and I can borrow 8

9 freely from him, for in times of general need he has grown rich without damage 9

10 to his soul. ${ }^{116}$

17 Epimenides went well last night and the large theatre was full. There was much I 17 18 wished you could have seen. Epimenides, Cunning, Oppression and Hope could 18 19 not have been cast better, although the whole [work] will never be clear to us, 19 20 since they always stumble around and almost naively miss the entrances. The 20 21 opinions of the well-intentioned about it are so completely masked in silence that 21 22 I prefer to remove myself when I can. Now they have to deal with the estates, and 22 23 that always means: who will get this or that job and what will be paid for it. I have 23 24 become almost anxious about it, which, observed from a neutral position, can be 24 25 awkward and uncomfortable, for they are taken up with external concerns which 25 26 they understand even less than the internal.

27 Right now a Parisian dancer with her husband ${ }^{117}$ are gods and the talk of 27 28 Berlin. That they can dance goes without saying, although you can hardly imagine 28 29 more unattractive long-legged persons. They are of the best school and one is 29 30 just astonished at the chasteness of their movements, whereas our people almost 30 31 demonstrate more of their body than anything outside it. That is their whole art. 31

33

113 Abraham Mendelssohn (1776-1835), banker in Berlin; father of Felix, Fanny, 38

Rebecca and Paul Mendelssohn Bartholdy. 
1 I saw the ballet Telemachus ${ }^{118}$ for the second time yesterday. The subject is 1 2 more suitable to a ballet than a libretto, ${ }^{119}$ which is lacking in meteorical style. 2 3 Mademoiselle Düring, who should visit you, ${ }^{120}$ plays Calypso and presents herself 3 4 really well as a young pretty girl to the 36-year-old ramrod Telemachus. But she 4 5 is able to match him with a series of unpleasant faces that would have made the 5 6 departure easier for the true Telemachus!

7 Epimenides's song, 'Hast du ein gegründet Haus', was left out yesterday ${ }^{121}$ and 8 I must confess I was sorry about it. I didn't like to mention it to Weber as I know 9 well that he is happy to be almost finished. He is like a coconut: one can only deal 10 with him knife in hand. You will have seen him at close quarters.

11 Yesterday we had a first reading of Faust, and just as we were about to begin, 11 12 all the young royalties announced themselves. As I had to read the beginning, it 12 13 turned out that we didn't let ourselves be disturbed and the honourable guests took 13 14 their places without much bowing and scraping. The thing went off as well as a first 14 15 rehearsal can in such a mixed circle and I will really have to assert myself more 15 16 and more [in order] to bring movement into the whole thing if no one else wants 16 17 to do it. The 'jovial person' - one of the counts - didn't seem to know the poem 17 18 at all. After the rehearsal he apologized to me for his bad reading, upon which he 18 19 expected a compliment. I replied that reading would not have been a bad thing and 19 20 that I feared his problem was the spelling. He made sheep's eyes at that.

21 Count Brühl played the poet quite decently. Lemm, the actor, improved and 21 22 gradually settled into his part. However, Prince Carl deteriorated and fell into a 22 23 preaching tone. We had finished Act One when the King arrived unexpectedly; 23 24 most likely he could not endure home any longer, as his children had all gone off. 24

25 The whole of Act One was repeated, and the King, who at first, as is usual, kept 25 26 quiet and in the background, after two hours of silence became sociable, chatty 26 27 and really amiable.

33118 Anatole's adaptation, Telemach auf Calypsos Insel, from the French Télémaque 34 dans l'île de Calypso by Pierre Gabriel Gardel, music by Ernest-Louis Müller; first 35 performed (with Benda's Pygmalion) in the opera house, Berlin, on 28 March 1816, with a 36 further performance on 5 April following the performance of Epimenides.

36119 Antonio Simone Sografi's libretto to Simon Mayr's opera of the same name: Telemaco all'Isola di Calipso.

$38 \quad 120$ Reference to Goethe's vain attempt to engage the Berlin actress Auguste Düring 39 for the Weimar Court Theatre.

$40 \quad 121$ Zelter had recommended that Epimenides's song should be declaimed rather 41 than sung; Goethe had suggested an off-stage chorus of spirits. Although Zelter wanted to

42 reach agreement with Weber about it, the song was omitted in this performance - possibly

43 because Weber's composition of this new section was not yet complete. In the 1816 edition 44 it was treated as an off-stage chorus. 
I will give this letter to Mendelssohn to take with him as he is leaving in the 1

2 morning and he will arrive in Weimar sooner than the post. ${ }^{122}$ The final rehearsal is 2

3 next Saturday because Radziwill is travelling to Posen with his family. 3

Your letters, dearest Friend, surprised me most agreeably in my garden - gave me 10 much to think about; they stimulated me to a wider-ranging conversation in the 11 distance. Then came Mendelssohn, and as I was just in the humour, and he was 12 recommended by you, I told him what I would probably have told you; this I think 13 he deserved; he talked very intelligently, and in the course of his conversation 14 discussed many important points in science, art, and life. Unfortunately I did not 15 see his people. They stayed only one afternoon; I should have liked to invite them 16 to breakfast today, and to have shown them all my things. [...]

Faust may, in future months, afford you many a confused hour. If you go on 18 being as rude as you were to the gloomy count, something will come of your 19

21 Last Sunday we celebrated the grand homage celebration. The honours, 21 22 distinctions, and compliments awarded to us told every sensible man among 22 23 us very plainly that he must give himself up for the time being. However, the 23 24 task allotted to me is the most pleasant one; I have nothing to do except what I 24 25 thoroughly understand, and I have only to continue doing what I have done for the 25 26 last 40 years, with ample means, great freedom, and without worry or hurry [...] 26 27 My last empty page I shall fill with a few verses; you can use them if you feel 27 28 inclined.

37 My Passion Music was as profitable as last year. The room was so full that several 37 38 hundred people had to be sent away. If I were a better mathematician than I am, 38

123 These poems were first published posthumously in Riemer's edition of the Goethe- 43 
1 I would have presumed I could claim for a good part of my trip ${ }^{124}$ from this loss 1

2 or non-profit. [...]

3 I was to have seen the Wolffs at Prince Radziwill's on Sunday, but they didn't 3

4 show up and instead sent the news that you were sick - critically ill! ${ }^{125}$ That was 4

5 the 21 st and your letter to me on the 14th mentioned nothing of the kind, and so 5

6 I hope that you have recovered again. Don't leave me in uncertainty about it and 6

7 if you don't want to write yourself, let me receive news from someone else. God! 7

8 How could I live without you? Have I not suffered enough? 8

9

10

11

12

15 I answer your dear letter at once. [...] For what will you say now when I tell you 15

16 that I, too, have had a severe blow lately? Pretty Berka on the Ilm, where we 16

17 experienced so much in company with Wolf and Weber and Dunker! ${ }^{126}$ Imagine, 17

18 first of all, that pretty Viennese piano, belonging to the organist Schütz, ${ }^{127}$ with the 18

19 music of Sebastian, Philip Emmanuel Bach, and so on. ${ }^{128}$ Well, Berka was burnt to 19

20 the ground, between 25 and 26 April. ${ }^{129}$ By dint of extraordinary presence of mind, 20

21 and the help of kind people, the piano was saved, as well as many other things in 21

22 the house, in a maximum of seven minutes, which is astonishing; for a tremendous 22

23 fire, which began at a baker's house, had, by half past eleven, spread its flames 23

24 far and wide. All the organist's old pieces by the Bach family and Handel, which 24

25 he had got from Kittel of Erfurt, ${ }^{130}$ are burnt, and that merely owing to a mindless 25

26 accident or chance: he had tidied them away into a rather remote room. 26

27 Of course, all these things are already engraved and in print; let me know how 27

28 I could get them from Härtel's ${ }^{131}$ in Leipzig, or elsewhere, for I should be glad to 28

29 give him a little solace in this way. Heaven bless copper, print and every other 29

30 means of multiplying things, so that a good work which has once existed can never 30

31

32124 To Wiesbaden, 14 July to 13 August, via Weimar, 5 to 8 July.

34125 Goethe's diary for 2 to 4 April records 'unwell these days', WA III/5, p .220. 34

35 Goethe reminds Zelter of the days they spent together in Berka from 23 to 28 July

$36 \quad 127$ Johann Heinrich Friedrich Schütz (1779-1829), spa inspector and organist in 36

37 Berka on the Ilm.

38128 Goethe recalls Schütz's performances of the music of J.S. Bach and his sons when 38

39 Goethe stayed with him in 1814 . 39

$40 \quad 129$ See Goethe's diary entry for 26 April: 'Sad news of the terrible fire which had 40

41 broken out in Bad Berka at 1 a.m.', WA III/5, p. 226.

42130 The bequest of the organist and composer, Johann Christian Kittel (1732-1809), 42

43 in Erfurt from 1756.

$44 \quad 131 \quad$ Breitkopf und Härtel, Leipzig. $\quad 44$ 
1 again be destroyed. If you should see Privy Councillor Wolf, give him my kindest 1

2 regards, but tell him also that the accursed little trumpet piece ${ }^{132}$ escaped being 2

3 burnt by the strangest chance, as I happened to have it in the town; like a good 3

4 many other things, it was saved by being housed in different places. 4

[...] I arrived back from Potsdam yesterday where I had spent a few days in the 11 Berlin, 8 to 12 May 18169

14 me to it, and it is only now that I could tear myself away from here. I would be 14

15 amazed, even astonished, that in six months these people achieve what we have 15

16 managed after 26 years of constant perseverance here in Berlin, if I did not realize 16

17 that my wheelings and dealings have worked in far-off places and will continue to 17

18 work if the model should fall apart after me.

19 You can imagine that these good people are really delighted with it and they 19 20 were all the more pleased with my approval since the court, in Potsdam for 20 21 communion on Good Friday, heard their Passion Music ${ }^{134}$ afterwards and judged 21 22 their performance on the unsuccessful details and considered it really bad.

23 The misfortune of that poor man [in] Berka has shaken me very badly because 23

24 for a long time now I have imagined a [similar] disaster, a blazing fire among my 24

25 lovely musical things, and I could not bear it any longer. It could happen so easily 25

26 because I live between nests of fire: being a stables, the Sing-Akademie and the 26

27 Kunstakademie contain so much hay and straw.

28 Therefore I send you fine manuscripts, ${ }^{135}$ of which I have two, in the hope that 28

29 they might give you comfort. They are yours and if you would like to give some 29

30 to the organist, Schütz, then that is fine too. BWV 992. For an account of the performance of this piece for Goethe in Bad Berka; 34 see Friedrich Wilhelm Riemer, Mitteilungen über Goethe (2 vols, Berlin: Duncker und 35 Humblot, 1841), vol. 1, pp. 266-8.

133 The Potsdam Institute, founded on 2 November 1814, was modelled on the Sing- 36 Akademie. The director was Carl Bernhard Wessely (1768-1826); see Carl Wey, 'Zwei 38 Briefe Karl Friedrich Zelters', Die Musikpflege 6 (1934): 91.

134 Graun's Der Tod Jesu, which was performed in Potsdam and Berlin until towards 39 the end of the nineteenth century.

135 A page which is in the collection, 'Goethe, Eingegangene Briefe', in the fascicle of 41 March 1831, could be identified as the contents pages for the dispatch to the spa inspector 42 and organist in Berka, and containing: (1) J.S. Bach, 24 Preludes and Fugues Part Two; 43 44 (2) Vom Himmel hoch da komm ich her (with canonic variations for the organ); (3) Aria 44 
1 I also send you two complete copies of my songs, which are finally available 1 2 once more. ${ }^{136} \mathrm{I}$ am now able to provide what one person or another is missing. 2

3 I will forward the first book of Johann Sebastian Bach's Preludes and Fugues; I 3

4 don't want to send the Leipzig edition ${ }^{137}$ because I don't consider it a good edition. 4

5 Part I is just as good as the second book but has no performative connection with 5

6 Part II. They are really singular works.

7 For the past two weeks I have been really enjoying the first two volumes of the

8 new edition of your works. The advance payment is so favourable and inexpensive

9 that I have just paid for them in full and if I receive a copy from you, I will give it

10 to my daughter. I have set to music the tiny poem with the title 'Gegenwart' ${ }^{\prime 38}$ on 10

11 page 59 for three soprano voices with piano accompaniment, as one would want to 11

12 receive an honoured, beloved person in reserved circles; I would imagine it would 12

13 work well, but I haven't heard it yet.

14 It is the same with me in the Sing-Akademie as it is for you with your actors. 14

15 When I am among them, I have no judgement. If I heard them in a different place, I 15

16 would have to pack them in. As a result I would like to have you here because you 16

17 are the person whose opinion I most value in music. [...] Beethoven has composed 17

18 a Battle Symphony that would make you as deaf as he is himself. ${ }^{139}[\ldots]$

199 May: Yesterday evening the Battle Symphony was given in the theatre, and 19

20 I heard it from the very farthest end of the parterre where all the deafening effect 20

21 is lost, and yet I was gripped, even overwhelmed. The piece is a real whole, the 21

22 parts of which can be intelligibly divided and connected. The English advance 22

23 from afar, drums beating; as they get nearer, 'Rule Britannia' tells us what they 23

24 are. Similarly, the opposing army moves forward, and is immediately recognized 24

25 by 'Marlborough s'en va-t-en guerre'. The fire of canon and small arms is easily 25

26 recognized on either side, the orchestral music, which consists of harmoniously 26

27 connected thoughts and interests the ear of the listener, works like the storm and 27

28

29 with variations for two manual harpsichord; (4) A set of 15 pieces ['Symphonies'] for 29

30 keyboard; (5) A set of 15 two-part keyboard inventions; (6) A volume (a long quarto) 30

31 of keyboard works by J.S. Bach. The minuet with variations at the end of the book is 31

32 probably by Friedemann Bach; (7) An organ fugue with an obbligato pedal by J.S. Bach; 32

33 (8) Four collections of Keyboard sonatas by C.P. Bach, in one volume; (9) Eight suites by 33

34 G.F. Handel; (10) Eight folios which together form two Lieder collections.

$35 \quad 136$ Zelter, Sämtliche Lieder, Balladen und Romanzen für das Piano-Forte (4 vols,

36 Berlin: Martin Schlesinger, 1816); a reprint of the 1815 volume.

$36 \quad 137$ The edition published by Kühnel and Hoffmeister in Leipzig in 1801 was severely

38 criticized by Johann Nikolaus Forkel and others, because it was edited from an inadequate

39 copy.

$39 \quad 138$ Zelter's setting of 'Gegenwart' has not been handed down.

40139 Wellington's Victory, also known as The Battle of Vittoria (op. 91); this short

41 orchestral work composed by Beethoven in 1813 depicts British victory over Napoleon,

42 and quotes various popular tunes including the British national anthem. It was conducted

43 by B.A. Weber on 8 May 1816 in the Königliches Theater; a week earlier, on 1 May, Ignaz

44 Schuppanzigh had conducted this work in Berlin. 
1 chaos of battle. The armies seem to be engaged in hand-to-hand fighting; terrible 1

2 onslaughts over wide stretches of land; the excitement mounting; one army yields, 2

3 the other pursues, now vehemently and close at hand, now at a distance; at last 3

4 there is respite. Then, as though issuing from the ground, muffled and mysterious, 4

5 the 'Air de Marlborough' echoes sorrowfully in the minor key, interrupted by the 5

6 dwindling accents of lament and sorrow. Then the victory of the conquerors is 6

7 made known by the air of 'God save the King' and finally comes a complete, vivid, 7

8 triumphal movement. All this hangs really well together, though it cannot be taken 8

9 in at once, even by a good ear. Yesterday it brought me unusual enjoyment. The 9

10 performance, too, was splendid, although 20 additional violins would not have 10

11 been too many. Vivat Genius! And the devil take all criticism! 11

12 Privy Councillor Wolf sends his best greetings and takes a lively interest in that 12

13 good man [in] Berka. He is now being punished for his dislike of the trumpet piece 13

14 which, to make matters worse, was saved. [...] 14

15 When the first meeting about the idea of a performance of Faust was held, 15

16 they formally invited me along. Princes, dukes, counts and lords were present. 16

17 I restrained myself until it came to my turn. My first request was giving out the 17

18 roles, which was soon finished. No one as yet had his own copy. We sent out 18

19 for them. The majority of the book dealers had none themselves. [A copy] was 19

20 lent to everyone. The poem was unknown to everyone [there] because it was also 20

21 new to the artists. At another opportunity I made the observation that a prince of 21

22 another country spoke better German than all of us and through so much diligence, 22

23 perseverance and love made us acquainted with our own [artistic] treasures. [...] 23

30 [...] I was very glad to get your report of Beethoven's Battle Symphony. That is 30

31 the advantage of [living in] a large city, which we lack.

38 [...] At all events I hoped you would find and experience much to your taste in 38

39 the first two volumes [of my works] and inspiration for many songs; thank you for 39

40 affirming that for me.

41 Eberwein gave me your letter. ${ }^{140} \mathrm{It}$, too, brought me great joy. You know 41

42 the young man's talent. It is an inherited, surface [talent] which is nourished by 42 
1 nothing, neither character nor love, neither feeling nor taste. For that reason it 1

2 remains stuck in the earth and cannot grasp why it cannot raise itself up from the

3 ground. He composed the most miserable prose in a little opera with contentment

4 and self-satisfaction. He was not going to grasp my intentions with Faust, but

5 he should have taken my lead and done what I want; then he would have seen

6 what it is about. This type of person, who, despite their good qualities, are lacking

7 in what is really important, doesn't understand why it won't work out for them.

8 They try to achieve it by intrigue and immediately offend the procured patron

9 through arrogance and ineptitude, and so the fairy tale evaporates and they have

10 gone backwards rather than forwards.

$11[\ldots]$ When I tell you, you hardy and much-tried son of the earth, that my dear 11

12 little wife has in these days left us, you will know what this means. ${ }^{141} \quad 12$

19 One can be as frightened as a child: yesterday the black seal of your letter dated 819

20 June (which State Councillor Schulz gave me as he opened his parcel) stopped me 20

21 short until I had opened it and recognized your own dear hand.

22 If only it were possible to be closer to you, to belong to you even more, it 22

23 would be in what I have taken from your bereavement. But I am so long yours and 23

24 no one else's that everything I do and don't do is in devotion to you and makes 24

25 me more of a spirit. I would not be surprised if you had premonitions of this. [...] 25

26 I am glad that Eberwein showed my letter to you because I wanted to strangle 26

27 him over a completely crazy argument in his letter where one fool responds to the 27

28 other without having a clue. [...] 28

29 My departure to the spa ${ }^{142}$ depends, taking the Cimmerian summer also into 29

30 account, on the arrival of Madame Catalani, ${ }^{143}$ because the professor must yield to 30

31 the patient. We hope to have this singer with us within the next week. [...] 31

32 Next Monday we will have another rehearsal of Faust. My prophecy appears 32

33 to be becoming true: we are making no progress. The good composer is so content 33

34 with what is there and with what is incidental to it that the idea of the whole is lost 34

35 in too much individual detail, where everyone is so happy that they occasionally 35

$37 \quad 141$ On 6 June 1816, the day Christiane died, Goethe wrote the lines, 'O Sun, you

38 strive in vain to cross dark clouds! It is my whole life's gain to weep her loss.' The news of

39 Christiane's death, written in Goethe's hand on a small card with a black border, is enclosed

40 with this letter in a letter to Christoph Ludwig Friedrich Schulz, with a stamp of receipt in

41 Zelter's hand.

$42 \quad 142$ Zelter left Berlin on 30 June 1816 to spend four days with Goethe in Weimar 42

43 (5-8 June) and from there travelled to Wiesbaden, where he remained for four weeks. 43

$44 \quad 143 \quad$ See $A M Z 18$ (1816), no. 29, 17 July, column 499; MA 20.3, p. 392. 
1 believe they know what is needed only to continue the old with new enthusiasm; 1

2 but I am not worried about getting help since Kotzebue is expected and Merkel is 2

3 already here, and so on. 3

11 well. They have assembled a singing society here and naturally they have started 11

12 the society with the freedom which amounts to leading the horse by the tail. 12

13 Incidentally they understand everything so well that I really took care not to find 13

14 it anything less than splendid, just as snuff from Offenbach and some very lively 14

15 girls' faces cannot fail to be appreciated. [...]

When you come here, be so good as to bring the two complete editions of 16 17 my songs ${ }^{146}$ with you, if you still have them. André made me a present of his 17 18 compositions and I should really give him something in return. I will replace them 18 19 for you when I return to Berlin.

26 [...] Before leaving, I shall send a copy of your songs to Offenbach, for André. 26

27 I am greatly pleased that my sombre Byzantine derivation could attract you, ${ }^{147} 27$

28 without some such foundation and derivation, all criticism is tomfoolery, and 28

29 even with it, nothing is done, for it still requires a whole lifetime of observation 29

Darstellungen seines Lebens. Zum ersten Male vollständig nach den Handschriften, 34 SchGG 44 (1931), p. 265. Hereafter referred to as Carl Friedrich Zelters Darstellungen 35 seines Lebens. Goethe knew André from his trip to Frankfurt in 1815 the previous year (see 36 Goethe's diary 31 August and 13 September 1815,WA III/5, pp. 179 and 181) and had also 36 met him in Jena on 28 May 1816.

145 Johann Christian André (1741-1799), composer and music publisher in 38 Offenbach, Kapellmeister in Berlin, 1777-84. Zelter mentions him in his autobiography; 39 see Schottländer, Carl Friedrich Zelters Darstellungen seines Lebens, p. iii. 40 146 Zelter, Sämtliche Lieder, Balladen und Romanzen für das Pianoforte (4 vols, 41 Berlin: Schlesinger, 1816). Zelter is referring to the copies he sent to Goethe in May 1816. 42 147 Goethe, Über Kunst und Altertum in den Rhein und Mayn Gegenden (Stuttgart: 43 Cotta, 1816). 
1 and action; therefore, to no one would I more willingly hand over the surface 1 2 of the earth, than to the bungler, who, with complacent cheerfulness demands 3 indulgence, with apparent earnestness desires a candid criticism and with modest 4 pretension wants to be thought a good deal of. ${ }^{148}$ May my commentary show its 5 gratitude to your text.

6 I have lately met with much kindness and affection. Friends from my youth, 7 not seen for 25 years, and now elderly men, came to see me unexpectedly, ${ }^{149}$ and 8 were glad to find many things in their old places, and much that had progressed, 9 progressing further. On the evening of 20 July I met Chladni, who is gaining great 10 kudos by his thorough and formidable study of meteoric stones and figures of 10 11 sound. ${ }^{150} \mathrm{He}$ is working for a time when men will once more rejoice to learn from 11 12 others and gratefully make use of what they, by the sacrifice of their lives, have 12 13 gained more for others than for themselves. Nowadays, when one speaks even to 13 14 illustrious men of something that they ought to learn through tradition, they assure 14 15 us that they have not yet had time to examine it. [...] 15

16 Things are looking quite cheerful in my household. August, as you know, 16 17 enters very intelligently into everything, and we have, in a few hours, planned the 17 18 programme for our next winter's entertainments. 18

25 [...] I have just come back now at nine in the evening from a concert which 25 26 Eberwein and the tenor Moltke ${ }^{151}$ gave in the auditorium of the spa, which I only 26 27 wish had had a larger audience. In particular I was really delighted with Eberwein's 27 28 violin concerto. His tone was pure, mellow and flexible. It isn't lacking in skill 28 29 and style and the Concerto in D minor, which is his own work, really surpassed 29 30 all expectations in the last two movements. Moltke has a pure, sweet voice, with 30 Singing Society in Offenbach. The equivalent passage has been underlined (by Goethe) in 35 Zelter's letter.

$36 \quad 149$ In addition to Chladni, Goethe's diary entry on 17, 18 and 19 July 1816 mentions 36 Friedrich von Laffert, court and chamber councillor in Celle, later Privy Councillor, WA 37 III/5, pp. 254-5.

$38 \quad 150$ The German physicist Ernst Florens Friedrich Chladni was already well known for

39 his publication Entdeckungen über die Theorie des Klanges (Leipzig: Weidmanns Erben

40 und Reich, 1787), in which he put forward the idea of sound figures (Klangfiguren), the

41 forms of vibration made visible; he developed his ideas further in 1816 in Nachrichten von

42 zwei neuen musikalischen Instrumenten und einigen andern Entdeckungen.

43 151 Carl Melchior Jakob Moltke (1783-1831), singer and actor, in Weimar from 441809. 
1 a range of two octaves and the delivery was good. But the good man sings arias 1

2 by Paer and Generali which were expressly made for others, and to him are like a 2

3 plank which does not want to come out of his mouth. I would like to bet that he has 3

4 heard Brizzi ${ }^{152}$ and believes now that he could follow suit: cool as you like but no 4

5 chance! The granite is missing in his voice, the roundness - in short, schooling. If 5

6 he were to sing German, as would be appropriate for a German and for his voice, 6

7 he would, I think, have been pleasing, which at least today was not the case. 7

14 [...] If the visual arts - even in their crudest form - are a religious affair by nature 14

15 and depend on having an educational spirit, which is nothing other than the living 15 breath which reveals itself though sound and music and, like an eternal source, sets 16

17 tongues and lips in vibration, then we encounter a Paternoster, Credo, Te Deum, 17

18 Kyrie, Gloria, Agnus Dei and so on which can well accompany the names of the 18

19 saints which are in these pictures. The antiquated elements of the musical style 19

20 also still fit perfectly with the fifteenth and sixteenth centuries. As a result the 20

21 outer, melodic [elements], regular, serious, structured, stand there hollow, lifeless 21

22 and sad and are in full accordance with the service of a church which only strives 22

23 to preserve itself outwardly anymore.

24 Here in the history of music the bridge between the old and the new is missing. 24

25 This was established afterwards through a harmony just as regulated, which 25

26 Rousseau considered a gothic, barbaric invention, ${ }^{153}$ as he saw it; and he saw 26

27 nothing else in it other than an overfilled lower abdomen out of proportion to the 27

28 general structure. 28 
$5[\ldots]$ It really delights me that you have taken up my derivation of new art from 5 6 the old. I am convinced myself of having laid a solid foundation. Your parallelism 6 7 with music ${ }^{154}$ is really welcome.

14 [...] I have once again made a detour from Darmstadt to Frankfurt in order to hear 14

15 Catalani sing. ${ }^{155} \mathrm{I}$ enclose what I had cause to say publicly, so you can also get 15

16 [something] from it. ${ }^{156}$ I also enjoyed something of the way people from Frankfurt 16

17 express themselves in such cases, which I found highly entertaining. The critics 17

18 discussed her age as being between 32, 38 and 42, her pretensions about Frankfurt 18

19 ducats and whether she was really the greatest of all singers, living or deceased, 19

20 because if one were younger, one could also sing higher and lower and so on. 20

21 I got to know Grüner ${ }^{157}$ in Darmstadt! [...] This director is hard to please 21

22 and much had to be repeated and each time something different came out of it. 22

23 Therefore I must treasure the honour I was granted because the Grand Duke (since 23

24 he had invited me personally to this rehearsal) seemed determined to have my seal 24

25 of approval on everything, which I was able to grant fully every time he asked for 25

26 it. He cannot know that there is a difference between a Duke's Kapellmeister and a 26

27 Kapellmeister who is a Duke ${ }^{158}$ because he cannot experience it. The performance 27

28

154 Zelter's remarks about the history of music, which are similar to Goethe's 30

31 developed thesis in the plastic arts. Conversations on this subject seem to have already 31

32 taken place during Zelter's visit to Weimar; see Goethe's diary of 7 July 1816: 'Went for

33 an early walk with Zelter. About the similarities between composition in music and in the

34 plastic arts', WA III/5, p. 250.

$35 \quad 155$ Angelica Catalani gave a concert in Frankfurt on 14 August 1816; see Zelter's

36 diary for this date (Schottländer, Carl Friedrich Zelters Darstellungen seines Lebens,

36
37 p. 271) and also $A M Z 18$ (1816), no. 42, 16 October, column $717 \mathrm{f}$.
156 Zelter's article on Catalani was published in the 'Berlinische Nachrichten von

38 Staats- und Gelehrten Sachen', Spenersche Zeitung, no. 95, 8 August 1816. It is also housed

39 in the Goethe-Schiller Archive (GSA 28/71); MA 20.3, pp. 402-403.

$40 \quad 157$ Franz Grüner, who - with Pius Alexander Wolff - studied acting with Goethe in 40

41 1803. He was engaged as director of the court theatre in Darmstadt for a short while; Zelter 41

42 visited him on 18 August 1816.

$43 \quad 158$ The Grand Duke Ludwig I von Hessen-Darmstadt conducted the orchestra in his 43

44 own court theatre. $\quad 44$ 
1 on Sunday was the most exact rendition one could hear. In particular, Grüner really 1

2 had a favourable effect on the girl who sang Romeo's part. 2

206. Zelter

9 I believe an anti-critic, Kanne, ${ }^{159}$ recognized as the great man, tapped one of my 9

10 reviews ${ }^{160}$ written many years ago, saying that what is there is not in the work and 10

11 that through deductions of this kind everyone could read into every work what 11

12 one wanted. This work is Handel's famous Messiah, whose text, put together from 12

14 In the review I had divided the work into stages: 1. The Annunciation of 14

15 the Messiah by the prophets; 2. The Birth [of the Messiah]; 3. The Life; 4. The 15

16 Suffering and Death 5. The Resurrection and Ascension into Heaven; and noted 16

17 that it derives from and returns to on High, and through this it distinguishes itself 17

18 from early artworks of this kind, but especially through the way that in music and 18

19 attitude the whole [work] is tied up with the complete concept of the redemption 19

20 and salvation: suffering and death is temporary and passing. [...]

21 Paulus's daughter ${ }^{161}$ has developed very well and plays Sebastian Bach quite 21

22 advantageously, although (like us all) outwardly she still wanders all around the 22

23 world, chewing the cud.

\section{Goethe}

30 Your dear letter came yesterday in time for me to enjoy it today and have a chat 30

31 with you. I am celebrating this birthday in special solitude. [...]

I have read with pleasure your article on Mesdames Catalani, Milder and 32

33 Mara; people never understand that beautiful hours, like beautiful talents, must 33

34 be enjoyed on the wing. You will already have seen from the newspapers how 34

35 preposterously the people in Leipzig have behaved on this occasion. ${ }^{162}$ I think we 35

160 In: Johann Friedrich Reichardt (ed.), Berlinische Musikalische Zeitung (1805), 38 no. 11, pp. 41-4 and no. 12, pp. 45-8. 
1 shall have to keep God's higher gifts from such an obnoxious group of people, so 1

2 that when an opportunity occurs, they may compare and elevate them. [...] 2

3 I have had reason lately to look into Teutonic poetry, and as usual I cannot 3

4 resist taking some steps at once. If in doing this I can seize upon any ballads for 4

5 you, that will be my greatest reward. $\quad 5$

6

208. Zelter

12 André from Offenbach writes to $\mathrm{me}^{163}$ that he has not received my songs ${ }^{164}$ and if 12

13 they have still not been sent yet, I will have them sent to him from Berlin. I would 13

14 like to know so that he doesn't unnecessarily receive them twice. 14

15 He offered to send me a detailed assessment of them, ${ }^{165}$ which I am in fact 15

16 looking forward to and hope they will be really methodically taken apart, as I 16

17 know his songs ${ }^{166}$ and his basic principles. He has fleeced Catalani, bitten, even 17

18 torn her apart, like an unskilled butcher who doesn't know where the throat is. ${ }^{167} 18$

25 [...] Among other things which I fashion here, I wrote a new setting of the song 25

26 'Wer nie sein Brot' from Wilhelm Meisters Lehrjahre, which you will perhaps like 26

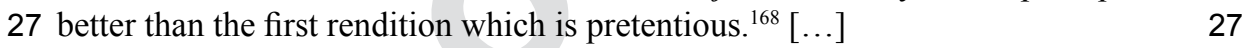

See Zelter's diary entry of 28 August: 'A letter from André in Offenbach of

163 J.A. André had written to Zelter on 20 August 1816; see Zelter's diary entry of 32 28 August; Schottländer, Carl Friedrich Zelters Darstellungen seines Lebens, p. 275.

164 Zelter, Sämtliche Lieder, Balladen und Romanzen; Zelter had asked Goethe on 15 July 1816 to give his copies to André, which Zelter would then replace, and Goethe had announced sending these to André in his letter of 22 July.

165 In Zelter's letter to André on 26 July 1816 he had, in fact, asked for André's 36 pinion; whether this requested report was ever written cannot be determined.

166 Johann Anton André, 48 Lieder und Gesänge, op. 38-40 (1819).

4020 August arrived with a bitter judgement about Madame Catalani'; Schottländer, Carl

41 Friedrich Zelters Darstellungen seines Lebens, p. 275.

42168 Zelter's first setting dates from 1795; the revised setting is entitled 'Heidelberg,

43 Sunday 25 August 1816' and at the end Zelter notes 'Completed [in] Baden, 2 September 1816'

44 (SBB PK Mus. ms. autogr. Zelter 21, I, no. 13). (1)

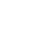

(4.

西

8


1 The judgement about Catalani in the Leipzig newspapers ${ }^{169}$ is known to me 1

2 only from what people say, but I can well imagine it, since I know the man, ${ }^{170}$ who 2

3 like a blind mail coach driver travels over the bad roads next to the good ones and 3

4 curses the bad roads. What annoys me [most] about it is that these people prostitute 4

5 German criticism and mislead the young generation, of which admittedly there is 5

6 not much to ruin.

7 Your hunting for ballads delights me and if the right huntsman comes, I am 7

8 not worried that there is game in the good German forests. I would love to see 8

9 the faces of the well educated as you take something up, observe it and show it 9

10 around, which they contemptuously let lie like Peter and the horseshoe. ${ }^{171}$ I gave 10

11 'Totentanz' ${ }^{172}$ to an educated woman, who is gladly counted as an admirer of yours, 11

12 to read before it was published. I must confess she said that: I cannot get anything 12

13 out of the poem and would not guess it was by Goethe if I hadn't [already] known, 13

14 but let me hear your setting. [...] What gives me the most pleasure is the belief of 14

15 many that I am carefully trained by you to set your poetry to music, because I don't 15

16 value compositions until they please you. For of all ideas they could have, they are 16

17 not content until they catch the densest.

18 At last I write to you, this time from Strasbourg where I arrived with Sulpiz ${ }^{173} 18$

19 on the 9th of this month at six o'clock. [...] At nine o'clock this morning in loveliest 19

20 sunlight we went back [to the cathedral]; first into the church, where for the first 20

21 time I heard a commendable mass which is not a [concert] mass with orchestral 21

22 accompaniment ${ }^{174}$ but an ordinary service accompanied just by the organ, which 22

23 was apparently a Silbermann, about which I will enquire.

2411 September: Organs [built] by Silbermann from Strasbourg ${ }^{175}$ have such a 24

25 beautiful sound that they can easily be singled out from the best organs of other 25

26 excellent masters. The cathedral organ is by the old Silbermann ${ }^{176}$ and is now 10226

27 years old. The most unusual thing about this organ is that no builder appears to have 27

28 thought of a space for it. This space must have been assigned to it and accepted 28

29 and it seems to me to be most dangerous in the church because of its proximity 29

30 to the hollow place between the towers. Now my master didn't provide the work 30

31 with pipes which are suitable for such a space. He put the whole work together, 31

32 dressed it up in his old way like a shot in a rifle where no grain of power is idle. 32

33

34

35

36

37

38

39

40

41

42

43

44

169 The essay, 'Ein Wort über Madame Catalani, nebst allgemeinen Bemerkungen über 34 den Gesang, und die Verschiedenheit des italienischen und deutschen'. AMZ 18 (1816), no. 35

34, 21 August, column 569-92.

170 Amadeus Wendt (1783-1836), philosopher and composer, professor in Leipzig. 37

171 A reference to Goethe's poem 'Legende'.

172 Zelter's setting of Goethe's ballad, enclosed in a letter to Goethe on 2 April 1814. 39

173 Johann Sulpiz Boisserée (1783-1854), art collector.

174 Fiedelmesse is slang for a concert mass with orchestral accompaniment. $\quad 41$

175 Johann Andreas Silbermann (1712-83) built the organ in the St Thomaskirche in 42

Strasbourg (1737-40) and in the new St Thomaskirche in Strasbourg (1748-9). 43

176 Andreas Silbermann (1678-1734). 
1 Outwardly the rest of the work looks like new. [...] I cannot praise highly enough 1

2 the song of the cantors in the mass. They let it be accompanied by two serpents, ${ }^{177}$

3 which works exceptionally well. The cantus firmus is not without mistakes, but it

4 is along the right lines and praiseworthy. Everything could easily be produced in

5 the best form by anyone who understood it correctly.

6 Against that, how abhorrent is the German mass of the Abbot, the Electoral

7 Palatinate Spiritual Councillor, the Court Kapellmeister and the state music

8 teacher of Mannheim, Herr Vogler, ${ }^{178}$ which he, to the shame of the Head of the

9 Church of Heidelberg in whose presence it was performed, had published. It is

10 pieced together from infamous popular songs and published by a reputable press, 10

11 circulated and should be a sign to me. I purposely bought this 'masterpiece' in 11

12 Offenbach and am bringing it with me. These gentlemen think that if you act 12

13 commonly and unworthily, you are close to the people.

14 Thursday, 12 September: Yesterday someone showed me your dissertation ${ }^{179} 14$

15 which I would gladly have copied, which, however, would never be permitted. 15

16 I have come directly from mass where I had the opportunity to see inside the 16

17 cathedral organ. I wanted to see the lungs which breathe into such a work and 17

18 my wish was granted. Six bellows, which hold at least 600 cubic feet of air and 18

19 which have 300 cubic feet always in reserve, and the strongest organist cannot 19

20 exhaust them if they are worked by two people. The way in which it is put together 20

21 can never fail, never embarrass and is a masterwork of mechanics. The weights 21

22 are [made] of lead and fixed in place, which is very important. Everywhere one 22

23 sees understanding, experience, thought and spirit: it is true to say the man [who 23

24

25

177 A bass wind instrument, descended from the cornett and a distant ancestor of the uba with a mouthpiece like a brass instrument but side holes like a woodwind; as the 26

name suggests, it usually has a snakelike shape. The instrument was invented by Canon

28 Edmé Guillaume in 1590 in Auxerre, France, and was first used to strengthen the sound

29 of choirs in plainchant. Around the middle of the eighteenth century it began to be used in

30 military bands and orchestras, but was replaced in the nineteenth century by a fully keyed

31 brass instrument, the ophicleide, and later on by valved bass brass instruments such as the 32 euphonium and tuba.

33178 Abbé Vogler, Deutsches Hochamt in A minor (1777, r.1807); first published as 33

34 Utile Dulci. Belehrende musikalische Herausgaben mit einer Zergliederung, die vorläufig 34

35 die Inaugural-Frage beantwortet: Hat die Musik seit 30 Jahren gewonnen oder verloren?

36 (Munich: Senefelder, 1808).

$37 \quad 179$ Goethe's treatise (written in Latin) De legislatoribus, which was not accepted by

38 the faculty: 'The dean, a bright lively man, began praising my work, then proceeded to its

39 questionable aspects, which he by degrees characterized as dangerous, and concluded by

39 saying that it might not be advisable to publish this work as an academic dissertation. The

40 candidate (he said) had demonstrated to the faculty that he was a young thinker of great

41 promise; and in order to avoid delay, they would gladly permit me to defend some theses,'

42 which Goethe did, and the doctorate was awarded, Dichtung und Wahrheit, Book 11, MA

4316, p. 507. Zelter could hardly have seen the submitted thesis, which was not to be found in

44 the faculty records, but rather an author's copy. 
1 made it] ${ }^{180}$ was a son of the muses. [...] According to the inscription, which I 1

2 read myself, the work began in 1713 and was finished in 1716, which is exactly 2

3100 years ago. If I had been here, I would have arranged to celebrate the day. Some 3

4 years ago it was renovated and the pipes were polished up. The organist who has to 4

5 play it twice a day has 548 steps to climb up and down! That amounts to 200,020 steps 5

6 per year and now he has to use the pedal as well! The two men who tread the pedals are 6

7 strong men with good stomach muscles which the weights respect! In some German 7

8 provinces one takes old, frail invalids there who are often so incapacitated that they 8

9 send their wives and children, who corrupt the bellows and cause more damage than 9

10 it costs to pay the organist. This misuse can never happen here because only one 10

11 [person] can tread the bellows and controls the fixed weight. [...] 11

18 Last time you found me in a sorrowful state, and now I must sadden you. The enclosed 18

19 letter contains the news of a great calamity, ${ }^{181}$ and my only comfort is to know you 19

20 are near me, and to feel that I am prepared to share your troubles with you. 20

180 Andreas Silbermann. 33

181 The death of Zelter's young daughter, Clara, which occurred during Zelter's absence 34 at Weimar. Goethe wrote on the blue envelope: 'Pardon the grim news' with reference to the 35 enclosed letter in which Lichtenstein informs Goethe of Clara's death, WA IV/27, p. 405. 36 When Goethe wrote the lines is not known. The letter from Martin Heinrich Lichtenstein 37 (1780-1857; Zoologist and Professor in Berlin), dated 19 September, must have arrived in 38 Weimar between 21 and 23 September; the earliest Zelter could have received the news is 38 28 September, when he arrived in Weimar at midday; it is possible the message was not 39 given to him until 29 September after he had a chance to rest, for he wrote to his daughter 40 Doris that day (GSA 95/I, 8, 19).

43 October 1816; Goethe mentions both performances in his diary, which sugests he attended 43 44 both. 
5 Many people here are very fired up about and ridiculing Aubri's dog. ${ }^{183}$ They say,

6 to bring a dog on stage is simply to bring the theatre to the dogs and so on. But

7 everyone is going to it and the house is always full. Yesterday I, too, was there and

8 stayed to the end. The work has the most lovely music, which runs through the

9 entire work without being sung. I would call the first two acts entertaining through

10 the simplicity of the motif: that a murderer will be discovered through the victim's 10

$11 \mathrm{dog}$. There is hardly anything to criticize in the production. It is nicely done and 11

12 fresh; true, the dog would have to be always on the stage and be continually around 12

13 his master as long as he lives. I'd be surprised if this is not in the stage directions, 13

14 since in this way the thing becomes natural and true to life. [...] 14

15 Today, Tuesday, Der standhafte Prinz is being performed. Unfortunately I 15

16 cannot go and report something about the performance. Let's hope it will run for 16

17 a while. [...]

18 Kapellmeister Winter has departed today. He put on a German opera, Zaïra 18

19 here, which was well received. However, the libretto is so bad that it was called 19

20 Ça ira, ${ }^{184}$ though the music is considered good. 20

21

27 [...] Our theatre offers some new things. Madame Seidler (née Wranitzky) plays 27

28 and sings in Johann von Paris ${ }^{185}$ to great acclaim. Wild, the tenor, ${ }^{186}$ is here from 28

29 Vienna and demands 5,000 thalers salary. Voice and style are good - very good. 29 with music by Ignaz Xaver von Seyfried; performed nine times in Berlin from 4 October to 3527 November; see $A M Z 18$ (1816), no. 46, 13 November, column 792.

$36 \quad 184$ 'That'll do'.

185 This Singspiel by François Adrien Boieldieu, libretto from the French of Saint Just, translated by Carl Herklots, had been performed in Berlin since 25 March 1813. The performance Zelter mentions took place on 26 October 1816; for reviews see $A M Z 18$ 39 (1816), no. 46, 13 November, column 795; Caroline Wranitzky-Seidler played the Princess 40 of Navarra.

$41 \quad 186$ The Viennese court opera singer Franz Wild (1792-1860) gave many guest

42 performances in Berlin in October and November 1816, first as Tamino in Mozart's Die

43 Zauberflöte; on 13 October he sang the title role in Johann von Paris; for reviews see AMZ

4418 (1816), no. 46, 13 November, column 794. 
1 Mademoiselle Brandt from Prague, ${ }^{187}$ a good young girl, is supposed to be very 1

2 nice. But all three seem to me planets that are too small to shine here for long - if 2

3 we keep them. They are asking for money to match the weight of their bones. 3

4 There is not much flesh in evidence! $\quad 4$

11 For a while now I have carried around the idea of composing music for the 11

12 Lutheran festival made up entirely of sayings by Luther. Please let me know your 12

13 thoughts on this, if you are not, in fact, the only man equipped with the knowledge 13

14 and ability to do this. ${ }^{188}[\ldots]$

The day before yesterday I had a letter from Madame Mara, ${ }^{189}$ who is staying 15 in Reval at present. In it she reported that she had wanted to come to Berlin this 16 17 autumn, but as this plan wasn't fulfilled, she would certainly come next summer. 17 18 Furthermore she is 68 years old now and would be welcome here, as I am also 18

187 Caroline Brandt's first performance took place in Berlin on 30 October 1816 in 28 the opera house where she played the title role of Nicolo Isouard's opera Röschen genannt: 29 Aescherling, with Franz Wild as Prince Ramiro; on 31 October she performed Wilhelmine 30 in Bretzner's comedy Das Räuschchen; for reviews of her guest performances see AMZ 1831 (1816), no. 51, 18 December, column 877.

188 In his letter to Zelter on 14 November 1816 Goethe answers Zelter's enquiry (first 33 raised on 31 October) about the possibility of a collaborated project, a Reformation Cantata, 34 and sends him a schematic plan and a detailed explanation of his ideas. In his following letter 35 on 10 December he sends a further developed version, in which the dramatic framework 36 and musical settings are indicated (Overture, choral passages). Despite such intensive 37 collaboration at the beginning of the project - reinforced by Goethe's work on an essay to 38 mark this celebration of the Reformation - work on the cantata came to a halt, was pushed 38 aside by other projects, until Zelter finally notes with resignation on 3 March 1817 'that my $\begin{array}{r}39 \\ 40\end{array}$

189 On 6 October 1816 the singer Gertrud Elizabeth Mara thanked Zelter for sending 41

42 her the article on Catalani from the Spenersche Zeitung, 8 August 1816, in which Zelter had 42

43 also praised Mara and named her 'Queen of female singers' (Königin der Sängerinnen). 43

44 Mara assured him that 'no praise had never had made her so happy as this [did]'. 
$5[\ldots]$ There's not much happening in our theatre now. I treat it like a business, but if 5 6 it succeeds, we want to expand again next winter [...]. And so I say this to you as 6 7 one who has seen the Sing-Akademie formed, has co-founded and preserved it. 7

14 The Federal anthem or Masonic song for the chamber council ${ }^{190}$ has been finished 14

15 for a long time but it is still fermenting. It takes time for me to work out a piece like 15

16 this and if it is to please others, it has to please me too. Don't take it badly if I jot 16

17 down in a quarter of an hour such a piece, which I cross out again after quarter of a 17

18 year. I'm glad I am not a painter for I would be annoyed to the point of distraction 18

19 if I painted something red which should be green. It is a very different thing for 19

20 a composer to cope with a real poet than to infuse ideas into the work of a mere 20

21 verse-maker. Naumann ${ }^{191}$ was right to prefer bad operas with which one is happy 21

22 when tailor and fiddler somehow bring a form to light. 22

29 The boatman melody ${ }^{192}$ is in an edition of Rousseau's song compositions ${ }^{193}$ which 29

30 came out about 30 years ago. Like a thousand other things, it has gone astray on 30

31 me, otherwise I would sent it to you. [...] 31

32 To prevent our friendly and lively discussion coming to a halt, I send you a 32

33 few words regarding your proposal to write a cantata for the Reformation Jubilee. 33

37 'Verschwiegenheit' in the Ausgabe letzter Hand (1827); Zelter's composition is entitled

38 'Männerkreis' in Goethe's version and 'Mauerlied' in the Berlin copy. The poem, with its

39 freemasonry ideas, may have been connected the successful entry of August von Goethe in

40 the lodge Amalia. Since 1812 Goethe had ceased to take an active role in the lodge. 40

41191 Johann Gottlieb Naumann (1741-1801), composer, Kapellmeister in Dresden. 41

$42 \quad 192$ The song of the Venetian gondoliers. 42

43193 Jean-Jacques Rousseau's posthumous Consolations des Misères de ma vie ou 43

44 Recueil d'Airs, Romances et Duos (Paris, 1781), p. 199. 
1 It would, I suppose, best fashion itself on the lines of Handel's Messiah, a work 1

2 which you have understood so deeply. 2

3 As the leading idea of Lutheranism rests on a very dignified foundation, ${ }^{194} 3$

4 it gives a fine opportunity for poetical as well as musical treatment. Now this 4

5 basis rests on the decided contrast between the Law and the Gospel, and second, 5

6 upon the accommodation of such extremes. And now, if in order to attain a higher 6

7 standpoint, we substitute for those two words the expressions 'necessity' and 7

8 'freedom', with their synonyms, their remoteness and proximity, you see clearly 8

9 that in this circle is contained everything that can interest mankind. [...] 9

10 To express these ideas in a poem adapted to music, I should begin with the 10

11 thunder on Mount Sinai, with the 'Thou shalt', and should conclude with the 11

12 Resurrection of Christ, and the 'Thou will!' 12

13 For the further development of my plan, I will add the successive order in 13

14 which the piece should be arranged: 14

$15 \longrightarrow \frac{15}{16}$

16 Part One 16

17 I The giving of the Law on Mount Sinai. 17

18 II The warlike pastoral life, as described in the Books of Judges, Ruth, etc. 18

19 III The consecration of Solomon's Temple. 19

20 IV The dispersion of the worshippers, who are driven to the mountains and 20

21 hilltops. 21

$22 \mathrm{~V}$ The destruction of Jerusalem followed by Babylonian captivity. 22

23 VI Prophets and Sibyls announcing the Messiah. 23

$24 \quad 24$

$25-25$

26 Part Two 26

27 I St John in the wilderness, taking up the Annunciation. 27

28 II The recognition by the Three Kings. 28

29 III Christ appears as a Teacher and draws the multitude to Him. Entry into 29

30 Jerusalem. 30

31 IV At the approach of danger, the multitude disperses. Christ's friends fall 31

32 asleep. 32

33 His sufferings on the Mount of Olives. 33

$34 \mathrm{~V}$ The Resurrection.

$35 \quad 35$

$36 \quad 36$

37 On comparing these two parts, the first seems intentionally longer, and has a 37

38 decided central point which, however, is not lacking in the second. 38

39 In Part One the first and fifth movements are parallel with each other; Sinai 39

40 and the Destruction, the time of the Judges and the service of Baal; the second and 40

194 The tension between 'law' and 'gospel', or as Goethe formulates it, 'necessity' 43 
1 fourth movements are idyllic, energetic - the consecration of the temple constitutes 1

2 the highest climax and so on.

3 In Part Two the first and fifth movements, the dawn preceding the sunrise,

4 would be expressed with gathering intensity. The second and fourth movements

5 form a contrast. The third movement, the entry into Jerusalem, might express the 6 unrestrained and pious joy of the people. [...]

7 A thousand other relationships will occur to you at first glance. These things

8 need not be historically but lyrically tied together. Everyone knows the whole and

9 will let themselves be carried from one place to another on the wings of the poetry.

10 The text should consist of passages from the Bible, well-known evangelical 10

11 hymns, bestrewn with new texts and whatever else can be found. Some words 11

12 by Luther can hardly be used as the excellent man is absolutely dogmatically 12

13 practical. So, too, is his enthusiasm. It is for you to look around in the Scriptures. 13

14 Above all, read the completely invaluable preface to the psaltery. In addition read 14

15 the prefaces and introductions to the remaining biblical books; you will probably 15

16 come across useful passages. At the same time you yourself will be filled with the 16

17 sense of the whole teaching whose gift we want to celebrate. 17

18 Perhaps this is the place to say a word about the Catholicism outlined above. 18

19 Soon after its origin and development the Christian religion suffered. It lost its 19

20 original purity through subtle and unsubtle heresies. But when they had to bring 20

21 under control and rule very brutish people and corrupted civilians, strong measures 21

22 were necessary. Not teaching but service was needed. The one mediator between 22

23 the highest God in heaven was not enough, as we all know, and so a type of 23

24 heathen Judaism was formed that is still with us to the present day. That had to be 24

25 overthrown, which was why Lutherism drew solely on the bible. Luther's method 25

26 is no secret and now that we are celebrating him, we only do it correctly if we 26

27 acknowledge his service and show what he gave to his age and following ages. 27

28 This feast should be celebrated in such a way that every well-meaning Catholic 28

29 could join in celebration. More about that another time. [...] 29

30

36 Nieymeyer of Halle, with whom I am now in contact about the Hallean choir, ${ }^{195} 36$ 37 asked me whether I had handed over his parcel together with his letter to you. ${ }^{196} 37$

$40 \quad 195$ The choir founded by Daniel Gottlob Türk (1750-1813) and later directed by 40

41 August Hermann Niemeyer (1754-1828).

42196 Niemeyer's book Religiöse Gedichte (Halle and Berlin, 1814), which is dedicated

43 to Goethe, and his letter to Goethe of 3 July 1816 were presumably both delivered to Goethe 44 on the evening of Zelter's arrival in Weimar on 5 July. On his summer vacation Zelter had 
1 Will you find a quarter of an hour to say a good word to him? ${ }^{197}$ Probably on 1

2 your account he gave me a friendly reception, for up to then I seem to have been 2

3 unappreciative of him and have not answered two of his letters. [...] 3

4

5

$10[\ldots]$ As yet I don't know the preface to the psalter at all, but will procure it 10

11 immediately. Like you, I take 'sayings by Luther' to mean 'biblical sayings'. If 11

12 one could use one or more of his church songs that would be good too. You have 12

13 perfect freedom and I will follow your lead as closely as possible. [...]

14 Evening, 24 November: I have just seen Madame Tilly ${ }^{198}$ perform Kotzebue's 14

15 Die Verwandtschaften. Act One is very good. The other four are very ordinary. 15

$16[\ldots]$ The leading lady would please you. ${ }^{199}[\ldots]$ She performs with feeling and 16

17 awareness.

20 I Giving of the Law on Mount Sinai. 20

21 II The warlike pastoral life. $\quad 21$

22 III The consecration of Solomon's Temple. 22

23 IV The dispersion of the worshippers 23

$24 \mathrm{~V}$ The destruction of Jerusalem; Babylonian captivity. 24

25 VI Prophets and Sibyls announce the Messiah. 25

$26 \quad 26$

27 Part Two 27

28 I St John in the wilderness, taking up the Annunciation. 28

29 II Recognition by the Three Kings. 29

30 III Christ appears as teacher, drawing the multitude to Him. Entry into Jerusalem. 30

31 IV At the approach of danger, the multitude disperses. Disciples sleep. Sufferings 31

32 on Mount Olive. 32

$33 \mathrm{~V}$ The Resurrection. 33

$34 \quad 34$

$35-35$

$36 \quad 36$

$\begin{array}{ll}37 & 37\end{array}$

$38 \quad 38$

39 passed through Halle and visited Niemeyer on 4 July; see Zelter's diary, 'With Niemeyer at 39

40 noon', Schottländer, Carl Friedrich Zelters Darstellungen seines Lebens, p. 264.

$41 \quad 197$ The requested letter is not extant. 41

$42 \quad 198$ Karoline Auguste Tilly (1800-28), actress in Berlin, Magdeberg and Dresden. 42

43199 Sophie Auguste Friederike Crelinger, née Düring (1795-1865), actress, from 181243

44 resident performer at the Königliches Theater, Berlin. 44 
5 [...] The little song ${ }^{200}$ is finally finished and I am also sending the poem back 5 6 again with it because I have provided directions regarding the presentation of the 6

7 melody in the different verses. It is in three parts - for two tenors and one bass. 7

8 The middle voice can also be sung by a bass if there are not two tenors. The whole 8

9 company $^{201}$ can repeat the last two lines of every verse, at which point the three 9

10 soloists can take a breather. Admittedly I should know what singers you have. This 10

11 time all will be well, but in the future I ask you to let me know how many singers 11

12 are available in each part. [...] 12

13 The tone of the song is not easily hit and the singers must do their best in order 13

14 to capture, in a flowing line, the contrasting elements: what is manifest and what 14

15 is known in quiet contemplation.

16 In only making this observation now when the song is in its completed form in 16

17 front of me, I wanted to tell you - for the reason that one doesn't know what one 17

18 is doing and would be lost if God himself didn't know. 18

19 On the back I have written a canon ${ }^{202}$ which would be suitable for that circle to 19

20 perform. The main reason I did it many years ago, was to treat a whole poem with 20

21 many stanzas in this way. The text should be the final stanza of a student song, 21

22 which begins:

24 My father was a rich man $\quad 24$

25 Who was lacking in money $\quad 25$

26 And were he not deceased $\quad 26$

$27 \quad$ He would still be in the world. $\quad 27$

$28 \quad 28$

29 So the song moves through the various verses until the final one which is notated. 29

$30 \mathrm{It}$ is the first clever student song which I have seen. I had long since striven to 30

31 get it right before I finally arrived at the enclosed version. Most likely you have 31

32 preferred to prop up an old song with a thought and there will undoubtedly be a 32

33 happy moment for composing something enjoyable to this version, as the original 33

34 nonsense is useless. $\quad 34$

$35 \quad 35$

$36 \quad 36$

$\begin{array}{ll}37 & 37\end{array}$

$38 \quad 38$

39200 Zelter's setting of Goethe's poem 'Wenn die Liebste zum Erwiedern', WA I/3, 39

40 p. 392. The autograph manuscript of Zelter's three-part male voice setting, entitled 40

41 'Männerkreis', is in Goethe's music collection (GSA 32/23). 41

$42 \quad 201$ Goethe's house choir. $\quad 42$

43202 On the reverse side of Zelter's manuscript is a canon at the octave for 4 [male] 43

44 voices. $\quad 44$ 
5 Your little song has arrived; ${ }^{203}$ we thank you heartily for what you have composed 5

6 so well. If the melody is varied to suit the text as you have indicated, it cannot 6

7 fail to be very effective. In return, I send you the scheme for the grand cantata, ${ }^{204} 7$

8 developed further; ${ }^{205}$ may it reach perfection with you! I have kept a copy of it 8

$9[\ldots]$

10 I hardly remember whether I thanked you with regard to Tilly and have a 10 11 question. 'She is not without a voice', you write. Does that mean that she can sing 11

12 or that at the most she would be necessary as a chorister? 12

14 Part One:

15 Overture

16 At the end, thunder on Mount Sinai

17 Semi-chorus (the citizens) crowding around. It is bent on seeing closely what goes 17

18 on

19 The Levites (a semi-chorus) restrain them. The people are forced back from Sinai 19

20 and worship their God 20

21 Aaron inaugurates the scene. He mentions the defection to the golden calf 21

22 The people humble themselves and receive the Law 22

23 Speaker (Joshua) 23

24 March through the desert $\quad 24$

25 Conquest of the land 25

26 Martial Shepherd Choruses, similar to those in my Pandora ${ }^{206} 26$

27 Speaker (Samuel) explains the wavering of the people between priesthood and 27

28 monarchy 28

29 Loyalty of the king and the people to the idea of the one national God 29

30 Solomon's accession to the throne 30

31 Choruses of women 31

32 The Sulamite, the best beloved, is far off 32

33 Choruses of Priests 33

34 Consecration of the Temple $\quad 34$

$35 \quad 35$

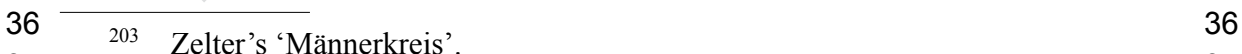

37204 Zelter's 'Männerkreis'.

38 first draft - was now divided into two parts. The text is based on Kräuter's copy (GSA 2538

39 XX, 15, pp. 10-12).

40205 Goethe's second draft for a Reformation cantata is clearly structured with regard 40

41 to the musical and scenic presentation: an overture, choirs (the people, different groups), 41

42 soloists, a speaker; at the same time notion of juxtaposing the Old and New Testaments has 42

43 been realized differently. $\quad 43$

$44 \quad 206 \quad M A 9$, p. 159f. $\quad 44$ 
1 Choruses of all kinds

2 Speaker (Elijah) 2

3 Preparing the way for the defection to Baal 3

4 Service on mountain tops and in the open air 4

5 Choruses of the people who are returning to the happiness of their former and freer 5

6 heavenly life 6

7 Joyful, less religious celebrations $\quad 7$

8 Choruses of the priests of Baal, imposing themselves with their clerical cruelty 8

9 and coarseness 9

10 Speaker (Jonas). Threats, prophesying the coming of swarms of enemies 10

11 Approach of the enemy 11

12 State of fear $\quad 12$

13 Downfall of the kingdom, with violence 13

14 Captivity. Gentle lamentation $\quad 14$

15 Speaker (Isaiah) presages salvation and future happiness $\quad 15$

16 Choruses, accepting the prophesy with gratitude but in an earthly sense 16

17 Choruses of Prophets and Sibyls, pointing to the spiritual and eternal 17

18 Triumphant Finale $\quad 18$

$19-19$

20 Part Two: $\quad 20$

21 Intermezzo $\quad 21$

22 Sunrise $\quad 22$

23 Beauty of the morning air $\quad 23$

24 Rural, not pastoral 24

25 Expanse of solitude $\quad 25$

26 Speaker (St John) $\quad 26$

27 He receives the promise $\quad 27$

28 He beholds the star of Bethlehem as the morning star 28

29 Ushering in the approach of the Three Kings 29

30 Procession of the Three Kings 30

31

32 There is nothing contradictory in Turkish music being used here, for it came to us 32

33 from beyond the Oxus. ${ }^{207}$ It would be especially appropriate on the arrival of the 33

34 third king, who is always represented as something of a barbarian. 34

35 (This scene would have to be decidedly dramatic for the sake of variety.) 35

$36 \quad 36$

37 Departure of the kings into the distance $\quad 37$

38 Speaker (Christ) 38

39 He appears as a teacher $\quad 39$

40 Chorus attentive, but wavering $\quad 40$

41 His teaching becomes more intense $\quad 41$

42 The people crowd around Him and cheer, but always in an earthly sense $\quad 42$

$43 \longrightarrow 43$

$44 \quad 207$ The ancient name for the river Amu Darya in Central Asia. $\quad 44$ 
1 Christ raises His teaching to the spiritual level 1

2 The people misunderstand Him more and more 2

3 Entry into Jerusalem 3

4 Speakers (Three Apostles) 4

5 Fear of danger $\quad 5$

6 Christ consoling, strengthening; and admonishing 6

7 Alone in suffering of the soul $\quad 7$

8 The intense affliction $\quad 8$

9 Speaker (Evangelist) 9

10 Allusion to physical suffering 10

11 Death. Resurrection 11

12 Angelic Chorus 12

13 Chorus of terrified watchmen 13

14 Chorus of women 14

15 Chorus of disciples $\quad 15$

16 Everything earthly dies away, and the spiritual soars higher and higher to the 16

17 Ascension and Immortality 17

$18 \quad 18$

19 The composer will accurately weigh up the relationship between the different parts 19

20 and in representing the thunder on Mount Sinai will insist on gradual intensification 20

21 to be achieved through alternations. 21

22 Taking Handel's Alexanderfest ${ }^{208}$ as my guide, instead of presenting the one 22

23 speaker - Timotheus of that work - I have introduced several speakers, who may 23

24 be imagined sometimes just reciting, sometimes singing, sometimes competing 24

25 with the chorus, just as it suits the development of the piece. 25

26 The speakers are mostly men, but should it be necessary, women may be 26

27 substituted. What I particularly wish to know is how the leading parts are to be 27

28 allocated and at what points one should introduce regular arias, for which biblical 28

29 and other pious sayings might then be adapted in such a way as to be recognizable, 29

30 and yet at the same time would be rhythmically smoother. 30

$32 \quad 32$

$33 \quad$ 222. Zelter 33

$34 \quad 34$

$35 \quad$ Berlin, 15 to 16 December 181635

$36 \quad 36$

37 [...] I have not heard Mademoiselle Tilly sing and if I said she is not without voice, 37

38 I meant by it that her voice is resonant but it is still not rounded, which only can 38

39 be attained by strict schooling.

40 I really like the plan for the cantata. You don't need to feel embarrassed by 40

41 it and can give what comes easily to you. Arias, choruses, recitative and the like 41

$43 \quad 208$ Zelter had expressed his enthusiasm for the choral writing in this oratorio during 43

44 the Sing-Akademie's performance of this work in 1807. 
1 form themselves. They must form themselves if the whole is to be clear without 1 2 being ordinary. 2

3 The overture has been composed already, but I cannot put closure to it until I 3

4 have the beginning of the [first] piece. The sense and spirit exists in the contrasts 4

5 you yourself indicated: You should! You will! And for that I need the ordinary 5

6 external means so that I am left with the (task of) broad development. [...] What 6

7 will require the most work is the concrete, both within the narrow context and in 7

8 the development. The mean between too short and too long is indefinable and to 8

9 strike it once you would have to be a god. 9

10 I would create the difference between choir and semichorus by four single 10

11 voices against the whole choir, if it is to be contrasting. 11

12 Besides, a female solo part is almost necessary in order to occupy a decent 12

13 singer, and if need be two. Otherwise all voices - soprano, alto, tenor and bass - 13

14 can be used as solo voices and the choir still exists separately. 14

15 I would imagine the whole work would be simple enough to stage so that one 15

16 could comfortably perform the music even where only a small theatre with the 16

17 necessary apparatus is available. One can also suggest Janissary music really well 17

18 without [using] the instruments themselves. I find there is greater art in having 18

19 something suggested, guessed, found, than in using people's backs for beating out 19

20 the rhythm, which is really a disgrace. ${ }^{209} \quad 20$

21 Of the arias, which should not be too long, one would be sufficient for the 21

22 soprano, one for the tenor and a third for the bass. That which is really lyrical is 22

23 arioso in style, even in recitative passages. Good biblical passages for the choir 23

24 would work best to lend to the whole a respectable abode for the soul to dwell in. 24

25 The arias could be placed wherever is most suitable, as long as they do not 25

26 come too near one another. 26

27 [Some] attractive songs are also finished: among them you would like 'Flieh, 27

28 Täubchen flieh!' ${ }^{210}$ and 'Wie sitzt mir das Liebchen'. ${ }^{211}$ The word order of your 28

29 verses is often so strange that at first glance I think that it could never be set. Yet 29

30

31209 Zelter is referring to the fifth poem ('Froh empfind ich mich nun auf klassischem

32 Boden begeistert') in Goethe's Roman Elegies, II. 15-17: 'I have even many a time

33 composed poetry in her arms, and softly, with fingering hand, counted out on her back the 34 hexameters' measure.'

35210 Setting of Goethe's occasional poem from 1773 or 1774, which he had revised

36 during his visit to the spa in Tennstadt. Goethe had given Zelter a fair copy (in the poet's

37 hand) during his visit to Weimar at the end of September 1816. Zelter's manuscript, entitled

38 'Mädchens Held', is dated Berlin 3 October 1816 (SBB PK: Mus. Ms. Autogr. Zelter 21,

38 1, no. 20). The song was first published in Sechs deutsche Lieder für die Altstimme (1826).

39 Whether Zelter sent a copy of the setting to Weimar is unknown; the copy in Goethe's music

40 collection, by an unknown hand (GSA 32/54) can be dated from the first publication. 40

41211 Setting of Goethe's poem published under the title 'Gegenseitig' in 1816; Zelter's

42 setting, which is entitled 'Der Entfernte' and dated 5 December 1816 (SBB PK: Mus.

43 Autogr. Zelter 21, 1, no. 19) first appeared under a different title, 'Im Fernen', in Zelter's

44 Neue Liedersammlung (1821). 
1 when I have a look at it from all sides, I find within myself what I would not have 1

2 searched for. Even I myself am surprised at 'Flieh, Täubchen'. However the verse, 2

3 'Und so soll mein deutsches Herz weich flöten', is a tricky one and won't settle. I 3

4 myself can't get my tongue around it.

5 The day after tomorrow I am travelling to Stettin. I will need a whole week 5

6 on this short journey because of the short days. Mendelssohn ${ }^{212}$ is travelling with 6

7 me, or rather I am going with him because I have nothing to do in Stettin and am 7

8 using the opportunity to visit my daughter ${ }^{213}$ in Bruchhagen ${ }^{214}$ and my son ${ }^{215}$ in 8

9 Steckelin ${ }^{216}[\ldots]$

I have received your letter in which you agree with my suggestions. For the time 16 17 being I am leaving it lie with my other papers because I cannot see clearly how I 17 8 can add anything. If we were together, then it would happen much more quickly. 18 9 Now, however, the weather along with a lot of [minor] details are a burden to me, 19

[...] I must convey the important news to you, namely that the last two strophes 28

of the unruly ballad 'Die Kinder sie hören es gerne' ${ }^{217}$ have arrived. [...] I sent a 29 song $^{218}$ for the artist's festival to Schadow, who gave me great pleasure through 30 the medal. ${ }^{219}$ May it help towards finally banishing the gloomy spirit which creeps 31 through our art halls. [...]

213 Juliane Huschka née Zelter (1791-1862), Zelter's second daughter from his first 35 marriage to Johanna Sophia Eleonora Zelter. 
5 [...] About the little ballad: that the children like to listen to it makes very me 6 happy and that Paria's prayer is still not answered also delights me, because I 7 thought it could only happen to me that something appears in the entertainment 8 which I have to subvert. It is one thing to have an idea and another to represent it 9 and so I often doubt the bit of talent I have. [...]

10 Your poem ${ }^{220}$ which you sent to our artistic society gave great joy. What 10 11 architects, painters, sculptors and the rest of us musicians have endured for this 11 12 year's celebration was not without gain. ${ }^{221}$ If I make an exception of the presentation 12 13 of Phidias, ${ }^{222}$ then nothing produced was without spirit. [...] 13

14 I mounted a little musical work for a group of living figures (Saul and David) ) $^{223} 14$

15 which would have sounded better if the room was not so narrow and [the ceiling] 15

16 so low. However, the little work was well received because one cannot appear 16

17 more pleasing to the general public than when one is not intellectual but gives 17

18 oneself over to deep feeling. [...] 18

19 I have read Luther's preface again, especially about the Old and New Testaments. 19

26 Prince Hardenberg has commissioned me to have a new organ ${ }^{224}$ built for him in 26 27 Neu-Hardenberg (formerly Quilitz) nine miles from here. This organ will be ready 27

29 display coin. Goethe thanked him on 27 December 1816 and requested further wax casts, 29 30 which he received in February 1817.

31220 'Zu erfinden, zu beschließen'.

$32 \quad 221$ In his explanations for the commemorative programme containing Goethe's

33 'Künstlerlied', Schadow himself had described in detail the Ephiphaniasfest on 6 January 33

341817 in the hall of the Englisches Haus. After his speech, Schadow read out Goethe's poem.

35 On an erected stage 'living tableaux' were shown against music by Zelter and Rungenhagen,

36 including Zelter's David and Saul. The images bearing homage mentioned by Zelter

36 and composed by Zelter are a homage to the art of sculpture and to the art of poetry; the

37 conclusion was made up of the 'farcical dramatic duet in doggerel [Knittelverse]'.

$38 \quad 222$ The actor August Wilhelm Mauer played the role of the Greek sculptor Phidias,

39 who - in a poem written by Konrad Levezow - begged the father of the gods, Zeus, to make

40 his image, as Homer describes it, arise in his imagination.

\section{4} 35 36 37

41223 Zelter, Gloria. Für den Künstlerverein Saul und David am H. drei K. Feste 181741

42 (SBB PK: Mus. ms. Autogr. Zelter 9). 42

$43 \quad 224$ Built by Johann Simon Buchholz and his son, Carl August Buchholz in 1817. Karl 43

44 Friedrich Schinkel designed the organ casing. 
1 for the Reformation Jubilee and I would really like to have something ready for 1

2 it. ${ }^{225}$ One should hardly use an old piece for it, although the new is never overrated 2

3 here.

4

5

Wild sang Orest for the last time today ${ }^{226}$ - a role which I would prefer to hear 10 [sung] by a natural baritone, so that here too both characters are distinguished 11

[...] I just devoured a new opera: Athalia by Racine in a version by Gottfried 20

23 great modesty with which it is presented. In fact one is happy once again to enjoy 23

24 a work which is not abrasive to the ears. A bit more aria, in the strict sense of the 24

25 word, would be of benefit. The German libretto would have some good passages if 25

26 only the character of Athalia were elevated a little. Here she is a coarse and stupid 26

27 woman, a real rascal; on the other hand little Joaschen is like a sausage stuffed 27

28 with wisdom, piety and many fine expressions. The best thing about it are the sets, 28

29 among which the interior of a temple and a landscape arranged by Schinkel are 29

30 highly commendable. [...]

39225 Zelter, Kirchenmusik zum Reformationsfeste für 4 Stimmen mit Orgel und 39

40 Bleichinstrumenten (1817). 40

41226 The Viennese opera singer Franz Wild (1792-1860) performed Orest in Gluck's 41

42 Iphigenie in Tauris in Berlin on 8 and 16 February 1817.

43227 Johann Nepomuk von Poißl (1783-1865). The opera was performed on 25 and 2843

44 February; Zelter attended the second performance. 
5 As I am in my theatre period, you must remain silent when I tell you something 6 else about Antonin. ${ }^{228}$ Today for the third time I saw him dance and playing the

7 guitar at the same time. This person is not only a really perfect dancer; he plays this

8 instrument masterfully. But this is not all: he combines both perfectly. He played

9 the Folie d'Espagne ${ }^{229}$ with variations and danced to it without any constraint. As

10 the alterations become livelier, the liveliness of the dance also increases, so that 10 11 there is no step, no leap, no movement that does not fit perfectly with the music. 11

12 The orchestra was completely silent and even with the swiftest movements not 12

13 a single note was lost. In short, I have never yet heard this imperfect instrument 13

14 played so perfectly. I was completely amazed at the security and the strength to 14

15 hold the instrument so firmly during the most energetic physical movements, and 15

16 to play so purely and so beguilingly.

23 [...] Athalia hasn't been performed yet because of Stromeyer's illness. ${ }^{230}$ We hope 23

24 to perform it next Saturday, the 15th of this month. 24

31 [...] My Easter concert is over ${ }^{231}$ and turned out very advantageously; I had a 31

32 pretty little sum left over and the music was what I call good. [...]

$36-228$ Parisian Dancer, based in St Petersburg from 1817 to 1827 ; for a review of 36

37 his Berlin performance see $A M Z 19$ (1817), no. 16, 16 April, column 279f; $M A 20.3$, 37

39229 Popular seventeenth-century theme by Farinelli.

40230 Poißl's opera Athalia was due to be performed in celebration of Maria Pawlowna's

41 birthday on 16 February. Due to illness of the leading singer, Heinrich Stromeyer, Bonini's

42 Drillinge was performed and Athalia was rescheduled for 15 March 1817.

43231 The annual performance of Graun's Der Tod Jesu; for reviews see AMZ 18 (1817), 43

44 no. 20, 14 May, column 348; MA 20.3, p. 439. 
5 We are expecting a new tragedy ${ }^{232}$ by Oehlenschläger here. I have read it because 5

6 I have to write some music for it, but I don't like it much. [...]

20 she is second to none and there is a better sense of awareness than with Catalani. 20

21 She also knows how to hold herself so that a lovely bust and perfectly beautiful 21

22 arms play their part. You may think I have fallen in love again. I am also on good 22

23 terms with her and again speak Italian, which is better than I have given myself 23

24 credit for $[\ldots]$

25 Finally, many thanks for the good reception of my Mendelssohns. ${ }^{234}$ The little 25

26 woman is of the very best and 20 years ago she really was exceptional, a true 26

27 dove.

34 [...] State Councillor Schulz ${ }^{235}$ very kindly invited me to Berlin and it sometimes 34 35 seems to me that such a trip would be advisable and possible. Then, however, my 35 April and 5 May 1817.

233 Maria Theresia Sessi, Viennese singer; Zelter refers to her concert on 13 June 39

1817 in the Königliches Opernhaus; for reviews of her performance see $A M Z 19$ (1817), 40

no. 29, 16 July, column 494f; MA 20.3, p. $444 . \quad 41$

234 Contrary to Zelter's supposition, the meeting between Hinni Mendelssohn and her 42

$44 \quad 235$ Christoph Ludwig Friedrich Schultz (1781-1834). 
1 opinion suddenly changes and in the end I don't see where the decision would 1

2 come from. It is best not to think about it at all, but to let Holy Week come and wait 2

3 to see whether in the end Graun's oratorio ${ }^{236}$ tips the scales. 3

$4 \quad 4$

525

6 235. Goethe 6

$7 \quad 7$

8 Jena, 16 December 18178

929

10 [...] Unfortunately when I think of music, it seems strange to me that I am cut off 10

11 from this highest and loveliest enjoyment. I find, at the same time, that still many 11

12 a song succeeds for me and your good profoundly artistic intentions always hover 12

13 around $m e[\ldots] \quad 13$

14

15

16

236. Zelter 16

17

Berlin, 21 December 181718

18

$\begin{array}{ll}19 & 19 \\ 20 \text { Your informative letter of the 16th of this month brightens the shortest and darkest } 20\end{array}$

21 day; at the same time it should abolish the long silence. I don't have much to report 21

22 about my activities and strivings. I have moved into a comfortable, quiet, though 22

23 expensive accommodation. ${ }^{237}$ Happily the new organ in Neu Hardenberg is ready 23

24 for the Reformation celebration and I have inaugurated it and the church itself 24

25 (which has undergone much renovation) with a sizeable piece of music which had 25

26 to be finished amongst much chaos. The best [news] is a little trip to Hamburg ${ }^{238} 26$

27 from which I am back a week and which gave me a great deal of pleasure despite 27

28 the wet weather. [...] Some fine musical antiquities were passed on to me and 28

29 with great delight I established them in our residence. In the Hamburg Theatre I 29

30 heard a new opera, Tancredi, by Rossini ${ }^{239}$ and found it quite pleasing and more 30

31 impressive than Italian opera is generally perceived to be in Germany. 31

$33-33$

$34 \quad 34$

$35-236 \quad 35$

$36 \quad 236$ Der Tod Jesu. 36

$37 \quad 237 \quad$ Friedrichstraße 129.

$38 \quad 23816$ November to 9 December 1817; for a detailed account of Zelter's activities

38 there - which included a visit to the Hamburg Sing-Akademie led by Reichardt's daughter,

39 Luise - see Zelter's correspondence with his daughter Doris on 20, 22-25, 26-28,

4030 November (GSA 95/I, 8, 19).

41239 Performed in Hamburg on 21 November 1817; for a more detailed - and very

42 critical account - see Zelter's letter to Doris on 22 November 1817 (GSA 95/I, 8, 19). Zelter

43 attended further performances of Tancredi in Berlin on 5 January 1818 and in Kassel during

44 the summer of 1818 . 
It was said here some days ago that Kapellmeister Müller in Weimar was 1

2 dead. ${ }^{240}$ Let me know whether it is true, because I am still indebted to him in artistic 2

3 matters. ${ }^{241}$ But what I am most concerned about is to know what is to happen to 3

4 his bequest. He possessed an old musical work by Bodenschatz ${ }^{242}$ which I would 4

5 like to purchase unless more worthy hands in Weimar would like to possess it. If 5

6 it is to be auctioned, be so kind as to let me know. I cannot spend too much on it; 6

7 I have [already] bought much this autumn. [...] 7

8 Do you not have some poems lying about to offer something reasonable to the 8

9 Liedertafel once more? Also don't forget to send me your report on Da Vinci's 9

10 Last Supper, about which I am curious. 10

17 First to your inquiry about Leonardo's Last Supper. Of this inestimable work, 17 18 the first complete painted fugue, ${ }^{243}$ which surpasses all that has gone before and 18

19 is not to yield to any successors; there is not the slightest inkling how the figures 19

20 approximately stood in relation to each other. [...] 20

21 At your suggestion I have been looking through the few scraps of poetry I 21

22 have to hand and find only the enclosed that may perhaps come in useful for your 22

23 society. It was an impromptu offering to my very old friend Knebel, on his seventy- 23

24 third birthday. ${ }^{244}$ Good luck to the society who will sing it at certain occasions. The 24

25 musical movement recalls the popular 'Lasset heut im edlen Kreise'. ${ }^{245}$ You will, 25

26 however, find the character very different and you will perform it in line with your 26

27 knowledge and conscience.

28 You shall hear about Müller's bequest next time. ${ }^{246} 28$

2929

30 Enclosed: 'Lustrum ist ein fremdes Wort' 30

$31 \quad 31$

$32 \quad 32$

$33-33$

$34-34$

$35 \quad 240 \quad$ August Eberhard Müller died on 3 December 1817.

$36 \quad 241$ On his previous visit to Weimar Zelter had borrowed 15 song settings from Müller 36

37 on 7 July 1816 and later had Franz Nicolovius settle the account. 37

$38 \quad 242$ Presumably the famous motet collection, Florilegium Portensee, first published by 38

39 Erhard Bodenschatz in 1603; a revised enlarged edition followed in 1618.

40243 Goethe also used this description, 'somewhat fugue-like', with reference to Carl 40

41 Leybold's drawing Charon. $\quad 41$

$42 \quad 244$ See Goethe's diary entry on 30 November 1817, WA III/6, p. 142 . 42

43245 The opening words of Goethe's poem 'Generalbeichte'. 43

44246 Goethe, in fact, never answered Zelter's request of 21 December. 44 
5 Be so good as to pass on the enclosed letter. It contains a short little song ${ }^{247}$ and 5 6 guidelines, to give old Knebel something to listen to.

7 Along with Langermann I have learned a lot from what you said about 7 8 Leonardo's Last Supper. [...]

15 Since you have been quick to give us the benefit of your artistic skills, ${ }^{248}$ so shall 15

16 our thanks for it not be delayed but be paid instantly. [...] We will not discover 16

17 what you have commemorated in this work, yet at the same time we know that it is 17

18 necessary and customary for you composers to work spontaneously. 18

19 Furthermore, the question is whether you are in a good enough mood to look 19

20 over the accompanying notes and give me your opinion. ${ }^{249}$ The circle from which 20

21 these songs arise is limited, but cheerful, brave and willing. I know full well that it 21

22 is no work of art. It is up to you whether we should drop it and reject it.

$23[\ldots]$ Rossini was once asked which of his operas pleased him best? His answer 23

24 was Il matrimonio segreto. ${ }^{250}[\ldots] \quad 24$

28247 Zelter's setting of Goethe's 'Lustrum ist ein fremdes Wort', which bears Zelter's

29 subtitle: 'Am 73 Geburtstag des 40jährigen Freundes' (GSA 32/19); the title 'Meinem

30 Freunde von Knebel zum 30 November 1817' in Kräuter's hand is written on page one.

31 Since the page handed down from Goethe's music collection was an autograph copy by 31

32 Zelter, Goethe either had a copy made and had this sent to Jena or at a later stage received 32

33 the copy back from Betty Wesselhöft.

$34 \quad 248$ Zelter's setting of 'Lustrum ist ein fremdes Wort'. 34

35249 Settings, with guitar accompaniment, by the theologian Adalbert Schoepke of 35

36 poems by Goethe. Goethe had received the settings on 1 January and replied in thanks on 36

3716 February; Zelter, in turn, judged the settings favourably and passed them onto Prince

38 Radziwill. Schöpke's settings have not been handed down.

39250 The source for this anecdote is Stendhal's Rome, Naples and Florence in 1817;

39 Goethe's knowledge of this source is first mentioned in his diary on 18 January $1818, W A$,

40 III/6, p. 159. In this work Stendhal records a conversation with Rossini: 'I told him of my

41 enthusiasm for l'Italiana in Algeri and I ask him what he loves best, whether l'Italiana

42 or Tancredi. He replies 'Il matrimonio segreto because it is forgotten as the tragedies of

43 Marmontel are forgotten in Paris'. Zelter had missed the point of the anecdote, which is

44 why Goethe - though himself in error - explained it to him in his next letter. 
In Act Two of Elena, an opera by old Mayr of Bergamo, ${ }^{251}$ there is said to be a 1

2 very effective sextet; it is said to be based on a popular Bohemian melody, a sort of 2

3 Notturno. $^{252}$ Would it be possible to get hold of the score of this sextet? 3

$4 \quad$ For several years past your $\operatorname{Fasch}^{253}$ has been lying among a number of papers 4

5 in Jena; I found it lately, and read it at one sitting, with great enlightenment. How 5

6 it transports us into another world! [...] 6

Furthermore one is embarrassed when one judges compositions whose texts 21 are set by oneself. Ultimately a poem, seen in isolation, becomes something of its 22 own right, like any other fragment of a whole, and yet at the same time something 23 different.

I feel that especially in my better attempts, which emerge from the first 25 impression and at the same time are the fruit of a passing mood which is bound up 26 with particular circumstances. And if it is published and stands clearly before me, 27 that is when I find the right sounds, and what is printed is painful to me.

251 Johann Simon Mayr, or Giovanni Simone Mayr (1763-1845), German-Italian 34 composer, b.Bavaria. Pupils include Donizetti.

252 A further reflection from Goethe's reading of Stendhal's book; on 20 November in 35 Milan Stendhal wrote 'They are producing Mayr's opera, Elena, again which they had being 36 playing before the Testa di Bronzo. What languishing! How ecstatic the sextet in Act 2 ! 37 Here is music, like a nocturne, sweet, tender, real melancholy music, such as I have often 38 heard it in Bohemia. This is a work of genius which Old Mayr has retained from his youth 39 or which has been given to him; it has sustained the whole opera.' What is intended is 40 Simon Mayr's opera Elena e Costantino (libretto by Leone Tottola), originally premiered 41 in Naples in 1814. 
1 The opera Il matrimonio segreto may well prove to be the work of several 1 2 composers $^{255}[\ldots]$ I will enquire after the opera Elena; if only [the manuscript] had 2 3 not been burnt. ${ }^{256}$

4 The unfortunate fire also proved to be detrimental for me, for apparently next 4 5 Good Friday will be the last one on which Graun's Passion will be performed 5 6 officially. What I will lose thereby I won't carry away in my trouser pockets. I 6 7 could have fully financed my trip to the spa with this income. 7

14 You have, my dear man, lavished gifts of fine and good words from the depths of 14 15 your musical talent so that I feel obliged to say something friendly in reply [...] 15

16 You didn't understand the joke which I told you. Someone named some of his 16

17 works to that composer and asked him which he considered his best. He answered 17

18 Il matrimonio segreto, meaning the composition by Paesiello. ${ }^{257}$ I don't need to 18

19 explain for you how witty and charming the answer was. [...] 19

26 [...] It is 20 days to Good Friday and you are commanded to be here on the day to 26 27 hear Graun's Passion. The King has even granted me the large opera house for it 27 28 and I have no hope of ever getting it again. [...] 28

29 Mayr's opera Elena was destroyed by fire; worse still the music is unknown. ${ }^{258} 29$ 30 In spite of that I commissioned them to get the piece you want. ${ }^{259}$ I suppose it is the 30 31 well-known Simon Mayr. ${ }^{260}$ You did not write his Christian name, and here no one 31 nineteenth centuries that dealt with the topos of marriage and characterized it with such words as 'scoperto' (discovery), per interesse (intrigue), 'per inganno' (deception).

$37 \quad 256$ The manuscript was presumably lost in the fire in the Königliches Schauspielhaus

38 on 29 July 1817; following the fire, theatrical performances took place in the Königliches

39 Opernhaus until the new theatre opened in 1821.

$40 \quad 257$ Goethe is mistaken here: the opera is by Domenico Cimarosa. 40

41258 The score was burnt in the fire in the Königliches Opernhaus in Berlin on 29 July 41

421817.

$43 \quad 259$ The sextet from the opera Elena e Costantino. 43

44260 The Italian opera composer of German origin Johann Simon Mayr (1763-1845). 44 
knows of any other Mayr among composers. No, no! One of my earlier disciples, 1

2 Meyerbeer by name, ${ }^{261}$ created a commotion in Padua last year with one of his 2

3 operas $^{262}$ and he might be the younger, as you speak of the old Mayr. 3

243. Goethe

My best thanks for 'Um Mitternacht'. ${ }^{263}$ Here is something about old Mayr that 10 will entertain you. ${ }^{264}$ How I wish I could be raised up on Faust's cloak ${ }^{265}$ and let 11 myself down in the opera house at your grand soirée. Human methods will hardly 12 bring me to Berlin. set a seal on your love and regard for me. My son, who is not easily moved, was 23 overjoyed and I fear that out of gratitude he will ask you to be godfather. ${ }^{267}[\ldots] \quad 24$

If I am to be frank with you, then this composure is only on the surface for 25 I have long wished to admire and enjoy precisely the musical character of your 26

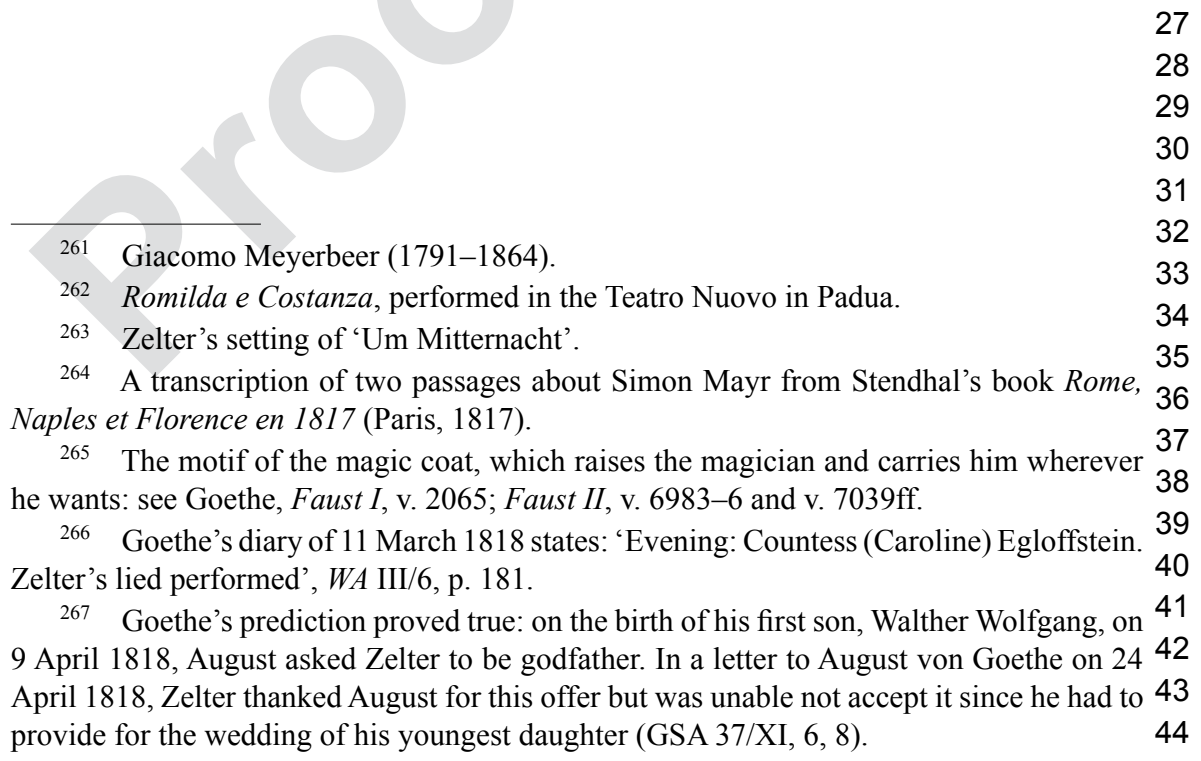

262 Romilda e Costanza, performed in the Teatro Nuovo in Padua. 33

263 Zelter's setting of 'Um Mitternacht'. 34

264 A transcription of two passages about Simon Mayr from Stendhal's book Rome 35 Naples et Florence en 1817 (Paris, 1817).
265 The motif of the magic coat, which raises the magician and carries him wherever 37 he wants: see Goethe, Faust I, v. 2065; Faust II, v. 6983-6 and v. 7039ff. 38 266 Goethe's diary of 11 March 1818 states: 'Evening: Countess (Caroline) Egloffstein. 39 Zelter's lied performed', WA III/6, p. 181.

267 Goethe's prediction proved true: on the birth of his first son, Walther Wolfgang, on 41 9 April 1818, August asked Zelter to be godfather. In a letter to August von Goethe on 2442 April 1818, Zelter thanked August for this offer but was unable not accept it since he had to 43 provide for the wedding of his youngest daughter (GSA 37/XI, 6, 8). 
1 Holy Week, ${ }^{268}$ and now eye and mind are focused on political and social instability 1

2 and anarchy. ${ }^{269}$

3 If I am to be perfectly honest, I take comfort in saying that if your feelings 3

4 are true towards me, you will not invite me to come to Berlin; and on this point 4

5 Schülz, Hirt, Schadow, ${ }^{270}$ and all who really wish me well, agree. It would be all 5

6 the same to our excellent friend Isegrimm ${ }^{271}$ (please remember me to him); in me, 6

7 he would merely have one more person to contradict. I have as much desire to 7

8 hear about the hundred hexameters as about the hundred days of Bonaparte's last 8

9 reign. ${ }^{272}$ God preserve me from German metrics as from a change of government 9

10 in France! The 6/8 time of your 'Um Mitternacht' does everything. Such quantities 10

11 and qualities of tone; such variety of movement, of pauses, and intake of breath; 11

12 this ever-changing sameness! Let the gentlemen with their long and short syllables 12

13 work towards a consensus for a long time, but they will not produce such work as 13

14 yours. [...]

15

16

17

245. Zelter

21 My Good Friday music went off so well ${ }^{273}$ as to bring me in [...] 1,000 thalers 21

22 profit, whereby I am able to supplement my earnings honestly because the entire 22

23 takings amounted to 1,551 thalers, 12 groschen. [...]

24 The poem ${ }^{274}$ looks strange on paper: like a workpiece, veined, grained and at 24

25 the same time transparent. It is like a crown in water. [...] 25

26 Now I am keeping your description together with the music and I am really 26

27 delighted by your ideas, as you recognize them as your own once more. [...] 27

28 Now, my Xenophon, I am sending a little work here once again. You will know 28

29 that the poem was already set to music by me once before and was published. 29

30

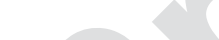

268 Goethe's desire to attend the Sing-Akademie's annual performance of Graun's Der

269 In the foreground Goethe is referring to the issue of censorship, but beyond that also symbolically to the wider issue of the alternation between confusion and order in the 36

37 world.

$38 \quad 270$ State Councillor Christoph Ludwig Friedrich Schultz, Aloys Hirt and Gottfried

39 Schadow had, like Zelter, repeatedly invited Goethe to Berlin.

40271 F. A. Wolf, philologist, author of Prolegomena ad Homerum.

$41 \quad 272 \quad$ T. A. Wolf, philologist, author of Prolegomena ad Homernm. 40

42 from Elba to Paris on 20 March 1815 to the final abdication of his throne on 8 July 1815.42

43273 See $A M Z 20$ (1818), no. 16, 22 April, column 298; MA 20.3, p. 468.

44274 'Um Mitternacht'. 44 
1 If only someone would say Handel composed music just as bad as I, ${ }^{275}$ a cask of 1

2 wine would not deter me from raising a toast to his health by drinking the lot. 2

$3[\ldots]$

$4 \quad$ What beautiful soul then was German enough to sing you that song ${ }^{276}$ without 4

5 Italianisms and with such life that you could not help being pleased, since I needed 5

6 your word to know whether it comes off and works? I have set for you 'Kennst 6

7 du das Land' for the sixth time, ${ }^{277}$ so as to do it once to my own satisfaction; I will 7

8 send the best settings to Weimar [...] 8

9 The enclosed letter is from Boisserée. A young musician from Cologne, ${ }^{278}$ who 9

10 attends my classes here, thought he would be passing through Weimar, which he 10

11 has not done and so he asks me to forward the letter to you. 11

18 You have here once again an industrious little song ${ }^{279}$ to which I would gladly let 18

19 you listen, although I have not yet heard it myself.

20 It became a little motet and I would like to know from you what you think 20

21 about the rearrangement of the verse, ${ }^{280}$ seeing that I had great fun working on the 21

22 poem. I had to set it twice because the first rendition was polemical in nature and 22

23 now it really should be more humorous.

24 Let me also know whether you are happy with the title or give me another, ${ }^{281} 24$

25 because our Tafellieder would have to have a handle, otherwise they fumble about 25

26 in the middle of the pot. [...]

275 Zelter's answer to Goethe's claim: 'Xenophon wrote prose that was just as bad as 32

276 Zelter's setting of Goethe's 'Um Mitternacht'.

277 Mignon's song from Goethe's Wilhelm Meisters Lehrjahre which Zelter had set 34 repeatedly in 1795, 1796, 1812, 1817, 1818.

278 Bernhard Joseph Klein (1793-1832), Director of Music at the Instutute for Church 36 Music in Berlin from 1818.

279 Zelter's four-part setting of Goethe's 'Sänge sind des Lebens Bild'; the autograph 38 entitled 'Apotheose', later altered by Goethe to 'Sängers Ermutigung', is in Goethe's music 39 collection (GSA 32/9). 
1 I would gladly undertake a journey to Göttingen: Forkel has $\operatorname{died}^{282}$ and his 1 2 artistic bequest is to be sold in its entirety. And so one would like to know what is 2 3 there and what the things look like. [...] 3

$4 \quad$ I am not supposed to know that you are sick; whether the danger has passed 4 5 I will hear from you. When you go, take me with you; take the true brother with 5 6 you.

13 I was delighted to receive your consignment of 21 June: it came at exactly the 13 14 right time, as I finally pulled myself together after being in disarray two weeks. 14 15 Actually it was only a cold, which is hard to avoid given the warm weather and 15 16 the sharp wind from the north east. All is well again and I am back to normal, but 16 17 don't know what to turn my attention to. [...]

18 Your motet ${ }^{283}$ delighted and dismayed me: delighted me in so far as I can 18

19 absorb it with the eye and could reasonably enjoy it; dismayed me as I must 19

20 relinquish hope of hearing it. For I have not once been able, with Knebel, to have 20

21 the fun of having the birthday song ${ }^{284}$ performed. There are really lovely voices 21

22 among the young people ${ }^{285}$ here and they also perform well as a choir. However, 22

23 whatever does not sound like 'Lützows wilde Jagd' ${ }^{286}$ has no meaning for anyone. 23

24 As things stand, it is also not advisable to close in on oneself: it is just as bad there 24

25

$26 \quad 282$ Johann Nikolaus Forkel (1749-1818), musicologist and Bach biographer, died on

2720 March 1818.

28283 Zelter's setting of Goethe's poem 'Sänge sind des Lebens Bild'.

29284 'Lustrum ist ein fremdes Wort'. In a letter to Goethe on 9 January 1818 Zelter had

30 enclosed a letter to Betty Wesselhöft and his setting of Goethe's occasional poem for Karl

31 Ludwig von Knebel's birthday with instructions 'to give old Knebel something to listen

32 to'; Betty Wesselhöft explained to Zelter on 4 October 1818 that the performance was

33 too difficult to organize because it involved travelling to Knebel and also because of the 34 unavailability of adequate singers (GSA 95/I, 7, 28).

35285 The students with whom Goethe often came into contact in the winter of 1817/early

36 1818, above all in Frommann's home. Without sympathizing with their ideas, Goethe had a

37 very fatherly forbearance towards them. In the meaning, however, the escalation of conflict

38 with political powers was foreseeable, as well as through the increasing politicization and

38 partly also the radicalization of the students (presumably Goethe knew of the more-or-less

39 partly also the radicalization of the students (presumably Goethe knew of the more-or-less

40 and also through the intensified attacks and countermeasures on the other side.

41286 Poem by Theodor Körner set by Carl Maria von Weber. The Lützow Hunter was a

42 famous volunteer corps in the War of Liberation 1813/1814; Theodor Körner had belonged

43 to it and had died during the war. The song was very popular at that time, particularly

44 among students, who inherited the liberal and national ideas of the War of Liberation. 
1 in Weimar. Moltke ${ }^{287}$ sings nothing other than his own songs, so that the society for 1

2 whose pleasure one would invite would ultimately want to run from it. [...] 2

3 If it is not disagreeable to you, I should like to send a copy of your motet 3

4 to Heidelberg for Thibaut; ${ }^{288}$ although a lawyer, he has a sensitive musical 4

5 temperament, and has, as I hear, gathered about him a circle of dedicated friends 5

6 who perform the compositions of the older masters devotedly, passionately and 6

7 precisely. ${ }^{289}$ It is a reflection of what you have inspired; I cannot say, indeed, how 7

8 good they were, but knowledgeable people were really pleased. [...] 8

9 In general it seems really miraculous when one watches people's activities 9

10 with seriousness and good will. (I speak only about the fine arts of which I am best 10

11 informed.) [...] If I am not mistaken, you composers have a great advantage in that 11

12 at the very beginning you can urge your students to take up the established laws. 12

13 I will also not investigate how it comes about that one individual after the other 13

14 loses their way arbitrarily.

21 As soon as I have recovered I am off to Darmstadt to wait upon my Grand Duke 21

22 of the orchestra ${ }^{290}$ who has coaxed a new opera from Spontini. ${ }^{291}$ In Cassel I heard 22

23 a first-rate performance of Rossini's world-famous opera, Tancredi. ${ }^{292}$ The music 23

24 is charming, which means it is of the genuine Italian kind, chiaro, puro e sicuro. ${ }^{293} 24$

287 The Weimar tenor and actor Carl Moltke, who also composed, and was a founder 28 member of Goethe's house choir.

288 Goethe became acquainted with the lawyer and writer on music, Anton Friedrich 30 Justus Thibaut during his Professorship in Jena (1802-06). Goethe resumed contact with 31 him first when August von Goethe heard Thibaut lecture in 1808 and later again during 32 Goethe's sojourn in Heidelberg in 1814/1815.

289 The musical gatherings that Thibaut held in his home from 1810 . 33

290 Under the direction of the Grand Duke Ludwig I from Hessen-Darmstadt, the 34 Krebs' Theatre-Society was taken over and reformed as the court theatre. Most of the 36 rehearsals, which were organized as social events in the early evening, were directed by $\begin{aligned} & 36 \\ & 37\end{aligned}$ the Grand Duke himself. German libretto by Ignaz Castelli) was premiered in Paris on 28 May 1817 and performed 40 in Darmstadt on 7 November 1819.

292 Zelter attended the performance on 20 August 1818 in the Kurfürstliches Hoftheater 42 in Cassel. 
1 Flowing melody, style and movement in every number; even the overture is nice, 1

2 although it has nothing to do with the piece

3 I also found a small, sweet Italian Mademoiselle Marinoni in Cassel. She is 3

420 , not too big, and teaches singing to the young princesses ${ }^{294}$ of the Electoral 4

5 Princess. ${ }^{295}$ Admittedly she would be much too good for that, but she has a slight 5

6 limp with her left foot and therefore will not take to the stage. She has a lovely full 6

7 mezzo-soprano voice which would already sound exceptional in a church; vocal 7

8 agility, taste and truth in all she does. I have induced her to learn to sing some 8

9 German works and you would have really liked your 'Nur wer die Sehnsucht 9

10 kennt' had you heard it. ${ }^{296}$ She took it very favourably when I mentioned to her 10

11 that the German people would not take it more amiss to hear good German from 11

12 her beautiful mouth than Italians do when they hear their language badly sung by 12

13 Germans $[. .] \quad$.

20 [...] The imperial mother ${ }^{297}$ arrived here between three and four o'clock on 20

21 Christmas Eve, accompanied by my King, ${ }^{298}$ who rode in front of her carriage. I 21

22 thought I recognized the Grand Duchess in the Empress's carriage. It was known 22

23 than the Empress would remain here until Sunday. The King had ordered the 23

24 museum, the library, the university, the art gallery, the Akademie der Künste, the 24

25 Charité, the maternity hospital, and everything else there is to see here, to be made 25

26 ready to receive the noble guests and I didn't think I would see the Empress in the 26

27 Sing-Akademie, since our present location ${ }^{299}$ - on account of building the academy 27

28 premises - is quite unsuitable to receive guests. It is so small that the society itself 28

295 Friederike Christiane Auguste, Princess of Prussia (1780-1841), daughter of

296 Presumably Zelter's rendition rather than the 1795 setting by Reichardt published in Goethe's novel.

37297 Maria Fjodorowna (1759-1828), widow of Tzar Paul I of Russia, mother of Alexander I of Russia and Maria Pawlowna of Sachsen-Weimar-Eisenach, who, on this occasion, accompanied her mother from Weimar to Berlin.

40298 Friedrich Wilhelm III (1770-1840) of Prussia. 40

41299 During the reconstruction of the academy building and in lieu of the round room

42 upstairs, the Sing-Akademie was assigned a room on the first floor of the new wing on

43 Universitätstraße. In a letter of 19 May 1818, Zelter complained bitterly about the 44 narrowness of the room; Schröder, Carl Friedrich Zelter und die Akademie, p. 23. 
1 doesn't have room and since it is above a stable, the smell is unbearable, just like 1

2 the cold because it cannot be heated.

3 However, completely unexpectedly Prince Radziwill sent [a message] to me 3

4 to say that the Empress wanted to hear the Sing-Akademie; the whole court was 4

5 looking forward to it and he wanted to give me his hall. It was the 11th day of 5

6 Christmas. Everyone was scattered about the city and it was no bagatelle to call 6

7 together 300 people in Berlin. On the second day of celebration around midday, 7

8 they came together and it was decided to wait on the noble guest at two o'clock. 8

9 Two hours later, around four o'clock, they assembled in Radziwill's palace ${ }^{300}$ and 9

10 around five o'clock the Empress arrived, led by the King, along with the whole 10

11 entourage. When the Empress stepped into the hall, she was immediately greeted 11

12 by the singing of a poem to the well-known melody: 'Heil Dir!' ${ }^{301}$ The two poems 12

13 were written and printed in two hours. Then a psalm by Fasch followed, 'Wohl 13

14 dem Manne der rechtschaffen lebet - Der ist wie ein Baum der seine Frucht bringet 14

15 zu seiner Zeit; und was er machet das gerät wohl. ${ }^{302}$ The whole thing closed with a 15

16 fugue: 'Meine Zunge rühmt im Wettgesang Dein Lob!' ${ }^{303}$ I had chosen this psalm 16

17 in connection with the recently celebrated birthday of Kaiser Alexander. ${ }^{304} \quad 17$

18 After [the performance of] these songs, which lasted less than half an hour, the 18

19 Empress approached the choir, greeting them and thanking them. My answers to 19

20 her questions about the foundation, progress, situation and age of the institution 20

21 seemed to please her and she departed from us then because the theatre festivities, 21

22 which the King had arranged, awaited her.

23 Whether this could have been a pleasure for a noble woman of such obvious 23

24 understanding, for whom it was thrown together in haste and which almost passed 24

25 by like a cool breeze, I cannot tell you. It was a day of celebration. Everyone was 25

26 busy in his house to celebrate a public holiday in which everyone played his own 26

27 part. Torn out here in a strange house, completely unprepared and so on. The music 27

28 went off perfectly because I am always prepared for all instances of this kind with 28

29 an existing repertoire. But to have an auditorium before you which one has no time 29

30 to enjoy and is only waiting for the end, take from that what you can.

30

31 Recommend me to your excellent Grand Duchess. I thought about nothing else 31

32 on the entire journey here from Weimar other than the enjoyment which I found 32

300 The performance is reported in the Vossische Zeitung, 29 December 1818 36

301 The melody for 'Heil Dir im Siegerkranz' first occurred in the anonymous setting 37 'God save the King' in Thesaurus Musicus (1744); both text and music were attributed to 38 Henry Carey.

303 The text is not word-for-word as in the biblical psalter; it is possibly one of the 41 many poetic versions of psalms written by various authors in the seventeenth century. The 42 304 Alexander I of Russia, Aleksandr Pavlovich (1777-1825). 
1 in her church service. ${ }^{305}$ It uplifted me greatly, and don't forget your promise to 1 2 provide me with the mass of Saint Chrysostom. ${ }^{306} 2$

$3[\ldots]$ If fish were not a dumb species, ${ }^{307}$ I would put the following setting of this 3

4 ballad in their mouths. ${ }^{308}$ Therefore, have it sung for you by such beings who are 4

5 not dumb but also not too restricted in sound and words. Some verses have driven 5

6 me almost to despair. Many are mastered except for the poetic enjambment in the 6

7 eighth strophe between verses three and four, which is lovely in itself but is very 7

8 disturbing when sung: would it be possible to alter it? 8

929

10 10

11 250. Goethe 11

$12 \quad 12$

13 Weimar, 4 January 181913

$14 \quad 14$

15 [...] Since you left ${ }^{309} \mathrm{I}$ have done next to nothing of what I had resolved to do. 15

16 On the occasion of an imperial visit ${ }^{310}$ I could not refuse to contribute to some 16

17 festivities, so I undertook to furnish a masque. The programme is enclosed - the 17

18 explanatory poems shall be sent to you later. ${ }^{311}$

19 The procession consisted of nearly 150 people. To dress them appropriately, 19

20 to group them, to arrange them in rank and file, and when they finally appeared to 20

21 explain what they were meant to represent, was no small task. It took me more than 21

22 five weeks. However, in return we obtained universal applause, which certainly 22

23 was well earned by the great outlay of imagination, time and expense. Those who 23

24

25305 Zelter had attended a service in the chapel erected for Maria Pawlowna and the 25

26 Russian orthodox community in Weimar on 1 November 1818. See Goethe's diary entry: 26

27 'Ottilie with Zelter and Nicholovius in the Greek chapel', WA III/6, p. 260.

28306 Under the name of Saint John Chrysostom an early liturgy from the Middle Ages 28

29 has been handed down, a small section of which can be attributed to Chrysostom. It is to 29

30 this day the official mass of the orthodox service. Apparently Zelter had heard it on his visit 30

31 to the Russian Orthodox Church in Weimar. 31

$32 \quad 307$ Like Zelter, Goethe also uses the image of a foolish fish as a metaphor for 32

33 unmusical people.

$34 \quad 308$ Zelter's setting of Goethe's ballad 'Herein, o du Guter!' for solo voice and piano. 34

35 Zelter's manuscript is in Goethe's music collection (GSA 32/25); a copy dated 20 October 35

361818 is found in Zelter's papers: (SBB PK: Mus. ms. Autogr. Zelter 29-2). 36

$37 \quad 309 \quad$ Zelter was in Weimar from 25 October to 1 November 1818.

$38 \quad 310$ The Russian Empress, Maria Fjodorowna, visited the Weimar Court from 3925 October to 21 December 1818.

39311 The last and most important of all Goethe's masques, Bei Allerhöchster Anwesenheit 39

40 The last and most important of all Goethe's masques, Bei AllerhöchsterAnwesenheit 40

41 during Goethe's visit to Berka, 17 November to 6 December. Although no longer Director

42 of the Weimar theatre, Goethe directed rehearsals and a spectacular performance took place

43 on 18 December 1818. The masque was published by Cotta in the Morgenblatt, no. 309 on 43

44 Christmas Day $1818 . \quad 44$ 
1 took part spared no expense in dressing themselves up. Yet ultimately all of this, 1

2 vanishing in a few moments like a firework that explodes in the air, was costly 2

3 enough.

$4 \quad$ I personally have little to complain of, for the poems, with which I took a great 4

5 deal of trouble, exist, and an expensive present from the Empress, ${ }^{312}$ enhanced by 5

6 the friendly, gracious and confidential way she received me, repaid me beyond all 6

7 expectation. [...]

8 Even the sight of your composition makes me happy again. I will endeavour to 8

9 hear it now and see that I amend the awkward passages in the song. 9

10 I must tell you, by the way, that I spent three consecutive weeks in Berka 10

11 writing the poems for the procession; the Inspector ${ }^{313}$ played to me every day for 11

12 from three to four hours and at my request, in historical order, selections from 12

13 Sebastian Bach to Beethoven, including Philipp Emanuel, Handel, Mozart, Haydn, 13

14 Dussek $^{314}$ too, and others like him. At the same time I studied Marperger's Der 14

15 vollkommene Capellmeister ${ }^{315}$ and could not help smiling as I learned. Yet how 15

16 serious and conscientious those days were, and how such a man must have felt the 16

17 trammel of a lack of culture that held him captive!

18 I have bought Das Wohltemperirte Clavier, as well as Bach's Chorales, and 18

19 have presented them to the Inspector as a Christmas gift, with which he may 19

20 refresh me when he comes here on a visit, and educate me when I go back to him 20

21 again.

22 With your guidance I should indeed like to sink myself into the world of the 22

23 chorale, into those depths where I do not know how to help myself unaided. The old 23

24 intonations and basic musical practice are constantly applied to modern songs, and 24

25 imitated by younger organists of more recent times; the ancient texts are set aside 25

26 and inferior ones substituted, etc. How different is the sound of the prohibited song 26

27 'Wie schön leuchtet der Morgenstern' from that of the revised version now sung to 27

28 the same melody; and yet the genuine and oldest version of all, probably a Latin 28

29 one, would be still more suitable and appropriate. ${ }^{316}$ You see I am again sniffing 29

30 about on the borders of your territory, but where I am fishing, nothing can come of 30

31 it. ${ }^{317}$ This, however, is not the only point which would make one despair. $\quad 31$

32

33

34

35

36

37
312 A box with the portrait of the Russian empress on it, valued at 400 thaler. 33

313 Johann Heinrich Friedrich Schütz (1779-1829). 34

314 Johann Ludwig Dussek (1760-1812), Bohemian composer and pianist 35

315 Johann Mattheson, Der vollkommene Capellmeister (Hamburg, 1739). Goethe 36 misnames the author as the music theoretician Friedrich Wilhelm Marpurg (1718-95); ZG 37 2 June 1819.

316 'Wie schön leuchtet der Morgenstern' is not in the revised edition of Herder's 39 Weimarisches Gesangbuch (1795, r.1820) but the volume contains seven hymns which can 40 be sung to the same melody. It is not clear to which of them Goethe's criticism is directed. 41

317 Goethe uses Zelter's metaphor to illustrate the difficulties of hearing vocal music 42 in Weimar; see Goethe's letter to Zelter on 4 May 1814. The house choir which Goethe 43 founded in 1807, which ceased its music-making in 1811. From the end of 1812 the choir 44 
5 Here I am sending the lament, ${ }^{318}$ which I found easier than I originally thought as 6 you will notice from the music. I would like a few comments from you. It is a very 7 easy melody. It is really a death march: harps, trumpets and muted timpani drums 8 are called for. The refrain is sung in unison by a choir of young voices and altos.

9 I have altered the second strophe because of a double syllable ${ }^{319}$ and in the last 10 line of the final strophe the words are changed around to suit the accentuation. ${ }^{320} 10$ 11 Let me know if it is not right and I will arrange it as it should go. [...] 11

12 We have had a rehearsal to mark our celebration of the Three Wise Men, ${ }^{321} 12$

13 which, because of the bean feast ${ }^{322}$ at the court, had to be postponed until tomorrow. 13

14 I have composed some music for it; ${ }^{323}$ however, on the whole I am not satisfied 14

15 with it. Schadow or someone else will tell you what it should all mean. It is a 15

16 mixture of many things and contains much good so that we don't all fall asleep. 16

17 The worst thing is that no one does what he can; because if we did what we could, 17

18 we would not be too bad. 18

19

27 only met occasionally as Goethe no longer had the same impetus to host a house choir on 27

28 account of the type of music that its members wanted to perform.

29318 Zelter's setting of Goethe's 'Klaggesang. Irisch' ('So singet laut den Pillalu'), 29

30 dated 6 January 1819, is in Goethe's music collection (GSA 32/22). The Berlin manuscript 30

31 carries the same date and additional dedication: 'For Langermann' (SBB Mus ms. Autogr. 31

32 Zelter 24, no. 7). The song was first published in Zelter's Sechs Deutsche Lieder für die 32

33 Bass-Stimme mit Begleitung des Pianoforte (1826).

$34 \quad 319$ In place of Goethe's 'Die Eule kam vorbei geschwingt [...] Ihr nun die Totensänge 35 singt', Zelter wrote: 'die Eule kam herbei geschwirrt [...] Ihr nun in toter Wüste irrt'.

$36 \quad 320$ Zelter replaced Goethe's 'Des Herrn einziger Sohn ist fort' with 'der einzige Sohn

36 des Herrn ist fort'.

37 The annual festival of the Berliner Künstlerverein (Society of Artists) which took

38 place on 9 January 1819 rather than on its usual date, 6 January; see Vossische Zeitung,

39 12 January 1819; MA 20.3, p. 482.

40322 A custom on the day or previous evening of the Festival of the Three Wise Men:

41 whoever from the society finds a bean baked in a cake is for that day the King of the Beans.

42 There are other games and carnival entertainment built around this.

$43 \quad 323$ Zelter, Gloria; a review of both work and performance is published in the Vossische 
5 Writing in haste I will only remark of ['Klaggesang'], enclosed in the last [letter], 5

6 that in the first and last four-line strophes, on the words 'Ochorro orro ollalu', the 6

7 notes of the melody must be:

8

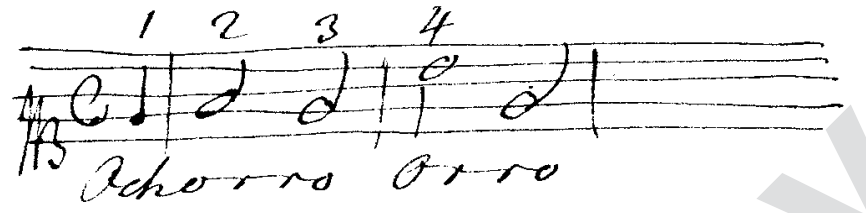

so that the note marked with 4 , which is ' $F$ ' in the manuscript I sent, should be 15 'B', as can be seen here, and again in the final strophe. Everything else remains 16 5

18 Should you be willing to send me your elucidatory poems, please do so as soon 18

19 as possible, as I am in the mood for composing right now; I always need more 19

20 time for freeing myself from my usual surroundings than I do for the actual work. 20

21 I could not help smiling, any more than you could, when I heard you had read 21

22 Mattheson's vollkommene Capellmeister. ${ }^{324}$ This man was Legation Secretary for 22

23 Great Britain up to the time of his death and an eminently useful statesman at the 23

24 same time. By the time he had reached his seventy-second year, he had written as 24

25 many works, mainly musical, which make a strange impression nowadays. I am 25

26 very fond of dipping into them, for they always give me ideas which I wouldn't 26

27 come across otherwise.

28 Some time ago I sent you a good manuscript copy of Das Wohltemperirte 28

29 Clavier, so you ought not to have been forced to buy it. ${ }^{325}$

30 The original Latin [text] of which our 'Wie schön leuchtet der Morgenstern' 30

31 might be a translation is not known; in old songbooks they like to give the Latin 31

32 beginning. It is attributed to Philipp Nicolai, Pastor of Hamburg, because it is 32

33 printed in his Freudenspiegel published in Hamburg in 1598. ${ }^{326}$ Wilhelm Ernst, 33

34 Count and Lord of Waldeck (a name with is encoded in the opening letters of 34

325 When Zelter sent Goethe a copy of J.S. Bach's Das Wohltemperirte Clavier is 37 unknown. It is possible that Zelter is mistaking it for the copy of the 24 Preludes and Fugues 38 which he had enclosed in a package to the inspector, Schütz, on 8 to 12 May 1816. Goethe's 39 reaction would seem to confirm this.

326 The well-known church song first appeared in Philipp Nicolai's FrewdenSpiegel 41

deß ewigen Lebens (Frankfurt am Main, 1599). Zelter's information '1598 in Hamburg' 42

43 is incorrect. Nicolai's song 'Wie schön leuchtet der Morgenstern' belongs to the most 43

44 important Protestant hymns and has been firmly established in the evangelical liturgy since 44 
1 the stanzas of the song), ${ }^{327}$ could be the author and perhaps in that case it is also 1

2 original. NB. It is in the Porst Songbook, ${ }^{328}$ because more recent editions don't 2

3 contain these facts. 3

10 Should an idea for a song for our artists' society occur to you, ${ }^{329}$ then I would 10 11 like you to write it. On festive occasions the women are brought along and there 11 12 is singing at table. As I have, however, mostly composed male-voice settings, 12 13 very little is suitable and you know our poets: you can't do anything with the 13 14 woolliness.

15 On my last trip to Weimar we searched for 'Dir zu eröffnen mein Herz' and it 15

16 was lost. I enclose it here once again. ${ }^{330}$ It is better that you have two copies than 16

17 none at all. The young bass ${ }^{331}$ whom I admired on the occasion of the service for 17

18 your Imperial Princess would certainly be able to sing it to your satisfaction with 18

19 his touching, clear voice. 19

20 You would certainly have been delighted with your Hafiz 'Aus wie vielen 20

21 Elementen' ${ }^{332}$ at our Liedertafel last Tuesday. The piece has a quiet, certain and 21

22 lively pathos, so I could hear it myself not without edification, and since I came 22

23 across the first draft when rummaging about, I also enclose this, even though you 23

24 might have it already. 24

25 Yesterday evening, Langermann sang ['Klaggesang'] for me for the first time. 25

26 The piece is striking and touching and I would like to know what you think about 26

the first half of the seventeenth century. The song has received countless arrangements from

33 Michael Praetorius and Samuel Scheidt down to the present day liturgical practice.

34 From 1588 to 1596 Nicolai Pfarrer was court preacher and tutor of Wilhelm Ernst Graf von Waldeck in Altwildung.

328 Anon., Geistliche und Liebliche Lieder Welche Der Geist des Glaubens [...] in den

36 vorigen und jetzigen Zeiten gedichtet [...] Nebst Einigen Gebeten, rev. edition edited by 37 Johann Porst (Berlin, 1708 r.1713).

$38 \quad 329$ The Berliner Künstlerverein founded by Gottfried Schadow on 22 November 391814.

$40 \quad 330$ The setting is no longer in Goethe's music collection. 40

41331 The name of the singer cannot be determined. 41

42332 A copy of a four-part setting by Zelter entitled 'Liederstoff' is in Goethe's music 42

43 collection (GSA 32/36); as a fair copy with few corrections, it is unlikely that it is the 'first 43

44 draft' enclosed here. $\quad 44$ 
it. Writing it, my feeling was between Irish and Iroquois, ${ }^{333}$ which is essentially all 1

2 the same to me because I know neither: it will be human. 2

3

4

5

6

7

8

$9[\ldots]$ Both the 'Ballade' and the 'Klaggesang' were performed to my greatest delight 9

10 by Inspector Schütz, whom I deliberately employed. I find both very successful, as 10

11 one discovers with repeated listening. [...]

Das Wohltemperirte Clavier would be doubly welcome, when it arrives, even as a 12

13 second copy. I will keep it in the town and the good inspector will not always need 13

14 to carry his here from Berka. The correction is also made to 'Klaggesang'. ${ }^{334} 14$

21 Your Festgedichte leaves me wanting more! ${ }^{335}$ If at first I read them through, one 21

22 after another, in order to become acquainted with the whole [work], now I enjoy 22

23 them for breakfast, before dinner, after dinner, in the evening and before going to 23

24 sleep, one after the other [...]. It reminds me of a Haydn minuet, which I enjoy in 24

25 a similar way.

It is a matter of course that you should like my Festgedichte, for while in Berka, 32

33 where I wrote them - reading Marperger and listening to Schütz playing - I thought 33

34 of you constantly and wished we were nearer one another. You have already got 34

35 more than I can say out of this little series. Variety and freedom of metre came 35

37333 The Irish origins of the song (from Caroline Lamb's novel Glenarvon) and the 37 exotic world of the north American Indians - a word play, perhaps, expressing something 38 foreign, barbaric and yet human.

40334 Goethe's correction can be identified in the vocal line (bar 11) of Zelter's 40 manuscript.

42335 A complete copy of Goethe's masque was published at the end of May 1819; 42

43 presumably Zelter received his copy from August von Goethe, who visited Zelter at this 43

44 time. 
1 fortuitously while I was at work and contemplating the many different subjects. 1

2 There is very little trace of modern artificiality; my main aim was the eight-line 2

3 stanza and it is really curious that not one sonnet would fit into the cycle; even 3

4 your instinct will hardly be able to suggest where it could have been introduced. 4

$5[\ldots] \quad 5$

$6 \quad 6$

$\begin{array}{ll}7 & 7 \\ 8 & 8\end{array}$

8 257. Zelter 8

9 (1) 9

$10 \quad$ Berlin, 2 June 181910

$11 \quad 11$

12 [...] Your Festgedichte are being passed from me to Langermann and back again. 12

$13 \mathrm{I}$, at least, did not feel the lack of a sonnet because, despite my efforts, I have never 13

14 been able to wrest from it a natural musical form. 14

15 You speak in your letter of having read Marperger. Do you not mean Marpurg 15

16 or Kirnberger? ${ }^{336}$ I don't know a Marperger. If it is Marpurg, he is one of the best, 16

17 for his style of writing is the best, but here, too, as in the plastic arts, words fail 17

18 to explain the essence and what one wants to know one can only learn by doing 18

19 oneself. He has written much, ${ }^{337}$ and was constantly at issue with Kirnberger about 19

20 matters in which, in my judgement, Kirnberger was right; although the latter, when 20

21 it came to writing, could not compare with the former, and consequently was 21

22 always at a disadvantage before the world. I knew both of those men personally, 22

23 and learnt from their conflicting opinions most of what I wished to know myself. 23

$24[\ldots] \quad 24$

25 The children will have plenty to tell you about the performance of the two 25

26 scenes from Faust; ${ }^{338}$ it was a start, anyhow, and there was no lack of goodwill. 26

27

28

29

$30-30$

$31+31$

$32 \quad 32$

$33-33$

$34-34$

$35-336 \quad$ Zelter wrote about both in his autobiographies; Kirnberger comes across as a very 35

$36 \quad 336$ Zelter wrote about both in his autobiographies; Kirnberger comes across as a very 36

37 angry person, although Zelter esteemed him as a critic of his early songs. 37

337 Friedrich Wilhelm Marpurg, Die Kunst das Clavier zu spielen (Berlin, 1750, enh.
38 ed. 1762; Hildesheim: G. Olms, reprint 1969); Kritische Briefe über die Tonkunst (Berlin,
39

39 1760-64; Hildesheim, New York: G. Olms, reprint 1974); Abhandlung von der Fuge 2 vols

40 (Berlin: A. Haude and JC Spener, 1753-54; Hildesheim: G. Olms, reprint 1970).

41338 Radziwill's setting and production of two scenes from Goethe's Faust were

42 rehearsed and performed in 1816. On 24 May 1819 the scenes were performed again for

43 Radziwill's birthday; see August von Goethe's letter to his father $(G J b 28,1907$, p. 36); the 43

44 performance was repeated on 7 June 1817. 
5 I arrived here last Saturday, after a six-day boat journey down the Danube from 5

6 Regensburg. ${ }^{339}$ [...] After my arrival on Saturday evening I went directly to the 6

7 Kärntnertortheater. The opera Othello, by Rossini, ${ }^{340}$ is a fine new score which 7

8 I heard performed really well here for the first time. The composer sacked the 8

9 poet $^{341}$ and set some kind of libretto to music, which one can piece together really 9

10 well from the score. He is, without doubt, a man of genius and knows how to use 10

11 the means at his disposal, without, like Gluck, first having to think of the invention 11

12 of the instruments needed to play his music. The music has crescendi which really 12

13 mount, he can really let go and finally the idea emerges clearly. He plays with the 13

14 notes and the notes play with him.

15 Sunday to the Marinelli Theatre. Three pieces were performed: (i) Die Werber ${ }^{342} 15$

16 (ii) Die Damenhüte im Theater ${ }^{343}$ (iii) a pantomime, Schulmeister Beistrich, 16

17 otherwise known as Das Donnerwetter. ${ }^{344}[\ldots]$

18 Wednesday, 21 July: A second work (Der lustige Fritz) ${ }^{345}$ in the Marinelli 18

19 Theatre, which was strongly recommended to me, was not a success. It is a popular 19

20 work with audiences yet all the mutual good will was not enough to bring it off. 20

21 Thursday: Yesterday evening I heard Rossini's fourth Opera, La Gazza 21

$22 \mathrm{Ladra} ;{ }^{346}$ the subject is lovely and something very fine might have been made of 22

23 it; properly speaking, there should be a comic figure - this, however, the poet ${ }^{347} 23$

24 has forgotten; on the other hand, the emotional element preponderates, and of this 24

25 again the composer has forgotten to make the most. On the whole, however, the 25

26 music is witty and unrestrained, even to the point of licentiousness, and in this 26

$339-$ In Zelter's library there is a travelogue, Donaureise von Regensburg bis Wien, 28 Angabe aller Ortschaften an beiden Ufern, ihrer Merkwürdigkeiten, und der Flüsse, welche 30 sich mit der Donau vereinigen (Regensburg, 1802).

340 The first German performance of this opera (in a libretto by Johann Christoph 31 Grünbaum) took place in Vienna on 29 April 1819; Zelter attended the performance on 32 17 July 1819 .

341 A reference to the original Italian librettist, Francesco Berio di Salsa, who took a 34

great deal of licence with Shakespeare's text.

342 Anton Sartori's comedy Die Werber oder Die belohnte Treue. 36

343 A local farce by Carl Meisl. 37

344 Carl Meisl's pantomime Das Donnerwetter, with music by Franz Joseph Volkert. 38

345 Carl Meisl's Der lustige Fritz. Ein Märchen aus neuer Zeit with music by Franz 39 Volkert. $\quad 40$

346 First performed in Joseph von Seyfried's translation, Die diebische Elster, on 41

3 May 1819 in the Theater an der Wien. Zelter attended the ninth performance on 21 July; 42 
1 respect it borders on Mozart, who, however, is more daring and profound. The 1

2 singing was not much to speak of, but the audience was content with everything as

3 everyone obviously did his best. [...]

4 Salieri, who has written more than forty operas, is the most honest fellow in the

5 world; he is as busy as ever in the most childlike way. ${ }^{348}$ He is now 69 years old,

6 and considers himself outdated; this he need not do, for his talent still flows, and

7 none of his pupils surpasses him. ${ }^{349}$

8 Evening: I have just seen and heard a performance of Mozart's Titus, ${ }^{350}$ which

9 I think I am right in saying was done more successfully at Weimar. ${ }^{351}$ All the ladies

10 (there were four of them) were old enough to have been grandmothers, but are well 10

11 trained. Campi ${ }^{352}$ must have been excellent in her youth; now, however, she looks 11

12 as if she had been old while still in the womb. Such a Titus has still to be born: he 12

13 is to be in love with all young women, who all want to kill him. 13

14 Saturday evening, 24 July: Yesterday I bought myself an umbrella for 26 florins. 14

15 With this in mind I went to the Prater after eating and got as wet as a drowned rat as 15

16 I had left the umbrella at home, so I went to the Marinelli Theatre to laugh myself 16

17 dry again. Now imagine my despair! Der verlorne Sohn $^{353}$ (as yesterday's play was 17

18 called), I thought, would be able to laugh himself and make others laugh: wrong! 18

19 The 'prodigal' [...] son is a moralistic melodrama, with choruses and dancing. 19

20 The son, who is a scoundrel, has a wife, has learnt absolutely nothing; accordingly 20

21 he loses everything and the piece ends after Act Four, in which the son becomes 21

22 fortunate once again instead of getting his just deserts. 22

23 The poet Carpani ${ }^{354}$ is one of my old acquaintances, whom I first got to know 23

24 in Teplitz in 1810. As the good old gentleman does not speak a word of German, 24

$25 \mathrm{I}$ am obliged to talk to him in Italian, which is getting better than I had expected 25

26 after so many years of not speaking it. You will remember Carpani when I remind 26

27 you of a little book of his, Le Haydine, which contains some very nice stories 27

28 about old Hadyn. 28

349 An ill-informed statement, considering Salieri's students included Beethoven, Schubert, Liszt, Meyerbeer and Moscheles.

350 Mozart's opera seria, La Clemenza di Tito, in German translation Titus der Gütige,

35 had been in the repertoire of the Kärnthnerthortheater since 1817; Zelter attended the 36 performance on 22 July 1819.

$37 \quad 351 \quad$ In Christian August Vulpius's translation on 21 December 1799. 37

$38 \quad 352$ In Christian August Vulpius's translation on 21 December 1799.

39 Vitellia.

The Italian singer Antonia Campi née Miklaszewicz (1773-1822) who played

40 Vitellia.

41 Melodrama by Ferdinand Rosenau with music by Joseph Drechsler.

354 Giuseppi Antonio Carpani (1751/2-1825), Italian writer and librettist, known

42 chiefly for his work Le Haydine (Milan, 1812), an enthusiastic eulogy on Haydn; the

43 biography is written in the form of 17 long letters to an anonymous friend. He also published

44 Le Rossiniane, a similar eulogy on Rossini. 
Weig ${ }^{355}$ has told me a great many interesting things about Mozart's youth and 1

2 last years. Weigl is a fine, stately man of the world; his works are pure, measured, 2

3 natural, and full of character; he doesn't aim very high and what he achieves has 3

4 an immediate effect.

5 The double bass is placed in a slanting position, so that the player sits beside it. 5

6 I have not noticed any loss of quality and should like to see this method universally 6

7 adopted. Those accursed goosenecks offend my eyes with their spikes; on the 7

8 other hand, the prompter's boxes here are as large as in other parts of Germany 8

9 and prevent the eye from finding a centre for itself, and in addition to this there is 9

10 the ridiculously high seat of the conductor, so intrusive in all his movements. One 10

11 can hardly understand why such vulgarity is allowed. 11

12 The Burg Theatre is in high repute here, but the actors are away on their 12

13 holidays until next month. I intend now and then to slip over from Baden to Vienna 13

14 and hope it will be worth it. The Theater an der Wien is an attractive house, big 14

15 enough with five rows of boxes, exclusive of the parterre boxes. One can see and 15

16 hear there very comfortably.

17 The Marinelli or Casperl Theatre (Leopoldstadt) is also a good one with 17 18 three rows of boxes, but the seats are so extremely narrow that I can hardly find 18

19 room for my knees. The Karntnerthor Theatre is the best; the music is attractive, 19

20 appropriate and on the whole quite good, but the singers and players are dreadfully 20

21 overworked and weary, for every day they have an opera and a rehearsal, and often 21

22 two rehearsals on the same day. The instruments hold up even less than the men. 22

23 The players in the orchestra are badly treated; several of them eat their dinner and 23

24 supper in the theatre because they have no other time for it. Weigl, too, complained 24

25 of the difficulty of his duties, and he has to compose as well.

26 Monday, 26 July. Yesterday was Sunday, and I saw the Prater in its Sunday 26

27 dress. Four rows of sturdy old chestnut trees form three avenues that begin at 27

28 the Leopoldstadt and continue for half a mile directly to the Danube. The middle 28

29 one, 45 feet wide, is for carriages; the two side avenues, 24 feet wide, are for 29

30 pedestrians. Several hundred carriages are to be seen on the move, some of them 30

31 are very splendid; the small carriages turn out too; close at hand are the foot 31

32 passengers, alone, in couples, or in groups. The variety is charming; it is delightful 32

33 to see a promenade of so many men and women, beautifully dressed in every kind 33

34 of costume, flitting about like shadows. On either side, cafes and resting areas are 34

35 set up under the shade of noble groups of trees; everything is a picture of neatness 35

36 and cleanliness. We sit down; music, issuing from the wood, echoes in our ears on 36

37 all sides; now we are at the opera, now at the ball, or on parade. Coffee and cakes 37

38 are served. A child presents me with a posy, a pretty girl offers me water as clear as 38

39 crystal, an old woman hands me a toothpick; all this is paid for by copper kreutzers 39

40 only, a good riddance for bad rubbish, for they are as heavy as one's conscience and 40

41 drag your pockets down to your feet. This avenue, however, is not the only thing 41

42

$43 \quad 355$ Joseph Weigl (1766-1846), Austrian composer, conductor and Kapellmeister at 43

44 the Vienna Court Theatre; best known as the composer of Die Schweizerfamilie. 
1 that forms the Prater. A second and third just like it fan out from the Leopoldstadt 1 2 towards the Danube (that is, an arm of the Danube). Here we see, as it were, how 3 the other half live, I mean the real people. The wider spaces of ground towards the 4 Danube are occupied by refreshment stalls where you can get beer, wine, meat, 5 ice-cream and drinks of all kinds, with the exception of coffee. The three single 6 cafes in the great avenues have exclusive rights in selling coffee. These second7 class bars so numerous, and so close to one another that the guests of one host 8 are indistinguishable from those of another, and one is in danger of consuming 9 what somebody else has paid for. This is Vienna proper; between these tables 10 and chairs, and drinking booths, smokers, bands, and merry-go-rounds, a happy 11 crowd moves backwards and forwards. People jog along, stop, meet a friend; it 11 12 is a constant rest and bustle at the same time. Nothing is closed in, and there is 12 13 no obstacle; for although the owners of houses are landlords, yet the ground and 13 14 soil belong to the Emperor, and must not be enclosed in any way. The impression 14 15 produced on the mind by the behaviour of the people - I will not call it the crowd - 15 16 is one of careless oblivion. I don't remember thinking or observing anything, and 16 17 what I now write, strictly speaking, I imagine, without being able to say: so it is, 17 18 and so it was. What gives a really pleasant aspect to the whole is the large crowd 18 19 of happy faces, belonging to all kinds of people, who, reconciled today with their 19 20 God, see the world as they would like it to be. Neither men, nor women, nor old 20 21 age, nor youth is here as it ought to be. There is an idea in existence, as there is an 21 22 existence in the idea. The first day I went into the theatre a violinist was tuning his 22 23 instrument. A waiter came into the pit, and sang in the same key as the violin: 23

24

25

26

27

28 2

3

6

7

9

0


1 it. Yesterday we had the finest weather imaginable. It had rained itself dry; there 1

2 was no dust, no evening fog, no breeze, but a dark purple and blue evening sky. 2

3 The rockets shot up straight as arrows, and everything went off successfully. There 3

4 were two principal displays - the first in honour of beautiful women, and the last 4

5 adorned with the name of St Anne. The thing had something magnificent about 5

6 it that is not easily achieved with ordinary fireworks on account of the expanse 6

7 of darkness at night. The scaffolding that is always erected for such occasions is 7

8 from 80 to 90 feet high, and from 160 to a 180 feet in length. The three levels of 8

9 boxes around the scaffolding, with the elevated Imperial box in the middle, easily 9

10 accommodate 1,000 people. The parterre, which was completely crowded, held 10

11 probably some 30,000 spectators; all the ladies were beautifully dressed, for it 11

12 is normal for the fair sex here to be tastefully and beautifully attired. The charm 12

13 of the scene is enhanced by the general satisfaction with everything, the way 13

14 everyone quietly takes it to heart if there is a failure, and the way they all rejoice 14

15 when it rights itself again.

This seems to me the only celebration in which the Austrians are willing to do 16 17 without music, which for us here is so intrusive. I was assured by a musician in 17

18 Carlsbad that music was a hard profession. I replied that the musicians are better 18

19 off than the visitors. 'How come?', he asked. 'Why, surely', I answered, 'they can 19

20 eat without music.' The good man went away abashed and I felt sorry for him, 20

21 although my point was valid. It is really cruel to plague patients and convalescents 21

22 in this manner. I can endure a good deal, but when I come away from the opera, 22

23 sit down to supper and some harpist or balladmonger tries to rekindle what I have 23

24 heard and enjoyed at the theatre - it is really too much - and I, poor fellow, quite 24

25 forget that this scribbling is also a great deal too much; so farewell with kind 25

26 regards and greetings to all your circle.

27 The Danube is now looking quite splendid. It has risen so high from the heavy 27

28 rains and the melting of the snow upon the hills that it rushes by, like an arrow. 28

29 I am just off for a drive with Salieri. God bless you!

30 Thursday, 29 July. The day before yesterday I had the most charming walk to 30

31 Schönbrunn and back with Salieri. The old fellow is still so full of music and melody 31

32 that he speaks as if he were singing and it seems as if he can only be understood in 32

33 that way. It is the greatest enjoyment for me to observe this genuine character and 33

34 to find him always truthful, always cheerful. I come back to this thought, now that I 34

35 have obtained the score of the new Requiem by Cherubini. ${ }^{356}$ This is a composition 35

36 which, in these dislocated days, must certainly achieve widespread popularity and 36

37 precisely because it contains no truth, and while everything is thought out and 37

38 realized, there is not the faintest feeling of a requiem aeternam. The composer is 38

39 only concerned to look up those passages in the poem where he can be boisterous - 39

40 dies irae-mors stupebit - rex tremendae majestatis - flammis acribus - and to 40

41 fill out the intervals with measured restlessness; in short, he highlights what is 41

42 subordinate and it is as if one were constantly and passionately saying, 'No', and 42 
1 at the same time nodding one's head. A review of this work, which I have before 1 2 me, is just as bewildering and as disingenuous as the work itself; the composer is 3 exalted into the seventh heaven, and then dragged down again, as one who has 4 dared to enter the lists with Mozart and wishes to rival him, when Mozart has done 5 it much better; as if nobody else were allowed to compose, or die, or find rest, after 6 Mozart! All the newest books of instruction are based upon this opinion; the old 7 perceptions are thrown aside; and that is the present form of art.

8 In the midst of all this, it is quite touching to observe the warm-hearted Salieri, 9 who exalts this state of things without any sorrow and looks at it as an advance in 10 Art that is necessary but unattainable by him. At the same time, he goes on writing 10 11 in his usual manner in a style full of unconscious irony and humour and spins his 11 12 own cocoon like a silkworm. He speaks with delight of a Requiem which he wrote 12 13 under the impression that he would soon follow his wife ${ }^{357}$ who died in 1807 ; but 13 14 as this has not yet taken place, he has now written a much shorter one, thinking it 14 15 was good enough for him. He has allowed me to copy a mass ${ }^{358}$ and an offertory ${ }^{359} 15$ 16 he wrote in the year 1766. The latter is in no way inferior to the very best Italian 16 17 works of the seventeenth century produced in this style. It is devotional, pure and 17 18 elevating, composed in a manner that observes the practical requirements of art 18 19 and the church. You should have seen his guileless gratification, when, at the very 19 20 first glance at this music, I was able to make some meaningful remarks about it; he 20 21 knows the whole thing from tradition, while I have only acquired it by observation 21 22 and study and have had to get a picture of it for myself, for the theory of an 22 23 ecclesiastical style of music has disappeared with the Church herself.

24 Beethoven, whom I should like to have seen once more in this life, is living 24 25 in the country and no one can tell me where. ${ }^{360}$ I was keen to write to him, but 25 26 people told me he was almost incommunicado on account of his almost complete 26 27 deafness. Perhaps it is better that we should remain as we are, since it might upset 27 28 me to discover him in bad form.

$29[\ldots]$ Among the local fortepiano virtuosi a Madame Cibbini (Kozeluch's 29 30 daughter $)^{361}$ stands out. With regard to playing as such, she belongs to those who are 30 31 not afraid to be heard. What one calls expression here is to me commonplace, and 31 32 makes no impression on me. I would always prefer to hear swift, pure, sprightly, 32 33 clear, rounded, clear playing than eternal pressing, pecking and nodding, as the 33 34 expression of nothing to nothing, which they call feeling. These eternal sonatas 34 35 (Grand Sonatas), ${ }^{362}$ which are between heaven and earth, between the lowest bass 35 36

$37 \quad 357 \quad$ Therese Salieri, née von Helfersdorfer (1755-1807).

$38 \quad 358$ Presumably the Missa capella in C major (1767).

40360 Beethoven spent the summer in Mödling near Vienna. 40

41361 Katharina Cibbini, daughter of the composer Leopold Kozeluch. For reviews of 41

42 her performance see $A M Z 21$ (1819), no. 8, 24 February, column 127; MA 20.3, p. 493.42

$43 \quad 362$ A term for large-scale sonatas for virtuoso performers (many of Beethoven's 43 44 sonatas were originally given the title 'Große Sonaten'). 
$1 \mathrm{C}$ and $\mathrm{A}$ four octaves above middle $\mathrm{C}$, float and wriggle like a thief in the gallows, 1

2 put me in bad humour because at the end one is always supposed to cry 'Bravo', 2

3 and thank God when the worst is over. 3

4 Friday. Yesterday I heard Madame Cibbini again. What she performs is, in 4

5 fact, extraordinary: nice, secure, controlled and - to put it in a nutshell - masterly. 5

6 Every finger appears to have five senses and all 50 together form an anarchy which 6

7 could not be more agreeable. And yet even this Madame Cibbini is supposed to 7

8 be surpassed by others. I listen to all this patiently for in fact I don't understand 8

9 it. $[\ldots]$

10 People know their music here and this is in direct contrast with Italy, which 10 11 considers itself the gate of paradise. The people here, however, are really well 11

12 educated. It is true they accept everything, but they only retain what is first-rate 12

13 work. They are happy to listen to a mediocre opera if the performers are good, 13

14 but a first-rate work, even if not performed in the best manner, remains popular 14

15 with them. Beethoven is praised to the heavens because he works very hard and is 15

16 still alive; but it is Haydn who presents their national humour to them, like a pure 16

17 fountain which does not mingle with any other streams, and it is he who dwells 17

18 within them, because he moves among them; they seem to forget him every day, 18

19 and daily he rises to life again amongst them.

20 Baden, 2 August. How can I thank you enough for your Morphologie, ${ }^{363}$ which 20

21 I am devouring with the greatest interest, applying it to the Theory of Sound, 21

22 and thereby arriving gradually at the Theory of Thought and Invention? ${ }^{364}$ How 22

23 naturally all this comes, and what will your honoured friend F.A. Wolf, say, when 23

24 he comes to read the first lines in Hafis? ${ }^{365}$ I am going continuously from one 24

25 thing to another. I read something here, then something there - which gives me 25

26 enormous pleasure, because with my distracted life here all sorts of ideas occur to 26

27 me at once.

28 [...] Today - 3 August is the anniversary of the death of my noble friend, 28

29 Fasch. Having lived with him for many years, without a cross word, I am delighted 29

30 to be able to say, after a period of 19 years, 'Look, old friend and master, your 30

31 work still lives! It is encouraged, it encourages others, they value it, and thank God 31

32 that I existed and still exist to preserve for you, myself and art!' You recognize a 32

33 sound idea years later.

349 August. To try something new, the day before yesterday I went to Ulrich's, 34

35 the local bookseller, where I found a reprint of your works, and amongst them, 35

363 Goethe's periodicalZurNaturwissenschaft überhaupt, besonders zur Morophologie 37 vol. 2, which Zelter had presumably received from Goethe during Zelter's visit to Weimar 38 on 22-25 July 1819.

40364 Perhaps a reference to Goethe's essay Meteore des literarischen Himmels, with 40

41 scientific-philosophic reflections.

365 The first edition of the Divan opens with the last sentences of 'Verwahrung': 42

43 'Poetic works come into the hands of the literary person first as letters of the alphabet; then 43

44 he sees them as books which he has to arrange and put in order'. 
1 the biography of Philipp Hackert, ${ }^{366}$ which forms the eighteenth volume of the 1

21811 edition. The way in which you have pieced together this little work out of 2

3 mere fragments is so typical and so natural that it did my heart good to read it. It 3

4 was as good as new to me, for in 1811, at Schweidnitz, I only had time to skim 4

5 through it. If you should still have a copy, please be so good as to send it to me at 5

6 your convenience, and address it to Berlin. Hackert's youngest brother, George, ${ }^{367} 6$

7 the engraver, was my closest school friend at the Drawing Academy in Berlin, 7

8 the Director of which in those days was the excellent Lesueur. Had I, at that time, 8

9 been less obedient to my mother, I should have gone with George to Naples. ${ }^{368} 9$

10 God knows how I envied him having a brother who could invite him there. Those 10

11 times were quite different from the present and the awareness of my inferior talent 11

12 lay so heavily on my youth that I did not understand how to work my way out of 12

13 it. The book has vividly recalled that time to me and at this moment makes me feel 13

1440 years younger. $\quad 14$

15 If I compare the simple narration of a fruitful, artistic life with other pretentiously 15

16 composed biographies in which the great appears small and the truth incredible, it 16

17 is evident to me what it takes for one not to aim too high. $\quad 17$

$18-18$

$19-19$

20 259. Zelter 20

$21 \quad 21$

22 Baden, Vienna, Prague, Dresden, 12 August to 1 October 181922

23

2416 August. Yesterday, I heard some more vocal music; Italian, of course, for people 24

25 here don't like speaking German let alone singing it. There is nothing but Rossini; 25

26 he rules whether he chooses to or not; there's freedom for you! And the Italians are 26

27 right. The voice will sing for its own sake, and whoever does what it wants has the 27

28 edge. Now, however, criticism is beginning to form here too, and it will seize upon 28

29 the nearest thing first; it might turn out badly for Rossini if he tries to do more than 29

30 he can. A couple of 16-year-old girls sang the music very well and very securely; 30

31 the craziest stuff sounds well as long as it is performed well. 31

32 Beethoven has retired to the country, but no one knows where; ${ }^{369}$ he has just 32

33 written a letter here from Baden to one of his lady friends ${ }^{370}$ and [yet] he is not 33

34

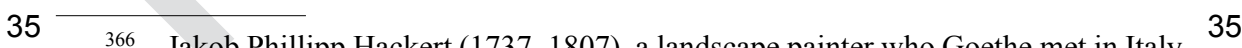

36 Jakob Phillipp Hackert (1737-1807), a landscape painter who Goethe met in Italy. 36

37 nach dessen eigenen Aufsätzen entworfen, vol. 18 (Cotta: 1811). 37

$38 \quad 367$ Georg Abraham Hackert (1755-1805), Zelter frequently mentions him in his 38

39 autobiography, Schottländer, Carl Friedrich Zelters Darstellungen seines Lebens, pp. 29, 39

40 46, 62, 80 and $221 . \quad 40$

$41 \quad 368$ Schottländer, Carl Friedrich Zelters Darstellungen seines Lebens, p. 22.

$42 \quad 369$ Beethoven spent the summer in Mödling near Vienna. 42

$43 \quad 370$ No letter exists in the Beethoven correspondence; the identity of the woman in 43

44 unknown. $\quad 44$ 
1 at Baden. He is said to be intolerably sulky; some say he is a fool. That's easy to 1

2 say. God forgive us! They say the poor man is completely deaf. I know how I feel 2

3 when I look at my fingers, for with me - poor devil - one finger after the other gets 3

4 useless. Lately, Beethoven went to a restaurant, sat down at the table, and after an 4

5 hour's meditation, called out to the waiter, 'How much do I owe you?' 'Why, your 5

6 honour has not eaten anything! What shall I bring you?' 'Bring what you like, and 6

7 leave me alone!'

8 His patron is said to be the Archduke Rudolf, ${ }^{371}$ who allows him 1,500 gulden a 8

9 year. With this he must try to manage like all other children of the muse. They are 9

10 kept there like cats, and any one who does not understand the art of mousing will 10

11 hardly save anything, and yet in spite of this, they are all as round and satisfied as 11

12 weasels. [...]

In Vienna, and here I have in vain tried to find the opera Elena e Costantino. ${ }^{372} 13$

14 Salieri and Weigl knew nothing about it. The opera is by Simon Mayr, and was 14

15 performed at Milan during the month of August 1816. ${ }^{373}$ The Baroness von Pereira 15

16 has promised me that she will write to Milan and get the sextet; the opera itself is 16

17 not popular - the sextet is said to give life to the whole work. [...]

18 31 August: I have now finished the music to a little poem 'Gleich und Gleich';74 18

19 you may like to hear it and see whether I can breathe on yet another little flower 19

20 that would give a tiny bee an appetite. I serve you as people offer sacrifices to the 20

21 gods, by bringing to them their own gifts. Take, my old friend, what is yours [...] 21

2214 September: The day before yesterday, I made a trip to Mödling to visit 22

23 Beethoven. At the same time he was travelling to Vienna and, meeting each other 23

24 on the road, we got out of our carriages and embraced each other most cordially. 24

25 The poor man is as good as deaf, and I could hardly hold back my tears when I saw 25

$26 \mathrm{him}$. Then I continued on my journey to Mödling and he to Vienna. ${ }^{375}[\ldots] \quad 26$

27 I have found my old idea realized - that of making the orchestra [pit] so deep, 27

28 that one does not see the woolly heads of the musicians; the music, too, which 28

29 is not nearly as well organized here as in Weimar, comes out clear and distinct. 29

371 Rudolph Johann Joseph Rainer (1788-1831), youngest son of Emperor Leopold II, 32 half-brother of the reigning Austrian Emperor Franz I; he was both a student and patron of 33 Beethoven's. Act 2 of this opera.

373 The first performance took place in Naples in 1814.

374 Goethe sent this poem to Zelter on 22 April 1814. There is no autograph of the 37 score in Goethe's music collection, only a copy of the published score (Wiener Allegemeine 38 musikalische Zeitung (1820), GSA 32/1469). The Berlin manuscript bears the dedication: 39 'To Anton Salieri, [performed at] the Baden Fair, from Prof. Zelter from Berlin on 40 28 September 1819' (SBB PK: Mus. ms. Autogr. Zelter 31). 41 375 Apart from this unexpected encounter on the road from Vienna to Mödling, 42 Beethoven and Zelter saw each other briefly at the theatre the same evening. It was not 43 possible for them to meet again because Zelter left Vienna on 20 September. 
1 I cannot imagine anything less becoming on a stage, than to see the fine forms 1

2 of well-dressed actors, and all that goes to make up a brilliant scene, fluttering 2

3 between the confounded mops [of hair] of the fiddlers in front. 3

415 September. Yesterday I made the acquaintance of Grillparzer, ${ }^{376}$ a well- 4

5 built young man, 26 years of age, quiet, but rather sickly. He makes a very good 5

6 impression. We drove through the country together and got on famously. [...] 6

$7 \quad$ I must admit comedy is cast very well here and the people are well rehearsed. 7

8 I have seen two works which went off well. Since Liebich's death ${ }^{377}$ it reeks of 8

9 anarchy. The music is almost too bad. The first violinist does not appear idle and 9

10 has the others tune up from him. He doesn't seem to notice that the men don't have 10

11 proper strings: [they think] whoever plays well doesn't need to tune. The double 11

12 basses hum and drone without having the proper number of cellos with them. 12

19 [...] No more for now in case the accompanying Divan $^{378}$ misses the post. May it 19 20 inspire you anew to clothe musically these basically naked songs and send them 20

21 out into the world! I am also busy in new ways and it bears fruit. 21

28 [...] Yesterday I set Suleika's little song (p. 166) ${ }^{379}$ to music and after several days 28

29 I will want to look at it again. Browsing through the Divan does bring something 29

30 to light.

376 Franz Seraphicus Grillparzer (1791-1872).

$38 \quad 377$ Johann Karl Liebich (1773-1816) died on 21 December 1816; he had directed 39 both corporative theatres in Prague since 4 August 1806.

40378 A special edition of Goethe's West-östlicher Divan which the poet had promised 41 Zelter.

$42 \quad 379$ Setting of Goethe's 'Suleika' ('Ach! Um deine feuchten Schwingen') on p. 166 in

43 the first edition of Goethe's Divan; a Berlin autograph which bears the title 'Suleika. Divan 43

$44166^{\prime}$, is dated Berlin 26 February 1820. 
5 Yesterday afternoon, an hour before I wanted to go to the performance of my Good 5

6 Friday music, ${ }^{380}$ I received your precious letter of 23 March with the parcel. ${ }^{381} 6$

7 In the last few days I have only been preoccupied by this music, so I read the 7

8 bound manuscript like a stranger ${ }^{382}$ until, with the most cheerful astonishment, I 8

9 finally worked out the most charming jest, which went from happiness to happiness, 9

10 because my music went off well and the house was packed.

11 The Duchess of Cumberland ${ }^{383}$ sent for me after the performance in order to 11

12 say the loveliest words about you and to send her greetings to you a thousand 12

13 times, whereupon I was able to say to her that I had just received your letter which 13

14 had contained assurance of your well-being.

15 Our music was also crowned with applause. The Duke ${ }^{384}$ had beat time in his 15

16 box - an industry for which he paid three ducats. [...] 16

I want a genuine Zelterian composition for the enclosed hymn, ${ }^{385}$ which might 23

24 be sung in chorus every Sunday before my home. If such a thing could reach my 24

25 daughter-in-law during the month of May, it would be rehearsed and give me a 25

26 pious and friendly welcome on my return at the beginning of June.

380 The annual performance of Graun's Passion, Der Tod Jesu, by the Sing-Akademie; 31 for reviews of the performance see $A M Z 20$ (1820), no. 16, 19 April, column 262; MA 20.3, 32 p. 506.

381 The parcel contained a copy of Zelter's Reisebriefe aus Wien occasioned by 33 Goethe, as well as Goethe's Über Kunst und Altertum, vol. 2, no. 2. and enjoy the trip. The 49 bound pages (in John's hand with corrections by Goethe), whir 36 bear the title 'Zelter's Summer Journey 1819', are in Zelter's estate (GSA 95/II, 3). Johannes 37 August Friedrich John (1794-1854) was a copyist in Weimar and Goethe's secretary from 38 1814; hereafter referred to as John. 39 383 Friederike Karoline Sophie Alexandrine of Great Britain and Hanover (1778- 40 1841). 
5 Our artists' society linked up with the Akademie der Künste for a celebration 6 of Raphael's birth, ${ }^{386}$ which in our way turned out very well. [...] Three large

7 pictures, the Madonna del Sisto, ${ }^{387}$ the Madonna del Pesce ${ }^{388}$ and a picture of

8 St Cecilia, ${ }^{389}$ were erected near one another, high up at the end of a 110-foot-

9 long hall. Among these Raphael's catafalque stood on a 7-foot-high dais. On

10 both sides of the platform were statues of the hero's four favourite muses: Poetry, 10

11 Painting, Architecture and Music, which stood 6-foot-high and beautifully draped 11

12 by Tieck. ${ }^{390}$ A burning candelabra was placed between every two muses rising up 12

13 over the figures, which crowned them really well. Over the catafalque was the 13

14 bust of Raphael, a good copy by Weitsch. ${ }^{391}$ All spaces were well festooned with 14

15 coloured cloth as well as the entire front area which was 40-foot deep. 15

16 A choir of 100 selected singers was [positioned] in this area: women clothed in 16

17 white and the men behind them in black, arranged in a semi-circle. The programme 17

18 was:

19

20 1. A Requiem by me. ${ }^{392}$

21 2. Raphael's life read by Professor Tölken. ${ }^{393} 21$

22 3. Antonio Lotti's [8-part] Crucifixus; noteworthy because of its grand style. 22

23 4. I read something to enhance understanding about this old work, in connection 23

24 with 24

25 5. Gloria in Excelsis Deo by Joseph Haydn ${ }^{394}$ in order to make the stylistic 25

26 differences of the two eras perceptible. 26

$27-27$

$28 \quad 28$

$29-29$

$30-386$ On the occasion of the three-hundredth anniversary of Raphael's death (6 April 30

31 On the occasion of the three-hundredth anniversary of Raphael's death (6 April

32 1520) a 'Festival in memory of Raffael' was celebrated by the Berliner Künstlerverein and

32 the Akademie der Künste.

$33 \quad 387$ Friedrich Bury's copy of Raphael's Sistine Madonna. 33

34388 Karl von Steuben's copy of Raphael's Madonna with the Fish. 34

35389 Raphael's St Cecilia with St Paul, John the Baptist, St Augustine and Mary 35

36 Magdalene: Karl Ludewig's copy from Dionysius Calvaert's copy in Dresden.

$37 \quad 390$ The Berlin architect Christian Friedrich Tieck (1776-1851). 37

$38 \quad 391$ Friedrich Weitsch's copy after a painting in Braunschweig, which today is believed 38

39 to be a portrait of a youth by one of the Giorgione circle. 39

$40 \quad 392$ Zelter's Requiem for Fasch (now lost). 40

41393 Ernst Heinrich Toelken's speech was later published; on behalf of the publisher 41

42 Zelter sent the printed version to Goethe on 16 June 1820.

$43 \quad 394$ Zelter's arrangement for eight voices of the Gloria from Haydn's Mass in 43

44 B major. $\quad 44$ 
1 The whole event took over an hour. What I read ${ }^{395}$ I enclose for clarity, should you 1

2 care to say something beneficial about it. 2

3

4

265. Goethe

9 Let me congratulate you on your Raphael Festival; it was well thought out, and I 9

10 feel certain that will have shown; it is hard for anyone to compete with you. [...] 10

11 I should like to have heard the music, though I am able to form some impression 11

12 of it from what you say. The purest and highest style of word painting in music 12

13 is that which you yourself also practise; the object is to transport the listener into 13

14 that frame of mind which the poem itself suggests; the imagination will then form 14

15 pictures from the text without knowing how it arrives at them. You have given 15

16 examples of this in your 'Johanna Sebus', 'Um Mitternacht' 'Über allen Gipfeln 16

17 ist Ruh'; where have you not realized it? Tell me anyone who has achieved this 17

18 to the same degree as you! Painting in tones of thunder, crash, splash and splosh 18

19 is detestable. A minimum amount of this, as you use it, merely dotting the i's, is 19

20 effective. So I, deprived of sound and hearing, though a good listener, transform 20

21 that great enjoyment into ideas and words. I know very well that on account of 21

22 this, I lose one third of life, but one must be able to adapt [...] 22

Eberwein has composed several songs; $; 96$ give me your opinion of them. I feel at 29 once that your compositions are identical with my songs; the music, like the gas 30 which is pumped into the balloon, merely raises them up. With other composers 31 I must first see how they have understood the song and what they have made out 32 of it. $[\ldots]$ 
1 Among those by Eberwein, 'Jussufs Reize möcht ich borgen'397 went down 1 2 well with me and with others. His wife sang really well, fluently and agreeably. 2

9 [...] As your letter speaks of word painting, should I say who else has done such 11 symphonies ${ }^{398}$ and The Battle Symphony, have drawn the most curious pictures, 11 12 and with distinction. What I have noticed is the following: if you take the words 12 13 away and the thing remains coherent, it calms down. The Battle Symphony, which 13 14 I have now heard four times, always puts me into a suitable hearty, fearful-fearless 14 15 and spiritual mood. Only I mustn't think explicitly of the score, because straight 15 16 away judgement, which is also biased, interferes. The English and French are 16 17 recognizable by their music - one does not know whether that is a failing or an 17 18 advantage.

19 The overture to Haydn's Creation is the most marvellous music in the world, 19 20 for by the ordinary, methodical, conventional resources of art a chaos is produced 20 21 which converts the feeling of deep disorder into one of delight. 21

22 In the overture which represents winter in The Seasons I freeze in comfort 22 23 at my warm stove, and at that moment I do not know whether there is anything 23 24 beautiful in the world apart from this.

25 What old Bach and Handel achieved has no limit, especially in terms of 25 26 quantity, just as every passing occasion gives rise to an abyss of feeling which 26 27 they note down with the familiar black dots. If human beings knew no limitations 27 28 and the external resources were rich enough, one would recognize, in the belly of 28 29 the earth and the bosom of the stars, the life of the All-Powerful [...] 29

36 So, to begin with the first rehearsal of Faust yesterday, ${ }^{399}$ about which I don't 36 37 know what else to say other than that today's [rehearsal] will turn out better. The 37 38

39397 Verse 8 from Goethe's poem, 'Lieb' um Liebe, Stund' um Stunde', from the 'Buch 39 40 Suleika'.

41398 Beethoven's Symphony no. 3 in E flat major, the Eroica Symphony (op. 55) and 41

42 Symphony no. 6. in F, the Pastoral Symphony (op. 68).

43399 As in 1819, Radziwill's settings of scenes from Goethe's Faust were performed on 43 44 his birthday on 24 May. 
1 new choruses - 'Wird er schreiben?' ${ }^{400}$ - and the final chorus didn't go too badly 1

2 for a first rehearsal, despite the sparse style. The dilettante cannot deny himself, 2

3 so he exaggerates everything and wants to express far too much. Nothing can be 3

4 done to help him, because this has already cost him so much work that he is just 4

5 happy to have it over. With a choir like ours he won't notice what's wrong, but if 5

6 he eventually gets into a real theatre, they will show him. 6

7 Then the scene with the jewellery box in Gretchen's room ${ }^{401}$ was performed for 7

8 the first time and not without some affectation by Madame Stich, ${ }^{402}$ who, to put it 8

9 mildly, tried far too hard. That will be rectified, however, because she is a person 9

10 with whom one can still discuss such things. [...] 10

11 The music runs through the whole scene, uninterrupted, and contains the 11

12 loveliest passages, but for this very reason it is disturbing because too much was 12

13 expressed, so that the rise and fall and fluency of delivery suffers. 13

14 The rat scene ${ }^{403}$ is the most remarkable. It is, in fact, spooky and not at all a petty 14

15 scene, just as it wasn't even played by Mephisto ${ }^{404}$ as well as many other [scenes]. 15

16 Incidentally the fun only lasted from six until after midnight. Today I think we 16

17 should have it easier, if the enormous number of organizers don't drag it out. 17

18 The Duchess of Cumberland, with her two consorts, ${ }^{405}$ was present and enjoyed 18

19 it, and apparently for your sake put up with all the reprises of a first rehearsal. She 19

20 says so much that is beautiful and good about you; in short, she is so much in love 20

21 with you that instead of hands, fingers, mouth and eyes, I would need to be all ears 21

22 in order to take everything in. [...] 22

23 I have set some [poems] from the Divan to music: (i) 'Suleika', p. 166; 23

24 (ii) 'Wiederfinden', p. 168; (iii) 'Elemente', p. 14; (iv) 'Erschaffen und Beleben', 24

25 p. 16; (v) 'Selige Sehnsucht', p. 30; ${ }^{406}$ (vi) 'So lang man nüchter[n] ist', p. 187; 25

400 Two short pieces from Faust I: the spirits' chorus, 'Wird er schreiben' (WA I/14, 29

30 pp. 3181-9) as extended variations to verses 1739f., as well as the departure chorus, 30 'Hinaus! Hinauf", to be inserted after verse 2072. Goethe had written the choral pieces 31 especially for Radziwill's Faust performance and sent them in a letter, dated 4 July 1819, 32 to Pius Alexander Wolff, who had taken over the direction for this performance. See also 33 Wolff's letter of thanks of 18 July 1819, WA IV/31, p. 381.

401 Faust I, v. $2783 \mathrm{ff}$.

402 The actress Sophie Auguste Crelinger, née Düring, married to Wilhelm Stich. 35

403 Faust I, v. $1512 \mathrm{ff}$.

404 Carl Friedrich August, Prince of Mecklenburg-Strelitz 37

405 Friederike von Mecklenburg-Strelitz, Duchess of Cumberland since 1815, with 38 her husband Ernst August, Duke of Cumberland and Prince Wilhelm of Prussia, brother of 39 King Friedrich Wilhelm III.

406 Goethe's verse 'Sagt es niemand, nur den Weisen', published under the title 41

43 öslicher Divan (1819). Zelter's setting was published as no. 4 in his Sechs Deutsche Lieder 43

44 für die Bass-Stimme mit Begleitung des Pianoforte. 
1 (vii) 'Alle Menschen', p. 212;407 (viii) 'In tausend Formen', p. 179. ${ }^{408}$ Most of 1

2 them need to be polished and are working themselves out in me. I still don't know 2

3 Eberwein's settings. He used to send them to me and since I did not answer him 3

4 directly, he eventually stopped doing it. [...] 4

5

6

7

269. Goethe 7

8

Carlsbad 24 May $1820 \quad 9$

9

10

11 As a parting gift I send you a little song ${ }^{409}$ which you may lovingly interpret and 11

12 compose. I have had a healthy, happy time. Now I am about to hurry home, where 12

13 I hope to hear from you.

14

15

16

270. Zelter

20 Yesterday was Princess Radziwill's birthday, and at last our Faust was smoothly 20

21 and soundly launched. ${ }^{410}$ The King ${ }^{411}$ was so pleased with us that his praises 21

22 seemed as sweet as honey to me, and I too can say I was pleased. [...]

23 The Duchess of Cumberland was full of your praises again, and regretted she 23

$24 \mathrm{had}$ not been able to attend all the rehearsals, as the piece is really a rare thing, so 24

25 that you cannot see it too often to probe its depth. 'Long live Goethe!' was shouted 25

26 at supper by everyone. It came three times from a hundred voices.

27 Even if Radziwill's music had no merit at all, he would be entitled to great 27

28 praise for having brought to light a poem up to now concealed in darkest shadow, 28

29 which everyone, after reading and feeling, thought himself obliged to withhold 29

30 from his neighbour. I, at all events, know no one else enthusiastic and innocent 30

31 enough to put such a banquet before such people, which enables them for the first 31

32 time to learn German.

35407 Goethe's poem ‘Alle Menschen groß und klein' was published without a title in

36 'Buch der Parabeln', West-östlicher Divan (1819). Zelter's composition is not extant.

37408 'In tausand Formen magst du dich verstecken'. On the evidence of two dated

38 manuscripts, Zelter's composition was only completed in 1823 (SBB PK: Mus. ms. Autogr.

39 Zelter 35: Berlin 2 March 1823 and GMD KK 832: 2 February 1823).

40409 Sankt Nepomuks Vorabend ('Lichtlein schwimmen auf dem Strome'). 40

41410 For a detailed account of the performance see: Franz Ulbrich: 'Radziwills 41

42 Privataufführungen von Goethes Faust in Berlin. Ein Abschnitt aus der Bühnengeschichte 42

43 des Goetheschen Faust' in Studien zur Literaturgeschichte (1912): 213-18. 43

$44411 \quad$ Friedrich Wilhelm III (1770-1840). 44 
1 Just think of the circle in which this goes on: a Prince is our Mephisto, ${ }^{412}$ our 1

2 first actor is Faust, ${ }^{413}$ our first actress is our Gretchen, ${ }^{414}$ a Prince is the composer, ${ }^{415} 2$

3 a noble king is principal critic, with his youngest children and all the court about 3

$4 \mathrm{him}$, the finest orchestra that can be found, ${ }^{416}$ and finally a chorus of the best 4

5 voices, ${ }^{417}$ the singers consisting of well-born ladies, beautiful girls (most of them) 5

6 and men of high rank - amongst them a consistorial councillor, a clergyman, a 6

7 consistorial councillor's daughter, court councillors and high officials. All this is 7

8 managed by the general music director, acting as stage director, conductor and 8

9 prompter; in the palace residence, in a royal castle $;^{418}$ - you cannot blame me for 9

10 wishing we had had you amongst us. 10

17 [...] Our general music director ${ }^{419}$ of the court ensemble has finally arrived and 17 18 his long awaited arrival was celebrated by [a performance of] one of his operas, ${ }^{420} 18$

19 which he received with great delight. [...]

415 Prince Anton Radziwill.

419 - Gaspare Luigi Pacifico Spontini (1774-1851). Zeler used his influence 35 with the Prussian king (behind Brühl's back), Spontini was, on 1 September 1819, bound 38 by contract to ten years as the main Kapellmeister and General Director of Music, whereby 39

40 de jure he was Brühl's subordinate but de facto from the very beginning became his most 40 intense rival. On 20 February when he was due to take up his position, he requested an 41

43 on 28 May 1820.

$44 \quad 420$ Die Vestalin; for reviews of the performance; see Vossische Zeitung, 3 June 1820. 44 
$5[\ldots]$ Now what am I to say in reply to your description of my Faust? The faithful 5 6 account of it, which I owe to you, transports me quite clearly into the most 6

7 wondrous region. After all, poetry is really a rattlesnake into the jaws of which one

8 falls with reluctance. Certainly, if you stay together as you have up to now, it must 9 be, become, and remain the most extraordinary work that the world has seen. 9

10 Many thanks for the singable returning Saints. The Holy Spirit will be developed 10 11 in its own good time, ${ }^{421}$ and so I want to announce the rest bit by bit, and some 11 12 things should be left which will be best done when we meet face to face. 12

19 [...] Spontini, whose acquaintance I made yesterday, is having his last opera, 19 20 Olympia, translated into German. ${ }^{422}$ For this work he wants 40 violins in his 20 21 orchestra (we have about half that number) and an extension of the space for the 21 22 orchestra in the opera house. If the rest of the band is to be arranged in this area, 22 23 the parterre may go and look for places outside. I, for my part, will learn from this 23 24 experience, although I see clearly enough how and where it must end if we are to 24 25 extract the kernel and get to the heart of the matter [...] 25

26 With the exception of the King and Crown Prince, who are not in Berlin, the 26 27 court was again present at the second performance of Faust, ${ }^{423}$ and they tried 27 28 beforehand to make Spontini acquainted with the poem by means of Madame de 28 29 Stael's explanations. What the Italian Frenchman will learn from Mephisto remains 29 30 to be seen. He is treated by the whole court with the distinction he deserves, when 30 31 one considers the hard work expended on his compositions and the readiness with 31 32 which be submits to alterations, which can hardly benefit the form of the whole. 32 $33[\ldots]$

34 Friday, 9 June. Yesterday evening I discovered Eberwein's fifth and sixth books 34 35 of songs, ${ }^{424}$ which had just arrived and are, in fact, better than his earlier volumes. 35

$37 \quad 421 \quad$ The hymn 'Veni Creator Spiritus'. 37

$38 \quad 422$ The hymn 'Veni Creator Spiritus'.

39422 Translation by E.T.A. Hoffmann; the first performance of the German version took 38 place on 14 May 1821.

40423 The Faust scenes were repeated in Spontini's honour in the Palais Monbijou on 40 417 June 1829.

$42 \quad 424$ Eberwein, Lieder in Musik gesetzt für Pianoforte vol. 5 (Hamburg: Johann August 42

43 Böhme, 1820) and Lieder aus Goethes West-östlichem Divan vol. 6 (Hamburg: Johann 43 44 August Böhme, 1820). Eberwein sent both volumes to Zelter on 1 June 1820 (GSA 95/2). 44 
1 The advantage of having a singer around ${ }^{425}$ is invaluable since it is a question 1

2 of making the melodies singable. This very seldom happens now, and though I 2

3 associate with singers sufficiently and give many songs away, I rarely have the 3

4 chance to hear one of them sung as I would wish, and in the end I hardly know why 4

$5-$ whether [the reason] lies with me or with the singer. And in addition every song, 5

6 like every poem, should be self-contained. So those who always want what is new 6

7 continually acquire what they already have. $\quad 7$

8 When I see a poem and restrict myself to its particular characteristics, then 8

9 a complete feeling is established which I can't get rid of and often the correct 9

10 tone is only discovered after a long time. This mood leads to a family of tone 10

11 colours and if one goes to table before the best is ready, the whole mealtime will be 11

12 incomplete. Then at last the limitations emerge which arise from the word order. 12

13 All too often there is a syllable too many where the [central] meaning lies or where 13

14 a keyword is conspicuously in a place to which the melody must be guided if the 14

15 poem should remain as it is. That is something to be observed, especially in your 15

16 poems, if the poem is to become music and not something else. By 'something 16

17 else' I mean if the words should become a mere foundation, a kind of trap for some 17

18 kind of melody or a crystallization thread, where one sings only to give movement 18

19 to the voice and not to be elevated by feeling and thought. 19

26 [...] If I think how you stand there with the singers and don't let them off the hook 26

27 until they have got to the crux of it, I enjoy your thanks like a fruit I have grown 27

28 myself and - I understand myself if I may [presume to] think I understand you. 28

30 Price Radziwill resumes his governorship once again ${ }^{426}$ and once more our 30

31 Faustiade $^{427}$ is resting in order to come to the boil slowly. I myself have nothing 31

32 to do with [the production], other than an odd word now and then - in the end I 32

33 might need to step in and wave the red pen to remove some bits. Since the work 33

34 comes into existence piecemeal, it is no surprise when some elements become 34

Zelter's reply is published in Johann-Wolfgang Schottländer, 'Zelters Beziehungen zu den 38 Komponisten seiner Zeit', JbSK 8 (1930): 223f. 39

$40 \quad 425$ Eberwein's wife, Henriette Eberwein née Haßler (1790-1849). 40

41426 Since 1815 Radziwill had held office as Prussian Governor in the Grand Duchy 41

42 of Posen.

43427 The readings, rehearsals and performances of scenes from Radziwill's setting of 43 
1 Tell me, how are Paul and Mary Magdalene connected with Saint Cecilia as 2 they are depicted on Raphael's painting? ?28 $^{428}$ is clear that they do not hear the 3 music from Heaven because they should not hear it on earth. Saint Cecilia is the 4 most important person in the picture for the very reason that she alone hears the 5 music. Should Paul or Mary Magdalene be part of the good which lies around us 6 on earth? [...]

136 July. Lobe, the flautist from Weimar, performed at our theatre yesterday ${ }^{429}$ to 13 14 great applause, which he also completely deserved. A pure scale through the whole 14 15 [range of] the instrument combined with the greatest skill is admirable. His own 15 16 composition ${ }^{430}$ was also rich in ideas, which are only lacking in the power which 16 17 will come when the fingering has been sufficiently worked out. 17

24 With regard to the picture of Saint Cecilia, I can only say that the saint stands in 24

25 the centre, and the small organ she holds in her hands she lets droop in such a way 25

26 that the pipes are slipping out, indicating that she is letting go of earthly music 26

27 while she looks upwards listening to the heavenly. The other saints ${ }^{431}$ do not stand 27

28 in any relation to her. Besides these, there are patron saints of the city, the church 28

29 and for whoever commissioned the painting. These have no connection with one 29

30 another, except that which the painter's imagination contrived to give them. The 30

31 Madonna del Pesce is composed in the same manner. The man who ordered the 31 today it is housed in the Pinacoteca Nationale, Bologna.

$37 \quad 429$ Johann Christian Lobe performed the intermezzi music for the play Das letzte

37 Mittel. The Weimar flautist had already asked Goethe for a letter of recommendation to

38 Zelter because he wanted to travel to Berlin during the theatre holidays. For a report of

39 his conversation with Goethe, in which he gives a remarkable appraisal of Zelter's songs,

40 Gespräche, vol. 3/1, pp. 154-63.

41430 AMZ 22 (1820), no. 33, 16 August 1820, column 564: 'Of the intermezzi, the

42 Weimar court musician, Herr Christian Lobe, deserves a special mention for [his] allegro

43 and variations for flute, which was received with applause'.

$44 \quad 431$ St Paul, John the Baptist, St Augustine and Mary Magdalene. 44 
1 picture was probably called Tobias. ${ }^{432}$ Let us hear something of you and of your 1

2 lively city. If I could be invisible or unidentified walking up and down by your 2

3 side, it would give me great pleasure. For the moment I must make do with the 3

4 wish frequently to hear something by you that gives me joy. In Weimar they are 4

5 singing the 'Nepomukslied' ${ }^{333}$ with great delight. I have still not heard it as I have 5

6 not yet gone across; I can use my days here completely undisturbed and yet one 6

7 does not make much progress. I am searching out what is decent from innumerable 7

8 papers which I have written on thousands of subjects. Admittedly, I realize one 8

9 cannot edit before one surveys the whole, and then the work does not progress so 9

10 quickly, strength decreases and the problems increase. 10

17 [...] I have now heard Spontini's Cortes $^{434}$ twice. The text is by de Jouy, and not 17 18 much better than the very bad German translation ${ }^{435}$ performed here. I am inclined 18

19 to prefer the music to that of La Vestale, but I need to hear it several times more, 19

20 for I have only got a general impression, but as yet no firm grasp of it. 20

21 There are certainly admirable passages, and the ballets are really good and 21

22 meaningful. What puzzles me most is that an aristocratic Italian, accomplished in 22

23 high art, should clothe high heroic subjects with small melodious forms, which 23

24 in themselves are problematic because challenged by the strength of the musical 24

25 accompaniment. But we shall see if we can find a way to grasp it. 25

26 With regard to the rest, as an artist I am on very good terms with this composer; 26

27 he approached me very personally of his own accord; and, what no Italian or 27

28 Frenchman has ever done before, he has visited the Sing-Akademie four times and 28

29 appears to take an interest in it, which I am glad to see.

30 What he has heard up to now were unrehearsed performances, for while I have 30

31 some works in the repertoire of the institute, there is always something we know 31

32 as well as something new throughout the year. And so we only prepare something 32

33 when public performances of unknown works are given, where every individual, 33

34 according to his capabilities, is formally required to have his voice ready. $\quad 34$

$37 \quad 432 \quad$ A reference to the Book of Tobias: Tobias was blinded by a bird; his son caught a 37

38 fish from the Tigris river and on the advice of the angel Raphael, Tobias used its heart, gall 38

39 and liver as medicine. 39

40433 Zelter's setting of Goethe's 'Sankt Nepomuks Vorabend'. 40

41434 Spontini's official inauguration as Kapellmeister was launched on 28 June 182041

42 with a performance of Ferdinand Cortez oder die Eroberung Mexicos; see Spenersche 42

43 Zeitung, 1 July 1820. Further performances took place on 10 and 17 July. 43

$44 \quad 435$ By Johann Christoph May (1757-1828), writer and translator in Berlin. $\quad 44$ 
1 And so our ensemble appears to have attracted his attention, as we do not set 1 2 out to turn out what one calls singers, but everyone is [required] to be or to become 2 3 a master of his voice.

4 What is terrible about such an institute is precisely what is good. For a society 4 5 of almost 300 regenerates itself by more than half every 10 to 15 years and since 5 6 new blood comes in from time to time, we are always starting over again. Yet we 6 7 remain eternally young and so we don't have an abundance of old women feminini 7 8 and masculini generis, ${ }^{436}$ and the choir doesn't look particularly bad even up close 8 9 and in the light. The little women can do themselves up for the rehearsal twice a 9 10 week, chat with one another, and through the pleasure which others get from it, 10 11 the thing expands.

12 Admittedly it has no easy existence anywhere else because in the end gossiping 12

13 becomes the main thing, which remains under control with us because every time 13

$14 \mathrm{I}$ am the first on the spot and whoever comes then, be it man or woman, I can deal 14

15 with appropriately. There is also the fact that now, after 30 years, the society has 15

16 become a family of men, women, siblings, children and relations, and watches 16

17 over itself very well so that no scandal of any kind has happened, other than what 17

18 I myself sometimes cause through a flop and which then, of course, is the talk of 18

19 the town for a week. 19

20 Only we now stand in a contradictory relationship with the singers who 20

21 otherwise formed the Italian opera and although their authority is recognized by 21

22 us, even regarded as a model, we were no professional Italian company kept for the 22

23 court and the highest ranks. Of necessity we are lacking everything that protection 23

24 [by the court] can give. Sharp eyes suspect they see a glimpse of envy and if we 24

25 were a foreign company, we would boast about some Pharaoh-like oppression. 25

26 Since, however, we didn't lose our position and only went forward where there 26

27 was space, we retained our strength without power and, in short, there was nothing 27

28 else to do but get on with it. 28

29 This alone is what we can be happy about, although today we still don't know 29

30 where we are to lay down our head. ${ }^{437}$ Spontini noticed this almost with shock. 30

31 Since, like many good souls, he wants to discover the moon in the moon, he finds 31

32 it inconceivable that a thing which the world knows by name but does not know, 32

33 lodges in stinking stables and must live off scourings. ${ }^{438}$

$34+34$

$35-35$

$36 \quad 36$

$37 \quad 37$

$38 \quad 38$

39436 Literally: old women of both sexes. 39

$40 \quad 437$ Zelter is referring to the ongoing need for rooms for the Sing-Akademie: at this 40

41 time the rehearsals were still taking place in the round room of the Akademie der Künste, 41

42 on the first floor of the royal stables on Unter den Linden. They had to wait until January 42

431827 for their own building. $\quad 43$

$44 \quad 438$ Zelter is referring to the parable of the Prodigal Son. $\quad 44$ 
278. Zelter 1

$5[\ldots]$ Nevertheless a little joy is granted to me. The $\operatorname{son}^{439}$ of the famous singer 5

6 Margarethe Schick $^{440}$ is Music Director of a military band of the local garrison 6

7 which is made up of almost 40 instruments. This young man, who lost his father 7

8 and mother very young and whom I knew as a child, has brought this choir together 8

9 so skilfully that it is a pleasure to hear symphonies and operatic pieces by Mozart, 9

10 Mehul, Haydn, Cherubini, Beethoven and other such composers performed on 10

11 nothing but wind instruments.

18 I request [a copy of] your setting of Epimeleia's famous confession! ${ }^{441}$ Prometheus 18

19 has turned up once again in Weimar. ${ }^{42}$ People are delighted by the idea that you 19

20 yourself once wrote music to it. Now I request only the individual piece. If you 20

21 would like to send more, it would also be warmly welcome. [...]

Towards New Year may you also shake your cornucopia so that 'Veni Creator 22

23 Spiritus' ${ }^{443}$ prepares a Whitsun feast in the middle of winter. [...] 23

24 Just as I want to sign off, the accompanying revision pages have arrived. ${ }^{444} 24$

25 You wanted the poem some years ago when I refused it. Now it has lost its sting 25

26 and I hope retains its charm. I want to keep it secret at present. Compose it for 26

27 the Liedertafel, keeping an eye on the voices and characters available. If a copy 27

28 appears by Easter, you would immediately bring this poem to life along with [the 28

29 Liedertafel]. May it crop up everywhere when appropriate. 29

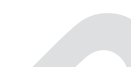

439 Friedrich Schick (1794-c.1858), clarinettist and composer, Prussian military $\begin{aligned} & 35 \\ & 36\end{aligned}$ Kapellmeister in Stralsund.

441 Epimeleia's monologue 'Einig, unverrückt, zusammenwandernd', from Goethe's 39

Pandora. Zelter's setting, composed in Teplitz in 1810, is not extant. 40 442 In Goethe's Pandora.

443 Goethe is reminding Zelter of the promised setting which, however, was never 42 finished. 
$5[\ldots]$ The greatest charm of an author's otherwise hazardous life is that while one is 5 6 personally silent to one's friends, one is meanwhile preparing a great conversation 6 7 with them in all parts of the world.

8 It is the same with the musician, who, however, must act differently, like certain 8

9 friends who do not allow their silent and absent acquaintances to benefit from the 9

10 rueful songs of gentle Magdalenes ${ }^{445}$ nor from the appeal to the Universal World 10

11 Genius. $^{446}[\ldots]$

281. Goethe

18 I recommend a warm reception to Herr and Frau Boucher, ${ }^{447}$ an admirable musical 18

19 couple, and at their delightful performance I ask that you remember me with 19 20 affection.

27 [...] At the moment we have a carnival consisting of opera, masquerades, balls, 27

28 concerts, some significant bankruptcies, eats (as Wolf ${ }^{448}$ is wont to say) and so 28

29 on. biblication term 'Magdalene', applied to Epimeleia, could apply to her compassionate role 37 in the drama.

38446 The first draft of Goethe's version of 'Veni Creator Spiritus' bore the title 'Appel 39 an Genie'; the setting Goethe sought was never finished.

$40 \quad 447$ The violin virtuoso Alexandre Jean Boucher and his wife, the harpist Céleste

41 Boucher, gave guest performances in Weimar in February 1821 and had visited Goethe

42 often; see Goethe's diary 19 to 27 February 1821, WA III/8, pp. 20-23. Goethe's Tag- und

43 Jahres-Hefte of 1821 gives an account of a 'private concert'. 
1 Schinkel's new concert hall ${ }^{449}$ should be inaugurated next Tuesday with 1

2 Dryden's Alexanderfest set to music by Handel. ${ }^{450}$ I myself am involved. 2

3 The confession of our good Epimeleia is also to follow. ${ }^{451}$ The score of it which 3

4 was written in Teplitz is not to be sent, however, and I must make a new copy, 4

5 which had been started when a really nasty eye infection held me back by five or 5

6 six weeks. Even after it has gone I should not undertake any writing or reading 6

7 on dark days, as a result of which ongoing work has gathered and I am still not 7

8 able to get back into it with the same interest. Everything appears cold to me and 8

9 unimportant. The next free hour should be well used. 9 had written.

449 According to the king's wishes, the new theatre built by Karl Friedrich Schinkel on 23 Gendarmenmarkt included a separate concert hall in addition to an auditorium with a stage 24 and all its equipment. The ceremonial opening of the hall took place on 27 February $1821 ; 25$ the opening of the theatre took place on 26 May 1821.

Your Magnus or Alexander Boucher ${ }^{452}$ played here yesterday to great applause. ${ }^{453} 16$ He reminds me of Baron Bagge, ${ }^{454}$ with one exception that when the fool is 17 subtracted from Boucher, a rare violinist is left.

Intonation; control of the fingerboard and bow; jaunty and earthy; sensitivity; 19 audacity to take on the most daring things and to conquer are as natural to him as 20 his dandyism. And so he can be praised for what he is. This is how one plays within 21

450 For a review of the concert see $A M Z 23$ (1821), no. 12, 21 March, column 196. 27

451 Goethe had enquired about the composition once again on 18 February 1821. 28

The setting which was conceived in Teplitz is not extant; the new composition was never 29 completed.

452 A reference to Alexander the Great and Alexandre Jean Boucher (1763-1861). 31 Spohr, who met this well-known French violin virtuoso at Brussels in 1819, spoke of his 32 conscious resemblance to Napoleon. He traded on this resemblance and, on one occasion, 33 advertised a concert in these terms: 'An unfortunate resemblance is forcing me to go into 34 exile. Therefore, before leaving my beautiful fatherland, I will give a farewell concert.' He 35 referred to himself as 'L'Alexandre des Violins'.

453 The French violinist and his wife gave a series of six concerts in the Berlin theatre 36 on 28 April, 9 May, 6, 17 and 25 June and 8 July, the success of which inspired three further 37 concerts in the autumn on 11 September, and 5 and 18 October. At the concert mentioned by 38 Zelter and in collaboration with the Königliche Kapelle and their leader, Friedrich Ludwig 39 Seidel, Boucher performed a violin concerto by Viotti and a Capriccio which he himself 40 43 musical enthusiast. For reports of his playing see AMZ 21 (1819), no. 10, 10 March
44 columns 152-62 and Zelter's letter to Johann Samuel Carl Possin (GSA 95/I, 8, 11). 
1 one's four walls. When I wasn't looking at him, I imagined him in a nightshirt and 1

2 slippers, and precisely this ability to stand alone on a three-foot-high stage before 2

3 the general public - I admired it with amusement. His likeness to Napoleon, which 3

4 was advertised beforehand, ${ }^{455}$ attracted several people, although the room was not 4

5 full.

6 I knew Baron Bagge very well. He was no chicken and in addition to his

7 imaginary originality, he has the best heart for art and young artists. He set the

8 rarest delicacies before the young people in order to teach us and some of us gave

9 him money. We teased him [about] being the best, but he was not put off and the 10 affection was mutual.

11 Madame Boucher ${ }^{456}$ was applauded even more. Her simultaneous playing 11

12 on the piano and harp ${ }^{457}$ shows equal mastery of both instruments, a feat which 12

13 demands long hours of practice, on account of the contrary motion of arms and 13

14 fingers; though the whole thing is very odd in itself. 14

15 Her composition of the concerto ${ }^{458}$ she played pleased me more than that of 15

16 her husband. 16

17 Kapellmeister Hummel has had an extraordinary reception; today he gives his 17

18 second concert, ${ }^{459}$ and if he does not return to Weimar exhausted, the heat can't be 18

19 blamed, for it is exceptional. 19

20 The King has been to hear my Passion Music this year, ${ }^{460}$ and sent me 2020

21 Friedrichs d'or, which were welcome as the little yellow discs are rare with me. 21

22

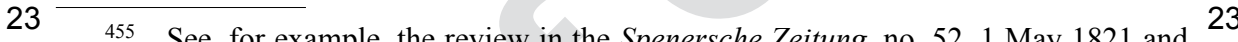

24 See, for example, the review in the Spenersche Zeitung, no. 52, 1 May 1821 and

24 also Eduard Devrient, Meine Erinnerungen an Felix Mendelssohn-Bartholdy und seine

25 Briefe an mich (Leipzig: J.J. Weber, 1869), p. 23.

26456 Céleste Boucher, née Gallyot (d.1841), principal pianist and harpist at the court of

27 King Karl IV of Spain and music teacher to the infanta of Spain.

$28 \quad 457$ A Duett-Concertante by Céleste Boucher performed by her on both instruments at

29 the same time [sic].

30458 Concerto for pedal harp composed and performed by Céleste Boucher; see the

31 review in $A M Z 23$ (1821), no. 20, 16 May, column 349.

32459 Johann Nepomuk Hummel (1778-1837), Austrian composer and pianist, Court

33 Kapellmeister to the Grand Duchy of Weimar from 1819, gave two concerts in April 1821 32

34 in Berlin, which included his own compositions. The first concert took place on 25 April 34

35 and was reviewed in the $A M Z 23$ (1821), no. 20, 16 May, column 349. The second concert, 35

36 on 30 April, included a Grand Trio by Hummel and a performance of Schiller's Kassandra 36

37 given by Auguste [Crelinger] Stich.

$38 \quad 460$ In a letter to the king on 13 March 1821, Count Brühl had recommended 'performing

39 this music on Palm Sunday, 15 April' since 'His Majesty the King himself wanted to attend

39 the Sing-Akademie's performance of the Passion Music' but he could not be present on

40 Good Friday, the traditional day of performance of Graun's Passion (GSA 95/I, 7, 1). Zelter

41 answered Count Brühl on 17 March that the proposal was to him 'all the more desirable

42 because it makes me happy that for the first time in my life I am able to fulfil a wish of

43 my King and Lord' (draft letter to Count Brühl). The postponed wish was realized on a

44 different occasion: on 15 April 1821 Graun's Passion Cantata, Der Tod Jesu, was performed 
1 Apart from this he has been so gracious as to give me a site near the University 1

2 Garden upon which a hall for my Sing-Akademie is to be built. ${ }^{461}[\ldots]$

3

4

5

6

7

8

9

in the presence of the king in the new concert hall of the Königliches Schauspielhaus; see $\begin{aligned} & 25 \\ & 26\end{aligned}$
$A M Z 23$ (1821), no. 20, 16 May, column 349.

284. Zelter $\quad 5$

Berlin, 10 May 18217

[...] Yesterday Herr Boucher together and his wife were heard once again to 9 greater applause ${ }^{462}$ and in a fuller auditorium. His tone is in fact beautiful and his 10 [technical] facility is really extraordinary. The way he played the Capriciose I 11 believe to have recognized as almost innate, because it is without affectation and 12 contains something romantic that one can respond to really well, though I would 13 use this bundle of talents differently.

The day before yesterday Herr Lortzing came ${ }^{463}$ and brought me your dear note of 3021 June and awoke me from dreams of the distant past to modern conscience. I didn't 22 want to refuse to give something to the son of a school friend and colleague, ${ }^{464}$ so I 23

461 After the completion of the opera trenches with the new guards, the designated 27 place for a new building for the Sing-Akademie beside the Ministry for Finance was 28 built. Schinkel was entrusted to draw up the plans, which were presented to the king on 29 27 March 1821 with a request for the handing-over of the plot in the chestnut woods. The 30 king granted permission for this on 27 April and Zelter was able to produce the royal papers 31 granting consent for the choir performing on 1 May. With that beginning - after decades of 32 complaints about the Sing-Akademie's need for rooms - the history of its own house, the 33 foundation stone, was laid on 30 June 1825 (ZG 1 to 2 July 1825) and the Sing-Akademie 34 entered their new premises on 2 January 1827 ( $Z G$ end of October 1826 to 23 January 35 1827). Today the building is the Maxim Gorky Theatre on Unter den Linden, Berlin.

462 For a review of the concert; see $A M Z 23$ (1821), no. 25, 20 June, column $438 \mathrm{f}$.

$\begin{array}{ll}463 & \text { Jor a review of the concert; see } A M Z 23(1821) \text {, no. 25, } 20 \text { June, column 438f. } 37 \\ 38\end{array}$ written a letter of introduction on 30 June 1821. See also Zelter's letter on 31 July 1821, 38 where he relates: 'According to what I hear, Lortzing was not able to come [here] to play 39 because his arrival was not prepared and Count Brühl is not present.'

464 Heinrich Friedrich Ludwig Rellstab (1799-1860), son of the composer and music 41 publisher Johann Carl Friedrich Rellstab (1759-1813), who published Zelter's early 42 compositions (for example, his viola concerto in 1779, as well as songs and piano pieces in 43 4 Rellstab's piano magazine, 1786/87). 
1 am sending you a couple of copies of a song collection which Nägeli in Zurich has 1

2 taken the trouble to bring to light, with a significant number of printing errors and 2

3 smudges. No one will recognize my portrait, which doesn't matter. There should 3

4 be an opportunity to observe the man himself with better eyes. 4

5 I am not sure if I have already thanked you for your prologue: ${ }^{465}$ it has been 5

6 staged here a thousand times, but what is special about this performance is that 6

7 it is, without exception, only one voice; the good humour which this prologue 7

8 generated on the very first day from the Most High down to the likes of me was 8

9 so perceptible in the deepest silence; it rose from quiet reverence to the loudest 9

10 jubilation in which the trumpets and timpani had joined in, as if under compulsion, 10

11 at the very last moment. Iphigenie has never had the same effect as today - even 11

12 on me. The Parzen's chorus shook everyone to the core - and it seemed as if they 12

13 never knew it before. [...] 13

14 Yesterday Boucher gave his sixth concert ${ }^{466}$ to a full house and he owes that 14

15 to you. ${ }^{467}$ The first time they wanted to laugh at him. I laughed so heartily at some 15

16 pieces that I earned the honourable title of 'bulldog'. Boucher is, incidentally, a 16

17 real musician; he knows how to shape his embouchure so that no air gets in. It is 17

18 as pleasant to hear this couple together as to hear one of them on their own. The 18

19 applause was extraordinary. We are on good terms with one another and I doubt 19

20 that this will be his last concert. ${ }^{468}$ In any case he will be here again in the winter. 20

$21 \mathrm{He}$ also thinks that, with the exception of Paris, it's not easy to find so many good 21

22 performers together. [...]

23 I almost forgot to say that the young man is called Rellstab and fought as 23

24 Lieutenant in the last war. He is a born Berliner, son of the famous publisher and 24

25 founder of a second Liedertafel here, ${ }^{469}$ for which he endeavours to write verses. 25

465 This passage refers to the official opening on 26 May 1821 of the new theatre 30

31 which King Friedrich Wilhelm III had founded in place of Schinkel's old theatre, which 31

32 had been destroyed by fire on 29 July 1817 . Both Berlin daily newspapers gave extensive

33 and glowing coverage - especially the Spenersche Zeitung. After an orchestral prologue

34 Auguste Stich performed Goethe's Prolog zu Eröffnung des Berliner Theaters im Mai 1821.

35 Then Goethe's Iphigenie auf Tauris was introduced by the overture from Gluck's Iphigenie in Aulis. The official opening was concluded with the ballet Die Rosen-Fee, and a public

36 address by the architect [and master builder], Karl Friedrich Schinkel.

37466 The concert took place on Sunday 8 July in the concert hall of the Königliches 38 Schauspielhaus.

$39 \quad 467$ Goethe gave the couple a letter of recommendation to pursue performances in 40 Berlin; GZ 23 February 1821.

41468 Zelter's supposition is correct: after their sojourn with Prince Radziwill in Posen,

42 Alexandre and Céleste Boucher gave three further concerts in Berlin.

\section{2} 33

43469 The Jüngere Liedertafel founded in April 1819 by Ludwig Rellstab together with 43

44 Ludwig Berger and Bernhard Klein, which included such members as E.T.A. Hoffmann. 44 
1 He wants to meet you and is a fine young man. As he made me an honorary member 1

2 of the Liedertafel without payment, I could not turn down his request. [...] 2

3

4 Enclosure: Songs from Zelter's New Song Collection. ${ }^{470} \quad 4$

286. Zelter

11 Boucher is still here and wants to follow the Radziwills to Posen where he will be 11

12 really welcome. He may well return as he has won the [heart of the] general public. 12

13 The chap is like an eel: he is easy to get on with. We are on good terms with one 13

14 another. Last Sunday he listened to a couple of my students with whom he was not 14

15 displeased. He asked for a violin concerto by Bach and acts as if he liked it. He has 15

16 already played it twice in private and the amateurs enjoyed it to the full. We are 16

17 learning from one another and he will give up the opinion that good old musical 17

18 works need to be chopped up and thrown together. He knows that I treasure what's 18

19 extraordinary in him and at the same time find what's ordinary extraordinary. He 19

20 is, in fact, a reasonable person. He holds you in special affection. Have you heard 20

21 him play? ?71 $^{2} 21$

22 I have to praise Eberwein, who faithfully sends me his songs. In exchange I 22

23 sent him one from the Divan, p. $26^{472}$ which I prepared for the Liedertafel. As it 23

24 stands I could not really use it because they don't sing it properly and ultimately 24

25 the melody needs to be sung well. If this has been successfully realized, please 25

26 temper your justice with mercy for I have attacked your verse and modelled [the 26

27 setting] on it.

28 What I liked best from the Divan is 'Worauf kommt es überall an'. ${ }^{473}$ You 28

29 might like it because I like it, and it has also been successful 29

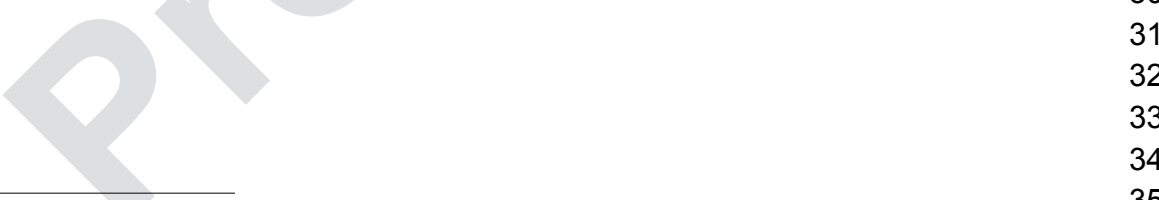

470 The two reviews from the Vossische Zeitung and Spenersche Zeitung were a 35 possibly enclosed as they are contained in the collection of letters received by Goethe (GSA 36 28/95, pp. 417-20). 37 471 Boucher and his wife had given a concert in Goethe's house on 22 February 38 Zelter's setting of 'Derb und Tüchtig': there are two copies in Goethe's music 40 ction (GSA 32/35, 32/37), both by the same copyist; presumably one of these copies 41 (GSA 32/35) was originally Eberwein's copy. 42

44 Setting of Goethe's poem 'Dreistigkeit'; Zelter's setting, entitled 'Entschluß', is 43 on the reverse side of 'Derb und Tüchtig' in Goethe's music collection (GSA 32/37). 44 
5 I must communicate to you an old discovery that I am now making myself for the 6 second time.

7 Flicking through my edition of my Lessing's works, ${ }^{474}$ in volume 23 I came

8 across the theatrical bequest, the Hercules Furens of Seneca, in which I found the

9 most wonderful subject for an opera, and what is more, towards the end Lessing

10 himself thinks the same [...]

11 I have a young pupil, now at work upon his third comic opera, to whom I 11

12 should like to give a serious subject. ${ }^{475}$ The boy's talent is solid; his work flows 12

13 spontaneously and his love of the art ensures he is industrious. When the time is 13

14 right, I think I will send him to Italy so that he can find his own way [...] 14

1529 August: Yesterday evening your birthday was celebrated at the Sing- 15

16 Akademie with Milton's Morgengesang. ${ }^{476}$ I hardly know whether you are alive, 16

17 so I must keep your memory alive in my own way. [...] 17

185 September: A new opera, Der Freischütz, by Maria von Weber, is causing a 18

19 commotion. ${ }^{477} \mathrm{~A}$ foolish huntsman, the hero of the opera, allows himself be enticed 19

20 by equally stupid sorcerers into casting so-called magic bullets by means of black 20

21 magic; if he fires the best shot, he will win the bride, who is already pledged to 21

$22 \mathrm{him}$. Does he finally kill her with this bullet? Not at all! He doesn't even manage to 22

23 hit her. She faints when she hears the shot, springs immediately to her feet again, 23

24 and marries him forthwith. Whether he hits it off in marriage any better, the story 24

25 does not say.

26 The music is greatly acclaimed and is really so good that the audience tolerates 26

27 all the smoke and steam. In all the huffing and puffing I can find but little genuine 27

28 passion. The women and children are crazy about it; the devil is black, virtue 28

29 white, theatre buzzing, orchestra lively, and that the composer is no Spinozist you 29

33474 Gotthold Ephraim Lessing, Sämtliche Schriften (30 vols, Berlin, 1771-94),

34 complete in Zelter's library (Catalogue no. 462-91).

35475 Felix Mendelssohn. The three operas were Soldatenliebschaft, Die beiden 35

36 Pädagogen and Die wandernden Komödianten.

37476 'On the Morning of Christ's Nativity' from John Milton's Paradise Lost in German 36

38 translation by Samuel Gottlob Bürde set to music by J.F. Reichardt.

$39 \quad 477$ Five weeks after the first performance of Spontini's Olympia, Brühl produced the

39 successful world premiere of Weber's Der Freischütz (18 June 1821) under the composer's

40 direction in the new Schauspielhaus designed by K.F. Schinkel. Whereas Spontini's

41 audience consisted mostly of royalty and nobility, Weber's was largely made up of wealthy

42 citizens, including Heinrich Heine, Hoffmann and Mendelssohn, which was symptomatic

43 of the rivalry between the two houses. For reports of the performance see AMZ 23 (1821),

44 no. 29,18 July, column 510. 
1 may gather from the fact that he has created such a prodigious work out of the 1

2 nothing suggested above.

317 September 1821: Last Tuesday Boucher gave his second last concert ${ }^{478}$ and 3

4 gained over 1,000 thaler profit.

5 Madame Campi ${ }^{479}$ has arrived from Vienna and played twice in succession to 5

6 an empty house. Yesterday a Mademoiselle Sessi ${ }^{480}$ was also heard before empty 6

7 benches. Both singers are important and are distinguished from one another in 7

8 that the latter, with a Caesar's nose, is quite young and the former, with a polish 8

9 nose - she is a Pole - is quite old. In comparison to Catalani both come out on top, 9

10 which doesn't make them any richer, and one observes: nature can do what it likes 10

11 and will always be victorious.

20 September 1821: There's no end to it: already another new singer. A 12

13 Mademoiselle Kainz, ${ }^{481}$ Viennese and a very capable girl, sang for me yesterday. 13

14 Her figure and appearance are acceptable, though she could be a bit taller [...] 14

15 but [with] a voice and a training, security, power and range which I have not 15

16 come across for a long time: round, clear, soft and well placed - a good heart and 16

17 willing.

18 I have now heard the little light-hearted work by Rossini as I wanted to. ${ }^{482}$ [...] 18

19 No, there is nothing better than a healthy human voice, and what I have known for 19

20 a long time and what no one will believe from me is that the Italians alone know 20

21 what opera is. Gluck took great pains with opera and he succeeded admirably in 21

22 what he set out to do. But a voice made by God knocks over a whole armoury of 22

23 artistic resources and whoever knows how to set it in motion is for me beyond 23

24 criticism. Boucher is now giving a third 'final concert' at which Mademoiselle 24

25 Kainz wants to sing. ${ }^{483} \mathrm{He}$ himself called it the second ['last concert'] in the paper. 25

26 I believe, however, he has lost count. 26

479 Antonia Campi, née Miklaszewicz, chamber and opera singer at the Viennese 32

Court; Zelter had attended her performance in Mozart's La Clemenza di Tito in Vienna 33 in 1819. Her Berlin concerts took place in the Königliches Schauspielhaus on 7 and 1334 September 1821. 28.

480 Maria Theresia Sessi, singer in Vienna; performed in Southern Germany 1819-35

$481 \quad$ Marianne Katharina Theresia Kainz, married name Holland and later von Kosteloot 37 (1800-66), singer in Prague, on guest performance tour from 1819. Her Berlin performance- 38 
5 [...] On arriving here, I find your dear letters and parcels, for which my best thanks;

8 If you would like to visit and make you own judgement and enjoy our work 8

9 here, decide when you would like to come, I suggest the second half of October, ${ }^{485} 9$

10 but let me know, don't surprise me. I have still two weeks' work to do here, and 10 11 there is neither time nor place, neither people nor the opportunity, to receive you. 11

12 Let me know in your next letter what you think, what you have planned and what 12

13 is possible for you. At this stage of my life, I can no longer improvise. 13

$14[\ldots]$ Music is beginning to take effect at present and so once again may you 14

15 work like a genuine musical friend. [...] 15

16 I had written this much when I first received your welcome letter of 20 August 16

17 to 20 September and, as you can easily imagine, it made me very happy. You 17

18 will receive the present [letter] through a pianist Hartknoch, ${ }^{486}$ a student of our 18

19 Hummel, who would like to recommend himself to you on the grand piano. The 19

20 best of thanks for everything communicated. 20

27 With regard to music, our sinful life $\mathrm{e}^{487}$ is, of course, as unnatural as possible and 27

28 we shouldn't be too far away from it to learn what all have known for a long time; 28

29 also it is fun to see my stupidity acknowledged. [...]

30 This autumn our town is like a tree in full bloom to which the dearest, migrant 30

31 songbirds fly to and fro. Singers, pipers, violinists form themselves naturally in 31

36 pp. 293-94) and 15 July, WA IV/35, p. 17. The grand piano was delivered by the music

36 dealer Peters in Leipzig on 14 July 1821.

$37 \quad 485$ Zelter, his daughter Doris, and Felix Mendelssohn visited Goethe on 4 November

39486 Karl Edward Hartknoch (1796-1834), pianist, composer, music teacher, student of

40 Hummel's, from 1824 in St Petersburg, from 1828 in Moscow. Hartknoch had examined

41 Goethe's Streicher grand piano and 'highly approved', Goethe to Rochlitz, 15 July 1821,

42 WA IV/34, p. 409.

43487 Zelter is taking up Goethe's phraseology of the 'sinful life of musicians in 43

44 Berlin'. 
1 a queue like patient lambs with music, violins, flutes, clarinets under the arm in 1

2 order not to surpass and, at best, outdo one another. Since we are wealthy people, 2

3 we also act that way: paid much for little and vice versa. [...] 3

4 On Thursday Boucher played the last of his final concerts ${ }^{488}$ to a full house 4

5 once more. As a result, Berlin is his Athens. This could turn out to be all he has, 5

6 as with Catalani, because what really pleases us, they find terrible in other places. 6

$7[\ldots]$

8 Nägeli had really hoped that I would be extremely happy with his edition of 8

9 my songs and is amazed at my impertinence in not improving the many errors and 9

10 smudges in it. Regarding the picture, I have the satisfaction of knowing that people 10

11 find me better looking. One can't take that amiss! [...] 11

12 Incidentally, something about the theatre [...] Boucher is the man of the 12

13 moment. Whoever wants a full house at a concert must have Boucher there. [...] 13

14 He knows the world and has feeling - even if it is French feeling! He has, in fact, 14

15 done something moral to temper the acquired national hatred based on lies. 15

[...] Eberwein is making arrangements for me to hear, instead of merely reading, 22 Jena, 14 October 182120

23 some of the music you kindly wrote for me, but if in the Chorus 'Dichten ist 23

24 ein Übermut' I restore the author contrary to your corrections without injuring 24

25 the musical rhythm, you will perhaps forgive me. A poet feels strange when he 25

26 discovers that he has been tricked, like the old gentleman fifteen hundred years 26

27 ago $^{489}[\ldots]$

28 I am glad that Boucher and his wife are successful for there's continuous hard 28

29 work backed by natural talent. I agree entirely with everything you say about the 29

30 human voice. When I heard Catalani in Carlsbad, ${ }^{490} \mathrm{I}$ said, with originality, on the 30

31 spur of the moment:

488 On 18 October 1821 with the music director Carl Moeser; AMZ 23 (1821), no. 47, 35 21 November, column 796. This was, in fact, the last concert for 1821. The following year, 37 in October 1822, Boucher performed in Berlin once again.

489 Namely, like the editor of the Iliad and the Odyssey, two and a half centuries ago. 38 The remark reveals Goethe's renewed interest in the Greek epics on account of his reading 39 Schubarth's essay 'Ideen über Homer und sein Zeitalter'.

490 Goethe had got to know the famous singer on 31 July 1818 in Prince Metternich's 41 house. Metternich wrote to his wife afterwards, 'Goethe arrives at the first rehearsal for the 42 is proud of', Gespräche, vol. 3/1, p. 71 . 
1 In the drawing room as in the stately hall, $\quad 1$

2 one never hears enough 2

3 One discovers for the first time 3

$4 \quad$ Why one has ears. $\quad 4$

5

626

$\begin{array}{lll}7 & \text { 291. Zelter } & 7\end{array}$

$8 \quad 8$

$9 \quad$ Berlin, Leipzig, 21 to 31 October $1821^{491} 9$

$10 \quad 10$

11 It would have hardly occurred to me, at this stage, to pass judgement on our new 11

12 theatre. Hopefully you are familiar enough with the plans to follow the points listed 12

13 here. $^{492}[\ldots]$ The latest hitches, since the house is now ready, are supposed to be 13

14 in the following: [...] the orchestral members [complained] about uncomfortable 14

15 entrances and steps to the orchestra. [...] The orchestra has stairs on both sides: 15

16 a straight one in order to leave the house quietly and a winding one to the stage. 16

17 [...] 17

18 Song, sound and speech can be heard well. As up to now I have heard all 18

19 performances from seats in the front stalls or from the orchestra, I cannot report 19

20 more about it. $\quad 20$

2123 October: About the concert hall ${ }^{493}$ I could still say that it is generally 21

22 acclaimed. It is true that musicians and singers complain about troublesome 22

23 execution. I have no confidence in their judgement about this because in the hall 23

24 itself, above and below and finally on the landings and on the stairs, music which 24

25 is played well resounds clearly and freely. $\quad 25$

26 One is much too accustomed to fingers and plucking to have an unbiased 26

27 opinion, and this too, and the infinitely petty foolings, rough and mad antics of 27

28 a Boucher, can be heard clearly from the remote staircases. I have just recently 28

29 conducted Handel's Alexanderfest $t^{494}$ and found it fine. 29

$30 \quad 30$

$31+31$

$32 \longrightarrow 32$

33491 Whether Zelter sent this letter from Leipzig or whether he delivered it himself 33

34 and came unannounced to Weimar is unknown. The letter has no address and no postmark. 34

35 At any rate, Goethe heard of Zelter's arrival on 3 November and travelled to Weimar the 35

36 following day to greet his friend; see Goethe's diary, 3 November 1821, WA III/8, p. 132.

$37 \quad 492$ Goethe had asked Zelter's opinion of the new Berlin theatre because after the

38 initial enthusiasm for the new Königliches Schauspielhaus on 26 May 1821, complaints

38 soon began.

39493 At the request of the Prussian King, Schinkel had included a concert hall as well

40 as rehearsal rooms and storerooms. Accordingly the 1,600-seater was smaller than the

41 previous theatre, which seated 2,000 .

42494 On 27 February 1821, before the official opening of theatre (26 May), the concert 42

43 hall was unofficially opened with a performance of Handel's Alexanderfest, under the 43

44 direction of Spontini and Zelter. $\quad 44$ 
126 October: Early tomorrow morning I, with my Doris and a pupil of mine, ${ }^{495} 1$

2 Mendelssohn's son, a lively boy of 12 years old, will set out for Wittenberg to 2

3 attend the festival. You shall hear from Wittenberg if all three of us are coming to 3

4 Weimar. As your house is full enough, I shall book into the Hotel Elephant, where 4

5 I have always been contented ${ }^{496}$ once I can see you. I long for your company! I 5

6 really want to introduce you to my Doris and to my best pupil, before I leave this 6

7 world - in which, however, it is my intention to remain as long as possible! The 7

8 pupil is a good and handsome youth, lively and well mannered. Admittedly, he is 8

9 the son of a Jew, but no Jew himself. ${ }^{497}$ The father, to his own disadvantage, has 9

10 not had his sons ${ }^{498}$ circumcised and educates them properly; it would really be 10

11 curious if the son of a Jew turned out to be an artist. 11

18 [...] My kind greetings to Dorchen, ${ }^{499}$ and thanks for her kindness to Ulrike, ${ }^{500} 18$

19 remember me to Felix and his parents too. Since you left, my piano has been 19

20 silent; one attempt to bring it back to life was almost a complete failure. However, 20

21 I hear a great deal of talk about music, which is always a poor substitute.

22 Farewell! In your glorious Berlin, think of me who, in my sunny little back 22

30 Yesterday the King listened to our Liedertafel with obvious pleasure ${ }^{502}$ and, contrary 30

31 to what is customary, it kept going from nine o'clock until after midnight. 31

496 Zelter mistakenly claims he has always been well looked after here, he had, in fact, 34

497 Abraham Mendelssohn had his children baptized into the Evangelican church in 36

37 the Berliner Neue Kirche; he himself converted to Christianity six years later.

38498 Felix and Paul Mendelssohn. 38

39499 Zelter's daughter Doris. $\quad 39$

40500 Ulrike von Pogwosch, Otillie von Goethe's younger sister (sister-in-law to August 40

41 von Goethe). 41

42501 Goethe's study. 42

43502 An account of King Friedrich Wilhelm III's visit to Zelter's Liedertafel on 43

4428 February 1822 is in Wilhelm Bornemann, Die Zeltersche Liedertafel in Berlin, ihre 44 
1 Prince Radziwill, who is a member of the Liedertafel, had summoned the 1 2 plenary meeting to his home.

3 A long table for 30 singers was served in a spacious hall. 3

4 As hostess, Princess Radziwill ${ }^{503}$ sat at the top section at a special round table 4

5 with the King, Crown Prince ${ }^{504}$ and the other princes and princesses of the royal 5

6 family, the Grand Duke of Mecklenburg-Strelitz and his wife. ${ }^{505} 6$

7 The generals and chief civil servants [sat] with the women and girls at another 7

8 three special round tables.

9 In between courses a series of 12 different songs were sung, among which 9

10 'Die heiligen drei Könige' ${ }^{506}$ and 'Soldatentrost' ${ }^{507}$ had a special effect on the 10

11 audience. 11

12 At the meal the King asked for the large bronze wine goblet, which is also 12

13 a pitched bell, and had me explain the meaning of it, along with the aims and 13

14 organization of the whole foundation.

15 What delights me about it was that the thing has substance and has not gone out 15

16 of fashion because we are almost ready to celebrate our third five-year anniversary. 16

17 Since it spreads from here north- and southwards over Weichsel, Main and Rhine, 17

18 one would readily find out that there are fish in the Spree. In Leipzig, where they 18

19 know everything ${ }^{508}$ and also have a Liedertafel, ${ }^{509}$ they acted modestly as if their 19

20 counterparts gave nothing away. ${ }^{510} 20$

21 Count Brühl has completely recovered and was also at our table where Prince 21

22 Radziwill was the most attentive host. [...] 22

$23 \quad 23$

$24+24$

$25 \quad 25$

$26 \quad 26$

$27 \quad 27$

$28+28$

$29-29$

$30 \quad 30$

31 Entstehung Stiftung und Fortgang (Berlin, 1851), p. xvf. 31

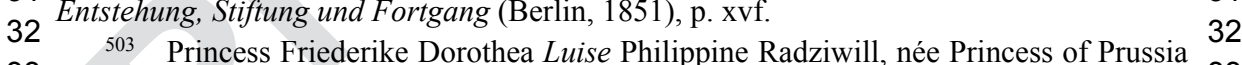

33 (1770-1834), daughter of Prince [August] Ferdinand, niece of Friedrich II, the Great 33

34 (1770-1834), daughter of Prince [August] Ferdinand, niece of Friedrich II, the Great. 34

35505 Georg Friedrich Karl Joseph von Mecklenburg-Strelitz (1779-1860) and Marie 35

36 Wilhelmine Friederike von Mecklenburg-Strelitz, née Princess of Hessen-Kassel (1796- 36

37 1880). 37

$38506 \quad$ Zelter's setting of Goethe's Ephiphaniasfest. 38

39507 'Soldatentrost' ('Nein! Hier hat es keine Not ...): the date of Zelter's setting of this 39

40 poem written in 1792 and published in 1815 is unknown. 40

$41 \quad 508$ A reference to Leipzig as the place of publication of Brockhaus' Enzyklopädie. 41

42509 The first Liedertafel in Leipzig was founded by Jakob Bernhard Limburger on 2442

43 October 1815.

$44 \quad 510$ Zelter's meaning here is that no one gives credit to the Liedertafel in Berlin. 44 
5 First and foremost, congratulations on the celebrated Liedertafel! It is really nice 5

6 that Prince Radziwill made it known to the King and let [him] enjoy the many 6

7 qualities he has around him.

14 [...] Enclosed are six organ sonatas by Carl Philipp Emanuel Bach for our good 14 15 spa-inspector ${ }^{511}$ and two more recent sonatas ${ }^{512}$ by my best students as [being] the 15 16 most up-to-date of their kind. He brought me a music manuscript which at first 16 17 glance I took for an original. Since he wanted to leave it, I offered him something 17 18 in exchange for it. Among the Bach Sonatas there is also an original, a real rarity, 18 19 which alone is worth more than the entire manuscript, which was composed by the 19 20 former Kapellmeister Stölzel. ${ }^{513}$

21 Felix is good and working well. His third opera ${ }^{514}$ is finished and scored out 21 22 and will soon be performed by his friends. After his return from Weimar he also 22 23 finished a Gloria ${ }^{515}$; besides writing more than half a piano concerto for his sister; ${ }^{516} 23$ 24 he has begun a Magnificat ${ }^{517}$ too. Even if I fail to produce anything much myself, 24 25 I keep my students focused and there are half-a-dozen I enjoy working with. 25 2623 March: Thank our beautiful gracious one for me for her lovely gift. It was 26 27 time that she went because I in fact began to be in love with her, as I of course was 27 28 and still am. The whole of Berlin is also in love with her and I cannot compete with 28 inspector and organist Schütz on 5 April 1822; see Goethe's diary WA III/8, p. 182.

513 An extract or handwritten passage from a theoretical work by Gottfried Heinrich 33 Stölzel, possibly one of the manuscripts housed in the Berlin Staatsbibliothek today: Anleitung zur musikalischen Setzkunst; Kurzer und gründlicher Unterricht, wie ein 36 Liebhaber der Musik (...) einen Contrapunctum simplicem (...) erlernen kann. libretto by Johann Ludwig Casper.

514 Felix Mendelssohn, Die wandernden Komödianten, one-act Singspiel (1822); 37 
1 the whole of Berlin, because I am already sufficiently beaten by ailing fingers, so

2 the misfortune is not greater than the stroke of good luck. Since she left everyone

3 sings Amynts Klagen über die Flucht der Lalage. ${ }^{518}$ The old cantata by Benda

4 would perhaps never have been awoken again and because of it Lalaruk ${ }^{519}$ is now

5 completely forgotten.

6 Next Good Friday I am thinking about putting on Handel's Messiah instead of

7 the favourite Graun setting of Ramler's Passion ${ }^{520}$ and I shall take a step forward

8 at my [own] risk, in so far as the choir is not completely happy with it. I am

9 in agreement with Merkutio: ${ }^{521}$ people have their freedom in order to renounce

10 it and Handel's Messiah is without doubt a more poetic work than Ramler's 10

11 Tod Jesu, which is founded on compassion. The Messiah contains nothing but the 11

12 consolation of redemption which should certainly be the point of all suffering. 12

19 [...] The ballet ${ }^{522}$ is, in fact, praiseworthy because of the lively interventions which 19 20 hold attention firmly through three not exactly short acts. There is an overflow of 20

21 material $[\ldots]$

22 Now, I have taken your advice and added the particular circumstances of my 22

23 apprentice and journeyman years into my little autobiography ${ }^{523}[\ldots]$

24 Easter Saturday evening: Yesterday evening our Messiah ${ }^{524}$ was launched like 24

25 a magnificent ship, and is now buried again for another year. The hall was packed 25

519 Spontini's setting of Thomas Moore's 'Lalla Rookh' (1817) composed for the court

30 celebration of the Russian Grand Duke Nikolaus Pawlowitsch and Alexandra Fjodorowna

31 née Princess Charlotte of Prussia, which took place after their wedding on 27 January 1821

32 in Berlin. The celebration was repeated on 11 February for a larger, educated audience.

520 Zelter was not alone in his acclamation of Graun; Graun's recitatives were cited in J.G. Sulzer's Allgemeine Theorie der schönen Künste as exemplary pieces in the genre. So, too, Scheibe noted not only the technical quality of Graun's music but also its expressiveness.

$36 \quad 521$ A relevant citation by Mercutio in Shakespeare's Romeo and Juliet could not be found.

522 Aline, Königin von Golkonda, ballet by Jean Pierre Aumer, music by Carl Blum,

39 adapted for the stage by François Michel Hoguet. Zelter attended the second performance

40 on 29 March 1822; the Berlin premiere had taken place on 28 March.

41523 Zelter's revised version of his autobiography; see Schottländer, Carl Friedrich

42 Zelters Darstellungen seines Lebens, pp. 215-19.

$43 \quad 524$ Mozart's arrangement of Handel's Messiah was performed on 5 April 1822 in the 43

44 concert hall of the royal theatre; the performance was given by the Königliche Kapelle, 44 
1 full and I think I have earned around 1,000 thalers. My audience also appeared to 1

2 be happy, which is also valuable when one plans to come again. 2

9 Yesterday, Saturday, Madame Mara ${ }^{525}$ came to me of her own accord - and on 9

10 foot - to help me count my well-deserved fee, or so she claimed. Just imagine 10

11 this 72-year-old matron, this demon of a singer, being moved by our Messiah. 11

12 She said the pain and the joy quite carried her away; those sitting near her must 12

13 have thought she was daft. [She believed] the fugues flowed smoothly: an organ of 13

14 living voices. She has sung this oratorio often enough in London ${ }^{526}$. She finished 14

15 by confessing that our performance might compete with those in London, of which 15

16 the English are proud enough. [...]

17 Now I must admit that after a single swift rehearsal (apart from a few mistakes 17

18 made by the Königliche Kapelle who were well paid by me), I was really happy 18

19 with it. That music lasting three hours can so continuously interest and satisfy 19

20 a crowded audience shows that the work of 32 years $^{527}$ has borne fruit here and 20
21 there. [...]

2211 April: The day before yesterday they held the Liedertafel ${ }^{528}$ without me; 22

23 I am not supposed to go out. It is little wonder that no one understands the Divan 23

24 because it is only [recently] known to me. I have quietly read the title a hundred 24

25 times and thought nothing other than how anyone could be called Müller, Schulze, 25

26 Noak. Now that I am setting to music one piece after another, I have discovered 26

27 what the Divan, what Hafis means, and I am not going to reveal it to you. But, 27

28 like the tongue of the Erfuhrt ${ }^{529}$ bell, it will strike your ear when you come and 28

29 hear 'Elemente', ${ }^{530}$ p. 14 and 'Dreistigkeit', p. $25 .{ }^{531}$ The effect of these pieces 29

30 captures the universal. I hear it resound when I am sitting around at home. If one 30 (1822), no. 21, 22 May, column 341.

525 Gertrud Elizabeth Mara, née Schmeling (1749-1833) had undertaken her final 34

English tour. On the return journey to her home in Reval, she visited Berlin.

$40 \quad 528$ In accordance with the statutes, the Liedertafel met once a month on the Tuesday 40 
1 has patience with people, then they have patience with themselves and will finally 1

2 notice that a poem has something in its words which is transcendent. The devil can 2

3 take me if these settings are not excellent; and if they are not, then he can have me 3

4 for nothing.

5

6

7

298. Zelter

$11[\ldots]$ On my arrival here in Bautzen I found the whole town in bustling activity. 11

12 One local inhabitant, ${ }^{532}$ who died many years ago, set up a trust to the effect that on 12

13 every third day of Whitsun some 100 thaler in groschen would be shared among 13

14 the poor. The action took place during organ playing and trumpet fanfares from 14

15 the town hall tower. The organist (Berg), whom I wanted to catch at work and 15

16 managed to get out of the inn, remarked, 'I get two thalers for which I must play 2916

17 strophes. I accept that and give two thalers to a blind matron, and without moving 17

18 a bone, I, poor devil, do much more good in life than that dead man who gives 18

19 away what he doesn't need.' 19

20 Dresden, 29 May: A Herrnhut literary figure by the name of Peter Mortimer, a 20

21 man of 72 years, five or six years ago sent an old manuscript to Berlin through old 21

22 Körner, ${ }^{53}$ in which he sets out various church music modes (which are also called 22

23 Greek modes) very clearly. 23

24 As the material was important to me for a long time, because I had tried to 24

25 assimilate much of it, as you have perhaps observed from many of my songs, 25

26 for example, 'Mahadoh', ${ }^{534}$ 'Der König in Thule', ${ }^{535}$ so the manuscript has been 26

27 published ${ }^{536}$ with the help of our minister. ${ }^{537}$ I myself wanted to correspond with 27

28 the author, [and] send him new experiments as actual first fruits of his theory. The 28

29 old fellow didn't answer and only once said to me what I had done was fine, which 29

30 I found very irritating.

31 Therefore, nothing has been concluded and our minister has permitted me to 31

32 track down Peter Mortimer in his Herrnhut community. [...] The original reason 32

33 for my journey was Peter; now I am here in Dresden and Peter hasn't eaten me; ${ }^{.38} 33$

34

$35 \quad 532$ Johann Christoph Prenzel (1718-94), senator and senior (town) treasurer. 35

$36 \quad 533$ Christian Gottfried Körner (1796-1831), lawyer, father of Theodor Körner. 36

37534 Zelter's setting of Goethe's ballad 'Der Gott und die Bajadere'. 37

38535 Zelter's setting of Goethe's 'Der König in Thule' which was published in his 38

39 Sämtliche Lieder, Balladen und Romanzen, vol. 3 (1812). 39

$40 \quad 536$ Peter Mortimer, Der Choral-Gesang zur Zeit der Reformation, oder Versuch, die 40

41 Frage zu beantworten: Woher kommt es, daß in den Choral-Melodien der Alten etwas ist, 41

42 was heut zu Tage nicht mehr erreicht wird? (Berlin: Georg Andreas Reimer, 1821). 42

$43 \quad 537$ Baron Carl von Stein zum Altstein (1770-1840), minister for finance and culture. 43

$44 \quad 538$ A reference to the Acts of the Apostles, 10, 13: 'Rise up, Peter, slaughter and eat'. 44 
1 rather, he is the best fellow in the world. Much is in his life that doesn't belong. His 1

2 marriage is superfluous and at the end of day he is a Herrnhuter. He will not admit 2

3 this, he has forgotten it and, in short, he is a scoundrel and your Hafis to a T. ${ }^{539}[\ldots] \quad 3$

$4 \mathrm{He}$ has devoted his life to writing Latin verses on matters of brotherhood, which 4

5 are praised, to translating missionary writing into different languages ${ }^{540}$ and finally, 5

6 for himself, to complete the above-named work on the Evangelical chorale ${ }^{541}$ with 6

7 the help of some old songbooks of the sixteenth century. [...] 7

8 Dresden, Monday, 2 June: I only wanted to spend two days in Dresden, but 8

9 yesterday I heard a mass and am now in Pretzsch on the Elbe between Torgau and 9

10 Wittenberg. The head preacher has founded a Singschule ${ }^{542}$ which I am inspecting 10

11 and everything is going well enough. I am very lucky to enjoy happiness in this 11

12 life and to see shoots of my good Fasch's seed appearing. ${ }^{543}$ In Frankfurt an der 12

13 Oder and in other places I discovered a really good choral society and an almost 13

14 better Liedertafel ${ }^{54}$ where your songs are sung. In Görlitz ${ }^{55}$ [it is] the same and 14

15 likewise in Dresden. ${ }^{546}$ In the latter the pupils of the Kreuz School up and down the 15

16 streets sing the most contemptible stuff which they don't even enjoy themselves. 16

17 Dessau, 6 June: I haven't exactly gone away satisfied from Wittenberg. The 17

18 music director ${ }^{577}$ loves to read, to speak, to eat and most of all to drink, but he 18

19 doesn't know how to behave. His organ is in decline $;{ }^{548}$ his assistant who treads the 19

539 The type of poetic figure portrayed in Goethe's 'Buch der Hafis', West-östlicher 22

540 Peter Mortimer, Geschichte der neuesten evangelischen Anstalten in England 24 (Barby, 1801-02) and Missions-Societät in England. Geschichte ihres Ursprungs und ihrer 25 ersten Unternehmungen (Herrnhut, 1797).

541 Peter Mortimer, Der Choral-Gesang zur Zeit der Reformation, oder Versuch, die 27 Frage zu beantworten: Woher kommt es, daß in den Choral-Melodien der Alten etwas ist, 28 was heut zu Tage nicht mehr erreicht wird? (Berlin: Georg Andreas Reimer, 1821).

543 Fasch's foundation of the Berlin Sing-Akademie in 1791 inspired the formation of 31 countless similar institutes throughout Germany.

544 See Zelter's letter to the minister on 20 June 1822 in Georg Schünemann, Carl 33

Friedrich Zelter der Begründer der Preussischen Musikpflege (Berlin, 1932), p. 49.

${ }_{545}$ Zelter is referring to the song society founded in 1813 and led by the organist 34

Johann Schneider. A Liedertafel was not founded in Görlitz until 1828.

546 Zelter is referring to the Dreyssing Sing-Akademie, which emerged from the 36 music circle which gathered in Christian Gottfied Körner's home. The $A M Z$ considered 37 it a 'very praiseworthy imitation of the Berlin Sing-Akademie', $A M Z, 14$ (1812), no. 9, 38 26 February, column 144.

547 Friedrich Philipp Christian Nothschiedler (dates unknown), active as music 40 director in Wittenberg from 1822.

548 The organ in the palace church, which had been built by Johann Ephraim Hübner; 42 an application by Friedrich Ladegast for its restoration was not made until 18 November 43 1858. 
1 bellows $^{549}$ endured a thunderclap in the accompaniment of an eight groschen work 1

2 and I found the bellows room full of dust. The whole nest has got into a terrible 2

3 state and the great bell is shattered and buzzes. I hurried to the fresh green Dessau, 3

4 where a good organ builder ${ }^{550}$ enticed me. 4

5

6

7

299. Goethe 7

8

Eger, 8 August $1822 \quad 9$

9

10

11 [...] On 19 June I arrived at Marienbad ${ }^{551}$ in very good weather to enjoy marvellous 11

12 accommodation $[\ldots]$ musical amateurs, pleasant evening entertainment $[\ldots] \quad 12$

19 Your lovely parcel arrived on the first musical evening which I have enjoyed in 19 20 years $^{552}$ and so immediately your rejuvenating settings of my poems were very 20

21 happily and powerfully performed. 21

28 Warmest thanks for the little song: ${ }^{553}$ I heard it first with my eyes and was pleased 28

29 with the charming characteristic consistency [with which you have set it]. With 29

30 your sympathetic mind you have grasped the other poems ${ }^{554}$ really well. One 30

31 would like to call it a duet cantata of direct farewell and movement with ever- 31

32 receding distance, just as the rainbow joins near and far. 32

38551 Goethe was in Marienbad from 19 June to 24 July, followed by a month in Eger;

39 he returned to Weimar on 29 August.

$40 \quad 552$ See in Goethe's diary of 5 December 1822: 'Musical evening. Graf Gleichen, 40

41 Act 1 (by Eberwein) rehearsed. Dispatch from Berlin, from both Zelter and Schultz', WA 41

$42 \mathrm{III} / 8$, p. 269.

43553 Zelter's setting of Goethe's 'Das Sträußchen. Alt böhmisch'. 43

$44 \quad 554$ 'Äolsharfe' ('Ich dacht ich habe keinen Schmerz'). 
Whether music, which is able to get close to the feeling of everything that 1

2 eludes concepts and even imagination, can [or] should intervene here - that is a 2

3 question for the master.

4

5

$21[\ldots]$ Have you [ever written] anything better than the Divan? What is there? 'Lied 21 22 und Gebilde ${ }^{557}[\ldots]$ My setting is for male voices [...] yet these are only notes, 22 23 seeds, which also take a living form [...] and I would never have known how to 23 24 set something to music without imagining a vivid model for myself. Look over it 24 25 once or twice, listen to it, you dear man, and let me know what you think - if not 25 26 about the setting then in addition to it. One only knows how one appears through 26 27 the mirror. [...]

2811 February: Right now I am rummaging through Neveu de Rameau. It would 28 29 be a shame if you hadn't kept a copy of the original. ${ }^{558}$ Comparing details, I would 29 30 share the opinion of Parisian friends that the person who translated it back would 30 31 have done well to stay closer to the German. You will know that you have been 31

43 Goethe had kept a copy of this manuscript, which he returned to the publisher Georg 43

44 Joachim Göschen. the Morgenblatt für gebildete Stände, 25 April 1823.

556 Zelter implies a lack of water here, meaning Wolf is skating over the top and hasn't 36 got the fundamentals sorted; in other words, Wolf is out of his depth.

557 Zelter's through-composed setting of Goethe's poem 'Mag der Grieche seinen 38 Ton'.

558 The entire paragraph refers to Goethe's notes to his translation of Diderot's 40 
1 taken for Diderot himself. Without causing a big sensation, the German translation 1

2 has been so influential that even I have noticed it. [...] 2

311 March: My Felix has entered his fifteenth year; he is growing up before 3

4 my very eyes. His astounding piano playing I may look upon as quite a secondary 4

5 matter; he may just as easily become a virtuoso violinist. Act Two of his fourth 5

6 opera is finished. All he does becomes more and more sound; he almost has the 6

7 strength and power he needs; everything comes from within, external events 7

8 remain external for him. Imagine my joy if we should have the experience of 8

9 seeing the boy live and fulfil the promise of his youth. He is healthy. I would love 9

10 his exquisite piano quartet to be dedicated to your Grand Princess. Tell me how we 10

11 should set about it, and advise me soon. It is quite modern, and is even better than 11

12 the one he performed in Weimar.

$13+13$

$14+14$

15 304. Goethe 15

$16 \quad 16$

17 Weimar, 23 March 182317

$18 \quad 18$

19 First sign of renewed life and love. Grateful. Affectionate. ${ }^{59}$

$20 \quad 20$

$21 \quad 21$

$22 \quad 305$. Zelter 22

$23 \quad 23$

24

Berlin, 29 March 182324

$25 \quad 25$

26 The first lines of your rebirth brightened more than a hundred eyes directly upon 26

27 their arrival. They were brought to me shortly before the Liedertafel, where they 27

28 were passed from hand to hand as an original signature to feast one's eyes on. [...] 28

29 For the following days it gave me courage to dig in and work until I had my 29

30 Good Friday music ${ }^{560}$ behind me. [...] 30

31 The public [...] were delighted ${ }^{561}$ that I put on my music again in the opera 31

32 hall $^{562}$ and although I cannot accommodate so many people here and my costs 32

33

$34-559-34$

$35 \quad 559$ The first lines which Goethe had written after a serious illness in February and 35

36 March; during this time August von Goethe had looked after his father's correspondence. 36

37560 Graun's Der Tod Jesu was performed by the Sing-Akademie on Good Friday, 37

3828 March 1823, in the Königliches Opernhaus with instrumentalists from the Hofkapelle, 38

39 directed by Zelter; see: $A M Z 25$ (1823), no. 17, 23 April, column 273.

$40 \quad 562$ Two years before, at the request of the king who wanted to attend the performance, 40

41 Graun's Passion Music was performed on Palm Sunday in the concert hall of the new 41

42 theatre; the previous year Zelter had performed Graun's Passion alongside Handel's 42

43 Messiah, likewise at the new theatre. The 1823 performance took place in the Oratorio 43

44 room of the opera house, which had just been reopened. 44 
1 were doubled, the hall in the new comedy house ${ }^{563}$ is more comfortable for the 1

2 listeners and has a good acoustic. 2

3 So I go on with it and silently lament that the ignorant understand my work 3

4 better than I do. Everyone wants to be in charge and conduct, and as soon as 4

5 my students realize they could be helpful to me, they are sick and I am the only 5

6 healthy one. [...] 6

7 Today is Saturday and for now I am free. Once more I have seen from my 7

8 audience how a fundamentally natural presentation of a 70-year-old work which 8

9 is well known and has been performed many hundreds of times ${ }^{564}$ is capable of 9

10 making a real impact. Ramler's libretto, be it what it may, and the same with 10

11 Graun's music, have created for themselves a following, a belief, which everything 11

12 created after it cannot destroy, no matter how much one is looking for something 12

13 new, better, up-to-date. The Königliche Kapelle, a breathless group, performed con 13

14 anima, con amore, this time taking pleasure in the work itself. The organizing and 14

15 direction of yours truly played a part in this, and if I don't have to give them orders, 15

16 nor do I have to say anything since I choose the best, pay them somewhat better 16

17 and therefore am in the position to conduct the entire work with my forefinger. 17

18 Yes, they almost see it as an honour to play with me. 18

19 The Königliche Kapelle had already performed this work to the best of their 19

20 ability before a full audience in the garrison church. ${ }^{565}$ One of them remarked 20

21 to me that their own performance compared to mine was like a dull plaster cast 21

22 compared to marble. $\quad 22$

29 Here, my dear man, only hurried so as not to miss the post, is the warmest thanks 29

30 for your Passion Week celebrations in which you let me take such a lively part. 30

37 As I have already written to you, [Wolf] responded favourably to our Good Friday 37 38 music and at the same time picked up some mistakes. For example, Graun had the 38

$40 \quad 563$ The concert hall of the new theatre on Gendarmenmarkt. $\quad 40$

41564 From its premiere on 26 March 1755, Graun's Passion was performed annually 41 42 until 1888.

4356526 March 1823 under the baton of Kapellmeister Seidl and the orchestral direction 43 44 of Seidler. 
1 following scansion: 'Und was er zusaget ${ }^{566}$ das hält er gewiß'. He considered that 1

2 such an obvious mistake could have been removed by the stroke of a pen, and the 2

3 latter was my work if not my duty. To start with, I considered this mistake as being 3

4 long forgiven and entered into the main book of common memory in which one 4

5 recognizes the work from such signs - like the bump on Cicero's nose. 5

6 Then it would still have to be settled whether the mistake is also in the 6

7 melody, which is acknowledged to be natural and expressing what is meant. The 7

8 text demands its own place as well as the music. A verse which cannot be sung 8

9 comfortably - which doesn't fit his thoughts like a light dress - could never be 9

10 good verse that would justify ruining the melody on its account. 10

11 Finally it is questionable to rectify such minutiae in first-rate work, where there 11

12 is often no end, if even an honourable poet like Homer ${ }^{567}$ were to lose his great 12

13 name because of the work of pedantic correctors. 13

14 The old orchestral member Mengis, ${ }^{568}$ a student of Graun, once asserted that 14

15 one could find no mistakes in his master's works because of the pure method 15

16 of composition. A smart Alec (that was me) denounced a couple of consecutive 16

17 fifths in the first chorale ${ }^{569}$ of Graun's Passion Music. I'd like to see that, Mengis 17

18 said. The published score was fetched and the fifths proven. After pondering a bit 18

19 the old Mengis said: so it is when lesser people have the presumption to correct 19

20 great men; these fifths are written with the best art and improve it in so far as they 20

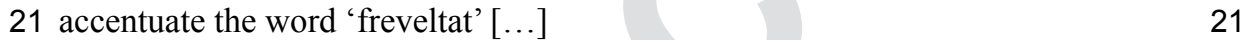

22 Now this approach to criticism is age-old, weighed down by the years and 22

23 ready for the grave, but despite it I still think with affection of the true old man 23

24 who was well disposed towards me until his death. [...] 24

$25 \quad 25$

$26 \quad 26$

27 308. Zelter 27

$28 \quad 28$

$29 \quad$ Berlin, 22 April 182329

$30 \quad 30$

31 For five months I have a student ${ }^{570}$ who makes the dreadful mistake of being rich. 31

32 A 17-year-old bright blonde, with fine jet-black little ringlets over the bluest of 32

33 eyes; firm flesh, lively movement and language; a voice like a glockenspiel and 33

34 with the best manners [takes] the most innocent delight in herself. For every lesson 34

$36 \quad 36$

37566 A false stress on the 'stem' syllable; the line, a quotation of Psalm 33, 4, comes 37

38 from the chorus, 'Freuet euch alle ihr Frommen'. 38

39567 Allusion to Friedrich August Wolf's Prolegomena ad Homerum in which the epics 39

40 of Homer's were regarded as the work of several authors. 40

41568 Christian Mengis, horn player. $\quad 41$

$42569 \quad$ 'Du, dessen Augen flossen'; an examination of this passage in the score confirms 42

43 that these fifths were intended by the composer. 43

44570 Marianne Angelika von Almonde (1804-66). 44 
1 I received a thaler and a kiss from the most beautiful lips which you yourself like 1

2 to assess.

3 Since [her arrival] I have taken out old arias, ${ }^{571}$ which I once composed in joy 3

4 and in sorrow for my heavenly Julia, ${ }^{572}$ and have found that singing alone makes 4

5 the song because Almonde (as the most graceful little Danzig girl is called) sings 5

6 me back 40 years. $\quad 6$

7 At the end of June Doris goes to Ems with Mendelssohn's sister, ${ }^{573}$ so I am 7

8 expecting a quiet summer, which I intend to use to adapt my little art works to the 8

9 new accommodation. $\quad 9$

16 Hensel, the painter, has set out to meet you with the actor Wolff. ${ }^{574}$ Has the young 16

17 fellow given you both gifts with a letter? He is travelling to Italy and is a nimble 17

18 sketcher; he travels at the King's expense and is royally commissioned to deliver 18

19 copies. $^{575}[\ldots]$

26 In reply to your welcome letter, dearest friend, which reached me at a very 26

27 fortunate moment, I shall, as I promised, write to you, before leaving the magic 27

28 circle of Bohemia, ${ }^{576}$ a letter you will warmly welcome because I have nothing but 28

29 good news to communicate.

571 Presumably the scenes by Metastasio which he mentions in his autobiography: 31

'Oh Dio, se in questo istante'; 'Vieni, audace nemio'; 'Barbaro, che a tuoi nodi'; 'Misero 33 me! ah! che veggo!'

572 Juliane Zelter née Pappritz, Zelter's second wife, who had died in 1806.

573 On 16 June 1823 Zelter's daughter Doris travelled to a spa in Ems with Recha 35 Meyer, Abraham Mendelssohn's sister and Hinni Mendelssohn, the wife of Joseph 36 Mendelssohn, Abraham's brother.

575 Hensel's main commission was to produce a full-scale copy of Raphael's 41

\section{Transfiguration.}


1 To start then, let me say that during the time spent recently in Marienbad, I 1

2 met with nothing disagreeable; on the contrary, it was happy like returning to life 2

3 again, and I am now feeling better than I have done for a long time. 3

4 Furthermore, I must tell you that after receiving that kiss, the bestower ${ }^{577}$ of 4

5 which you probably guessed, I was favoured by another splendid gift from Berlin; 5

6 for I have heard Madame Milder sing four little songs, which she contrived to 6

7 make so great that the memory of them still brings tears to my eyes. ${ }^{578}$ So the 7

8 praise I have heard bestowed upon her for so many years past is no longer a cold 8

9 historical account but awakens true and deeply felt emotion. Give her my very best 9

10 wishes. She asked me for something from my own hand and will receive through 10

11 you this first page - not altogether unworthy of her. ${ }^{579} \quad 11$

12 Madame Szymanowska, ${ }^{580}$ an incredibly fine pianist, affected me just as 12

13 powerfully, though in quite a different way. I imagine she might be compared to 13

14 our Hummel, only that she is a beautiful and loveable Polish lady. When Hummel 14

15 stops playing, a gnome rises up before us, who, by the help of powerful demons, 15

16 has performed such wonders, that one scarcely dares thank him for them; but when 16

17 she stops playing and comes and looks at us, we are not sure whether we should 17

18 not consider ourselves fortunate that she has stopped. Welcome her warmly when 18

19 she comes to Berlin, which will probably be not before very long; remember me 19

20 to her and help her where you feel appropriate [...]

21 This brings me to the painter Hensel, who delivered the gifts to me. He has, 21

22 like so many others, an innate talent which could be developed, that's clear- not to 22

23 God, who is hardly worried about such things - but I know it, having watched such 23

24 misdirection for more than 20 years. He, too, is stuck in the shallow dilettantism 24

25 of the time, which searches for a false foundation in the art of antiquity and the 25

26 fatherland, seeks to find his element in a false piety, an atmosphere in which 26

27 noble women, undiscerning patrons and incompetent amateurs so gladly meet one 27

28 another; where an empty jargon one has created sounds so honeyed; a robe of 28

29 maxims, which one had tailor-made to the puny body, dresses one in grand style; 29

30 is everyday ailing with uncertainty, gnawed and consumed within, only to live and 30

31

577 Elizabeth (Lili) Klein, née Parthey, later married to the composer Bernhard Klein,

580 Maria Agata Szymanowska, née Wolowska (1789-1831), Polish composer and pianist, based in St Petersburg from 1828. Goethe acknowledged his acquaintance with her in his diary on 14 to 20 August (WA III/9, pp. 93-6) and celebrated her musicality in 40 the poem 'Aussöhnung' in Trilogie der Leidenschaft. The pianist and her sister, Casimira 40 Wolowska, visited Goethe in Weimar from 24 October to 5 November, where they were daily guests at Goethe's table and Maria Szymanowska 'through her lively, accomplished,

42 improvisatory piano playing soothed the love-sick heart of the divine poet and was able to

43 ease the pain of loss of the lover', from Zelter's autobiographical report (GSA 25/II, 6,8Aa), 44 WA I, 5/2, p. 21.

(3)


1 totter on and deceive oneself in the most ignominious way. Forgive and let me be 1

2 silent. I have already said too much [...] 2

3 To free myself from such things as from aesthetic conversations and lectures, 3

$4 \mathrm{I}$ devoted myself for six weeks to a very pretty child, ${ }^{581}$ and by this I was perfectly 4

5 secured against anything disagreeable. ${ }^{582} \quad 5$

6 But now for the strangest thing of all! The immense power that music had 6

7 over me in those days! Milder's voice, the rich sounds of Szymanowska, even 7

8 the public performances of the local hunting corps untwisted me, just as one 8

9 lets a clenched fist gently flatten itself out. By way of partially explaining this, 9

10 I say to myself, 'For two years and more you have not heard any music at all, 10

11 except Hummel, twice, and therefore this faculty - as far as it exists in you - has 11

12 been lying imprisoned and isolated; now, all of a sudden, the divine art descends 12

13 upon you, and through performances of great talent exercises her full power over 13

14 you, claims all her rights and awakens all your latent recollections.' I am totally 14

15 convinced that I would have to leave the hall at the first bar I might hear from 15

16 your Sing-Akademie. And when I now consider what it is to hear an opera, as we 16

17 perform them once a week (a Don Juan ${ }^{583}$ or a Il matrimonio segreto ${ }^{584}$ ), renewing 17

18 it within oneself and assimilating this feeling to the others that form part of an 18

19 active life, then for the first time do I understand what it is to have relinquished 19

20 such enjoyment, which, like all the higher enjoyments of life, takes a man out of 20

21 and above himself, and lifts him, at the same time, out of the world and above it. 21

22 How good, how imperative then it would be for me to have an opportunity 22

23 of spending some time with you. By gently guiding and directing me, you would 23

24 cure my unhealthy irritability, which, after all, must be regarded as the cause of 24

25 the above phenomenon, and you would, little by little, enable me to absorb into 25

26 myself the whole wealth of God's glorious revelation. Now I must see how I can 26

27 go through a silent and shapeless winter, which, to some degree, I look forward to 27

28 with trepidation. However, we must endeavour, with good humour and courage, to 28

29 use the dark days to the advantage of ourselves and our friends. 29

581 Ulrike von Levetzow, daughter of Amalie von Levetzow, who inspired Goethe's 37

Pandora. Ulrike was Goethe's Muse in the 'Elegie' of Trilogie der Leidenschaft.

582 This refers to a previous paragraph where Goethe condemns contemporary 39 dilettantism, including Fanny Hensel's husband, Wilhelm Hensel.

583 Mozart's Don Giovanni, which had been in the repertoire of the Weimar Court 41 Theatre since 1792 .

584 Cimarosa's opera buffa, Il matrimonio segreto, which had been regularly performed 43 
529 August: Yesterday the Liedertafel gathered in celebration of your birthday, ${ }^{585}$ as

6 you will see in the Spenersche Zeitung on 30 August. To our delight, all elements

7 came together like old friends. It was an indescribably beautiful day.

14 [...] That you gave me back so faithfully the message of the poem through inner 14 15 sympathy was actually only a repetition of what you give to me through your 15 16 compositions for a long time. But it was so characteristic that you wanted to read 16 17 and read again. ${ }^{586}$ You repeatedly let me hear what is dear to me through your 17 18 gentle organ, full of feeling, to a degree which I don't like to admit to myself, and 18 19 which no longer belongs to me anymore since I feel that you have made it your 19 20 own. I would not like to let it out of my hands, but if we lived close by, you would 20

21 have to recite it to me and sing it to me until you knew it by heart. [...]

22 I myself must admit that after my return journey this time I should have spared 22

23 myself, and still have to spare myself because the enormous excitability, which, 23

24 as you know, manifested itself through music, is really what put me in danger; 24

25 although I cannot be hostile towards her since I have to thank her for every poem, 25

26 through which feeling and imagination is so readily ignited from time to time. 26

27 [...] Do you know the following lines? I have become very attached to them; 27

28 you really must set them free again by putting them to music: 28

$30 \quad$ Yes, I would compare you to an Iris, 30

$31 \quad$ A loving sign, a miracle 31

$32 \quad$ Gliding with splendour, bright with harmony, 32

33 Ever the same and ever new, as she. ${ }^{57} \quad 33$

$34-34$

$35-35$

$36 \quad 36$

$\begin{array}{ll}37 & 37\end{array}$

$38 \quad 38$

39585 The Liedertafel celebrated Goethe's birthday with a gondola trip to Treptow, 39

40 festival songs and a celebratory lunch.

$41586 \quad$ Zelter's rereading of the Marienbad Elegy. $\quad 41$

42587 The concluding verse of Goethe's 'Äolsharfe'. Goethe had sent the 'Cantata duet' 42

43 to Zelter on 14 December 1822, asking for a setting, and he repeats the request here; it was, 43

44 however, never set by Zelter. $\quad 44$ 
313. Zelter 1

5 [...] Early Wednesday, 17 December, departed from Naumberg and reached 5

6 Weissenfels at noon. I have met a 19-year-old efficient music teacher who made the 6

7 most charming progress with his choir. Healthy, cheerful, powerful, ready, willing, 7

8 true-hearted; he is called Hentschel ${ }^{588}$ and he deserves to be recommended. [...] 8

9 Thursday, 18 December, via Merseberg, where there is a lovely organ ${ }^{589}$ in the 9

10 cathedral ${ }^{590}$ and on to Halle. [...] Here the local music director's position of the 10

11 deceased Türk ${ }^{591}$ is filled by one of my student ${ }^{592}$ who is no sorcerer and usually 11

12 prefers to see me going than coming. This time it was different. He had offered a 12

13 collection of church liturgies and choral works to the King ${ }^{593}$ and the King was so 13

14 favourable to him as to grant him 3,000 thalers for it because the things were really 14

15 good and are well preserved. As a result he is really delighted and since I have to 15

16 accept them, he gave me a very good reception. In the evening in the Freemason's 16

17 lodge he conducted a tolerable concert. I was there and was invited to a frugal 17

18 meal after the music, where I had to be very well behaved because it was a table 18

19 of over 200 people of high nobilities and professors with wives and daughters. A 19

20 handsome choir of students, near me, sang really well. A bottle of champagne was 20

21 placed in front of me, which I gave to the singers and I was already in bed asleep 21

22 when I heard really lively singing on the street before my door, instead of which I 22

23 would have expected earlier that one would break the windows on me. [...] 23

248 January: Maria Szymanowska has just departed. I have given her a 24

25 recommendation for an old female acquaintance in Hanover that will certainly be 25

26 useful for her. Yesterday she gave her second concerto ${ }^{594}$ and to my delight she had 26

In Merseburg Cathedral (in Zelter's day) there was an organ by Zacharias Thayssner 30 hidden behind the Baroque screen; the organ was newly restored by Friedrich Ladegast and 31 many of Liszt's large-scale organ works were premiered there.

590 St John the Baptist and St Laurence Cathedral, founded in 1085, originally a 33 cruciform Basilica, converted into a late gothic church with several naves.

591 Daniel Gottlob Türk (1750-1813).

592 Johann Friedrich Naue whose artistic work was especially aimed at improving the 35 quality of church singing.

593 Johann Friedrich Naue's work on liturgical music, publicized in the Versuch eine 37 musikalischen Agenda, oder Altargesänge zum Gebrauch im protestantischen Kirchen 38 (Halle, 1818), caught the attention of Friedrich Wilhelm III of Prussia, who purchased this 39 publication as well as a large portion of Naue's personal library in $1824 . \quad 40$

594 Maria Szymanowska gave two guest performances in Berlin. The first performance 41 took place on 10 December 1823 as part of the Königliche Kapelle concerts, in which she 42 included a piano concert by Hummel. The second concert was given on 7 January 1824 at 43 noon in the Musikalishe Morgen-Unterhaltung held in the newly built Alder Hall (Unter den 44 
1 a full hall. Her playing rests on a mature talent and you have judged her really well. 1

2 Had she experienced a happy hour, then everyone would have to share our opinion. 2

3 She was exhausted from nerves and performance and yet always played like a true 3

4 talent. The King was present with his entire court. She is madly in love with you 4

5 and gave me a hundred kisses on the mouth for you. Her younger sister is also of a 5

6 pleasant gentle nature and in her maturity still has a hint of blossom. [...] 6

7 Since you like to read letters from me, I enclose one here. ${ }^{595}$ Doris is copying 7

8 another to you. I am almost tormented by this kind of thing, yet I cannot help 8

9 keeping an eye on the young men who leave my school to make their way in the 9

10 world. The young man is Loewe, the music director in Stettin, and though neither 10

11 without knowledge nor skill, he wishes to do exactly what God has not granted 11

12 him. If he wanted to do what he could, what he knows, what he should do, he 12

13 would not have to ask me. It would be difficult not to want to answer him at all. He 13

14 will hardly show the letter to anyone; and so there is no harm in your seeing it. 14

15

16

17

314. Zelter

21 [...] Yesterday evening, we had a private performance of Felix's fourth opera, 21

22 complete with dialogue. ${ }^{596}$ There are three acts, which, with two ballets, occupy 22

23 some two-and-a-half hours; the work had its fair share of applause. The text, too, 23

24 by Dr Casper, is clever enough, as the poet is musical.

25 From my inferior position I can hardly master my surprise at a youth just 1525

26 years old, progressing so quickly. Everywhere I find novelty, beauty, real originality; 26

27 there is intellect, movement, serenity, sonority, completeness, dramatic force. The 27

28 handling of the ensemble is that of a master. The orchestration is interesting, not 28

29 heavy or tedious, nor mere accompaniment. The musicians enjoy playing it, and 29

30 yet it is not exactly easy. Familiar things come and pass by. They are not taken for 30

31 granted but rather are welcome and appropriate, each in its own place. Liveliness, 31

32 exultation without haste; tenderness, elegance, love, passion, innocence. 32

Linden 76). Here - in a very extensive concert programme - she took part in a performance

37 of a piano quintet by Beethoven, performed a piano trio by Prince Louis of Prussia and

38 concluded the concert with John Field's Rondo alla Polacca.

38595 Copy of Zelter's letter to Carl Loewe, 10 January 1824 (GSA 28/109, no. 233).

39 The original letter is contained in Zelter's bequest (GSA 95/3).

40596 Felix Mendelssohn, Die beiden Neffen or Der Onkel aus Boston, comic opera,

41 performed in Mendelssohn's family home, Neue Promenade no. 7. The rehearsals are

42 described by Sebastien Hensel (ed.), Die Familie Mendelssohn 1729 bis 1847. Nach Briefen

43 und Tagebüchern (Frankfurt am Main and Leipzig: Insel Verlag, r.1995), p. 175. Hereafter

44 referred to as Die Familie Mendelssohn. 
The overture is a strange thing. Imagine a painter, flinging a dab of colour 1

2 on his canvas, spreads it out with finger and brush until at last, to our increasing 2

3 astonishment, one finally looks around for the actual occasion of it, since what 3

4 has happened must be true. Admittedly, I speak like a grandfather who spoils his 4

5 grandchildren. Not to worry. I know what I am saying and insist that I have said 5

6 nothing that I cannot prove.

7 First of all, by the lavish applause of the orchestra and singers; it is easy to 7

8 see whether coldness and repugnance, or love and favour move their fingers and 8

9 throats. You must know all about that. [...] 9 17 auction, a manuscript bearing the title Tabulatur-Buch geistlicher Gesänge Dr 17 18 Martini Lutheri und anderer gottseliger Männer, samt beigefügten Choralfugen 18 19 durchs ganze Jahr. Allen Liebhabern des Claviers componiert von Johann 19 20 Pachelbeln, Organisten zu St. Sebald in Nürnberg, 1704. ${ }^{597}$ If it would interest 20 21 you, I could send it to you at least to have a look at. It is bound in leather, gilt- 21 22 edged, and looks exactly like an old piece of church furniture, although in a good 22 23 state of preservation; it contains 247 melodies.

24 What you report about Felix is desirable, and touching when considered as text 24 25 and commentary; I wish I could give you a similar account of one of my scholars, 25 26 but unfortunately poetry and the fine arts have no recognized basis like yours. The 26 27 most absurd empiricism is met with everywhere - artists and amateurs are equally 27 28 inadequate; one creates, the other criticises without any reason, and as a result we 28 29 have to wait till a man of unmistakable talent steps forward and is able to perceive 29 30 the rational outside himself, because it lies concealed within him. [...] Messias' (in his first volume, Für Freunde der Tonkunst, p. 227) ${ }^{598}$ has persuaded 32

597 Anna Amalia Bibliothek in Weimar, Signatur Q 341. An undated prefatory note 34 written by Carl Georg von Winterfeld (1784-1852) gives further clues to its contents: 36 'The tablature book only goes as far as no. 160 inclusive; apparently it is not in the author's 37 hand, but rather a hurried copy by his son, Wilhelm Hieronymus, who was organist in 38 Wöhrd, Nürnberg, around 1704.' Pachelbel had no connection with the remaining part.
38
Nos 161-176 are from Freilinghausen's Neues geistreiches Gesangbuch (Halle, 1714); 39 the rest is from the fifth edition of an older songbook by the same collector published in 40 1710. Johann Pachelbel had already died on 3 March 1706. A later owner of the book had 41 included the other melodies and inserted them in the table of contents. 
1 me to take up the Handel-Mozart score, ${ }^{599}$ from which, it is true, I can only pick 1

2 out the rhythmical motives; I hope soon to become better acquainted with the 2

3 harmonic structures as well through Eberwein's performance. ${ }^{600}$ This would have 3

4 been an interesting topic for our meeting, which, compared with former ones, 4

5 would have turned out badly had it not been for the good influence of the principal 5

6 subject of our conversation. Here's to meeting soon! 6

7

8

316. Goethe

13 After a short time, my dear friend, I come forward again, and this time with a wish 13 14 and a suggestion. Listen then to my proposal.

15 I enclose a poem, ${ }^{601}$ in explanation of which it may be necessary to state the 15

16 following. State Councillor Thaer, ${ }^{602}$ of whom you are sure to know something in 16

17 general, as well as in particular, will be 73 on 14 May. On that day his pupils, from 17

18 near and far, are going to meet at his house in Mögelin, where they intend to give 18

19 him a wonderful party. Now they want to have some newly-composed drinking 19

20 songs for the occasion, and so have addressed themselves in well-written and polite 20

21 petitions to Weimar, to the actual agora of poetry in Germany. Our friends, too, are 21

22 not averse to helping them. ${ }^{603}$ With this in mind, the enclosed poem came into my 22

23 head; for an initial understanding of it I attach the following commentary: 23

26 on 21 February 1824. Shortly afterwards, in a review of this book, Goethe wrote, the

27 'account of Handel's Messiah (...) aroused in me an irresistible desire to hear much of

28 the work once again, which introduced me earlier to the serious study of music, with the

29 result that the old feelings which had faded away could come to life again and the youthful 30 pleasures, in spirit and soul, could be renewed once more.'

31599 Mozart had arranged Handel's oratorio in March 1789; the first edition of this 31 32 score was published by Breitkopf \& Härtel in 1803. Zelter's performance on 5 April 1822 33 used this edition.

$34 \quad 600$ In his review of Rochlitz's essay, Goethe continued: 'I succeeded in this, under the 35 direction of a decent music director with the participation of composers and amateurs. I can 36 now appreciate the structure of this inestimable work, aided by this introduction.'

$36 \quad 601$ Goethe's occasional poem 'Zum vierzehnten Mai 1824', written for the birthday

37 and anniversary of 50 years of service of Albrecht Thaer. The original enclosure in lost.

38 Zelter set the poem and sent it to Goethe on 4 April.

39602 Albrecht Daniel Thaer (1752-1828), farmer, doctor and educator of civil servants 40 at Berlin University.

41603 At Goethe's request, Eckermann wrote an occasional poem which Eberwein set

42 (see Goethe's letter to Eckermann, 8 March 1824, WA IV/38, p. 72) and Riemer contributed 43 a festival ode (see Goethe's letter of thanks to Riemer on 24 March 1824, WA IV/38, 44 pp. 87-8). 
1 Strophe 1: Thaer, a physician, esteemed both as a practitioner and theorist, is searching about 1

2 for a cheerful occupation in the field of Nature and becomes engrossed in gardening. 2

3 Strophe 2: But he soon finds his powers limited and longs for a wider range of activity; he 3

4 turns his attention to agriculture. 4

5 Strophe 3: He learns of the English system of husbandry, and the very basic axiom: that 5

6 with more activity and more intelligent farming a far greater advantage may be gained 6

7 than by following the old familiar methods.

8 Strophe 4: And so he manages to persuade landowners to rotate their crops, gains students 8 and disciples who find his teaching and directives excellent and propose now to give 9 him, in his advanced years, a loud and public acknowledgment of their gratitude.

12 I hope that this poem, which is meant to be sung by a great number of landowners 12 seated at a banquet, may incite you to set it to some bright music; it is a celebration 13 that will not occur again, and I should like our two names to be joined together on 14 this occasion. The man belongs first of all to Prussia, but after that to the world at 15 large as well; his fame and reputation are completely genuine, and so one would be 16 justified in undertaking something to celebrate with him and his friends.

I trust you will be able to send me a successful score soon, which I will then 18 attend to further. Initially I should like to keep it to ourselves. If you know too little 19

21 enough to persuade you to undertake this project. Perhaps some one of his pupils, 21

22 travelling here and there, will join your Liedertafel at a later date, in which case 22

23 you could not entertain such a guest any better.

24 I carry on my usual routine as normal and am glad to say it keeps me going. 24

$25[\ldots]$ I am back on my feet again.

Your last letter from 11 March, which reached me a few hours after the earlier one 32

33 dated 8 March, almost shocked me; I feared something sinister. The beginning of 33

34 the letter expelled the worry. The poem to old Thaer contained in it is already set to 34

35 music and that's enough; there is time for it to settle slightly, but if you would like 35

36 to have it immediately, you only have to tell me. I knew Privy Councillor Thaer 36

37 really well and have seen him often enough with Count Itzenplitz in Cunersdorf 37

38 (near Möggelin). [...]

39 I anticipated that my accounts of Felix's progress would be of interest to you. 39

40 You know the misery with most students longer than I: great intentions, little 40

41 talent; enormous effort for nothing - that is the worst and so one is happy when he 41

42 finds someone who does what he can and always has enough in reserve no matter 42

43 what happens. 
1 Send me the Pachelbel manuscript - the sooner the better - and how long can 2 I hold onto it? Since I will be more and more preoccupied now with my Easter 3 music, ${ }^{604}$ I would also like to see it soon.

4 Your reference to Handel reminds me that I must still thank Rochlitz; he 5 sent me his book too, in which he made plenty of complimentary remarks about 6 Handel and me. Somewhere Herder calls Handel's Messiah a Christian Epic; 605 7 in this he has hit the nail on the head, for in fact in its fragmentary arrangement 8 the work contains the complete complexity of Handel's Christianity, as truly and 9 honourably as it is rationally poetical. I have always considered the intention of 10 the whole, viewed as a work, as being accidental in origin, and I cannot get rid of 10 11 that impression.

12 In Handel's time the main Christian festivals gave composers the opportunity

13 to set biblical verses to music for all the gospels, from which the loveliest details

14 had to come into being. Handel, who had taste and heart enough to cast aside the 15 disgraceful church texts of Brokkes, Picander and others, at which he, Bach and

16 Telemann ${ }^{606}$ had to labour, finally gathered the choruses relating to the Passion into 17 one group, had some clever man supply the connecting hooks and rings between 18 them - if he didn't do it himself - and so a cyclical work followed, which I divide 19 up into four or five parts:

21 1. The proclamation of the Messiah by the prophets [sent here] from above; the 21 22 business of the redemption; secretive, morning; 'Comfort Zion! Speaks your 22

23 God'. Breathing spring freshness.

24 2. The Birth on earth, first known to shepherds: Introduction (Siciliana) - an 24 attractive pastoral piece would have to go before the chorus 'Unto us a child 25 is born'. In Mozart's score the chorus, incorrectly, is first. The chorus begins, 26 playfully and rocking, childlike, even childish and builds up to colossal 27 proportions with the words 'Which ruler is at his shoulder.' Life and teaching: 28 the good shepherd 'He feeds his flock'; 'Come, you who are burdened.'

30 3. Suffering and death: misunderstood, scorn, maltreatment. 'Come and see the 30

31 Lamb'; He suffers our torment'; 'We are like sheep who have gone astray'; 'He 31 calls on the Lord, who gave him safe keeping'; such shame breaks his heart; 32

604 The Sing-Akademie's annual performance of Graun's Tod Jesu took place on Good

605 In Letter no. 46 of Briefe, das Studium der Theologie betreffend (1786): 'O friend!

38 What a marvellous work is this Messiah - a true Christian epic in musical form', Johann

40606 Barthold Heinrich Brockes's Passion Oratorio Der für die Sünde der Welt 41 gemarterte und Sterbende Jesus (1712) was set by Handel and Telemann, among others.

42 Christian Friedrich Heinrici (pseudonym Picander) greatly benefited from Bach having used

43 countless of Picander's spiritual poems in his compositions, for example, the St Matthew

44 Passion, the Christmas Oratorio, as well as many cantatas. 
'Behold and see' and so on. Suffering is completed through death and through 1 this, victory [is gained]. The redemption is achieved. Now the consequence: 2 $\begin{array}{ll}\text { Resurrection and eternal life: as above, back to infinity. Prophecy steps forward, } & 3 \\ \text { declaiming: 'Open the gates wide!' The King of Glory enters: } & 4\end{array}$ 'The Lord gave the word!' 5

'Why do the heathens rage 6

'Rise Up! Break their bonds! Halleluja!' $\quad 7$ 'I know my Redeemer liveth! 8 'Since through one man came Death' 9

5. Apotheose: 'Worthy is the Lamb' 10 'Praise and worship' 11 'Amen!' 12

The expression of such work is to be appreciated as a whole, although everywhere 14 there is no lack of good, even fine work. 15

The overture is only part of the work to the extent that it serves as a foreground 16 or foil to set the blue radiant heavens of prophecy against it: the splendour of the 17 Lord God is to be revealed. Clarity, power, truth govern all of part one. 18

21 In Part Three, suffering and death. Short without [being] condensed. Great, 21 22 quiet, touching; no torment; no crucifixion or the like. The suffering of the 22 23 righteous over humiliation of the good and beautiful is the foundation, the abyss 23 24 through which a crystal spring hurries away. 'Behold and see! Who recognizes 24 25 such torment'.

26 This final piece is a true cavatina ${ }^{607}$ and leads us into the history of musical 26 27 forms, about which the following is to be said:

28 I view the German chorale as a kind of original form, which makes the 28 29 distinction between the Protestant and Catholic churches. Through the chorale as 29 30 congregational song, which contains the gospel, the congregation becomes the 30 31 conduit of the service.

32 The old cantus firmus had declined into something shapeless. The chorale, 32 33 which developed out of it, presents a firm form: it is an image, the setting of 33 34 strophe to voice, the idea to ear and memory.

Now, as usual, the thing goes further; song based on figured bass comes into 35 36 being. In the beginning one would not tolerate it in the church. What does the 36 37 composer do? He figures the chorale, gives it a colourful bass line and figured bass 37 38 is smuggled into the church. 38

41607 Here, as in Handel, a lyrical solo song; however, also a two-part song, arioso in 41

42 style, which developed out of the early eighteenth-century cavata and employed a simple 42

43 lied-like form, an economical use of coloratura passages and textual repetition common to 43 
1 The tenor, as the sustaining, principal and leading voice carried by the 2 foundation, the bass voice, becomes thin in the great church. Three-part harmony 3 is identified; a third voice becomes necessary. There is no foundation below the

4 bass; one looks above it. The alto emerges as the upper voice and the tenor, who

5 formerly ruled, is now covered above and below. Youngsters at school are brought 6 into the choir; the alto line is too deep for them and above the alto the soprano

7 emerges; four-part harmony is formed. Ground bass is discovered and now the 8 theory of consonance becomes the theory of dissonance.

9 The new choir is established and wants to be employed. The chorus comes into

10 being and finally the fugue [emerges], which always includes the chorale, if not

11 as a theme, then as cantus firmus. Now a strict tempo becomes increasingly more 11

12 important, the strict movement continues unabated and the motet is developed 12

13 (from motus meaning movement) and the proud chorale, just like the powerful sea 13

14 hardly wants to move in space, even less in time, dances to the tune of the piper. 14

15 From this point the vast possibilities [presented by] church style become more 15

16 like a microcosm. The flexible voice becomes aware of itself, likes it sound and 16

17 wants to please; the rigorous tenor has lost his fame and the soprano tyrannically 17

18 rules the whole. 18

19 The church stirs, however, and will not endure it, so music seeks a place outside 19

20 the church. The cantata, the oratorio, the opera appears: here the singer is a central 20

21 person; the chorus is no fool and accompanies him. 21

22 In opera everything is centred round the action; passion, evolving, ripening to a 22

23 turning point, which needs a point where it can let go, so the cavatina (aria) comes 23

24 into being, in which a definite feeling is given full expression. 24

25 The singer is now the sole representative of the whole. He is pleasing to himself 25

26 and others; therefore the da capo emerges. This da capo is finally taken up into 26

27 the form and now no one knows any longer what all the talk is about: the da capo 27

28 itself becomes a worthless residue, bad coins alone are valid and no one has a use 28

29 for pure metal. 29

30 Now the composer does not want to be deprived of the original form; so the 30

31 cavatina comes into being, and this is nothing other than an aria without its second 31

32 section, which cannot be sung as a da capo, and we find such a true cavatina in the 32

33 Messiah: 'Behold and see! He who knows such torment, heavy like his torment,' 33

34 whereby the whole [notion of] suffering is summed up quietly and the business of 34

35 atonement is perfected. $\quad 35$

36 If you want to treat yourself to a particular pictorial pleasure, then look at the 36

37 chorus once more: 'Unto us a child is born'. 37

38 After the pastoral folk have heard the message of the angel on the nightly 38

39 plains and recovered from the fear, a part begins - 'Unto us a child is born' - and 39

40 innocently dallies with the idea; then others follow in this manner, next the third 40

41 [voice], then the fourth and finally with the words 'wonderful', 'mighty' and so on, 41

42 everyone is in accord: the shepherds of the fields, the army of stars of the entire 42

43 heavens, everyone wakes and is courageous and happy. 43

$44 \quad 44$ 
1 Now enough, ye muses, if not too much. When you have heard your Messiah, 1

2 I would also like to hear about it from you. I always learn something when you 2

3 speak about such matters.

4 The good Rochlitz deserves much thanks but his history of the development 4

5 of the Messiah a priori appears to me like all history (which can be [justifiably] so 5

6 called). The history of an artwork (and every artwork has his individual history) 6

7 can't be so simple, if nature itself needs a millennium in order to make one such 7

8 fellow, who is also only there by chance. Necessity itself cannot exist without 8

9 chance.

10 So something occurs to me: that I already formulated the hypothesis outlined 10 11 above about the fortuitous nature of Handel's Messiah, viewed as a complete work, 11

1220 years ago in a review which, then as now, met with appropriate contradiction. 12

13 The review is in the Berliner Musikalische Zeitung from 1805 or $1806,{ }^{608}$ which 13

14 Reichardt brought out and it is definitely in your library. 14

15 Let everyone think about it in his own way; for me this accidental element is a 15

16 necessary beauty in every work of a genius. It is easier for me in that I can enjoy 16

17 it undisturbed and don't need to excuse anything. If I see all that in it, it is really 17

18 there; if anyone wants to take it out, for him it is not there.

In Rochlitz's book (p. 76), ${ }^{609}$ Mara [Mlle Schmeling] is said to have petitioned 19

20 the King [Frederick the Great] three times for permission to marry Mara and to 20

21 have obtained it the third time. That, I am sorry to point out, is not true. The King 21

22 roundly refused.

23 When she ran away on the first occasion, and what is more, ran away from her 23

24 engagement as first singer to the King, she was still Mademoiselle Schmeling. 24

25 Mara was engaged on a good salary as a virtuoso in Prince Henry's orchestra, ${ }^{610}$ so 25

26 he was to be punished as a kidnapper.

27 The King wanted to keep Mara, but she had not wished to engage herself for 27

28 life. Now, however, she offered herself to the King on a permanent contract for life 28

29 providing the King would allow Mara, now advanced to the post of percussionist, 29

30 to be relieved of his duties and give her permission to marry him. Consent was 30

31 granted, and now, for the first time as a married couple, they absconded again. 31

32 That was in 1778, after Mara had sung the part of Rodelinda ${ }^{611}$ in January. When 32

33 they arrested her again, the King ordered them to let her go.

34 The King hated Mara, who was much more than a member of Prince Henry's 34

35 orchestra; but it was the noble prince who served his favourite [musician]. It must 35

36 have been impossible to get at Mara's heart by a secret staircase and through 36

37 thousands of favours. He was the commonest scamp and maltreated his master 37

39608 The article, signed ' $Z$ ', was published in the Berlinische Musikalische Zeitung 39

40 (1805), nos. 11 and 12 (1805). $\quad 40$

41609 Article on Gertrud Elizabeth Mara in Friedrich Rochlitz's essay collection Für 41

42 Freude der Tonkunst, pp. 49-117. 42

$43 \quad 610$ Friedrich Heinrich Ludwig of Prussia (1726-1802), Brother of Friedrich II. 43

$44 \quad 611$ Title role in Carl Heinrich Graun's opera. 
1 outrageously. He sulked at him for weeks on end and behaved impiously, disturbing 1

2 the Sunday services and the sermon in Rheinsberg. ${ }^{612} \mathrm{He}$ would go to the kitchen 2

3 and eat up the dishes ordered for the Prince, and he got really drunk when he 3

4 should have been playing.

5 All was overlooked year after year. The King knew about it but was

6 unwilling to spoil his brother's game. At last there was a catastrophe. Around

7 the time of the carnival, Prince Henry was in Berlin with all his court and hosted

8 masquerades which far surpassed the King's masked balls and all the other courtly

9 entertainments. On one occasion the entire court had been invited to a concert

10 given by Prince Henry to hear the admired Mara upon the violoncello. Everyone 10

11 appeared including Mara, who was drunk and refused to play. Prince Henry, in 11

12 despair at such a public affront, commanded, begged, entreated. Mara did not play 12

13 and this formed the basis of the King's hatred. 13

14 I tell you this story based on authentic chronicles ${ }^{613}$ because according to 14

15 Rochlitz's book the King appears as a tyrant who practiced his revenge upon Mara 15

16 and cruelly separated a married couple. At that time they were not yet engaged. 16

17 Mara's relation to Reichardt, who had just become the King's Kapellmeister, ${ }^{614}$ is 17

18 also not clarified, much to the composer's disadvantage. 18

19

25 Your esteemed letter brought me more than an important gift and so I want to 25

26 tell you first that the chorale book is going off by return of post. Tell me about its 26

27 value, especially with regard to the epoch from which it emerged.

28 You have provided me with enlightenment by your analysis of Handel's 28

29 Messiah. Moreover, your conviction of the unconscious origin of this work is quite 29

30 in accordance with my own opinion: for it is quite possible for the mind to raise 30

31 up out of fragmentary elements a funeral pyre and finally to point its flame like a 31

32 pyramid to Heaven.

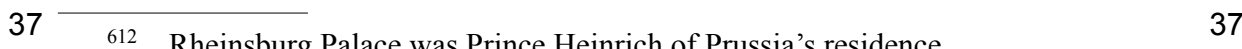

40 The 23-year-old Reichardt, who had just been appointed Court Kapellmeister to

41 Frederick the Great at the end of 1775, had - through his determination to reform the Berlin

42 Orchestra and to control the prima donnas - created many enemies, including the singer

43 Gertrud Elizabeth Mara, who had been in Berlin since 1771. The incident is recorded in her 44 autobiography. The dispute was settled at a later date.

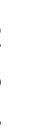
5

\section{6}

8

8

9

(1)

11

2

3

5

17

(1)

7

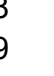

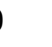

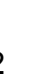


1 One evening, recently, I was listening to the Messiah; ${ }^{615}$ some day or other I 1

2 shall say a few words on the subject myself, but meanwhile I will be following 2

3 your guidance. I am grateful for the lead given by Rochlitz, though I find that 3

4 here as elsewhere his honest intention and hard work are obvious, and one can 4

5 only wish that he was capable of taking a firmer grasp of the subject and carrying 5

6 through more decisively what he has recognized 6

7 Now I want to thank you that you lent a friendly ear to the request regarding 7

8 Thaer and have already taken action. Admittedly they would like the announcement 8

9 as soon as possible, since both poem and music should be printed before that 9

10 deadline. But let the work remain with you. I will send you an address near to you 10

11 where you can deliver it in good time. ${ }^{616}$ Write both our names on it and though 11

12 apart, we can still fondly celebrate the great festival. Send me a copy. ${ }^{617} \quad 12$

13 The chronicle-like notices of the adventures of Schmeling-Mara certainly 13

14 have the true character of an empirical world; so it is that everything historical is 14

15 surrounded by a strange enigmatic character, and it really gets comical when we 15

16 consider how determined we are to be certain about what is long past. [...] 16

17 When you have had a look through the chorale book, hold onto it; I will enquire 17

18 about it again at Easter. 18

19

25 I am returning the Pachelbel chorale book to you with my sincere thanks. ${ }^{618} 25$

26 I almost believed I had made a real discovery in that I considered it to be an 26

27 autograph manuscript. It is, however, a copy, admittedly by an unsteady hand, and 27

28 contains quite a few transcription errors with which the published choir books of 28

29 that time are also marred.

$615 \quad 16$ March 1824 the evening. I had a musical treat of a high order at Goethe's house, where some fine 34 singers, under the direction of Eberwein, performed part of Handel's Messiah. Countess 35 Caroline von Egloffstein, Fräulein von Froriep as well as Frau von Pogwisch and Frau von 36 Goethe joined the female singers, and thereby kindly gratified a wish that Goethe had long 37 since entertained', Eckermann, p. 118.

616 Later Goethe asked the main organizer of the festival, Schultze from Heinrichsdorf, 39 to collect the poem and setting from Zelter.

617 Zelter enclosed a copy in his letter to Goethe on 4 April 1824. A copy is in Goethe's 41 music collection (GSA 32/8). 
1 This Pachelbel is a worthy man in his own way and has been praised by the best 1 2 of his colleagues, for he lived in the midst of the best chorale writers, from Luther 2 3 up to Sebastian Bach, in genuine possession of the traditional Church modes. [...] 3 4

5

6 Conrad

7 Ludwig

8 Ludwig

9 Heinrich

10 Johann Hermann

11 Samuel

12 Johann

13 Kaspar

14 Johann Jakob

15 Wolfgang Caspar

16 Johann

17 Daniel

18 Alessandro

19 Johann

20 Georg Philipp

21 Johann Sebastian

Rupsch
Senfl
Johann Walter
Schütz
Schein
Scheidt
Rosenmüller
Kerll
Froberger
Printz
Theile
Vetter
Scarlatti
Pachelbel
Telemann
Bach

$\begin{array}{rrr}\text { Born } & \text { Died } & 5 \\ 1475 & 1530 & 6 \\ 1486 & 1542 / 3 & 7 \\ 1496 & 1570 & 8 \\ 1585 & 1672 & 9 \\ 1586 & 1630 & 10 \\ 1587 & 1654 & 11 \\ c .1619 & 1684 & 12 \\ 1627 & 1693 & 13 \\ 1616 & 1667 & 14 \\ 1641 & 1717 & 15 \\ 1646 & 1724 & 16 \\ 1657 / 58 & 1721 & 17 \\ 1660 & 1725 & 18 \\ 1653 & 1706 & 19 \\ 1681 & 1767 & 20 \\ 1685 & 1750 & 21 \\ & & 22\end{array}$

22

23 This may be an approximate, incomplete list of the names ${ }^{619}$ which cannot be 23

24 denied their historical place, and no doubt there are several more. The above- 24

25 named Heinrich Schütz, Schein, and Scheidt are often called the Trinity of the 25

26 Three Great S's.

27 There is plenty of confusion in this manuscript, especially from page 16127

28 onwards, and one can see the transition of the strong, deep stream into the broad 28

29 flat wilderness. The song 'Auf auf!', on page $61,{ }^{620}$ is a veritable and really fine 29

30 minuet. There is a little Gavotte on page $184^{621}$ and so everything moves really 30

31 softly and pleasantly into the popular mode of songwriting in Halle. ${ }^{622}$ What 31

32 mainly contributes to this is the smuggling in of triple time which the large space 32

33 spurns because it is not a natural metre, and so it takes flight to the narrow space 33

34 between the walls of the living rooms and has brought about the whole great 34

$38 \quad 619 \quad$ I have completed and corrected Zelter's list of dates. 38

39620 Johann Anastasius Freylinghausen's hymn, ‘Auf, auf, weil er Tag erschienen'. 39

40 no. 161 in Pachelbel's Choralbuch. 40

41621 No. 184 lists L.J Schlicht's hymn 'Ach mein Jesu sieh ich trette'. 41

42622 At the beginning of no. 161 in the Tabulatur Buch, the inclusion of Johann 42

43 Anastasius Freylinghausen's Neuem Geist-reichen Gesangbuch (Halle, 1714) is indicated 43

44 by the title 'Neu-Hallische Gesänge'. 
1 general devotional movement. By comparison, read the Divan, p. 62, under the 1 2 title 'Old Persian'. ${ }^{623}$ 'Kennst du es wohl?'624 2

3 I intend to find a special use for your tablature book. By that I mean the little 3 4 preludes which are called fugues here, which come before the chorale. They serve 4 5 to pitch the chorale in its appropriate key, with the help of the organ, whereby 5 6 soloists and congregation are able to enter securely. They are fugues in so far as 6 7 the leading theme (theme, subject) and accompanying theme (countersubject and 7 8 answer) should take turns with the art and modulation. This practice belongs -8

9 like the sacred modes - to the church, although it can and does produce really 9

10 nice fugues and on the contrary gives rise to fugues which cannot be considered 10 11 church-like for the very reason that they are outside this tradition.

In former times, when an organist or Kapellmeister was examined for official 12 13 duty in the church, a subject was given to him (the $d u x$ ) for which he himself was 13 14 obliged to find the answer extempore. He had to work out a similar task on paper in 14 15 a room by himself; once that was done, the exercise was judged by the Committee 15 16 of Examiners and such a fugal work then received the name of ricercar. [...] 16 17 Since you have tasted a little of Handel's Messiah, I only want to say that on a 17 18 similar occasion I met and spoke with our Crown Princess ${ }^{625}$ for the first time last 18 19 Wednesday. Our Crown Prince invited a choir of eight to ten members of the Sing- 19 20 Akademie into his living room in the King's residence in Frederick the Great's 20 21 music room and in the presence of his court had them sing many magnificent 21 22 movements of the great work ${ }^{626}$ to a mere piano accompaniment. I was invited less 22 23 as a collaborator than as a guest among the audience. Much as I have to accept 23 24 this as an honour, I was deeply saddened. I am used to rehearsing and realizing 24 25 this divine work with the dignity due to it for the last 30 years, and with 180 fresh 25 26 voices, in order to present what music is. Now I stand like a poor sinner and see 26 27 the living work dead before me in a narrow coffin where it cannot move its limbs. 27 28 I immediately drowned the deepest sorrow in a flood of champagne, which was no 28 29 compensation. One would go mad if one were not mad already. They want to carry 29 30 such a work in a knitted bag. Messiah wasn't up to it and they went off for a meal 30 31 where things went much better.

623 The section 'Ältere Perser', in the first edition of Noten und Abhandlungen zu 36 besserem Verständnis des West-östlichen Divans (1819), p. 262, deals with the metamorphosis 37 of the 'noble, pure nature religion' into a 'common cult'; Zelter recognizes a similarity in 38 what is discussed here about the 'general religious devotion'.

${ }^{624}$ Zelter is playing on a line from Mignon's lied 'Kennst du das Land?' from Wilhelm 40

Meisters Lehrjahre.

${ }^{625}$ Elizabeth Ludovike of Prussia, née Princess of Bavaria (1801-73), married to the 42

626 Handel's Messiah. 
$5[\ldots]$ Today I am having rehearsal of the Passion Music which the Crown Prince 6 will visit. I am almost expecting the King himself, who is eating with the Crown

7 Prince at noon and could well stroll in with him after lunch, which would be very

8 pleasant for me since he could always throw me a pair of Friedrichs d'or once 9 again.

10 Privy Councillor Wolf, who wants to pass through Weimar, ${ }^{627}$ insists on some kind 10

11 of letter and so I am sending these lines with him. I still don't even know whether you 11

12 have already received my last letter with the chorale book I returned. [...] 12

\section{Goethe}

19 [...] The chorale book is back again. I had hoped you would have been more 19 20 excited about it. Admittedly this dispatch had the advantage that you were able to 20 21 add such good words of praise.

22 As chief organizer of this festival in Möglin and Freyenwalde, Schultze [...] 22

23 will have collected the poem and composition from you. Warmest thanks that you 23

24 have been willing to follow my wishes with this request. The melody and style 24

25 are really delightful. I would really like to hear these country voices manage it. 25

26 However, I hear they have brought some musicians into the circle. 26

27 I hope [Graun's] Tod Jesu has also prepared a happy Easter for you this year. ${ }^{628} 27$

28 The most lamentable of all events has been turned to such profit by clerics, and 28

29 painters have also become wealthy on it, so why should the musician not cash 29 30 in?

31 My Messiah is of great benefit to me; not all of it, but the kernel of it. ${ }^{629}$ At least 31

32 the idea is becoming clearer and this is a good deal for someone like me. I am not 32

627 Friedrich August Wolf had requested a year's sabbatical from the Prussian king in recover his health, after a severe bout of pneumonia. Before receiving an affirmative reply,

38 he left Berlin on 14 April and travelled to Weimar via Wittenberg, where he stayed from

3818 to 25 April. He died in Marseille on 8 August 1824.

39628 The Sing-Akademie gave their annual performance of Graun's Der Tod Jesu on

40 Friday, 16 April 1824 . Zelter profited from the performance. In his letter of 18 April, which

41 never reached Goethe, he wrote, 'Yesterday my Passion Music was well received again by a

42 very full house. I took in much money and there could be no complaints about our music.'

43629 This refers to the performance of excerpts of Handel's Messiah with piano 44 accompaniment which took place in Goethe's house on 16 March and 14 April 1824 at the 
1 against the idea that it is a collection, a compilation garnered from a number of 1

2 sources, for in reality it doesn't matter whether the unity forms itself at the beginning 2

3 or at the end; it is always the mind that produces it, and moreover the unity was 3

4 implied in the Christian Old and New Testaments. In the end this very thing may be 4

5 relevant to Homer, ${ }^{630}$ only one must not say so to Wolf, who, when people admit that 5

6 he is in the right, assures them they do not understand the matter [...] 6

13 [...] Yesterday evening your Tasso was read at the Mendelssohn's. ${ }^{631}$ Wolff, his 13 14 wife $^{632}$ and house guests acquitted themselves well and approximately 30 friends 14

15 got great pleasure from it. [...]

It delights me that you feel as I do about the Messiah. The artist took a lofty 16 17 stance. He didn't try to work around the clerical positions; he simply flew above 17 18 them, and the ideal of the redemption stands out clearly.

Perhaps you would like to look at the following little book $^{633}$ which is a translation 19

20 by a contemporary art colleague here. Leaving aside some Philistines, he is not so slap- 20

21 dash and fragmented as the contemporary critic who turns the man into a market doll 21

22 and sees him as being no different from everyone else. Please return it to me sometime; 22

23 it has become rare like any writings of Mattheson, ${ }^{634}$ who has written some 80 books. 23

18 May: The festival ${ }^{635}$ went well and the good old fellow earned the honourable 24

25 title of the German Woll-Thaer. ${ }^{636}$ One of my best students had taken over the choir. 25

26 I feared the challenge was too much for him and I went along myself, accompanied 26

630 Goethe is, of course, referring to Friedrich August Wolf's Prolegomena ad 30 Homerum, in which he considered Homer's epics, the Iliad and the Odyssey, to be 31 rhapsodies. From 1820 Abraham Mendelssohn held a salon in his figures in Berlin society were invited, including, for example, the Humboldts, Hegel and 34 Heinrich Heine. 
1 by eight capable singers. The people came from all directions: 250 people were at 1

2 table and it must have been planned spontaneously. In short, the thing went well 2

3 enough, although poet and composer had set it up for regular troupes. They had 3

4 published your poem in the textbook ${ }^{637}$ at the very end, keeping the best till last. 4

5 One soon found it and it had to be sung at the beginning and once more at the 5

6 end. What delighted me about it was that the refrain was sung by the whole table, 6

7 farmers and nobility together; and I had set it up that way [...] 7

8 Ascension Thursday: On the day of repentance Spontini performed Handel's 8

9 Alexanderfest for his charity performance. ${ }^{638} \mathrm{He}$ could have left it out, but he did 9

10 no harm by it: what he didn't earn he has gained. 10

17 [...] Recently I heard a very charming performance of the Thaer cantata and once 17 18 more was delighted with the music: with every strophe the meaning is deepened 18

19 along with the feeling [...] 19

2614 July: Eberwein has arrived in order to promote his opera, ${ }^{639}$ since he will fight to 26

27 see our shameful side. We are drowning in misery and expecting an explosion. As I 27

28 have had nothing to do with such matters, I am equally close to both sides. Trojans 28

29 and Greeks: one is the same as the other. An acquaintance of mine compiled a 29

30 collection of documents about the quarrel over the opera Euryanthe ${ }^{640}$ which is 30

Festgaben, dem Königlichen Preußischen Geheim-Ober-Regierungs-Rate Herrn

(SBB PK, Yf 2823-158).

$38 \quad 638$ Spontini conducted Handel's Alexanderfest on 12 May 1824; for reviews of the

39 performance see $A M Z 26$ (1824), no. 26, 24 June, column 421; MA 20.3, p. 633.

40639 Der Graf von Gleichen (libretto by Friedrich Schmidt) premiered in Weimar on 41 May 1824.

42640 For the reception history of this work, composed by Carl Maria von Weber

43 1822-23; see Friedrich Wilhelm Jähns, Carl Maria von Weber in seinen Werken (Berlin:

44 Schlesinger, 1871, r.1967), pp. 366-75. 
1 more interesting than the thing itself. Privy Councillor Schmidt ${ }^{641}$ will take this 1

2 letter with him. [...] 2

3 Three years ago for our second Liedertafe ${ }^{642}$ I composed a drinking song by 3

4 Förster, ${ }^{643}$ to which one attaches a satirical, political connotation. Oddly enough 4

5 Bierey from Breslau has set this poem to music and has had it published. ${ }^{644} 5$

6 It is published under your name in the Caecilia which comes out in Mainz, ${ }^{645}$ and 6

7 was negatively reviewed. ${ }^{646}$ The poem is spared criticism because your name is on 7

8 it, but the music was written off. I mention this simply in case you hear of it. 8

9 Bierey is hardly likely to produce anything worthwhile. As long as the people 9

10 write serious opera, they will find in the so-called passions an occasion and an 10

11 excuse for all the rough and tumble with which they torment themselves and 11

12 others. In humorous circumstances one recognizes the impoverished nature and so 12

13 it is with the above-named composition. The critic was right - not that his review 13

14 is any better.

$21[\ldots]$ I would like to have given a report about the new theatre ${ }^{647}$ but, to tell the 21

22 truth, I have not been in it often enough. [...] Among the singers Spizeder ${ }^{648}$ is 22

23 excellent in comedy; a Madame Biedenfeld, ${ }^{649}$ true Italian art and voice; Madame 23

${ }^{643}$ Friedrich Förster's 'Frühlingsmusikanten' ('Es wollt einmal in Königreich'), 29 composed by Zelter on 25 May 1821.

${ }^{644}$ Dämagogisch. Gedicht von Goethe, für eine Singstimme und vier Frösche, mit 31 Begleitung des Pianoforte, in Musik gesetzt von G.M. Bierey (Breslau: C.G. Förster, 32 1824).

645 Cäcilia, eine Zeitschrift für die musikalische Welt, vol. 1 (Mainz 1824), pp. 133-9. 33 ${ }_{646}$ Ibid., MA 20.3, p. 638.

${ }_{647}$ On 4 August 1824 the Königstädtisches Theater was opened; it was the first 35 . On 4 August 1824 the Konngstadtisches Theater was opened, it was the first large- 36 scale private theatre alongside the two court theatres. The need for a third theatre was to 37 accommodate lighter entertainment; Carl Friedrich Cerf got concession from the court to 38 run the theatre for 99 years on the condition that no serious operas or dramas would be 38 performed and that there would be a two-year delay in taking up works which had been 39 performed by the court. A directory of six bankers was founded and the first directorship 40 was given to Carl Friedrich Kunowski; for an account of the opening see AMZ 26 (1824), 41 no. 39, 23 September, column 633f.; MA 20.3, p. 644. 648 Joseph Spitzeder (1795/96-1832), singer and actor. 43 ${ }_{649}$ Eugenie Freifrau von Biedenfeld née Bonasegla (1788-1862), singer. $\quad 44$ 
1 Spizeder $^{650}$ and Mademoiselle Eunike ${ }^{651}$ [are] very good and almost no one is bad. 1

2 A first-rate tenor seems to be lacking. Of the orchestra I will only say that it is 2

3 developing; that is to say, it will be nothing if the Director of Music ${ }^{652}$ remains a 3

4 vain fool who, in spite of his merit, still doesn't know where the beginning is. He 4

5 has fine young people under him, who see through him if they don't ignore him. 5

$6[\ldots]$

13 As a counter-piece to the lovely things you inform me of, I am sending you a 13 14 comedy leaflet, ${ }^{653}$ from which you may well see that we are making progress while 14 15 going backwards. For the first time in my life I saw Die Mitschuldigen ${ }^{654}$ yesterday 15 16 and in a quite good performance. The four principals ${ }^{655}$ were well cast and well 16 17 rehearsed. Schmelka and Mademoiselle Sutorius were outstanding, and it is worth 17 18 remembering, well received. I was as amazed at the heartiness of the direction as 18 19 at their knowledge of the local audience, which gladly attending every good play 19 20 knew how to distinguish itself by it arousing applause, in contrast to the people in 20 21 the first row, where I had my place today.

22 The impression the play made on us in the front row I would like to compare 22

23 to the impact of Die Wahlverwandtschaften, which is intellectual without being 23

24 beneficial. Yes, even Kotzebue's small-town dwellers ${ }^{656}$ occurred to me because 24

25 no one wants to be in the stocks: everyone wants to watch. A common theft carried 25

26 out openly by a reckless person and all good or decent people are guilty; that made 26

27 us feel so bitter that one would want to veil one's face before looking in the mirror. 27

28

651 Katharina Friederike Dorothea Bernadine Eunike (1804-42), singer and actress.

652 Carl Wilhelm Henning (1784-1867), composer and Kapellmeister, music director 34 at the Königstädtisches Theater from 1824 to 1826.

$35 \quad 653$ The theatre leaflet from the Königstädtisches Theater, 26 November 1824, with 36 the announcement of Goethe's Die Mitschuldigen and the Singspiel Der Sänger und der

36 Schneider (Text and Music by Friedrich von Dreiberg); the enclosed leaflet has not been 37 handed down.

$42 \quad 655$ Alcest was played by Ludwig Meyer; Sophie was played by Auguste Sutorius; the 43 landlord by Heinrich Ludwig Schmelka; Söller by Wohlbruch. 
1 In short, good or not so good - it should dawn on us: the greater the theft, the more 1

2 refined the public $\quad 2$

$3[\ldots]$ Once again we have been visited by a pair of virtuosi murderers: Madame 3

4 Grünbaum (formerly Wenzel-Müller) ${ }^{657}$ and Moscheles, the pianist. ${ }^{658}$ The former 4

5 sings our Milder and Seidler ${ }^{659}$ clean off the earth, and Moscheles really plays in 5

6 such a fashion that he makes one take a draught of Lethe and forget all who went 6

7 before him. Why, the fellow has hands which he turns inside out like a shirt, and 7

8 even his nails can play. Among the more recent composers, I like his style next 8

9 to Hummel's. I had heard of him some time ago and in 1819 travelled through 9

10 Prague to Vienna on his account; I missed him there because he was expected in 10

11 both places. [...] 11

12 I heard Madame Grünbaum in 1810 in Prague when she was still single. ${ }^{660} 12$

13 Her voice is quite mellow and has a good range, [but] has neither the metal nor 13

14 the power of Milder and Catalani. Our Seidler has more brilliance in both tone 14

15 and expression. Grünbaum is instructive to me because I find my preconceived 15

16 opinion of Rossini confirmed by her. She makes his ornaments come to life so 16

17 vividly that you believe you are hearing a song bird that is not yet known. She is 17

18 also praised for her performance of Mozart's works, in which I have never heard 18

19 her. Against that I have heard her three times in Rossini's Barber of Seville ${ }^{661}-$ one 19

20 [performance] after the other - where she made me delighted with the composer 20

21 as well. [...] 21

22

657 Therese Grünbaum née Müller, daughter of the composer, Wenzel Müller; engaged in Vienna from 1818. Guest appearances in Berlin from September 1824 included Donna 25 Anna in Mozart's Don Giovanni (28 September, 2 and 26 November); the countess in 26 Mozart's Figaro (1 and 24 October, 14 and 23 November); Rosine in Rossini's Barbier von 27 Sevilla; Amazily in Spontini's Ferdinand Cortez (5 and 21 November); Julia in Spontini's 28

Vestalin (3 and 10 October, 10 December). She concluded her visit with a performance of 29 the title role in Spontini's Olympia on 28 December 1824. She won the acclaim not only of 30 Berlin audiences but also the critics; see, for example, Spenersche Zeitung of 16 September 31 and $A M Z$ (1824), no. 52, 23 December, column 858. visit Moscheles met the 15-year-old Mendelssohn and, at Lea's request, gave him some 34 finishing lessons on the piano. In later years Moscheles appeared with Mendelssohn in his 35 first Gewandhaus concerts in 1835 and was appointed principal professor of piano at the 36 Leipzig Conservatory, founded by Mendelssohn. Following the composer's death in 1847, 37 he resolved to maintain the high standard of teaching for which Mendelssohn strove.

659 Berlin singers Anna Milder-Hauptmann (1785-1838), Caroline Wranitzky-Seidler $\begin{array}{r}38 \\ 39\end{array}$ (1790/4-1872). 
$5[\ldots]$ Your musical reports have been [...] of incredible value to me; ${ }^{662}$ as far as it 6 is possible to grasp music conceptually, you have enabled me to do so, and at all

7 events, I now understand why of all Rossini's works, Il Barbiere di Seviglia is

8 the one most generally praised. One evening recently I heard Tancredi; ${ }^{663}$ it was

9 a very commendable performance and I would have been really happy if only no

10 helmets, armour, weapons and trophies had appeared upon the stage. However, 10

11 I got past the difficulty immediately and transformed the performance into a 11

12 favola boscareccia, ${ }^{664}$ something like the Pastor Fido ${ }^{665} \mathrm{I}$ also imagined the stage 12

13 decorated by graceful Poussin landscapes; I peopled the scene with actors of my 13

14 own so that there was no lack of ideal shepherds and shepherdesses as in Daphnis 14

15 und Chloe, ${ }^{666}$ and even fauns; and then there was nothing to criticize because the 15

16 meaningless pretensions of a heroic opera fell away. 16

23 [...] You will have found in the Wiener Theaterzeitung a letter by Mozart ${ }^{667}$ sent to 23

24 a dear, good baron who had sent him compositions seeking advice and instruction 24

25 but was actually wanting to learn the secret very briefly [of] how one manages 25

$27 \quad 662$ Zelter's account of Die Mitschuldigen in the new Königstädtisches Theater on

28 Alexanderplatz.

29663 Goethe went to the performance of Tancredi (in Italian) at the Weimar Court 29

30 Theatre on 27 November 1824.

31664 A pastoral play.

32665 Il pastor fido, pastoral comedy by Giovanni Battista Guarini, who was also the

33 librettist. The enduring popularity of his libretti spanned the seventeenth and eighteenth 34 centuries.

$35 \quad 666$ Longos's pastoral novel.

\section{2} 33

39 likely a counterfeit. Goethe didn't respond to Zelter's hint but he did read the letter two 39 years later through Chancellor von Müller, as Eckermann's record for 13 December shows: 40 'I read a letter by Mozart today, in reply to a baron, who had sent him his composition: "You dilettantes must be scolded because you are characterized by two faults: either you have

42 no thoughts of your own and take those of others or, if you do have ideas of your own, you

43 don't know what to do with them." Isn't that divine? And doesn't this fine remark which

44 Mozart voiced about music, apply to all other arts?', Eckermann, p. 194. 
1 to send something quite beautiful out into the world. The letter is a golden letter 1

2 and reassures me about my old way of teaching: that one should not go to too 2

3 much trouble with the young art enthusiasts. Whoever wants real knowledge will 3

4 manage and whoever wants to win will invest. That's as much as I know and I keep 4

5 on learning. [...] 5

6 To provide occasions for my enterprise in addition to the two Sing-Akademie 6

7 days I have, for more than 20 years, a Friday collegium in my home, ${ }^{668}$ where I am 7

8 both master and servant. In addition to their formal studies, the most capable of my 8

9 young students take part in the performance of excellent musical works from the 9

10 past. Additionally I talk about my own experience and insights. Some days more 10

11 is spoken and discussed than sung and played. [...] 11

12 Felix is still my best student. His admirable industry is the fruit of a healthy 12

13 root, and his sister, Fanny, has completed her thirty-second fugue. The young 13

14 people are wide awake, and when they have picked up anything that suits them, 14

15 you see it in their work; they are as pleased as if they had conquered Mexico, ${ }^{669} 15$

16 and they are fond of me, just as they find me, and come and go like bees about 16

17 flowers $[\ldots]$

$24[\ldots]$ Today my Felix is to let us hear his latest double concerto. ${ }^{670}$ The lad stems 24

25 from a root that gives promise of a healthy tree. His individuality becomes more 25

26 and more apparent and entwines so well with the spirit of the age that it seems to 26

27 peep out of it like a bird from the egg. [...] 
$5 \mathrm{I}$ had shared something from your letter with Madame Schulze, ${ }^{671}$ who sings and 5 6 acts Tancredi ${ }^{672}$ better than anyone, and lo and behold she appeared as a well-built 6 7 youth with a strong, full, clear voice and with only a suggestion of a helmet - 7 8 whether it was to support what you said ${ }^{673}$ or to avoid hiding her manly face with 8 9 a strong Caesar's nose, big blue eyes, pearly teeth and ample lips so that the music 9 10 meant more to me for its good qualities.

11 They had cut the opera, which can take a knock because a ballet in three acts 11

12 still followed, but with the purpose of putting in something foreign - and that was 12

13 good? It was a choral work from an Italian oratorio, I pellegrini al sepolcro di N.S. 13

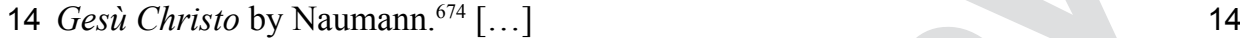

15 Our head chef and courtly train are trying to erect a memorial of the great 15

16 minds by an evening meal at midday whereby the goblet must do its best. ${ }^{675}$ The 16

17 day before yesterday Mozart had to suffer, ${ }^{676}$ and the thing was decent enough if 17

18 one takes on board that approximately 300 heads were together with the same 18

19 intention. They were, in fact, all cheerful and remained that way, for the effect of 19

20 champagne is to transform the truth. The health of those celebrated ${ }^{677}$ was spoken 20

21 in German by our general music director, Spontini, and as nothing rhymes in 21

22 German, one would expect the thing to have come out as awkward and unrhymed, 22

23 and it was - exactly like that! [...] 23

38673 Reference to Goethe's critique of the Weimar performance, where 'helmets,

39 armour, weapons and trophies' were used on stage.

$40 \quad 674$ Johann Gottlieb Naumann.

41675 Dinner party, essentially a celebratory evening meal, on this occasion brought 41

42 forward to midday.

$43 \quad 676$ Celebration of Mozart's birthday on 27 January. 43

$44 \quad 677$ W.A. Mozart. $\quad 44$ 
5 Everything which makes your circumstances clear to me and can bring me to your 5

6 side is really welcome to me at any time: one moment I find you at the opera ${ }^{678}$ and 6

7 the next revelling in a big feast ${ }^{679}$ in true Berlin style. [...]

14 [...] I am performing Der Tod Jesu today. ${ }^{680}$ The seats are all sold and yesterday's 14 15 rehearsal had around 800 listeners, many of whom had given up their purchased 15 16 tickets in order not to roast the following day. Such a rehearsal provides a tolerable 16 17 performance.

18 Easter Saturday: My hall ${ }^{681}$ was packed full yesterday. In the evening, after the 18 19 performance, I found a lovely big silver goblet on my table, with which 100 of my 19 20 female students had honoured me. The inscription on it was: 'Drink, old man! The 20

Chladni, who is here, ${ }^{682}$ finds everything according to his taste and at the same 28

680 On Good Friday, 1 April 1825, Zelter conducted his annual performance of Graun's 36

Der Tod Jesu.

681 Concert hall in the Königliches Opernhaus, in which Der Tod Jesu had been 38 performed.

682 As reported in the Vossische Zeitung on 30 March 1825, Chladni was in Berlin to 40

41 give lectures on acoustics in the house of chemist and Privy Councillor Sigismund Friedrich 41

42 Hermbstädt (1760-1833).

$43 \quad 683$ The new theatre, which had opened on 4 August 1824, was also used as a concert 43 44 hall. 
1 and beauty lie in the music and in the orchestra everything has its own part to 1

2 play. $\quad 2$

3 The entrance of the female singers as far as the footlights is a cheap trick with 3

4 the audience to attract applause.

5 A voice, which is strained, doesn't know its limitations and is not the best. A 5

6 beautiful voice sounds best from a proper distance. No one wants to hear a violin 6

7 played too loudly or a flute overblown.

8 You are an old practitioner and so I am asking for my own sake, since an expert 8

9 opinion about such effects demands understanding and experience. 9

10 If I could build a theatre with my money, I would try to cut off and retract the 10

11 area between the curtains and the orchestra with a straight line, whereby perhaps 11

12 the prompter's box, which I always hated, would be excluded. 12

$13 \quad 13$

$142 \ldots 14$

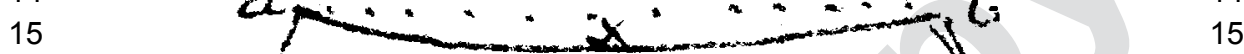

1616

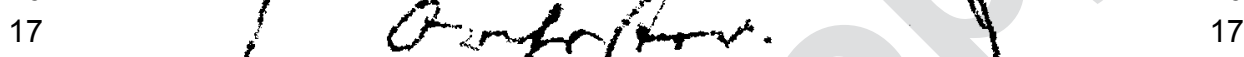

1818

19

20

21 The requested profile ${ }^{684}$ is enclosed here and Ottmer asks for it back after you have 21

22 made use of it. $\quad 22$

23 Best of all, perhaps, would be if Coudray himself were to come to Berlin: 23

24 blessed are those who see and also believe. ${ }^{685} \quad 24$

25 In confidence I will still only say as a simple musician that a bad performance 25

26 can seldom be attributed to the house, because with the cursed virtuoso musicians 26

27 there is no thought given to the orchestral work. A proper orchestra can come 27

28 about only where a concert master can build up a school around him. It doesn't 28

29 matter if someone has the talent to tickle people here and there where they like it, 29

30 as long as it does not have an influence on the students. 30

$31 \quad 31$

$32 \quad 32$

$33-33$

$34-34$

$35-35$

$36 \quad 36$

$37 \quad 37$

$38 \quad 38$

$39-39$

$40 \quad 684$ The requested selection of architectural plans for the Königstädtisches Theater 40

41 in Coudray's letter of 31 March 1825. According to Goethe's diary on 19 April 1825 (WA 41

$42 \mathrm{III} / 10$, p. 45), there were two pages of plans, which he returned to Coudray on 7 June. 42

43685 A reference to Christ's words to the Apostles, 'Blessed are those who don't see 43

44 and yet believe'. $\quad 44$ 
334. Zelter 1

5 That you remember me in your correspondence with Schiller really cheered me 5

6 up again. Your support for Scutaris ${ }^{686}$ and what you said about folksongs are both 6

7 so close to my heart that I can substantiate them. It was exactly in this vein that I 7

8 responded to a young man ${ }^{687}$ who set Herder's folksongs and gave them to me for 8

9 my assessment. [...]

Our building of the Sing-Akademie has started, ${ }^{688}$ which means we are digging 16

25 Mendelssohn stayed with us too short a time on his return journey from Paris; ${ }^{689} 25$

26 Felix produced his last quartet ${ }^{690}$ and astonished everyone. This personal musical 26

27 dedication has done me a lot of good. I could only speak very fleetingly with his 27

28 father, for I was prevented and distracted by the music and by a large concourse 28

686 Two articles in a new edition of Über Kunst und Altertum, the first a translation of 31 a Serbian song sent to Goethe on 8 May 1824 by Jacob Grimm; the second, Goethe's essay, 32 Serbische Lieder, introduced by general observations on folksongs and their melodies. 33 687 Presumably Carl Loewe; in a letter of 30 December 1823 Loewe had requested 34 Zelter's opinion of his edition of three ballads, which included a setting of Herder's 35 'Edward'; Zelter replied on 10 January 1824 and outlined in his letter remarkable principles 36

42690 Piano Quartet in B minor, opus 3, dedicated to Goethe. Goethe noted in his diary, 42

43 'In the evening concert and company. Mendelssohn performed a quartet with Eberwein and 43

44 some other musicians', WA III/ 10, p. 57. 
1 of people. I would like to have heard something about Paris from him. Felix 1

2 told the ladies something about the state of musical affairs there which is very 2

3 characteristic of the time. Give my best wishes to the family and also keep me in 3

4 the memory of that circle.

5

6

337. Zelter

11 Felix has returned from Paris ${ }^{691}$ and has made quite a name for himself in these 11

12 few months. There he composed a Kyrie ${ }^{692}$ for Cherubini that will stand up to 12

13 performance and examination, all the more as that good fellow, following his 13

14 clever instincts, has taken up the piece almost ironically, in a spirit which, if not 14

15 the right one, is at any rate very much what Cherubini has always been on the look 15

16 out for and, if I am not much mistaken, has never found. 16

17 I am amused that you study my letters! It must be a pretty awkward bundle 17

18 that I wouldn't mind seeing myself! The letters may include academic matters, but 18

19 they account for my life in the 25 years in which I first began to live. ${ }^{693} 19$

20 [Abraham] Mendelssohn has brought his younger sister ${ }^{64}$ back with him from 20

21 Paris; for some 20 years she lived there as governess to General Sebastiani's 21

22 newly-wed daughter, and having realized a considerable pension, she now intends 22

23 to reside in Berlin where she was born. The free and loveable disposition, which 23

24 this girl has retained from childhood through the Parisian descent into hell, is 24

25 to be commended. It is enough to reconcile one again to the Prophets: that the 25

26 old, failing father should see the promise of Abraham fulfilled in all his children. 26

27 Farewell, my dear friend! I am looking forward to your new complete edition with 27

28 great anticipation. 28

$31 \longrightarrow 31$

$32 \quad 32$

$33-33$

$34 \quad 34$

$35-691$ Abraham Mendelssohn had taken Felix with him on a business trip to Paris, from 35

$36{ }_{691}$ Abraham Mendelssohn had taken Felix with him on a business trip to Paris, from 36

37 March to May 1825, in order to introduce him to Cherubini, whose opinion of his son's talent he sought.

$38{ }_{692}$ This work cannot be identified for certain; the most likely work is the Kyrie in

$39 \mathrm{C}$ minor for choir and orchestra, housed in the Staatsbibliothek in Berlin.

$40 \quad 693$ Zelter finds his identity at the beginning of his friendship with Goethe and here

41 considers that he has really begun to live since then.

42694 Abraham Mendelssohn's sister Henriette had lived in Paris since 1802, first

43 as headmistress of a boarding school for girls and from 1812 as governess to General

44 Sebastiani's daughter Fanny, after whose wedding she returned to Paris in 1824. 
You may receive more reliable reports from other sources about our 1

2 celebrations. ${ }^{695}$ As yet I haven't seen the new magic opera Alcidor, ${ }^{696}$ I write 2

3 'seen', and I will have to wait until those, who have booked all the seats well in 3

4 advance for the sole reason that they want to test the newly-created title for it - All 4

5 too Amazing: A Magic Opera - have scolded it enough. ${ }^{697}[\ldots]$... 5

6 Our man from Heidelberg ${ }^{698}$ chooses to be like someone who, astronomically 6

7 speaking, knows only one pole. He thinks the most terrible tricks were played on 7

8 Mozart with the words Misericordias Domini cantabo in aeternum, ${ }^{699}$ in that he 8

9 composed the opening words devoutly and the final words jubilantly. 9

10 The work appears to be very advanced and is an exercise in counterpoint 10

11 to bind two contrasting themes with one another, taking the first words which 11

12 occurred to the writer. [...] 12

19 [...] Our new massively heavy magic opera, Alcidor, which plays for four hours, 19 20 has now survived two performances. Two quarrelling magic princes, of whom one 20 21 rules a golden island with its residences keeps technical staff and decorators very 21

22 busy. Choirs of gnomes and sylphs enact the magic work. A loving pair, plagued 22

23 by the gnome folk and protected by the other side, is at last reunited and made 23

24 human.

25 The libretto is written in French by Théolon and set to music in a French manner. 25

26 So we finally possess a Berlin original - that is: changed into a new dress.

27 The music is an astonishing piece of work: one would have to be a really fine 27

28 musician in order to admire it, let alone treasure it. It is a chaos of the rarest effects 28

29 that want to wear one another down, like the singing princes, and presupposes 29

695 Celebrations for the wedding ceremony of Prince Friedrich of Netherland to 32 Princess Louise of Prussia on 21 May 1825, to which the Vossische Zeitung gave extensive 33 coverage on 24 May.

${ }^{696}$ Spontini's opera (libretto by Carl Herklots, adapted from the French by Marie 35 Emmanuel Guillaume Théaulon de Lambert) was first performed in a lavish production 36 which cost 16,000 thalers on 23 May in the Königliches Opernhaus in Berlin; AMZ 2737 (1825), no. 24, 15 June, column 404-406. Further performances were given on 26 and 38 697 Spontini's high income was common knowledge; Zelter's comments also refer to 39

40 the amount of money spent on the production of this Zauberoper opera, which lasted four 40

41 hours.

$42 \quad 698$ Anton Friedrich Justus Thibaut (1772-1840), lawyer and professor in Kiel (from 42

43 1798), in Jena (from 1803) and Heidelberg (from 1806), also a writer on music. 
1 immeasurable industry on the part of the composer. There must be ten years work 1

2 in the piece. I could kill myself and would not bring forth anything like it. 2

3 In published and unpublished form the immediate critics here do the 3

4 composition a disservice ${ }^{700}$ insofar as what one throws away, the other deals with 4

5 by coldly raising it up.

6 In what he set out to do, he succeeded only too well. He had wanted to excite

7 surprise, wanted to shock, and with me he fully reached his objective. He seemed

8 to me like his golden king who flings gold at the people, giving them holes in the

9 head.

10 Since the performed music is based on excess, the great demands made by it 10

11 are not unjustified and the complaints of the orchestra about the difficulties are 11

12 nothing compared to what the ear has to withstand - to last so long in a thicket of 12

13 sounds which is far too attractive, and, at the same time, too burdensome to be cast 13

14 off. I know well what I can endure and I thought I would find it easier to cope with 14

15 yesterday than the first time. But eyes and ears, even skin and bones are still sore 15

16 today from watching, listening and sitting. 16

17 All of that is not just peculiar to me. It is characteristic of the period which 17

18 leads to perdition everyone who is forced to let himself be carried away. Since 18

19 I am reading the Wincklemann letters now, I see clearly that I, too, make undue 19

20 concessions to the epoch. In short, the work is remarkable in all external respects 20

21 because of the style, which is pushed to extremes, a style that expresses the strong 21

22 and the lovely through travesty. With complete emptiness, it has a bewildering, 22

23 even deadly effect. 23

24 What tries to be melodic seems to me like a contour drawing which always 24

25 discontinues instead of flowing and loses itself in caricature. 25

26 Similar things of this period could be found in the completely extraordinary 26

27 Beethoven, who could be compared with Michelangelo in the past and in the 27

28 present with Spontini, for whom Cherubini paved the way. 28

29 What am I actually trying to say? Should one condemn that in which one is 29

30 present? Should one suffer what is not to be endured? So (like Wieland) we need 30

31 to live and let live.

$32 \quad 32$

$33-33$

34 339. Goethe 34

$35 \quad 35$

$36 \quad$ Weimar, 6 June 182536

$37 \quad 37$

38 [...] The Serbian folksongs have just been published at Halle in an attractive octavo 38

39 volume. $^{701}$ The introduction, a short outline of the history of the fallen Serbian 39

40 empire, is extremely good and exhibits [the author's] extensive knowledge; 40 41

$42700 \quad$ Spenersche Zeitung, no. 125, 2 June 1825 and no. 126, 3 June 1825.

43701 Volkslieder der Serben, metrisch übersetzt und historisch eingeleitet von Talvj (2 43

44 vols, Halle, 1825-26); volume one, which Goethe is referring to, contained a dedication to 44 
1 a sufficient though uninteresting account. To have - just as I wished - all the 1

2 national songs before you in one volume is extremely delightful and informative; 2

3 you know at once what they are and what they are meant to be. 3

4 I cannot close without again recalling that overcharged music, ${ }^{702}$ but, dear 4

5 friend, everything nowadays is ultra, everything inexorably transcendent, in 5

6 thought as in action. No one understands the element in which he moves and 6

7 works; no one the subject that he is treating. There is no simplicity but plenty that 7

8 is simplistic. [...]

15 Hauser, ${ }^{703}$ a really fine bass, is travelling from Cassel to Dresden and then through 15

16 Weimar with the sole purpose of meeting you and performing a song for you. He 16

17 mentioned to me that he has already approached you once, but he was lost for 17

18 words and so he asked me to put in a word with you on his behalf.

Just do whatever you would like and can manage. I owe him a favour. When he 19

20 sang for me for the first time and had repeated for the umpteenth time all kinds of 20

21 excuses which more or less all singers have learned, I came down on him probably 21

22 harder than he had ever experienced before.

him. See Goethe's correspondence with Therese Albertine Louise von Jakob, who concealed 33 her identity with the acronym, Talvj, Gjb 12 (1891), pp. 33-77.

[...] I hope you are impressed that I guessed your riddle: it is the first which I 29 ever unravelled in my whole life. ${ }^{704}$ In Mendelssohn's house ${ }^{705}$ where I am, as a 30 702 The recent Berlin performance of Spontini's Alcidor 34

703 - Franz Hauser (1794-1870), 35 ${ }^{703}$ Franz Hauser (1794-1870), singer and music teacher, in Prague from 1817, in 36 Cassel (1821-25), engaged in Dresden in 1825 by Carl Maria von Weber. He announced 37 himself at Goethe's house on 23 June 1825 and offered a recital which included performances
by his wife and his sister-in-law (see Goethe's diary, $W A$ III/10, p. 71). Goethe wrote to Meyer on 24 June 1825 , 'A singer sent by our Zelter presented himself; my daughter, who 39 had heard him perform, praised him highly, so once again I will hear some welcome music', 40 WA IV/39, pp. 235-6. 704 Zelter unravelled Goethe's Rätsel nach dem Griechischen (MA 20.1, p. 841) as 42 'sleep' which Goethe confirmed, $M A$ 20.1, p. 850. 705 Abraham Mendelssohn's house (since 1825), Leipziger Straße 3. 
1 rule, twice a week, the same happens often enough. However, the children ${ }^{706}$ are 1

2 so superior to me at it that before long I could not completely unravel one of my 2

3 own charades invented earlier: 'My first is feminine, my other one is masculine, 3

4 my whole thing sour'. [...]

5 Count Brühl is thrown into confusion about the new opera. ${ }^{707}$ The uninterrupted 5

6 rehearsals for the past 8 to 12 weeks have - because of the numerous scene changes - 6

7 held up the entire theatre so that nothing else of any consequence could be 7

8 performed. Now this wonder work was launched at last and the house was so 8

9 crammed that the audience was stifled and perspiring with the heat. Directly after 9

10 the first performance Spontini demanded the regulation 1,050 thaler, which he gets 10

11 for every new work; it was taken from the ticket sales and they have nothing left. 11

12 People now say, 'Spontini takes the money which the others have to sweat.' 12

$13 \quad 13$

$14+14$

$15 \quad$ 342. Zelter $\quad 15$

$16 \quad 16$

$17 \quad$ Berlin, 26 June 182517

$18 \quad 18$

19 Our general music director, Spontini, asks me for a recommendation to the great 19

20 Goethe, which should hardly be necessary between such kindred spirits in art. Yet, 20

21 as I cannot help wishing that all my friends could be acquainted with each other, 21

22 and I have discovered an opportunity of sending you one more warm greeting, 22

23 may you not regret meeting the composer of the latest and greatest opera face to 23

24 face. He is going to Paris [with his wife] and will return from there around the time 24

25 of our next carnival. ${ }^{708}[\ldots] \quad 25$

$26 \quad 26$

$27 \quad 27$

28 343. Zelter 28

$29 \quad 29$

$30 \quad$ Berlin, 1 to 2 July 182530

31

32 We have progressed with the building of our Sing-Akademie as far as the road 32

33 surface and early yesterday morning at five o'clock I lay the foundation stone in 33

34 the company of the chairman and sub-directors. ${ }^{709} \quad 34$

$35 \quad 35$

$36 \quad 36$

$\begin{array}{ll}37 & 37\end{array}$

$38706 \quad$ Fanny and Felix Mendelssohn. 38

39707 Spontini's Alcidor, a Zauberoper. The opera never travelled beyond Berlin. 39

40708 The following day Zelter wrote a letter of recommendation to Goethe for the 40

41 composer. $\quad 41$

42709 Johann Wilhelm Bornemann (1766-1851), director of the Prussian State Lottery, 42

43 Privy Councillor Christian Philip Köhler (1778-1842) and theologian Georg Carl Benjamin 43

44 Ritschl (1783-1876). $\quad 44$ 
Thirty apprentices, five teaching staff and twenty-two servants formed a semi- 1

2 circle from two foremen; the other half consisted of the architect Ottmer, ${ }^{710}$ the 2

3 bricklayers, the carpenters, the stonemasons and the managers. The foundation 3

4 stone was in the centre. I stood in front of the foundation stone and the following 4

5 was spoken by me: $\quad 5$

6

28 Long live the King! $!^{711}$ Long live Fasch, our founder! ${ }^{712}$ Long live the members 28

29 of the Sing-Akademie, the providers, the protectors, the patrons! Long live the 29

30 architect! Long live the masters, apprentices and servants and may every hand be 30

31 blessed that works for the good here. Amen! Those present took the hammer one 31

32 after the other and tapped the stone. The business was concluded.

33 The morning stillness with the rich green surroundings of the site ${ }^{713}$ was not 33

34 without a festive effect. The weather could not have been nicer and I am now hoping 34

35 to lay the first beams in four weeks. The building contains a large hall 84-foot 35

36 long, 41-foot wide and 30-foot high and a smaller one. Downstairs there is a really 36

37 nice living space ${ }^{714}$ and a vaulted cellar in the basement. There is still a lot to do 37

42713 The construction site for the Sing-Akademie lay in the so-called chestnut woods 42 
1 and I will have to keep at it. Please stay alive that I may live and at least leave 1

2 behind this memorial to my art. 2

3 Spontini was in such a hurry and wanted to leave after the performance of 3

4 Alcidor last Tuesday. I now hear that he is still here. People here make too little of 4

5 him and begrudge his success which, to tell the truth, is in jeopardy. I would not 5

6 swap places with him for twice the money. [...] 6

7 I end by thanking you for your beautiful love-letter to my Felix. ${ }^{715}$ Any good 7

8 that comes to him, I enjoy tenfold. He is almost finished composing his fifth 8

9 opera, ${ }^{716}$ and I rejoice to see that it sparkles with real life and does not rest upon 9

10 mannerisms. He seizes the age with both hands and carries it along with him. 10

17 [...] Spontini passed through [Weimar] very quickly. ${ }^{717}$ By chance, I was not at 17 18 home and yet I managed to speak to him for quarter of an hour. How well we get 18 19 on together you may guess from the fact that we ended the conversation with an 19 20 embrace and it was the best acknowledgment of your introduction. 20

27 [...] You will not mind if I take great delight that the Königstädter Theater has 27

28 turned out so well. I wish the same with your music hall, ${ }^{718}$ of which I am hoping 28

29 to hear the best news. [...]

716 Die Hochzeit des Camacho, comic opera in two acts. The libretto is variously attributed to Baron Karl von Lichtenstein, Karl Klingemann, or the elder August Klingemann (R. Larry Todd, Mendelssohn: A Life in Music (Oxford: Oxford University Press, 2003),

39 p. 168. Rudolf Elvers has argued convincingly that Friedrich Voigt's contributed to

40 Act 1 and parts of Act 2 in 'Nichts ist so schwer gut zu componiren als Strophen': Zur

41 Entstehungsgeschichte des Librettos von Felix Mendelssohns Oper 'Die Hochzeit des

42 Camacho'(Berlin and Basel: Veröffentlichung der Mendelssohn-Gesellschaft e.V. 1976).

$43 \quad 717$ On his travels from Berlin to Paris, Spontini visited Goethe on 4 July 1825.

44718 The new building for the Sing-Akademie. 
5 Our director of music and concert master, Moeser, ${ }^{719}$ a first-rate violinist who 5

6 alone knows know to conduct Spontini's operas and also handle my large musical 6

7 works, wants to leave soon and meet my old Goethe. So let him meet you and be 7

8 nice to him. ${ }^{720}[\ldots]$

15 The enclosed poems ${ }^{721}$ relate to a silver jubilee of the Sing-Akademie and 15 16 Liedertafel, and since it is permitted on such occasions to turn [wearing] a silly face 16 17 into a good deed, I am saying nothing other than that I am happy with everything, 17 18 and, in fact, have been very surprised because I want to celebrate this day in my 18 19 own way, as you will see from the accompanying speech, no. 1. [Speech] no. 2 was 19 20 spoken a week after the festival. ${ }^{722}[\ldots]$

21 The little song ${ }^{723}$ enclosed has been lying around for many years. At that time 21 22 it was intended as a kind of exercise which I intended to tackle on good days. I 22 23 am looking through it again now and I recognize the risks for that time and today. 23

719 Carl Moeser, who had written to Zelter on 29 July 1825 requesting a letter of 26

27 recommendation to Goethe.

29721 Festgesänge zum 4ten August, a 16-page booklet with festival poems for the 29

30 celebration of Zelter's 25 years of service as Director of the Sing-Akademie. The texts 30

31 were written by Spiker, Körner, Köhler, Förster, Bornemann, Tscherning and Lange, with 31

32 (unpublished) compositions by Rungenhagen, Ritschl, Wollank, Zelter and Flemming. The 32

33 booklet sent by Zelter is no longer in Goethe's library. A copy in the bequest of Karoline 33

34 Schulze, a student of Zelter, is held in the Staatsbibliothek (SBB PK: Mus. Ms. Theor. 34 35 1540).

722 A manuscript of four pages (in Doris Zelter's hand) with amendments and additions 36 added by Zelter has been preserved.

723 Zelter's setting of Goethe's poem 'Blumengruß', set to music by Zelter in $1810 ; 37$ the autograph copy entitled 'Der 28. August 1749. Wilkommen', dated Berlin 3 September 39 1810, is held in Berlin (SBB PK: Mus. Ms. Zelter 7). There are several copies of this song in 40 Zelter's estate: an undated copy entitled 'Zum Geburtstage'; a further autograph copy, dated 40

42 Berlin, Monday 3 September 1810, entitled 'Der 28. August 1749' and a further manuscript 41

43 the title 'Willkommen dem 28. August 1749', vol. 2, no. 3. A copy of 'Blumengruß' is not 43

44 in Goethe's music collection. 
5 [...] I remember well when I performed your poems and Schiller's for you that

7 you felt, and what could you feel naturally if it were not the basis on which your 7

8 own ideal could be reproduced?

9 Since this time I have never again tried to invent a new melody, but rather to 9

10 seek out much more that which you unconsciously have in mind if you wanted a 10

11 certain sentiment revealed. You would best be able to teach me about this in so far 11

12 as there must be some things among my songs which you have not disowned. 12

13 So that the grass would not grow under my feet, I set the enclosed song to 13

14 music for your birthday, ${ }^{724}$ and the local friends of Weimar celebrated the Jubilee 14

15 of your Grand Duke ${ }^{725}$ very devotedly. This group had me so fired up that the 15

16 strength of my enthusiasm drove me in the early evening to undertake a difficult 16

17 walk to Charlottenburg, after which I hit my bed completely fatigued and achieved 17

18 a good night's sleep. 18

25 [...] The newspapers had already given me good reports of your very creditable 25

26 festival and I could profoundly relate to the poems forwarded by post. I have 26

27 assimilated your good and well-intentioned words. Of the three enclosed poems, 27

28 if you would like to see the middle poem $^{726}$ as referring to you personally and to 28

29 dedicate it to your Liedertafel, to fortify the belief of all well-disposed [persons], 29

30 I will be very grateful to you.

31 That you celebrated my birthday in such a friendly, festive way is also much 31

37724 Zelter's enclosed setting of Friedrich Förster's poem 'Am 28sten August 1825',

38 for solo voices and choir, is published in facsimile in Gedichte und Briefe, Glückwünsche

39 zum 28. August 1825 with the title page signed 'Förster and Zelter' (GSA 28/115, p. 405f).

40 A further autograph copy, dated Berlin, 1 September 1825, presented by Liepmanssohn (in

41 collaboration with Thomas Richter) is in the archival catalogue, no. 174.

$42 \quad 725$ The fiftieth anniversary of the day on which Carl August took office on 3 September 42

43 (his birthday). $\quad 43$

$44 \quad 726$ Zelter's setting of Goethe's poem 'Laßt fahren hin das allzu Flüchtige!' $\quad 44$ 
$5[\ldots]$ On his return from Paris, ${ }^{727}$ the King arranged for a very nice present to be 5

6 delivered to me for the Sing-Akademie (the latest mass by Cherubini) ${ }^{728}$ which he 6

7 had brought with him. Such a present from the King is doubly welcome, or even 7

8 more, since during its growth the Sing-Akademie had to console itself in the face 8

9 of many secret insinuations: it is unnecessary to promote music that everyone 9

10 else already devours; second, German song is a nothing; third, we are clinging 10

11 to the past and hindering progress; fourth, we are leaning towards Catholicism; 11

12 five, it is a marriage bureau. There is truth in all of them. To examine only the 12

13 last: over the years the Sing-Akademie has consisted of nothing but parents and 13

14 children, married couples, siblings. They are all mixed in together and watch over 14

15 one another. Then it is also a place of blissfully happy freedom. From princes 15

16 down to tradesmen an equality undeniably exists, through which every talent can 16

17 be exalted.

246 November. [...] My Felix is making progress and working hard. He has just 24

25 finished an octet for eight obbligato instruments; it is very solid. ${ }^{729}$ Apart from that, 25

26 a few weeks ago he gave his worthy tutor, Heyse, a nice birthday present, - namely 26

27 a metrical translation of a comedy by Terence (The Girl from Andros) ${ }^{730}$ which he 27

28 made of his own accord. They say it contains really good verses; I have not seen it 28

29 yet. He plays the piano like the devil and he is not behind with stringed instruments; 29

30 besides this, he is healthy and strong and swims quite well upstream! 30

727 Friedrich Wilhelm III's journey through Magdeburg, Braunschweig, Lippstadt, 35 Cologne, Coblenz, Aachen, Brussels, reaching Paris on 23 September where he visited 36 museums, churches and state buildings, before returning to Potsdam on 18 September. 37

728 Mass in A major for three-part choir and orchestra (1825); an autograph copy is in 38 the Staatsbibliothek, Berlin.

730 Felix Mendelssohn, Das Mädchen von Andros, eine Komödie des Terentius, in den 41

Versmaßen des Originals übersetzt von $F^{* * * *}$ Mendelssohn, edited with an introduction by 42

3 K.W.L. Heyse (Berlin, 1826). Goethe received the work in a letter from Felix Mendelssohn 43 
1 In the Berliner Musikalische Zeitung they have given his quartets and 1 2 symphonies a rather cold reception ${ }^{731}$ which cannot hurt him, for these reviewers 2 3 are also young fellows, looking for the hat which they hold in their hands. If 3 4 one did not remember how Gluck's and Mozart's compositions were criticized 4 540 years ago, one might despair. These gentlemen move hastily over things that 5 6 would never have occurred to them, and would assess the value of the house by 6 7 a single brick. And I must give him credit for this, that he invariably works from 7 8 the whole to the whole, finishing everything that he has begun, let it turn out 8 9 whatever way it will; this accounts for his showing no special affection for what is 9 10 completed. To be sure, there is no lack of heterogeneous material that gets swept 10 11 away by the stream, and ordinary faults and weaknesses are rare. 11

18 Early yesterday our Sing-Akademie [building] was adorned with the most 18 19 beautiful garlands $^{732}$ [..] A procession of almost a hundred masons and carpenters 19 20 had brought it out of my house through the pleasure garden, past the front of the 20 21 King's palace, ${ }^{733}$ to the place it was destined for. On its arrival the song 'Gott segne 21 22 den König' ${ }^{734}$ resounded and an edifying carpenter's sermon was given from the 22 23 balcony. [...]

$30[\ldots]$ Forkel $^{735}$ was Doctor of Philosophy and Doctor of Music at the same time. His 30

31 whole life long he came into immediate contact neither with the one nor the other 31

32 and had a bad ending. He began a history of music and stopped at the point where 32

33 a history of music is possible for us. 33

37731 This journal, founded by A.B. Marx with Heinrich Dorn and the poet Rellstab

38 (1824-30), assumed a leading role in the city's music journalism. For the review of

39 Mendelssohn's Piano Quartet, op. 3; see the Berliner Allgemeine Musikalische Zeitung,

40 1825, no. 44, 2 November, pp. 353-5 and no. 45, 9 November, pp. 361-3.

$41 \quad 732$ In other words, the shell of the building was complete to the roof ridge. 41

42733 Beside the Königliches Oper, Unter den Linden. 42

43734 Prussian hymn, composed by Bernhard Klein. 43

44735 Johann Nikolaus Forkel (1749-1818), musicologist, Bach scholar. 44 
He was really furious about Gluck's success and wanted to suppress his 1

2 operas. ${ }^{736} \mathrm{He}$ was no more ready to acknowledge Mozart and would not have 2

3 been alone in this. Sebastian Bach was his hero, who nevertheless drove him to 3

4 despair, in so far as he didn't know how to marry his strictness, his petulance, his 4

5 artistic licence and impertinence with a greatness and depth which certainly is not 5

6 to be denied. In the end he wrote Bach's life ${ }^{737}$ with this purpose in mind, without 6

7 knowing anything about it but what is known to the world anyway. 7

At midday yesterday I had good, almost naughty, fun. In company to which I 14 was disparaged in the Spenersche Zeitung on 4 November. ${ }^{738}$
wention came up about a symp

Berlin, 8 to 10 December 182512

My neighbour, ${ }^{739}$ sitting close to my right, repeated with pleasure the words of the 17 reviewer. He, too, attacked the presumption of the young composer in performing 18 a complete (so called 'Great') symphony in four movements, which offered more 19

20 to complain about than real enjoyment. After he had spoken, I answered to the 20

21 contrary that the review had always used the word 'we' in its assessment, which I, 21

22 however, would not wish extended to me because I did not want to be the ass that 22

23 would see an industrious orderly work dismissed so contemptuously.

24 I had hardly said this than the face of my neighbour turned as red as beetroot 24

25 enough to turn the tablecloth red; in short, it was the reviewer himself, because he 25

26 assured us that the review, while it was not by him, he would have to confess etc. 26

27 In fright - and you will forgive me being a little shocked - I grabbed my bottle 27

28 of wine and missing my glass, poured it into his. He raised it to his lips and called 28

29 my wine a potent full-bodied drink.

736 See Forkel's article, 'Über die Musik des Ritters Christoph von Gluck' in 33 Musikalisch-kritische Bibliothek, vol. 1 (1778), pp. 53-210.

737 Forkel, Über Johann Sebastien Bachs Leben, Kunst und Kunstwerke (Leipzig: 35 Hoffmeister \& Kühnel, 1802), reproduced with an introduction by Walther Vetter (Kassel: 36 Bärenreiter-Verlag, 1968).

738 In the aforementioned excerpt from the Spenersche Zeitung (no. 258) there is an 37 anonymous review of a concert on 25 October. Included, among other things, is a critique 38 of a symphony by Felix Mendelssohn, conducted by the composer: 'We would prefer not 39 to hear the symphony by the latter again because it is a chaotic mass, in which, while we 40 cannot deny a diligent schooling, at the same time the listeners have more to complain 41 about than enjoy. We had to admire the composure of the orchestra, led by Herr Seidler, 42 under the hasty direction of the young virtuoso'. 
1 The whole affair is not painful to me but also not relished because the man is 1 2 intelligent, astute, and well intentioned towards me. He wrote the flattering Latin 2 3 poem for my Jubilee, ${ }^{740}$ which I may well have sent you. 3

4 And what should a reviewer do? Especially one who edits all of the scientific 4 5 articles of a political daily newspaper? If he is to praise what is good, he must have 5 6 time at his disposal which he doesn't have; so he gets out it of it by condemning 6 7 what is not to his taste and takes money for it.

8 On the other hand, a musician is worse off than painters and writers. I know 8 9 only too well what I had to suffer and overcame in my attempts to bring an orchestra 9 10 together, even when paid to perform religious works. Then there is the audience 10 11 and above all the non-paying guests who expect nothing at all and demand the 11 12 unattainable. They do not grasp how one can be so presumptuous as to want to 12 13 hold their attention. One has to fight for oneself and others. 13

14 After dinner our reviewer persuaded me to go with him to the theatre and to 14 15 see a work which was still unknown to me, Die Lästerschule (if I am not mistaken, 15 16 after Sheridan). [...] I found the work very unpleasant. One finds oneself among 16 17 bad folk; the best of whom are worth nothing. In such a frame of mind I forgot 17 18 myself and said to him I wished this piece were by Felix and Felix's symphony by 18 19 this author. With this I turned around expecting an answer and found a complete 19 20 stranger sitting beside me, who looked at me wide-eyed. This second surprise in 20 21 one day made me cheerful again and virtue itself would not make me attend a 21 22 performance of Die Lästerschule ${ }^{741}$ again [...] 22

29 [...] Yesterday a new translation of Macbeth by our state librarian, Spiker, was 29 30 performed at our theatre ${ }^{742}[\ldots]$ The special novelty was a new incidental overture, 30 31 with the witches' choruses and dances. The composer, Conductor Spohr of Cassel, 31

740 This poem has not been identified. The Festgesänge zum 4ten August 1825 contains only a single Latin poem, 'Integer vitae, scelerisque purus', an ode by Horace, composed by Flemming. Spiker's occasional poem for 4 August 1825, 'Willkommen! Tönen unsere

38 Lieder', and a further festival poem by him, 'Blüten einen sich zu Kränzen', were both 38 written in German.

$39{ }_{741}$ Comedy, adopted by Johann Leonhardi from Richard Brinsley Sheridan's The

40 School for Scandal; Zelter attended the performance on 7 December 1825 in the Königliches 41 Schauspielhaus.

$427_{742}$ Shakespeare's tragedy Macbeth, in German translation by Samuel Heinrich Spiker,

43 first published by Duncker \& Humblot in 1826, first performed in Berlin in the opera house 44 on 15 December 1825, with incidental music by Louis Spohr. 
1 is a clever man, and were it not too much of a good thing, everything would 1

2 perhaps be better. 2

3 I have nothing to say against the idea, for if the orchestra is present, it may just 3

4 as well play what is appropriate. But what is appropriate is another matter. [...] 4

5 The play is coarse stuff and requires an earthy style. That was missing, and so 5

6 one rejoiced when the murderers went to work again. $\quad 6$

7

8

Yesterday, Maria von Weber's latest Opera, Euryanthe, got its first favourable 13 14 reception in our grand theatre. ${ }^{743}$ In Vienna, Dresden and elsewhere, the work 14 15 failed to impress; $;{ }^{74}$ there are numerous reasons for this. The libretto itself is not 15 16 suitable. Count Brühl has staged the work very impressively as is fitting to a friend 16 17 and producer and in a style suitable to historical Romantic opera. At the curtain 17 18 call everybody was applauded. The composer first was obliged to show himself 18 19 after the first act, and deserves every encouragement for his intense industry, made 19 20 twice as difficult by his feeble health.

21 Afterwards there was plenty of feasting and celebration; ${ }^{745}$ such things bring 21 22 enormous satisfaction and ultimately reconciliation. Several of his friends carried 22 23 the composer away with them, choruses of singers and horns followed, and the 23 24 celebrations continued into the early hours of the morning. You need not be 24 25 surprised that an old fellow like myself must always be at hand on these occasions, 25 26 for I am not such a fool as to go into a corner with begrudgers or to be put out by 26 27 anyone's success in Vienna. Weber conducted the Berlin premiere on 23 December 1825 , followed by a 39 second performance shortly after.

744 After the Viennese premiere the work was performed in Dresden, Prague and 41

Frankfurt am Main in 1824. The reception by the general public was not euphoric, as it had 42

3 been with Der Freischütz. 


\section{Section III 1 \\ 2 Tater Years' Correspondence $1826-1832$ \\ Later Years' Correspondence 1826-1832 \\ 357. Zelter

12 Someone wrote a new setting of your Jery und Bätely and as I hear, in great 12 13 style. However, it is supposed to have run its course and now they are asking for 13 14 Reichardt's setting once again. ${ }^{1}$ The new composer edits the local music paper. ${ }^{2}$ In 14 15 this there was much talk about the weakness of Reichardt's work which was once 15 16 acclaimed. [...]

2327 January: The little piece by Director Struve ${ }^{3}$ informs and delights me, since it 23 24 contains nothing which contradicts my melodic handling of both ballads. August 24 25 Schlegel, who was in Berlin at that time ${ }^{4}$ when I set both pieces to music, ${ }^{5}$ and for 25 26 whom I performed them often enough, was also in agreement. Likewise Tieck, 26 27 who is hard to please musically, was particularly pleased by my melody to 'Die 27

28 Braut von Korinth'.

311 The new setting, by A.B. Marx, was performed on 7 May 1825 in the Königliches 31 32 Opernhaus, $A M Z 27$ (1825), no. 24, 15 June, column 404: 'On 7 May the royal company 32

33 of actors performed a one-act comic opera by Goethe in a new setting by Adolph Bernhard 33

34 Marx (editor of the Berliner Allgemeine Musikalische Zeitung). This pleasant Singspiel, 34

35 which Reichardt originally set to music, had been forgotten for years. The reappearance of 35

36 this setting gave rise to hopes which were not fulfilled, however, and even up to now there 35

36 has been no repeat performance of the operetta. The composer [A.B. Marx] had the idea 36

37 of creating a grand opera out of the Singspiel. Therein lies the indisputable reason why his 37

38 excellent opulent music, original in concept, did not make the same impression which it 38

39 would have under different circumstances.'

402 Marx had founded the Berliner Allgemeine Musikalische Zeitung in 1824 and was 40

41 prominent as editor. $\quad 41$

423 Carl Ludwig Struve (1785-1838), Director of the Gymnasium in Königsberg. 42

$43 \quad 4$ August Wilhelm Schlegel was in Berlin from 1801 to 1804.

445 Die Zauberlehrling (1799) and Die Braut von Corinth (1797). 44 
5 I shall wait quietly to see how the enclosed page, by which I set great store, will 5

6 appear to the connoisseurs and other kindred spirits. ${ }^{6}$ The experts in musical harmony 6

7 will be sure to find something fugue-like in it, ${ }^{7}$ where manifold complications 7

8 move, separate, meet, and answer one another. This page was distributed with 8

9 the Stuttgarter Kunstblatt ${ }^{8}$ but, folded as it is, it cannot be fully appreciated there. 9

10 Take care of it and think it over. [...] 10

17 I received your lovely consignment of 18th March on Good Friday when I had 17 18 completed arrangements for my Passion Music ${ }^{9}$ and was just about to bring it to 18 19 performance.

20 The first comfort from your Charon was that our art of fugue is still living, 20 21 and that what we build will not fall to ruins. Certainly, without your explanation I 21 22 should have had to reflect a long time, in order to get a clear picture of the beautiful 22 23 contrasts (counterpoint), the way that here what is most serious stands in delightful 23 24 conflict with the most innocent love of life. So, too, the poetry into which you have 24 25 woven it will be his delight as well as mine.

26 I had a similar experience with old Haydn. In reviewing his Creation, and 26 27 particularly the overture which has the heading 'Chaos', I had remarked that such 27 28 a theme was not suitable for art; ${ }^{10}$ but that genius everywhere has surmounted 28

6 Johann Aloys Mayer's lithograph (after Carl Leybold's) Charon to Goethe's poem. 31 A reproduction is published in $M A 20.3$, p. 732. to the vocal lines in polyphony, or more specifically to fugue. Goethe often used the word 34 'fugue' with reference to painting and considered Leonardo's The Last Supper to be the first 35 painted fugue. 6 February 1826.

8 The lithograph was published as a supplement in the Kunstblatt, no. 10/11, 36 each year on Good Friday; for reviews of the performances; see $A M Z 28$ (1826) no. 16, 1939

41 April, column 265.

10 There are two reviews of Haydn's Creation in the AMZ: the first following a 41

43 letter, Berlin 8 January' $A M Z 3$ (1800/01), no. 17, 21 January 1801, columns 289-96); 43

44 the second following the appearance of the score in Vienna $(A M Z 4(1801 / 02)$, no. 24,44 
1 impossibilities, and therefore did so here - giving my reasons for this statement. 1

2 Old Haydn let me know that, with regard to this matter, he had not thought about 2

3 it beforehand at all but that my analysis concurred with his own conception, which 3

4 he was only now aware of, and that he saw himself obliged to acknowledge the 4

5 images I had referred to. ${ }^{11}$ Other critics had hopelessly condemned the musical 5

6 paintings in the work, but now I was justified. [...] 6

74 April: We are expecting your gnome-like virtuoso ${ }^{12}$ who will grate on our 7

8 ears once again. I will gladly listen to him once more because he is the best of his 8

9 kind, and as Wolf is given to saying, 'The shepherd is also the ox'. 9

$16[\ldots]$ However often I have read these letters already, I still read almost every page 16

17 two or three times and the clearest view comes to me through stone and rock into 17

18 the belly of the deepest past. I am examining the genuine originals before me and 18

19 I recognize the difference between them and a reproduction. It is much the same 19

20 for me: I hear a good piece of music and then look at the score. Very often I find a 20

21 thick wall between the two, if not the impossibility that both things are the same. 21

22 Even what supports education serves the decline of art. [...]

23 All good singers are either sick, getting sick or are travelling abroad. Madame 23

24 Schröder has arrived again, ${ }^{13}$ who will help a lot, even if she is as corpulent as she 24

25 was, and [if] we had half-a-dozen [like her] we could walk in the loveliest shade 25

26 [they provide]! $\quad 26$

$27 \quad 27$

$28+28$

$29-29$

$30-30$

$31+31$

$32 \quad 32$

$33-33$

$34-34$

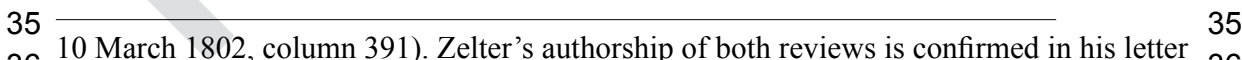

3610 March 1802, column 391). Zelter's authorship of both reviews is confirmed in his letter 36

37 to the editor, Friedrich Rochlitz, on 23 February 1802, MA 20.3, p. 734 . 37

38 Haydn wrote to Zelter on 25 February 1804: 'You are a deeply perceptive musician;

39 the correct analysis of my Chaos proves that you would have done the same as Haydn; I am
grateful to you for your interest', Joseph Haydn, Gesammelte Briefe und Aufzeichnungen,

40 ed. and enlarged from the collection of source materials by H.C. Robbins Landon, by Dénes

41 Bartha (Kassel, Basel, Paris, London, New York: Bärenreiter-Verlag, 1965), p. 436.

$42 \quad 12$ Johann Nepomuk Hummel. 42

4313 Antoine Luise Sophie Schröder, née Bürger (1781-1868) had been advertised but 43

44 her arrival was, in fact, postponed. $\quad 44$ 
5 First of all, my best thanks for the score of that truly enthusiastic song. ${ }^{14}$ It is now a 5

6 full 30 years old, and dates from the time when a rich, youthful spirit still identified 6

7 itself with the universe, in the belief that it could fill it out and even reproduce it 7

8 in its various parts. That audacious drive has bequeathed to us a pure and lasting 8

9 influence upon life, and however much we may have progressed in philosophical 9

10 knowledge and poetic treatment, still it was important at that time, and, as I can 10

11 see on a daily basis, it inspired and guided many. [...] 11

12 We, too, had a fleeting visit from Matthisson; ${ }^{15}$ our disciples of the Muses gave 12

$13 \mathrm{him}$ a warm reception, sang his poems, presented him with laurel wreaths, and did 13

14 all this at a celebratory dinner, which went off appropriately and well. [...] $\quad 14$

15 When one thinks how many distinguished men finally float about like drops 15

16 of oil on water, and at most come in contact only at one point, one can understand 16

17 how one was so often in life thrust back into solitude. However, the fact of our 17

18 having lived so long near one another, as we did with Wolf, ${ }^{16}$ may have shaped and 18

19 benefitted our endeavors more than we know or are aware of. [...] 19

20 It is evident from all of this that I was busy with your old letters again. I want 20

21 to see now that I can catch up with some things for you. [...] 21

22 If you would like to tell me something about Hummel's performance in your 22

23 own way, in my present state you would give me [double joy]. 23

30 Tuesday, 23 May: Hummel has given two profitable concerts, ${ }^{17}$ although the time 30

31 of his arrival was not the most favourable. In my judgement, he is the epitome 31

32 of contemporary pianoforte playing, for he combines what is genuine and new 32

33 with feeling and virtuosity. One forgets fingers and keys, one hears the music; 33

14 Zelter's setting of Goethe's poem 'Weltseele'.

15 Friedrich von Matthisson (1761-1831), writer, theatre manager and librarian in 37 Stuttgart from 1812, visted Weimar at the end of March.

16 F.A. Wolf, who was in regular contact with Goethe from 1795 on the question of 39 ancient literature.

17 Hummel gave two concerts on 24 April and 4 May in the concert hall of the 41

Königliches Schauspielhaus, in which his Concerto in E major, his Rondo brillant 42

44 May, column 318f; see also no. 24, 14 June, column 392; MA 20.3, p. 741. 
1 everything sounds as secure and easy as it is difficult. A pot made of the worst clay, 1

2 filled with Pandora's treasures.

3 The Liedertafel takes place today and you will be remembered there. Count 3

4 Sierakowski, whom Prince Radziwill of Posen recommended to me, is my guest. ${ }^{18} 4$

5 My building progresses slowly and I have to drive myself mad with it, otherwise 5

6 nothing at all would happen. I thought I would be out of here and Satan leads me 6

7 back again. Soon I will have to take up residence, leave the lovely nest I have 7

8 now and move again to a completely new house. The gods will decide what is to 8

9 become of me. $\quad 9$

16 When he was ten years old, my Felix discovered with his lynx eyes, in the score 16 17 of a splendid concerto by Sebastian Bach, ${ }^{19}$ six pure consecutive fifths, which I 17 18 doubt I should ever have found, as in the larger works I pay no heed to such things, 18 19 and this passage is scored in six parts. But the handwriting on the manuscript 19 20 is beautiful and clear, and the passage occurs twice. Now, is it an oversight or 20 21 a licence? Either the composer has altered one part and forgotten to erase the 21 22 other, or an accident, as I myself have experienced, could be the reason. I once 22 23 maintained, when we were having a debate about harmony, that I could let them 23 24 hear half a dozen pure fifths, one after the other, and they would never find it out, 24 25 and I proved my point. It may have been so with old Bach, the purest, the finest, 25 26 the most daring of all artists, quo nihil sol majus optet. ${ }^{20}[\ldots] \quad 26$

27 The enthusiastic song, as you yourself call it, ${ }^{21}$ I myself don't know how to call 27 28 it anything else other than: 'Aus der Luft' (Out of the Air). I read it, how often, 28 29 and only certain durations of notes - spheres, planets and things of that nature 29 30 - occurred to me as definite sounds, with which I had to do all the rest. And now, 30 31 when you provide me with information, I am none the wiser, since you too have 31 32 been driven to exhuberant expression by an infinite, indefinable idea. I have been 32 33 asked about it more than once and I replied: it is my wedding song. 33

$36-18$ As was customary every two months, guests could be invited to the Liedertafel, 36

37 As was customary every two months, guests could be invited to the Liedertafel;

37 Zelter had originally planned to invite Charles and Selina Bracebridge on this occasion.

3819 Brandenburg Concerto no. 5; see Albert Schweitzer, J.S.Bach (Leipzig: Breitkopf \&

39 Härtel, 1908), p. 378; Johann Sebastian Bach. Neue Ausgabe sämtliche Werke, ed. Johann-

40 Sebastian-Bach-Institut Göttingen and the Bach-Archiv Leipzig (Kassel, Bärenreiter, 1956),

41 Kritischer Bericht, p. 111; Alfred Dürr, Bach-Jahrbuch 61 (1975): 65.

4220 Latin words in imitation of Horace's Carmen saeculare, v. 9-12: 'the sun may 42

43 never choose [to shine on] anything greater'. $\quad 43$

$44 \quad 21$ Zelter's setting of Goethe's poem 'Weltseele'. 
I have written to you about Hummel. For me he is more than a virtuoso, much 1

2 more. I gladly listen to him improvising in spite of the presumption that he could 2

3 wrest a fantasy from himself before a gaping crowd. And yet he manages to bring 3

4 it off, although his facade plays a role with its rather abnormal sound figures. His 4

5 playing has what one can hardly call expression, that is, free from affectation and 5

6 inhibition. Whoever really understands would have to admire how innocently the 6

7 most amazing things come to light.

8 The local music papers don't do justice to his playing. ${ }^{22}$ They are all young, 8

9 lively fellows, dilettantes, and their editor, a certain Marcus or Marx from Halle, ${ }^{23} 9$

10 may have been baptized with gall, for his excrement has a grey-green-yellow 10

11 colour. $^{24}$ They are like flies: they shit what tastes good to them. [...] 11

13 Enclosed: Zelter's essay on Haydn: Performance of The Creation on Joseph 13

14 Haydn's birthday, 31 March $1826 .^{25}$

$21[\ldots]$ In the next few days our correspondence will be before me, neatly transcribed, 21

22 bound in several volumes. ${ }^{26}$ You should undertake a pilgrimage once in order to 22

22 See, for example, 'Über das Konzert des Herrn Kapellmeister Hummel', Berliner 24 Allgemeine Musikalische Zeitung 18 (1826), 3 May, p. 141. The review, signed '4', in which 25 Hummel's reputation 'as a pianist equally outstanding in solid performance and admirable 26 skill' was fully recognized, limited itself explicitly 'to an analysis of what the concert 27

28 pianist offered the general public as composer', in particular Hummel's piano concerto in 28

29 E major. The promised discussion of this work hardly goes further than the admission of the 29

30 reviewer that 'it would always be difficult to judge a musical piece after one hearing'. $\quad 30$ ignited by Marx's public criticism of Zelter's early music performances. Marx rebuked 34 Zelter for performing irrelevant eighteenth century repertoire, failing to add 'modern' 35 wind instruments to Handel's orchestral scores, choosing improper tempos and altering 36 composer's scores (e.g. smoothing out expressive leaps in Graun's recitatives).

25 GSA, 25/XXXVIII, 1, 52a; $M A$ 20.3, pp. 743-5.

26 Goethe announces here the conclusion - for the time being - of a project begun in 38 up to and including 1825 . Bringing together the letters and copying the correspondence was 40

41 originally intended to jog Goethe's memory for his work on the Tag-und Jahres Hefte. The 41

42 
1 pay due homage to such a work. I will go through it carefully in quiet evenings 1

2 and see how it would best hold up in the future. It is a strange document, with real 2

3 substance and baroque-like character. ${ }^{27}$ Its like would hardly be found again. [...] 3

4 If, my dearest Zelter, you were to give me permission to score out your hymn 4

5 for Mozart's birthday, ${ }^{28}$ I would make an attempt at it as far as it is possible for me. 5

6 We could come to some agreement about the employment. [...] 6

7

8

9

366. Zelter

Berlin, 6 to

13 [...] The permission needed to score the hymn to Mozart's birthday is no less 13

14 problematic to me. In case the little manuscript sent about Haydn is what what you 14

15 meant, you have complete freedom with it, of course, since I have not committed 15

16 it elsewhere. [...] 16

17 Old Madame Mara has written again from Reval ${ }^{29}$ and recommends to me a 17

18 student, ${ }^{30}$ whom I have neither seen nor heard. She writes like a man, like a clever 18

19 woman, and it is a joy to read her hand. 19

20 Felix has again finished another quintet ${ }^{31}$ that we are soon to hear. I do everything 20

21 I can to encourage him, as he drives himself on to experiment in the various new 21

22 and more conventional forms. What really pleases me is that his music is really 22

23 well paid by the publishers. In addition to this, he is very cheerful, and is very 23

24 skilled at gymnastics, riding and swimming; I prefer to advise him not to fence 24

25 because he really plays well. [...] 25

26 When you ask me to grant permission to knock my writing into shape, it weighs 26

27 heavily on my conscience how I have sometimes dealt with your poems without 27

28 asking you. 28

29 In order to admit my offence and to beg for absolution, I enclose a little 29

30 experiment. ${ }^{32}$ The piece is from the early stages of our Liedertafel, which will 30

31

$32-32$

$33 \quad 27$ Perhaps Goethe is thinking of the polyhistoric diversity, lack of homogeneity of the

34 themes and areas touched upon.

$35 \quad 28$ Despite the erroneous title, Goethe is referring to Zelter's essay on Haydn's Creation.

35 By the musical metaphor 'to score out your hymn', Goethe means the proofreading which

36 Zelter had requested as well as his own editorial work.

$37 \quad 29 \quad$ A letter of recommendation from the singer Gertrud Elizabeth Mara for one of her

38 students, who, on an immanent journey to Berlin, 'wanted to meet the founder of the world-

39 famous Sing-Akademie, GMD (1958), p. 31, no. 10.

$40 \quad 30$ Frau von Baer. $\quad 40$

4131 String Quintet no. 1 in A major, op. 18, first movement. The second movement was 41

42 composed in 1832 .

$43 \quad 32$ Among the Goethe settings in Gesänge der Liedertafel (Berlin 1811), vol. 1, are 43

44 some in which text alterations were made: in 'Generalbeichte', 3 strophe, v. 5-6: 'Manche 44 
1 soon begin its twenty-first year. ${ }^{33}$ If I had not kept after them, the thing would have 1

2 turned into simple feasting. Now the other [Liedertafel] are there and if they do 2

3 not collaborate, then each [society] suits itself; in short, it survives. Then it is also 3

4 important with such songs to keep the plenary meeting light and cheerful. When 4

5 one person sings solo for too long, the others cannot keep quiet and misbehave. 5

6 Many a Liedertafel dies away over the Leipzig fair offerings because poet and 6

7 composer don't have the real objective before their eyes. 7

14 I gave young Bohn, ${ }^{34}$ lately married to one of Seebeck's daughters, ${ }^{35}$ a short letter 14 15 to the good Ernestine ${ }^{36}$ and a little song, which Felix's sister has set very nicely 15 16 to music. ${ }^{37}$ It is a poem by Vo $\beta^{38}$ on the death of our friend Schulz, ${ }^{39}$ and I set it to 16 17 music for him when I was in Heidelberg. ${ }^{40}$ By chance Fanny happens to have set it 17

rasche Schäferstunde,/ Flücht'gen Kuß von lieben Munde' (G) to 'Manche rasche gute 20 Stunde,/ Manches Lied vom lieben Munde' (Z); some slight alterations in 'Ergo bibamus!', 21 in Ephiphaniasfest Zelter repeats the final verses as a refrain but with alterations for the 22 Liedertafel, for example in strophe 5, verses 4 and 5 are altered from: 'Ich esse gern, ich 23 trinke gern,/ Ich esse, trinke und bedanke mich gern' $(G)$ to 'So, so, Herr Gern, auch Sie 24 Herr Gern./ Sie essen, trinken, und bedanken sich gern.' (Z); finally an alteration in verse 225 of 'Vers memorials' from 'Reminiscere $\mathrm{O}$ wäre ich Braut' $(\mathrm{G})$ to 'Reminiscere mir juckt die 26 Haut!' Which of the texts Zelter sent as an 'experiment' could not be determined; Goethe 27 had received all of these compositions at an earlier stage, from which two copies are in his 28 music collection.

33 The constituent assembly of Zelter's Liedertafel was on 21 December 1808 (though 30 the first rehearsal took place on 24 January 1809); the twentieth anniversary, beginning the 31 fifth cycle of five years [the fifth lustrum], would begin in 1828.

35 Marie Therese Henriette Johanne Rosalie Bohn née Seebeck (1798-1888) 34

36 Zelter's letter to Ernestine Voß has not been handed down. 35

37 Fanny Mendelssohn, 'Begräbnislied', composed on 6 May 1826, WoO 26, 5; the 36 manuscript is held in Berlin (SBB PK, Mendelssohn Archiv, MS 35, pp. 46-8).

38 Johann Heinrich Voß, 'Begräbnislied' ('Ruhe sanft bestattet'), 1800, published in 38

Voß's Sämtliche Gedichte (Königsberg: Nicolovius, 1802). the Voß family on 30 August. Zelter's diary entry of 1 September states: 'Wrote to Voß in 42

Heidelberg on 30 August and sent him the lament for Schulz's death', Schottländer, Carl 43

4 Friedrich Zelters Darstellungen seines Lebens, p. 275. 
1 too and as she has captured the spirit of it better than I have, I have sent it to Voß's 1

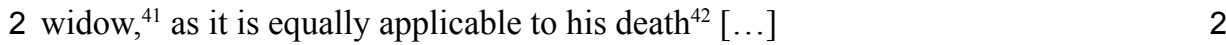

3 Our theatres limp along on all fours. It is summer. True the [financial] 3

4 embarrassment affects the management, which must impose itself through money 4

5 and becomes contemptible as soon as this energy is missing. So cliques and even 5

6 artistic sects are forming. Opera and Schauspiel are quoted within the four walls 6

7 of family societies and the artists take part in it themselves in order to forget their 7

8 troublesome boards. $\quad 8$

9 Just the day before yesterday people would have it that Carl Maria von Weber 9

10 had died in London: ${ }^{43}$ like Achilles at the height of his glory; but as the news is 10

11 not confirmed, it is only believable because of his frail condition. Owing to his 11

12 congenial manner, he has won widespread popularity and, considering the extent 12

13 of his talent, he has certainly worked hard enough; all his works reveal strenuous 13

14 effort and he had severe illnesses to fight against [...] 14

15

16

17

368. Zelter

2128 July: Enclosed here is your little song, ${ }^{44}$ which has been notated easily enough. 21

22 Two tenors and a bass play their part and the women can also sing along in the 22

23 tutti section.

24 The Swarto $^{45}$ has already been transcribed ${ }^{46}$ and needs to be put aside a while 24

25 in order to mature. [...]

2841 Marie Christiane Henriette Ernestine Voß née Boie (1756-1834). 28

2942 Voß died on 29 March 1826 in Heidelberg. 29

$30 \quad 43$ Carl Maria von Weber died in London on 5 June 1826.

3144 Zelter's setting of Goethe's 'Wanderlied' ('Von dem Berge zu den Hügeln'). 31

32 Three strophes, which are divided up differently, had already appeared in Wilhelm 32

33 Meisters Wanderjahre. The second strophe from this early version is missing from Zelter's 33

34 compositional text, where verse 3 replaces verse 2 and a new third strophe is added, which 34

35 Zelter appears to have received especially for Goethe's birthday during his stay in Weimar

36 on 8 July 1826 . Goethe wrote in his diary on 8 July 1826: 'I adapted [my] "Wanderlied" for

37 August' (WA III/10, p. 214) and the new version was published in an article, 'Zusammenfeier

38 des Geburtsfestes von Hegel und Goethe' in the Vossische Zeitung, 203, 31 August 1826.

38 Zelter read out this article at the joint festivities for friends and former students on 27/28

39 August; his manuscript setting is in Goethe's music collection (GSA 32/7), dated B. 25 July 401826.

4145 Goethe's translation of Swarto's monologue ('Vom Franken ein Gesandter!') from

42 Manzoni's tragedy.

4346 Zelter mentions his setting again on 2 to 3 February 1827, but he never signed off 43

44 on it and never sent it to Weimar. 2 4 . 5 6

(

8

9

2

3
9 
Since sheet music still has its place, a [single] key canon will be put to regular 1

2 use. ${ }^{47}$ The artistry consists in the way each of the four voices starts from the same 2

3 note of the scale and every voice sings from its own clef. The canon is very strict 3

4 in the first five bars and the arrangement will be repeated three, four or five times, 4

5 whereupon the piece comes to an end. [...] 5

6 Minister von Humboldt sends his warm greetings. He enquired after your well- 6

7 being yesterday and we spoke a lot about you. He, too, has begun to read Schiller's 7

8 correspondence $^{48}[\ldots]$ and considers [it] a welcome gift to the world since the 8

9 genesis of [Schiller's] best works become clear in it and how his development 9

10 was dependent on you. It is certain that since Schiller's ascension to a higher 10

11 sphere, the desire to understand your works has increased constantly. With Schiller 11

12 everything works from without to within; with you everything comes from within 12

13 to without; people want to understand what they feel. This gives rise to deductions 13

14 which are Schiller's forte and this turns our minds in the same direction. 14

15 I notice that it is the same in music. It is only since Mozart that there has 15

16 arisen a greater inclination to understand Sebastian Bach, for the latter appears 16

17 thoroughly mystic, where the former impresses us clearly from without and there 17

18 is a lighter air about him, seeing that he is inspired by life around him. I myself 18

19 felt no pure pleasure in Mozart's works because I had known Bach much earlier. 19

20 Compared with him, Mozart seemed like the Flemish painters are to Italian and 20

21 Greek artists, and it is only since I gradually began to gain more clarity on these 21

22 points that I esteem both at the highest value, without demanding of one what the 22

23 other achieves. The mystical must and will remain what it is, otherwise it would 23

24 not be mystical; I can sleep quietly on that, while the whole throng is after me, 24

25 screaming for a verbal explanation while it stumbles over the sense. 25

26 Mozart stands much nearer to Sebastian Bach than Emanuel Bach and Haydn, 26

27 who, both original, stand between the first two. Don Juan and Die Zauberflöte 27

28 show plainly enough that Mozart had something mystical within him, and that he 28

29 is all the more sure of an easy effect, the more he works from without to within, 29

30 where it is still bright and only becomes dark very gradually.

1 August: Tell me something about Madame Sontag. ${ }^{49}$ She will be here 31

47 Canon on the toast 'Dieses Glas dem guten Geist' on the same manscript as 35 'Wanderlied' (GSA 32/7). Zelter explains the title 'key-canon' in the following passage.

48 From the beginning Wilhelm von Humboldt was in on Goethe's plans to publish 37 his correspondence with Schiller (see Goethe's diary 13 and 14 November 1823) and often 38 acted as mediator and advisor between Goethe and Schiller's heirs. A public report of the 39 planned publication was still not circulated; the contract with the publisher, Cotta, was 40 drawn up in September 1826 and certified the following December.

49 Gertrud Walpurgis Henriette Sontag (1806-54), German soprano, who had made 42 her debút at the Berlin Königstädter Theater as Isabella (L'italiana in Algeri) on 3 August 43 1825. 
5 You dear musical hieroglyphs ${ }^{50}$ shall soon dissolve into music for my ears and I 5 6 will certainly be delighted and refreshed by it. [...] 6

13 When I surveyed the catalogue of your multiple settings from the Divan, ${ }^{51}$ it 13 14 occurred to me in general that we treat the good and the noble which we encounter 14 15 every day far too carelessly and let go of it as easily as the usual commonplace 15 16 [things]. I regretted that so many lovely compositions by you had passed through 16 17 my hands without my knowing where they went. My discontentment was assuaged 17 18 as I opened the music cabinet and discovered it like an old archive: unused but 18 19 unspoilt.

20 The catalogue, ${ }^{52}$ which I made immediately, is enclosed here for which an 20

21 additional song or two might perhaps turn up. See what else you can comfortably 21

22 pass on to me. Some settings have already been given to Eberwein. ${ }^{53} \mathrm{He}$ wants to 22

23 have them performed for me by the choristers and seminarians. [...] 23

24 I have heard nothing further of Madame Sontag other than what is common 24

25 knowledge: that she concluded with Die heimlische Heirat to great applause. ${ }^{54} 25$

26 Developments next time. $\quad 26$

50 The compositions sent with Zelter's last letter: Goethe's 'Wanderlied' and accompanying canon. By solving the musical hieroglyph, Goethe means the performance of Zelter's musical text. The day before he wrote to Zelter, Goethe had given 'some Zelter compositions' to Eberwein, director of his house choir; see Goethe's diary 4 August 1826, 36 (WA III/ 10, pp. 225-6).

$36 \quad 51 \quad$ Assembled in Goethe's diary on 7 August 1826, WA IIL/10, p. 227.

$\begin{array}{lll}36 & 51 & \text { Assembled in Goethe's diary on } 7 \text { August } 1826, \text { WA III/10, p. } 227 . \\ 38 & 52 & \text { A catalogue of Zelter's compositions to poems from Goethe's West-östlicher }\end{array}$

38 Divan is neither preserved in the version sent to Zelter nor in the copy retained by Goethe.

39 In Goethe's music collection a copy Zeltersche Kompositionen Goethescher Gedichte

40 in Kräuter's hand (GSA 32/1509) includes settings of poems not included in the Divan

41 and also copies of settings which were sent to Goethe after August 1826, for example

42 'Kriegsglück'.

4353 In his role as director of Goethe's house concerts. 43

$44 \quad 54 \quad$ See, for example, Spenersche Zeitung, no. 177, 1 August 1826. 
$5[\ldots]$ Your nightingale is still fluttering around. They say she has gone to the sea ${ }^{55} 5$

6 and will come to us at the end of next month at the earliest, since we too are hoping 6 7 to admire her. [...]

8 On taking up Streckfuß's translation of Dante a few days ago, I admired the 8

9 ease with which it moved within the given metre, and when I compared it to the 9

10 original and tried to make some of the passages clearer and more flowing in my 10

11 own way, I soon found out that this had already been achieved and that nothing 11

12 would come of tinkering with the work. Meantime it gave rise to a little poem ${ }^{56} 12$

13 which I wrote in the accompanying book.

14 Let Streckfuß keep Manzoni's tragedy Adelchi as a remembrance from me. 14

15 If he doesn't know it already, he will be pleased with it. If he feels inclined to 15

16 translate it, he would render a service to German iambics as well as to the trimeter 16

17 if he would in a similar way follow the Italian style of writing, which would be all 17

18 the easier as the rhyme does not hinder him. What I think about this is clearly seen 18

19 from the monologue of Swarto and it would in any case be immediately apparent 19

20 to such a clear-sighted man. The whole tragedy may be resolved into recitative. 20

$21 \mathrm{I}$ am anxious to have your composition. ${ }^{57} \quad 21$ received the text from Goethe) Zelter recorded on 26 July 1826 that the composition was 39 'already written down'. Even after a reminder from Goethe, Zelter never signed off on the 40 setting. Whether Goethe ever received this composition is, at least, in question. There is a 40 any details. Goethe's Italian diary on 4 November 1825 , which records that he discussed the 43 monologue with Eberwein, suggests Eberwein as the likely composer. 
5 [...] You have added fine improvements to our Haydn, ${ }^{58}$ for which I send the best of 5 6 thanks. I didn't name the Handel [work] as I would have had to name many pieces, 6 7 because the same applies to Hasse, Graun, Mozart, Gluck, Mayer and others. 7

8 Of Mademoiselle Sontag we know as much as you. She still hasn't come back 8 9 and the supreme court misses the old wigged gentlemen who have run to Paris 9 10 with her because court cases are held up.

1111 August: Your dear letter of 8 August has just arrived and I will set about 11 12 copying a new piece ${ }^{59}$ for you immediately. It is far too serious, even curt, although 12 13 good work. It is designed for a church ${ }^{60}$ during a long anniversary sermon at which 13 $14 \mathrm{I}$ had to function without understanding a word. Then I thought of the poem ${ }^{61}$ and 14 15 it was thought out very quickly. See how you get on with it. [...] 15

1619 August: This page should have arrived with you last week if the music 16 17 transcriber had not taken so long over the musical score. ${ }^{62}$ Keep in touch because 17 18 I have a long list of questions. Yesterday afternoon my former students, ${ }^{63}$ all of 18 19 them now music directors, drove me by coach to Stralow, where they organized an 19 20 enjoyable evening for themselves and me. They are able to do that because they 20 21 are with me very often. One such occasion is a seminar at which they discover 21 22 things with all kinds of merriment, for which they search in vain in the textbooks 22 23 and I learn the most in the process.

2858 Zelter's essay on Haydn was edited by Goethe and published in Goethe, Über

29 Kunst und Altertum, vol. 1 (Stuttgart, 1812-32; reprint Bern, 1970), v 3 (hereafter referred

30 to as $K u A$ ). A new copy dating from the time this letter was written has still not been found.

31 However, Zelter received an advance copy on 5 August.

3259 Zelter's setting of Goethe's 'Zwischengesang'. There is a part-song (for four solo

33 voices and four-part choir) based on this poem in Goethe's music collection (GSA 32/95),

34 with the parts written in a different hand, for which the authorship can be validly accepted as

35 Zelter, as Goethe wrote to Zelter on 26 August 1826 'the score which I received thankfully is being written out'. Johann Nepomuk Hummel was asked by Goethe for a setting of the

36 song on 3 September 1825 and so he, too, would be considered a possible author; however,

37 his setting (published in $\operatorname{SchGG} 31$, p. 149) is not identical with the one named.

3860 Zelter mentions this context again years later in a letter to Ottilie von Goethe on

3911 April 1832, in which he thanks her for using his setting, 'Laßt fahren hin', at Goethe's

40 funeral, $\operatorname{Sch} G G 28$, p. 28.

4161 'Zwischengesang', from the poetic trilogy Zur Logenfeier des dritten Septembers

$43 \quad 62$ Zelter's setting of Goethe's 'Zwischengesang'.

$44 \quad 63$ The identity of the student has not yet been established. 44 
5 With Riemer I am reading through the correspondence, ${ }^{64}$ which we find informative 5

6 and entertaining. I still have not found a single word which one should take back. 6

$\begin{array}{lll}7 & \text { On the contrary, we sound very charming in our limited day-to-day discourse. } & 7\end{array}$

8 The score, which I received thankfully, is being written out ${ }^{65}$ when the holidays 8

9 are over, when the songbirds have all flown, I can surely expect to receive this and 9

10 other dear works by you.

17 A song which for a long time wasn't to the taste of our Tafel members, because 17 18 they can't take a good joke, is starting to find favour now. ${ }^{66} \mathrm{I}$ don't see it in your 18 19 catalogue and so I enclose it here.

20 It makes itself a clear favourite: light, cheerful, playful the way they sing it at 20 21 the second Liedertafel. ${ }^{67}$ All the drummers play the drums like tambourines and 21 22 end suddenly together, which has a delightful effect.

23 On your birthday, which fell on an academy day, ${ }^{68}$ we first sang your poem 23

24 'Laßt fahren hin das Allzuflüchtige', three times, one after the other - the third 24

25 time it went exquisitely - followed by Handel's Te Deum. ${ }^{69}$ Since they all knew 25

26 what was meant (there were about two hundred singing), they roused themselves 26

27 and it wouldn't surprise me if you had heard it!

28 The Te Deum contains passages which could move a child in its mother's 28

29 womb. The 'Omnis terra veneratur'; the 'Sanctus'; the 'Te ergo quaesumus'; 29

30 the 'Te patrem immensae Majestatis' - one could say the heavens opened up so 30 music collection (GSA 32/27) for solo voices and choir. Goethe's poem was written in 37 February 1814 and published the following year. 38 67 The Liedertafel founded by Ludwig Berger and Bernhard Klein in 1819.

6828 August 1826 fell on a Monday, the traditional Akademietag, yet the celebration 40 took place on the Tuesday. Either Zelter changed this or he meant the rehearsal on the 41 Monday, at which all singers were not present, however. 
1 that you could see the world of holiness and adoration with your own eyes. And 1

2 it's clear that the musician in particular doesn't produce something genuine that 2

3 doesn't dwell within him as image; at the same time Chladni's sound figures really 3

4 occur to me everytime. [...]

52 September: Last Sunday I was called to a special conference in the consistory. 5

6 A spiritual counsellor gave the lecture: $\quad 6$

$7 \quad 7$

8 1. The churches shall have choirs again. $\quad 8$

9 2. Whether the still existing choirs can be used for this? And if they are not suitable 9

10 because not good enough or morally unfit, then 10

113 . How to abolish them and replace them with completely new ones? 11

$12 \quad 12$

13 The matter was discussed backwards and forwards at great length, so that the first 13

14 point was completely overshadowed. I myself could hardly get a word in. The 14

15 city councillor doesn't want to contribute to it and he may be right. He advocates 15

16 closure. From my early years I am used to building; let him who can and will tear 16

17 down and throw away. $\quad 17$

18

19

20

375. Goethe 20

$21 \quad 21$

$22 \quad$ Weimar, 6 to 9 September 182622

$23 \quad 23$

24 The table of the Theory of Sound, ${ }^{70}$ which is the result of many years' study, was 24

25 written, as you may remember, somewhere around 1810, after discussion with 25

26 you. It was not my intention to meet the demands of a discourse upon physics in 26

27 any way, ${ }^{71}$ but to make the scope and substance of the subject clear to myself, and 27

28 to point them out to others. I was undertaking to give an outline of all the various 28

29 branches of physics in this way. I found this table when clearing out the music 29

30 cupboard; I had not quite forgotten it, but did not know where to look for it. I do 30

31 not know whether I have ever shown it to you. In the same way I have also lost 31

32 several essays, which some chance occurrence may obligingly deliver into my 32

33 hands again. [...] 33

$34+34$

$35-35$

$36-70 \quad 36$

$37 \quad 70$ Goethe's Tonlehre was sketched when he concluded his Farbenlehre. The attempt 37

38 to carry reflections on his theory of colour into the area of acoustics was the result of 38

39 conversations between Goethe and Zelter in Carlsbad in 1810. See Goethe's draft letter to

39 Sartorius on 19 July 1810, WA IV/21, pp. 251-4. At Goethe's request Zelter returned the

40 table on 10 July 1827 . Whether the copy sent between Weimar and Berlin is the same as the

41 copy in Goethe's bequest (GSA 26/LIX 14, I) cannot be ascertained.

4271 The corresponding report is not extant. A similar attempt found in Goethe's bequest

43 is the sketch In Sachen Physik contra Physik; an engagement with physics is also mentioned

44 in Goethe's Tag- und Jahres-Hefte of 1810, MA 14, p. 216. 
1 The composition of the little song really delighted me. ${ }^{72}$ Even here no one 1

2 wanted to see the joke. The dear women of the society found it all too close to 2

3 home and had to make admissions that annoyed them. The patriotic veil ${ }^{73}$ served 3

4 to cover up much; one slipped in behind it in the usual way - as happens in lover's 4

5 intrigues.

6 That Mademoiselle Sontag has passed through here with her wealth of sounds

7 and tones was certainly a unique event. Everyone says, of course, that one should 7

8 hear such singers regularly and the majority would like to go to the Königstädter 8

9 Theater again today. So would I. For in reality, first of all one ought to think of 9

10 her and understand her as an individual, to know her in a contemporary context, to 10

11 assimilate and accustom oneself to her; then she would remain a lovely pleasure. 11

12 When heard in an impromptu performance, her talent confused rather than delighted 12

$13 \mathrm{me}$. The good that passes by without returning leaves behind it an impression that 13

14 may be compared to a void and is felt like a deficiency. $\quad 14$

15

16 Enclosure 3: Goethe's Table: Theory of Sound

19 The Science of Music

21 Develops the laws of the audible. This arises from the vibrations of bodies, and for 21

22 us more particularly from the vibration of the air.

24 In the broad sense the audible is infinite. But from this we set aside: noise, sound 24

25 and speech.

27 There remains that with which we have immediately to do, the musically audible 27

28 (musical sound). 28

30 This comes from the purity of material and the measure of the body that vibrates 30

31 or causes vibrations.

33 To come to this measure, let us first take the sounding body as a whole.

73 Goethe's poem is a light-hearted satire on war experiences in 1806 and 1813.37 Eckermann reports a conversation which took place over dinner in Goethe's house during 39 Zelter's visit to Weimar on 4 December 1823: 'Goethe's social song, 'Kriegsglück', was 40 then cheerfully discussed. Zelter was inexhaustible in his anecdotes of wounded soldiers 40
and beautiful women and they all tended to show the truthfulness of the poem. Goethe 41

42 himself admitted that he had no need to go far for such realities; he had witnessed them all 42

43 in Weimar. Frau von Goethe maintained a lively opposition saying that she would not admit 43

44 women were so bad as that "nasty" poem represented them to be.' 
1 The definite sound given by the whole of itself is called the 'basic sound'. 1

2

3 The whole, diminished, gives a higher note, enlarged, a lower note.

5 We may diminish the whole gradually and continuously. This produces no 5 6 proportional parts.

8 We can divide the whole; this gives proportions.

9

10 The chief proportional parts are at some distance from each other (chords).

12 The space between these is filled by intermediate relationships, resulting in a kind 12

13 of gradual progression (scale). $\quad 13$

15 By these steps the basic sound proceeds upwards and downwards, until it finds 15

16 itself again (octave). 16

18 More than this is not necessary at the beginning. The rest must be developed, 18

19 modified and explained by performance. The theory is founded on the whole 19

20 experience, and is presented in three sections. The musically audible appears to 20

21 us: (1) Organically (subjectively); (2) Mechanically (partly subjectively, partly 21

22 objectively); and (3) Mathematically (objectively). All three are ultimately united: 22

23 naturally by the power of the musician, and in a more complex manner by scientific 23

24 demonstration. $\quad 24$

$25 \quad 25$

$26 \quad 26$

27 I Organic (Subjective) [Music] 27

$28 \quad 28$

29 As the world of sound is revealed out of and through mankind, it appears in 29

30 the voice, is received again by the ear, exciting the whole body to respond, and 30

31 providing a mental and moral inspiration, and a development of the inner and 31

32 outer senses.

$34 \quad 34$

35 Science of Singing $\quad 35$

$36 \quad 36$

37 Song is perfectly productive in itself. The natural gift of the outer sense and the 37

38 genius of the inner spirit are absolutely required. 38

$39 \quad 39$

40 The Chest Voice $\quad 40$

$41 \quad 41$

42 The voices, varying in height and depth, are as follows, from the lowest to the 42

43 highest: bass, tenor, alto and treble. Each is to be considered complete. Each 43

44 comprises over an octave. They overlap one another, and together make up about 44 
1 three octaves. They are divided between the two sexes. Hence the significance of 1

2 puberty and subsequent change of voice that can be prevented by castration. 2

3

4 Register

5

6 That means the limit of the chest voice.

8 The Head Voice

10 Transition into the mechanical. Union of both voices. Detailed explanation of the 10

11 organization of chest and throat. Adding in the voices of animals, especially of 11

12 birds.

16 Receptiveness of the ear. Its apparent passivity and indifference (adiaphoria). 16

17 Compared to [vision], hearing is a less-perceptive sense - only part of a sense. 17

18 Yet we must ascribe to the ear, as to something highly organized, both reaction 18

19 and demand, whereby that sense is by itself capable of taking up and grasping that 19

20 which is presented to it from without. But in the case of the ear, special attention 20

21 has always to be given to the medium of the sound, which actively produces the 21

22 effect. The productivity of the voice is thereby generated, aroused, elevated and 22

23 multiplied. The whole body is stimulated.

25 Rhythm 25

27 The whole body is incited to move in step (march), or in skips (dance and 27

28 gesture). $\quad 28$

$29 \quad 29$

30 All organic movements are manifested by means of systole and diastole. 30

32 It is one thing to lift the foot, another to put it down.

34 Hence arise rhythmic weight and counterpoise.

40 Kinds of time: even, and uneven. These movements can be considered alone; but 40

41 soon they are necessarily combined with modulation. 
1 II Mechancial [Music] (Mixed)

2 2

3 Tones produced by various means, in accordance with musical laws. 3

$4 \quad 4$

5 Instruments

$6 \quad 6$

7 Material. Its tone quality, purity and elasticity.

$8 \quad 8$

9 Form. Natural, organic and artificial, metal, wood, glass. Reeds, length and area. 9

$10 \quad 10$

11 Method of exciting vibrations. Stroking. Blowing. Horizontally or vertically. 11

$12 \quad 12$

13 Striking. Relation to mathematics. The instruments result from knowledge of the 13

14 proportions of measure and number, and increase this knowledge by means of 14

15 multiplicity. $\quad 15$

$16 \quad 16$

17 Discovery of natural relations of tones other than those shown by the monochord. 17

18 Relation to the human voice. These are a substitute for that, and inferior to it, but 18

19 are raised on a level with it, by treatment that is expressive and spiritual. 19

20

$21 \quad 21$

22 III Mathematical [Music] (Objective) 22

$23 \quad 23$

24 How the elements of music are revealed in the simplest bodies outside us and are 24

25 reduced to relationships of number and measure. $\quad 25$

$26 \quad 26$

27 The Monochord $\quad 27$

$28 \quad 28$

29 Sounding together of the harmonic tones. Different ways of describing how it 29

30 happens. Sympathetic vibrations. Mechanical vibrations. Organic demand for and 30

31 subjective excitement of complementary sounds. 31

$32 \quad 32$

33 Objective converse proof through sympathetic vibrations of strings in tune with 33

34 one another. $\quad 34$

$35 \quad 35$

36 Foundation of the simplest tone proportions. Diatonic scales. The demands of 36

37 nature [are] not to be satisfied in this way. Practical exemplifications [are] not to 37

38 be accounted for or shown in this way. 38

39

40 Reference to the minor mode. It does not originate in the first series of harmonic 40

41 tones. It is manifested by means of less obvious relationships of number and 41

42 measure, and yet is perfectly suited to the nature of mankind, even more perfectly 42

43 than the major mode. $\quad 43$

$44+44$ 
1 Objective proof through the sound of tuned strings, which is discovered by 1

2 practical experiment. (Thus the basic key of $\mathrm{C}$ gives the harmony of $\mathrm{C}$ major when 2

3 ascending, and the tonality of $\mathrm{F}$ minor descending.) 3

4

5 The major and minor modes are the polarities of musical theory. The first principle 5

6 of both: the major is generated from rising, the tendency to ascend, and to extend 6

7 all intervals upwards; the minor, from falling, its tendency is to descend, and to 7

8 extend its intervals downwards. (The minor scale raised becomes major.) Working 8

9 out of this contrast as the basis of all music. 9

$10 \quad 10$

11 Origin and necessity of the leading note. The semitone rising and the minor third 11

12 falling. 12

13

14 Connection of the two modes by dominant and tonic. (The first must always be 14

15 major. Question as to whether the latter must always be minor?) 15

17 Origin of Arsis and Thesis in all movement of this type, as also of the cooperation 17

18 of material bodies and of rhythm. 18

20 Artistic Treatment

22 Limitation of the octave.

23 Identical transpositions

24 of the octave. Definition

25 of tone proportions. With

26 and against nature.

27

28

29

30

34 Limitation of the octave. Identical transpositions of the octave. Definition of tone 34

35 proportions. With and against nature.

The art of rendering tones nebulous and rounding tones in order to make different keys accessible to one another and to make it possible to use one as well as the other

37 The art of rendering tones nebulous and rounding tones in order to make different 37

38 keys accessible to one another and to make it possible to use one as well as the 38

39 other.

41 Instruction in singing. Exercises, to acquire insight into what is easy and what is 41

42 difficult in the fundamental and derivative elements of singing. Application of 42

43 genius and talent, and the employment of all that has been said before as material 43

44 and tool. 
1 Union of speech with song, particularly with canto fermo, recitative, and quasi 1

2 parlando. 2

3

4 Distinction (of song) from speech by a kind of register, and transition to this and 4

5 therefore to meaning. $\quad 5$

6

7 Sound (noise). Transition into the formless and the accidental.

$8 \quad 8$

929

10 376. Goethe 10

11 11

12 Weimar, 15 September 182612

$13 \quad 13$

14 Here, dearest friend, the latest thing of the day (or more precisely) of the hour! ${ }^{74} 14$

15 The poem has just been recited, but now we should like to sing it too. ${ }^{75} \quad 15$

16 The rhythm is similar to Thaer's song. Admittedly the more important subject 16

17 matter deserves a more serious treatment; this will be up to you. 17

$18 \quad 18$

$19-19$

20 377. Zelter 20

$21 \quad 21$

$22 \quad$ Berlin, 1 October 182622

23

24 Schiller's son, who is taking leave of me now, is leaving tomorrow, and wants to 24

25 take something with him. So I am hurrying to make a fair copy of this little song. 25

26 The music transcriber can fill in the following verses in the parts which are scored 26

27 out. In performance it would be nice if every second verse were to be sung by a 27

28 soloist so as to create some variety. It is really written for your choristers to be 28

29 sung before your house. This little piece, in the squares in Weimar, might also be 29

30 on the lookout for other friends. 30

$31 \quad 31$

$32 \quad 32$

$33-33$

$34-34$

$35-35$

$36 \quad 36$

$37 \quad 37$

3874 Goethe's poem, marking the return of the youngest son of Carl August from 38

39 America: 'Dem glücklich-bereicherten, Ihrem Durchlauchtigsten Bruder Herren Carl 39

40 Bernhard, Herzog von Sachen-Weimar-Eisenach Hoheit die verbundenen Brüder der Loge 40

41 Amalia zu Weimar'. The poem was performed on the occasion of a celebration of Goethe's 41

42 son, August, in the freemasons lodge in Weimar. Goethe presumably sent Zelter the once- 42

43 off publication of the poem for this occasion. $\quad 43$

$44 \quad 75$ Goethe's request remained unfulfilled. $\quad 44$ 
$5[\ldots]$ The little songbook ${ }^{76}$ is really curious and there should be no niggly criticism 5

6 of your judgement. I find it really appropriate and I imagine friends will also find 6

7 it so. I thought the introduction was fine and good. Who does not want to look at 7

8 himself in a favourable mirror? Let me know the author and the best of thanks. 8

$9[\ldots]$

10 Do not delay in writing your reaction to the table I sent you. ${ }^{77}$ You will see from 10

11 it how serious my endeavour was to define at least for science the boundaries of that 11

12 limitless realm. Every chapter, every paragraph points to something meaningful; 12

13 the method of arrangement may be allowed to pass; I chose it, because I thought of 13

14 making it somewhat similar in form to my Farbenlehre. I intended to have done a 14

15 good deal more, but it had to be set aside, owing to the frantic pace of my life. 15

16 One ought to say to oneself at times that it is advisable to avoid everything one 16

17 cannot assimilate with enjoyment or do productively for one's own pleasure and 17

18 that of others $[\ldots]$

Now, in haste, let me ask you kindly to thank most warmly the excellent 19

20 and energetic Felix for that splendid copy of his careful aesthetic studies; ${ }^{78}$ his 20

21 work, as well as that of his master, is to provide educational entertainment for our 21

22 Weimar art lovers during the long winter evenings, which are now drawing near. 22

23 These friends have just examined the festival songs very closely and your claim 23

24 remains completely unchallenged. They also want to try to say something about 24

25 the character and value of other unnamed songs. Warmest thanks for the song sent 25

26 through Schiller. ${ }^{79}$ I hope that with such help my surroundings will gradually be 26

27 blessed by the sound of songs. [...]

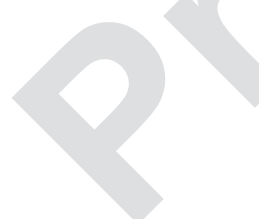

76 The published booklet, Das Goethe-Fest in Berlin. Gefeiert von der Mittwochs- 36 Gesellschaft am 28. August 1826, with an address and 12 festival poems, presumably 37 brought back from Berlin by Ulrike von Pogwisch; see Goethe's diary 4 October 1826, ${ }^{38}$ WA III/10, p. 252.

78 At the end of September 1826 Felix Mendelssohn had sent a copy of his translation 41 of the Terence comedy Das Mädchen aus Andros to Goethe, who had organized a reading 42 of it in Weimar. 
5 [...] Incidentally I understand well that you are extremely busy at the moment, 5 6 but let the present arouse you to cast a glance and send a word in my direction. I 6 7 will ask you especially that you don't lose the musical table ${ }^{80}$ in the confusion of 7 8 relocating. I was led to some very nice thoughts by which the matter was rounded 8 9 off very nicely for me. Whether they are also appropriate for others the final 9 10 communication will show.

17 I don't see that there is anything to criticize with regard to your table and the way 17 18 it is laid out. I am in complete agreement with it.

19 Art is infinite. If it is to become a science, if it is to be taught, it must be limited, 19 20 made finite. That is what has happened up to now since one cannot do anything 20 21 else. We have accepted the tonic, but the concept of it was confused enough in 21 22 both old and new manuals. One called the sounds intervals (relationships), but the 22 23 root (the tonic) was not to be an interval, as if the ratio $2: 1$ could not just as easily 23

24 be 1:2.

25 Türk himself didn't want to admit this. ${ }^{81} \mathrm{He}$ stayed with the idea that the 25 26 relationships (the numbers) were derived from the division of the whole and he 26 27 could not understand that the whole (the first note to be divided) was a finite entity 27 28 separated off from the infinite. And as I said to him: like must come from like; 28 29 sound from sound; man from man; a cat could eat as many mice as she wanted, 29 30 she would never produce a mouse herself. He appeared to take it badly. The more 30 31 recent theorists are all much more inferior to Türk, but Chladni ${ }^{82}$ is not to be 31 32 confused with them.

$43 \quad 82$ Through his textbook, Die Akustik, Ernst Florens Friedrich Chladni became the 43 
$1[\ldots]$ The table ${ }^{83}$ is safe and sound and placed where I can see it everyday. The 1

2 teaching room stands on good columns but will have to be examined carefully, 2

3 since with regard to architecture it is more or less necessary to to forget oneself, 3

4 especially in days when science and art (which, when separated, are nothing at all) 4

5 suffer more and more from critical indifference. 5

6 Since 2 January our Sing-Akademie has quietly entered the new building ${ }^{84}$ and 6

7 is trying out the most suitable positions. The acoustics are good; Chladni who was 7

8 here recently considers them first-rate. At the same time nothing is completely 8

9 finished. Today the doors were still not hanging, the seats are still not finished and 9

10 the smell of the different paints in a completely new building will not disappear 10

11 until everyone has smelt his share of it. [...] My move should take place at the end 11

12 of March and there is much to do, since once again I must begin to learn a new 12

13 trade, which no one seems interested in learning.

1423 January: The Crown Prince with his wife ${ }^{85}$ and the other royal princes ${ }^{86}$ want 14

15 to visit the Sing-Akademie today. ${ }^{87}$ If one were in the main prepared, one would 15

16 want to examine the building and its advantages, but so much is still lacking, the 16

17 completion of which has been hindered by the short, cold days. 17

24 So that the correspondence begins to flow again, I want to say first that Privy 24

25 Governing Councillor Streckfuß had me read his letter from you and I have given 25

26 him Swarto (written in your hand) to copy. My music to it is long finished and I 26

27 have not had a chance to glance through it again. It is entirely suitable as a sung 27

28 recitation. I already made the same remark about theatrical works by Calderon. In 28

29 reading Die Tochter der Luft again and twice in succession I find recitatives, arias, 29

30 duets, trios and every kind of ensemble given very clearly. If anyone wanted to set 30

31 it to music, he would just have to take hold of it. 31

83 Goethe's Tonlehre; Zelter is answering Goethe's request to keep an eye out for it $\begin{aligned} & 35 \\ & 36\end{aligned}$ during the move.

84 The Sing-Akademie building was so far finished at the beginning of January 182737 that the concert hall could be used. The ceremonial opening took place on 8 April 1827.

${ }^{85}$ Friedrich Wilhelm of Prussia (later King Friedrich Wilhelm IV) and Elizabeth née 39 Princess of Bavaria.

86 Friedrich Wilhelm Ludwig, Friedrich Carl Alexander and Friedrich Heinrich Albert 41

44 Zelter on 22 January 1827 (GSA 143/13); MA 20.3, p. 785. 
5 As usual, I had almost forgotten an important point that his Royal Highness, the 5

6 Crown Prince, had said to me about your musical performance in the new hall. ${ }^{88} 6$

7 He seemed to be satisfied with the new building, spoke about your institution with 7

8 interest and remarked that there was a very large audience. Tell me something 8

9 from your side about this blessed official opening. [...] 9

16 [...] It was almost the same with me when I read the appendix which is found on 16 17 the last page of your letter for the first time. Certainly these noblemen ${ }^{89}$ were in 17 18 the Sing-Akademie on 23 January and spoke about everything most graciously, 18 19 even though the building is still not finished enough to greet such guests with due 19 20 honour. Since they wanted to travel to Weimar and could assume they would find 20 21 you interested in this now well-known institution, they must at least have seen 21 22 it and heard its acoustic shortly before. Apart from these members of our royal 22 23 family, there is nothing much to say about our other listeners, for they were made 23 24 up entirely of members of the Sing-Akademie. On the day there were 209 people 24 25 (apart from me), which I can be certain of since every Tuesday the names of those 25 26 present are written down. [...] If I have to admit it (and I would prefer not to), 26 27 the thing has wound itself around me since I worked with Fasch from my own 27 28 financial resources; now there is a shortage of money through which the whole 28 29 thing becomes more widely resepected in the world. 29

36 [...] My Felix has accepted an invitation to Stettin, to conduct his latest works 36 37 there; ${ }^{90}$ he left Berlin on the 16th. The boy reached his nineteenth year on the third 37

$39 \quad 88$ The (unofficial) opening of the concert hall of the Sing-Akademie, officially opened 40 on 8 April 1827.

4189 The Prussian Crown Prince, his wife and brothers. 41

4290 In February 1827 Felix Mendelssohn undertook a journey to Stettin, where he 42

43 was able to conduct a performance of his overture to Shakespeare's A Midsummer Night's 43

44 Dream (op. 21) to great acclaim. 
1 of this month and his art grows in maturity and individuality. His last opera, ${ }^{91}$ which 1

2 takes a whole evening to perform, has now been waiting for more than a year to 2

3 be granted a performance at the Königliches Theater and never sees the light of 3

4 day, while all manner of French rubbish and nonsense is on the stage and hardly 4

5 survives a second performance. When we are young, and all other advantages are 5

6 on our side for which many others have to wear away the best part of their life, it 6

7 cannot do us very much damage - if I did not wish that with his industry he might 7

8 as soon as possible outgrow our time, which we have to accommodate, whether 8

9 we like it or not. I dare say I might still be of some use to him, by making him fall 9

10 back upon himself more and more. 10

17 A true fragment to the restauration of Phaethon was found, to which I wish 17 18 success. $^{92}[\ldots]$ From my youth I had a great interest in the fable. It was the first 18 19 opera which I saw and heard when I was 12 , performed by the Italian theatre here. 19 20 I remember the liveliest, youthful shock of the marionette crashing down to the 20 21 accompaniment of thunderclaps. I still have Graun's music to $i^{93}$ and it surely 21 22 makes a strange impression alongside the text of Euripides, although the libretto 22 23 is not the worst compared to its time, even though the meaning of the fable is 23 24 completely ignored. Because of the throne, Phaeton wants to marry a princess who 24 25 has been promised to a son of Jupiter (Epaphus). This Epaphus cries to his father 25 26 for revenge, [his plea] is heard, and Phaeton is thrown out down of his carriage. 26 
5 [...] I read in Aristotle's Politics (in Garve's translation) ${ }^{94}$ what was written about 6 music $^{95}$ with respect to education. Here, too, you have completely enlightened 7 me. ${ }^{96}$ Who knows what music is and was and where it is heading. It is strange 8 enough how everything is demanded from the arts, especially from music, since 9 everyone can see in himself what he achieves and what he gains from it.

10 I am just as delighted with your remarks about Handel's music, ${ }^{97}$ which you 10

11 consider rich in material. Handel has created a master work without further ado 11

12 simply by handling it dramatically. I am venturing to bring the whole thing onto 12

13 the stage just as it is and to full theatrical effect. The poem, ${ }^{98}$ on the whole, is 13

14 epic in proportions and Dryden (as an Englishman) thought that as long as the 14

15 material is musical, the composer will also find welcome material. That must be 15

16 what our deceased philologist $\mathrm{t}^{99}$ meant when he said to me after the performance 16

17 that the music was neither really antique nor modern, which would be exactly right 17

18 because it is dramatic and therefore contains everything. 18

19 Regarding an epic treatment in a musical context: right from the beginning 19

20 I could not have thought of 'Der Gott und die Bajadere' as being anything other 20

21 than rhapsodic. ${ }^{100}$ I believe I noticed the same about the general effect: when I 21

22 performed the work to you and to Schiller, ${ }^{101}$ you both mimed it. ${ }^{102} 22$

2594 Aristotle. Die Politik. Übersetzt von Christian Garve, ed. Georg Gustav Fülleborn.

26 (2 vols, Breslau: Korn, 1799-1802). Volume 1 is listed in the register for Zelter's library

2895 Aristotle, like Plato, allocated a place to music in the section on education; but he 28

29 also considered music to be the object of pleasure and distinguished between music which

30 is morally good and morally beautiful.

3196 Namely, by introducing him to Aristotle's writing on music.

\section{9}

3297 'The effects of music are [more] material, like what Handel has produced in his

33 Alexanderfest', Goethe, Nachlese zu Aristoteles'Poetik, MA 13.1, p. 342.

3498 John Dryden, 'Alexander's Feast or The Power of Music. An Ode in honour of St.

100 Zelter set Goethe's ballad 'Der Gott und die Bajadere' as a simple strophic song,

The syllabic vocal setting, the indication Romanzenton, Zelter's insistence on a harp accompaniment for the singer, are all features of the 'epic' treatment of the ballad throughout

40 the composition which are mentioned in the letter. By 'rhapsodic' rendering, Zelter means

41 the kind of performance by a Greek singer with kithara accompaniment.

42101 During Zelter's first visit to Weimar from 24 to 28 February 1802 . Schiller's visits

43 are recorded in Goethe's diary on 24, 25 and 26 February 1802, WA III/3, pp. 51-2.

$44 \quad 102$ Zelter recalls it in GZ 8 September 1825. 
5 How should a friend answer his friend in such a case ${ }^{103}$ A similar crisis ${ }^{104}$ drew us 5

6 so close to each other, that the bond between us could not be more intimate. The

7 present misfortune leaves us as we are, and that of itself is so much.

8 The fates are never weary of relating to one another the old myth of the night 8

9 descending thousands of times and always once more. To live long means to 9

10 outlive many; ${ }^{105}$ such is the pitiful chorus of our vaudeville-like listless life; it 10

11 comes round again and again, troubling us and at the same time goading us to new 11

12 and serious ventures.[...]

388. Goethe

It still remains to be reported briefly that the revision of our correspondence ${ }^{106} 19$ always gives myself and Riemer opportunities for discussion and provides the 20 $\begin{array}{ll}\text { most engaging entertainment you could want. } & 21\end{array}$

288 April: On the occasion of this first edition of Shakespeare ${ }^{107} \mathrm{I}$ am reminded of 28

29 Dr Forkel, ${ }^{108}$ who in his judgement of the prolific Sebastian Bach insists that it 29

30 would be better to put aside the youthful works of such men of such genius than 30 to Johanna Sophia Eleonora: Georg Friedrich Zelter (1789-1827) who was Zelter's only 34 remaining son.

104 The suicide of Zelter's stepson, Carl Flöricke; in his letter of consolation of $3 \begin{aligned} & 35 \\ & 36\end{aligned}$ February 1812 , Goethe had changed over to the 'du' form of address. 105 See GZ 26 March 1816 on the death of Zelter's son, Adolf: 'Unfortunately it is the 37 old cliché that to live long is to outlive many.'

106 The editorial check through the copy of the Goethe-Zelter correspondence which 39 had been made on Goethe's orders. VI, 1. 
1 to preserve them to the disadvantage of a purified taste. The Gods have graciously 1

2 preserved me from such a purification principle up to now. Familiar with every

3 single pen stroke of my hero who belongs to the unfathomable, I collect what I can

4 and constantly purchase the most important thing at a ridiculously low price, for

5 what flows from this source into our era could remain secret for a long time, since

6 it cannot be compared with what exists today. Sometimes it seems to me as if I saw

7 a cross-section of the universe and the connection of one half with the other, and it

8 is all nothing but music: no German or Italian music - just music.

9 To gain this intimacy with him, I had acted more or less as you and Schiller did

10 with Shakespeare's Macbeth ${ }^{109}$ Old Bach, with all his originality, is a son of his

11 country and of his age, and could not escape French influence, and in particular 11

12 that of Couperin. One wants to please and thus something is created which does 12

13 not endure. One can, however, dissociate him from this foreign element like 13

14 [removing] a thin froth, and the brilliant substance lies immediately beneath. 14

15 Consequently, I have arranged much of his religious music, ${ }^{110}$ purely for myself, 15

16 and my heart tells me that old Bach gives me the nod of approval, just as honest 16

17 Haydn used to say, 'Yes, yes, that was what I intended!' [...] 17

18 The greatest stumbling block in our time is easily discovered in those entirely 18

19 damnable German church texts which serve the polemical seriousness of the 19

20 Reformation. Through the thick fumes of confessional belief they stir up unbelief 20

21 that no one wants. The extraordinary thing about Bach is that a genius, in whom 21

22 taste is innate, should from such a soil have revealed a spirit that must have very 22

23 deep roots. He is most marvellous when he is in a hurry and is not in the mood. I 23

24 possess manuscripts of his where he has thrice begun and then crossed it out again. 24

25 It wasn't working, but next Sunday there was a wedding or funeral to prepare for. 25

26 Even the very worst rough draft seems to have been scarce sometimes, but the 26

27 work had to be done, now it begins to flow, and at last the great artist is there to a 27

$28 \mathrm{~T}$. He makes his improvements, quite as an afterthought, and with the tight writing 28

29 it becomes dark, unclear and learned. He uses his own signs, which not everyone 29

30 can decipher, so that I have to refrain almost entirely from tampering with his 30

31 manuscripts, because I find it no easy matter to put them down again. [...] 31

32

109 In the early months of 1800 Schiller realized his old plan for a translation and

35 adaptation of Shakespeare's Macbeth. Zelter is stressing here Schiller's high-handedness

36 in dealing with the original.

$37 \quad 110$ Georg Schünemann goes as far as stating that Zelter rearranged the aria 'Ich folge

38 dir gleichfalls' from St John's Passion according to the taste of the Berlin Liederschule. See

39 Georg Schünemann, 'Die Bachpflege der Berliner Singakademie', Bach-Jahrbuch (1928):

138-71. Apart from Zelter's many alterations to the music text of Bach's manuscript,

40 there is such marginalia as the following: 'I have put together this score from the collected

41 fragments which were, in part, in the author's hand, and out of an old devotion to the great

42 master I have wanted to make much of this material accessible for the ability of my students

43 who are a hundred years younger [than Bach]. In doing this my intent is to be in agreement

44 with him should I come ever meet the good Bach'. 2 4 5 6

9

0

11

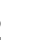

3

5

6

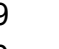


Chladni's death hit me very badly. ${ }^{111} \mathrm{He}$ was still with me a few weeks ago. He 1

2 wanted to come to Berlin again, and now one must follow him. [...] 2

3 Easter Saturday. Today my weeks of torture come to an end. ${ }^{112}$ Yesterday my 3

4 Passion Music was performed for the first time in the new hall ${ }^{113}$ and I had the 4

5 honour of seeing the King among my audience. Your letter of 10 April arrived 5

6 yesterday and really cheered me up, for the burden of the last few days was very 6

7 heavy.

14 Madame Catalani has sniffed out a few extra groschen, which I begrudge her. ${ }^{114} 14$

15 Too much is too much! She still makes no preparation for her departure, for she 15

16 has a couple of rehashed, transformed airs which she would like to churn out 16

17 gratis. After all, what are a few thousand of our thalers when we get 'God save the 17

18 King' $^{115}$ as an encore!

It really is a pity! What a voice! A golden bowl with common mushrooms in 19

20 it! And we - one could almost curse oneself for admiring what is so contemptible! 20

21 It is unbelievable. An irrational animal would despair. What an impossible state of 21

22 affairs! An Italian turkey comes to Germany - Germany with her academies and 22

23 high schools, and old students and young professors sit to listen, while she sings 23

24 in English - yes, English - Handel's German arias. ${ }^{116}$ What a disgrace, when it is 24

25 meant as an honour! In the heart of Germany too! [...] 25

112 The pressure Zelter felt on account of the many annual musical performamces 30

113 For a glowing report of the performance; see $A M Z 29$ (1827), no. 20, 16 May, 32 column 338; MA 20.3, p. 816.

114 The singer Angelika Catalani, whom Zelter had long admired, could - despite 34 her advancing age - set up numerous concerts during her visit to Berlin in April 1827 on 35 account of her earlier success. She gave a concert of spiritual music on 6 April 1827 at the 36 Königliches Opernhaus, where 'despite being double the standard price for the opera, the 37 beautiful, spacious house was completely full'; Spenersche Zeitung, 9 April; see also $A M Z 37$

115 Catalani usually closed her concerts with the British national anthem; see Zelter's 39

40 account of the concert in Frankfurt am Main on 14 August 1816; Schottländer, Carl 40

41 Friedrich Zelters Darstellungen seines Lebens, p. 271.

$42 \quad 116$ Handel had, of course, composed the arias of the oratorio using the English texts. It 42

43 was customary to perform the operas and oratorios in translation; Zelter himself had made 43

44 a singing translation of Handel's Alexanderfest. 
5 I was very much struck by your significant remark that Bach, who was basically so 5

6 original, had allowed himself to be affected by a foreign influence; I immediately 6

7 looked up Franz Couperin in the biographical dictionary, ${ }^{117}$ and understand how, 7

8 given the great activity of the arts and sciences at that time, a Gallic influence ${ }^{118} \quad 8$

9 may have been blown over here [...]

10 But to return to Couperin and Bach, I do entreat you to let me hear some 10

11 important remarks from you about what you call French froth and which you 11

12 distinguish from what is fundamental in German music; and so, in one way or 12

13 another, clarify for me this enlightening relationship [...] 13

$14[\ldots]$ It is a shame about Chladni. He was an active and good man who remained 14

15 true to his subject, to which he had devoted himself and so could work effectively 15

16 on the most disparate things. You can see that he could be entirely disinterested, so 16

17 the meteor stones, after the sound figures, extracted from him the love and desire 17

18 to give them constant scientific treatment. 18

19 Now I must tell you how yesterday evening, when revising our correspondence 19

20 with Riemer, I was really delighted with your splendid letter of 20 March 1824, 20

21 where, while tracing the development of Handel's Messiah, you so admirably 21

22 show how the chorale, which grew out of the canto fermo, gradually developed 22

23 into four parts. This leads me to the hope that you will continue to think me worthy 23

24 of instruction on similar subjects, and therefore that you will soon, as a friend, 24

25 converse with me by letter about Couperin and Bach. 25

3224 April: This week Felix's most recent opera is to be performed ${ }^{119}$ - if it ever does

33 come off we have yet to see. He has had to alter a great deal, the libretto is not 32

34 worth talking about and so even the improvements are unlikely to be brilliant. 34

35 My Good Friday music was received fairly well. I cleared several hundred 35

36 thalers and can be satisfied with that. [...] 36

$\begin{array}{ll}37 & 37\end{array}$

$38 \quad 38$

$39-39$

$40 \quad 117$ Johann Gottfried Walters, Musicalisches Lexicon oder Musicalische Bibliothec 40

41 (Leipzig 1732) in Goethe's library (Ruppert, no. 2602). 41

$42 \quad 118$ Zelter had mentioned the French influence-in particular, the influence of Couperin- 42

43 on J.S. Bach. $\quad 43$

$44 \quad 119$ Die Hochzeit des Camacho. The Berlin premiere took place on 29 April $1827 . \quad 44$ 
5 You will get the best report of our opening celebrations ${ }^{120}$ from the newspapers. I 5

6 greeted the noble couple with my people along with many thousand others and saw 6

7 the gracious little head nodding towards us. At the new opera in the evening, ${ }^{121}$ the 7

8 celebrated couple were greeted with prolonged welcoming signs that were repeated 8

9 just as continuously at the close of the performance. The special thing about it, 9

10 which has never happened before, was that all our best singers and dancers, ${ }^{122}$ who 10

11 gladly dispute their ranking, were all able to give of their best. 11

What I called Sebastian Bach's French froth ${ }^{123}$ is not so easily skimmed off that you 18

20 for the greatest of harmonists, and rightly so. One can scarcely dare to call him a 20

21 poet of the highest order, although he belongs to those who, like your Shakespeare, 21

22 are far above childish theatre. As a servant of the church he composed only for the 22

23 church, though his music is not church-like. His style is Bach-like, like everything 23

24 about him. That he is necessarily obliged to use such common signs and names as 24

25 Toccata, Sonata, Concerto is like saying a man is called Joseph, or Christopher. 25

26 Bach's original element is seclusion, as you actually admitted when you once 26

Prussia in Potsdam on 24 May 1827 and in Charlottenburg on 25 May on the occasion 29

of their marriage on 26 May, as well as the celebrated arrival of the couple in their Berlin 30 residence on 28 May; see Spenersche Zeitung, no. 121, 26 May, no. 122, 28 May $1827 . \quad 31$

33 Raupach, on 28 May in the Königliches Opernhaus. The opera was 'only half-composed 33

34 by the knight Spontini without a new overture', $A M Z 29$ (1827), no. 28, 11 July, column 34

${ }_{122}$ The performance of the opera was preceeded by a ballet, Amphion, anakreontisches 36 Divertissement, by the royal choreographer, Titus.

123 In the explantion requested by Goethe, Zelter names historical facts which 37 manifest themselves in Bach's works in many dimensions: Bach remains unaffected by the 39 discussion, which was sparked off by the ideal of the gallant homme. Above all, however, 40 he assimilated the heterogeneous stylistic features of French music, be it in his orchestral suites (BWV 1066-1070), composed after the model of French ballet, be it in his suites 41

42 for piano (among others the French Suites BWV 812-817), solo violin and solo cello. In 42

43 particular, French harpsichord practice, in the form of François Couperin's textbook L'art 43

44 de toucher le clavecin (Paris, 1716) had a lasting influence on Bach. 
1 said, 'I lie down in bed ${ }^{124}$ and make our organist, the mayor of Berka, ${ }^{125}$ play me 1 2 Sebastian.' That's what he is; you have to eavesdrop on him. 2

3 Well, besides that he was a man, a father, a godfather, a cantor in Leipzig, 3 4 and, as such, no more than anyone else, even if not much less than a Couperin, 4 5 who served two kings of France for over 40 years. ${ }^{126}$ In the year 1713 Couperin 5 6 published and dedicated to his king ${ }^{127}$ this first bit of fundamental advice: do not 6 7 strike the piano but play it.

8 A king of France playing the piano, perhaps even the organ, pedals and all! 9 Who would not immediately have imitated him? Couperin's new method consisted 10 mainly in the introduction of the thumb, which makes even and sure execution 11 possible. (If I am not mistaken, in Carlo Dolce's picture of Saint Cecilia, ${ }^{128}$ the 11 12 thumbs, if not hanging down, are not in use!) The more advanced Germans and 12 13 Bach had long since practised this method as the obvious one and yet it was still 13 14 limited to the right hand, the left hand being evidently spared. ${ }^{129}$ The Bach method 14 15 makes use of all ten fingers, which, with their different length and power, are meant 15 16 to perform every kind of service; to this method we are indebted for the incredible 16 17 performances of the latest toucheurs. Now as all men must be French, if they mean 17 18 to live, Bach made his sons practice the small, delicate, graceful Couperin notes 18 19 with their ornaments; he himself even made highly successful efforts as a composer 19 20 in this manner, and so the French decorations wove themselves into his style.

21 Bach's compositions are partly vocal, partly instrumental, or both. In the vocal 21 22 pieces there is often much more than the words imply, and often enough he has 22 23 been taken to task for this. Nor is he strict in the observance of the rules of harmony 23 24 and melody, and he breaks the rules with great audacity. But when biblical texts, 24 25 such as:

124 This phrase is not from this correspondence but dates back to the time in early summer 1814, which Goethe and Zelter spent together in the house of the spa inspector and organist Schütz. In a letter written there Zelter told Christoph Ludwig Friedrich Schultz that Goethe had 'Schütz play Bach's work to him for an hour every evening, laid down in bed beforehand, as he maintained it shouldn't be obvious that one is listening to Bach's music,

36 since the music is being performed for itself', Gespräche, vol. 2, p. 914. The content is 37 similar to Goethe's remarks about Schütz in GZ 4 January 1819 and 29 May 1819.

38125 Johann Heinrich Schütz, spa inspector and organist in Berka.

39126 From 1693 until his death in 1733 Couperin was organist and harpsichordist at the

$42 \quad 128$ This picture by the Florentine painter Carlo Dolce has not been identified. $\quad 42$

$43 \quad 129$ I have interpreted this passage to make musical sense of: 'auf rechte und linke 43

44 Hand beschränkt wobei die letztere sichtbar geschont ist'. 44 
'Ye shall cry and lament,' and so on, ${ }^{131}$

'Jesus took the twelve unto himself,' and so on, ${ }^{132}$

6 are composed as choruses, I am often inclined to marvel at the sacred freedom 6

7 in these passages, the apostolic irony with which some quite unexpected effect is 7

8 produced, without raising a doubt about the sense and taste inherent in it. A 'passus 8

9 et sepultus' introduces the last pulsations of the silent powers; a 'resurrexit' or a 9

10 'gloria Dei patris', ${ }^{134}$ the eternal regions of sanctified suffering, in contrast with 10

11 the hollowness of earthly desires. This feeling, however, is, as it were, impervious 11

12 to analysis, and it would be difficult to extract from it a melody or anything of a 12

13 material nature. It only renews itself, strengthens itself, continually gathers up its 13

14 strength again through repetition of the whole.

In all this, Bach is to that point still dependent on some kind of theme. One 15

16 should follow him to the organ. This is his own peculiar soul into which he 16

17 immediately inspires living breath. His theme is the newly born feeling, which, 17

18 like the spark from the stone, invariably springs forth from the first chance pressure 18

19 of the foot on the pedal. So by degrees he gets into it until he isolates himself and 19

20 feels alone, and then an inexhaustible stream flows into the infinite ocean. His 20

21 eldest son, Friedemann (of Halle), ${ }^{135}$ who died here, referred to the same quality 21

22 when he admitted, 'Compared with him, we all remain children. ${ }^{136}$ Not a few of 22

23 his grander compositions for the organ come to an end somehow, but they are 23

24 never over; there is no end to them.

25 Here I must stop, however, though much remains to be said. Weighing every 25

26 possible testimony against him, this Leipzig cantor is one of God's phenomena; 26

27 clear, but inexplicable. I might cry out to him, 'You've made me work and I've 27

28 brought you to light again. ${ }^{137} \quad 28$

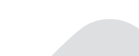

130 Opening chorus to Cantata BWV 39.

131 Opening chorus to Cantata BWV 103.

132 Opening chorus to Cantata BWV 22.

133 Opening chorus to Cantata BWV 110.

134 Sections of the Credo from the Catholic mass.

135 Friedemann Bach was active as a composer in Halle from 1764; he died in Berlin 39 on 1 July 1784.

136 This expression presumably dates back to Johann Nikolaus Forkel, who, at the 41 beginning of chapter four in his Bach biography (1802), wrote, 'W. Friedemann was also a 42 child in this respect compared to his father, and declared himself to be so in all honesty'. 43 
5 In the periodical Cäcilia, volume 24, you will find an important essay on 'The 5

6 Condition of Music in Naples' written by a F.S. Kandler, ${ }^{138}$ a man whom I would

7 like to know more about. I found everything very pleasing in this little treatise, as

8 one may call it: a calm mind, true knowledge, overview, interest in detail, serious

9 established beliefs, casualness towards the living, and moderation. His honesty is

10 so pure that - allowing for the praiseworthy and the reprehensible existing side by 10

11 side as a consequence of the past and as indispensable to the present and it makes 11

12 sense of many a moment - it still seems a worthy quality. 12

13 This little book made this impression on me as a layman. It speaks purely 13

14 to my historical understanding but doesn't contradict what I already know and 14

15 understand. So then I may trust that artistic colleague who as a person thinks very 15

16 meaningfully, honestly and logically, and also, in so far as one also considers him 16

17 as a sociable musician, appears really charming. I would hope that your judgement 17

18 would confirm my impression. 18

19 [...] On this occasion some of my old observations surfaced again and I will 19

20 voice them here. The musician, if in other areas of his life he lives with his senses 20

21 and is sensible, is moral and decorous, enjoys great advantages in the course of his 21

22 life, because he can assimilate himself better than others to the course of life and 22

23 to all kinds of pleasures. For this reason, your descriptions of your travels ${ }^{139}$ have 23

24 a distinct and double charm: the architect and musician are combined with the man 24

25 of sterling value, and the extent of this society can hardly be appraised [...] 25

26 If you come across my musical table ${ }^{140}$ when unpacking, do send it to me. I 26

27 would like to have a look at it once again, for I think I have gained new insights 27

28 into this area. [...] 28

$30-30$

$31+31$

$32 \quad 32$

$33-33$

$34-34$

$35-35$

$36 \quad 36$

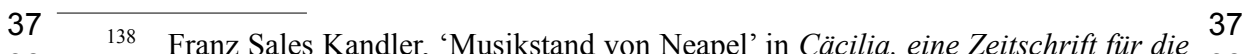

38 musikalische Welt 6/24 (1827): 235-96; the article was published with an accompanying 38

39 manuscript of a Neopolitan Tarantella melody and La Monacella. Goethe knew the journal

40 for a long time and possessed a copy himself (Ruppert, no. 2549); he started a review of 40

41 Kandler's treatise which, unfortunately, remained a fragment. 41

$42 \quad 139$ Zelter's travelogue in letters from his journey to Vienna in 1819.

$43 \quad 140$ Goethe's Tonlehre, which he had sent to Zelter in a letter of 6 to 9 September 1826; 43

44 Zelter returned it to him on 10 July 1827. 
5 At last we have in our hands the much-disputed score of Mozart's Requiem, ${ }^{141} 5$

6 corrected from manuscripts, and we know what we knew. ${ }^{142}$ Since you are familiar 6

7 with the periodical Cäcilia, you must have become acquainted with the bitter, 7

8 sour jabbering of Gottfried Weber ${ }^{143}$ of Darmstadt against the authenticity of this 8

9 posthumous work. There he affirms that the Requiem is as good as not Mozart's 9

10 at all, and that if were, it is the weakest, nay, the wickedest thing, that ever came 10

11 from the pen of that illustrious man. So he says Mozart left the work incomplete, 11

12 but after his death Süßmeyer ${ }^{144}$ came along and suppressed Mozart's thoughts, so 12

13 that the work, through his completion of it, was corrupted, if not poisoned - and 13

14 since Mozart's death, the world has been living in an astonished and astonishing 14

15 state of deception about this legacy - a deception based on a fanciful origin of the 15

16 work - and no one hitherto has had the courage to bring to light the blunders, spots 16

17 and faults of a spurious work of art. So much for Weber's humour.

But we, too, have been in the world since childhood; Mozart was born two 18

19 years before me (1756) and we remember, only too well, the circumstances of his 19

21 Mozart, I say, who had been so soundly taught that he could compose very 21

22 easily and have time left for hundreds of things besides - dallying with women 22

23 and the like - had thereby run his good natural disposition too close. In this way he 23

24 comes to have a wife and children and falls into the extreme of poverty in which 24

25 his basis for existence is lost. Lying on his sickbed, wretched in his home, worried, 25

141 In a rough draft of this letter, Zelter wrote: 'At last I have the latest long-awaited 27 score of Mozart's Requiem. The score also includes indications of the passages which are 28 known to be genuine.' The score was published by Johann André in Offenbach in 1827.

142 The corresponding passage in Zelter's draft letter, again clearly differentiated from 30 the letter sent, states, 'This Requiem is a posthumous work of the composer, to which, on 31 its first appearance, a mysterious genesis was attributed and this was due to the death of the 32 composer at this time. Because of this, it initially received great recognition, which it has 33 retained up to now in its own right' (GSA 95/I, 8, 4).

143 Gottfried Weber had published two comprehensive articles on the question of 35 the authenticity of Mozart's Requiem: 'Über die Echtheit des Mozarts Requiem' in the 36 periodical, Cäcilia 3/11 (1825): 205-29, and 'Weitere Nachtrichten über die Echtheit des 37 Mozartschen Requiem', Cäcilia 4/16 (1826): 257-352. In the first essay Weber wrote, 38 'After all these considerations the authenticity of the work, to say the very least, is highly 38 suspect, and the truth, that the greater part of it is not by Mozart but by Süssmayer, is highly 40 plausible', p. 211. Mozart's Requiem, 'as we now possess it, is vastly different from what 40 Mozart wanted to have given us - and the worst thing about it is that he had already given 41

it to us, but up to now it has still not been passed down to us.' Ibid. 
1 decried, with no helpful friends, in the end he is without even the commonest 1

2 necessities of life.

3 An honest fellow orders any work Mozart may choose, so as to give him a

4 little money in the most delicate way. A libretto is not forthcoming at the moment

5 and Mozart says, 'I have a mind to write a Requiem which you may use for my

6 funeral.' ${ }^{145}$ The weakness increases; he begins to care for his soul, and in solemn,

7 solitary self-introspection, certain beginnings of single parts of the Requiem are

8 unfolded, (as once, with so much truth, you placed them in the mouth of your

9 Gretchen $)^{146}$ Dies irae - Tuba mirum - Rex tremendæ - Confutatis - Lacrimosa ${ }^{147}$

10 and it is precisely these pieces which reveal the deepest contrition of a religious

11 mind, showing at the same time, on one side, the last remains of a great school, 11

12 and on the other, the passionate feeling of a dramatic composer. Consequently the 12

13 style is a medley - uneven, nay, fragmentary - and so arises like that confusion, in 13

14 which the criticism of today takes such delight. Tradition ran like that at the time, 14

15 but no honest man would repeat it out loud.

16 After Mozart's death, worthy Süßmeyer comes forward as the true friend, 16

17 puts the Requiem together, and completes what is wanting, so that the suffering 17

18 family gains some money to meet its basic needs. The work is sold and printed; ${ }^{148} 18$

19 Süßmeyer makes as good an explanation as he can of his share in the work, and 19

20 soon afterwards follows his friend into Eternity.

21 Now comes the aforesaid Hans Taps, ${ }^{149}$ accuses the friend of adulteration 21

22 and lying, and talks in the most contemptuous tone about a well-meaning friend, 22

23

145 This unverified remark of Mozart's goes back to reports and memoirs which were in circulation after the death of the composer in 1791. In connection with the first public

26 mention of the Requiem, the Salzburger Intelligenzblatt wrote in the form of an anecdotal

27 report: 'Now Mozart had to write, which he often did with tears in his eyes, and said:

28 "I fear that I am writing a Requiem for myself"; he completed it a few days before his

29 death. When his death was common knowledge, the servant came back and brought the

30 other 30 ducats, didn't ask for the Requiem and there was never any enquiry about it. It

31 was also true that it [...] was performed in his memory in St Michael's church.' So, too, in

32 Franz Xaver Niemeczek's Mozart Biography, which is based on information from Mozart's

33 wife, Constanze, it states: 'On the evening of his death he had the score brought to his bed.

34 "Have I never mentioned before that I wrote this Requiem for myself?"” Two years later a

35 report by Friedrich Rochlitz in the $A M Z 1$ (1798) states Mozart believed, 'that he worked on this piece for his own funeral. He never gave up on this idea; he worked like Raphael on his transfiguration, always with a feeling of his impending death, and like [Raphael]

37 produced this transfiguration of himself', Christoph Wolff, Mozarts Requiem. Geschichte,

38 Musik, Dokumente, Partitur des Fragments (Munich, Kassel, Basel: dtv and Bärenreiter,

39 1991), pp. 122, 124 and 15.

$40 \quad 146$ Faust 1, Cathedral scene. $\quad 40$

$41 \quad 147$ Parts of the Latin Requiem Mass.

42148 Mozarts Requiem. The first edition was published by Breitkopf and Härtel (Leipzig) 42

43 in 1800 .

$44 \quad 149$ Gottfried Weber in his essays published in the journal Cäcilia. 44 
1 without suggesting any safe criterion as to what is Mozart and what is Süßmeyer, 1

2 ascribing to Süßmeyer what he cannot possibly have written, and vice versa; without 2

3 reflecting that if a clever man like Süßmeyer puts his mind to it, he can quite well 3

4 avoid the Dormitat Homerus himself. ${ }^{150}$ And this really happened. The Benedictus 4

5 is as good as it can be and cannot be Mozart; the school decides as much. Süßmeyer 5

6 knew Mozart's school but he had not been in it; he had not been through it in his 6

7 youth, and here and there traces of this are found in the beautiful Benedictus. 7

8 On the other hand, whatever is found fault with in Mozart's work, Süßmeyer is 8

9 said to have done. Thus the critic explains that the first number in the Requiem 9

10 has been borrowed from Handel, ${ }^{151}$ and consequently cannot be by Mozart -10

11 who often and unquestionably attempted to write in the Handelian manner, in 11

12 order to convince himself that he, too, could do that kind of thing. In this piece 12

13 we have besides the choral music, a cantus firmus, and an old melody too; guess 13

14 what? It is the simple melody - (how does the 'Magnificat anima mea' 152 come into 14

15 a Requiem?) in a word, it is the old cantus firmus to be found in the Luther Chorale 15

16 Book up to this very day, 'Meine Seele erhebt den Herrn'. ${ }^{153}$ Just now I called the 16

17 work fragmentary and uneven, by which I mean that the movements collectively 17

18 are like a mosaic and he who insists on considering them as a whole is mistaken, 18

19 as are several excellent composers. The whole Requiem consists of such pieces, 19

20 and in spite of that, it is the very best I know of in the last century. 20

21 Before Mozart had taken a look round north Germany, ${ }^{154}$ Handel may have 21

22 shone out for him as the most powerful talent in Germany; some of his compositions 22

23 bear the superscription 'Nel Stilo di Haendel'. Then Mozart arrives in Leipzig, 23

24 while Hiller is yet alive, and pricks his ears up at Sebastian Bach, to the great 24

25 astonishment of Hiller, who is trying to fill the St Thomas choirboys with horror 25

26 at the crudities of that Sebastian. What does Mozart do? He tries his hand at this 26

27 style with a dexterity that only such a school can give. Just listen to the music of 27

28

29

30 slips one can make. Thomaskirche.

151 The musical material of the Introitus is, to a large extent, derived from the opening 31 chorus of Handel's Funeral Anthem for Queen Caroline, HWV 264.

150 Reference to Horace, Ars Poetica, v. 359. Literally, 'Homer nods', meaning the 29 46-55. 34 The opening words of Mary's hymn of praise ('My soul glorifies the Lord') Luke 1, 33

153 For the 'Te decet hymnus Deus in Sion', in Part One of the Requiem Mozart chose 35 the 'tonus peregrinus', occasionally called Psalm no. 9, to which the German Magnificat of 36 the Lutheran Liturgy is sung ('Meine Seele erhebt den Herrn'). Luther's German translation 37 of the text of the Latin Magnificat found its way into the Porst songbooks used in Berlin. 38

154 In 1789 Mozart undertook a journey with Prince Karl von Lichnowsky to Berlin, 39 where he received a commission for a string quartet from King Friedrich Wilhelm II. On 40 his return journey through Leipzig he sought out Johann Friedrich Doles, a student of Bach, 40 who, on account of quarrels with the rector, had retired from his position of Cantor at 41 the St Thomas Kirche. Doles arranged for the Thomaskirche choir to demonstrate Bach's 42 motet Singet dem Herrn for Mozart, who performed and improvised on the organ at the 43 
1 the black men in Die Zauberflöte (before the ordeal by fire). It is inlaid; it is the 1

2 Luther Chorale 'Wenn wir in höchsten Nöthen', ${ }^{155}$ interwoven with the orchestra 2

3 in Bach's style - and so on.

4 I can help with your desire to discover more about Kandler through the 4

5 enclosure, where you will see that once again we are of the same opinion about 5

6 the same subject. The report on the condition of music in Naples also pleases 6

7 me. I have also never regretted seeing the contemporary nature of my art with 7

8 favourable eyes in comparison with the earlier cherished conditions of art in Italy. 8

9 One can do the art lovers of the last century too much honour if one wanted to 9

10 attribute too much artistic integrity to them. The beautiful and the great are often 10

11 found isolated, floating on a sea of Mannerism. Admittedly it is still to be admired 11

12 that Italian commonness still has a certain greatness founded, as it were, itself 12

13 on their right of ownership. Whoever, with a healthy sense, wants to convince 13

14 himself of this should come to us and see and listen to how a beautiful feminine 14

15 creature with a magnificent voice of a rich nature fills our opera house, innocently, 15

16 naturally with buck-trills, hackneyed mannerisms, chromatic botched-up work, 16

17 and discredits the nobler attributes we really have. One sees it with disapproval, 17

18 criticizes, goes back again. So it was and is. 18

19 The best of the Italians have - everyone knows - been surpassed by Handel and 19

20 Hasse here and also by the more flawed Graun. But [the Italians] were on home 20

21 [territory] [...] the foreigner has to take care and at least wins back his stake. 21

22 Your table ${ }^{156}$ is firmly fixed on my wall. I thought you would have kept a copy. 22

23 Now you will have it copied first, which I would not be able to do in the next few 23

24 days. 24

25 Nineteen letters from 1826 are enclosed here. ${ }^{157}$ It will be a strong collection. 25

$26[\ldots] \quad 26$

27 The 'Altschottish' is an excellent work; ${ }^{158}$ the metre is very manageable. The tone 27

28 of the whole piece is not so easily found. In a peculiar way your own handwritten 28

29 copy is at the same time very significant to me. Something similar happened me 29

30 with the 'Pillalu', ${ }^{159}$ which, if I am not mistaken, is completely successful in that 30

31 I was really lucky to capture the right mourning tone of the funeral march, the 31

32 metre of which was going round in my head. We have no concept of such work 32

33 afterwards and yet how would we know whether it hits the right tone when we 33

34 have no image of it? In 'Pillalu' I see the entire procession marching by me. [...] 34

$36 \quad 155$ Zelter means the song of the two men in armour, 'Der, welcher wandert diese

37 Straße voll Beschwerden'; this does not hark back to the chorale melody mentioned by

38 Zelter but uses the melody for 'Ach Gott von Himmel, sieh darein'.

$39 \quad 156$ Goethe's Tonlehre which Zelter returned on 16 July.

$40 \quad 157$ Seventeen letters from 1826 have been handed down; possibly Zelter included

41 Goethe's letter of 30 December (which arrived on 3 January) and counted one of the long 41

42 correspondences, for example 6-9 September, as two letters

$43 \quad 158 \quad$ Enclosed GZ 9 June 1827.

$44 \quad 159$ Zelter's setting of Goethe's poem 'Klaggesang. Irisch'. 
$5[\ldots]$ Monday. Yesterday there was a pleasant festival in our new music hall. ${ }^{160}$ The 5

6 local horticultural society ${ }^{161}$ celebrated the anniversary of its foundation [...] The 6

7 King was invited but didn't appear. [...]

8 Tuesday. According to the agreement this lovely garden kingdom was to have 8

9 been cleared away by yesterday morning. I asked them to stay till this evening 9

10 so that all the members of the Sing-Akademie, which meets on Mondays and 10

11 Tuesdays, could enjoy it, whereby I had also invited the horticultural society as 11

12 audience. I had also suspected something which, in fact, came true. Yesterday 12

13 evening around six o'clock the Sing-Akademie was still there and the King asked 13

14 whether the exhibition was still there and if he could see it in private. I replied, 14

15 'After seven', and released the members around this time. Then he appeared with 15

16 his entourage to find only me, looked through everything attentively, named many 16

17 of the plants saying, 'I have that too'. (They were all out of his gardens.) He praised 17

18 the hall: lovely proportions, tasteful and so on [...] From this noble gathering of 18

19 approximately 12 people, Princess Marie remained behind with her husband, Prince 19

20 Carl. ${ }^{162}$ Her first question was how you are [...] She had me show her the remaining 20

21 rooms of the hall, sat down on a chair here or there [...] asked about this thing or 21

22 that in the most gracious manner and finally enquired about little Felix who is now 22

23 an 18-year-old student at the university, ${ }^{163}$ almost an adult, and whom I could praise 23

24 from the heart on account of his continuous industry in everything which is worthy 24

25 of being known, about which she showed her appreciation and delight. 25

26 Imagine now your gruff old fish in the presence of a quiet, intelligent, very 26

27 young, newly-wed, royal princess, who is listening graciously and patiently 27

28 to what the spur of the moment places on the lips of an old man. At the same 28

29 time imagine a calm pleasant coolness of the evening after surviving Catalani 29

30 in an oppressive opera house. There is nothing more to report other than that an 30

31 approaching rainstorm perhaps robbed me of such a sweet presence ${ }^{164}$ somewhat 31

32 earlier [than expected]. I was on my own home territory where one may speak 32 was hired out to other organizers. See, for example, the review of an exhibition in the Sing- 36 Akademie hall on 17 June, Vossische Zeitung, 193, 18 June 1827.

161 Berliner Verein zur Beförderung des Gartenbaues in den Königl. Preußischen 37 Staaten (The Berlin Horticultural Society).

${ }_{162}$ Maria Luise Alexandrine of Prussia, née Princess of Sachsen-Weimar-Eisenach 39 (1808-77) married Prince Carl Alexander of Prussia (1801-83), third son of King Friedrich 40 Wilhelm III, on 26 May 1827.

163 Felix Mendelssohn registered at Berlin University in the Autumn of 1827. The 42 publication of the Terenz translation was accepted as proof of his qualifications. 
1 freely otherwise perhaps many words would have been spared. In the course of 1

2 the conversation I had named Felix as the best performer. The Prince asked hastily, 2

3 'Better than Hummel?' I no longer remember exactly what I answered; let's say: 3

4 the best person which one can be in every situation. 4

5

6

398. Goethe

11 It is clear from your invaluable writings, ${ }^{165}$ my dear Zelter, that you have developed 11

12 the gift of teaching perfectly and thereby are very thorough with your students in 12

13 every case. You have answered my question in such a way that - as difficult and as 13

14 remote as it is - I can approach it feeling some relief. It is really strange that music, 14

15 as it emerges from its first simple depths, soon belongs to the fleeting moment and 15

16 must caress frivolous ears. No wonder that after so many years it finally runs off 16

17 on the course we now see it following.

$24[\ldots]$ At this juncture I thought of the worthy organist of Berka; for it was there, 24

25 when my mind was in a state of perfect composure and free from external 25

26 distraction, that I first obtained some idea of your Grand Master (Sebastian Bach). 26

27 I said to myself, it is as if the eternal harmony were conversing with itself, as it 27

28 may have done in the bosom of God just before the creation of world. So likewise 28

29 did it move in my inmost soul, and it seemed as if I neither possessed nor needed 29

30 ears nor any other sense - least of all the eyes.

31 As soon as music makes the first vigorous advance towards having an outward 31

32 expression, it powerfully excites our inborn sense of rhythm, of step and dance, 32

33 of song and rejoicing by degrees, it runs off into the transoxanic, (vulgo Janissary 33

34 music) or into the yodel, into the love-cooing of birds. 34

35 Now, however, a higher culture steps in; the pure Cantilena flatters and charms 35

36 us; gradually, the harmonic Chorus is developed, and thus developed, the whole 36

37 strives to return again to its divine origin $\quad 37$

40

41

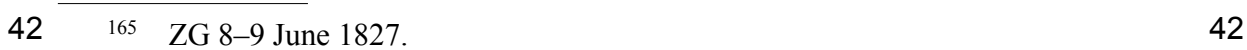

43166 This letter is from MA 20.3, p. 833; the letter is marked 'Cassiertes Mundum', 43

44 meaning an invalid fair copy. 
5 [...] The Theory of Sound [table] is copied and is included here ${ }^{167}$ with a request 5

6 for forgiveness if it should have suffered through being pinned. My ideas for some 6

7 parts still have to be developed. [...]

14 [...] The high pressure of musical, prosaic, dramatic, literary, scientific and 14 15 other performances [in Berlin], which the newspapers thrust on us, could almost 15 16 disconcert and overpower a distant recluse. However, I like to believe that, in the 16 17 midst of all this activity, one may remain true to oneself, just as it is possible to 17 18 find inspiration on the shores of a raging ocean. [...] 18

25 I have finally seen, heard and tasted your La Roche and in Il matrimonio segreto. ${ }^{168} 25$

26 The roles of the absent Spizeder have fallen to him; Spizeder ${ }^{169}$ is rightly a favourite 26

27 [actor], and so, as people were saying, La Roche was not likely to appeal, and so 27

28 he really surprised me. He sang the Privy Trade Councillor in this opera well 28

29 and acted excellently. Besides being a vain half-deaf fool, he is also a father. The 29

30 whole thing is very funny. opinion of both actor and opera: 'But La Roche is a true actor. Disposition, feeling, spirit, 38 bearing, tone and voice are so well fused, that no particular apect stands out and it is good 38 to find a practitioner who doesn't want more than he should or can [be]. Here we have only
one such actor (Beschort), who nonetheless is not without characteristics which reveal his 40 individual personality. The whole opera, which, on the whole, I would gladly listen to, went 41 
519 August: Our friend Nägeli produced a musical work which was philosophically, 6 theosophically, pedagogically, historically and critically prophetic; claiming that 7 the new instrumental music, which is raised up to the highest point and is to be 8 intensified to an infinite degree, as ideally the highest ${ }^{170}$ - finally combined with a 9 choir of a hundred voices ${ }^{171}$ - will end by representing transfigured humanity in a 10 transfigured sound creation.

11 There is something attractive about his ideas which I would envy him, if one 11 12 had not also had such notions 50 years ago, and now - I am still groping around in 12 13 your songs. He claims such choirs of 100 voices were already in existence in his 13 14 Swiss and southern German towns: 'I can, with full certainly, and with an eye on 14 15 the previous course of development, predict how and through what main means 15 16 instrumental music will and must reach a boundless idealization' ${ }^{172}$ and so on. 16 17 Mozart suffers rather badly; Pleyel is always treated with esteem; ${ }^{173}$ old Bach and 17 18 Beethoven come out the best. Since you hardly ever read such things you might like 18 19 to accept a private note about it and this will be a good way for me to get rid of it. 19 20 With regard to your Theory of Sound ${ }^{174}$ I have something that will make you 20 21 happy. It is still not ready, although I have already carried it around with me for 21 22 years. It concerns the minor scale. It is as if it were nailed into me, but one is torn 22 23 this way and that. When the opportunity is there to talk about it, it abandons me. 23

24 Then if I hear others speaking about it again, I want to laugh out loud at my own 24

25 ideas.

170 'Once a principle of such a transfigured and transfiguring music has taken root, if 31

32 the artists as such are able, in this way, to honour truth in beauty, then a time comes about

33 when instrumental and vocal music is to a large extent linked. Then superb folk choirs will

34 be formed and the artists will be able create the true and the genuine for them in a grandiose

35 style so that instrumental music, with all its effusive splendour serving as a background

35 to a hundred voice choirs, will represent a transfigured humanity in a transfigured music

36 creation'; Hans Georg Nägeli, Vorlesungen über Musik mit Berücksichtigung der Dilettanten

37 (Stuttgart, Tübingen, 1826), p. 282.

38171 'Such choirs of a hundred voices are already in existence in our Swiss towns and

39 those of Southern Germany', Nägeli, p. 282.

$41 \quad 173$ The Austrian composer Ignaz Joseph Pleyel (1757-1831) is favourably presented; 41

42 Nägeli, p. 181.

$43 \quad 174$ Zelter didn't follow this up in the letters which follow, but may have discussed it 43

44 with Goethe on his visit to Weimar on 12 to 18 October 1827. 
404. Goethe 1

5 [...] Put on paper what you have in mind about the minor scale: it would arrive 5

6 exactly at the right time. I have also thought out something with Riemer about it. ${ }^{175} 6$

7 I want to dictate it, seal it and wait for your consignment rather than send it straight 7

8 away. It would be really nice if we reached the same conclusion in different ways. 8

$9[\ldots]$

10 I would like to have your OJemine $^{176}[\ldots]$ as a text forming the basis of a long, 10 11 serious sermon. I suspect a sense for music should accompany each and every 11

12 artistic sense. I would like to support my claim through theory and experience. 12

tember: If I could give you on a good day (because it is suitable to that 20 21 time) one of Bach's motets to listen to, you would feel yourself at the centre of 21 22 the world, where someone like you belongs. I am listening to the work for the 22 23 hundredth time and am still not finished with it and never will be. 'Compared to 23 24 him we are all children', his son Philipp Emanuel remarked. Yes, children! I feel 24 25 myself raised up and destroyed. He is terrible but divine. The majority of us are 25 26 also not hawfinches, so it is amusing how they act at the beginning and do not 26 27 come to themselves until they have left Rossini behind.

28 Munich, 22 September: Today they are expecting the King ${ }^{177}$ at the assembly 28 29 and so I also want to go. I saw him and his beautiful wife ${ }^{178}$ at the opera ${ }^{179}$ yesterday 29

30 evening. I was with Spontini in the artistic director's box, but I only enjoyed Act 30

31 One because I was also invited with Cornelius and Bertram to the von Cotta's. [...] 31

32 They have not settled in yet and could not entertain properly, which suits me fine. 32

33 The evening was really pleasant and no one else was there other than Cornelius 33

34 and Bertram. [...] 34

176 Zelter's 'O gemini!', suggestive of twins and of a general cry of terror, is directed 38 at the Humboldt brothers.

40177 Ludwig I of Bavaria (1786-1868). 40

$41 \quad 178$ Therese Charlotte Luise Friederkike Amalia of Bavaria, née Princess of Sachsen- 41

42 Hildburghausen (1792-1854). 
1 A good part of the evening conversation here is concerned with the theatre. They 2 complained generally about plays and operas: everything should have been much 3 better, even incomparable, and until yesterday evening I listened to everything 4 quietly. They demanded a comparison with Berlin: [...] As a guest I cannot know 5 how it is here. With us the audience is divided. One demands Italian opera, the 6 other German opera. Typical Italian opera really exists; individual attempts can

7 turn out one way or another. Even one successful performance is enough for 8 reconciliation. A German opera (of this kind) does not exist at all. They want to 9 call good works from earlier times obsolete and the very latest works are never 10 new. The composers complain about the poets, the singers about the composers, 10 11 and vice versa. You'd get the impression that the poet, the composer, the singer - 11 12 no one understands his profession and knows what he wants. A lady offered me 12 13 her arm to let me lead her to table: 'Why have you not spoken about it with the 13 14 scientists?' The evening was incidentally very cheerful and pleasant. [...] $\quad 14$ 1526 September: I have been to the Königliche Bibliothek ${ }^{180}$ three times. It is 15 16 really well stocked and contains rare musical codices and manuscripts from the 16 17 sixteenth century which are splendidly produced and well preserved. I myself am 17 18 mainly interested in the majority of works from the second half of the seventeenth 18 19 century and the first half of the eighteenth century in order to enrich my Sing- 19 20 Akademie even more, because we have assembled a really good collection in 20 21 Berlin. The earlier works belong to the Catholic Church as the mass vestments 21 22 belong to the priests. In the Altschneider, formerly the Frauenhofer Institute, ${ }^{181}$ I 22 23 had to admire the largest telescope and smaller instruments as well. The institution 23 24 itself is in full swing and appears to be bombarded with work.

25 Thursday. There was an opera yesterday evening: Die Prinzessin von Provence, 25 26 an original magic opera in three acts. The libretto and the music are by von Poißl, ${ }^{182} 26$ 27 artistic director of the local Nationaltheater.

28 The poet and composer has been my very good friend for some years and right 28

29 now an especially dear friend. Recently he lost the mother of his children ${ }^{183}$ and 29

30 his eldest grown daughter. We sat beside each other in the box and here I fully 30 31 realized what it means to speak the truth to such a kind friend and double author, 31 32 when he gladly listens and compares it to accepted judgements. The house was 32 33 full: theatre and orchestra equipped as an author would want who has the power 33 34 in his hands. Loud applause does not happen here in the presence of the nobility 34 35 and so sitting next to a friend I was able to be honest about every single passage 35

$37 \quad 180$ In the former Jesuit college Neuhauserstraße; the building for the Bayerische

38 Staatsbibliothek was built by Friedrich Gärtner between 1832 and 1842 .

$39 \quad 181$ The Mathematisch-mechanische Institut founded by Joseph von Utzschneider,

40 Georg von Reichenbach and Joseph Liebherr in 1804 was, in 1819, united with the Institute

41 founded in Benedicktbeuren by Joseph von Fraunhofer in 1807.

$42 \quad 182$ Baron Johann Nepomuk von Poißl (1783-1865), composer. 42

$43 \quad 183$ Baroness Maria Walpurga von Poißl, née Countess von Hegnenberg-Dux (1778- 43

44 1826). 
1 which could be praised and pass over in silence what he himself considered to 1

2 be successful. But it is and remains a hopeless situation, all the more since it can 2

3 easily be observed that the author does not lack public favour. So I left the box 3

4 quietly, mixed among the people (the faithful followers) who will always be there, 4

5 gently pressing forward and holding back and discovered what all the wisdom 5

6 in me could only have discovered late: the opera is a masterpiece of a musical 6

7 amateur and not one among many thousands will match the author in what he has 7

8 achieved here. I would have been able to sleep peacefully if before going to bed 8

9 I had not drunk an inordinate amount of Bavarian beer, which a stranger has to 9

10 respect. [...]

1127 September: I got into a conversation about the origins of language with 11

12 Professor Martius who spent four years in India. ${ }^{184}$ If I understood him correctly, 12

13 he believed he had discovered there the infancy of humanity. He sets against our 13

14 music their way of communicating with one another through pure sound and 14

15 physical movement and thereby seems to conclude that language is older than 15

16 singing. He also was able to offer many examples, which I don't remember but 16

17 which would be opposed to anything that could be deemed lyrical. [...] 17

18 Sunday: Today Spontini is conducting his Die Vestalin in the Königliches 18

19 Theater. ${ }^{185}$ The orchestra are enchanted by the opera and also with his direction. 19

20 That's a recipe for success.

21 Nuremberg, 4 October. [...] Yesterday I got to know the 82-year-old von 21

22 Imhof, ${ }^{186}$ former senior civil servant at the royal castle, who at the same time was 22

23 willing, at the request of the ladies, to perform old arias from his era for me on the 23

24 fortepiano for half an hour, and to improvise. The good old fellow became highly 24

25 animated as he told me about Hasse, Gluck, Emanuel Bach and Haydn, whom he 25

26 had known personally, and was able to make me green with envy. I was able to 26

27 praise his playing honestly; it was not too bad.

288 October: We arrive at the [St] Sebald basilica to the sound of the loveliest 28

29 bells. Trumpets play the chorale Jesus meine Zuversicht from the tower and then 29

30 finally, as we passed other churches, all the bells came together. We arrived at the 30

31 door of the graveyard gates. Here a coffin was uncovered [...] A choir of brass 31

32 instruments played the funeral music softly [...] The coffin was put into the tomb 32

184 The botanist Carl Friedrich Philipp von Martius had taken part in an expedition to 35 Brazil (not India), after which he published a three-volume work and an atlas with Johann 37 Baptist von Spix, Reise in Brasilien auf Befehl Sr. Majestät Maximilian Joseph I. Königs 38 von Baiern in den Jahren 1817 bis 1820 gemacht und beschrieben (Munich, 1823, 1828 and 38 1831). As Spix died in 1826, only volume one and three chapters of volume two are by both 39 authors); see exhibition catalogue, Brasilianische Reise 1817-1820. Carl Friedrich Philipp 40 von Martius zum 200. Geburtstag, ed. Jörg Helbig (Munich: Hirmer Verlag, 1994). 41

185 On 30 September 1827 in the Munich Nationaltheater; a second performance took 42 place on 11 October; AMZ 29 (1827), no. 52, 26 December, column 888f. 
1 to the accompaniment of Klopstock's Lied 'Auferstehen wirst du' ${ }^{187}$ I also saw 1

2 Dürer's grave in this atmosphere, and went for something to eat and only got my 2

3 appetite back by eating.

4 Coburg, 11 October: Here again I discovered Kapellmeister Schneider, ${ }^{188} 4$

5 whom I have known for 30 years. His brother took lessons with me with Fasch 5

6 in Berlin: an odd fellow who called himself 'Seneiders' because the name 6

7 'Schneider' sounded too common to him. [...] I have just come from an opera 7

8 rehearsal where they were rehearsing, and not badly, the opera Euryanthe by Carl 8

9 Maria von Weber, ${ }^{189}$ which is to be performed tomorrow. What one seldom finds 9

10 can be found here: all the singers on the stage are better than the orchestra, who 10

11 admittedly are badly directed. A bass by the name of Schmitt ${ }^{190}$ is even first-rate: 11

12 voice, physique, and range of performance, age - everything comes together; at 12

13 the same time he is also valued as an actor here. Of all the others I could not 13

14 call one bad. The first soprano ${ }^{191}$ and first tenor ${ }^{192}$ are even good and everyone is 14

15 very musical. Even the choruses were good and stood out. I am not in a position 15

16 to judge the production. I place the music to Euryanthe above Der Freischütz 16

17 (which I admittedly cannot stand). As in all of Weber's compositions there is also 17

18 much in it that is striven after, so many bits and pieces, a combination of fine 18

19 morsels; difficult and foreign passages together; forced liveliness, and, amid all 19

20 this, certainly good passages and a diligence which I admire with horror because 20

21 all the junk doesn't deserve it. The Germans, who begrudge the Italians their fame, 21

22 nonetheless want to reproduce the parlare cantando or cantare parlando and don't 22

23 grasp that the Germans don't learn to speak. Whoever can speak like the Italians 23

24 will sing automatically. Everything else is irritating. To drum, blow and bow is still 24

25 not singing - not by a long shot. 25

$32 \quad 187$ 'Die Auferstehung', first published in Klopstock's Geistliche Lieder, vol. 132

33 (Kopenhagen und Leipzig, 1758); set by Carl Heinrich Graun in 1758, by C.P.E. Bach in

34 1787, later composed by Friedrich Heinrich Himmel and Bernhard Klein, well known as a

35 funeral hymn from the beginning of the nineteenth century.

35188 Georg Laurenz Schneider (1766-1855), composer, music director and organist at

$37 \quad 189$ The premiere of Carl Maria von Weber's Euryanthe took place on 11 October

38 1827, a few months after the ducal theatre of Sachsen-Koburg-Gotha had been set up on

391 June. See Rudolf Potyra and Jürgen Erdmann, Die Theatermusikalien der Landesbibliothek

40 Coburg (2 vols, Munich: G. Henle Verlag, 1995). 40

$41 \quad 190$ Johann Adam Schmitt (c.1790-1827/28), singer and actor. 41

42191 Either Anna Posch or Auguste Weinkauf, née Amberg (1796-1833), both of whom 42

43 were singers at the Coburg Theatre at this time. 43

$44 \quad 192$ Julius Rochow (d.1863). $\quad 44$ 
5 Admittedly our correspondence over many years has not been lacking in material. 5

6 You have really taken an interest in my bit of musical knowledge, where the rest 6

7 of us [musicians] stagger around. Who was to tell us?

14 Admittedly, my dear Zelter, it is a difficult task if we expect the average fellow 14 15 to sing such poems ${ }^{194}$ and to see any meaning in them. If someone demanded a 15 16 commentary ${ }^{195}$ from me, I would offer to write another poem with the same content 16 17 and meaning but comprehensible and more accessible. If I were successful, I would 17 18 also ask you likewise to compose it for the Liedertafel and to get it going without 18 19 revealing the purpose, and then announce the task: they are to elucidate the abstruse 19 20 text and assimilate it. We could indulge in such cheerful and basically useful and 20 21 meaningful exchanges. With distance such actions are hardly conceivable.

I don't recall having a conversation about Serbian poetry. ${ }^{196}$ Don't neglect 22 23 to introduce yourself to these remarkable products of our southern neighbours, 23 24 which, for us, are also gradually sprouting, blossoming and bearing fruit. If one 24 25 or other of the little songs speaks to you, don't begrudge them your penetrating 25 26 harmonic expression. In general, the achievements of the eastern languages, which 26 27 take in such an enormous area, are gradually becoming of interest to us. 27

193 This letter was dictated at the earliest on 12 or 13 March 1827 and answers Zelter's 36 letter of 26 February to 10 March which arrived in Weimar on 12 March. Presumably the 37 letter was not sent due to the news of the death of Zelter's son, Georg, on 15 March. Goethe 38 handed the letter to Zelter on 17 October during his stay in Weimar from 12 to 18 October. 39 194 Namely, 'Dreistigkeit'. $\quad 40$ 195 On 26 February Zelter mentioned that he had been asked for an explanation of 41 Goethe's poem.

196 Goethe's first reference to the Serbian poems published in $K u A$ VI, 1. See also GZ 43 
5 Old Voß once said to me, when I had merely altered the position of a single word 5

6 in his 'Friedensreigen', 'You may leave that alone!' - and of course I might have 6

7 done so, but it would have been all bound up with my love of the poem. I must be 7

8 allowed to appropriate a part of it, in order to make it completely my own; what 8

9 do I care about the poet? His word is a stone, hurled into space, which I pick up, 9

10 and how I pick it up, and how I look at it, know and interpret it is my affair; and if 10

11 he wants to be just, and if he has understood me, as I have understood him, he will 11

12 remember that his word is printed, and remains his own. [...] Naumann of Dresden ${ }^{198} 12$

13 had not altered a single word in Schiller's 'Die Ideal', and Schiller scolded like 13

14 a fishwife at that famous man's composition, because it turned a beautiful poem 14

15 into a throat exercise for a prima donna. But with no words am I more cautious, 15

16 more pure, than with yours. The very first time I read your poems, I grasp the 16

17 sense, the feeling of the whole, and the melody comes at once; I only stop short 17

18 at a word, a phrase; then I let it lie, until - Heaven knows how long afterwards - 18

19 my word comes of itself and then I finish. A number of your poems have been 19

20 lying thus for years. [...]

27 [...] I have had the pleasure of seeing Mademoisselle Sontag twice at the 27

28 Königliches Theater, as Myrha in the Opferfest, and Susanna in Mozart's Figaro. ${ }^{199} 28$

29 Though I cannot particularize any special quality in her, her entire being is suited 29

30 to the stage. She knows how to look well on the larger stage, whether as third, 30

31 fourth or fifth and so on, surrounded by so much that is strange, and her ability 31

32 to vocalize and articulate perfectly raises her above much stronger voices like a 32

33 bright star. Her face moves with the melody, as do her arms and hands, and all that 33

34 without repetition; it is always the same, and yet it is new. One duet was called for 34

38 This letter is from MA 20.3, p. 867, where it is entitled: 'Draft to a letter that was 39 never written or was never sent'.

41199 Henriette Sontag appeared in Peter von Winter's opera Das unterbrochene

42 Opferfest (libretto by Xaver Huber) on 25 October 1827 and in Mozart's Die Hochzeit des

43 Figaro on 27 October 1827; see AMZ 29 (1827), no. 47, 21 November, column 794; MA 4420.3 , p. 874-5. 
1 again; the two singers came back ${ }^{200}$ as they had gone off; first she had stood on the 1

2 right side, now she stood on the left and the whole duet seemed like a new piece, 2

3 which I, at all events, could have heard for the third time. Some people also called 3

4 out 'da capo' again. [...]

5

6

7

410. Goethe 7

8

End of October to 6 November $1827 \quad 9$

116 November: Thank you for your delightful account, which helped me to realize the 11

12 gracefulness of that dainty singer, ${ }^{201}$ my ear is long unaccustomed to the pleasures 12

13 of such music, but my spirit is still receptive. The recent performance of Die 13

14 Zauberflöte $^{202}$ had an ill effect upon me; in the past I was more susceptible to such 14

15 things, even though the performances were not any better. Now two imperfections 15

16 had to do with this, one external, the other internal, and the sensations produced 16

17 were such as one experiences when striking a bell with a crack in it. It is very 17

18 strange; for even the repetition of your much-loved songs was not going to 18

19 succeed. It is better to put up with such a state of affairs than to continually talk or 19

20 even write much about it. $\quad 20$

21

22

23

27 What I wrote to you about Madame Sontag was meant as an explanation of the 27

28 general impression. One can imagine that such a person, who can put aside an 28

29 honorarium of 11,000 thalers in a few weeks (not counting significant presents) 29

30 will arouse envy among those around them. Those performing with her admit to 30

31 her that they enjoy acting and singing with her and that the effect is good. 31

32 A composition of one of my students ${ }^{203}$ may reach you. The girl was sent to 32

33 me for lessons from the Friedrich Society in Danzig. Pretty, healthy, 20 years old, 33

34 a lovely voice, talent and invincible desire. She is the third one who comes back 34

35 from Danzig already well trained. If she remains so and her talent is not wasted, 35

36 she could turn out very well. She has already gone far enough on the piano for it 36

37 to be useful to her. [...]

39200 Henriette Sontag and Carl Adam Bader in Myrrha and Murney's Duet, 'Wenn mir 39

40 Dein Auge strahlet', from Winter's Das unterbrochene Opferfest; see Spenersche Zeitung 40

41 no. 252, 27 October 1827.

$42 \quad 201 \quad$ Zelter's account of Henriette Sontag's performances, ZG 28 October $1827 . \quad 42$

43202 On 20 October 1827 at the Weimar Court Theatre. 43

$44 \quad 203$ The identity of the student has not been established. 44 
5 I must report to you that our wandering nightingale ${ }^{204}$ arrived on Sunday, 115

6 November, but owing to some unsuperable confusion, the result of misapprehension, 6

7 neglect, ill-will and intrigue, she has not appeared in public. ${ }^{205}$ On Monday she 7

8 sang at a breakfast arranged by the Dowager Grand Duchess, ${ }^{206}$ and was greatly 8

9 applauded; afterwards, she paid me a visit, and gave us some little examples of her 9

10 extraordinary talent; these were enough for me, in so far as the impression I had of 10

11 her was confirmed and reaffirmed. [...] 11

18 [...] Our King ${ }^{207}$ occasionally has his own quirk: for example, he refuses to have 18

19 any virtuoso as his Kapellmeister. Bernhard Romberg, who is a composer as well, 19

20 is clearly ahead of all virtuosi. He got there with patronage and great effort when 20

21 he discovered that the King had engaged Spontini in Paris. At this time I pointed 21

22 out to him that a king should in any case be allowed to do what the most ordinary 22

23 person would do - namely to spend his money and buy a conductor wherever he 23

24 liked. So Romberg still bears me a grudge, although he wishes to become once 24

25 more what he didn't want to remain - and could still be if he had followed my 25

26 friendly advice. 26

27 [...] Privy Councillor Bunsen arrived from Rome with treasures, ${ }^{208}$ some 27

28 of which the Sing-Akademie will enjoy. The Crown Prince wants to attend a 28

31204 Henriette Sontag. From the time of her first performance in Berlin she was 31

32 continually referred to by the press as a nightingale; see, for example, the Spenersche 32

33 Zeitung of 5 August 1825 and 9 September 1825.

34205 See, for example, $A M Z 30$ (1828), no. 5, 30 January, column 74: 'Sontag, who we

35 had hoped to hear at the theatre on her journey through [Weimar], sang only at the court for

36 a royal audience, accompanied on the piano.'

37206 Maria Pawlowna, wife of the future Grand Duke, Carl Friedrich of Sachsen-

38 Weimar-Eisenach.

$38 \quad 207$ King Wilhelm Friedrich III.

39208 Kunsen's official commission was to accompany the Raphael painting Madonna 39

40 Bunsen's official commission was to accompany the Raphael painting Madonna

40 della famiglia di Lante from Rome to the Berlin museum, where it was to be housed.

41 The Sing-Akademie treasures Zelter refers to concern the church music from the Vatican

42 collection. See the chapter 'Reise nach Berlin 1827-1828' in Christian Carl Josias von

43 Bunsen, Aus seinen Briefen und nach eigener Erinnerung geschildert von seiner Witwe

44 (3 vols, Leipzig: F.A. Brockhaus 1868-71), vol.1, pp. 275-334. 
1 performance of 'O Roma Nobilis' ${ }^{209}$ from the seventeenth century with us today. I 1

2 have never been to Rome and don't know anything about it. The melody from the 2

3 seventh century is modern enough; the current papal Kapellmeister Baini arranged 3

4 it in four-part harmony. ${ }^{210} \quad 4$

5

6

7

8

$11[\ldots]$ When I think of all the things happening above your head whose influence 11

12 you cannot completely fend off, I am not surprised that, caught up in a whirlpool 12

13 of musical, aesthetic, physical and natural-philosophical exhibitions, you could 13

14 hardly ever have time to yourself, even if you did not have to play such an important 14

15 role yourself. Cast a glance around you once again and report some things so that 15

16 the year 1828 will not be turn out to be too thin. Send me my letters from 1827 so 16

17 that I can lay out the codices. Also enclose the little book by Kandler again: the 17

18 way this man lives musically and lets live made a particular impression on me. 18

Berlin, 28 January 1828 to 3 February 182823

28 January. [...] Our building has cost money, more than we have, ${ }^{211}$ so Judas had 25 to be called in - not the one with the purse. ${ }^{212}$ It was not in the budget, however, 26 $\begin{array}{ll}\text { and - scraping money together becomes more difficult as I grow older. [...] } & 27\end{array}$ Breidenstein, whom the ministry sent to Bonn five years ago as Professor and 28 Director of Music so that he might learn from the students there, has come back 29 to Berlin because he couldn't make any headway there. He read a lecture about 30 presumably stemming from Verona (tenth century); it celebrates in song Rome as the scene 34 of the martyrdom of the Apostles, in particular St Peter and St Paul, whose feast day it 35 celebrates. The text is an amalgam of early church songs dedicated to the Apostles. For 36 further information; see Ludwig Traube, 'O Roma nobilis', Abhandlung der Bayerischen 37 Akademie der Wissenschaften 19/2 (1891): 299-395.

210 A score in Zelter's own hand for solo voice and piano is entitled 'O Roma nobilis 38 aus dem VII Jahrhunderte (spätestens) Harmonie v. Baini, korrigiert von Zelter' (SBB PK: ${ }^{39}$ Mus. Ms. Autogr. Zelter 34). $\quad 40$

211 The new building was estimated at 28,000 thaler. $\quad 41$

212 Judas Maccabaeus not Judas Iscariot. The Sing-Akademie performance of 42 Handel's oratorio took place on 17 January 1828; see $A M Z 30$ (1828), no. 9, 27 February, 43 column 146; MA 20.3, p. 890. 
1 musical theory ${ }^{213}$ here for men and women, specialists and laity. I was also present 1

2 at the first lecture. He then expatiated on those who live from hand to mouth and 2

3 since I am one of these and know it, I left him to his theories. [...] 3

4 The letters from the year 1827 are enclosed. ${ }^{214}$ The little Kandler book is also 4

5 enclosed. ${ }^{215}$ Of the latter I will only remark that the information about Hasse is 5

6 taken from Gerber's musical dictionary, ${ }^{216}$ which the French Lexicon ${ }^{217}$ and also 6

7 the latest Italian Lexicon of Pietro Lichtenthal ${ }^{218}$ have regurgitated with all its 7

8 imperfections. [...]

9 Next Wednesday we will perform Judas Maccabaeus ${ }^{219}$ for the general public 9

10 once more. If only you could hear it. The way people talk and write about it, 10

11 neither Handel nor anyone else would recognize his work. 11

$12 \quad 12$

$13+13$

14 416. Zelter 14

$15 \quad 15$

$16 \quad$ Berlin, 7 to 9 February 182816

$17 \quad 17$

18 [...] Our Judas Maccabaeus was set to sea with a favouring wind and to our 18

19 advantage. The King found us worthy enough to listen to and paid 20 Friedrichs 19

20 d'or for his box and in person showed his approval of me. This is of infinite value 20

21 to me, just as his pieces of gold are necessary to us because we have to raise 21

22

$23 \quad 213$ Zelter had already been highly critical of Heinrich Carl Breidenstein (1796-1876)

24 as Director of Music at the University of Bonn when Zelter had visited Bonn in November

25 1823. Breidenstein, who had been made Professor of Music in Bonn in 1826 (and holder

26 of the first chair of musicology in Germany), spent his sabbatical in Berlin in 1827/28. On

279 November he gave the first of a series of 12 lectures on the Theory of Music; these events

28 were intended for those connected with the opera and the orchestra, but they were open to 28

29 all who were interested. 29

30214 Goethe's letters to Zelter from 1827 which were being sent to Weimar to be 30

31 copied. 31

$32 \quad 215$ Kandler's biography of the composer Hasse, which Zelter had requested again on 32

3324 January; Goethe returned the book on 8 January 1829.

$34 \quad 216$ The article 'Johann Adolf Hasse' in Ernst Ludwig Gerbers, Neues historisch- 34

35 biographisches Lexikon der Tonkünstler (4 vols, Leipzig: Breitkopf, 1790-92), pp. 590- 35

36 601, or in the revised version of the dictionary, Neues historisch-biographisches Lexikon

37 (Leipzig: Kuhnel, 1812-14), pp. 517-19. Zelter had both editions. Further editions were

37 published in 1835, 1860 and 1873, the most recent edited by Othmar Wessley 4 vols in 3

38 (Graz: Akademische-Druck und Verlaganstalt, 1966).

39217 Dictionnaire historique des musiciens (2 vols, Paris 1810-11, r.1817). 39

$40 \quad 218$ In his preface to his Dizionario e bibliographia della musica (2 vols, Milan: 40

41 A. Fontana, 1826), Peter Lichtenthal acknowledged the use of Gerber's lexikon; he didn't 41

42 include a biographical article on Hasse. 42

43219 The Sing-Akademie's second performance of Handel's Judas Maccabaeus took 43

44 place on 6 February 1828. 
1 over 3,000 thalers per annum. Otherwise we are quite enjoying ourself as already 1

2 reported: carnival, German opera, French comedy, masked balls and balls. [...] 2

3 I hear yesterday's perfomance of our music praised from all sides. That comes 3

4 from a clever Italian Prince (Lucchese), ${ }^{220}$ who said that if one wants to hear good 4

5 music, one has to come to Germany. [...] 5

6 The post is leaving. I still want to report that the Gesellschaft der Musikfreude 6

7 of the Imperial Austrian State ${ }^{221}$ unexpectedly appointed me an honorary member 7

8 and sent me their diploma certifying it. 8

417. Goethe

A review of my Tafellieder ${ }^{223}$ said that the absolute value of my songs was not 23

Berlin, 10 to 23 February 182821 as great as the aesthetic value - which I would gladly take as praise except that 24 it wasn't meant as such. The aesthetic value of a song is the umbrella concept 25

221 The Gesellschaft der Musikfreunde, established in 1812, was known for its lavish 28 performances of Handel's oratorios; the man who was responsible for this was Ignaz 29 Franz Edler von Mosel, who, next to Zelter, was one of the leading figures in the Handel 30 Renaissance brought about by amateur choirs.

33 to Berlin mid-February for the confinement of her daughter, Maria of Prussia, who had 33

34 married Prince Carl of Prussia in 1827. Goethe had asked Varnhagen von Ense 'to wait 34

35 upon' the future Grand Duchess.

223 Ludwig Rellstab's review series in the Berliner Allegemeine Musikalische Zeitung 36 4 (1827), no. 7, 14 February, p. 51f. and no. 8, 21 February, pp. 59-62: Tafellieder für 37 Männerstimmen, vol. 1 by Friedrich Wollanck, vol. 2 by C.F. Rungenhagen, vol. 3 by C.L. 38 Hellwig, vol. 4 by F.F. Fleming, vol. 5 by C.F. Zelter, vol. 6 by Fr. Lauska. The correct title 39 was Gesänge der Zelterschen Liedertafel in Berlin für Männerstimmen (Berlin: T. Trautwein 40 o.J, 1827). The passage Zelter refers to in vol. 5 reads: 'It is, however, not to be denied that 40 the absolute musical value of his songs is, in general, not as great as the aesthetic value in 41 
1 and embraces the musical, which would otherwise not be aesthetic. So the review 1

2 wants to set me up, itself devoid of understanding, and ultimately criticizes me 2

3 without understanding me, in that it misses many songs in the collection which 3

4 are already well known. The collection also contains my latest Lieder, which are 4

5 still unknown because I don't want the public to buy what it already has free of 5

6 charge. $[\ldots]$

7 Telemann (of Hamburg) said, 'One must be able to set a custom's document to 7

8 music'. Here is a joke about it. A member of our Liedertafel, ${ }^{224}$ who we aren't glad 8

9 to see missing on account of his lovely voice, excuses himself more often than he 9

10 should. So I set his last letter of excuse to music and now we will see whether the 10

11 chap improves himself or wants to be left in prose. ${ }^{225} \quad 11$

12

13

14

15

16

419. Zelter

Berlin, 5 to 8 March 182816

18 I waited on your Grand Duchess ${ }^{226}$ last Saturday. She recognized me immediately 18

19 in von Humbold's lecture and made an appointment around ten o'clock today 19

20 through His Excellency von Henkel. ${ }^{227}$

21 Yesterday evening after five, just as the Sing-Akademie gathered together, 21

22 Her Highness quietly announced her presence through Chamberlain von Oelsen 22

23 and immediately refused any fuss. Our lighting is very rudimentary when we 23

24 are without noble guests; but we just about managed to light up the court box. 24

25 Reichardt's 'Morgengesang' ${ }^{228}$ (in Bürde's translation of Thomson), ${ }^{229}$ which has 25

26

$27 \quad 224$ Staberoh, a merchant and member of Zelter's Liedertafel from 1817 to 1840.

28225 The note had the following wording: 'My dear friend! Since I am feeling slightly

29 off-colour, I cannot enjoy the pleasure of attending the Liedertafel today. As far as the choice

30 of the new Table Officials, I gladly submit to the majority voice. Your humble Staberoh'.

31 Zelter composed a witty amusing little song to be sung by the soloists Hellwig and Gern,

32 accompanied by the Liedertafel chorus. Despite Goethe's request, Zelter did not sent a copy 30

33 to him; the autograph copy, entitled 'Indisposition' and signed 'Poetry by Staberoh. Music

34 by Zelter' is in Zelter's estate (SBB PK: Mus. Ms. Autogr. Zelter).

$35 \quad 226$ Maria Pawlowna of Sachsen-Weimar-Eisenach.

$35 \quad 227$ Countess Ottilie Henckel of Donnersmarck, grandmother to Ottilie and Ulrike von

37 Pogwisch, senior stewardess to Maria Pawlowna since 1804.

38 Reichardt had composed the hymn Miltons Morgengesang 'for the Berlin Sing-

39 Akademie of the noble master, Fasch' and it was published in Kassel in 1808. The date of

39 composition is unknown, but it was certainly composed during Fasch's lifetime because

40 Zelter mentions it in his Fasch biography of 1801.

41229 The text, which comes from Milton's Paradise Lost, was translated into German

42 by Gottlob Bürde (Berlin 1793). It is not clear which Thomson Zelter is referring to,

43 presumably the English poet James Thomson. His 'Hymn to the Seasons', widely used in

44 Germany, does not show any similarities to the given text. Since Gottfried von Swieten's 
1 long been cast aside, was performed once more to complete the annual repertoire 1

2 and because the work is not easy, it is now time to load the guns. Now that is the 2

3 advantage, even the privilege of the Sing-Akademie that I can let the choir go on 3

4 at an easy pace without much lecturing from one week to the next, but when it is 4

5 essential and they know that I mean it, no one messes about and I myself am more 5

6 likely to make a mistake, which they all notice very readily and are clear about. 6

7 The psalm lasts almost an hour. After the music her Highness called me to 7

8 her box and revealed herself to be someone who has a proper understanding of 8

9 music, although she seemed surprised that Reichardt would be capable of such 9

10 style and such a work. It truly delighted me to hear that from a noble connoisseur, 10

11 the likes of which one is not used to here because Reichardt was no mere kitten. 11

12 His talent was genuinely musical; but there wasn't enough for him to do here. And 12

13 his political striving drowned him. ${ }^{230}$ Water has no beams. He wanted to climb: 13

14 how? Where? And he drowned.

15 Doris has just returned from the palace. Her Highness really enjoyed herself 15

16 with us and in the evening spoke of an enjoyment which is not usual for her. In 16

17 particular the tenor Stümer appealed to her and he is my student. ${ }^{231} \mathrm{I}$ have brought 17

18 him up from the Currende ${ }^{232}$, taught him for three years; now he is on the payroll of 18

19 the Königliches Theater, ${ }^{233}$ has taken for his wife a pretty woman ${ }^{234}$ - the daughter 19

20 of one of my friends ${ }^{235}$ - who is also not poor. What's it got to do with you? 20

21 Enough! That's the way it is. [...] 21

22 The Sing-Akademie, an ensemble of 150 to 180 trained voices, must have 22

23 an undreamed of effect on someone who hears it for the first time. I put the 23

24 thing together like so many small pieces of a mosaic and keep it in shape. [...] 24

25 What distinguishes our choir completely are the inner voices: the crux of a true 25

27 libretto for Haydn's Creation is based on Milton, it is possible that it is confused with The 27

28 Seasons, which is based on Thomson. 28

29230 Reichardt's open sympathy with the aims of the French Revolution; his sans- 29

30 culottism reinforced the hostile attitude towards him and this was shared by the king, who 30

31 had become mistrustful of him.

231 Johann Daniel Heinrich Stümer (1789-1856), who 'joined the Sing-Akademie in 32 1804, where he sang as male alto and had the opportunity to hear classical church works, 33 which was a major influence on his artistic development in later years (...) From 5 April 34 1814, he was a member of the oldest Liedertafel established by Zelter', Carl von Ledebur, 35 Tonkünstlerlexikon Berlins. Von den ältesten Zeiten bis auf die Gegenwart (Berlin: L. Rauh, 36 1861), p. 80 f.

232 Literally 'runners'. From currere, to run. A choir of needy schoolchildren who 37 ran singing through the street; this tradition of busking, which extended into the eighteenth 38 century, could still be encountered in the nineteenth century, at which time it began to peter 39 out.

233 Heinrich Stümer was engaged as a tenor by the Königliches Theater from 181141 until his retirement in March 1831.

234 Anna Christina Henriette Stümer, née Weltz (1794-1865). 
1 choir. Nowhere else in the world is there such a choir of beautiful female alto 1

2 voices, and that is no small feat because everyone wants to sing high and boys 2

3 voices break, whereas the female voices increase in fullness and character with 3

4 the years.

5 The day before yesterday (Thursday) Hummel gave a delightful new public 5

6 performance of his concerto (in A flat major) in the royal concert hall. ${ }^{236}$ The 6

7 applause was unanimous, although the work was not found to be of the same 7

8 standard as his previous ones. That comes down to the people again, who want to 8

9 have the first impression repeated like a da capo of an eclipse of the moon. 9

16 For the last 25 years our good singer Milder has been a credit to our opera and has 16 17 deserved the favour of all well-disposed people.

18 A number of friends, among whom I am one of the most favoured, will, on 18

199 April, present a porcelain vase with her portrait to the lovely heroine ${ }^{237}$ and 19 20 would love a few favourable words from you. ${ }^{238}$ If you can you find a free moment 20

21 since you also belong to the circle of friends, your Zelter would be very grateful 21

22 to you.

33236 On his way to Breslau and Warsaw, the Weimar Court Kapellmeister Johann 33

34 Nepomuk Hummel gave a concert in the Königliches Schauspielhaus in Berlin; his 35 programme included his latest Piano Concerto in A Major; see AMZ 30 (1828) and 36 Spenersche Zeitung, 12 March 1828.

$37 \quad 237$ The vase is still in the possession of the Sing-Akademie; a picture of it is in Werner

38 Bollert (ed.), Sing-Akademie zu Berlin. Festschrift zum 175jährigen Bestehen (Berlin:

39 Rembrandt Verlag, 1966), p. 24.

39238 Goethe had already dedicated a verse (on 12 June 1826) to the famous singer

40 whom he had met in Marienbad. The autograph - enclosed in the letter from Zelter in

41 thanks for the songs which she had performed in Marienbad on 24 August 1823 - may have

42 contained [additional] verses which have not been handed down. Due to time constraints,

43 Goethe was not able to fulfil Zelter's request for a poem in celebration of Milder's 25 years 44 on stage.

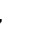

西

(1)


5 How gladly I would have fulfilled, your request, dear Zelter, and write a few friendly 5

6 poetic words for the celebration of our valiant and well-deserving Milder. ${ }^{239} \mathrm{I}$ was 6

7 intending to do it right until the last minute, but it just wasn't going to happen 7

8 because it's a long time since I have been so hard-pressed as in recent weeks. If I 8

9 were to say how [pressurized], you would hear the most wonderful quodlibet. 9

10 Your Easter concert went off well. ${ }^{240}$ You have really won favour with our 10

11 Crown Grand Duchess and it earned for me the really special consolation that this 11

12 splendid lady has become aware of your endeavours and achievements. The effect 12

13 was as good as you could have wished for. May the means to such lovely ends not 13

14 turn out too sour for you. [...]

15 My surroundings remain tuneless and unmelodious. Recently I sought solace 15

16 in the opera, ${ }^{241}$ but the bass drum, which made our whole wooden house shake to 16

17 the rafters, frightened me off any further attempt. [...] 17

18 Our 1827 correspondence increases in the number of transcribed sheets. The 18

19 little volume for this year is still far too thin. ${ }^{242} \quad 19$

[...] Our fete in honour of Milder, held at my house on the 9th [April], ${ }^{243}$ as well 26 27 as the Dürer fete on the 18th [April], surpassed all expectation. ${ }^{244}$ For the latter 27

240 Zelter had conducted the traditional performance of Graun's Der Tod Jesu on 31 Good Friday, 4 April 1828. 1828. Possibilities at this time include Rossini's Die Belagerung von Corinth and Tancredi, 34 as well as Mozart's Hochzeit des Figaro; it is also possible that he attended a rehearsal of 35 Carl Maria von Weber's Oberon (premiered on 28 May 1828).

242 The copy of the letters made in 1827 with a view to posthumous publication. 36 
1 occasion Felix wrote music, ${ }^{245}$ which, in spite of the words, contains beautiful 1

2 passages; the technical work is masterly throughout. 2

3

4

5

423. Zelter

6

Berlin, 27 April $1828 \quad 7$

9 [...] If you could only spend four weeks with me here in my corner room. ${ }^{246}[\ldots] 9$

10 At midday when the guards change [one hears] the best military music ${ }^{247}$ - the 10

11 loveliest works by Beethoven, Mozart, Cherubini, Spontini, Rossini - without 11

12 putting a foot outside the door. If I don't want to listen, I go back into my corner 12

13 room. [...] 13

14

15

16

424. Zelter 16

17

Berlin, 30 April to 11 May 182818

18

19

20 That should have counted as a day of repentance ${ }^{248}-$ and I count it as one. All 20

21 theatres were closed; there has to be a day when the bewitched actors themselves 21

22 can get drunk undisturbed.

23 To keep such a day holy our general music director set up a charitable 23

24 foundation for musicians, ${ }^{249}$ since spiritual works are being performed in the 24

25 theatre by orchestra and singers.

31246 Zelter's new accommodation in the Sing-Akademie building on Dorotheenstraße 31

32 since March 1827.

33247 Harmoniemusik - arrangements of operas, overtures and symphonies for wind

34 instruments - were extremely popular and through which audiences became acquainted

35 with many works. Military music played a special role in promoting opera. In Berlin, Georg

36 Abraham Schneider, music director, Kapellmeister and director of the army band, arranged

37 Spontini's Olympia, for example, and Friedrich Weller arranged Weber's Oberon before its

38 Berlin premiere. In addition to their official engagements, this military band gave countless

38 garden and promenade performances, and their contribution to the musical life of Berlin

39 cannot be overrated.

40248 Annual official day of repentence, at that time in Prussia on the Wednesday

41 following the third Sunday after Easter.

$42 \quad 249$ The Spontini-Fonds was established in 1826 to support the theatre personnel and,

43 above all, members of the orchestra and choir; an annual benefit concert took place every 44 year. 
Today's choice consisted of the most exquisite rare works: two powerful 1

2 symphonies by Beethoven, ${ }^{250}$ half of a mass by the same, ${ }^{251}$ half of a Credo ${ }^{252}$ by 2

3 Sebastian Bach and a German Sanctus by Emanuel Bach. ${ }^{253} 3$

$4 \quad$ The critical public ${ }^{254}$ found this combination rather too much like a miscellany 4

5 and scattered, rather than clever and appropriate - even if at other times it is inclined 5

6 to find that an entire work is nearly always too complete for them. Neither one nor 6

7 the other composer was going to make a complete work which hung together, but 7

8 the intention was much more to achieve a great variety of individual pieces. The 8

9 good intention was obvious here: to offer the ears the most entertaining piquant 9

10 [music] of today's and yesterday's world of art, which also became so substantial 10

11 to me that I could never forget it, as long as similar things are not on offer too 11

12 frequently. Since they recognized no enemies among themselves, commanders and 12

13 generals, officers and the general public argued with such zeal as if they had the 13

14 new manifesto in the bag. The dear audience (nearly all connoisseurs who don't 14

15 pay) were beside themselves with pleasure over the most noticeable oversights. I 15

16 myself was surprised how they dispersed all bright and comforted at the end as 16

17 if nothing had happened to them. I was almost beaten because I didn't join in the 17

18 abuse, but I was beaten and tortured for their sins! ${ }^{255}$ I had a glass of wine; the 18

19 general music director, ${ }^{256}$ however, was sick.

208 May: Today our Albrecht Dürer Celebration Music was to have been repeated 20

21 on account of many requests. We cancelled it. ${ }^{257}$ Musical life moves here like a 21

22

23

24

25

26

27

28

29

30

31

32

33

34

250 Beethoven, Symphony no. 5 in C minor, op. 67 and the Coriolan Overture 23 op. 62 .

251 Kyrie and Gloria from Beethoven's Mass in D Major, op. 123. 25

252 Six lines of the Credo from J.S. Bach's Mass in B minor, BWV 232.

253 C.P.E. Bach's Heilig for double choir, Wq 217.

254 In an announcement of the concert in the Berliner Allgemeine Musikalische 28 Zeitung, no. 18, 30 April 1828, column 146. A.B. Marx criticized the programme: 'the 29 compilation of so many different works and mere fragments of works, which are very 30 worthy of a complete performance, makes a highly unfavourable impression; a later review, 31 in the Berliner Allgemeine Musikalische Zeitung (1828), no. 19, 7 May, columns 152-4, 32 uses the latter criticism as a reproach aimed at Zelter, namely that J.S. Bach's works had not 33 yet been performed in Berlin.

255 Isiah, 54, v. 4. The text 'I was beaten and tortured for their sins' is a reference to the 35 suffering servant of God: 'We considered him, namely the suffering servant of God, who 36 was tormented and beaten and martyred by God, but he has been wounded for our misdeeds 37 and bruised for our sins.'

256 Spontini.

257 Mendelssohn's Cantata for mixed choir, soloists and orchestra, which was 39 premiered at the Dürerfest marking the 300th anniversary of Dürer's death, should have 40 been repeated on 8 May 1828 in the Sing-Akademie hall and the profits given to the 41 building fund. The day before the scheduled performance a notice in the Berlin newspapers 42 announced that the advertised concert had been postponed; the reasons for this cancellation 43 have not been determined. 
$1 \mathrm{crab}$ in a kettle. Everyone is critical [of the theatre], makes negative comments 1

2 about it, and no one can get enough. They keep on going there and come away 2

3 unchallenged. 3

4 年 4

525

6 425. Goethe 6

$7 \quad 7$

8 Weimar, 21 May 18288

929

10 Regarding the missing letters, I have the following to report for the present: in 10 11 my copy the letters have not been numbered, but on close examination the copy is 11

12 complete. On the other hand a gap remains in your original letters as I have them. 12

13 The last letter from you is from 14 June and announces Frau von Zschokke. The 13

14 next letter is from 5 September and discusses the Begas portrait. Such [a gap] 14

15 has to be explained in the following way: when he was finished, the copyist put 15

16 the originals into order again. One must have been moved from this pile, as can 16

17 happen with even the best of organization. The original version will certainly turn 17

18 up and your letters will follow immediately. In any case the copies are there and 18

19 the gap could be filled in different ways. [...] 19

$20 \quad 20$

$21 \quad 21$

22 426. Goethe 22

$23 \quad 23$

$24 \quad$ Weimar, 2 June 182824

$25 \quad 25$

26 So much for now, as this is essentially a letter of recommendation for a young 26

27 man, von Schwendler, ${ }^{258}$ who is presently studying in Berlin. Welcome him for 27

28 my sake because we owe a great deal to his parents. ${ }^{259}$ He will report to you with 28

29 a page from me. ${ }^{260} \mathrm{He}$ is supposed to have a musical bent and some experience in 29

30 it, which I would like you to assess and foster accordingly. 30

31

$32 \quad 32$

$33-33$

$34-34$

$35-35$

$36 \quad 36$

$37-258$ See Goethe's diary for 25 May 1828: 'President von Schwendler's thanks in 37

38 advance for the provisional recommendation of his son to Zelter', WA III/11, p. 223. 38

39 Reinhold von Schwendler studied law in Berlin; the planned visit to Zelter had still not 39

40 taken place on 5 June. 40

41259 Friedrich Christian August von Schwendler (c.1772-1844), president of regional 41

42 administration, and his wife, Henriette August Sophie Schwendler née Mützschefahl, 42

43 divorced Countess von Schlabrendorff (1773-1853). 43

$44 \quad 260 \quad$ A letter of recommendation, GZ 2 June. 
$5[\ldots]$ The day before yesterday our good Weitsch ${ }^{261}$ the painter died [...] He was 5

6 musical and liked to lecture me about it, much to the amusement of my friends - I 6

7 listened quietly to him and they knew quite well what I am like with professional 7

8 musicians. He will be buried tomorrow: we will all follow the coffin, apart from 8

9 me. I have the desire still to wait a little and he should not take that badly; I will 9

10 follow in my own time. [...]

1711 June: Yesterday our Grand Duke was in the Sing-Akademie accompanied by 17 18 Major von Germar ${ }^{262}$ and Major von Staff. ${ }^{263}$ Prince Carl $^{264}$ came afterwards. The 18 19 old fellow endured some short pieces by me, by Fasch and von Stölzel very nicely. 19 $20 \mathrm{He}$ came shortly after six and we were finished at seven. For a delicate unspoilt 20 21 ear we view such things exactly the same as an operation. I hardly know myself 21 22 how I would endure it if it were offered to me for the first time. Our performance 22 23 room seemed to please the Duke. The music, in fact, sounded very good and the 23 24 pieces went without a hitch, as is almost always the case when such esteemed 24 25 guests honour us.

23 June: The music director Rungenhagen (second conductor of the Sing- 32

33 Akademie), the music director Bach (not belonging to the old family), the Supreme 33

34 Court Councillor Gedike (son of the famous Biestergedike), all the students and 34

35 participants of the Sing-Akademie are on tour southwards through Thüringen and 35

$37 \quad 261 \quad$ Friedrich Georg Weitsch (1758-1828), painter; member of the Akademie der 37

43264 Prince Carl of Prussia, son of King Friedrich Wilhelm III, since 1827 married to 43

44 Princess Maria of Sachsen-Weimar, a granddaughter of Carl August. 
1 will bring these lines with them. ${ }^{265}$ Should your current chaos and physical health 1

2 allow you to see these good people briefly, they will tell you that they have left me 2

3 in good health. I will be busy through their two-month absence and have lighter 3

4 work to do. One gets things done best without so-called help. [...]

5

6

430. Zelter

11 A lady in Königsberg ${ }^{266}$ said, 'In our songs the music is to the poetry as stone is 11

12 to steel.' Saemann, who has untertaken a Liedertafel in Königsberg, ${ }^{267}$ told me 12

13 that and I have given him a number of contributions for it. Admittedly one cannot 13

14 live off such comfort from a distance. However, one feels that one lives and only 14

15 giving means living. [...] 15

16 Weber's new opera, Oberon, ${ }^{268}$ is still new here and friends of the departed 16

17 won't be neglected. Unfortunately I still have not seen the opera because it has 17

18 only been performed when I myself am working. Whoever on these occasions 18

19 doesn't drop everything and join the throng is not looked on favourably. I see them 19

20 coming back and hear them as they slave away trying to be funny and lay claim to 20

21 singers, actors, painters and everything else. At the end of it all the most important 21

22 thing is the conversation, to which one never comes too late. 22

29 [...] It would be great if you could tell me of an author from whom I could gain 29

30 information as to what kind of musical system was used during the first half of 30

31 the seventeenth century, and how it could have been so expressed that a Hamburg 31 meeting (and handing-over of the letter) did not take place on account of Carl August's death.

37 See Goethe's letter to Rungenhagen on 21 October 1828 in response to this 'cancellation' and also to Rungenhagen's request for poems for Zelter's birthday which he, Mendelssohn and Hellwig might set.

39266 Her identity has not been established.

267 A choral society founded by Karl Heinrich Saemann in Königsberg in 1818. 40

41268 Carl Maria von Weber, Oberon, Königin der Elfen, a three-act romantic opera

42 (libretto by James Robinson Planché after Wieland's Oberon, translated by Theodor Hell);

43 premiered in London in 1826 . The Berlin premiere took place on 2 July 1828 with repeat 44 performances on 4 and 9 July. 
1 Rector $^{269}$ of that day was able to pass it down to his pupils on three printed pages?

2 Right now I am engaged in studying that important epoch to which we owe so 2

3 much.

432. Zelter 6

Berlin, Beginning [of August] to 4 August $1828 \quad 8$

You ask me - what kind of musical system was used during the first half of the 10 seventeenth century, and how it could have been so expressed that a Hamburg 11 Rector of that day could pass it down to his pupils on three printed sheets? In 12 the first place - so far as I can tell you - there were many such treatises, partly 13 transcribed by students of music, partly dictated by teachers; these take up very 14 little room, inasmuch as they contain only isolated examples, or none at all. In 15 Vienna I saw another such volume, the work of Wolfgang Amadeus Mozart; ${ }^{270} 16$ I myself have dictated several to many of my pupils - possibly Eberwein, your 17 musical director, may have kept one of them. [...] A relic of that time, still in great 18 demand, containing a collection of musical theories is David Kellner's Instruction 19 in Ground Bass, ${ }^{271}$ a little tract consisting of less than a hundred pages, printed at 20 Hamburg, in quarto, in 1732; this has been reprinted many times. [...] 21

If one wanted to undertake a basic investigation of the first teachings of 22 melody and harmony, one would have to realize that they were all built on the 23 foundations of singing schools. ${ }^{272}$ But who still thinks of the invaluable discovery 24 of Joachim Jungius, for whom he had intended to create a 'thorough memorial' in his essay 27 Leben und Verdienste des Doktor Joachim Jungius, Rektors zu Hamburg. (See Goethe's 28 letter to Soret on 2 July $1828, W A$ IV/43, p. 1.) The desire to study Jungius's writing came 29 about through Goethe's preoccupation with De Candolles' botanical work, in which Goethe 30 saw a forerunner to the Theory of Metamorphosis. Goethe was awaiting information from 31 Zelter on Jungius's Harmonie. 270 Zelter presumably meant the textbook for Barbara [Babette] Ployer, KV 453 b, 33 in the possession of Abbé Maximilian Stadler, whom Zelter had met in Vienna on 1434 September 1819, alhough Zelter could also have meant the Kurzgefaßte Generalbaßlehre 35 which was falsely attributed to Mozart in the publication in Vienna in 1817 and in Berlin 36 in 1822.

271 A draft letter deals with this more fully: 'This is not just a book on ground bass for $\begin{array}{r}37 \\ 38\end{array}$ the use of a keyboard player but for all other players and singers. If it is not found in your 38 library, we have it here for your use. The trouble with all these works and large compendia 39 is the lack of sufficient examples which an experienced teacher can give, although a real 40 talent doesn't need much guidance since the best part always has to be intuitive' (GSA 41 28/1028). $\quad 42$ 272 Perhaps Zelter is referring to Johann Josef Fux, Singfundament, which was praised 43 in the $A M Z 30$ (1828), no. 3, 16 January, columns 35-41. 
1 of nine numbers and the 24 [German] letters of the alphabet? I am happy to refer 1

2 you to your own words in Über Kunst und Altertum, Volume VI, Book 24, p. $29 .{ }^{273} 2$

3 What is said there about the old Greek style of painting I am inclined to apply here: 3

4 what is called light and shadow in the new painting can be thought of as chromatic 4

5 (dissonant) in new music, ${ }^{274}$ in that the music from this point onwards takes on 5

6 a dramatic character which it didn't have up to now. So the seventeenth century 6

7 separates art written in servitude from governing art which stands by itself. ${ }^{275} 7$

8 Rhyme that as well as you can and say something about it. 8

9 Pietro della Valle, ${ }^{276}$ whom you know better than I do, ${ }^{277}$ places the music of 9

10 his time high above that of the fifteenth and sixteenth centuries; the chromatic 10

11 scale had crept in, and had given to the music character, flexibility and freedom. 11

12 Here expanded rules were now necessary in order not to lose the old foundation: 12

13 melodic progressions into larger than big and smaller than small intervals should 13

14 be avoided. One called them augmented and diminished in so far as they were 14

15 not comfortable enough to sing, and since the notation itself was also lacking 15

16 there, they were not [used] as a rule. Against that an aesthetic foundation was not 16

17 lacking because they were supposed to introduce the passionate, the luxuriant. 17

18 To the finer types still belonged: the cautious use of the minor third at cadences; 18

19 the progressions through parallel movement between voices, in octaves, sixths, 19

20 fifths, fourths, and thirds, whereby the teaching of double counterpoint already 20

21 announced itself because this would also have been practised, [as would] the 21

22 handling of dissonance and so on. 22

23 These finer innovations, by which mastery was supposed to be recognized, 23

24 were already systematized at the end of the seventeenth century, although they 24

25 were handed down only by tradition to favoured musicians. The product of 25

26 that time appeared in a work by John Joseph Fux, Gradus ad Parnassum, sive 26

27 manuductio ad compositionem musica regularem, nova ac certa nondum ante tam 27

28

31273 Review of Peintures de Polygnote dans la Lesche de Delphe par Riepenhausen, 31

32 most likely written by Johann Heinrich Meyer, KuA VI, 2, p. 289.

$33 \quad 274$ In the following passage Zelter describes the change in musical style around 1600.

34 The 'stil antico', which in the nineteenth century was primarily associated with Palestrina,

35 is set against contemporary performance practice in which the music primarily expresses

36 the dramatic intention of the text.

$36 \quad 275$ With the controversy between Claudio Monteverdi and Giovanni Maria Artusi

37 over the relationship between words and music at the beginning of the seventeenth century,

38 a new epoch in the writing of music history was ushered in. The dramatic expression of the

39 spoken word in Monteverdi was known as seconda practica and was set against the older

40 style of polyphony.

41276 Pietro della Valle, known as il Pellegrino, (1586-1652), Italian composer and 42 music theorist.

43277 See Goethe's treatise on Pietro della Valle in the Noten und Abhandlung zu

44 besserem Verständnis des West-östlichen Divans (MA 11.1.2, p. 236ff). 
1 exacta ordine in lucem edita. ${ }^{278}$ In accordance with this theory, the author had for 1

2 years trained his illustrious pupil, Carl VI, ${ }^{279}$ who became a master in the art; and 2

3 the cost of publishing the work in the Latin language, in a splendid folio edition, 3

4 was defrayed by the Emperor in the year 1725. The work has been translated into 4

5 German; ${ }^{280}$ the Latin edition is getting scarce, although I have two copies in my 5

6 possession.

7 The work is written, as all the educational works of Germany were in those 7

8 days, in question and answer between master and pupil and, for that reason, it is 8

9 often laughed at today. The master was unwilling to appear publicly as superior 9

10 to his illustrious pupil, and names the pupil Joseph (the author himself), but [he 10

11 names] the master Aloysius, namely Praenestinus, ${ }^{281}$ whose principles are here 11

12 preserved for posterity as unsurpassable. These principles form the groundwork 12

13 of all great and beautiful masterpieces of music up to the present day; they are 13

14 the techniques of composition, and they leave to anyone who has mastered them 14

15 plenty of scope to write what is beautiful correctly. ${ }^{282} \quad 15$

278 Johann Josef Fux, Steps to Parnassus, or introduction to the standard composition 21 of music. This introduction is new and established and, to date, has never been published in 22 such an organized form (Vienna: Johann Peter van Ghelen, 1725, reprint New York: Broude 23 Brothers, 1966).

279 Joseph Franz Carl VI, King of Spain (as Carl III) from 1703 and Holy Roman 24 Emperor of the German nation from 1711.

280 By Lorenz Christoph Mizler von Kolof (1711-78), musicologist 26

281 Franz Sales Kandler records the Latin name for Palestrina as written on his 27 gravestone: 'Johannes Petrus Aloysius Praenestinus Musicae Princeps'; Franz Sales 28 Kandler, 'Memorabilien aus G. Pierluigis da Palestrina Leben'. In: AMZ 31 (1829), no. 49, 29 9 December, column 803.

282 In a rough draft of this letter Zelter wrote: 'This work is, actually, the connection 31 of the old teaching with the new, the old style with the new, because Beethoven, Mozart, 32 Haydn, Handel, Sebastian Bach, Graun and whoever else has worked according to these 33 principles like men of genius. Approximately 40 years before Fux, the work of Prinz 34 Wolfgang Caspar of Waldthurn Musikalische Wissenschaft de concordantiis singulis 35 appeared, which only deals with the unison, the octave, fifth, major and minor third, fourths, 36 major and minor sixths, and it is is unmistakable how far the theory lags behind the practice 37 because [Johann] Sebastian Bach, born in Eisenach in 1685, who, through a continual series 38 such a 39 all is the old style. Reichardt and many others after him believed they made exception to 40

41 the rules and all have been left behind: art has progressed. Because, as in the plastic arts, 41

42 all definitions of the elements are based on a type that is in Nature, so also in melody and 42

43 harmony, everything dissonant has to rest on the consonant; from there the theory of ground 43

44 bass re-emerges' (GSA 28/1028). 
$5[\ldots]$ I am twice as delighted with my old friend, Joachim Jungius, for having 6 inspired you to write so kindly that instructive page; it is just what I needed, and 7 something more: just as much as I understand, and in addition to that, something 8 that I have a presentiment of. This may well be enough since you yourself give 9 your communication a symbolic turn.

10 If we want to get even half way to the proper understanding of a man, we must, 10 11 above all things, study the age in which he lived, perhaps completely ignoring him 11

12 for a while; but discover, when we return to him, the greatest satisfaction with his 12

13 discourse. Therefore, I made it my business to learn, if only imperfectly, what this 13 14 extremely thorough man might have dictated to his pupils in the first half of the 14 15 seventeenth century. Even at a very early age, he was Professor of Mathematics 15 16 and Physics at Gießen, ${ }^{283}$ where later on what was normally known of the Theory 16 17 of Sound could not have been an undiscovered or unfamiliar study to him. 17

24 [...] Your derivation of the new Greek education jumped out at me. What I have 24

25 long treasured in my heart I was able to add here. Music has only old natural laws. 25

26 Today's theorists want to have new rules for sham music or for what is more than 26

27 music. Let them get on with it. The genius will discover the new through the old 27

28 and the philistines need no rules to go to the devil.

35 I am asked to announce and recommend to you Chélard, Maître de la Chapelle de 35 36 S. M. Le Roi de Bavière. ${ }^{284}$ He brings me this request from Weimar, whither he 36

40 Medicine in Rostock and Helmstedt from 1624 to 1626; from 1626 until his death he was 41 rector of the academic grammar school and (until 1640) of the Johanneum in Hamburg.

$42 \quad 284$ The French composer Hippolyte André Jean Baptiste Chélard visited Goethe 39

43 in Dornburg on 25 August 1828. Goethe mentioned this meeting in his diary: 'I had a 43 44 pleasant conversation with him about the current state of music and literature in Paris. 44 
1 came with good letters of introduction; you will recognize him from his works. 1

2 I am not quite clear on his position; in Paris he wrote an opera, Macbeth, ${ }^{285}$ with 2

3 which he probably expected to open up a new path for himself; it appears to me 3

4 it was never performed there; anyhow, I have never read anything about it in the 4

5 Parisian papers. I suppose it was either rejected or it was a failure; he took his 5

6 score, travelled to Germany, and came to Munich, where a German translation 6

7 was used ${ }^{286}$ and the work was performed to great applause. ${ }^{287}$ The King conferred 7

8 on him the above title. ${ }^{288} \quad 8$

$9 \mathrm{He}$ is now going to Berlin, ${ }^{289}$ presumably to make arrangements for a 9

10 performance there, and if possible to double the good name he has gained and re- 10

11 establish his fame in his own country. In addition to this, he may be looking about 11

12 for other opportunities in German music to further his own ends. All this you will 12

13 soon see and be able to judge for yourself and assist him, as you think fit. [...] 13

14 If you will add a few notes to the enclosed verses, ${ }^{290}$ I would be delighted to 14

15 receive them and see them live anew. 15

16

17 Enclosed: 'Dem aufgehenden Vollmonde' 17

$24[\ldots]$ Your Kapellmeister ${ }^{291}$ has still not arrived here and he shall be made welcome. 24

25 Hopefully with respect to music he will encounter the most brilliant things we 25

28 When questioned, he named the musical reviewer for The Globe, Vitet. He didn't seem 28

29 to be too happy with him but admitted that he was an enthusiastic musical amateur', 29 WA III/11, p. 268.

285 Chélard's first tragic opera, Macbeth (libretto by Rouget de l'Isle and Auguste Hix), 31 was premiered in Paris on 29 June 1827, but the critical reception was rather indifferent and 32 he was granted only five performances.

286 As indicated on the programme, 'freely adapted' by Cäsar Max Heigel.

287 On 20 June 1828 in the Königliches Hof-und Nationaltheater in Munich; a second 34 performance took place on 24 June 'in an abridged version by the composer' (programme $\begin{aligned} & 35 \\ & 36\end{aligned}$ note).

288 After the successful German premiere of Chélard's Macbeth, Ludwig I of Bavaria 37 appointed him Königlicher Bayerischer Kapellmeister 'without service', as the reporter in 38
the Berliner Allegemeine Musikalische Zeitung remarked on 24 September 1824 .

290 Goethe enclosed a copy of his poem 'Dem aufgehenden Vollmonde' in this 41 letter. Zelter's intention to set the poem to music (ZG 30 August 1828) was, in fact, never 42 
1 have to offer [...] for apparently all our magnificent operas are to appear one 1 2 after the other. Von Humbold and Lichtenstein are constantly preoccupied with 2

3 the reception of such esteemed guests. Time will tell, since one wants to show that 3

4 good hosts are worthy of good guests. [...] 4

5 Bach has gone back to Teplitz and Rungenhagen is the only one completely 5

6 unharmed. He, however, grieves all the more that he has to miss you since he did 6

7 not want to leave his travel companions. ${ }^{292}$ I can't console him. 7

8 The strange cloud formations which pass in front of and by the moon have 8

9 awoken the Ossian in me and I have a desire to set your verses to music, although 9

$10 \mathrm{I}$ am completely out of my routine. ${ }^{293} \mathrm{I}$ had to promise Madame Milder an aria, 10

11 which is started but unfortunately it is not going to get finished of its own accord. 11

18 Your dear didactic pages of 5 October came just in time to preserve me from the 18

19 unpleasant after-effects of an annoying conference. ${ }^{294}$ How much there would have 19

20 been to report if one had been able to enjoy, hear, understand and assimilate from 20

21 so many long scholarly presentations. [...] For my part I wanted to do something 21

22 for the amusement of the guests. The day before the opening of the meeting, the 22

23 Sing-Akademie had performed Handel's Alexanderfest, ${ }^{295}$ although with a pretty 23

24 incomplete rehearsal as two of the soloists were missing. Despite this the choir was 24

25 in flying form and I didn't have to find fault with them. When they are effective, 25

26 they sing as one voice. Then, for our money, we served a lunch for our foreign and 26

27 local guests for our Liedertafel. ${ }^{296}$ There were seven to eight hundred participants 27

28 gathered. Both Berlin Liedertafel had got together ${ }^{297}$ and since the restaurant is 28

29 wide and high enough in its new parade house, the thing went off much better than 29

292 Carl Friedrich Rungenhagen, August Wilhlem Bach and Wilhelm Gedike were

33 supposed to bring a letter to Goethe from Zelter on their journey through Thüringen. As the

34 visit never happened, Rungenhagen had posted the letter in Dresden.

$35 \quad 293$ The composition - or even a fragment- is neither in Zelter's bequest nor in

36 Goethe's music collection; it was obviously never set to music.

$36 \quad 294$ The septennial conference of the Gesellschaft deutscher Naturforscher und Ärzte

37 (Society of German Scientists and Doctors) in Berlin from 18 to 26 September 1828. The

38 first session, opened by Alexander von Humboldt, took place in the Sing-Akademie hall, as

39 did the other public sessions.

40295 Handel's oratorio was performed in the Sing-Akademie hall on 17 September

41 1828; see $A M Z 30$ (1828), no. 44, 29 October, column 741; MA 20.3, pp. 953-4. 41

$42 \quad 296$ AMZ 30 (1828), no. 44, 29 October, column 742; MA 20.3, pp. 954.

$43 \quad 297$ Zelter's Liedertafel as well as the Jüngere Liedertafel (modeled on Zelter's) which 43

44 had been founded by Ludwig Berger, Bernhard Klein and Ludwig Rellstab in 1819. 
1 I expected. Seventy male voices, all in good voice, made themselves so powerful 1

2 that one could hear the words clearly from outside and many of our guests swore 2

3 that they had never heard the likes of it, where no flattering remark was needed 3

4 in so far as it is an ensemble. I have one last wish that you had heard the material 4

5 performed ('Aus wie vielen Elementen'). ${ }^{298}$ One must not imagine the poem; one 5

6 must hear it, which does the job and awakens the unnameable everytime. 6

719 October: Yesterday evening out of despair I went to the theatre-Preciosa. ${ }^{299} 7$

$8[\ldots]$ The story is illustrated by dance and choral music - with recitatives spoken to 8

9 music, so that you understand neither the one nor the other - they call it melodrama, 9

10 and it is described on the programme as a play with incidental music and dance, 10

11 which means neither one thing nor the other through four short acts; even these 11

12 are much too long as really there is no action and everyone is bored. The actors 12

13 do not understand themselves why they are so done up; one is always waiting for 13

14 the other to do something. The composer has taken the greatest pains, by strange 14

15 modulation and all kinds of tempi, to produce a sad but humoristic work that 15

16 will characterize a group of bandits. The audience and orchestral members do not 16

17 know what they are listening to, or what they are playing, and the public sits as 17

18 quiet as a mouse until it is all over.

19 A pretty stranger ${ }^{300}$ appeared for the first time as Preciosa. She is said to be the 19

20 intimate friend of her prince. Who would like to see the object of his affections 20

21 running around on the street like that? Were she mine, she should remain nicely 21

22 at home.

23 It now occurs to me, for the first time, that poet and composer are no longer 23

24 alive. De mortuis nil. ${ }^{301}$ You can see what kind of humour I am in. Throw away the 24

25 page and forgive your 25

298 Zelter's setting of Goethe's poem 'Elemente'

299 Pius Alexander Wolff. Romantic play in four acts with song and dance, overture 37 and incidental music by Carl Maria von Weber, part of the theatre repertoire in Berlin from 38 1821. Zelter is referring to the performance in the Schauspielhaus on 18 October 1828, in 39 which the actress Lina Kuhn gave a guest performance of the title role.

300 The actress Lina Kuhn, from the Grand Ducal Court Theatre in Baden, Karlsruhe. 41

Her guest appearance in Berlin was, in fact, this single performance as Preciosa on 1842

October 1828. 
5 [...] Von Cotta's wife ${ }^{302}$ sent me through Doris two delightful arabesque 6 illustrations ${ }^{303}$ of Bavarian folksongs by a young artist from Munich. The melodies 7 are also so charming and unsophisticated. I would not want be able to do the same; 8 it is characteristic of the area.

15 If I may announce to you, my good Zelter, that I also possess the two charming 15 16 pages of the illustrated songs from Tyrol $^{304}$, I can also add that the same young artist 16 17 called Neureuther has also decorated many of my ballads with similar charming 17 18 glossy borders. ${ }^{305}$ This news will be very pleasant to you, but more pleasant some 18 19 day will be your contemplation of those works, which are the most spiritual and 19 20 most proper which have come to me in a long time. [...] 20

31302 Elizabeth von Cotta, née Baroness von Gemmingen-Guttenberg (1789-1859), 31

32 Cotta's second wife from 1824, who was interested in publishing and was editor of the

33 Taschenbuch für Damen, for which she could even count Ludwig I of Bavaria among its 34 authors.

$35 \quad 303$ Like Goethe, Zelter also received two lithograph pages of pen-and-ink drawings 36 by Eugen Neureuther, a young artist from Munich. These are clearly sketches for the work 37 Baierische Gebirgslieder mit Bildern, gezeichnet von Eugen Neureuther (Munich: Cotta, 38 1831); Zelter later praised these pages as 'really charming and fresh'.

$38 \quad 304$ In Dornburg Goethe had received Neureuther's lithographs along with drawings

39 for his own ballads and romances, with accompanying letters from Neureuther's teacher,

40 Peter von Cornelius, and from Neureuther himself on 30 August 1828. Of Neureuther's

41 pictures Goethe noted in his diary the following day, 'carefully observed'.

42305 Cornelius's dispatch contained two drawings by Neureuther, where Goethe's poems

43 were illustrated in arabesque borders. Shortly afterwards Goethe spoke very highly of them 44 in letters to Councillor von Müller (1 September) and Heinrich Meyer (6 September). 
5 Yesterday evening we treated the public to Handel's Samson. ${ }^{306}$ With real power 5

6 Handel has set to music the essence and last hours of a strong man who succumbs

7 to a woman. The ear becomes the eye: one thinks one distinguishes colours, forms, 7

8 sexes.

9 We had just received the tragic news of the death of the Russian Dowager 9

10 Empress. $^{307}$ That brought us a double loss in that the King $^{308}$ could not come. 10

11 Otherwise it was an attentive, responsive audience. The Duke of Cumberland, ${ }^{309} 11$

12 who usually thinks we are lacking an organ, declared himself very gratified this 12

13 time.

14 Handel, who was a distinguished organist, ${ }^{310}$ did not write an organ part for 14

15 any of his oratorios, ${ }^{311}$ though he treated the chorus carefully and artistically. Were 15

16 he still alive, he would have to say, 'With such a chorus as that, I don't need an 16

17 organ!' Even if he did not say it, he did it. An organ may be necessary, either to 17

18 mask or to compensate for the weakness of a chorus. On the other hand, played 18

19 neither wisely nor well, it may weaken and ruin the best choir. I was obliged to say 19

20 as much to Cramer, ${ }^{312}$ the English king's Kapellmeister, ${ }^{313}$ who was here a short 20

21 time ago, for I know from the best source (Handel himself) what choirs are like 21

22 throughout England and it is still the same now. People might confuse us if we 22

306 The performance of Handel's oratorio on 13 November 1828; the performance was 25 very favourably reviewed in the Spenersche Zeitung, no. 269, 15 November 1828 and the 26

310 As a budding musician Handel had already taken organ lessons with Friedrich 32 Wilhelm Zachow, the organist of the Liebfrauenkirche in Halle. In 1702 Handel was 33 appointed organist at the castle and cathedral in Halle. In Italy Handel continued to play 34 the organ and he composed organ concerti for the first time in England, which were used 35 as intermezzi for the oratorios Esther and Deborah (1732/33). Handel's fame as an organ 36 virtuoso was founded on his own performances of these concerti. Through printing the 36 three collections of organ concerti, each containing six concerti, were widely known in the 37 eighteenth century by virtue of being printed.

311 For the performance practice of Handel's oratorio with organ as a continuo 39 instrument; see Friedrich Rochlitz's revised edition of his essay on Handel's Messiah, first 40 published in 1824, in Für Freunde der Tonkunst (Leipzig, r.1830), vol. 1, p. 260f. 41 312 Franz Cramer (1772-1848), violinist and leader of the orchestra, member of the 42 
1 hadn't lived too. If they are in love with themselves and their pitmines, who shall 1

2 blame us for loving what we are able to have? What do they know about Handel? 2

3 Our knight, Spontini, was full of admiration and said, 'Laissez moi vos 3

4 Chœurs'. ${ }^{314}$ It is true: youth and beauty of every rank, trained, brought into order, 4

5 with great energy and properly balanced, should make an impression upon anyone, 5

6 unless, like me, he has for years had to work from the centre of the organization 6

7 outwards and, all through the varying seasons of success and failure, continue 7

8 showing things up energetically and untiringly. 8

9 The cost of training the Chorus for the Königliches Theater amounts to 6,000 9

10 thalers per annum; for that sum they ought to be better, if the teachers fulfilled 10

11 even the most basic duties. Many of the chorus do not know their parts, and have 11

12 them drummed into them by a violin, badly played. Our choruses are sung by all 12

13 at sight and the most difficult music often goes as well as possible at the third 13

14 rehearsal, for they work together and talking is not tolerated. The late King of 14

15 Saxony $^{315}$ was the first and last who conversed with me on the subject like a man 15

16 who understood it - and he gave me the loveliest gold snuffbox. 16

23 [...] Rungenhagen's music to your words has been very successfully received, ${ }^{316}$

24 to which I must add my praise.

$37 \quad 316$ Rungenhagen's cantata for three choirs ('Dichtende', 'Singende' and 'Bauende')

38 and fundamento (continuo). Zelters siebzigster Geburtstag, gefeiert von Bauernden,

39 Dichtenden, Singenden am 11ten Dezember 1828, a hand-written score of 82 pages is in

39 Goethe's music collection (GSA 32/70). The performance was reviewed in the AMZ: 'On

40 the same evening the Sing-Akademie celebrated the 70th birthday of (...) Professor Zelter

41 with a celebratory performance of a cantata to poems by Goethe, which the Director of

42 Music, Rungenhagen, the real assistant to Zelter [sic], had set to music with considered

43 order [of form], clarity and warmth of feeling, simple and melodic, as appropriate', $A M Z$

4431 (1829), no. 1, 7 January, column 18. 
5 Enclosed herewith you have at last a transcription of the excellent Jungius's 5

6 Harmonie ${ }^{317}$ it was difficult enough to get this done, - the type of translation you 6

7 desired could not be managed. Amongst your musical colleagues and students 7

8 there must be someone who understands Latin and who would go through the 8

9 work with you; afterwards I should like a solid account of it, for I am anxious to 9

10 erect a substantial memorial to that worthy man.

11 I enclose a copy of the letter you sent at my request; what you say has special 11

12 relevance to the close of the seventeenth and the beginning of the eighteenth 12

13 century; but with regard to the state of music in 1650, the most reliable information 13

14 is probably to be got from the pamphlet in question, for though the man was first 14

15 and foremost a mathematician and logician, he had spontaneously devoted himself 15

16 to living nature and had written works that were ahead of his time. Amongst the 16

17 things that interested me was that he was a contemporary of Bacon, ${ }^{318}$ Descartes, ${ }^{319} 17$

18 and Galileo, ${ }^{320}$ and yet he managed to retain his originality both in his studies and 18

19 his teaching.

317 The copy of Joachimi Jungii Lubecensis Harmonica (Hamburg, 1679), which 28

Goethe had requested from Zelter on 24 October. The 23-page copy in John's hand is in the 29

31 Goethe had borrowed the printed publication, which had been bound with another work by 31 Jungius (Praecipuae opiniones physicae) from the library in Jena on 10 July 1828 . He sent 32 the book, together with other works by Jungius, to Friedrich Siegmund Voigt emphasizing: 33 'The middle blue signs indicate a representation of harmonic relations in music.' Voigt 34 returned it to Goethe on 23 August and it was returned to the library on 8 September, 35 shortly before Goethe's return to Weimar. It was borrowed by Goethe once again on 36 15 October, presumably for making a copy. The title Riemer gave in the first edition of 36 these letters (Harmonica Theoretica, compendiosissime et optima methodo sonorum et 37 sonorum proportiones et distinguendorum instrumentorum musicorum rationem exhibens 38

40 existed anstrans. E Ms Auctoris edita a Joh. Vagetio. Prof. Hamb. (Hamburg 1768)) never 39

41 Begründung der Chemie als Wissenschaft (Wiesbasden: Franz Steiner, 1968), p. $351 . \quad 41$

$42 \quad 318$ The English philosopher and statesman Francis Bacon (1561-1626). 42

$43 \quad 319$ René Descartes (1596-1650), French philosopher and natural scientist. 43

$44 \quad 320$ Galileo Galilei (1564-1642), Italian physicist and astronomer. 
$5[\ldots]$ You did well not to spare my lazy modesty; I can read the little book fairly 6 well myself. Because of the musical content, I could spell out what is problematic 7 in it more easily than many a Latin scholar could put it into German for me; for 8 many a mistake has arisen from coining Greek and Latin artistic terms in German.

9 The basic principles of harmony, as outlined here, were carried out in practice by

10 Hans Leo Hassler, Palestrina and others as early as the beginning of the sixteenth 10 11 century, and they are still applicable, though the most modern theorists will try 11 12 to convince us that it is all quite different now. This is so little the case, that even 12 13 the old mistaken definitions, quite as mistakenly Germanized, are still valid: for 13 14 example 'Soni dissoni sunt, quorum mixtura auditui ingrata est' ${ }^{321}$ - which to this 14 15 day still means: 'A dissonance is a cacophony'. But a dissonance (if you do not 15 16 mean by that something absolutely unmusical) is no cacophony. It is in its origin 16 17 as well as its resolution consonant, and is to be looked on as the consonance into 17 18 which it must resolve itself. Similarly, major and minor are neither 'hard' nor 18 19 'soft', yet everyone knows what is meant by the terms as long as people do not 19 20 translate them into German!

2129 December: On account of the feast days in the next few weeks, I hardly know 21

22 what day it is. We wanted to perform Handel's Messiah on 4 January since they 22

23 have laid another foundation stone again. Then jubilee anniversaries, weddings, 23

24 operas, balls, carnival follow and everything I don't need. My choirs are very well 24

25 rehearsed. Everything is running like clockwork; and with meaning and sense. 25

$32[\ldots]$ My mother was often wont to say when she was overrun with visitors, 'They 32 33 did not allow me to blow my nose'. It amuses me to think of you in a similar 33 34 predicament.

$35[\ldots]$ No one understands how I value a succession of hours, for the interrupted 35 36 ones are, in my opinion, not only completely lost, but must be considered as 36 37 harmful and destructive. It is the same with strangers, who do not understand what 37 38 exactly I am robbed of by an interruption. And yet it is always disagreeable to me 38 39 when, in self-protection, I have to refuse seeing people who have travelled a long 39 40 way. You might complain of something similar, but as musician you are forced 40 41

42 
1 to keep up with the world; the world has nothing of me, except what it can see in 1

2 black and white.

2
3

4

$9[\ldots]$ It surprised me to know the time and place of your verses for the Jubilee 9

10 celebration of your immortalized master, ${ }^{322}$ 'Laßt fahren hin das Allzuflüchtige'. I 10

11 believe I conceived the melody in the church of St Nicolas during a Jubilee sermon 11

12 which I had to sit through and couldn't understand anything. I regarded it as being 12

13 too serious, even pedantic, and now I see that I would do it the same way again, 13

14 now that I know more about it. [...] 14

$21[\ldots]$ Our Messiah was launched smoothly enough, after it had rocked long enough 21

22 at anchor. ${ }^{323}$ On this occasion I again learnt what you and I already know. In the 22

23 end the music had to be performed without the help of the court musicians. ${ }^{324} 23$ 5 6

\section{8} 9 
1 There is no lack of skill in my choir, but they are afraid to be on show [as a 1

2 group] and individually. In the end that was overcome and lo and behold! If they 2

3 were unwilling at first and timid, it finally changed. They became lord and lady, 3

4 they proved themselves to be independent; they expressed themselves, which is 4

5 precisely the wrong thing, and out of the fully convinced, sincere and heartfelt 5

6 'Ich weiß daß mein Erlöser lebt' ${ }^{325}$ we got a sad, whining thing like - a fart. ${ }^{326} 6$

7 Meanwhile one must not knock three times. You have to attack sometimes! 7

8

9

10

447. Goethe

$14[\ldots]$ I think I understand your complaints, or more exactly your invectives against 14

15 limited performances of music prepared long beforehand. The tendency of the 15

16 day to drag down everything into weakness and wretchedness is becoming more 16

17 widespread. I could show you half a dozen poems which have been written to 17

18 praise and honour me and yet treat me as is if I am already one of the blessed 18

19 departed. In the end, according to the latest system of philosophy, everything will 19

20 disintegrate into nothing before it has yet begun to be. [...] 20

21

27 Make sure that I have my own copy of your correspondence with Schiller. ${ }^{327}$ I have 27

28 to give back the copy I am reading. What extraordinary people you both are. The 28

29 correspondence is splendid.

3012 February: You have another wedding ${ }^{328}$ and we have the carnival without 30

31 Spontini's operas. Our Princes, who left the day before yesterday, will fill you in 31

326 Goethe explained the passage on The Messiah in Zelter's letter to Eckermann, who, in turn, tones Zelter's words down, saying 'this weakness is characteristic of our century ... where an aria is sung in too mellow, too delicately [or] too sentimental a way'.

327 Of the six volumes of Briefwechsel zwischen Schiller und Goethe in den Jahren 1794-1805 (Stuttgart and Tübingen: Cotta, 1828-29), vols 1 and 2 (November 1828) were

39 available at the time of this letter; the remaining four volumes were issued throughout 401829 .

41328 Prince Wilhelm of Prussia, the second son of King Friedrich Wilhelm III, had

42 travelled to Weimar for his engagement to Augusta von Sachsen-Weimar-Eisenach,

43 daughter of the Grand Duke Carl Friedrich; he arrived on 14 February, on the day after

44 his brother, the Crown Prince Friedrich Wilhelm. The engagement party took place on 
1 on it. It is boring, irksome and is known around the town in its various versions. 1

2 From Paris they had described Spontini as a schemer. Now that I can see it is 2

3 about to affect me in my situation, I neither have to complain nor to take sides. 3

$4 \mathrm{He}$, however, appears to have offended everyone so much at the theatre itself, the 4

5 court, the general public, that his best, even his highest patrons are compromised. 5

6 I was mistaken in him in so far as I took him for a man of the world and regarded 6

$7 \mathrm{him}$ as being more clever than - dense. For example, he persuaded Kapellmeister 7

8 Schneider (in the director's room) before the general rehearsal to go into the theatre 8

9 and to ask the orchestra in open forum whether they would prefer to see the opera 9

10 La Muette de Portici conducted by Spontini ${ }^{329}$ than by Kapellmeister Schneider. ${ }^{330} 10$

11 That took place and the orchestra played La Muette de Portici. Schneider asks 11

12 loudly one more time and repeatedly, but there is still no answer. And all that 12

13 in the presence of the King who doesn't know anything about it and should not 13

14 and would not, and with all his power is not in a position to lend his support 14

15 to such stupidity. They say Prince Carl asked the King very graciously to spare 15

16 his wedding celebration from Spontini's latest opera ${ }^{331}$ because half an opera was 16

17 not sufficient for a whole wedding. As is well known, this opera Agnes was to 17

18 have been performed at the wedding of Prince Wilhelm, but only Act One was 18

19 performed because the whole thing was not finished. Now it is still not ready and 19

20 they are worried that the wedding might have to be postponed for that reason. 20

2114 February 1829: [...] Yesterday, for the first time, I heard [Auber's] Muette 21

22 von Portici. ${ }^{332}$ One may look upon the work as the beginning of a new genre, for it 22

23 is neither an opera proper, nor a play, but a true melodrama which is not spoken but 23

24 sung. It hangs together well, and the interest is sufficiently sustained throughout 24

25 the five acts to give them real unity. Scribe's text is nothing special. The leading 25

26 character, a Neapolitan fisherwoman, has been seduced by the son of the Viceroy, 26

27 who then gets married to a princess. But why, and from what cause the lady is 27

28 dumb, never emerges. Running through all this is a conspiracy of the Neapolitans 28

29

F February; on 19 the Crown Prince set out for Berlin after visiting Goethe on 16 February. 31 The engaged couple were with Goethe on 11 March before Prince Wilhelm returned to 32 Berlin on 28 March.

329 General director at the Königliche Oper in Berlin.

330 Georg Abraham Schneider (1770-1839), hornist, cellist, Kapellmeister and leader 35 of the court opera. ceremony of Prince Carl with Princess Maria, at which Act 1 had been performed on 38 28 May 1827. The complete opera in three acts was premiered on 12 June 1829 , with stage 38 set designed by Schinkel.

$40 \quad 332$ Daniel François Espirit Auber, La Muette de Portici, grand opera in 5 acts (libretto 40

41 by Eugène Scribe, adapted for the German stage, under the title Die Stumme von Portici 41

42 by Baron Karl August von Lichtenstein); performed for the first time in the Königliches 42

43 Opernhaus on 12 August 1829; see AMZ 31 (1829), no. 8, 25 February, column 128f. and 43

44 no. 10, 11 March, columns 166-9. Zelter attended the performance on 13 February 1829.44 
1 against the Viceroy, who is rebuked as a tyrant. The staging of this music drama is 1 2 regal. ${ }^{333}$ Whoever has not witnessed Vesuvius in action ${ }^{334}$ should come to Naples- 2

3 Berlin and be astonished! 3

10 One of the 13 dramatists, our Willibald Alexis, has cast his shadow over the muse 10 11 of the King's suburb with a melodrama, ${ }^{335}$ discussed in the enclosed. ${ }^{336}$ It is called a 11 12 melodrama because by virtue of its serious content it would not have been allowed 12 13 to be performed at this theatre. ${ }^{337}$ So a famous unnamed composer ${ }^{338}$ (the editorial 13 14 staff of the local musical paper) made a completely homogenous setting of it, which 14 15 I heard yesterday. If the composer didn't know where he was going, he showed 15 16 clearly enough from where he was coming because his painstaking botched-up 16 17 job only exists in bones and droppings from Beethoven's table, ${ }^{339}$ wrapped in such 17 18 terrible noise that children in the womb would get goosepimples. I thought I was 18 19 hearing the standard examples from all the musical textbooks reeled off one after 19 20 the other in their different keys. Afterwards the orchestral members looked as if 20 21 they had escaped from their graves. Actually the opus uplifted me - as this brother 21 22 Marcus (now Marx) ${ }^{340}$ tormented himself and mounted his fortepiano. There I don't 22 23 begrudge the joker anything and the King's suburbian audience showed no sign of 23

$28 \quad 334$ The flaming Vesuvius, into which the mute protagonist throws himself at the end 28

29 of the opera, had impressed the critics; $A M Z 31$ (1829), no. 5, 4 February, column 73; $M A$

31335 Die Rache wartet, melodrama in three acts by Wilhelm Alexis (namely Wilhelm 31

32 Häring) on 22 February 1829, performed for the first time at the Königstädtisches Theater;

33 Zelter attended the second performance on 25 February.

$34 \quad 336$ A critical review of Die Rache wartet in the Berliner Courier, no. 622, 23 February 1829.

$36 \quad 337$ In accordance with the articles of association, neither serious dramas nor heroic

36 operas were permitted to be performed at the Königstädtisches Theater to avoid rivalry with the court theatre.

$38 \quad 338$ A.B. Marx, founder and editor of the Berliner Allgemeine Musikalische Zeitung.

39 Marx included a passage on Wilhelm Alexis's Melodrama in his autography; see A.B. Marx,

40 Aus meinen Leben (2 vols, Berlin: Otto Janke, 1865), vol. 2, p. 42.

41339 Marx was a founder of the Romantic image of Beethoven which reached a pinnacle

42 in his two-volume Beethoven biography (1859).

\section{2}

$43 \quad 340$ With reference to Mark the Evangelist, who is often represented at the scriptorium 43

44 or at a desk; it could also be a reference to the journalistic activities of the composer. $\quad 44$ 
1 curiosity about the identity of the perpetractor of the confused murder rumpus. We 1

2 won't talk about it any further. 2

450. Zelter $\quad 5$

9 You will already have seen from the paper that we are going to perform Bach's 9

10 Passion. ${ }^{341}$ Felix has studied it under me, and is going to conduct it, so I will give 10

11 up my desk to him. I will send you the text shortly, to which I have written a 11

12 preface. Felix has been invited to London by Moscheles; ${ }^{342}$ after that he may go to 12

13 Italy. ${ }^{343}$ The lad brings great comfort to me and it is good for him to get away from 13

14 the parental home. All that he needs intellectually he can take with him, and soon 14

15 I hope to hear more of him.

411 in C minor (op. 11) and his Midsummer Night's Dream Overture (op. 21). He found the 41

42 English a benevolent, later even an enthusiastic audience, and travelled to England ten 42

43 times as a conductor and performer.

44343 Mendelssohn's journey to Italy began mid-May 1830 and lasted until July 1832. 44 
5 Our Bach performance came off successfully yesterday, ${ }^{344}$ and Felix proved to be 6 a calm, competent director. The King ${ }^{345}$ and the entire court witnessed a closely

7 packed house before them; I sat with my score in a little corner near the orchestra, 8 from where I could survey my students and the public equally well. About the work 9 itself, I scarcely know what to say. It is a wonderful, sentimental mixture of music 10 in general. [...]

11 If the melody did not bear occasional resemblance to the more modern German 11 12 operatic composers, such as Gluck and Mozart, bringing us back again for a 12 13 moment to our own time, we should feel ourselves between heaven and earth and 13 14 at the same time 30 years older! And it may be this that makes the music difficult 14 15 to perform. But if only old Bach could have heard our performance! That was my 15 16 feeling at every successful passage, and here I cannot praise highly enough the 16 17 whole body of my pupils at the Sing-Akademie, as well as the solo singers, and 17 18 the double orchestra. ${ }^{346}$ You might describe the whole as an organ, in which every 18 19 pipe was gifted with reason, power and will, nothing forced, no mannerism. There 19 20 is no duet, no fugue, no beginning, no end, and yet all is as one, and everything in 20 21 its place with its singularity and connection to the whole. A wonderful dramatic 21 22 truth is created: one hears the false witnesses - that is, one sees them step forth; 22

26344 The first performance since Bach's death of the St Matthew Passion was given by 27 the Sing-Akademie, conducted by Felix Mendelssohn, on 11 March 1829. The soloists were 28 the sopranos Anna Milder-Hauptmann (who had left Berlin over a quarrel with Spontini),

29 17-year-old Pauline von Schätzel, alto Auguste Türrschmidt, tenors Heinrich Stümer

30 (Evangelist) and Carl Adam Bader (Peter), baritone Eduard Devrient (Christ), and basses

31 J.E. Busolt (High Priest and Governor) and Weppler (Judas). The chorus was 158 strong

32 (47 sopranos, 36 altos, 34 tenors and 41 basses), nowhere near the 300 to 400 mentioned 33 in Devrient's account (See Martin Geck, Die Wiederentdeckung der Matthäuspassion im 34 19. Jahrhundert (Regensburg: Gustav Bosse, 1967), p, 34, based on Georg Schünemann, 35 Die Singakademie zu Berlin: 1791-1941 (Regensburg: Gustav Bosse, 1941), p. 54). Most 36 of the orchestral personnel were amateurs from the Philharmonische Gesellschaft founded by Eduard Rietz in 1826 (the first chairs of the strings and the winds were members of the Königliche Kapelle). Using a baton, Felix conducted from a piano placed diagonally on 39 the stage, with the first chorus behind and second chorus and orchestra before him. The 39 performance was an enormous success; see $A M Z, 31$ (1829), no. 16, 22 August, column 40 258f.; MA 20.3, p. 993.

41345 Friedrich Wilhelm III of Prussia.

$42 \quad 346$ The total conception of the St Matthew Passion is documented on the title page

43 and in the heading of Bach's autograph manuscript (SBB PK): a due cori. By coro Bach 44 intended the choir, instrumental voices including soloists. 
1 one sees the high priests with their 'Es taugt nicht' and so on, 'es ist Blutgeld', ${ }^{347} 1$

2 and the crowd, 'Ja nicht auf das Fest' and so on, and the disciples, true, honourable 2

3 followers, ruffians, 'Wozu dienet dieser Unrat'. ${ }^{348}$ They seem to be very original 3

4 tones which we did not know but are now compelled to recognize. Then, in the 4

5 middle of it all, the heartfelt lament for the glorious Son of Man, the Friend, the 5

6 Counsellor, the Helper, the Judge, and so on. That that is all new now and natural 6

7 is noticeable in this, that it is not so much gladly received and grasped afterwards 7

8 as that one immediately wants to hear it again and again and again and finally 8

9 would like to understand it. It is all of a piece, no matter how scattered the plot is 9

10 in the text.

11 The Evangelist, Stümer of the Königliches Theater, ${ }^{349}$ one of my former pupils, 11

12 sang the narrative part so admirably (especially in the execution of it) that you 12

13 heard the repetition of the Gospel words with delight. Before the performance I 13

14 had advised him not to hinder the progress of the story by sentimentality, and he 14

15 did it excellently.

In response to many requests we repeated the Passion Music once again before a 16

17 full house. The old audience returned, and new listeners came as well. The opinions 17

18 are justifiably different; and amongst many, one only shall be named, who has the 18

19 right to judge - a right as great as that of any other, and greater. Philosophers, who 19

20 divide the real from the ideal, and throw away the tree in order to recognize the 20

21 fruit, are to us musicians as we are to their philosophy, of which we understand 21

22 nothing further than that we bring before their door the treasure which we have 22

23 found. Take Hegel, for example! He is currently giving lectures on music; Felix 23

24 takes very good notes ${ }^{350}$ and with the freedom of a bird with extreme naivety and 24

25 all his personal idiosyncrasies he understands how to reproduce them. In Hegel's 25

26 opinion Bach is not the right kind of music; ${ }^{351}$ we have advanced further, although 26

27

Bach, St Matthew Passion, Part II, High Priests' Chorus (Matthew 27, 6), 28

High Priests' Chorus, 4b (Matthew 26, 5) and the Disciples, 4d (Matthew 26, 8f). 30

See review in the Spenersche Zeitung, no. 61, 13 March 1829; MA 20.3, p. $994 . \quad 33$

350 Felix Mendelssohn's notes from Hegel's course of lectures, Ästhetik oder 34

Philosophie der Kunst, in the winter semester 1828/29 are in private possession; see 35 Rudolf Elvers, 'Felix Mendelssohn Bartholdys Nachlaß' in Carl Dahlhaus, Das Problem 36 Mendelssohn (Regensburg: Gustav Bosse Verlag, 1974), p. 43. Mendelssohn discussed 37 Hegel's lectures in a letter to his parents from Weimar in May 1830; Gespräche, vol. III/2, 38 p. 625. Passages on musical logic from an unpublished letter from Hegel to Mendelssohn 39 on 30 June 1829 are cited in Eric Werner, Mendelssohn: Leben und Werk in neuer Sicht ${ }_{40}^{39}$ (Zurich: Atlantis, 1980), p. 102.

351 What Zelter is explaining here is in contradiction with Hegel's view in his Ästhetik, 41

42 where the philosopher offers a much more positive view of Bach's music: 'Protestants also 42

43 have produced musicians of great depth as well as of religious sensibility, solid musicianship 43

44 and variety of invention and style. A prime example is Sebastian Bach, a master whose 44 
1 we are still a long way from the right thing. Well, that we know or don't know as

2 well as he, if he could only explain to us musically whether he has discovered the

3 right thing. We all don't know what we should pray for and still carry on and so

4 let the others do the same.

5 The biography of Mozart ${ }^{352}$ which I am reading gives me the greatest joy owing

6 to the original things it contains. The letters are invaluable ${ }^{353}$ as they confirm to me

7 every opinion about this wonderful man and coincide perfectly with my artistic

8 outlook on the whole. If one looks at the mass of contemporary artist rabble by way

9 of comparison one hardly knows whether one should laugh at the young people

10 or weep for Jerusalem. ${ }^{354}$ Mozart's love for his parents ${ }^{355}$ and for his sister ${ }^{356}$ is

11 really admirable. His father was an excellent musician; his violin tutor ${ }^{357}$ is a work 11

12 which is very useful as long as a violin remains a violin. It is so well written. How 12

13 this family must have dragged themselves around. I envy their misery and think: 13

14 nothing more agreeable could have happened me than to have the opportunity 14

15 to imbibe the wide world. Eating hay and straw would not have prevented me 15

16 if, out of obedience to my father and mother, I enjoyed the best with loathing. 16

17 I wrote to my son Carl at the border of Italy where he had no desire to go, ${ }^{358}$ that I 17

18 would gladly pull a waggon to Italy and France if I could still be in his position. 18

19 I had prepared the loveliest opportunities for him though Minister Humboldt. ${ }^{359} 19$

$20 \mathrm{He}$ could have gone where he wanted. And I have to be grateful and am. Forgive 20

21 my tears. Bye for now. 21

25 magnificent, genuinely Protestant, strong and yet learned genius we have recently learned 25

26 to value again completely'; Hegel, Ästhetik, ed. Friedrich Bassenge (Berlin: Aufbau, 1955), 26

27 p. 859.

$28 \quad 352$ Most likely Georg Nikolaus Nissen's Biographie W.A. Mozarts nach Originalbriefen 28

29 (Leipzig: Breitkopf und Härtel, 1828). In the list of subscribers at the beginning of the

30 original edition, Zelter is cited as a customer who has ordered a printed copy.

$31 \quad 353$ Available today in Mozart. Briefe und Aufzeichnungen, collected and annotated by

32 Wilhelm A. Bauer and Otto Erich Deutsch (Kassel: Bärenreiter, 1971).

$33 \quad 354$ Reference to Luke 19, v. 41.

34

355 Johann Georg Leopold Mozart (1719-87) and Anna Maria Walpurga Mozart née Pertl (1720-78).

356 Maria Anna ('Nannerl') Mozart (1749-1829), pianist and ultimately piano teacher in Strassburg.

$37 \quad 357$ Leopold Mozart, Versuch einer gründlichen Violinschule (Augsburg: J.J. Lotter,

38 1756).

39358 See Zelter's letter to his stepson in Karlsruhe; Max Hecker, 'Vater und Sohn.

40 Briefe Carl Friedrich Zelters an seinen Stiefsohn Carl Flöricke' in Funde und Forschungen.

41 Eine Festgabe für Julius Wahle (Leipzig: Insel, 1921), p. 18f . According to the letters, Carl

42 Flöricke's plans to set out on his years of travel from Karlsruhe to France and Italy were

43 unrealized because of his tragic suicide.

44359 Wilhelm von Humboldt.

8 9 10

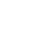

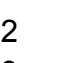

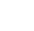

年

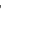

(1)

\section{7}

\section{9} 30 
5 Your last letters, my dearest friend, serious and lighthearted, arrived at the right 5

6 time to do me good. The most recent, bringing news of the successful performance 6

7 of that grand old musical work ${ }^{360}$ has set me thinking. I seem to hear the distant 7

8 roar of the sea. Consequently, I must congratulate you on such a perfectly 8

9 successful rendering of that which it is almost impossible to represent. I imagine 9

10 the connoisseur and witness of such an art, when listening to such works, has 10

11 the same mental experience that I myself had lately when I set the legacy of 11

12 Mantegna $^{361}$ before my eyes again. It is already complete art, its possibilities and 12

13 impossibilities are fully alive, yet are still not developed; were it mature it would 13

14 not be what it is here, not so illustrious, not so rich in hope and in essence. I 14

15 heartily rejoice with you about Felix; I have hardly been as fortunate with even a 15

16 few of my students $[\ldots]$

23 [...] A Madame Müller from Brunswick, a beautiful 25-year-old woman, performed 23

24 here the day before yesterday. ${ }^{362}$ Her husband ${ }^{363}$ is a violinist in the Brunswick 24

25 band and is supposed to be excellent. The woman has an alto voice of the loveliest 25

26 range: clear, even, pure; one could mistake it for an Italian voice. She is looking 26

27 for employment here, which she will find hard because - you know the way things 27

28 are here. She lacks nothing other than experience because she is very shy. If you 28

361 At noon Eckermann showed Goethe a copy of Mantegna's original copper plate 32 engraving Triumphal Procession with the Elephant and Andriani's woodcut; see Goethe's 33 diary 20 March 1829, WA III/12, p. 41. Goethe and Eckermann's preoccupation with 34 Mantegna's triumphal procession is almost documented daily from 20 to 27 March. Goethe, 35 who was already acquainted with Mantegna's work from his Italian journey, possessed an 36 extensive collection of prints in the style of Mantegna. In Über Kunst und Altertum (1823) 37 he published an extensive study of Mantegna's Julius Caesar's Triumphal Procession, 38 which were available to him on single pages and above all in Andrea Andriani's woodcuts. 38 
1 can use someone like her in Weimar let me know, but soon, because I don't believe 1

2 that they will be able to stay here long. They would perhaps be able to make do 2

3 with a reasonable salary. On top of that the woman is very musical, a pianist and is 3

4 very attractive-looking. A kiss from her is no mean thing. ${ }^{364}$ Her husband has fallen 4

5 out with his family on account of his marriage to her. That is all I know and maybe 5

6 that's why they decided to leave Brunswick. A tall, thin figure like our Crelinger ${ }^{365} 6$

7 but with more natural charm, she sang arias by Rossini really well, ${ }^{366}$ pure and 7

8 supple, although self-conscious. Her voice is also full, bright and not straining 8

9 like many Italians; she would have to learn such mistakes from the great Divas. 9

10 Since you wrote to me a few weeks ago that your theatre is beginning to pick up, 10

11 I mention her. Perhaps it would be also possible to use the young woman as an 11

12 actress. The husband is Müller's younger brother, who is leader of the orchestra in 12

13 Brunswick. ${ }^{367}$ As an orchestral violinist he is better than his brother, who is more 13

14 a virtuoso.

15

16

17

18

19

454. Zelter

21 Our theatre is a nest of anarchy. All the singers are against Spontini. ${ }^{368}$ The singer, 21

22 Bader, complained to the King about him and asked for the satisfaction of never 22

23 singing in one of his operas again. Madame Wolff can tell you in person. ${ }^{369}$ It's 23

24 tedious to me.

25

26

366 In the programme the two Rossini arias are unnamed; she also sang an aria by

Anschütz and a duet with Carl Adam Bader; again more exact programme details are by Brühl's resignation in December 1828. A difference of opinion soon arose with the successor in office, Count Wilhelm von Redern, appointed on 13 December, ultimately

39 over the rejuvination of the ensemble demanded by Spontini. Spontini's plan to replace a

40 personnel that was exhausted by age and sickness - and not least by the constant demands

41 put on them by the composer - by younger forces to be signed on from all parts of Germany

42 caused great opposition to him from established singers, male and female.

$43 \quad 369$ At the end of April Amalie Wolff traveled to Weimar for a long engagement as 44 guest performer. 
5 I immediately passed on to Kapellmeister Hummel your friendly news of a first- 5

6 rate [female] singer. After consultation with colleagues and superiors he brought 6

7 me an appreciative but negative reply. In their constrained circumstances an alto 7

8 would be no help to them. If you could allocate such a soprano to them, they would 8

9 be grateful. And the way things stand, this is the most pressing requirement of our 9

10 theatre. [...]

16 [...] I enclose you an account of a similar little dispute ${ }^{370}$ going on at the moment; 16 17 it will allow you to see what one has to contend with. In return, I present my 17 18 adversary with a snare for so-called connoisseurs, and if he falls into it, he shall 18 19 have it hotter this time. He is a serious admirer of the compositions of Wilhelm 19 20 Friedemann Bach, (eldest son of Sebastian Bach), which I am not, for which he 20 21 finds fault with me. Apropos of this, he sent me an Organ Concerto by Friedemann 21 22 Bach, $^{371}$ and copied for me the saying of Quintilian ${ }^{372}$ referred to in the letter. To 22 23 save you the trouble of looking up chapter and page for yourself, here it is: 23

370 Goethe had returned Bendavid's note with the extract from Franklin's writing 28 in his letter to Zelter on 2 April; Goethe had written his reply to Bendavid's note on the 29 same sheet of writing paper. Zelter made a copy of this note and forwarded it to Bendavid. 30 Lazarus Bendavid (Ben David) (1762-1832), philosopher and mathematician, director of 31 the public Jewish school in Berlin.

371 Wilhelm Friedemann Bach had passed off his father's, Johann Sebastian Bach's 33 organ arrangement of Antonio Vivaldi's Concerto in D minor for two violins and orchestra 34 (RV 565) as his own work, writing on the top of his father's manuscript 'di W.F. Bach, manu 35 mei Patris descript' (by Wilhelm Friedemann Bach in the hand of my father). See Zelter's 36 discussion of this work in his letter to Griepenkerl (GSA 28/1024, no. 378).

372 A quotation from Quintilian's Institutio oratoria, Book 10, chapter 7: 'One should, $\begin{aligned} & 37 \\ & 38\end{aligned}$ however, be moderate in one's judgements of such great men, so that one doesn't dismiss 38 (like the majority of people) what one doesn't understand', Quintilian, on misinterpretation 39 of the great orators and writers. The passage was well known to Goethe, who had already 40 referenced it in Ephemeriden; see Otto Seel, 'Quintilian bei Goethe' in Quintilian oder Die 41 Kunst des Redens und Schweigens (Stuttgart: Klett-Cotta, 1977), pp. 288-313. 42

43373 'Judgement, however, about such men should be modest
44 happens to many people, they condemn what they don't understand.' 
1 This Friedemann Bach of Halle ${ }^{374}$ was the most consummate organist ${ }^{375}$ I have 1

2 ever known. He died here in 1784, when I was already a citizen and stonemason. 2

3 He was considered obstinate because he would not play for everybody; he was not 3

4 arrogant towards us young people and he would play for hours. As a composer he 4

5 had the odd characteristic of being original, of distancing himself from father and 5

6 brothers, and consequently he sank into affectation, pettiness, barrenness whereby 6

7 he was as easily recognized as one who shuts his eyes to become invisible. We 7

8 were continually arguing about this and as to this very day my æsthetic companion 8

9 still holds such original views, I cannot help confronting him [...] 9

16 Good Friday, 17 April: Today, instead of Graun's Passion Music, which is 16

17 customary, I mean, by special request, to give another performance of Bach's 17

18 Passion $^{376}$ in defiance of my old bent fingers, for my assistant, Felix, is swimming 18

19 on the seas past Helioland to England, where he has been invited. As he plays the 19

20 organ well, and there the organs are better than the organists, I think he may try 20

21 his luck there too. [...]

22 Saturday evening: My hall was full yesterday. The King, ${ }^{377}$ Prince and Princess 22

23 Wilhelm, ${ }^{378}$ the Duchess of Cumberland ${ }^{379}$ and several people from the court were 23

24 there. The others complained about the terrible heat and you can imagine how dear 24

25 it is to me if they all sweat through and through as I did, too. I am happy to sweat. 25

26 The cool grave will put me right again. One can take one's time. One has the whole 26

27 of eternity before one.

28 Paganini with his damned violin concertos is driving men and women mad 28

29 here $^{380}$ and will carry off from Berlin 10,000 thalers once more, if he does not first 29

374 Wilhelm Friedemann Bach (1710-84), eldest son of J.S. Bach, worked in Halle from 1746 to 1770 before taking up residence in Berlin after a four-year sojourn in Brunswick.

35 375 See Zelter's draft letter to Griepenkerl (GSA 28/1024, no. 378).

376 Third performance of Bach's St Matthew Passion in the Sing-Akademie hall.

$37 \quad 378$ The king's brother, Prince Wilhelm, and his wife, Marianne.

380 Although originally only four concerts by the violin virtuoso Niccolò Paganini,

41 were planned (on 4, 13, 19 and 28 which was postponed to $30 \mathrm{March}$ ), he gave a further ten

42 concerts between March and May 1829 mainly in the opera house, but also occasionally

43 in the hall of the new theatre $(6,16,25,29$ April, 5, 9, 13 May). In these concerts he 42 43

44 played mainly his own compositions, above all his Violin Concerto and Variations for solo 44 
1 lose them again at Faro. I have not enough funds to give him two thalars for each 1

2 performance and have heard nothing of him, beyond seeing his portrait in which 2

3 he resembles the son of a witch. The real misfortune he brings upon us is that he is 3

4 the complete ruin of the young violinists in our orchestra. 4

5

6

458. Goethe

5

8

This reminds me that you still have a score of my Cantata Rinaldo, composed 14 by Winter for Prince Frederick of Gotha. ${ }^{382}$ I still have the vocal parts, and many 15 17 find it. [...]

A Frenchman has set eight passages of my Faust to music, and sends me the score 11 memories are associated with this opus. So let me have it back again if you can 16

violin, but also virtuoso works by other composers. Two such works played by Paganini 23 on his German tour were the sets of variations on Il Carnevale di Venezia and 'God save 24 the King', the main feature of the latter being an intermingling of left-hand pizzicato with 25 bowed notes, probably the first example of such a complicated technique. The reviews were 26 extremely positive; see, for example, $A M Z 31$ (1829), no. 16, 22 April, column $215 \mathrm{ff}$ and 26 no. 22, 3 June, column 364f; $M A$ 20.3, p. 1005.

381 On 10 April 1829 Hector Berlioz sent Goethe two copies of the score of his setting 28 of eight scenes from Faust, based on Gérard de Nerval's translation, and an accompanying 29 letter (HA Briefe an Goethe, vol. 2, p. 506). The composer, Ferdinand Hiller, wrote to 30 Eckermann about it on 23 March 1829: 'A good friend of mine, a young talented composer 31 by the name of Berlioz, has set eight scenes from Faust, unfortunately in the French 32 translation. He is going to send Goethe a copy. You would do a good turn if you could 33 get Goethe to write a few lines to him. It would make the young man very happy as he is 34 besotted by Goethe' (GMD: KK 3700). Eckermann answered: 'Goethe showed me the copy 35 and tried to sight-read the score. He had the deepest desire to hear it performed. A very 36 well-written letter from Hector Berlioz was enclosed, which Goethe also gave me to read, 37 and whose educated, very polite tone pleased us both. He will definitely answer Berlioz, 38 if he has not done so already.' Goethe never replied to Berlioz, presumably on the basis of 39 Zelter's crushing judegment. 382 Goethe's cantata Rinaldo was set to music by the Munich Kapellmeister Peter von 40 Winter in 1822. It was composed for Prince Friedrich of Sachsen-Gotha (Duke Friedrich IV 41 from 1822). When Goethe handed over this score to Zelter is unknown (perhaps on Zelter's 42

44 Weyland and received from Goethe the fair copy he requested on 11 June 1829. 
5 Last Tuesday Paganini visited me at the academy and listened to our performance; 6 and the following day I finally heard him play. ${ }^{383}$ It is extraordinary what the man

7 has achieved, and I must say this, that his technical mastery, which everyone

8 would be glad to possess, quite surpasses the comprehension of other virtuosi

9 upon his instrument. His being is therefore more than music, without being higher

10 music, and I expect I would have the same opinion if I heard him more often. I was

11 positioned where I could see every movement of his hand and arm, which - as his 11

12 figure is rather small - must possess some rare flexibility, strength, and elasticity, 12

13 for he is never tired of mastering difficult passages in an ascending scale, with the 13

14 same regularity as a clock which contains a soul. The hundred techniques of his 14

15 bow and fingers, to each one of which he has devoted thought and practice, follow 15

16 each other in good taste and order, and also distinguish him as a composer. But 16

17 in any case, he is, in the highest degree, a perfect master of his instrument; that 17

18 which, with the best will in the world, he does not succeed in, is heard as a bold 18

19 variation. $[. .$.

20 The score of Rinaldo is returned here with thanks. I wanted to copy it myself, 20

21 even improve it. The willing mind at first thought it had eyes and time for the 21

22 work. But if you have a reasonable music copyist, I would like to have a copy. 22

23 Please send your Frenchman's Faust one of these days; the subject is attractive 23

24 to composers. [...]

25 Sunday 3 May: Water and rain and the cold: the swallows have gone away 25

26 again and von Praun, ${ }^{384}$ a new violinist, is here and I heard him yesterday. The 26

27 boy is 18 years old and plays better than a Baron. ${ }^{385}$ He would be finished with 27

28 technique if he could master material and limbs, which cloak the music in finger 28

29 execution that one notices nothing other than hands and feet. What you have 29

30 too little of one must tire of here. We drown in patchwork music and Grünberg 30

31 champagne. One is like a hen on a tremendous heap of rubbish and scratches and 31

32 picks a few seeds out which the high-spirited suiters have overlooked. Laborious 32

33 work but one learns from it. [...] 33

$34+34$

$35-35$

$36 \quad 36$

$37 \quad 37$

$38 \quad 38$

39383 On 29 April 1829 in the Berlin opera house. 39

40384 Baron Sigismund Otto von Praun gave a concert in the Königstädtisches Theater 40

41 on 2 May 1829 following a free adaptation of Gellert von Holbein's play Die Witwe und 41

42 der Witwer or Treue bis in den Tod. He performed, among other works, a violin concerto by 42

43 Lafontaine, variations by de Beriot, a caprice by Paganini and a polonaise by Mayseder. 43

$44 \quad 385$ Most likely a reference to the violinist and amateur musician Baron Bagge. 44 
5 In the table of your Theory of Sound, which I look at daily, ${ }^{386}$ line ten states: 'Key 5

6 relationships are distant from one another./ Chords.' I recommend putting 'tonic 6

7 chords' or 'primary chords' because they develop first of all from the home key, 7

8 then modulate into less remote relationships until the root finds itself in the second 8

9 octave and the series comes to an end by itself. A primary chord is therefore one 9

10 which is composed of thirds, placed one on top of the other: 10

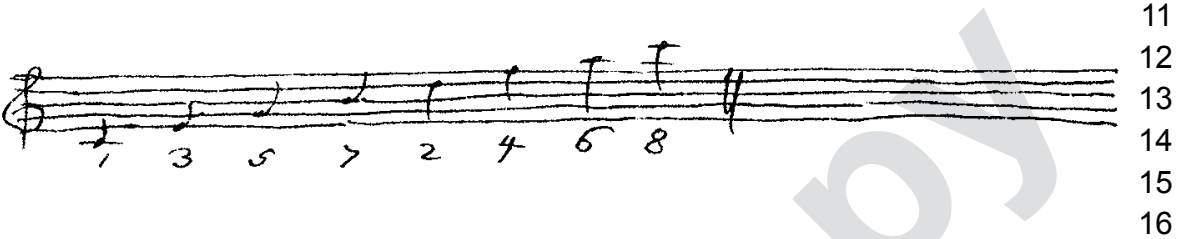

17 From this the intervals of the diatonic scale were built and even closer 17 18 interrelationships, which from the ascent of diatonic intervals or their descent call 18 19 forth a melody (gently progressing), which ultimately brings about the theory of 19 20 dissonance through which music becomes art.

21 Take note of this: the intervals of the triad in root position show no tendency 21

22 to change or movement. Such a tendency comes about with the 'third third' (the 22

23 seventh of the scale), which longs for resolution at the octave, through which it 23

24 forms a dissonance against the root, and so on with the ninth or the second, eleventh 24

25 or perfect fourth, and third or sixth. Here the theory of consonance and dissonance 25

26 comes into being in relation to the root through which music becomes the art of 26

27 artists. Through the tendency of dissonance to impetus, modulation comes about; 27

28 the exception [being] the demand of one key to move from its tonal centre in order 28

29 to establish a new tonality without which no context could come about and at the 29

30 same time provide the answer to the old question: whether melody or harmony 30

31 comes first, since a series of tones unrelated to the tonic could not appeal to the ear. 31

32 Through this consideration of dissonance we are led to the key with respect to high 32

33 and low (smaller or greater vibrations). A single chord, whether it is consonant or 33

34 dissonant is still not a key: the latter is first established through the dominant chord 34

35 (the major chord on the fifth). In these two chords following one after the other, the 35

36 dominant and tonic, or tonic and dominant, my individual feeling finds the original 36

37 elements of metre: arsis and thesis or thesis and arsis, which my ear hears on the 37

38 stroke of the hour and in the beat of the pulse, even in the quiet movement of the 38

41386 Goethe had sent Zelter the table of his Tonlehre in September 1826, but requested it 41

42 back the following year as new ideas had occurred to him. Zelter had returned it to Weimar 42

43 on 10 July 1827, after he had taken a copy of it. Goethe's request for Zelter's opinion of the 43

44 Tonlehre in October 1826 is eventually answered here. 
1 pendulum just as the latter is already metre which relates to rhythm in the same 1

2 way as narrow to wide, as restriction to freedom: 2

3
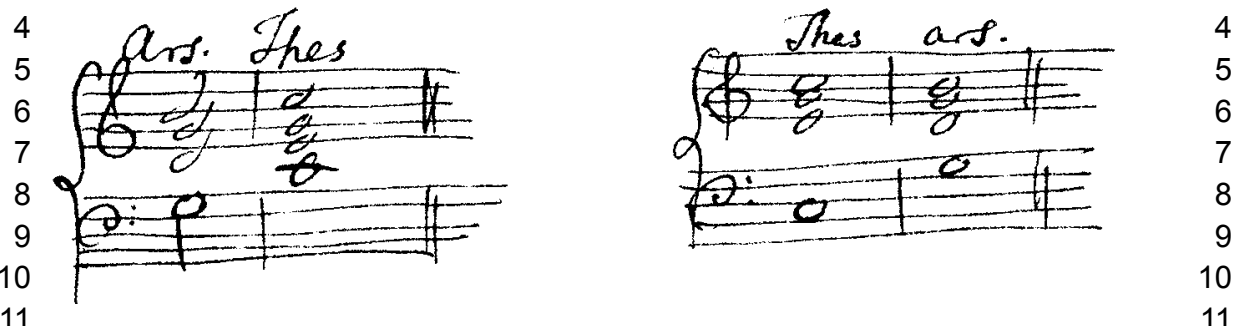

13 I find here the foundations of the rule against consecutive fifths in so far as they, 13 14 according to the basic laws of both chords of the dominant and tonic, are not 14 15 modulatory and therefore are offensive. $\quad 15$

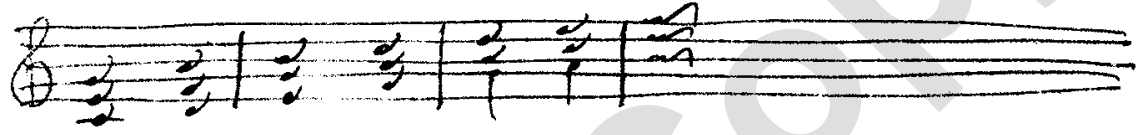

21 They are offensive because they don't relate to the tonic key and don't form a 21

$22 \mathrm{key}$, in that every chord is in itself a foreign primary chord and therefore is also 22

23 unrhythmic. They become completely offensive when they occur on consecutive 23

24 strong beats.

25 However, at the same time they cease to be offensive if they appear rhythmically 25

26 (from arsis and thesis) in a manner which is well thought-out, that is when they are 26

27 prepared through a dominant triad:

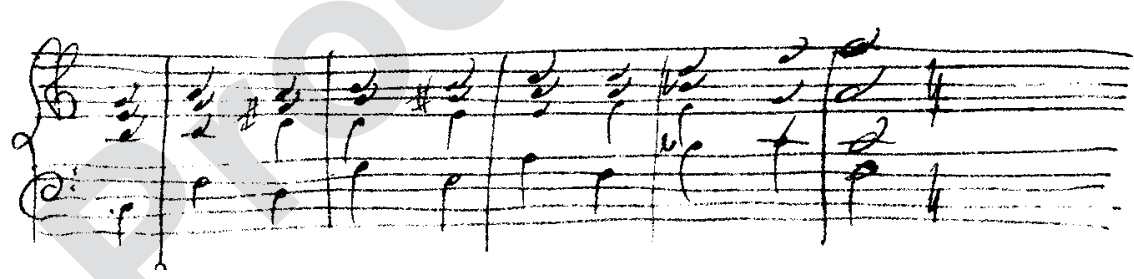

36 This rule soon led to the expansion of a fine phrase and melodic progressions so 36

37 that it had to be treated with extreme rigour; it gave genius an opening to creations 37

38 of great beauty.

39 Since you are so good as to keep my scribblings, I ask your permission to send 39 40 numerous letters sometimes which contain scientific responses and as they turn 40 41 out to be negative, they are not well received and are even hidden away by the 41 
1 recipients. One of my former students, ${ }^{387}$ who became a schoolmaster in Breslau 1

2 and is an active young man, had the idea of writing a joint Festschrift for our 2

3 Chladni and the deceased organist Berner. ${ }^{388}$ He is gathering together contributions 3

4 and has written a biography of Berner $^{389}$ for this purpose. Then he sent me 504

5 copies which I should sell off. At first I wanted to answer him that I would give one 5

6 Friedrichs d'or for Chladni and took another back for Berner. But what's the point 6

7 of long quarrels and talking with such people? So I am sending him the money 7

8 for the copies and am clear of it. The copy of the letter is also enclosed; use it as 8

9 you wish. I should also lay a copy at the feet of the Russian Emperess ${ }^{390}$ for this 9

10 purpose; the Russian messenger Count von Alopeus ${ }^{391}$ is doing that for me since 10

11 the Empress is passing through Breslau. 11

12 Yesterday I heard Paganini again; ${ }^{392}$ the man is a rarity - he is the violin. One 12

13 is amazed, one laughs, one is in despair at the most daring escapades; the difficulty 13

14 is clear to all, for the effect is experienced by all. Grace and spirit are not wanting, 14

15 and even that which is not perfectly successful, is still new and interesting. 15 beginning of December. He 'was lucky enough to be able to enjoy lessons with Professor 29 Zelter in music theory, as well as in singing and to be able to visit his Sing-Akademie', Carl 30 Julius Adolf Hoffmann (ed.), Die Tonkünstler Schlesiens (Breslau, 1830), p. 198.

388 Hientzsch had issued a 'request for contributions' for a memorial for Chladni and 32 Berner in the journal Cäcilia, issue 9, 35 p. $181 \mathrm{ff}$. 389 Johann Gottfried Hientzsch, Friedrich Wilhelm Bemer (..)nach seinen Lebenund 33 Wirken in der Musik dargestellt. Zugleich ein Beitrag zur Geschichte des Musikwesens 34 Breslau während der letzten 20-30 Jahre besonders abgedruckt aus der Eusihwesens von 35 Breslau während der letzten 20-30 Jahre; besonders abgedruckt aus der Eutonia (Breslau, 36 1829) with an announcement on the title page: 'The proceeds from the purchased copies 36 are intended as a contribution towards erecting a memorial for Chladni and Berner'. 390 Alexandra Fjodorowna née Princess Charlotte of Prussia, daughter of Friedrich $\begin{aligned} & 38 \\ & 39\end{aligned}$ Wilhelm III, married to Emperor Nikolaus I Pawlowitsch of Russia.

392 On 13 May 1829 Paganini gave his last concert in Berlin: a benefit concert for 41 the Spontini Foundation in the opera house. The orchestra along with many well-known 42 
5 [...] In Letter 345 [of your Correspondence with Schiller] ${ }^{393}$ he writes that the

8 he had thought it impossible for the same melody to be repeated so often without

9 becoming wearisome and on the contrary to became more effective. Admittedly

10 my singing is not much to speak of, but against that, many a singer cannot declaim 10

11 [a poem]. Besides, Schiller was quite satisfied with my music to 'Der Taucher', ${ }^{396} 11$

12 and he complained vehemently to Naumann, who had just set 'Die Ideale'. ${ }^{397}$ I 12

13 had won a similar wager with 'Der Taucher'. One of our friends was dissatisfied 13

14 with the ballad forms used by the poets, and exclaimed, 'Who could think of 14

15 setting such verses, such a diver to music?' Several of us were there, and I, who 15

16 had been listening silently to the whole conversation, called out, 'I could! and 16

17 Schiller himself shall praise it!' There and then I wrote down the notes, and so 17

18 they have remained, however clumsy they may appear. When I presented them 18

19 immediately afterwards (for I knew the poem by heart), an anything-but-musical 19

20 matron planted herself by my side and made the movement of a metronome with 20

21 her knitting needle. Hardly was the last word over when she exclaimed amidst 21

22 floods of tears, 'Well, that was an infamous king!' 398

\begin{tabular}{ll}
27 & 27 \\
\hline & \\
28 & 28
\end{tabular}

33 Schiller's letter to Goethe, 7 August 1797: 'Recently Zelter sent me the melody for he ballad doesn't fit all verses so well, but for some, as in the third last verse, the choir for 'Wir tragen die Jugend' works particularly well; $M A$ 8.1, p. 382.

37394 Zelter's setting of Goethe's ballad 'Der Gott und die Bajadere'.

38395 During Zelter's first visit to Weimar, on 25 or 26 February 1802; see Goethe's

39 diary, 'To a concert in the palace. At the palace in the evening.' WA III/3, p. 52.

$40 \quad 396$ Zelter's setting of Schiller's ballad 'Der Taucher'. 40

41397 Johann Gottlieb Naumann's setting of Schiller's poem 'Die Ideale', first published 41

42 in the Musen-Almanach für das Jahr 1796.

$43 \quad 398$ The infamous king (in Schiller's Der Taucher), who sends the diver down a second 43

44 time to retrieve the golden chalice and thereby has him drowned. 44 
5 First of all, let me thank you heartily for your description of Paganini. When 5

6 I compare it to what is to be read in the Berlin newspapers, ${ }^{399}$ my reason and 6

7 imagination give me what seems a comprehensible picture. What one must have 7

8 actually heard becomes to some extent clear to the intellect. I am glad he had such 8

9 a listener, and you such a virtuoso.

10 You also deserve gratitude for explaining the important musical principles in 10 11 your last letter. Resolve to do the same from time to time and you yourself will 11

12 be storing up a treasure in my books. I am happy with my table ${ }^{400}$ as a naked but 12

13 well-stuctured skeleton to which a genuine artist might add the necessary flesh, 13

14 skin and entrails and bring it to life through practice and thought. By this means 14

$15 \mathrm{I}$ look across in a wonderful way to a region in which I was not supposed to find 15

16 enjoyment, let alone find joy in reflecting on it. [...] 16

23 I am gradually making my way through Part Two of the Schiller letters, about 23

24 the first appearance of Wilhelm Meister, which took place just when I made my 24

25 first contact with you. ${ }^{401}$ A new phase in my life had emerged out of the deepest 25

26 affliction. ${ }^{402} \mathrm{I}$ had just been happily married to my second wife, whom I had known 26

27 from her childhood, for I had attended the same Gymnasium as her brothers. ${ }^{403} 27$

399 Spenersche Zeitung, no. 55, 6 March; no. 64, 13 March; no. 68, 21 March; no. 83, 29

8 April; no. 98, 28 April; no. 101, 1 May; no. 107, 8 May.

401 Zelter, who had three of the six volumes of Goethe and Schiller's correspondence 32 by May 1829, was rereading the letters of 1796 in volume two. Of the principal themes 33 discussed mid-year, Zelter is preoccupied with the discussion of the final book of Wilhelm 34 Meisters Lehrjahre as well as the appearance of Part IV of the novel in October 1796, 35 but also the earliest documentation of Goethe's contact with Zelter on the occasion of the 36 settings for Schiller's Musenalmanach. Zelter himself remembers this fateful year of 1796, 37 which not only was the year of his remarriage (to Juliane Pappritz) but of his first published 38 settings of Goethe's poems in his collection Zwölf Lieder am Klavier zu singen and in 39 
1 Before this I had given her lessons in singing, or rather through her crystal voice 1

2 and clarity of delivery, I had experienced for the first time what no teaching can 2

3 give. I could not help being pleased with my own arias when she performed them. 3

4 People held their breath, so as not to miss even the smallest nuance. At that time 4

5 I had already written down my first impressions of your poems on a series of 5

6 sheets $^{404}$ which unfortunately have been lost, for they marked the transition from 6

7 life as a civilian to my natural vocation. $\quad 7$

8 I had so many children, so many mouths to feed, so much work, such delight in 8

9 my strength, and then, I had another gentle wife, who took the children in hand - 9

10 and when the father came home, we had great fun. I built houses for people, who 10

11 to this day owe me the money which I laid out. When others worried about what 11

12 it would all come to, I was as cheerful as possible. Clearly there were difficulties; 12

13 I spoiled my customers, who had too much of a good time and wanted to have 13

14 what I myself did not possess. That was what was amusing. Then Wilhelm Meister 14

15 enters my household ${ }^{405}$ with his lively company of rational and irrational beasts. 15

16 People said I had lost my wits. I saw only green fields and the sky full of fiddles. 16

$17[\ldots]$

18

19

20

21

22

23

24 Although I cannot believe, dear Zelter, that you could ever take notice again of my 24

25 crazed unsteady hero in Winter's score, ${ }^{406}$ I will send a clean copy, according to 25

26 your early request, with the wish and hope that it will be alright with you.

404 That Zelter is thinking of his handwritten Sammlung von kleinen Liedern zum Singen beim Klaviere gesammlet und komponiert von C.F. Zelter (Berlin, 1780) must be questioned, for he says the pages are 'unfortunately lost'; this collection was still held by the Bibliothek des Berliner Grauen Klosters in 1936; it was lost or destroyed during the Second World War.

38405 Wilhelm Meisters Lehrjahre was published by Unger in Goethe's neue Schriften in 391795 (vols 3-5) and 1796 (vol. 6).

40406 Goethe's cantata Rinaldo had already been produced in Winter's setting in 1812;

41 however, the score was not in Goethe's possession at that time. When Goethe received it

42 and when he gave it to Zelter is unknown. Goethe requested it back from Zelter on 28 April

43 1829, and Zelter had Philipp Christian Weyland return it to Weimar for him after he had 44 made a copy of it. 
5 This page, my dear Goethe, is to recommend you the most agreeable fat little 5

6 Blondine, ${ }^{407}$ who is the best contralto we have in the Sing-Akademie and is 6

7 travelling through Weimar to meet you. She is travelling all alone to Holland, 7

8 without her husband and the loveliest children, to see her mother again.

I have recommended her to Ulrike whom she knows and if Ulrike is in good 9

10 health, she will oblige by introducing Madame Türrschmidt to you. 10

Our friend Madame Szymanowska recommends a talented Polish compatriot and 17 18 poet, especially to you as Prince of poets. ${ }^{408} \mathrm{He}$ is called Mickiewicz and wants to 18 19 travel through Germany on his way to Italy. Madame Szymanowska is now in St 19 20 Petersburg, is giving lessons, has separated from her husband, ${ }^{409}$ has two daughters 20 21 and a son. ${ }^{410}$ The young man already speaks fairly good German and is especially 21 22 recommended. You can discover the rest from him himself. [...]

2321 June: Certain people can only show their awareness and appreciation by 23

24 means of loud coughing, snorting, croaking and spitting; Berlioz seems to be one 24

25 of these. ${ }^{411}$ The sulphur smell of Mephisto attracts him, and so he must sneeze 25

26 and puff, until all the instruments in the orchestra get the jumps - only not a 26

27 hair of Faust's head moves. However, thank you for sending me the music; the 27

28 opportunity will turn up to make use of it in a lecture as an abscess, an aborted 28

29 work, which arises from the most terrible incest. 1823 and who settled in St Petersburg with her three children after touring as a concert 36
pianist, had recommended the Polish poet Adam Mickiewicz, presumably in a letter to 38

39 Zelter which has not been handed down. Szymanowska had come to know Mickiewicz in 38

St Petersburg where he lived after he had been banished from Poland as politically suspect 39
in 1824; he later married her eldest daughter, Celina.

41409 Jósef Szymanowski.

42410 Celina, Helena and Romuald. 42

43411 Zelter's devastating critique of Hector Berlioz's Huit Scènes de Faust; Goethe had 43

44 sent him the second copy of the printed score on 11 June 1829. 
1 Worthy Winter's Rinaldo has, on the contrary, a human form of some kind, 1 2 which is suitable for a tenor; but now we are as far removed from that, as that so- 2 3 called artificiality of tones is from music. [...] 3

416 July: The Polish poet recommended by Madame Szymanowska asked for a 4 5 letter for you and has not collected it! $\quad 5$

12 [...] Since I can well imagine now you will be in demand in the next few days, ${ }^{412} \mathrm{I} 12$

13 will say nothing further other that that I am as well, for apart from my relationship 13 14 to the Sing-Akademie I am now committed to 42 lessons a week ${ }^{413}$ and to the 14 15 teaching of rudiments of singing to boys and lads, who (long taught) discover for 15 16 the first time and to everyone's surprise that while singing one has to open the 16 17 mouth, have an expression, and must be able to walk [out] and stand [correctly]. 17 18 It begins to give me real joy to start from the beginning once more, and to let 18 19 myself be laughed at by the bunglers who reveal the secret attractions of vocally 19 20 demanding grand operas to the young girls of Berlin.

27 Naue, the Director of Music, ${ }^{414}$ has me (in the papers) coming to Halle to his 27

28 festival of music and then he invites me afterwards. You needn't lose sleep over it: 28

29 I have to sweep before my door and also know to be busy!

3020 August: Naue does not know how to occupy himself in his position. He 30

31 once went through my school and, with the help of all kinds of patrons, took over 31

32 the position of the deceased Türk and in addition Professor Maß’s daughter. ${ }^{415} 32$

33 May he serve her better because she is the first of those he needs to bring in to 33

413 The musical seminars for students at the University of Berlin, initially organized

38 by Bernard Klein, were taken over by Zelter in 1829. In the early months of 1830 Zelter

38 formed a Collegium musicum vocale from the most gifted singers. The musical seminars,

39 which were originally intended for theological students, were very popular with the student

40 community in general.

41414 Johann Friedrich Naue (1787-1858), Director of Music at the University of 41

42 Halle.

43415 Naue's wife, a foster-daugher of Johann Gebhard Ehrenreich Maaß, Professor of 43

44 Philosophy in Halle. 
1 do his work for him. Now he comes and asks to be able to place my name beside 1

2 the names Spontini, Moeser and so on, in what is for him a completely unfruitful 2

3 undertaking. I didn't say no only because I would not allow myself any rejection 3

4 of these men and will give no opportunity for importunity to the indiscretion of 4

5 a vain music director - that's [the end of ] the story. Afterwards he wants to send 5

6 a carriage for me and my household - good accommodation and catering at a 6

7 desirable location is to be made ready - which I can honourably decline and not 7

8 be under a compliment. [...]

9 Felix is in Scotland ${ }^{416}$ and has already written down to us from the Highlands. ${ }^{417} 9$

10 I have commissioned him to transcribe the national songs and dances ${ }^{418}$ more 10

11 accurately than those travelling amateurs and untutored copyists from whom we 11

12 have derived our knowledge up to now. The dear rascal has the luck of finding 12

13 and making friends everywhere; he has even met Walter Scott. ${ }^{419}$ Then in London 13

14 he met a young Hanoverian ${ }^{420}$ who was attached to the English Embassy here and 14

15 who is now his companion on this instructive journey, whether they travel by foot, 15

16 by horse, or by water. From there, via Ireland and Holland, he will come home in 16 family on 3 and 7 August; Mendelssohn Briefe, pp. 79-85; a letter from Felix to Zelter from 28 this time in unknown.

416 At the end of July Felix undertook a one-month tour of Scotland and the Hebrides 22 with Karl Klingemann. Their journey is documented in Mendelssohn's letters to his family, 23 the first of which was written to his father from Edinburgh; see Rudolf Elvers (ed.), Felix Mendelssohn Bartholdy. Briefe (Frankfurt am Main: Fischer, 1984), p. 79ff. Hereafter 25 referred to as Mendelssohn Briefe.

417 Perhaps Zelter means the letter of 28 July to his father, or those written to his 27

418 Scottish folk music was very popular, as illustrated by the arrangements of Haydn 30 and Beethoven. In unpublished letters of 5 July and 6 August 1829 (Werner, Mendelssohn, 31 p. 184), Zelter tells Mendelssohn to pay attention to folk music but Mendelssohn wrote to 32 10,000 devils take all national traditions. Here I am in Wales, and oh, how lovely! A harpist 34 sits in the lobby of every respectable inn playing so-called folk melodies to you-dreadful, 35 vulgar, fake, and simultaneously a hurdy-gurdy is tooting out melodies - it's enough to 36 drive you insane!'

419 In a letter to the Mendelssohn's from Abbotsford on 31 July, Karl Klingemann 37 described the visit effusively but ironically and in a postscript to the letter, Mendelssohn 38 added, 'Klingemann is lying above; we found Walter Scott about to leave Abbotsford, we 39 looked at him as we would at a new gate, we travelled 80 miles and lost a day in order 40 to have half an hour of insignificant conversation'; Sebastien Hensel (ed.), Die Familie 41

42 Mendelssohn 1729 bis 1847. Nach Briefen und Tagebüchern (Frankfurt am Main and 42

43 Leipzig: Insel Verlag, r.1995), p. 274. 
1 the autumn for his sister's marriage with the court painter Hensel, ${ }^{421}$ and then set 1 2 out for Italy. ${ }^{422} \mathrm{He}$ is hard at it, building his career, and there is no lack of stone. 2

18 [...] Felix sent me a young Scotsman from Edinburgh, ${ }^{424}$ who unfortunately 18 19 doesn't speak anything apart from English. He is, however, very musical and so 19 20 we will have to deal with each other through music. Since these islanders set great 20 21 value by what they have, he was all ears last Friday when he could listen to a piece 21 22 of music by old Bach prima vista with a score in hand, which at least went off 22 23 smoothly. If I placed my Scotsman against your Polish poet and Englishman, ${ }^{425}$ we 23

24 would have a trio, the like of which you don't find everyday, in order to crack open 24

25 a piece by Klopstock. [...]

31421 On 3 October 1829 Fanny Mendelssohn married the court painter Wilhelm Hensel, 31

32 whose work embraced historical and church pictures as well as numerous portraits of 32

33 the Mendelssohn family. Felix's attendance at the ceremony was prevented by a coach 34 accident.

$35 \quad 422$ Felix's two-year journey through Italy, Switzerland and France began in May young man, J. Thompson, who brings you the letter speaks neither German nor French; you must act as if you were in Edinburgh and go on speaking English through thick and thin. He

40 really loves music; I know an attractive trio he composed and also some songs which I really

41 like', Hensel, Die Familie Mendelssohn, p. 270. The Scottish composer John Thomson had

42 befriended Mendelssohn on his tour of Scotland; returning to Edinburgh after a sojourn in

43 Germany, he became best known for his music for Scott's The House of Aspen.

$44 \quad 425$ John Thomson, Adam Mickiewicz and Henry Crabb Robinson. 44 
5 In Halle 4,000 thalers in excess of the takings is to be paid. ${ }^{426}$ To achieve this, 5

6 willing hearts are being sought. They have the courage to continue with such 6

7 festivals, ${ }^{427}$ even to move to Berlin and Potsdam, which is why we want to see a 7

8 similar festival nearby. No one fails to applaud the performance of major works 8

9 since such works were rehearsed by our best people well in advance. If one doesn't 9

10 want to be too strict, such festivals are a means for making some thousands of 10

11 thalers circulate, which, of course, would be everything. [...]

Will you be so good as to have the enclosed canon ${ }^{428}$ delivered to the Chief 12

13 County Councillor Töpfer? ${ }^{429}$ They were so nice in the shooting society as to 13

14 repeat, for our sake, the shooting which had already taken place before noon. I 14

15 don't know any other way of showing my appreciation since they presented a 15

16 copy of their songbook to me which was partly decorated by your poems. As they 16

17 couldn't stop singing, the simple canon may go down well with them and travel 17

18 to foreign parts.

44 from Zelter.

'that the takings had still not reached 3,000 thaler, leaving a deficit of over 1,000 thaler'; 26 Schottländer, Carl Friedrich Zelters Darstellungen seines Lebens, p. 294. 'The festival 27 accounts' were also discussed with Naue's wife the following day. Ibid., p. 295. Whether 28 the different information about the amout of the deficit is based on a mistake by Zelter or 29 on new information is unknown.

427 As a result of the postive reception of the festival in Halle - see, for example, the 31 Spenersche Zeitung of 23 September (MA 20.3, p. 1040) - the idea of continuing this event 32 soon arose; see Zelter's conversation with Naue recorded in his diary on 25 September, 'and 33 so he still has the courage to uproot and move his Thuringian music festival to Potsdam and 34 to offer me the direction. So I could become a Pots-doctor to the Potsdamers - let's think 35 about it between now and then?' Schottländer, Carl Friedrich Zelters Darstellungen seines 36 Lebens, p. 295. Despite the financial fiasco in Halle, Naue announced a 'Big Music Festival 36 in Potsdam'; Berliner Allgemeine Musikalische Zeitung (1830), column 270.

428 'Der Schütze sang mit Freuden', probably by Christian Philip Köhler, composed 39 Zelter for the Weimar Crossbow Society. To Councillor Töpfer, passed on for further safe keeping' (GSA 29/512a). On 4 October 42

3 Töpfer paid a visit to Goethe to thank him, on behalf of the society, for the consignment 43 
$5[\ldots]$ Now here is the greatest wonder of antiquity for those that have eyes to see 5 6 the good of the moment and what this is worth. For although by the most terrible 6 7 misfortune these pictures were buried among ruins for nearly two thousand years, 7 8 they are still just as fresh, as outstanding, as successful, as they were in the hour of 8 9 fame and contentment which preceded their fearful entombment. If we were asked 9 10 what they represent, one would find it rather difficult to find an answer; meantime 10 11 I should say that these forms give us the feeling that the moment must be pregnant 11 12 and sufficient to itself if it is to become a worthy segment of time and eternity. 12

13 What is said here about plastic art applies in reality even better to music, and 13 14 when you, old fellow, reflect upon your own work and your own institution, you 14 15 will accept this opinion as being valid. Indeed, from this point of view, music fills 15 16 up the present moment more decisively than anything else, whether it awakens 16 17 in the tranquil mind reverence and worship, or whether it summons the active 17 18 senses to dance and celebration - leaving the rest to devout and true feelings and 18 19 to discerning thoughts. 19

2626 October: In London my Felix has met with an accident.430 he has been thrown 26

27 out of a carriage and is unable to attend his sister's wedding in Berlin. I am afraid 27

28 he may have broken something for it is a long delay and he cannot write; still, they 28

29 say he is getting better. As he is expected to return through Calais, he will, I am 29 30 sure, travel via France to Weimar ${ }^{431}$ and pay you a visit [...] 30 (t)erday a stupid little gig I was travelling in tipped over and robbed me of a nice bit

of skin with accompanying flesh, black trouser cloth, etc, and Dr Kind gave me strict 40 orders to remain quietly in bed for four to five days'; Elvers, Mendelssohns Briefe, p. 94.

40 Mendelssohn's knee injury was worse than it at first appeared, and delayed his departure 41 from England until the end of November.

42431 Mendelssohn's return journey was from Calais (29 November) to Brussels

43 (1 December), Maastricht (2 December), Cologne (3 December) to Berlin, without passing 44 through Weimar. 
5 I will say this much about the most immediate concerns: one of the four English 5

6 people in Ulrike's care is quite distraught that he has not heard your musical 6

7 achievements. He is - I don't know whether by talent and profession - passionately 7

8 dedicated to music. Every day he plays the cello for three hours with our Haase ${ }^{432} 8$

9 and never goes anywhere except where there is playing and singing. This is the 9

10 one Ulrike thought was worthy of you receiving him, in so far as circumstances 10

11 allowed. They had firmly resolved and promised to be here again on Wednesday 11

12 evening and on Thursday evening to attend a ball, which has had to be cancelled 12

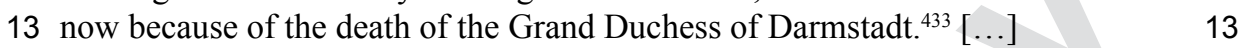

20 Yesterday on 4th of this month we gave a public academy concert for the benefit of 20

21 the unfortunate Silesians who were victims of the flood and we are able to donate 21

22 around 250 thalers. ${ }^{434}$ That is the reason no listeners were let into the rehearsals. ${ }^{435} 22$

23 The young fogies have to be addressed in German sometimes and that cannot 23

24 be edifying for foreigners. Now I have worries for us because our creditors are 24

25 demanding interest which has to be earned by the poor Sing-Akademie, and at the 25

26 same time one still has to be charitable as if one had something to give. Those are 26

27 the current people. Their successors will take double the amount to no purpose and 27

28 will be no cleverer than their forefathers. 28

433 Luise von Hessen-Darmstadt, sister-in-law of Duchess Louise of Sachsen-Weimar- 36 
$5[\ldots] \mathrm{I}$, too, have now heard Paganini ${ }^{436}$ and immediately afterwards, on the very 6 same evening, I opened your letter, ${ }^{437}$ which allowed me to imagine that my

7 estimate of these marvels was fairly accurate. I thought something was lacking

8 to make up what we call enjoyment, something which for me is always hovering 9 between sense and understanding - a base to this pillar of flame and cloud. ${ }^{438}$

10 Were I in Berlin, I should seldom miss the Moeser quartet evenings. ${ }^{439} \mathrm{I}$ have 10

11 always found performances of this kind more intelligible than other instrumental 11

12 music: one hears four rational persons conversing together, and imagines one gains 12

13 something from their discourse and becomes acquainted with the peculiarities of 13

14 their different instruments. This time I felt such a foundation was lacking - both 14

15 mentally and orally; I only heard something meteoric, and could not interpret it 15

16 further for myself. Yet it is strange to hear people, and especially women, talk 16

17 about it: their opinions are essentially confessions which they express with great 17

18 confidentiality. 18

19 And now I want to know whether you have received good news from the 19

20 worthy Felix; ${ }^{440}$ I take the greatest interest in him; it is very painful to see an 20

21 individual who has made such great strides held back by an unfortunate accident. 21

22 Let me have a few comforting words about him [...] 22

33 (1830), no. 7, 17 February, column 109. Goethe mentions his performance in an earlier 34 letter on 1 November 1829.

$35 \quad 437$ Presumably Zelter's letter of 1-5 May 1829, in which he reported meeting Paganini

37438 See Exodus, Book 2, 13, 21. The meaning of the Old Testament image used

37 here can be found in the essay Israel in der Wüste, Noten und Abhandlungen zu besserem

38 Verständnis des West-östlichen Divans; MA 11, 1.2, p. 215. Applied to Paganini, the divine

39 presence can be seen as a pillar of cloud by day and as a fire meteor by night; in other words

40 as a leading light, an example to be followed.

41439 Carl Moeser's Quartet-Soirées, set up in 1813, 'the true refuge of classical music' 41

42 which had to accept the reproach that it neglected contemporary composition. 42

43440 About the accident, Zelter could now report that Felix Mendelssohn's arrival in 43

44 London was now immanent. 
5 [...] Some time ago I wrote to you about Berlioz's music to your Faust. ${ }^{441}$ Now I 5

6 am sending the Berlin musical newspaper, ${ }^{442}$ which in general is always half and 6

7 half except that the editor ${ }^{433}$ is more than that: half a Christian and a total Jew. This 7

8 paper affects me like damp cloud passing by the moon; it blocks the light which I 8

9 receive and reflect because I don't fly their flag. I am better off and although I have 9

10 not forgotten how to fence, why should I slave away for nothing? 10

11 I would also like to send you a later page in the newspaper. ${ }^{444}$ It contains a 11

12 critique of our Wednesday music, which went off quite smoothly. I had placed my 12

13 student, the organist Grell, ${ }^{445}$ at the grand piano. To my delight the critic praised 13

14 his direction ${ }^{446}$ and happily didn't notice who conducted it. That tickled me! 14

21 Your letter of 9 November has just arrived. What you say about Paganni ${ }^{447}$ is pure 21

22 reason and exactly the way I see it. The first time he seemed to me like Moses who 22

442 Berliner Allgemeine Musikalische Zeitung no. 39, 26 September 1829, review of 25 Berlioz Huit Scènes de Faust, by A.B. Marx; the enclosed copy has not been recorded. In 26 contrast to Zelter's scathing criticism, the critic here calmly weighs up praise and criticism 27

and also includes a consideration of the problems of the French translation. 'Should a 28

29 French composer feel the need to give his native land a new music, then he will be led 29

30 astray by French translations of German poems, if he himself has not learnt the German 30 language in Germany, doesn't assimilate it according to its full meaning and spirit and 31 then with an educated German artistic spirit makes his mother tongue into a poetic musical 32 language. What the reviewer overlooks is that in his translation of Faust 1 (1828) Gerard 33 de Nerval (1808-55) succeeded in presenting a 'French Faust' which inspired Berlioz's 34 setting and which Goethe, in fact, preferred to his own: see my introductory essay to this 34 volume: A Musical Odyssey: Thirty-Five Years of Correspondence between Goethe and 36 Zelter, p. XX.

$42 \quad 447$ A draft letter of Zelter's contains further remarks about the Paganini phenomenon: 42

43 'I have just read in the paper that Paganini has also paraded in Halberstadt. The report is quite 43

44 intelligently and freely written; I would bet [written by] a woman, perhaps Madame Körte. 44 
1 displayed his arts to the Eygptians. ${ }^{448}$ I was spoiling for a fight. It was the same 2 the second time and I want to see whether that impression lasts when he comes 3 again. In general it is like the woman who, with her nose in the air, punishes 4 the non-believers like aetheists as if they were all Eves giving away paradise for 5 an almond. What focuses attention on these virtuosi is essentially a mingling of 6 what's fashionable with a desire not be rooted in anything. It is a mania but without 7 manners: a special individual but without anything unique because, like a thread 8 that always becomes thinner, it leads to nothing. It makes music desirable in the 9 same way as an imitation oyster, peppered, pickled, is swallowed.

10 According to the latest news: Felix is leaving London on 17 November and 11 could be in Germany sometime this month. ${ }^{449}$

12 What I must envy you and at the same don't begrudge you is your desire to

13 read and ability to do so. [...] What distresses me most is that I am beginning to 14 find it hard to read music. The more this ability is taken away, the more I need it 14 15 since I am becoming more and more alone. When a young bird is fully fledged, 15 16 it will throw itself into everything. If I no longer knew how to do this, I would be 16 17 long gone.

18 Your sharing of literary news from Paris is highly pleasant to me since I am 18 19 normally not up to date with the latest thing and a word from you teaches me more 19 20 than my own reading. [...] The French are the other species on the continent. 20 21 They dance around everything and consider themselves blessed to come into the 21 22 suburbs. Their mannered music is still what it was: they drive everything forward 22 23 and drag everything with them. Only the Italians appear to let the spectre pass by 23 24 calmly until such time as the next genius will arrive to settle among them. Until 24 25 then they at least hold onto their caricature, which at least suits them even if it is 25 26 botched up.

2714 November: That fine word Faustus, Fauste, Faust, ${ }^{450}$ has been imbued by 27

28 you with such ominous meaning that it is only right that you ought to become 28 29 acutely aware of its further consequences. So listen: yesterday evening, for the 29

31 Then your words about women came back to me - "it is actually a complete confession 31

32 which is pronounced with complete confidence" - absolutely! One could agree because he

33 scratches where he is itchy and that can be honestly admitted. But he is an Italian, by nature

34 a person of good taste. One must hear him without the accompaniment of other people and

35 [one must hear] his own compositions as pieces where a sound hand obeys the dictates of

36 a sound mind. Under his bow other people's music seem to me like fluids of a different

37 nature; the field of his art is limited, which is why he needs to include other people's music

37 [in his programme] in order to add musical variety' (GSA 95/I, 8, 4, no. 54).

$38 \quad 448$ In other words, to put on a show of deception.

39449 It is not known where Zelter received this news. In the last published letter to his

40 family from London on 6 November 1829, Felix was afraid that he would have to wait two 41 weeks for departure.

42450 What Zelter presents in the rhetorical figure of detractio is the derivation of the

43 name 'Faust' from the Latin adjective 'faustus' (meaning 'lucky, happy'), whereby he also 44 plays on the ominous nuance which the name has aquired through Goethe's poetic figure. 3

4

16

9

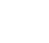

4

6

9
32

\section{3} 34 35 36 37 
1 first time, I heard and saw, from beginning to end, Faust, the Grand Opera by J.C. 1

2 Bernard and Spohr. ${ }^{451}$ If I am not mistaken, the composer got together a Sanedrin, 2

3 or whatever they call it, ${ }^{452}$ in order that they might jointly sanction laws that are 3

4 valid for grand and light opera, which are made clear from the above monumental 4

5 work. Whether an understanding was arrived at, I don't know, nor have I asked. 5

6 Yesterday's performance of this full, highly developed work, received my 6

7 greatest praise, and the full house did not fail to applaud it. The orchestra, the 7

8 highest faculty of an opera, sounded like one voice; the singers were as perfect 8

9 as possible; supernumeraries, machinery, decorations, witches, ghosts, and other 9

10 monsters - all received recognition and the best reception [...] Now, with regard 10

11 to the work of the composer, who certainly merits more recognition for his artistry 11

12 than as a musician and melodist. Everything is astonishingly well worked out, 12

13 down out to the smallest detail, so as to outwit, to outbid even the most attentive 13

14 ear. Compared to it the finest Brabant lace is coarse work. You can't do without the 14

15 book at the performance because the expression of words, high and low, bright and 15

16 dark, firm and loose is razor-sharp, worked like a beehive [...] With regards to the 16

17 composer and the orchestra, the performance can't be praised highly enough. 17

24 The way you speak of Moeser's quartets, it seems you must have heard them even 24

25 as far as Weimar. I must say, although I rarely go to hear them, they are the things I 25

26 like best of their kind. I don't know whether I ever wrote to you upon this subject, 26

27 but I doubt if Haydn, Mozart and Beethoven ever enjoyed such a pure, healthy and 27

28 secure rendering of their quartets as is given here when Moeser is at his best; for 28

451 The Berlin premiere of Louis Spohr's Faust (with libretto by Joseph Carl Bernard) - 30

31 first performed in Prague in 1816 - took place on 14 November in the Königliches 31

32 Opernhaus. A second performance took place on 17 November; a third with new scenery 32

33 took place on 22 November. The original two-act Romantic opera was reworked as a three- 33

34 act grand opera. It is unclear why Zelter speaks of a grand opera as early as 1829 . It is most 34 likely bound up with the decision of the Berlin opera to stage the opera in five acts - much 35 to Spohr's displeasure - and to use Spohr's overture to Macbeth before Act 5. The libretto 36 is primarily based on Friedrich Maximilian Klinger's Faust Leben, Taten und Höllenfahrt 37 of 1791 .

452 Sanhedrin: during the Roman occupation, the top Jewish authority, the high 38 council of Jerusalem, correctly quoted by Zelter, bringing the article into line with the 39 German translation. With 'Sanedrin' Zelter is probably referring to Spohr's 'Call to German 40 Composers' which had appeared in the AMZ 25 (1823), columns 457-64. The article calls 41 upon composers to create through-composed German grand opera, and Spohr's Faust was 42 
1 it would be too much to ask that he could produce that every day. He knows how 1

2 to electrify his fellow players. The listeners also don't know what is happening to 2

3 them. They feel as if they are playing along, they understand the incomprehensible. 3

4 They are gripped and don't know from what. At the same time he doesn't look as if 4

5 he is even there. Unfortunately he is not lucky in love and is doing a lot of penance 5

6 to which two divorced ladies (the third is dead) contribute, and apart from them 6

7 the one who has him now makes her contribution. Anyway, he is also an excellent 7

8 leader of an orchestra. It would be presumptious of me, standing in the aisle of the 8

9 Opera House, to say whether Moeser or another was playing first violin. I gladly 9

10 have him in the performances of my oratorios. He does not contradict and if I turn 10

11 my eyes towards, him he understands and is secure like a God. He is the only one 11

12 with whom I can be completely at ease, since I cannot abide the damned baton. 12

13 Now the dreadful nonsense is rampant in the Königliches Theater: that of making 13

14 the first violin musical director. The court orchesta has four of them. ${ }^{453}$ Three don't 14

15 function at all, since no one will play under the other. At comedies (apart from the 15

16 opera) a fifth person joins the first violins ${ }^{454}$ and then the other four do nothing 16

17 at all. You can well imagine it, since you are familiar with how it goes. Whether 17

18 the newly appointed intendant ${ }^{455}$ (about whom nothing is still clear) will want to 18

19 agree to this institution, since it happens under the direction of the general music 19

20 director, ${ }^{456}$ time will tell. At the same time that a performance is still possible, such 20

21 as I heard a few days ago and reported to you, is no surprise with an orchestra of 21

2230 violins and the amount of rehearsals which are held because of the singers who 22

23 don't learn their parts at home but in rehearsal. [...] 23

24

25

26

27

28

29

30

31

32

$33-33$

(1) 27

28

$\begin{array}{ll}28 & 29\end{array}$

30

31

$34-453-34$

$35{ }^{453}$ Presumably Friedrich Ludwig Seidel (1765-1831), Georg Abraham Schneider

36 (1770-1839), Director of Music from 1820, Carl Moeser (1774-1851), Director of Music

37 from 1825 and promoted to first leader of the orchestra, and Karl Heinrich Blum (c.178637 1844).

$38 \quad 454$ Perhaps Carl Wilhelm Henning, who had given up his position as Director of Music

39 at the Königstädtisches Theater in 1826 and had gone back to being leader of the orchestra

40 at the Königliches Oper, where he was eventually made Director of Music in 1836.

41455 Count Wilhelm von Redern; following Brühl's resignation at the beginning of 41

42 December 1828, Redern was made acting manager and artistic director; his postion was 42

43 made permanent in 1831 . 43

$44 \quad 456$ Spontini. $\quad 44$ 
5 I may not refrain from speaking out: that you agree about the mental enjoyment 5

6 of music does me good because I must content myself with that. ${ }^{457}$ It is always 6

7 constructive to convince onself that in old age, intellectual reason or, if you like, 7

8 reasonable understanding, can be a legitimate substitute for the senses. ${ }^{458}$ You will 8

9 never be in this category, on account of your fortunate profession, to need this 9

10 serious surrogate.

11 Your account of Spohr's opera gives further proof that although the poetry 11

12 dissolves into nothing, the musician can at the same time have his chance, give a 12 satisfactory interpretation and even partly delight [his audience].

14 Tonight Die Stumme von Portici is being performed for the third time ${ }^{459}$ and I 14

15 am hearing much that is good about the way the whole thing has been introduced 15

16 and carried out. I have already heard elaborate accounts from my grandsons, and 16

17 further up the scale ${ }^{460}$ from the well-disposed audience. In terms of progress and 17

18 coherence, it would seem to be an attractive lively work. [...] 18

25 Small causes and great effects! A mute fishermaiden, seduced by the son of the 25 26 Viceroy of Naples, is the heroine of a famous French Opera, La muette de Portici ${ }^{461} 26$ 's quartets, it seems you must have heard them even as far away as Weimar.' $\quad 31$ 458 This could be read as a critical reflection on Kant, who, in Kritik der reinen Vernunft, 32 sees 'reason' as distinguished by the tendency to transcend the realm of experience.

459 Daniel François Espirit Auber's opera Die Stumme von Portici (libretto by Eugène 34 Scribe's La Muette de Portici, translated by Theodor von Haupt) was performed in Weimar 35 for the first time on 21 November 1829; a second performance took place on 28 November 36 and a third performance took place on 12 December.

460 Goethe had received reports from his son August, who wrote a critique on the 37 opening night of the Weimar premiere; on 22 January Coudray followed and in the afternoon 38 Eckermann and his grandson, Wolfgang. Eckermann's diary on 23 January records the 39 lasting success of the work: 'Die Stumme von Portici was played for the sixth time to a 40 packed house. In front of the Sonne [hotel] I counted 60 sleighs, Privy Councillor counted 41 70 before the Swan, Elephant, and the Erbprince [hotels]', Houben, vol. 1, p. 451 . About 42 the same time as Goethe's letter, Zelter, too, writes about the opera. 
1 The maiden is mute as a fish, but all the others, Herr Auber ${ }^{462}$ at their head, make 1

2 such a horrible commotion, five acts long, that at last even Vesuvius awakes and, 2

3 grumbling and roaring, spits its furious inside at the sky. Our public revels in this 3

4 dinner of the Titans, which it has now devoured for the twenty-seventh time and 4

5 never has enough! The singers and players are half roasted afterwards and I came 5

6 away really well done myself. However, there is no lack of wit [..] 6

7 This evening our Samson by Milton and Handel ${ }^{463}$ will add to the atmosphere. 7

8 The quality of the singing is properly prepared with full orchestra. May the Gods 8

9 be merciful. I was only able to hold one full rehearsal and must watch out like a 9

10 shooting snipe. Pray for me! I have no time to do it myself. [...] 10

1118 December: I have just heard Auber's opera Die Braut. ${ }^{464}$ When you speak 11

12 of a man, you should at least recall two of his actions. The lady wants to and is 12

13 supposed to marry an upholsterer and gets a cavalry officer in his place; a great 13

14 commotion arises from this, which the orchestra has to make, and does make, alone, 14

15 because on this occasion thunder and lightning are missing or are somewhere else. 15

16 Wit and entertainment, fullness and force are not wanting, although everything 16

17 revolves around itself. - They have just brought me your letter of the 16th, in 17

18 which you speak of the Muette by this same composer. You have formed your 18

19 own opinion and I agree with you. All true music can only be and work mentally; 19

20 what is beyond that has been already forbidden by Lycurgus ${ }^{465}$ and rightly so, for 20

21 it is bad! But in spite of that severe lawgiver, I must make an exception in favour 21

22 of the organ, because from my youth that [instrument] has stirred my deepest 22

23 conscience, like a serious confessor, as you showed quite involuntarily in Faust. ${ }^{466} 23$

24 That scene, in its place, is crushing in effect, and if no one knows how, I know it, 24

25 for I have the whole church before my eyes [...] 25

$26 \quad 26$

$27 \quad 27$

$28+28$

$29-29$

$30-30$

$31+31$

$32 \quad 32$

$33-462 \quad 33$

$34 \quad 462$ Daniel François Espirit Auber (1782-1871), composer of the opera. 34

35463 Handel's oratorio Samson, performed by the Sing-Akademie on 17 December 35

36 1829; see $A M Z 32$ (1830), no. 3, 20 January, column 46.

$37 \quad 464$ Daniel François Espirit Auber, Die Braut (libretto by Eugène Scribe, La fiancée), 37

38 performed in Berlin for the first time in Karl August Lichtenstein's adaptation on 3 August 38

39465 The legendary Spartan legislator had also defined the function of music in the state: 39

40 already an important component of education (Agoge), above all it served to stimulate the 40

41 war-like virtues of mental armament; see Plutarch's Vergleichende Lebensbeschreibungen 41

42 (Lykurg, chapter 21). $\quad 42$

43466 Faust 1, The Cathedral scene, Gretchen's words 'Mir ist als ob die Orgel mir/ Den 43

44 Atem versetzte', v. 3809f.; MA 6.1, p. 647. 
5 I gather from your letter, dear friend, that it was Milton's tragedy that induced 5

6 Handel to write his Samson. However, I should be curious to know how he treated 6

7 that glorious poetic work, and how he epitomized it. I read Milton's Samson 7

8 last summer, with an English man of letters ${ }^{467}$ who was staying with us, and my 8

9 admiration of it was boundless. I could not mention any work that expressed so 9

10 closely the meaning and style of ancient Greek tragedy, nor one whose text and 10

11 performance deserved equal recognition. Handel has probably dealt with it, as with 11

12 the Bible, extracting - in accordance with dramatic rules - the most expressive, 12

13 the most important and, at the same time, the parts of the story which are most 13

14 singable. If a short programme was printed for your performance, ${ }^{468}$ pray let me 14

15 see it, or tell me how I can find the information I desire.

I enclose a copy of our Samson. ${ }^{469}$ It is wonderful what Handel has made of it. The 22

23 lament of the loss of sight (p. 6) (47 $^{470}$ can only be composed by a man who (the same 23

24 as Samson), with a premonition of terrible emptiness, must end the most active 24

25 of lives, for Handel was blind when he died. When I heard this aria for the first 25

26 time, my eyes closed involuntarily. In the second section (p. 10) the aria which 26

27 is performed with the choir has a shattering yet positive effect. ${ }^{471}$ I have never 27

28 experienced the like of it. If I don't open my eyes, the whole work is like a dramatic 28

29 performance for me: I see and feel it with the ears. Since after all one must himself 29

30 enjoy what is supposed to be appetizing, I immediately sent to the Königliche 30

31 Bibliothek for a good translation of Milton's tragedy and happily discovered my 31

467 Goethe had already written to Zelter on 20 August a detailed account of the reading 34 the first part of Milton's Samson Agonistes with the English lawyer and writer Henry Crabb 35 Robinson on 18 August 1829. On that occasion Goethe had not praised Milton [to Robinson] 36 with the warmth with which he eulogized Byron; Gespräche, vol. III/2, p. 458.

468 Samson. Ein Oratorium aus dem Englischen des Milton zu Händels Musik frei 38 übersetzt (...) von I.F. Mosel (Berlin, 1828); Zelter sent the libretto to Goethe on 7 January 39 1830.

469 Ibid. The libretto is no longer in Goethe's library. 41

470 Samson's aria 'Total eclipse' from Act 1.

471 Micah's Aria 'Hear my plea O mighty God!', answered by the Chorus of Israelites 43

'They are trampling your servant into the dust and count him among the dead'. 
1 Handel as Samson and Milton once again. I would not have understood either so 1

2 well if I did not understand you. 2

484. Zelter

9 Back again with our Samson. If it is too much, it is partly your fault. You will 9 10 remember that earlier I found this subject useful for a tragic opera ${ }^{472}$ and that it 10 11 would be able to fit comfortably into three acts. Admittedly the cast are Jews, 11 12 but they are characters from antiquity: a hero, a beautiful woman, an uncommon 12 13 relationship between the two; tribal factions, a brilliant catastrophe -what more 13 14 can one want!

15 In his tragedy ${ }^{473}$ Milton has Delila run off; they don't know where she is. 15

16 Samson can never forgive her; the misfortune is too great and he himself carries 16 17 the greater half of the guilt. Before the world she is to be excused: she is a woman, 17 18 from an enemy tribe; she really loves, is jealous not without cause; besieged by 18 19 priests and relations but she is not bought. In short she is a Dejanira. Samson 19 20 didn't want to go to the temple and is compelled; Delila must also not want it; she 20 21 is persuaded and hopes to do some good, if not to obtain forgiveness. She is the 21 22 keystone of the catastrophe. As she approaches to offer her hand in reconciliation, 22 23 he seizes the pillars and pulls them back and forth; so she must also be destroyed. 23 24 The collapse of the temple would not have to happen at the same time. On all sides 24 25 people try to escape; whereever they flee is to their death. 25

32 [...] Your letters from the years 1828 and 1829 lie before me ordered very neatly; ${ }^{474} 32$

33 for that reason send mine now from both years so that the older codices, which were 33

474 There were regular dispatches of Goethe's earlier letters exchanged between Berlin

39 and Weimar from the time Goethe first requested an occasional handing-over of his letters

40 written to Zelter in order to have a complete copy made of the letters. The last exchange

41 took place in February 1828, when Zelter sent Goethe's letters from 1827 to be copied; they

42 were returned to Zelter in May 1828. On 18 January 1830 Zelter sent Goethe's letters from

431828 to Weimar to be copied; the letters of 1829 were sent as soon as Goethe's 1828 letters 44 were returned to him on 12 April 1828. 
1 drawn up, do not remain incomplete. Even with that the copyist ${ }^{475}$ will have three 1

2 months work to do. On the other hand we can also see from the correspondence 2

3 with Schiller how the day always brings the best to serious friends through which 3

4 the year, when the days are added up, guarantees an incalculable advantage. The 4

5 individual details are actually the life; the results should be treasured, but they 5

6 astonish people more than they are of use to them. 6

$7 \quad[\ldots]$ In Milton, according to classical style the woman wasn't able to come 7

8 on stage again after that scene of hatred and violence. ${ }^{476}$ I understand that the 8

9 musician would have further need of her, all the more so because an audience of 9

10 more recent times demands a complete resolution, whether for good or for evil. 10

11 I will enquire whether the score is perhaps still in the Chamberlain's office from 11

12 long ago and then delight myself with further comparisons. [...] 12

A curious thing happened yesterday evening. I went to a concert to hear Chélard's 27 overture to Macbeth. ${ }^{478}$ The orchestral leader ${ }^{479}$ had placed it at the end, directly 28

476 Johann John (see Goethe's diary of 25 January 1830, WA III/12, p. 186). 33 don't know where she is', ZG 9 January 1830.

477 On 14 January 1830; the programme included works by Leonardo Leo, Johan 35 Sebastian Bach, Joseph Haydn, Wolfgang Amadeus Mozart, Karl Friedrich Fasch, Felix 36 Mendelssohn and Zelter's motet Der Mensch lebt und besteht; the concert was very 37 favourably received; see Spenersche Zeitung, 16 January 1830 and $A M Z 32$ (1830), no. 9 , 38 3 March, column 139f. and the Berliner Allgemeine musikalische Zeitung 7 (1830), no. 3, 39 16 January, columns $20 \mathrm{f}$. and 23f. $\quad 40$ 478 Carl Moeser organized a big concert on 16 January 1830 in the hall of the 41

Königliches Schauspielhaus; the last item on the programme was the overture from Andre 42

Chélard's opera Macbeth. $\quad 43$

4479 Carl Moeser. $\quad 44$ 
1 after a long, heavy church scene from Spontini's last opera ${ }^{480}$ where church, organ 1

2 and nun's chorus are all muddled up. The scene seemed to be unending-something 2

3 at which our Spontini is a master. Finally the close came and everyone got up 3

4 to go. I, poor devil, had listened to the whole muddle and swallowed down the 4

5 overture to Macbeth along with the scene, organ and nuns [...] If I were a critic, ${ }^{481} 5$

6 I would receive such things badly. [...] 6

7

8

9

488. Zelter

13 Yesterday we had our first carnival opera, The Siege of Corinth, ${ }^{482}$ music by Rossini, 13 14 whom the German critics, ${ }^{483}$ for the last 15 years, have worn themselves out writing 14 15 against. The libretto is a strange melange [...] The music to this sad story has a 15 16 fresh, jaunty character with powerful passages which explode like fireworks. That 16 17 one with such rich talent could make the most perfect music which is also only 17 18 tolerated is undoubtedly true, however, and is its own excuse. I like the continual 18 19 praying least of all and after that the hand-clapping. Our performance is really 19 20 splendid; but since one is also used to that here, I heard this opera referred to, on 20 21 many sides, as the weakest by this composer. We hardly know how to recognize 21 22 what one person has, and what he doesn't have he cannot give. He cannot be worse 22 23 off than when he writes for his own time and its people. It would have to be so 23 24 easy for him as for one who like an impatient horse would prefer to run around the 24 25 same circle 20 times and so feels free, rather than let himself be seized and held. 25 26 Nevertheless you can imagine that the whole thing was entertaining because the 26

28480 The penultimate item on the programme read: 'Dramatic scene, consising of the

29 nun's chorus, followed by an aria and duet from Act 2 of the opera Agnes von Hohenstaufen

30 by Spontini, performed by Fräulein von Schätzel, the royal singer, Zschiesche and the choir

31 of the Königliches Theater'.

32481 The critic of the Spenersche Zeitung, no. 15, 19 January 1830, praised the rendition 33 of Spontini's work but criticized the concluding overture.

$34 \quad 482$ Opera by Gioachino Rossini (libretto by Guiseppe Luigi Balocchi and Alexandre 34

35 Soumet, Le siege de Corinthe); the Berlin premiere of the German version (by Joseph 35

36 Kupelwieser) took place on 25 January 1830. See the review in the $A M Z 32$ (1830), no. 7, 36

3717 February, column 115.

$38 \quad 483$ In contrast to the enthusiasm for Rossini among the general public, the reception of

39 the critics was changeable and split. The centre of rejection of Rossini was in Berlin; above

39 all the violation of 'dramatic truth', 'failure of characterization' and the lack of sensitivity to

40 the meaning of the words were reprimanded (essentially by advocates of German national

41 opera) in the Berliner Allgemeine Musikalische Zeitung. For Rossini's reception in the

42 Leipziger Allgemeine Musikalische Zeitung see J. Loschfelder, 'Rossinis Bild und Zerbild

43 in der Allgemeine Musikalische Zeitung Leipzig' in Bolletino del centro Rossiniano di studi

44 (Pesaro, 1973), vols. 1 and 2, pp. 23-42. 
1 music also holds my interest in its derivative shapes. So I find myself compelled to 1

2 confess that he could not put it down and will not leave it [alone]. The dance music 2

3 is so lovely, lively and exciting that it makes one want to dance to it. [...] 3

4

5 finally called for and seen as valid. [...]

489. Goethe

Weimar, 26 to 27 January 18308

9

The letters sent here from 1828 have arrived and will be written out carefully with 10 mine to the end. I am looking forward to these years and to seeing the whole thing 11 bound. This 30-year correspondence gains such an attractive appearance that a 12 royal Egyptian booklover would hardly fail to take it into his collection. [...] 13

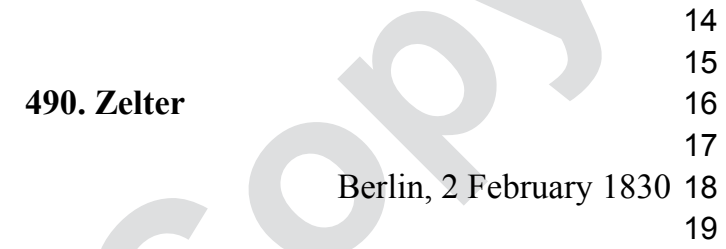

[...] The enjoyment which I by nature and habit have in works of art is, in general, 20 indefinite until I take pen in hand and as it were lay out an equation mathematically, 21 through which an image of the object appears to me, which, like the artist with his 22 model on a moveable tripod, I can then turn over and change, [and judge] whether 23 the parts fit the whole. I also really like to listen to a piece of music when the throng 24 has expressed itself loudly or through its silence, through which I gain a certain 25

The two psalms and the organ work deserve praise - if they are only beginnings. 28

29 The best which the world knows also began somewhere.

30 In my humble opinion the musical working of a psalm, for example, is like a 30

31 sermon to a text, which should always become clearer, more powerful through the 31

32 sermon. If the sermon doesn't do that, it shatters the text into incomprehensibility; 32

33 so it is no better than if a stone were attached to it and it sank into the sea; because 33

34 it is work lost and no one pays attention to it.

35 Applying this theory to musical composition, we know that even the great 35 36 masters were not always successful in their application and the same could be 36 37 expected from their students. The student can expect, demand that it would be 37 38 explained to him what art is and what it has to achieve; that even the best only do 38 39 what they can is self-evident. 
5 [...] This evening at seven you might keep your fingers crossed for me. We are 5 6 launching our Judas Maccabaeus (by Handel). ${ }^{484}$ Our orchestra is 200 strong. A 6 7 single long rehearsal was granted to us on account of the carnival and terribly 7 8 stormy weather.

15 [...] When I wrote my [biography of] Fasch, who I admittedly loved dearly, I read 15 16 the manuscript in the Sing-Akademie directly after his death before more than 16 17 one hundred members, more or less all of whom had known the good man during 17 18 his life. I asked that if someone or other did not recognize our man in the one 18 19 described, or found him different, to share it with me since I would gratefully take 19 20 up every memory and make corrections accordingly before publication. When 20 21 the manuscript appeared in print, I found before me Fasch's oldest friends, who 21 22 had drunk with him, smoked and had associated with him politically, surprised to 22 23 discover their cheerful everyday journeyman as a serious, deep, highly educated 23 24 artist; but it seemed unbelievable how I, as a modest citizen, should become the 24 25 biographer of such a man. If someone stepped forward to say he helped me, he 25 26 would hardly have been without support.

27 My first word to the society after Fasch's death was, 'Fasch's place with 27

28 us remains open and I retain my position at the grand piano.' This speech gave 28

29 the directors at that time (to which I didn't belong) the courage to see me as an 29

30 ordinary member, as a subordinate until the opportunity appeared through which 30

31 the leading chairman suddenly resigned from his office and handed over the 31

32 monitory affairs. I immediately made the third chairman into the first, ordered him 32

33 to take over the money and to make some kind of arrangement according to which 33

34 every contributing member can see for himself the condition of the economy, since 34

35 the box office is visibly increasing in size. $\quad 35$

$36 \quad 36$

$37 \quad 37$

$38 \quad 38$

$39 \quad 39$

40484 Handel's oratorio, performed as the fourth and final subscription concert of the 41 Sing-Akademie on 11 February 1830 with the soloists Pauline von Schätzel, Auguste

42 Türrschmidt and Eduard Mantius, was well received by the critics; see Spenersche Zeitung, 43 no. 37, 13 February 1830 and AMZ 32 (1830), no. 11, 17 March, column 170 and Berliner 43 44 Allgemeine Musikalische Zeitung 7 (1830), 13 February, p. 56. 
$5[\ldots]$ Tomorrow we are to perform Mozart's Requiem in public. ${ }^{485}$ It is happening in 5

6 honour of your deceased Princess. They wanted to hear Bach's Passion once again 6

7 and thought that no one was dead. Against that it was argued that the Requiem was 7

8 made in full health for the living. [...] So may Mozart's Requiem and God grant 8

9 us a pleasant hour, because we had to get by with one long rehearsal on account of 9

10 the wretched opera. ${ }^{486}$ Your Princesses and mine are invited. ${ }^{487}$ I'll be surprised if 10

11 they respond and whether their situation permits them to attend.

Last Sunday I endured Spontini's opera Olympia ${ }^{488}$ from beginning to end 12

13 it lasts almost four hours. It is a shame to put up with so much in the enjoyment 13

14 of such a commendable work of art; I cannot approve of it, nor can I let it alone. 14

15 What I learn from it is that I cannot live without music. Your metaphor about the 15

16 silkworm in Tasso struck a chord with me every time I heard it. ${ }^{489}$ One recognizes 16

17 oneself $[\ldots]$

$24[\ldots]$ Felix has undertaken to deliver the facade of the Count Redern's house to 24

25 you. The drawing is by Schinkel and you will be familiar with the design already 25

26 from Florence. The Count asked me to send you the page myself and if you care to 26

Performance of Mozart's Requiem and Handel's Psalm 'O preiset den Herrn mit 30 einem Munde' on 11 March 1830 by the Sing-Akademie, conducted by Zelter; see AMZ 3231 (1830), no. 16, 21 April, p. 252. organizing rehearsals and performances was not only made more difficult but also meant 35

487 Princess Maria Luisa Alexandrine of Prussia (1808-77), eldest daughter of Maria 36 Augusta von Prussia (1811-90), second daughter of Maria Pawlowna of Sachsen-Weimar- $\begin{aligned} & 38 \\ & 39\end{aligned}$

39 Eisenach and Prince William's wife.

$40 \quad 488$ See ZG 7 to 9 June 1820; Zelter attended the performance on Sunday, 7 March 40

43 himself $\mathrm{G} /$ From his most secret being he unfolds/ The costly wool, and never doth he rest $/ 43$

44 Till in his coffin he himself hath sealed. Torquato Tasso, Act 2, v. 2453-7. 
1 send a favourable reply through me, it would be to my advantage since I frequently 1

2 need to seek his favour. [...] 2

3 Our Requiem was very effective. I myself was very moved despite the careful 3

4 concentration which was needed. Every time Spontini is astonished by what we 4

5 can achieve with one rehearsal, when he works away and gets annoyed 20 to 5

625 times and still does not come away from it without mistakes, although his 6

7 direction is calm and intelligent. There is no greater mistake in rehearsing than 7

8 to upset the good will of decent people through dissatisfaction over secondary 8

9 matters. Those who are capable don't make the same mistake twice; they trust 9

10 me as I trust them and so I come away better than with many repetitions which 10

11 bore the best people because they are sympathetic. The worst thing for us are the 11

12 distracting social conditions, since there is hardly a house is in Berlin which could 12

13 not produce a quartet itself and no evening during the week at which all kinds 13

14 of musical desirables and undesirables would be assembled. Now one cannot 14

15 expect anything of amateurs at public performances (which the Sing-Akademie 15

16 undertake) because they don't understand how to listen. As a result one must have 16

17 good professionals and then again that is expensive. Then these would also have 17

18 to be doubly skilful in order to handle older works well, which always go down 18

19 best under my direction. Two years ago Spontini included a Credo by old $\mathrm{Bach}^{490} 19$

20 in a benefit concert for the widows of musical directors. ${ }^{491}$ It was a disaster: out of 20

21 sheer fear no one knew what he was to play. 21

22 There are now at least four song societies here in Berlin, of which mine is 22

23 not the best. I and several of my age are not to be killed off and those new on the 23

24 scene are not even as good as we were. Against that the second Liedertafel ${ }^{492}$ is in 24

25 fact the best. It consists of young people with good voices. They write the songs 25

26 themselves and there is no shortage of good old songs. I can honestly say that I 26

27 prefer to be here than with our group. I only know of the existence of the other 27

28 two, and there are perhaps a couple of others. 28

29 From Easter onwards I intend to conduct an experiment with students from 29

30 our university ${ }^{493}$ and I will see how I get on with the young people. Perhaps I will 30

31 prefer them to the old wigs, with whom nothing can be done because they have to 31

32 be in bed by ten o'clock. It will, however, cost me money again. Whoever wants to 32

33

34

490 From Bach's B Minor Mass, BWV 232.

$36 \quad 491$ On 30 April 1828.

37492 The 'Jüngere Liedertafel' founded by Ludwig Rellstab, Ludwig Berger and Bernhard Klein.

$39 \quad 493$ Zelter took over the direction of the university choir for church music formerly

39 directed by Bernhard Klein, who had to step down from this position on account of his

40 planned studies in Italy. The register for lectures in Berlin University during the summer

41 semester 1830 announced: 'The academic choir, in which students may participate free

42 of charge, is led by Herr Zelter', quoted by Wilhelm Röntz, 'C.F. Zelter und die Zeit

43 seines akademischen Singkollegiums. 1830-32' in Sonderabdruck aus der Deutschen

44 Sängerbundeszeitung 22 (1930), no. 30, 26 July 1930, p. 4. 
1 feast with students must learn to borrow. The minister ${ }^{494}$ will give me 200 thalers 1

2 and we will decide in what way it should be spent.

3 On the day of our Requiem our honest to God bass singer, Gern, ${ }^{495}$ died 3

4 shortly before the performance. His voice had the ease, power and beauty of a 4

5 god. Madame Mara was enchanted by his sound. He was also a good actor. His 5

6 [roles as] Friar Laurence in Romeo and Juliet, his water-carrier and so on, were 6

7 incomparable. When he sang 'Generalbeichte' at the Liedertafel and spoke the 7

8 absolution, we were all free of $\sin$. He was 70 . 8

[...] What flourishes most now are the complaints about the new songbook. ${ }^{496}$ The 15 enlightened don't want to sing the mouldy German anymore and the old faithfuls 16 n't want to let the reformers be considered poets. Bunsen is said to have written 17 18 to the King of Rome and have interceded for the old songbook. ${ }^{497}$ One of his 18

495 Johann Georg Gern died on 11 March 1830; Johann Philipp Schmidt praised him 22

in his obituary in the Spenersche Zeitung as 'a real gem and a pillar of German opera, 23 always active, undaunted, without a trace of artist temperament and demands, free from 24 envy and amore proper. [Gern] dedicated his talent to the truly good and beautiful of every 25 genre, whole-heartedly and with all his strength'; Spenersche Zeitung, no. 64, 17 March 26 1830; see also $A M Z 32$ (1830), no. 16, 21 April, column 250.

496 For a detailed account of the revision of the Berlin evangelical songbook, which 27 was inspired in the years after 1806 but only completed in 1827 (through a commission 28 set up 1818), and [finally] established by a royal decree in 1830; see 'Das neue Berliner 29 Gesangbuch von Jahre 1829' in Johann Friedrich Bachmann, Zur Geschichte der Berliner 30 Gesangbücher. Ein hymnologischer Beitrag (Berlin: Wilhelm Schultze Verlag, 1856; reprint 31 Hildesheim/New York: Georg Olms Verlag, 1970), pp. 218-31. The public controversy 32 starting immediately about the reform found expression in the following publications: 33 Friedrich Schleiermacher, Über das Berliner Gesangbuch. Ein Sendschreiben an Dr. Ritschl 34 (Berlin: Riemer, 1830); Schleiermacher, Unparteiisches Gutachten über das neue Berliner 35 Gesangbuch (Leipzig: Tauchnitz, 1830); Klaus Harms, Beleuchtung des vielseitigen Tadels 36 (Berlin, 1830); the Evangelische Kirchen-Zeitung, February 1830 and the Homiletisch- 37 literarischen Korrespondenz-Blatte (1830).

497 Bunsen, who had put together an Allgemeines Evangelisches Gesangbuch in 38 deutschen Kirche, 'drawing on established canons', stated his critical opinion of the new 39 Berlin songbook in a letter to Niebuhr from Rome on 19 June 1830: 'The appearance of 40 the Berlin hymn book has induced me to write a series of letters about it, which, for the 41 time being, I concluded with the presentation of my canons. The first letter was written 42 in the hope that it would not be too late to warn the King and the congregrations against 43 such untenable work. Friends of mine had it published in church papers and I gather that 44 
1 arguments is that many songs of the old songbook were written by royal ancestors 1

2 and women. [...]

3 Felix, who departs from here in the next few days, will bring this page to you 4 and the facade of the house of Count Redern. ${ }^{498}$

$11[\ldots]$ It really delighted me that you expressed your need for music: what pours out 11

12 of you, you also want to hear outside. One demands the other and true enjoyment 12

13 only exists in such exchange. [...] 13

14 Invaluable, on a smaller scale, but nicely brought off within this context, are 14

15 the two volumes of Neureuther's pictorial musical compositions alongside my 15

16 ballads. ${ }^{499}$ They have been in the shops for a long time and should have already 16

17 arrived with you. [...]

18 The correspondence from 1828 is transcribed; you will receive your originals 18 19 first; ${ }^{500}$ then send $1829^{501}$ and take care that the current year, 1830 , will be very rich, 19

it found favour beyond its immediate readership. It is in good company with some essays by Raumer on the same subject'; Baron Christian Carl Josias von Bunsen, Aus seinen Briefen und nach eigener Erinnerung geschildert von seiner Witwe (3 vols, Leipzig: F. A.

Brockhaus 1868-71), vol. 1 p. 376.

27 Italy, had to postpone the journey because he was ill with measles. Abraham Mendelssohn

28 posted Zelter's letter to Goethe with Julius Schoppe's lithograph of von Redern's palace

29 (after a drawing by Karl Friedrich Schinkel).

$30 \quad 499$ Eugen Neureuther's series of lithographs Randzeichnungen zu Goethes Balladen

31 und Romanzen (Stuttgart: Cotta, 1829). Volume one (dedicated to Goethe) contained:

32 'Heidenröslein'; 'Der König in Thule'; 'Legende'; 'Mignons Sehnsucht'; 'Das Blümlein

33 Wunderschön' and 'Der Totentanz'. Volume two contained: 'Der Gott und die Bajadere'; 33

34 'Der Sänger'; 'Vor Gerricht'; 'Schäfers Klagelied'; 'Erlkönig' and 'Der untreue Knabe'. 34

35 Volume 3, dated 1829, became available with volume 4 in 1830; vols1-4 are in Goethe's

36 library (Ruppert, no. 2463). Goethe praises the 'figurative, musical' effect of the

37 arabesques time and time again. On 23 September 1828 he described them to Neureuther

37 as a pictorial expression 'which accompanies every single poem like a kind of melody'

38 and on 12 December Goethe considered them 'a new form of art (...) a progressive poem

39 accompanied by a moving image as in a melody'. On 24 April 1831 he described them

40 to Sulpiz Boisserée as: 'a large sheet $(\ldots)$ with commentary or much more, a musical

41 performance of the Parabel.'

42500 Goethe posted them on 7 April; Zelter received them on 12 April. 42

43501 Zelter announced the new dispatch on 12 April 'in the course of next week'; as 43

44 he already enquired about Goethe's receipt of them in the next letter, they must have been 44 
1 whereby our exchange of letters will not end someday like those with Schiller, like 1

2 the Rhine lost in the general run of the day. ${ }^{502} 2$

3 My kindest remembrances to Felix, whose arrival you inform me of. ${ }^{503}$ I am 3

4 not mentioning it here so that the pleasure of seeing him again may be increased 4

5 by the surprise. $\quad 5$

6

12 I have seen a born-again adaptation of Shakespeare's Julius Caesar by Dr Förster 12

13 twice $[\ldots]$ During the victory procession the people sing my melody to the words 13

14 'Gallias Caesar subegit, Nicomedes Caesarem'. ${ }^{504}$ At the same time the vermin 14

15 who shortly before made herself so lousy-mousy, looked so pious as if she was on 15

16 a pilgrimage. I could not guess what the orchestra piped and fiddled in between. 16

17 I also don't know whether I should be annoyed or delighted that I understand my 17

18 Suetonius better than these Romans. [...]

19 Your letter of 27 March has arrived just now [...] Felix sent a letter to you over 19

20 a week ago and the drawing of Count Redern's house. Now Felix is laid up and 20

21 has the measles.

28 Increasingly it seems to me that I have nothing to apologize to Rossini for, because 28

29 he gradually insinuates himself here against all opposition so that one hardly 29

30 listens if he is criticized. The accusations against one or another of his works are 30

sent in a separate dispatch without an accompanying letter. (Their return was confirmed by 34 Zelter on 15 July 1830.)

502 With similar resignation about the published correspondence, Goethe expressed 35 his opinion in a letter to Caroline von Wolzogen on 29 September: 'it gives me a sad feeling, 37 with our time, we become extremely annoyed with ourselves and others because of wasted 38 days.' 
1 admittedly not without [justification]. People don't need to make allowances for 1

$2 \mathrm{him}$. He wouldn't thank them for it. [...] 2

3 Last week Mademoiselle Sontag made her first appearance as Desdemona ${ }^{505}$ in 3

4 Rossini's Othell $^{506}$ at the grand opera. I have already spoken highly of her to you 4

5 and I don't need to take anything back. [...] In short everything about her from 5

6 head to foot - even her very dress - is song. 6

7 This is Eastertide, and since in the meantime I have conducted two versions of 7

8 the Passion Music ${ }^{507}$ on Palm Sunday (for the benefit of our mortgage) and Good 8

9 Friday (for my cellar which is full of water), I have had plenty to do. By this, I 9

10 wished to satisfy, as far as I could, two sections of my good Berlin, by putting on 10

11 one after the other in the one week, two genuine German religious composers: 11

12 Johann Sebastian Bach, whom people here compare to Calderón, and Carl 12

13 Heinrich Graun, whom his friends like to compare to Tasso. Each performance 13

14 attracted its own audience. Der Tod Jesu is especially valued by those who have 14

15 received Communion on Good Friday and Bach's Passion attracts persons, who 15

16 understand something more than the general public. I wanted to show the latter 16

17 the mutual relationship of two original German geniuses - the second of whom 17

18 formed himself entirely upon Italian models and generally worked upon Italian 18

19 texts, while the other never went out of Germany, and (to my knowledge) never set 19

20 any Italian piece. They are distinguished by nature from each other, one by depth, 20

21 another by clarity, while in terms of productivity they are equal; with regard to the 21

22 Cantilena where they speak to us in general, however, both are genuinely Italian, 22

23 which means they are natural. 23

24 Yesterday, after accompanying to the grave my oldest friend, who died at the 24

25 age of $90,{ }^{508}$ I went straight to Mozart's Figaro, and found the charming Sontag as 25

26 brilliant and delightful a Susanna as possible. ${ }^{509}[\ldots]$ In this role she delighted me 26

27 because her natural gift reveals how this opera, as I feel it, differs from Mozart's 27

28 other works: by the style of intrigue in the music. One finds this style perhaps in 28

31505 Henriette Sontag, engaged at the Königstädtisches Theater from 1825 to 1827,31

32 had gone to Paris at the beginning of 1828 and after triumphant success at the opera and in 32

33 England, had returned to Berlin as a guest artist in 1830. Her first appearance as Desdemona 33

34 in the Königliches Opernhaus on 3 April, as well as her performance as Rosina in Rossini's 34

35 Barbier von Sevilla on 6 April, were both enthusiastically received; see Spenersche Zeitung,

36 no. 80, 5 April 1830 and no. 83, 8 April 1830; MA 20.3, p. 1103.

$36 \quad 506$ Rossini's opera Othello was performed in Johann Christoph Grünbaum's German

37 version from 1821. The performance, Othello, der Mohr in Venedig, which Zelter speaks of

38 here, was performed on 3 April 1830; see $A M Z 32$ (1830), no. 21, 26 May, column 342f.

39507 Bach's St Matthew Passion was performed in the hall of the Sing-Akademie on

40 Palm Sunday, 4 April and Graun's Der Tod Jesu was performed on Good Friday, 9 April

41 1830; see $A M Z 32$ (1830), no. 22, 3 June, column 357f.

42508 The man's identity has not yet been discovered. 42

43509 On 10 April 1830 in the Königliches Opernhaus; see $A M Z 32$ (1830), no. 21, 43

4426 May, column 343. 
1 the individual pieces of any other Italian composer (Cimarosa, Grétry too, and 1

2 others) but here it starts suddenly with the overture pervading the whole action and 2

3 this seems to me to be original. 3

$4 \quad$ Felix had a letter from me to you and has stayed here because of ill-health; ${ }^{510} \quad 4$

5 I had instructed him to send the letter to you and I hope it has happened. They say 5

6 here that your son August is going to Italy with Eckermann, ${ }^{511}$ I wish him a safe 6

7 arrival, lovely weather, and an eruption of Vesuvius.

14 I have just come back again from Rossini's Othello; ${ }^{512}$ Spontini collected me in his 14

15 carriage. He, too, (like all the critics) ${ }^{513}$ is totally against this opera. He affirms that 15

16 there are hardly six bars suitable to the action: a Charivari, a Galimathias without 16

17 dignity, ${ }^{514}$ strength, sense, and so on. For his justification, I had again read right 17

18 through Shakespeare's Othello to discover the cruel effect of jealousy in a moral 18

19 depolarization - true, I cannot refute Rossini's enemies and I observe an obedient 19

20 silence. The work is quite strange [...] Basically, I cannot find anything wrong 20

21 with it, even if I were forced to go yet again; if that most senseless play, opera 21

22 with its songs and dances, light-heartedness and significance, is to have its own 22

23 place, then to me Rossini is a born opera composer, so I have been delighted - 23

24 and so have all the others against their will. The clapping, shouting and calling 24

25 went on and on and the house was full and beside itself with enthusiasm. Finally, 25

26 I agree with Rossini himself that he is a man of genius, and besides that he knows 26

27 his trade $[\ldots] \quad 27$

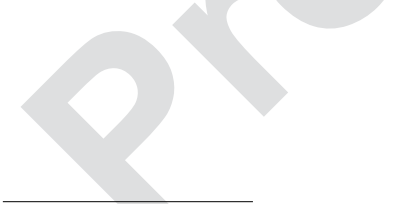

510 Zelter's letter of 26 March 1830; on account of his son's illness, Abraham 35

Mendelssohn posted the letter (and accompanying lithograph) on 1 April 1830.

511 August von Goethe set out on his Italian journey accompanied by Eckermann on 37 22 April 1830.

512 The performance Zelter mentions took place on 16 April 1830 in the Königliches 39

Opernhaus, with Henriette Sontag in the role of Desdemona; it was the same production as 40

Zelter had attended on 3 April.

513 See, for example, Rossini's reception in the Spenersche Zeitung, no. 16, 6 February 42 1821. 
118 to 19 April: [...] Madame Milder, on her journey to St Petersburg, ${ }^{515}$ passed 1

2 by Reval and helped celebrate the eightieth birthday of our Elizabeth Mara. ${ }^{516}$ That 2

3 ancient nightingale still sings, and cannot give it up; she gives singing lessons, and 3

4 is true to the confession she made to me, 'I shall die, when I no longer sing.' 4

5

6

7

500. Zelter

$11[\ldots]$ Haydn's Creation is to be performed next Wednesday in the Garnison church 11

12 for charity ${ }^{517}$ and that has to be ready at the right time as if one had nothing at all to 12

13 do. No one asks then whether the wheels and horses will hold out! [...] 13

20 Once again we have finished a performance of Haydn's Creation, ${ }^{518}$ and again we 20

21 have not exhausted it. Everyone who calls himself a musical director in name, 21

22 status and dignity - assembled upon this occasion to celebrate the work, under 22

23 Spontini's direction. ${ }^{519}$ To me it was as if I were to enjoy it for the first time today 23

$27 \quad 515 \quad$ 'Anna Milder was engaged in the Berliner Königliches Theater from 1816. On

28 account of a dispute with Spontini, whose operas she had brought to prominence through 28

29 endless performances, she left Berlin and indeed Germany for many years. She travelled 29

30 to Russia first; in St Petersburg she celebrated her last triumphs as a dramatic singer'; 30

31 Gustav Schilling (ed.), Encyclopädie der gesamten musikalischen Wissenschaften (6 vols. 31

32 Stuttgart: Franz Heinrich Köhler, 1836-38), article on Milder.

33516 After her stage and concert career, the famous singer had lived in Moscow from

341802 to 1812 , where she lost all her possessions in the fire of 1812 . She first moved to Reval

35 and at 70 moved to London for two years; she returned to Reval in 1822 and celebrated her 36 eightieth birthday there on 23 February 1829.

$36 \quad 517$ The performance in aid of the 'patriotic society in support of destitute soldiers of

37 the Berlin Garrison' took place on 28 April in the Garrison church before an audience of

38 4,000; see Berliner Allgemeine Musikalische Zeitung 7 (1830), no. 18, 1 May and AMZ 32

39 (1830), no. 22, 3 June, column 358.

$40 \quad 518$ Ibid. 40

41519 The Königliche Kapelle, the choir of the Sing-Akademie under Zelter's direction, 41

42 the singers Henriette Sontag, Mlle Hoffmann, Carl Adam Bader, Carl (or Heinrich) Blum 42

43 and Eduard Devrient were involved in the benefit concert; Spontini was General Director 43

44 of Music for the event. 44 
1 since I pursued it publicly it 30 years ago ${ }^{520}$ against the accusations of inadmissible 1

2 descriptions of external objects. What my predecessors had failed to see was the 2

3 simple fact that the text took on the task of outlining the story of creation and 3

4 it comes down to this: how to do it and afterwards throw away the words like a 4

5 scaffolding and have an architectonic work before you, which one takes up like 5

6 a significant symphony or sonata, which at the same time it is not, in which it is 6

7 raised up from imaginable negativity to large quantities of unimaginably good 7

8 material. The nothingness; the emptiness; the wilderness; the depths; the darkness 8

9 was granted; the chaos. ${ }^{521}$ - May God grant that this be so - let there be light; 9

10 let there be sun, moon and stars; children of the light should become the eyes 10

11 of that which does not exist and that which will arise from the chaos. Now the 11

12 Music; beginning; initially monsterous unison between unrecognizable heights 12

13 and depths; the space between the poles - 'the world in its deepest foundations', 13

14 hard and wide, not major, not minor - 'With longing, without sound' - one sound 14

15 and no sound, heavy, thick, pea-soup fog. Resounding with electric power - 'a 15

16 painful sigh!' ${ }^{522}$ It rises, moves, differentiates itself distinguishing one thing from 16

17 another; it starts to flow; forms itself into groups, attracts and repels; life makes 17

18 room for itself, the pulse beats, seeks a rhythm, the shape, the measured appears, 18

19 takes shape; a planet which is just completed rises up, moves, climbs, runs through 19

20 its course and stands as nailed to its place in the firmament: and so it continues 20

21 until final order. What more can I say? Put your ideas of 'God and Word' on this 21

22 image of chaos and so it fits as if the lid of the pot.

23 Since this chaos, even without the words, is artistically comprehensible, 23

24 healthy, intensely enjoyable; so I envisage, leaving the words out of the whole 24

25 work. Then to consider what the amateur judges as brushwork - from the growling 25 occasions. Neither review took issue with the discussion about tone-painting in music 28 which had started up again in relation to Haydn's Creation, having originated in Johann 29 Jacob Engel's theoretical writing and Sulzer's Allgemeine Theorie der schönen Kunste. 30 The first review handles the question in the background, while the second review goes into 31 it only indirectly through a preliminary appreciation of Haydn's instrumental music. The 32 most significant criticism levelled against Haydn was published after Zelter's first review 33 in Triest's 'Bemerkungen über die Ausbildung der Tonkunst in Deutschland im achtzehnten 34 Jahrhundert', AMZ 3 (1800/01), nos.14-26; see in particular no. 24, column 408. See also 35 Friedrich Ludwig Aemilius Kunzen in the Zeitung für die elegante Welt, 1 (1801), no. 153, 36 22 December 1801, columns 1228-32. In his remarks Triest announced a fundamental 37 'attempt at limiting the representational possibilities of music, especially with regard to 38 tone painting' (column 409, footnote). In reponse to this debate over The Creation, Zelter 38 took up his firm position of support once again in his review of Haydn's Creation, AMZ 639 (1804), columns 513-29 and validated Haydn's particular form of tone-painting. $\quad 40$

${ }_{521}$ Zelter takes up the wording from his first review of Haydn's Creation; AMZ 341 (1800/01), column 291f.; MA 20.3, p. 1111.

44 Divan, published in the section, 'Gott und die Welt'; Zelter quotes verses 9, 24 and 14. 
1 and bellows of Behemot ${ }^{523}$ and the lion to the sound of the nightingale - to be a 1 2 suite of delightful phenomenon which the sensitive ear decodes.. And that was 3 good! Admittedly, towards the end, since no poet can ever stop chattering, there 4 must be a Part Three, ${ }^{524}$ man appears, the philistine, the word is hardly out: be 5 fruitful and multiply! And so it goes with kisses and marriages; you can almost see 6 with your eyes old Haydn with his Marzebille live in the music, ${ }^{525}$ waltzing and 7 courting, so that saliva gathers in my mouth: this hound of poets ${ }^{526}$ who corrupts 8 man's nature.

91 May: I have left others to read the newspapers, since I have the advantage 10 over you to discover the latest news from conversationalists in the Monday Club ${ }^{527}$ 11 who are avid readers ${ }^{528}$ and to spare my eyes [...]

12 As you will hardly read as far as page 208 of Dr Lautier's System of Figured

$13 \mathrm{Bass}$, let me recommend you read the last 14 lines of that page, ${ }^{529}$ for they say what 14 the whole book means and what of course is self-evident.

19 T23 The giant described in the Book of Job 40, 15-21; Trio no. 19 from Haydn's 19

22524 Part Three of Haydn's Creation deals with God's praise through Adam and Eve,

23 the apotheosis of marriage and the warning to the first man and woman: 'Do not know more than you should!' Again this passage is echoed in Zelter's review of the score; $A M Z 4$ 24 (1801/2), no. 24, 10 March 1802, column 395; MA 20.3, p. 1111.

27 Octavians (after

28 the Christian hero, loved and conquered Marzebille, daughter of the Sultan of Babylon).

29526 Adaptation of Goethe's poem 'Musen und Grazien in der Mark', v. 7-8. 29

$30 \quad 527$ A society of the religious elite of Berlin, founded in 1749 by Georg Schultheß and 30

31 Johann Georg Sulzer, originally with only eight members and strict statutes for entry. The 31

32 statutes of the Berlin Monday Club were newly formulated, as a result of which the number 33 of members increased.

34528 Zelter's answer to Goethe's remark that he has 'done away with reading all 34 35 newspapers'.

$36 \quad 529 \quad$ 'As a result anyone can accurately state: there are essentially no rules because 37 every conceivable harmonic step - and, in general, breaking every rule - is possible; it 38 can also be stated just as validly: everything holds or there are no rules. Whoever has overlooked the rules must then follow this path through and in particular establish no new rules. Even so it must be added: all rules are valid because breaking a rule is only 40 correct in so far as it is a rule and follows the system. The opposition of this compositional method is not a mere protest but an understandable and recognized opposition, which the

43 des Grundbasses der Musik und Philosophie, als erste Abteilung eines Grundrisses des 44 Systems der Tonwissenschaft (Berlin, 1827), p. 208. 
To say a word about the performance of the Creation last Wednesday: I hear 1

2 it praised and am in agreement. They praise the personal strength of our choir, ${ }^{530} 2$

3 as above all Spontini did himself. There were 230 of us; that is philisitinism, 3

4 however. In total we are over 400, since we have to be so strong as to support 4

5 ourselves economically. One has to make sure that not everyone comes because 5

6 everyone would like to take part. The effect is produced by half of them and we 6

7 have to be careful that what is over and above that is not harmful. One would have 7

8 to be much stricter if one were to be strong enough to resist the fairer sex. There 8

9 is, however, a good attitude in general. The breeder is prepared to be criticized if 9

10 only the stock is good!

[...] How are things with Felix? Has he recovered in order to delight us soon?

24 With regard to my singing colloquium at the university, 50 lads have not got off to 24

25 a bad start for a first time, and if they want to keep up the pace, I think it will turn 25

26 out well for them. The ones among them who started out cheeky and boisterous 26

27 became flexible, even charming in the course of my instruction, since they had to 27

28 represent themselves through their own element (the voice). They endeavoured 28

29 [to do] what I recommended and lo and behold they seemed to be pleased with 29

30 themselves. We will wait and see what happens. The little library and collection 30

31 of musical materials of the institution, ${ }^{531}$ which I am now taking over, needs to be 31

32 reordered, for which I have requested money from the minister. [...] 32 contained collections of books and manuscripts from Forkel's bequest, purchased through 40 
1 I have now heard Mademoiselle Sontag three times in Othello. ${ }^{532}$ I wanted to 2 see if she was always mistress of the situation. She was different on each occasion 3 and yet she was always Desdemona. [...] Unfortunately the sweet creature is about 4 to become a countess! $!^{533}$

5 Felix, to whom I have given a letter for you, has, day after day, been on the 6 point of setting out. ${ }^{534}$ On Friday he played another concerto of old Bach's at my 7 house, like a true master because the concerto is as difficult as it is beautiful, and it 8 would have been worth old Bach himself hearing it. I can hardly wait for the time 9 when the lad will leave the wild jingling of Berlin behind and go to Italy; in my 10 opinion, he ought to have gone there at the beginning. [...]

11 Today is already 10 May and I don't know whether Felix is still here; he 11

12 wanted to leave today. If he calls by before the post leaves, he can take this letter 12 13 with him.

20 A few minutes ago, at half past nine this morning the first-rate Felix left for Jena ${ }^{535}$

21 with Ottilie, Ulrike and the children, accompanied by the clearest weather and the 21 22 brightest sunshine, after having spent a cheerful fortnight with us ${ }^{536}$ and delighting 22

26532 Performances of Rossini's Othello with the Königliche Kammersängerin ['royal

27 chamber singer', a title awarded to a singer of outstanding merit] as a guest artist in the

28 role of Desdemona, were given on 3 April (to a full house), and on 16 and 7 May; see $A M Z$

2932 (1830), no. 21, 26 May, column 342f. During April and May 1830 Henriette Sontag 30 appeared as guest artist in the following operas: as Rosina in Der Barbier von Sevilla on 6

31 April; as Susanna in Die Hochzeit des Figaro on 10 April; as Hannchen in Joconde on 14

32 April, 23 and 24 April in Potsdam; as Donna Anna in Don Juan on 20 April and 17 May;

33 as Pamyra in Die Belagerung von Corinth on 26 and 30 April; as Anna in Die Dame auf

34 Schloß Avenel on 11 and 13 May; and the title role in the premiere of Semiramis on 15, 3519 and 21 May.

533 Already before her return to Berlin (probably in 1828) Henriette Sontag had married

36 Count Carlo Rossi, diplomat from Sardinia; in 1830 she was elevated to the nobility by the

37 Prussian King and called herself Countess Rossi Sontag von Lauenstein from then on.

39 home on 21 May 1830 (see Goethe's diary WA III/12, p. 245) and delivered Zelter's letter 40 of 10 May.

41535 The Fromann family; see Mendelssohn's letter of 6 June 1830, Gespräche, vol. $42 \mathrm{III} / 2$, p. 632.

43536 At Goethe's request, Felix stayed with the poet for two weeks, from 21 May to 443 June. From Weimar he travelled to Munich en route to Italy. 2 3 5 6

\section{0} .

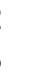
4

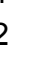

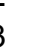
5 27

\section{8} 29 30 31 32 33 34 35 36 37 38 39 
1 everyone with his accomplished, lovable art: ${ }^{537}$ there, too, he will enthral our well- 1

2 disposed friends and will leave behind a memory which will always be treasured 2

3 in our neighbourhood. 3

$4 \quad$ To me his presence was especially beneficial, for I found that my relation to 4

5 music is still the same as ever; I listen to it with pleasure, interest and reflection, 5

6 and I love the historical part of it. Who can understand any kind of occurrence if 6

7 he is not thoroughly acquainted with its development down to the present time? 7

8 What was great for me was that Felix understood this progressive advancement 8

9 admirably and luckily his excellent memory enables him to call before him at 9

10 will every kind of example. Beginning with the Bach epoch, he brought Haydn, 10

11 Mozart and Gluck to life again for me, ${ }^{538}$ gave me a fairly good impression of the 11

12 great masters of technique in more modern times, and finally led me to experience 12

13 and contemplate his own compositions; so he parted from me with my fervent 13

14 blessing. 14

15 All this I have written off to you very hastily that I may challenge you to a new 15

16 letter. Give the best most serious praise you can to the parents of this outstanding 16

17 young artist; give an eager botanical friend the enclosed note, ${ }^{539}$ and think of me as 17

18 of a friend who is not indeed always easy, but is passionately active, aspiring and 18

19 keen to learn from the examples you send him. 19

\section{Zelter}

26 The tender, paternal affection with which you have honoured our Felix has raised 26

27 his parents and siblings into the seventh heaven. I give you every thanks I can; it 27

28 will be a lifelong joy to him. At times I get rather worried when I look at the course 28

${ }^{537}$ As recorded in Goethe's diary, Mendelssohn gave daily recitals at the piano, 30

31 explaining the historical progession of music (24 May 1830) and in the evening he played 31

32 'significant works, old, new, including his own compositions'; (31 May 1830), WA III/12, 32

33 pp. 246 and $249-50$.

538 In a letter dated 25 May 1830 Felix wrote to his parents, 'I have to play to him 34 for an hour in the morning all the great composers in historical sequence and explain to 35 hith what each has done to further the art, while he sits there in a dark corner, his old eyes 36 flashing fire like a thundering Jupiter. He didn't want to hear anything by Beethoven - but 37 I said to him I can't help that and performed the first movement of the C minor Symphony. 38 That had a very strange effect on him. He said at first, that does not move one at all; it only 39

539 Goethe's note to Heinrich Friedrich Link (1767-1851), Professor of the Botanical 41

42 Gardens, Berlin; Goethe's note, which has not been handed down, contained a request 42

43 for plant seeds, to which Link replied on 10 or 11 June 1830; GZ 13 to 15 June 1830, 43

44 enclosure. 
1 of the boy's life. Up to now he has met hardly any opposition. As a pupil I neither 1

2 overestimated him nor found it necessary to praise him, although I can only view

3 with pleasure his natural docility and the drive to busy himself mentally when he

4 is not forced to do anything. I can think of myself as having taught him the truth,

5 as I recognize it fulfilled in him to the second and third degree. He takes away with

6 him from here a complete system, upon which he can build what genius inspires

7 him with, and if he continues to develop in this way, he will have reason to think

8 of his teacher. [...]

9 I am busy enough at the moment. Apart from my other functions I now have 76

10 students, ${ }^{540}$ lads and lasses, twice a week at my house and I would like to see who

11 can criticize me. We are preparing to sing a first-rate work (in the great University 11

12 Concert Hall on 25 December), for a festival of the Augsburg Confession ${ }^{541}$ which

13 we ourselves are planning, to tug the fur of the frosty academics. No one thought

14 that it would come off and look, it's happening! As I live and work at the university,

15 the boys are at hand every minute. As I begin directly with the first one, they race

16 to be first in the queue. And I, poor fool, am delighted about it and for that reason

17 would swap a pair of our professors if you could see me among my fellows and

18 hear the German power that lives in a willing generation who doesn't want to give

19 less than the best. If it comes off, I am thinking of preparing a party for them so

20 that they will also remember me afterwards. They still can't do anything, but they

21 should learn something and at the same time not know how they managed it. 12 13 14 15 16 17 18 19 20

2215 June: A letter from Felix to his parents has just arrived from Munich, ${ }^{542}$

23 where he has had first-rate introductions. The lad still basks in the happiness that

24 he experienced in Weimar and in Jena.

28540 The university choir had expanded so much that in a petition to the minister on 30

29 May, Zelter had asked for permission to copy the available music materials and requested

3050 thalers for new acquisitions, because four to five men had to sing from one part; see

31 Wilhelm Röntz, 'C.F. Zelter und die Zeit seines akademischen Singkollegiums 1830-32',

32 Sonderabdruck aus der Deutschen Sängerbundeszeitung 22 (1930), no. 30, 26 July, p. 4.

33541 To mark the third centenary of the handing-over of the Augsburg Confessions

34 (confession of faith of the Lutheran Church, in the version by Melanchton and Luther, and

35 presented on 25 June 1530), a solemn service was held in the cathedral on 25 June 1830 in

36 the presence of the king and all members of the university. After it a celebration was held

37 in the university lecture hall. The varied programme - which included festival speeches by

38 Hegel and Marheineke and doctoral degree ceremonies - began and ended with music from

38 Zelter's university choir, including the performance of Eine feste Burg ist unser Gott see

39 Spenersche Zeitung, no. 146, 28 June 1830; MA 20.3, p. 1116.

$40 \quad 542$ In a letter from Munich on 6 June 1830, Felix Mendelssohn told his parents about

41 his visit to Goethe. In: Reisebriefe von Felix Mendelssohn Bartholdy aus den Jahren 1830

42 bis 1832, ed. Paul Mendelssohn Bartholdy, 3rd edn (Leipzig: Hermann Mendelssohn, 1862,

43 reprint Bonn: H.C. Schaack, o.J., 1947), pp. 11-14; hereafter referred to as Reisebriefe 44 (1862); excerpts in Gespräche, III//2, p. $631 \mathrm{f}$. 
5 [...] I must tell you that Felix has recalled his amiable presence to our minds by a 5

6 very charming letter from Munich, ${ }^{543}$ in which he discusses that marvellous place 6

7 with great judgement. He made friends there especially with the court painter 7

8 Stieler, ${ }^{544}$ who, when painting my portrait during a stay of more than eight weeks 8

9 here, became quite one of ourselves. It is pleasant to learn what such a man, at 9

10 such a time, and under such circumstances, thought he found and was prepared 10

11 to assimilate. ${ }^{55}$ Furthermore, I am sure I must have mentioned to you before, 11

12 that my son and Dr Eckermann started for the south at the end of April. My son's 12

13 journals $^{546}$ on the way as far as Milan, and from there to Venice, testify to his clear 13

14 views of worldly matters, his thoughtful activity in learning to know and make 14

15 himself familiar with men and circumstances. The great advantage that this will be 15

16 to him, and to us, is that he will get to know himself and will discover what is in 16

17 him, which in our simple and limited surroundings cannot be discovered with any 17

18 great clarity. In all this you will give him your blessing. [...] 18

19 I just want to find out, to hear in your words and in your own way, how the 19

20 singing went off with the newly formed and newly taught choir, ${ }^{547}$ of which the 20

21 papers only report the general [impression]. 21

28 [...] My students, 81 in total, have, on the occasion of the centenary celebration, 28

29 performed a piece of music the likes of which the Pope himself doesn't have. 29

30 Our Te Deum and Lutheran chorale, 'Ein' feste Burg ist unser Gott', ${ }^{548}$ sung and 30

543 Felix Mendelssohn's letter to Goethe from Munich on 16 June 1830; see GJb 12,32

545 Mendelssohn had written about Stieler, 'the way he spoke to me about you and 35 yours, the warmth and joy which radiated from his whole being, the more he recalled his 36 time spent with you, the more I was won over by him'; GJb 12, 1891, p. 83.

546 Since his departure in April, August von Goethe had kept a diary through regular 38 correspondence and had sent it in sections to Weimar; see Goethe's diary, 1-4 May, 12 May, 39 2 June and 4 July 1830, WA III/12, pp. 235-6, 241, 250-51 and 268-9.

547 The university choir's performance at the 300th anniversary festival of the 41 Augsburg Confessions. 
1 declaimed in good Lutheran tradition by vigorous, capable, lively lads, raised the 1

2 roof of the university building and made the whole area resound. A senator asked 2

3 whether it had to be so strong. Yes (was the answer) [...]. 3

4 Now it is all go for 3 August (the King's ${ }^{549}$ birthday). A new Latin ode is being 4

5 rehearsed and my boys are as I want to have them. Last week they really delighted 5

6 me in the evening with some of your songs. The university garden in front of my 6

7 window is as if designed for it; they are also able to serenade me very comfortably 7

8 from there and I hope I deserve it! 8

9 9 9

$10 \quad 10$

11 508. Goethe 11

$12 \quad 12$

$13 \quad$ Weimar, 18 July 183013

$14 \quad 14$

15 It has been absolutely impossible to contribute anything to the brothers' worthy 15

16 Taschenbuch. Should you care to give them the cantata and song ${ }^{550}$ written for 16

17 your birthday, I would not object. While it is well known to a certain circle, it is 17

18 also well forgotten. Enough said! All I mean is: do just as you like and as are fitting 18

19 to the circumstances. [...] 19

20 Every success to your student chorus! I can quite imagine that a contemporary 20

21 audience, who care for nothing but sentimental droning and humming, should find 21

22 a powerful style of song, which lifts the heart and splits the roof, horrendous; their 22

23 choral singing is never anything else but 'Ein laues Bad ist unser Tee' ${ }^{551}$ and then 23

24 they imagine nevertheless that they have something of a sure stronghold and that 24

25 some kind of deity is troubling himself about them. [...] 25

$26 \quad 26$

$27 \quad 27$

$28+28$

$29-29$

$30-30$

$31 \quad 31$

$32 \longrightarrow 32$

33 was sung after the announcement of the competition by Hegel. After the Te deum laudamus, 33

34 which, according to the Vossische Zeitung, was a setting by Eduard Grell, Marheineke's 34

35 speech brought the academic ceremony to a close.

$36 \quad 549 \quad$ King Friedrich Wilhelm III of Prussia. 36

37550 Goethe's cantata Zelters Siebzigste Geburtstag, gefeiert von Bauenden, Dichtenden, 37

38 Singenden am 11ten December 1828 ('Schmückt die priestlichen Hallen', MA 18, 1, p. 29) 38

38 and Goethe's Tischlied, Zelters siebzigstem Geburtstage ('Lasset heut am edlen Ort', MA

39 18, 1, p. 34). Goethe's cantata was actually printed under the title Zwei Festgedichte von

40 Goethe in the Berliner Musenalmanach für 1831: 3-7. A facsimile of the published poem

41 was published in Dem würdigen Bruderfeste Johanni 1830 ('Funfzig Jahre sind vorüber',

42 MA 18, 1, p. 42).

43551 'Our tea is all a lukewarm bath': Goethe's word play here is a parody on the 43

44 Lutheran chorale Ein feste Burg ist unser Gott, with reference to the Singtees. 44 
5 [...] Yesterday, for the first time for several months, I went to the theatre. 5

6 Deinhardstein's Hans Sachs ${ }^{52}$ is rather well staged here; the poet has very 6

7 cleverly contrasted the position of a craftsman who has also acquired intellectual 7

8 distinction over that of other citizens and artisans. In general the everyday citizen 8

9 is quite right, and in particular instances it is just the same with them as with the 9

10 higher and the highest classes. You, too, have had enough to say on the subject 10

11 and experience this more and more every day. But you must feel glad that you 11

12 suggested this pretty play by your honourable mention of the ancient father of 12

13 German poets. ${ }^{53}$ The house was not full, but the play had a good effect - on me at 13

14 any rate, if not to such an extent on any other of the audience as with me. 14

15 One of our young musicians in the orchestra had composed music for the 15

16 Entr'acte, ${ }^{554}$ which seemed to me quite charming, if only because it does not attempt 16

17 to say what it cannot. Many composers of this class will repeat after the end of an 17

18 act the very thing we are glad to be rid of, or else they betray beforehand what is 18

19 to come, tormenting the ear which doesn't know what they are at. Consequently, 19

20 the value of a suitable piece of music, which falls into its right place and fills up 20

21 the given time successfully, is immense. 21

28 [...] Yesterday, on your birthday, my students began their holidays very 28 29 ceremoniously. They had written poems in praise of you and set them to music 29 30 and surprised me with them. Von Seckendorff ${ }^{55}$ produced the best and in your 30 31 name I thanked them for their love. I must confess that the young people become 31 32 dearer to me every day. If I attribute part of it to my way of teaching, admittedly 32

552 Two years before Count Brühl had asked Goethe's permission to use his poem 34 'Hans Sachsens poetische Sendung' as a prologue to Johann Ludwig Deinhardstein's libretto 36 Hans Sachs; it was first performed on 13 February 1828 in the Königliches Schauspielhaus 36 in Berlin. Zelter had attended the performance on 26 August 1830, at which the one-act 37 melodrama by Friedrich Wilhelm Gotter with music by Georg Benda was also performed.

${ }_{553}$ Goethe's poem 'Dein Ehrenandenken des Altvaters der deutschen Dichter', 39 published earlier in the Teutschen Merkur (1776). 40 554 The identity has not been discovered; there is no information on the theatre 41

44 universities of Leipzig and Berlin (1828-30). 
1 long-enough practised, you can imagine that the work itself becomes a vacation on 1 2 which I feast because it is material that I am already familiar with. 2

9 For over a week now I am obsessed with a lively song ${ }^{556}$ that I drafted in freely 9 10 when I was reading. Like [a hen] with an egg I cannot lay it and cannot manage 10 11 to make it round. The poem is insignificant, but it has something that offered me a 11 12 particular structural form.

13 Another by Förster is completely successful - metrically I would even consider 13 14 it a masterwork. He sent it to you himself because he wrote it in Rome for your 14 15 birthday. It is called 'Die Campanelle' ${ }^{557}$ and it is really good. It is also valuable 15 16 to me because I composed it a week ago for your birthday. Hegel was with us 16 17 that evening and since then he is laid up with a fever. [...] One of my students, 17 18 Baron Emil von Seckendorf, had also written two poems and set them to music. ${ }^{558} 18$ 19 I promised to send you a fair copy. It is the basic conviction that I revere and 19 20 recognize. Words are water and water doesn't do it. I am already working on a 20 21 supply for the winter semester in order to make them worthy of my audience. It 21 22 would amaze me if someone were so smart as to write down what I tell them. I 22 23 confess that I myself would like to read it. As soon as I lift the pen, I am blank and 23 24 write only what I already know. [...]

25 A guest singer, Mademoiselle Heinefetter, has just arrived. I have to praise her; 25 26 she is capable of a lot and doesn't do too much. That is rare! She really pleased 26 27 me as Desdemona ${ }^{559}$ without reminding me of Madamoiselle Sontag, and that tells 27 28 me something! 28

557 Friedrich Förster's poem 'Die Campanelle', set to music by Zelter in 1830; the text was published (without any acknowledgement of the author) in Ottilie von Goethe's journal

$37 \quad 558$ There are no settings by Emil von Seckendorff in Goethe's music collection. 37

38559 Sabine Heinefetter (1809-72), the prima donna of Italian opera in Paris, gave 39 guest performances in the Berlin opera house during August and September 1830. The 40 performance of Rossini's Othello mentioned by Zelter had taken place on 31 August 1830; 40 the performance scheduled for 27 August had to be cancelled on account of the singer's 41 hoarseness. Further guest appearances given by Heinefetter in Berlin were: the title role 42 in Fidelio on 20 August; Sextus in Titus on 25 August; Agathe in Der Freischütz on 5 and 4317 September; the title role in Semiramis on 9 and 12 September; Susanna in Die Hochzeit 43 44 des Figaro on 15 and 21 September; and Amazili in Ferdinand Cortez on 24 September. 
5 [...] I have no comfort to give you about musical matters; I carry on in my old way 5

6 and let the rest of the world get on with it. Marx or Markus, ${ }^{560}$ not the Evangelist - 6

7 although in the Musikalische Zeitung he preaches the doctrine of bunglers - 7

8 brought me greetings from Felix who is in Munich; ${ }^{561}$ the message is fine, though 8

9 there is no good understanding between me and the bearer. This Marx has just 9

10 published in quarto a Kunst des Gesanges, ${ }^{562}$ at which, by his own account, he has 10

11 worked for nine years - finally to make Italian music a grief to the Germans. The 11

12 work begins thus: 'We now find ourselves at the end of a period in the art of music 12

13 in which Italian music fills all countries, Germany included, almost making us 13

14 forget what German art and German music are. ${ }^{563}$ If that were true, undoubtedly 14

15 the best thing the Germans could do would be to compose music that would make 15

16 us glad to forego the Italian. But the attack on the excesses of the Italian style, as 16

17 exemplified in the once salv. ven. castrati and other forgotten horrors, ${ }^{564}$ is as stale 17

18 as the whole doctrine of Marx. Have but talent, my worthy Germans, and with 18

19 that go where you will find ears, eyes, joy and meaning; foreign countries will 19

20 do you no harm. Dürer, Hackert, Goethe, and many others besides, strengthened 20

21 and confirmed their talent in Italy, and he who takes nothing there will bring 21

22 nothing back. Handel, Graun, Hasse, Mozart made music wherever they were; 22

23 whether Scottish, Italian, Evangelical, it was all the same to them - and the world 23

24 is filled with what they did and did well. All honour to your German science -24

25 ye professorial gentlemen - if you will only let music be music still! 25

26 The quarrels over the new Berlin hymn book ${ }^{565}$ are still going on; the truth may 26

27 lie in the middle, though each faction may be far from it. The Porst hymn book ${ }^{566} 27$

28 is, of course, useless, unless one venerates the sentiment, the earnestness, and the 28

29 truth contained in it. The new book, on the contrary, is neither a new one nor the 29

30 old one - even the very necessity of a new one just now could be contested when 30

31 the inability to make a new one is so candidly confessed. The soling and peeling 31 1824

A.B. Marx was editor of the Berliner Allgemeine Musikalische Zeitung from $\begin{aligned} & 33 \\ & 34\end{aligned}$

561 During his stay in Munich Felix Mendelssohn had, in fact, met Marx, who 35 subsequently wrote to Fanny Hensel about her brother's activities in Munich.

562 A.B. Marx, Die Kunst des Gesanges, theoretisch-praktisch (Berlin: Adolph Martin 37

Schlesinger, 1826); Marx's preface is largely directed against the degeneration of Italian 38 singing (namely, unintelligible words, exaggerated ornamentation). The main body of the 39 text is, however, a factual, elementary introduction to the art of singing. $\quad 40$ 563 Ibid., preface, p. iii. $\quad 41$

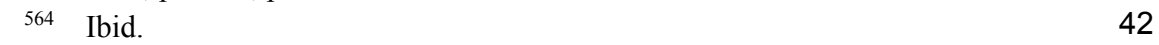


1 of the old ox-hide verses is - however brave a name one may attach to it - at best 1 2 a green fig-leaf to the original sin. [...] 2

3 Would you be so kind as to hand over the enclosed to Madame Milder when 3 4 she reaches you? ${ }^{567} \quad 4$

11 [...] I will gladly publish the music to 'Campanelle' in Chaos $^{568}$ - I just want to 11 12 hear it first [to see] whether it shows what I put into it. Let me know the final 12 13 deadline when you must have it. May I also ask for a complete copy at the end of 13 14 the year? I have some individual pieces which are doing the rounds amongst my 14 15 art-loving Francophile and Anglophile ladies. 15

16 It would mean a great deal to me if my music to 'Generalbeichte' had 16 17 contributed to making your Taunus-hearted Frankfurt people ${ }^{569}$ to do penance. The 17 18 music has 30 years around its neck. We still sing it and I am the one who gladly 18 19 hears it again. [...] 19

20 In the evening the Liedertafel took place; the second (of which I am an honorary 20 21 member) made me happy because it endeavours to outdo the first (of which I am 21 22 chairman). ${ }^{570}$ When they got together at the beginning, they wanted our songs. 22 with Spontini and now gave guest performances in different opera houses across Europe.

27 She was guest performer at the Weimar Court Theatre in October 1830 and visited Goethe

28 on 7 October (see Goethe's diary, WA III/12, pp. 313-14). She returned to Berlin at the 29 beginning of November.

$30 \quad 568$ ZG 4-7 September 1830 and GZ 12 September 1830, where he wrote, 'They have 31 accepted Die Campanella in Chaos; if you were to send your setting of it, we could also see 32 the music in print'; Zelter sent Goethe the requested composition on 10 May 1831.

33569 For Goethe's 81st birthday 13 citizens of Frankurt had sent Goethe a silver 33 34 goblet and two cases of wine, with an accompanying letter which concluded with verse 34 355 of Goethe's poem 'Generalbeichte'; see Wolfgang Hecht, Allerlei freundliche Dinge. 35 36 Geburtstagsgeschenke für Goethe (Weimar: Neue Folge (GSA), 1985), p. 65f; an image of 36 37 the goblet is included on p. 67.

$38 \quad 570$ The Jüngere Liedertafel had been founded by Ludwig Berger and Bernhard Klein 39 in Berlin; they distinguished themselves from the first Liedertafel founded by Zelter by not 40 having a cap on the number of members and because they 'represented the new political 40 tendencies'; see Peter Nitsche, 'Die Liedertafel im System der Zelterschen Gründungen' 41 in Carl Dahlhaus (ed.), Studien zur Musikgeschichte Berlins im frühen 19. Jahrhundert,

42 (Regensburg: Bosse, 1980), p. 11-26, quote 21. Zelter had been an honorary member of the

43 Jüngere Liedertafel since January 1830; he always spoke well of the society, even ranked it 44 higher than his own - despite the natural suspicion that he perceived them as rivals.

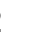
(1)

15

6

年

19

9


1 I said then, 'If you want to be a mere shadow of us, you are no good at all. Instead 1

2 you should consider your society as a good sequel to a good thing, so write some 2

3 songs or steal them as you can.' They did this. I myself wrote some completely 3

4 new songs for them and some of their members have supplied such good settings 4

5 that one would have to praise them. 'In allen guten Stunden'571 I like better than 5

6 my own composition, which admittedly is orginal, and if they gradually get rid 6

7 of 'Sandwirt' 572 and other lugubrious patriotic songs, they could compete with 7

8 everyone. They are vigorous young people, somewhat inclined to anarchy, but 8

9 really decent and well disposed towards all that is good, though they are like my 9

10 barometer which is always dancing up and down to good weather without ever 10

11 becoming settled. 11

18 [...] As a wind-up to the royal wedding festivities (of Prince Albrecht), they gave 18

19 us a grand performance of Wilhelm Tell en masque at the opera. The real Wilhelm 19

20 Tell was composed by Rossini for Paris; it gave offence, however, on account of 20

21 its revolutionary tendency, so they offered us a completely new text, and the opera 21

22 is now called Andreas Hofer. ${ }^{573}$ No one is supposed to notice this. Essentially they 22

23 are just like little children, who imagine that no one can scent them out if they keep 23

24 their eyes shut.

What kind of a man Rossini is will now be revealed. My reputation is at stake. 25

26 If, however, the work pleases, I have won; because I affirm that no poet can fault 26

$27 \mathrm{him}$, nor write him off. One of these days some one will venture to fit a Figaro into 27

571 Setting of Goethe's poem 'Bundeslied' by Gustav Reichardt (1797-1884), 32 published as no. 1 of 6 Tafelgesängen für vier Männerstimmen, op. 5, full score and parts 33 (Berlin, 1825).

572 Also known as 'Sandwirt Hofer' and 'Andreas Hofer', set to music by Ludwig 35 Berger, no. 5 in Tafelgesänge, vol. 1, op. 20 (Berlin, 1825). alias De Jouy and Hippolyte Louis Florent Bis; premiere on 3 on account of its seemingly revolutionary content - only allowed to be performed 38 completely distorted German version: 'Andreas Hofer, Grand Opera with ballet in 4 acts, 39 after the contents of the English opera of the same name by (James Robinson) Planché, with 40 accompanying music by Rossini, freely adapted for the German stage and organized into 41 
1 his Semiramis. ${ }^{574}$ I haven't even heard the work yet. I don't like to say that I am 1

2 sick because no one would believe it, but I can't really not say it. [...] 2

3 Tell me something about Madame Milder's stay with you. ${ }^{575}$ She is so quiet 3

4 with me and I can't really get anything out of her. 4

5

6

7

515. Goethe

11 [...] I saw the dear Milder briefly here, but unfortunately I didn't hear her. I no 11

12 longer go to the theatre and it wasn't possible to arrange a concert in my home. I 12

13 also could not speak with Frau von Wahl whom you recommended earlier, who, 13

14 according to Ottilie, is back from Italy cheerful and well. To think of other people's 14

15 situations no longer suits me. I have to direct and settle my own affairs. [...] 15

22 Yesterday, I, at length, saw and heard the much-abused soi-disant Andreas Hofer 22

23 ci-devant Wilhelm Tell ${ }^{576}$ - and I think I have won my game.

24 This time the composer has written an opera for Paris, ${ }^{577}$ which has a capital 24

25 orchestra and screamers for singers. I recognized the man himself in his complete 25

26 individuality; still, his work is a novelty as his ground is new. Actually I consider 26

27 this opera actually unfeasible in Italy, as the singers will decline to sing it, and the 27

28 orchestra cannot play it. The work is in four acts, and throughout all is spirit and 28

29 life. Although in Rossini's Italian operas we may have many a dreary moment, 29

30 here there is nothing but continuous animation, fire and variety. The libretto is a 30

31 ridiculous falsification of the history of our time, and reminds one of the countless 31

$34 \quad 574$ German title of Rossini's opera Semiramide (libretto by Gaetano Rossi) with a 34 35 quite different protagonist, distorted in the same way as Rossini's William Tell.

575 Anna Milder appeared as guest artist of the Weimar Court Theatre on 9 October in

37 the role of Elvira in Mozart's Don Juan (in the German adaptation by Friedrich Rochlitz); on

3813 October she sang Clytamnestra in Gluck's Iphigenie in Aulis; her final guest appearance

38 was given on 16 October in the title role of Gluck's Iphigenie in Tauris. Goethe mentioned

39 her visit on 7 October in GZ 29 October 1830.

$40 \quad 576$ The title of the politically correct German adaptation of Rossini's William

$41 \mathrm{Tell}$; Zelter attended the third (and final) performance in the Königliches Opernhaus on

4231 October 1830; see $A M Z 32$ (1830), no. 51, 22 December, column 829.

43577 Since 1824 Rossini had lived in Paris, where he was director of the Théâtre Italien; 43

44 his William Tell was premiered there on 3 August 1829. 
1 defeats of the triumphant party, nay, of the disgraceful fall of a brave patriot, about 1

2 whom no one has troubled himself, except the enemy of the Fatherland. ${ }^{578}[\ldots] 2$

3 The music excited me so much that I could not sleep that night; perhaps I will send 3

4 you more details about the second performance. [...]

5 Frau von Wahl arrived here yesterday and I have still not seen her; I was 5

6 rehearsing our music which we intend to put on this week for the general 6 7 public. . $^{59}$

8 Felix will, I expect, be in Rome now, ${ }^{580}$ whereat I greatly rejoice, as his mother 8

9 was always opposed to Italy. I dreaded seeing him here, and in the country too, 9

10 dissolving like a jelly under the corrupting influence of family gossip, for I 10

11 consider him really a first-rate player because he plays everything and is a master 11

12 of all styles. Let him go forth, therefore, into the world and discover his masters, 12

13 and awake them, and begin where the beginning is; the materials for that he brings 13

14 with him. [...]

21 As to that branch of your Liedertafel, ${ }^{581}$ you are not dissatisfied with it and I 21

22 should say that these excellent young people, in accordance with the advancing 22

23 age, naturally also want to go forward; but where to? That is the question! The 23

24 rest of us, as all our songs prove, required birth within the bounds of sociability, 24

25 and placed ourselves in innocent opposition to the Philistines. They, it is true, 25

26 are neither conquered nor exterminated, but no longer come into consideration. 26

27 The more modern boon companions seek their opponents on a higher stage and 27

28 it would surprise me if your pupils did not follow in Béranger's footsteps ${ }^{582}$ That 28

29 certainly is a field where there is still something to be done, and where they can 29

30 outbid us, provided they have as much talent as the aforesaid. However, let us 30

31 commend this, with much besides, to those demons who have their fingers in every 31

32 pie of this kind. 
5 [...] The day before yesterday I heard Il matrimonio segreto ${ }^{583}$ once more at the 6 Königstädter Theater. One sits there calmly on the chair without further ado, hears 7 the hundred thousandth story of all the days that were and will be. One is at ease 8 with the sorrow. I am fanned by the lightest, cheekiest, most innocent eternally 9 relevant musical play, despite all the trouble they go to up there to turn white 10 into black or something else. I have heard the music often enough and went back 10 11 to hear a Mademoiselle Vio ${ }^{584}$ who has to replace Madame Sontag ${ }^{585}$ and seems 11 12 to have been well tolerated in her place. In concentrating on the music I have 12 13 forgotten the rest: I have to be able to do that once in my life! [...] 13

20 [...] Die Räuber ${ }^{586}$ was a play which wounded me as deeply as it delighted me greatly. 20

21 [...] Then appeared Kabale und Liebe, in which a musician was represented, ${ }^{587} 21$

22 in whom I recognized the exact counterpart of our Stadtpfeifer, George. ${ }^{588}$ This 22

23 man was a first-rate hand at various instruments, a well-intentioned fellow, though 23

24 of rough manners, and entirely devoted to me. Then there appeared a review of 24

25 Kabale und Liebe, which made me angry - I think Moritz was the author of it. 25

27583 Domenico Cimarosa's comic opera (libretto by Giovanni Bertati) was performed 27

28 in the Königstädtisches Theater in the German adaptation entitled Die heimliche Ehe; Zelter 28

29 attended the performance on 10 November 1830.

$30 \quad 584$ The singer and actress Elizabeth (Betty) Spitzeder née Vio (1806/08-72), engaged 30

31 at the Josephstädter Theater in Vienna, employed at the Königstädtisches Theater in Berlin 31

32 from 1830.

33585 Henriette Sontag was employed by the Königstädter Theater Berlin from 1825

34 and by the Paris opera from the beginning of 1828; she returned to Berlin in 1830 but had

35 to give up her operatic career according to the orders of King Karl Albert of Sardinia on 36 account of her marriage to the Sardinian diplomat Carl Graf Rossi.

$37 \quad 586 \quad$ Schiller's Die Räuber was published in 1781; Franz and Karl Moor were contrasting 37 brothers, sons of the principal protagonist, Count von Moor.

$38{ }_{587}$ The Berlin premiere of Schiller's tragedy Kabale und Liebe took place on

3922 November 1784; one of the characters in this play is Miller, 'local musician or 40 professional piper'.

41588 As a young man Zelter had taken lessons with Johann Friedrich Georg, the town

42 musician who lived in the Königstädter suburb of Berlin; Zelter mentions him many

43 times as a friend and teacher in his autobiography; Schottländer, Carl Friedrich Zelters

44 Darstellungen seines Lebens, pp. 40-45; 122-6; 226f and 240. 
1 I could have killed the reviewer; I declared so often and so loudly against him, that 1

2 my father ${ }^{589}$ once said to me, 'You seem to me like one who washes himself with 2

3 dirty water, for you take pleasure in that which displeases you, you love going on 3

4 about what vexes you; I think you can do something better than what you have 4

5 never learnt to do, nor do I myself understand it.' This - like everything that my 5

6 father used to say - made me reflect; and when Fiesco ${ }^{590}$ appeared and was played 6

7 here by Fleck with great applause, there arose a coolness in me which almost 7

8 passed into coldness - so that now, what I liked best was to take my part as a player 8

9 in old Döbbelin's Orchestra, ${ }^{591}$ let the operas be what they may. This second epoch 9

10 extended itself up to the time of Wallenstein. ${ }^{592} \mathrm{I}$ had then become more intimately 10

11 acquainted with Engel, Nicolai, Zöllner, Moritz, and others. ${ }^{593}$ When I heard the 11

12 faults of the play discussed - it was not in harmony with history; it had cost eight 12

13 years' work and was still so incomplete and so on - I was obliged to hold my 13

14 tongue, though I could not agree with them. Fleck's acting of Wallenstein was 14

15 masterly; the more I saw him, the more I was attracted. I summed up to myself 15

16 all that I had heard about Schiller up to that point, and a deep desire arose within 16

17 me to make the personal acquaintance of the poet. Speaking sincerely, the chief 17

18 inducement in coming to you people in the first instance was that I might get to 18

19 know Schiller, and therefore I came by way of Jena, because I did not know that 19

20 Schiller had already settled in Weimar.

21 Schiller was not long back from Dresden. ${ }^{594}$ Naumann had composed music for 21

22 his 'Ideale', ${ }^{595}$ and made a pupil of his, a Mdlle Schäfer, ${ }^{596}$ sing it to the poet. The 22

590 The Berlin premiere of Schiller's Die Verschwörung des Fiesco zu Genua (1783/84) 25 took place on 2 January 1787.

28 Doebbelin's theatre; see Schottländer, Carl Friedrich Zelters Darstellungen seines Lebens, 28

29 p. 111. Carl Theophilus Doebbelin had taken over many actors and the orchestra of the Koch 29

30 troupe, and as a private entrepeneur had founded a theatre with them in the Komödienhaus 30 on Behrenstraße.

592 The three plays of Schiller's Wallenstein Trilogy received their Berlin premiere at 32 different times: Die Piccolomini was first performed on 18 February 1799, Wallensteins Tod 33

Zelter was introduced to the writer Johann Jacob Engel (1741-1802), in Bejamin $\begin{aligned} & 35 \\ & 36\end{aligned}$ Veitel Ephraim's house in 1783. Zelter formed a long acquaintance with the writer and 36 publisher Christoph Friedrich Nicolai (1733-1811), and rebuilt his home, Brüderstr.13, in 1788. Johann Friedrich Zöllner was chief councillor of the consistory in Berlin. Zelte mentions his friendship with the writer Karl Philip Moritz (1756-93) in his autobiography; 39 see Schottländer, Carl Friedrich Zelters Darstellungen seines Lebens, pp. 51 and 120. 
1 first thing that Schiller talked to me about was this composition, over which he got 1

2 quite angry - that so illustrious a man could so belabour a poem, as to tear its soul 2

3 to tatters with his vile tweedle-dee - and so he launched out against composers as 3

4 a body!

5 I need not describe the effect of so comforting an oration. I had brought 5

6 Schiller's and your poems in my bag, and in one moment lost all desire to unpack 6

7 them. This was before dinner. Schiller and I were to dine with you. 7

8 His wife came and said, 'Schiller, you must go and dress - time's up.' So 8

9 Schiller goes into the next room and leaves me alone. I seat myself at the piano, 9

10 play a few chords, and hum 'Der Taucher' quite quietly to myself. Towards the end 10

11 of the strophe, the door opens, and Schiller - only half-dressed - steals in. 'Yes, 11

12 that's right, that's as it ought to be,' and so on. Then the wife begins again; 'Dear 12

13 Schiller, it is past two o'clock; do just dress first, you know Goethe does not like 13

14 waiting too long.' - And so it all came right. 14

15 You will remember how often in those days I showed off my musical 15

16 divertissements before him and you and all the rest, and how you used to send 16

17 Ehlers $^{597}$ to my room to practise the little pieces with me, and how well he 17

18 performed several of them. 18

19 Forgive me for being such a gossip. Today is Sunday, when one has an hour's 19

20 peace, though I have already attended a stiff three-hour musical rehearsal. I pretty 20

21 well agree with what I find in Thomas Carlyle about Schubart, ${ }^{598} \mathrm{I}$, too, felt strongly 21

22 about the violent treatment he met with, for he was a musician, though his music 22

23 gave me no pleasure; nor did his Asthetik der Tonkunst, wherein he taught what I 23

24 was just on the point of abjuring - how to break through the wall, so as to penetrate 24

25 into the sanctuary when the door is close by. He had learnt nothing and is gone to 25

26 the place from where he came.

27 This letter was not intended to go until I knew some more particulars about 27

28 you, but today is 18 [November], so I shall send it. Felix arrived in Rome on 128

29 November and has written to his parents from there. ${ }^{599}$ Let me have a word from 29

30 you; I cannot set foot in the street, without being asked how you are. ${ }^{600} \quad 30$

31

$32 \quad 32$

$33-33$

$34 \quad 34$

$35-597 \quad$ Johann Wilhelm Ehlers (1774-1845), singer, actor, composer of songs with 35

36597 Johann Wilhelm Ehlers (1774-1845), singer, actor, composer of songs with guitar 36

37 accompaniment.

38 Christian Friedrich Daniel Schubart (1739-1816), court music director in Stuttgart.

39 Carylyle's biography Leben Schillers concludes with a 20-page highly critical appendix on

39 Christian Schubart; MA 20.2, pp. 1143-44.

40599 Felix Mendelssohn reported his arrival in Rome in a letter to his parents on 40

412 November 1829.

42600 Goethe was, in fact, seriously ill in late November 1830, which strengthened 42

43 his resolve to complete the remaining parts of Faust, Dichtung und Wahrheit and this 43

44 correspondence with Zelter. $\quad 44$ 
5 Yesterday Prince Radziwill let me hear three new scenes from his Faust. ${ }^{601}$ I cannot 5

6 sufficiently praise the care with which everything is thought out, right down to the 6

7 smallest details. The first of the scenes is the Requiem mass for the mother ${ }^{602}$ It 7

8 opens in front of the church. Gretchen already hears the sound of the organ from 8

9 a distance, goes into the pew, the Requiem begins and the mass gets under way. 9

10 During the choral song of the Dies irae and so on, Mephisto, in person, as it were, 10

11 steps behind the sinner in the place of conscience and loudly declaims the well- 11

12 known lamentations. Though everything is skilfully and industriously woven and 12

13 fitted into the course of the action, nevertheless it doesn't work because not only 13

14 the prayers of the sinner but also the church service itself, namely the choral song, 14

15 is disturbed through the spoken interruptions. It is also not Catholic. As I said, one 15

16 would have to praise the work; I would not like to complain about the [artistic] 16

17 intention or the effect because the work is there and the critics have come too late. 17

18 The second scene is 'Spaziergang vor dem Tor' ${ }^{603}$ with Wagner, in particular the 18

19 conversation about the poodle. Metrically the verses are opportunely inserted into 19

20 the on-going instrumental music as if the action could seem real and the orchestra 20

21 could not go along with it.

22 The third scene pleased me most of all, although it is also set melodramatically 22

23 as they say. 'Spaziergang im Garten':604 Faust with Gretchen, and Mephisto with 23

24 Martha, move in a circle around a broad grass area so that the couple who speaks 24

25 is seen while the other couple walks among the bushes. Here the music moves 25

26 forward really well, one minute delightful, the next ironic; with tasteful continuity. 26

27 Verse and rhyme are so delicately and metrically interwoven in the course of 27

28 the music that I would consider it the best which has been ventured of its kind. 28

29 Admittedly it would also be required that the declaimers are musically good and 29

30 that all the musicians together provide such a feast to the ears that they slow the 30

31 tempo and increase it again. Here the accursed baton has to do its duty, for without 31

32 it one would never be able to stand up again and go to bed.

33 The concert given by our Madame Milder ${ }^{605}$ went off successfully enough last 33

34 Thursday, in spite of opposition from all quarters. In accordance with her wish 34

35 and the first announcement, I was to conduct the music, though I only did so as a 35

36 mediator, for without my presence it would have been difficult to avoid a complete 36

37

'Garten', v. 3073-3205.

43 passages from Handel's Messiah and scenes from Gluck's Alceste with chorus; see Iris im 43

44 Gebiete der Tonkunst (1830), nos. 43 and 44. 
1 breach with friends and those opposed to her moods, caprice, bad behaviour and so 1

2 on. She appears to like giving orders. Even then her voice is a work of God. 2

3 Nothing is announced yet about the forthcoming carnival. Spontini is being 3

4 sought after, ${ }^{606}$ if not hoped for. In Paris he is said to have praised Berlin, just as he 4

5 praised Paris when he was here. No new operas have been heard of, ${ }^{607}$ and Andreas 5

$6 \mathrm{Hofer}^{608}$ has not yet been performed again. The ballet is in vogue now and little 6

$7 \mathrm{El} \mathrm{ner}^{609}$ really dances, or rather I should say twists and pirouettes marvellously. 7

8 Madame Birch-Pfeiffer has not appeared again; ${ }^{610}$ she did not go down well. She 8

9 could not get into the running, and tried to with tragedies which are not popular 9

10 here. Also the critics did not exactly express themselves in her favour, and that 10

11 counts for something; now and then they, too, are right. [...]

12

13

14

15

521. Zelter

18 [...] The Sing-Akademie will find it difficult to train and support an administrator. 18

19 I have spoilt them. They live and operate to please me and I have lived through two 19

20 generations of them, and I still like them. But where do I get it from and what do I 20

21 draw on? Our bank manager, now deceased, once asked me innocently what I get 21

22 from it, and that is a long time ago. But I have lived and live and must treasure it 22

23 if the least of our 400 members abroad refers to himself as a member of the Sing- 23

24 Akademie in Berlin. [...]

25

26

31606 Spontini, whose ten-year fixed contract as General Director of Music at the 31

32 Königliches Theater had expired, had gone to Paris in the autumn of 1830 before any

33 decision could be made about extending his contract. He resumed his post in Berlin at the 34 beginning of April 1831.

$35 \quad 607$ Spontini was bound by his contract to produce two large-scale works every three 36 years. $36 \quad 608$ After its third performance on 31 October 1830, Andreas Hofer was not performed 38 again in Berlin.

39609 Franziska (Fanny) Elßler (1810-84), leading dancer at the K.K. Hoftheater,

39 Kärntnertor, Vienna, gave guest performances - mostly with her sister, Theresia Elßler 40 (1808-78) - from October 1830 to January 1831 in Berlin.

41610 Charlotte Birch-Pfeiffer (1799/1800-68) gave five guest appearances at the

42 Königliches Schauspielhaus in October and November 1830; the final performance took

43 place on 11 November. Her acting abilities were strongly criticized in the Spenersche

44 Zeitung, no. 260, 8 November 1830. 
5 My concert yesterday (The Seasons by Joseph Haydn) had a good and joyful 5

6 reception. ${ }^{611}$ Apart from an obvious mistake which I myself made, I hardly noticed 6

7 anything else and I can be happy since the accursed theatre-ballets and wretched 7

8 opera nonsense prevent even one prolonged, continuous rehearsal because there is 8

9 always one or other important individual missing. If my primary singer, Fräulein 9

10 von Schätzel, were not the most pleasant girl with the loveliest voice, irrepressible 10

11 good spirits, docility and impertinence, one could not trust the public performance 11

12 of such a great, difficult work to good luck. Although you are older than I, you 12

13 probably haven't seen the like of it. At the same time she sightreads and has a 13

14 natural ability to sustain, tackling the most difficult [music] on the spot. I also 14

15 had to be on top of the situation. Apart from that she does nothing but laugh and 15

16 concentrate like someone shooting woodcocks. May God grant that the theatre 16

17 doesn't corrupt her. While the others are at one another's throats, she is laughing. 17

24 [...] Just for so long as opera has been drawing plays and tragedy along in its 24

25 wake, now the ballet exercises its sovereignty over the theatre, which can thus find 25

26 it difficult to survive on account of the significant money for itinerant virtuosi. 26

27 Yesterday's completely new opera ${ }^{612}$ must have been so well supported merely 27

28 because of the ballet that followed it. Two Viennese dancers ${ }^{613}$ show themselves 28

29 to their advantage through well-proportioned bodies, lightness and grace in the 29

30 most wonderful jumps and positions; the light clothing which displays the outline 30

31 of the whole body keeps lustful eyes busy. The girls are very young, very pretty, 31

32 not too thin and since both act well, it is a shame that there is no choreographer to 32

611 Performance of Haydn's The Four Seasons on 2 December 1830; it was the Sing- 35 Akademie's second subsription concert; see $A M Z 33$ (1831), no. 3, 19 January, column 36
42f.

${ }_{612}$ The Berlin premiere of Alfred der Große König von England took place on 2837 November 1830; Zelter attended the second performance on 5 December.

$40 \quad 613$ The sisters Fanny and Theresa Elßler made their Berlin debut in the ballet Das 39 Schweizer Milchmädchen on 8 October 1830 (with further performances on 21 October). 40 They appeared in Die neue Amazone (29 October, 4, 9 and 17 November) and Oberon, König 41

43 der Elfen ( 7 November) and the Berlin audiences were delighted by their extraordinary 42

43 dancing; see Spenersche Zeitung, 1 November 1830 and $A M Z 33$ (1831), no. 4, 26 January, 43

44 column 54; MA 20.3, p. 1150. 
1 occupy such talents more worthily. Our ballet is called Die Nachtwandlerin ${ }^{614}-1$

2 who through her sleepwalking is found by her fiancé in bed with a cavalier, from 2

3 which discord, sorrow and joy then ensue. 3

4 The new opera by Theodor Körner and J.P. Schmidt ${ }^{615}$ is called Alfred der 4

$5 \mathrm{Gro} \beta \mathrm{e}^{616}$ in the war against the Danes, the king loses his bride, but wins her back 5

6 again intact. The libretto may be a weak one, but the composer broadcasted his 6

7 own weakness so loudly, that I should gladly have gone to sleep, if the devil had 7

8 not led me into the midst of the batteries, for I was in the orchestra, having given 8

9 up my reserved seat to my daughter Rosamunde. [...] 9

16 [...] I think I told you that we had a performance of Haydn's Seasons, ${ }^{617}$ with 16 17 Thomson's words; this music ought to be esteemed [as] one of our lost treasures, 17 18 sung as it is by rustics, vine-dressers and tillers of the soil - countrified, yet with a 18 19 brilliancy of its own - so realistic that I am always transported by it to a condition of 19 20 innocence and perfect mental equilibrium. Two factions emerged in the rehearsals. 20 21 The special people didn't want to join in singing the 'Heida! Hopsa! Juche!' ${ }^{618}$ of 21 22 the grape harvest with the simple country folk. And bearing in mind the time, I was 22 23 inclined to leave these pieces out because, performed without enthusiasm, they 23 24 couldn't be received with enthusiasm. Now, since I didn't show any real aversion 24 25 to it, I have the satisfaction of knowing the best of the people on my side and the 25 26 others remained reasonable, since they were not treated as automatons, and are now 26 27 critical amongst themselves. The performance went down extraordinarily well ${ }^{19} 27$ 28 and now they want to hear the whole thing again. They can come to me about it. 28 29 I added an introduction to the text in order to give connoisseurs an overview, 29 30 which, as I hear, was appreciated. I am enclosing it here ${ }^{620}[\ldots] \quad 30$ Somnambule ou l'Arrivée d'un nouveau seigne
with music by Louis Joseph Ferdinand Hérold.

$36 \quad 615$ Johann Philipp Samuel Schmidt (1779-1853).

614 Therese, die Nachtwanderlin, ballet with mime by A. Titus, after the French $L a$ 32

37 The opera Alfred der Große, König von England was performed twice in Berlin: on

3728 November and 5 December 1830; see $A M Z 33$ (1831), no. 1, 5 January, column 13. 617 On 2 December; ZG 2 December 1830 and ZG 2 to 4 December 1830.

39618 No. 16, Choral song, 'Juhe, juhe! der Wein ist da!' (from 'Autumn').

40619 See Ludwig Rellstab's review in the Vossische Zeitung, no. 283, 4 Decemmber

41 1830; Spenersche Zeitung, no. 284, 6 December 1830, enclosure and AMZ 33 (1831), no. 3,

4219 January, column 42f.; MA 20.3, p. 1154-5.

$43 \quad 620$ In the libretto The Seasons. After Thomson. Set to Music by Joseph Haydn (Berlin 43

44 1830); Zelter signed the first three pages ' $Z$ '; the enclosure has not been handed down. In the 44 
525. Zelter 1

5 [...] A letter from Felix, dated Rome, 1 December, tells me of the Pope's death, ${ }^{621} 5$

6 which occurred the evening before at the Quirinal. ${ }^{622}$ That lad came into the world 6

7 at a happy hour. In Hungary he sees an Imperial head crowned, in Rome he finds a 7

8 Conclave, and Vesuvius is getting itself ready for a performance. In Rome I gave 8

9 him an introduction to the Maestro di Capella, del Sommo Pontefice, Baini, and to 9

10 the Abbate Santini. ${ }^{623}$ The latter, a musical antiquary and collector, writes to me, 10

11 'Oh, what a brilliant youth that is! With what pleasure do I call him my friend; 11

12 one may well say of him, as Scaliger used to say, when speaking of Pico della 12

13 Mirandola, 'He is a monster without vice.'

14 Santini has written an Italian version of Ramler's words to Graun's Passion 14

15 Music, and they write to him from Naples about it, 'All our connoisseurs nowadays 15

16 will listen to nothing else but the music of Graun and Handel; how true it is that the 16

17 truly beautiful can never be lost.' ${ }^{624}$

24 Felix, whose successful visit to Rome you report on, cannot but be favourably 24 25 received wherever he goes: such great gifts, so young, so charming! [...] 25

28 foreword Zelter comparison of Haydn's two oratorios, The Creation and Die Jahreszeiten, 28

29 is followed by a general appreciation of Haydn's work before concluding with a short 29

30 commentary on the musical programme for The Seasons. Zelter closes with a short note 30

31 justifying the reduced version of the oratorio, thereby subtly answering the dispute before 31 the Sing-Akademie's first performance of Haydn's oratorio: 'So we have also left out some 32 passages here in order not to run over time. May such licence be forgiven if for no other 33 621 In a letter written on 1 December 1830, Felix Mendelssohn describes his 34 impressions of Rome and the performances of the Capella del sommo pontifice (in the 36 papal chapel) and in the Sistine Chapel which Mendelssohn had visited four times. Apart 36 from that he reported, 'I have come directly from the Quirinal, where the Pope (Pius VIII) 37 died yesterday evening.'

623 Fortunato Santini (1778-1861) was one of the great nineteenth-century music 40 collectors. Through his translation of German religious works into Latin, he contributed 41 greatly to the distribution of the music of Handel, Graun and Bach throughout Italy. Today 42 his library is held by the Cathedral of the Bishopric. 
1 In the evenings Ottilie is reading me our correspondence. ${ }^{625}$ There is in both of 1

2 us a calm, constant, serious-passionate activity, always going in the same direction. 2

3 Outwardly little is asked, everyone goes his way and lets the rest happen. [...] And 3

4 now a pregnant little word in conclusion: Ottilie says that our correspondence is 4

5 more entertaining for the reader that the one with Schiller. What she means by this 5

6 and how she explains it you shall, if possible, hear some day soon. ${ }^{626} \quad 6$

7

8

9

527. Zelter

13 The day before yesterday I was again at the opera to hear Die Vestalin, ${ }^{627}$ which 13 14 was very well performed. The work itself is incredibly lightweight, and at the 14 15 same time provides a perfectly valid criterion for the current state of art in Europe; 15 16 for this opera is considered on every account as one of the better ones - a work 16 17 in the grand style. It is the most ungraceful bagatelle I can imagine. The audience 17 18 were delighted and the overture had to be repeated, which one may take as a sign 18 19 of the hopes which are entertained for the piece. 19

26 In rereading your letter, I again come across your view of Niebuhr's work in 26

27 relation to the individuality of the writer, ${ }^{628}$ and I enclose the programme with 27

28 the words of Handel's Te Deum which was performed here last week to show the 28

29 preface I wrote for the work. ${ }^{629}$ Strictly speaking, no one knows what a Te Deum 29

${ }^{625}$ Goethe's diary on 29 October 1830 records for the first time: 'With Ottilie later.

33 We began to read the Zelter correspondence'; WA III/12, p. 323.

$34 \quad 626$ Ottilie's comparison between Goethe's correspondence with Schiller and his 34

35 correspondence with Zelter was never communicated, despite Zelter's request; ZG 35

367 January 1831 .

$37 \quad 627$ Spontini's opera was performed for the first time in Berlin on 18 January 1831.

38 Wilhelmine Schröder-Devrient made a guest appearance as Julia on 5 January 1831; see

38 AMZ 33 (1831), no. 8, 23 February, column 122.

$39 \quad 628$ Niebuhr was a member of the Berliner Akademie der Wissenschaften; in this

40 capacity he held lectures in ancient history at the university until his departure to Rome in 411816.

42629 Das Dettingensche Tedeum von Georg Friedrich Handel. Voher: Hymnus zur Feier

43 des Confessionsfestes. Nach aufgegebenen Worten des 119ten Psalms von Eduard Grell.

44 Darauf: Das Göttliche. Hymnus von Goethe and Rungenhagen (Berlin, 1831), Ruppert, no. 44 
1 ought to be, although thousands have written more than one. Here I wanted to 1

2 explain how Handel treated it in this one case, namely as a German in England, 2

3 as a Lutheran German Christian, and as none other than Handel. Of course I have 3

4 been acquainted with the work for the last 50 years. 4

5 Rungenhagen set your poem 'Das Göttliche' to music. ${ }^{630} \mathrm{He}$ shouldn't have 5

6 bothered. The music is to be praised in itself: only the devil took the divine, which 6

7 is perhaps all he is interested in. $\quad 7$

14 [...] Your introduction to Handel's Te Deum is splendid and quite worthy of you. 14

15 That beloved contemporary audience of ours thinks that one must always serve up 15

16 fresh cakes hot from the pan. They have no idea that first one has to be educated 16

17 up to anything new or any really antique novelty. But how could they know this? 17

18 Why, they are always being born anew. [...]

Ottilie continues to read the correspondence to me in the evenings, where there 19

20 is the most delightful contrast of a man who lives, enjoys travels and is continually 20

21 active in the world as an artist with a friend who is more or less stationary, 21

22 contemplative, sacrificing the present, and devoting himself to the future.

23 The manuscript that you know is neatly written out, but it is full of particular 23

24 defects which we are finding and noting as we read through it. ${ }^{631}$ Professor Riemer 24

25 is taking on the future publication for a fair honorarium. In my lifetime I will try 25

26 to see the manuscript is cleaned up as far as possible and confer with him about it. 26

27 I can easily correct omissions and mistakes for which one would have to carry out 27

28 many futile investigations later on. [...] 28

2586. Zelter had not only written an extensive four-page preface but had also provided a 32 translation of the Dettinger Te Deum. Handel's Te Deum and the two hymns were performed 33 at a Sing-Akademie subscription concert on 13 January 1831.

630 Carl Friedrich Rungenhagen's hymn on Goethe's poem 'Das Göttliche' was 35 performed on 13 January 1831; see $A M Z 33$ (1831), no. 8, 23 February, column 123; MA 36 20.3, p. 1166.

631 There is an interesting passage about the future publication of the correspondence 38 in Goethe's will, section 6, paragraph 4: 'Correspondence with Professor Zelter in Berlin. 39 Of this we can say for the present, that after the death of both men, the [correspondence]
should be printed in full and offered for sale. One half of the profits is for my grandchildren, the other half to both daughters of my friend Zelter, Doris and Rosamunde, as yet unmarried. 41

42 I hereby decree that one half shall and must be paid to both [women] - or to their heirs - 42

43 since their father has granted me exclusive ownership of the correspondence under this 43

44 condition.' 
5 I have to thank you very much for the trouble you have taken to bring the 6 manuscript of our correspondence into respectable order for posterity. Although I

7 am not worried but am instead convinced that the topical subjects of the moment

8 which are suitable to communication by letters cannot appear to the world in the

9 same form, I am amazed by your work in editing such a copious correspondence, 10 for which I would not have the patience. It runs like an independent thread through 10 11 a portentous age. [...]

12 I am delighted that you praise my introduction to Handel's Te Deum, since it 12

13 was received very nicely here. Someone said, one knows what one is hearing when 13

14 one sees so many mouths open at the same time. If I think now how it has often 14

15 been for me, the wonderful secret play of characters in me, as on Chladni's glass 15

16 table, ${ }^{632}$ I know no more than anyone else and even from the writings of good old 16

17 Rochlitz on the Messiah ${ }^{633}$ one should conclude the wheel of fate is still spinning, 17

18 since the world, and he with it, have long been profited by it and continue to enjoy 18

19 their winnings. One mystifies oneself and that's the true name of the child. 19

26 [..] Now don't forget to send the letters from the previous year, 1830, as soon as 26

27 possible, so that they can be taken up in the series of folio volumes. A precaution 27

28 occurs to me. Your travel diaries brighten up the correspondence in places. ${ }^{634}$ You 28

29 have copies of them; ${ }^{635}$ hold on to them and keep them secret; and take care that 29

30 neither now nor in the future any copies will be made. The publishers are all the 30

31 more dangerous since they want to be considered honourable, even generous 31

32 people and always want to be in the right because no law prevails in this anarchy. 32

$33[\ldots]$

$36-632$ In 36

$37 \quad 632$ In his autobiography, which was published as an obituary in Cäcilia 6/24 (1827):

37 297ff, Chladni describes his discovery of his so-called 'sound-figures'; see MA 20.3, 38 p. 1169.

$39{ }_{633}$ Friedrich Rochlitz, 'Handels Messias' in Für Freude der Tonkunst, vol 1, 39

40 pp. 227-80.

41634 Zelter's travel diary written in letters of his journeys to Vienna, the Baltic Sea, 41

42 Herrnhut, Holland and Munich during the years 1819 to 1827.

43635 Goethe had copies made of Zelter's travel diaries, four of which are included in 43

44 this correspondence: Vienna (and Prague), Herrnhut, Holland and Munich. 44 
5 [...] The dear Mara, justifiably loved and admired by you, celebrates way up in 5

6 Thule, I think Reval, a very advanced birthday ${ }^{636}$. They want to arrange something 6

7 pleasant for her there. They have asked Hummel for music and through him, me 7

8 for something poetic. ${ }^{637}$ It was pleasant for me to remember that in 1771 , as an 8

9 excitable little student, I had furiously applauded Mademoiselle Schmeling. ${ }^{638}$ This 9

10 gave a good counter image and so a couple of verses were easily produced. ${ }^{639} 10$

11 Admittedly, with ingenious musical collaboration this lady could have been 11

12 given the most boundless joy of remembering, it if were to fit the first verse to the 12

13 [musical] motifs of Santa Elana al Calvario so celebrated at that time, through 13

14 which she would have been painfully yet charmingly drawn back to her youth. I 14

15 had already thought out the programme, but it remained closed in my breast. I don't 15

16 know what happened. I am sending off the two verses to you. Most likely they will 16

17 be revealed either from there or elsewhere; but I don't want to anticipate. 17

$\begin{array}{ll}18 & \text { What I have written so far can be sent as a way of receiving warm memories. } \\ 19 & 18\end{array}$

21
$2+2$

$21-1$
$-\quad 22$

636 The singer Gertrud Elizabeth Mara, née Schmeling, impoverished since 1822, had 27 returned to live in Reval, where she celebrated her 82nd birthday on 23 February 1831; see 28 AMZ 33 (1831), no. 24, 15 June, column 396.

637 See Goethe's diary on 17 January 1831: 'Privy Councillor von Müller soliciting 30 an occasional poem for Madam Mara. I wrote one before going to sleep since a happy 31 theme was found in the past'; WA III/13, pp. 12-13. The following day Goethe sent the 32 poem to Chancellor von Müller: 'The memory that in the course of my apprenticeship 33 years I belonged to the enthusiastic admirers of Mademoiselle Schmeling made it possible 34 for me to fulfil the request made of me. May the modest enclosure please distant friends - 35 Kapellmeister Hummel will be free in his musical treatment and will handle the verses as 36 he pleases.'

638 Goethe had attended a performance of Johann Adolf Hasse's oratorio Santa Elena 37 al Calvario given by Corona Schröter and Gertrud Elizabeth Schmeling in December 176738
(not 1771); he recalled the performance in his review of Rochlitz's book Für Freude der

40 Tonkunst in 1824: 'I was amazed by Mademoiselle Schmeling, at that time a developing 40 singer and, for us inexperienced boys, a highly-polished one. I can still recall the arias, 41

43 Calvariberg. 
56 February: Last Friday I was at Beethoven's Fidelio ${ }^{640}$ and wanted to describe the 6 charming, lucrative music to you, but when I went out, deep snow, water and ice

7 had gathered and I fell so heavily on my old back that suddenly it cast out every

8 thought that I had pieced together so well. The house was full (even without the

9 court) and if the opera is given again, you won't be allowed to miss it. [...]

11 have them printed. I would love to know them and would not let them out of 11

12 my hands. ${ }^{641}$ I myself am no longer so quick and certain of producing something 12

13 successful. With knowledge comes doubt. I have a number of works which started 13

14 out well. If I were in control of my good hours it wouldn't take much, and of 14

15 course that would be the ideal.

22 Yesterday a new opera by Ferdinand Ries $^{642}$ was given for the second time, with

23 the applause of his friends, myself included. The technical part is admirable; the 23

24 orchestra, though it worked hard, kept an artistic fete-day and covered itself with 24

25 glory. The piece is called Die Räuberbraut ${ }^{643}$ [...] Madame Schröder-Devrient ${ }^{644} 25$

26 made a very dainty bride, and her singing left nothing to be desired. In my 26

28640 Performance of Beethoven's opera on 4 February 1831 in the Königliches

29 Opernhaus with Wilhelmine Schröder-Devrient in the title role; see $A M Z 33$ (1831), no. 13, 29

3030 March, column 207.

$31 \quad 641$ A publication by Hummel has not been discovered. 31

$32 \quad 642$ Die Räuberbraut by Ferdinand Ries (libretto by Christian Wilhelm Häser) was

33 first performed in Berlin on 8 February 1831; it received three further performances on 11

34 and 20 February and 13 March 1831; see $A M Z 33$ (1831), no. 13, 30 March, columns 207-

35 209. Ferdinand Ries is the pupil of whom Beethoven said, 'He imitates me too much. His

36 works are learned, but they have no vitality or real genius in them'; he is best remembered

37 for his Biographical Notices of Ludwig van Beethoven, parts of which were translated into

38 English by Moscheles.

38643 In conversation with Felix Mendelssohn on 24 May 1830, Goethe made the

39 following judgement: 'Then the conversation embraced anything and everything; he

40 believed Die Räuberbraut by Ries contained everything which an artist needs today in

41 order to be a success - a robber, a bride - and then he criticized the prevalent feeling among

42 the younger generation who were so melancholic'; Felix Mendelssohn to his parents, 21 to

4324 May 1830, Reisebriefe (1862), p. 4. 
1 judgement, she is superior to her illustrious mother, inasmuch as she combines this 1

2 gift with smooth acting, dignity, and womanliness [...] 2

9 To accompany the enclosure I will only add that our music from the day before 9 10 yesterday ${ }^{645}$ was launched smoothly enough and met with approval. ${ }^{646}$ That surely 10 11 means something, with masses gathered together of more than two hundred 11

12 Berliners, one from every corner of the town, with and without trousers, since it is 12

13 impossible to hold even one rehearsal of an entire work. The completely different 13

14 dependencies of the performers, solo singers and instrumentalists from family and 14

15 servant relationships that leave no time at present, become like a lottery ticket, 15

16 which if it comes out and wins, helps the old director to a sleepless but enjoyable 16

17 night. Only afterwards he realizes he doesn't understand, since we all don't know 17

18 how we do it.

Our Scotsman Müller ${ }^{647}$ still didn't want to perform. However, yesterday he 19 20 had to play the viola to a mass by old Bach. ${ }^{648} \mathrm{He}$ thought it was strange but 20

21 gradually he got the hang of it!

[...] As I can refuse you nothing, the stanzas on Mara's festival are enclosed. ${ }^{649}$ I 28 do not know whether Hummel has set them. ${ }^{650}$ According to my idea, the first verse 29 
1 would have to be reminiscent of Hasse's Santa Elana al Calvario; the second can 1

2 be as original and modern as one wants.

3 And now for something really commendable! I have now gradually come to

4 realize that I must become accustomed to living without my son and the enforced

5 attempt at acting as head of the family again is not succeeding at all badly; ${ }^{651}$ but

6 that the echo of that sincere nature may not subside so suddenly for his patrons, I

7 have recorded, primarily for his Italian friends, a very short sketch of his travels, ${ }^{652}$

8 a copy of which I shall send you some day soon. ${ }^{653}$ There is always something: 8

9 his diaries are certainly most interesting, ${ }^{654}$ but due to the recurring evidence of 9

10 those traits to which you were no stranger, they cannot be made public in their own 10

11 energetic and penetrating style. They would be good reading for us some day, if 11

12 things could be so happily arranged that you could visit us again; the swan would 12

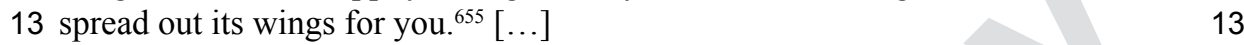

15 Enclosure: To Madamoiselle Schmeling. After a Performance of Hasse's Sta Elan 15

16 al Calvario. Leipzig, 1771

17

18 With clearest voice, with cheerful heart

28 Weimar, 1831.

$31 \quad 651$ This theme recurs in Goethe's letters around this time; see GZ 21 November 183031

32 and also Goethe's letter to Count Sternberg on 4 January 1831; WA IV/48, pp .69-71.

33652 Enclosed in Goethe's letter to Kestner on 27 December 1830; Goethe picked up 34 the report of August's Italian journey in a draft letter to Mylius on 3 February 1831; WA 35 IV/48, pp. 107-10; he also sent a copy to Zelter.

$36 \quad 653$ GZ 23 February 1831. diaries have reached us continually and made us very happy.' In the same letter he quotes a report in an English newspaper: 'Goethe, Father and Son - the son of the great German poet,

39 Goethe, the Chamberlain Goethe, has just drawn up a diary of his journey through Italy, which

40 Goethe, the father, is about to publish', which Goethe commented on as follows, 'the above

41 (...) we can let stand; it is my wish that you would edit your diaries and would bring them to

42 completion; it would make a pleasant occupation for you'; WA IV/48, p. 275.

43655 A figurative allusion to the inn, Zum weißen Schwan, where Zelter often stayed on 44 his visits to the poet; GZ 17 June 1826 and GZ 18 February 1827. 
16 My son was travelling to recover his health. ${ }^{656}$ His first letters from beyond the 16 $17 \mathrm{Alps}^{657}$ were a great comfort and a delight to me; he had seen and visited with real, 17 18 living sympathy Milan and Lombardy with its fertile fields and glorious lakes, ${ }^{658} 18$ returning there after he had been to Venice. The unbroken narrative of his diary 19

20 bore witness to his open, unclouded views of nature and of art, and he was happy 20

21 in applying and increasing the wide-ranging knowledge he had formerly acquired. 21

22 So it continued up to Genoa where, to his delight, he met up with an old friend 22

23 Sterling, ${ }^{659}$ through whom I had been made acquainted with Lord Byron. At that 23

656 August von Goethe left Weimar on 22 April 1830, accompanied by Eckermann; 27 in his first letter to Ottilie from Milan on 13 May he gave a frank account of his desolate, 28

29 physical and psychological condition: 'I was so ill leaving Weimar that I didn't believe I 29

30 would reach Frankfurt alive (...) it was a choice between an outing (...) to the cemetery or 30

31 into the wide world.' In his letters to August, Goethe himself expressed the hope 'that your 31

32 physical and mental health will greatly improve'; 5 July 1830, WA IV/47, pp. 130-32; after 32 the news of August von Goethe's death reached Weimar, Goethe's comment spread that he 33 had already despaired for his son when August left Weimar; Gespräche, vol. III/2, p. 676. 34

657 On 11 May following his arrival in Milan on the evening of 10 May; from Milan 35 on 30 May and 2 June; from Venice on 10 and 21 June.

658 Chancellor von Müller reported on 8 June 1831, 'communication of the travel route 36

43 with Ottilie von Goethe in 1824, looked after August following his accident in La Spezia 43 
1 point he parted with Dr Eckermann, who had accompanied him so far and now 1 2 returned to Germany. ${ }^{660}$

3 The fracture of his collarbone, which unhappily occurred when he was on his 3

4 way from Genoa to Spezzia, ${ }^{661}$ kept him there nearly four weeks, but even this 4

5 accident, and a skin disease that attacked him at the same time and was also very 5

6 troublesome in the great heat, he endured manfully and with good humour. $\mathrm{He} 6$

7 continued writing his diary and did not leave the place until he had seen all the 7

8 surrounding countryside and even visited the quarantine buildings. ${ }^{662} \mathrm{He}$ knew 8

9 how to make the very best of his short stay in Carrara ${ }^{663}$ and his longer visit to 9

10 Florence, ${ }^{664}$ always paying logical attention to things. His diary might serve as a 10

11 guide to any like-minded person. 11

12 After leaving Livorno by steamboat and encountering a heavy storm, he landed 12

13 in Naples on a day of festivities. There he found the able artist Zahn, ${ }^{665}$ who 13

14 developed a warm relationship with us during his stay in Germany. He received 14

15

$16 \quad 660$ Eckermann reported from Genoa on 12 September 1830, 'It was Sunday morning

1725 July at 4 a.m. when we embraced each other in farewell on the streets of Genoa.' For

18 Eckermann's reasons for cutting short the journey, completely explained only to Goethe

19 himself; see Gespräche, pp. 496-509. Eduard Castle records the most important travel

20 dates (also for August's winter journey) in the volume of commentary for his edition of the

21 Gespräche (Berlin, 1916), p. $202 \mathrm{f}$.

22661 On 27 July August wrote to Goethe from La Spezia, 'Monday 26 July we left at

232 a.m. in order to benefit from the coolness; I dozed a little, and then [the carriage] overturned

24 and unfortunately I felt that I had broken my left collar bone (...) naturally I developed a fever from the wound and I have to be patient'; WA IV/47, pp. 204-205.

662 There were isolation wards for the protection from epidemics in Italian ports

26 and in the most important borders even in the sixteenth century and also in La Spezia, in

27 one of Italy's largest natural ports; see Goethe's father's account about his internment in

28 Palmanova in the preface to his Viaggio per Italia (1740; reproduced as Johann Caspar

29 Goethe, Reise durch Italien im Jahre 1740, trans. Albert Meier (Munich: Deutscher

30 Taschenbuch Verlag, 1986, reprint 1999) and Ludwig Schudt, Italienreisende im 17. und

31 18. Jahrhundert (Vienna \& Munich, 1958), p. 159. The quarantine practice, which was

32 already reduced in the nineteenth century, was revived again in La Spezia in 1829 when the

33 Prussian General Carl von Müffling was interned there on his return journey after the peace

34 talks at Adrianopolis, which was a reason for August von Goethe to explore the area; see

35 Goethe's letter to Ernst August von Gersdorff, 3 September 1830, WA IV/47, pp .451-2.

$36 \quad 663$ On 19 August.

665 The archaeologist Wilhelm Zahn, professor at the Berliner Kunstakademie from
38 , 1829 , was in Weimar from 7 to 15 September after one of his many Italian journeys and had brought Goethe drawings and copies of the excavations in Pompeii. Goethe had remained

40 in correspondence with him since that time, occupied himself with this information and

41 following Zahn's most recent visit (from 13 to 16 March 1830), Goethe published an

42 extensive review of the wall decorations, Die schönsten Ornamente und merkwürdigsten

43 Gemälde aus Pompeii, Herculaneum and Stabiae; MA 18.2, p. 297. August met Zahn in

44 Pompeii on 7 October at the uncovering of a villa which he named Casa di Goethe after 
$1 \mathrm{him}$ in the most friendly way and now proved himself to be a most desirable guide 1

2 and assistant.

3 His letters from this place, however, I must confess did not altogether satisfy 3

$4 \mathrm{me}$; they showed me a certain haste, an unhealthy state of exaltation, although, 4

5 with a view to recording his careful observations, he retained a certain equilibrium 5

6 in himself. He felt quite at home in Pompeii; his thoughts, observations, and 6

7 activities in that city show that he was cheerful, even in high spirits. 7

8 A quick journey to Rome ${ }^{666}$ did not calm his already overwrought disposition, 8

9 and he only seems to have enjoyed, with a kind a feverish haste, the honourable 9

10 and friendly reception given him by the German people and distinguished artists 10

11 residing here. ${ }^{667}$ After a few days he was carried to his rest near the Pyramid of 11

12 Cestius, ${ }^{668}$ in the place his father used to long for in poetic dreams before he was 12

13 born. ${ }^{69}$ Perhaps in future days his diaries will give us an opportunity of reviving 13

667 Named in Goethe's letter of thanks to Georg August Christian Kestner on 2724 December 1830: the Prussian diplomat and archaeologist Carl von Bunsen, the Saxon legate, 25 painter and art historian Ernst Zacharias Platner, the Danish sculptor Bertel Thorvaldsen 26 and the Weimar painter Friedrich Preller. In his letter to Kestner on 16 November 1830, 26 Chancellor von Müller extended Goethe's thanks to the painter Rudoph Meyer from 27 Dresden 'for heartfelt sympathy and care'.

668 On the night of 26/27 October 1830 in Kestner's house (Via di Porta Pinciana 17) 29 August von Goethe died of a stroke as the result of pox which didn't break out visibly; 30 see Kestner's letter to Weimar on 28 October, following the post-mortem; GJb 1956, 31 pp. 180-89. August was buried on 29 October in the Protestant cemetery beside the Cestius 32

33 Pyramid in Rome. The grave is marked with the words: 'Son of Goethe, preceding the 33 father, died at the age of 40/1830' and with a bronze relief by Thorvaldsen (a circular relief 34 containing a profile of August's head). to the underworld'; see also Goethe's letter to Fritz von Stein from Rome on 16 February 38 1788: 'You wrote recently of the grave of Miss Gore in Rome. Some evenings ago when 39

40 I was melancholic I drew mine by Cestius's pyramid'; see Goethe's drawings, Gerhard 40

40 Femmel (ed.), Corpus der Goethezeichnungen vols 1-7 (Leipzig: E.A. Seemann, 1958- 40
41 73; Munich, reprint 1972-81). See also his second Roman visit in the Italian journey on 41

4222 February, where he writes, 'If in the meantime I am laid to rest next to the pyramid, these 42

43 two poems ['Hans Sachsens poetische Sendung' and 'Auf Miedings Tod'] can serve as my 43

44 biographical data and funeral oration.' 
1 and recommending to sympathetic friends the memory of this special young 1 $2 \operatorname{man}^{670}$ And so, over graves and onwards!

538. Zelter

11 Thank you for sending those two glorious little poems, which, across a gap of 11

1260 years, carry a double meaning, revealing two active living individuals. Our 12

13 lady is about a year younger than you and throughout her long career as an artist 13

14 has retained her special characteristics, independence and individuality. She wrote 14

15 to me two years ago to tell me that she was thinking of writing her biography, as 15

16 people knew one side of her and by no means the right side - which we now await. 16

17 To the very end she proved capable of nobly ignoring the original source of her 17

18 many sorrows, and that was her husband, the most promiscuous of all Greeks. 18

19 She came to us from Leipzig, as Mdlle Schmeling, in the year 1771 and made 19

20 her debut in Hasse's Piramo e Tisbo with Concialini, to the admiration of the 20

21 king, who would hardly listen to her before, because presumably her paternal 21

22 name sounded so typically German to him. From that time until 1773 she sang 22

23 here in the festival operas: Britannico, Ifigenia, Merope. Then she fell in love with 23

24 Mara, a violoncello player and Ganymed to Prince Henry (the brother of the king), 24

25 and as neither of these gentlemen would permit a marriage between Berlin and 25

26 Rheinsberg, the lovers eloped without permission. They were caught and Mara 26

27 was transferred to a regiment at Cüstrin, where he was obliged to play a fife in the 27

28 band. Mdlle Schmeling was reappointed for life. Mara came back to Berlin and 28

29 was allowed to marry her. From December 1773 onwards she sang in the following 29

30 festival operas as Madame Mara: 1. Arminio; 2. Demofoonte; 3. Europa galante; 30

31 4. Parthenope; 5. Attilio Regolo; 6. Orfeo; 7. Angelica e Medoro; 8. Cleofide; 9. 31

32 Artemisia; 10. Rodelinda.

33 In 1779 there was no festival on account of the Bavarian War of Succession 33

34 and in the following year 1780, after a relaunch of the opera Rodelinda, man and 34

35 wife secretly took flight for the second time. Once again they were taken into 35

36 custody, but the king ordered them to be let go because, even at a high price to 36

37 himself, he wanted to dismiss the husband. We have written records of this, but our 37

38 friend declines to recognize it and it is quite conceivable that she could complain 38

40670 August's travel record, collected in two folio-fascicles, entitled 'August von

41 Goethe. Tagebuch einer Reise nach Süden (1830)' and 'Separat-Faszikel zu dem Tagebuch

42 auf einer Reise Augusts von Goethe nach Süden (1830)' (GSA 28/354), were published by

43 Gabriele Radecke and Andreas Bayer (eds), August von Goethes Tagebuch auf einer Reise

44 nach Süden 1830 (Munich: Carl Hanser Verlag, 1999, r. dtv 2003). 
1 of force. The widespread acclaim she received began with her appearance in 1

2 the opera of Britannico as Agrippina, where she sang the aria 'Mi paventi il 2

3 figlio indegno!', addressing someone behind the scenes with a voice of thunder 3

4 transposed into maternal femininity. I cried floods of bitter tears every time I heard 4

5 her perform. The aria is a true bravura aria of those days; it was as if a thousand 5

6 nightingales cried for vengeance. In all tragic parts she looked a foot taller. I have 6

7 heard nothing grander than her Queen Rodelinda. Connoisseurs blamed her for 7

8 being too composed in passionate roles. 'What!' she exclaimed, 'am I to sing 8

9 with my hands and legs? I am a singer; what I can't do with my voice, I will not 9

10 perform.' The relations between such a person and her husband were a subject of 10

11 general concern. ${ }^{671}[\ldots]$

I don't say this for the pleasure of being unkind, although Mara was no great 12

13 friend of mine, but in defence of the great king, who got as little praise for this as 13

14 for the Müller-Arnold trial, since one does not praise the right thing, and, indeed, 14

15 would rather not know what the right thing is. There was a good deal besides: 15

16 beautiful Rheinsberg, close to the Mecklenburg country, was a nest of smugglers, 16

17 whom, since they were under the favourite's protection, one who valued his life 17

18 dared to disturb. However, the king knew exactly where the smuggler's thread 18

19 began, which through the Court carriages of Rheinsberg it unraveled itself as far 19

20 as Berlin. Mara ended his days here in complete depravity, although his wife never 20

21 really left him. I once confessed to her my admiration of her noble behaviour 21

22 towards him, whereupon she remarked, 'But you must own, he was the most 22

23 handsome man you could behold.' Reichardt, too, had constant arguments with him 23

24 because Mara wanted to get involved in the Königliche Kapelle. Once the king let 24

25 him sleep all through the entire festival in the guardhouse on the plank beds, where 25

26 the ordinary soldiers were allowed to have their fun with him. That made Reichardt 26

27 feel in a strong position, and now as a young patronized Kapellmeister he wrote 27

28 many letters of complaint to the king about the senior musicians. Thereupon the 28

29 king said, 'I thought I had freed myself from the opera but now I have the same 29

30 problem as well as another fool.' Had Reichardt thrown Mara into the river Spree, 30

31 he would have been punished, but it would have been better for him in the end. 31

32 Such was the king whom he had vexed. I have begun to gossip. Forgive me, these 32

33 are common topics, but I cannot forget them [...]

34 I do not know whether I told you that it was the eldest Schmeling who 34

35 denounced me as a composer to my father. In the evening my father used to join 35

36 a select circle of citizens -clergymen, musicians, and so on - to converse over 36

37 beer and tobacco. On one occasion, when they were reading the newspaper, they 37

38 came across the announcement for one of my compositions - I think it was the 38

39 Pianoforte Variations on an air of Cherubino's in Beaumarchais' Figaro. My father 39

40 said it was the first time he had ever found mention of his own name unconnected 40

41 with himself, at which point Schmeling replied, 'It is your son, too, whom I know.' 41

42

43

671 The story of Herr Mara's refusal to play which follows is already related in ZG 2043

44 to 23 March 1824. 
1 The following day at dinner my father asked me what that meant and whether 1

2 I knew the man. 'Oh, yes,' I answered, 'and you, dear father, also know him.' 2

3 'Then it is you they are acclaiming. Take care that they praise your drawing and 3

4 geometry', which as far as I know, never happened. 4

5 It would surprise me if Hummel is familiar with Hasse's Santa Elana al 5

6 Calvario. ${ }^{672}$ These spiritual dramas (which gave rise to the opera) are now 6

7 overshadowed by the cantata. The cantata belongs to chamber music but the 7

8 oratorio, even if it is not part of the liturgy, belongs to the church, like the musical 8

9 vespers and so on. Hasse composed two settings of this oratorio by Metastasio - 9

10 one for Dresden and the second for Vienna. Possibly what you heard in Leipzig in 10

111771 was the first setting. I was lucky enough to come across the arrangement for 11

12 Vienna just as you discovered your [Annibale] Caracci ${ }^{673}$; I got it from distinguished 12

13 connoisseurs, for people imagine one is better than the other, because it is the 13

14 other. Hasse wrote about a hundred operas, if not more, quite apart from his sacred 14

15 compositions. Each of his works contains powerful passages, such as only a German 15

16 genius educated in the better times of Italy could compose. In spirit, energy, grace 16

17 and productivity he surpassed people such as Leo, Durante, Vinci, and Pergolosi, 17

18 as well as the master, Alexander Scarlatti, whom he acclaimed. If you cast aside 18

19 the Italian mannerisms universally adopted in those days, you have an original 19

20 work in all its German power and glory. Besides that, he was a universal favourite, 20

21 so that, having full confidence, both in the world and in himself, he could give the 21

22 world what it wished and at the same time slip in what is really his own; the result 22

23 being that, too easily accepted, he is not properly appreciated himself [...] 23

24 What you write about our August is lovely for me to read, for in answer to 24

25 repeated questions, I boldly ventured, as is my wont, to give the same answer, 25

26 founded on your earlier letters, and daily and yearly records; Felix's letters from 26

27 home, too, agree beautifully with your account. ${ }^{674}$ That fine fellow has always given 27

28 me pleasure. Art goes on crutches in Italy. Outsiders dominate it intentionally or 28

29 unintentionally; still the Italians are industrious and if they stay at sea, there will 29

30 be good sailing weather again. [...]

31 Our Scotsman Müller keeps me busy. First I must prepare myself in the basics. 31

32 He has already composed a large sonata and other such works but knows neither the 32

$33 \mathrm{ABC}$ nor the ten commandments of music, and since he wants to, we have almost 33

34 started from the beginning and he is always surprised at the basics. However, he 34

35 doesn't play badly, is with me daily and appears to be at ease with my family. 35

36 Since there is music here every day and he lives relatively close by, it is also easy 36

37

$38 \quad 672$ This refers to Goethe's idea that Hummel might use a motif from Hasse's oratorio

39 Santa Elena al Calvario in Hummel's setting of stanza one of Goethe's occasional poem for

40 Gertrud Elizabeth Mara, to evoke the memory of the performance in Leipzig in 1767 which

41 Goethe's verse commemorates.

$42 \quad 673$ Annibale Caracci (1560-1609). 42

$43 \quad 674$ Zelter is referring to Goethe's Italienische Reise; a letter from Felix to Zelter from 43

44 Rome from January or February 1831 has not been handed down. 44 
1 enough for him. I will close for now; I hear my students coming. [...] At midday I 1

2 will be with Prince Radziwill, who is probably preoccupied with his Faust. 2

3

4

5

6

9 [...] Commend me to His Highness Prince Radziwill most warmly. ${ }^{675}$ Do let 9

10 me know also whether Faust gradually proves to be more harmonious in these 10

11 discordant times. ${ }^{676}[\ldots]$

539. Goethe

Weimar, 9 March 18317

12

18 [...] Princess Amalia once let me see her collection of music manuscripts ${ }^{677}$ - the 18

19 titles - through a glass cabinet. Then she took out a work, held it in her hands, 19

20 turned over the pages and let me look through it. As I took hold of it, I took the 20

21 folio volume out of her hands. She stepped back and made eyes as big as carriage 21

22 wheels: they were the eyes of her great brother. If I had already known Homer at 22

23 the time, she would have been my oxen-eyed goddess. In short, whoever wanted 23

24 to learn something here at that time was not allowed if he refused to clean stalls, 24

25 to wait on children and to chew the rinds which the Lords were not able to bite. 25

26 If I look at the striving of the contemporary young art world which, with all its 26

27 money and facilities, only political jokes are produced in turbulent times - which 27

28 the Sultan, the prince of all believers and Rothschild, the believer of all princes 28

29 are - there is little hope of the precious collection having an educational function 29

30 for our time.

31 Prince Radziwill's Faust moves forward slowly. [... I I want to go quietly about 31

32 my Easter music and see what I can do well with my people. Let time bring what 32

33 it has and what it costs must be paid, and with that - it is not much but enough for 33

34 today. 34

675 Radziwill had enquired about the latest edition of Diderot's works, presumably 36 Mémoires, correspondance et ouvrages inédits de Diderot, publiés d'après les manuscripts confiés, en mourant, par l'auteur a Grimm, which appeared in 1830 and 1831 but did not 38
contain Diderot's Neveu de Rameau.

41677 For a description of the music collection of Princess Anna Amalia of Prussia; see 41

42 Eva Renate Blechschmidt, Die Amalienbibliothek. Musikbibliothek der Prinzessin Anna 42

43 Amalie von Preußen (1723-1787). Historische Einordnung und Katalog mit Hinweisen auf 43

44 die Schreiber der Handschriften (Berlin: Berlin Studien zur Musikwissenschaft, 1965). 
5 First of all I must tell you that I have received a delightful, detailed letter from Felix, 6 dated Rome, 5 March, which portrays a clear picture of that exceptional young 7 man. ${ }^{678}$ His parents and friends in Berlin will no doubt receive similar accounts,

8 reported with the same controlled freedom. There is nothing to be concerned about

9 there; the fine swimming-jacket of his talent will carry him safely through the 10 waves and breakers of the dreaded barbarism.

11 Now, you will remember well that I have always passionately adopted the 11 12 cause of the minor third, ${ }^{679}$ and was angry that you theoretical music fellows 12 13 would not allow it to be a given of nature. Of course a string made of gut or wire 13 14 is not so precious that nature should exclusively confide her harmonies to it alone. 14 15 Man is worth more and nature has awarded him the minor third to enable him to 15 16 express an undefinable yearning with intimate pleasure. Man belongs to nature, 16 17 and he is the one who can take up into himself, control and modify the most subtle 17 18 connections of all the elementary phenomena. Chemists need the animal organism 18 19 as a reagent and shall we continue to hold onto mechanically definable relations 19 20 of sound, while we are driving the noblest of gifts out of nature into the realm 20 21 of arbitrary and artificial laws? Forgive me. My interest in the subject has been 21 22 excited lately and above all I would like to let you know where I wilfully remain 22 23 and why $[\ldots] \quad 23$

30 Spontini, who is singing your praises, let me know immediately that you are in 30 31 good form. He is going to send you his Athéniennes; ${ }^{680}$ you have promised him 31 describes the impression which the plastic arts - especially Titian - made on him; he also records the election of the pope and the carnival which followed immediately after it but was suppressed by military for fear of revolutionary activies in the wake of the Paris July revolution (GJb 12, 1891, pp. 85-93. The arrival of Felix's letter is recorded in Goethe's diary on 22 March 1831; WA III/3, pp.50-51; on the same day Eckermann records Goethe reading Felix's letter to him and paraphrases the contents; Eckermann, p. 503.

$40 \quad 679$ GZ 22 June 1808. 40

41680 On the occasion of Spontini's third visit to Weimar, Goethe recorded in his diary: 41

42 'Coming from Paris, Spontini reports on his new opera which he is planning with Jouy. 42

43 Promised to send the libretto'; Spontini sent Goethe Jouy's libretto - through Doris Zelter - 43

44 for the planned opera Les Athéniennes at the beginning of January 1832. 
1 good advice, which I hope will meet with an equally good reception. My Easter 1

2 performances $^{681}$ are behind me and it is curious that I know nothing at all to write 2

3 in a time when the world is in such flux and many must be in the same position. 3

4 [...] My Scotsman, Müller, ${ }^{62}$ is a good, true soul and very industrious because I 4

5 have him working flat out. He gradually sees the virtuoso phenomenon for what 5

6 it is and is working at becoming a very thorough teacher. [...] he is often in my 6

7 house and so he can visit freely all the good concerts. $\quad 7$

8 [...] I have heard Beethoven's Fidelio again, with great pleasure. ${ }^{63}$ The 8

9 composer has been admirably successful, precisely in those parts where the poem 9

10 is far too weak; he has breathed such life into one sad, dreary scene in particular, 10

11 that I marvel again and again when I hear it. This is the advantage that distinguishes 11

12 genius: it insults and reconciles, it wounds and heals; one must go along with it; 12

13 there is no use stopping and loitering. 13

14

15

20 Recently I attended a performance of Der Gott und die Bajadere, a new opera 20 21 by Scribe, with music, songs and ballet by Auber ${ }^{684}[\ldots]$ The music is not to be 21 22 despised, and contains many good passages though it is much criticized, and so 22 23 am I, for trying to discover a good thread which runs through it. On the other hand, 23 24 Madame Romain, ${ }^{685}$ the Bajadere elect, was, despite some disapproval, incessantly 24 25 applauded. She bared her not altogether attractive body for groping hands. 25

26 Your enthusiasm in defending the minor third is admirable. ${ }^{686}$ At some point I 26 27 must have expressed myself ineptly if not incorrectly. The minor third is contained 27

681 Bach's St Matthew Passion was performed by the Sing-Akademie on Palm Sunday, 30 27 March 1831 and Graun's Der Tod Jesu was performed on Good Friday, 1 April 1831; see 31 AMZ 33 (1831), no 17, 27 April, column 280f.

684 Opera with ballet and mime by Daniel François Espirit Auber (libretto by Eugène 35 Scribe, German adaptation by Karl August von Lichtenstein); Berlin premiere on 8 April 36 1831; see AMZ 33 (1831), no. 22, 1 June, columns 359-61. Whether Zelter attended the 37 premiere or the second performance on 12 April is unclear from this letter. 38 685 Angélique Robert née Mees-Saint Romain danced the role of Zoloé, one of the 39 three Bajaderes.

686 For the following very condensed and unclear summary of the case of the minor 41

42 third, Zelter gives various derivative ideas which had been discussed in his day: 1. The 42

43 minor third can appear as the upper third of the major chord between the 5 th and 6 th partials 43

44 of the overtone series. The term 'mediant' is used here in a broad sense to indicate the third 44 
1 even in the upper part of the harmonic triad, although not as the third of the

2 fundamental tone but rather [as the third] of the mediant. Against this the minor

3 third as such lives and sounds along in the fifth below ${ }^{687}$ of the harmonic triad,

4 from which it can be deduced that nature itself demands that the minor key be in

5 command and that the triad with a major third [with a minor third above it] is the

6 dominant harmony, the true leading chord for the minor key. That the lowest note

7 of a triad lies in the middle and above it that of the major third, while under it the

8 minor third sounds along ${ }^{68}$ was observed by Rameau and became the basis of his

9 theory of [musical] sound, which admittedly did not go unchallenged. Meanwhile

10 we must all follow nature, whether we want to or not.

11 Your honest, sympathetic interest in my music is ever present with me, so that 11

12 I think of you as one of our audience, especially when everything is well rehearsed 12

13 and comes off well. Our late cathedral organist, Schale, ${ }^{689}$ Graun's most devoted 13

14 worshipper, told me as far back as 36 years ago, that he wished his departed friend, 14

15 Graun, could have heard our performances of his music. I need not feel ashamed of 15

17 of the tonic key, which in the harmonic series does not produce a minor third. 2 . In the

18 fictitious 'undertone' series, which was not derived from Rameau's ideas but developed

19 through contemporary discussions, the minor chord is symmetrical to the major chord of the

20 overtone series [if you consider the major chord as rising and the minor chord as descending

21 from the same note. Starting from the same note, 'C', for example, the major chord would

22 ascend by a major third (C-E) followed by a minor third $(\mathrm{E}-\mathrm{G})$ giving the chord of

$23 \mathrm{C}$ major, whereas the minor chord would descend by a major third (C-A flat) followed by

24 a minor third (A flat-F) giving the chord of F minor]. Since the sense of cadence is given

25 by the descending fifth [in the bass], the major triad of the overtone series would be on

25 the fifth degree of the minor key. 3 . The contradictory remark that 'the lowest note of a

26 triad lies in the middle' presumably arises from the double derivation of the minor chord

27 from the keynote in the middle, which is, in this configuration, the source of the major

28 chord (rising) and the minor chord (descending). These three derivations have their roots

29 in Rameau, though not only in his groundbreaking theory of sound, Traité d l'harmonie

30 réduite à ses principes naturels (Paris, 1722). It is debatable whether or not Zelter knew this

31 work in the original. His brief summary points to d'Alembert's synopsis of Rameau's ideas

32 in Systematische Einleitung in die Musikalische Setzkunst nach den Lehrsätzen des Herrn

33 Rameau which had been translated into German by Friedrich Wilhelm Marpurg (Leipzig:

34 Breitkopf, 1757) and which had been responsible for the dissemination of Rameau's ideas 35 throughout Germany.

$36 \quad 687$ Zelter probably means that when the major triad is considered from the top down,

36 for example in a C major triad read as G, E, C, the minor third G to E would come first and

37 consequently be in command.

$38 \quad 688$ Zelter appears to mean that the fundamental of the harmonic series that is related

39 to the triad is in the middle, for example $\mathrm{C}$ in the middle, with $\mathrm{E}$ above (a major third

40 higher) and A below (a minor third lower).

41689 Christian Friedrich Schale (1713-1800), composer, cellist, member of the

42 Königliche Kapelle in Berlin from 1763 and cathedral organist; Zelter mentions him in

43 his autobiography; see Schottländer, Carl Friedrich Zelters Darstellungen seines Lebens, 44 p. $110 \mathrm{f}$. 
1 that, when I have already earned nearly twenty thousand thalers from this work, ${ }^{690} 1$

2 which have been gobbled up. Who knows how else I would have been forced to 2

3 earn the money? [...] 3

4 Yesterday I visited Prince Radziwill, who warmly returns your greetings. [...] 4

5 Dr Seebeck has sent me your two poems for the birthday celebration of our old 5

6 friend Mara; ${ }^{691}$ they were printed in Reval with another verse by a local poet. I 6

7 suppose you have received a copy. $\quad 7$

14 The good Dr Müller from Bremen, who in 1814 introduced us to his dear little 14

15 daughter, who you wanted to pair off with one of our theologians, has just sent me 15

16 his Einleitungen in die Wissenschaft der Tonkunst ${ }^{692}$ in two sizable octavo volumes 16

17 and complains bitterly that, despite his request, I shared nothing historical with 17

18 him about my artistic life. Obviously I should have answered him. The truth is that 18

19 I forgot to and now when I see his book I don't regret it, since I must consider his 19

20 introduction a shambles. He finds the current state of music to be of the highest 20

21 standards. His knowledge of the history of music is inept and his criticisms risible: 21

22 salon gossip that we hear everyday after sitting through an opera or concert. The 22

23 men he sets store by are Rochlitz, the two Webers, ${ }^{693}$ Nägeli, ${ }^{694}$ and all those who 23

24 have a lot to say. But it is a book for which I will always have a certain respect 24

25 because I am not capable of writing such a book. Probably he has sent it to you and 25

26 so you yourself might like to look into it. ${ }^{695}$

27 Yesterday we heard an extraordinarily good performance here of Beethoven's 27

28 oratorio Christus am Ölberge, conducted by Moeser. ${ }^{696}$ The work appears to be 28

690 Graun's Passion Der Tod Jesu. 33

691 A letter from Thomas Johann Seebeck to Zelter has not been handed down; the 34 poems were published for the first time in WA I 5/2, p. 190.

692 A letter from the music writer Wilhelm Christian Müller has not been handed 36 down; the enclosed work is Ästhetisch-historische Einleitungen in die Wissenschaft der 37 Tonkunst. Versuch einer Ästhetik der Tonkunst (2 vols, Leipzig, 1830). 38 693 Jacob Gottfried Weber (1779-1839) and probably Friedrich Dionys Weber (1766- 39 1842), both of whom were known for their music theoretical works. 40 694 Hans Georg Nägeli (1773-1836), Swiss composer and music educationalist. $\quad 41$ 695 Müller's book is not in Goethe's library. 42 696 The work was performed on 18 April 1831 as part of a Beethoven (memorial) 43 festival in the hall of the English house organized by Carl Moeser. 
1 a fragment and it seems as if the composer had adapted the text ${ }^{697}$ for his own 1

2 purpose. Here is a sample: $\quad 2$

4 1. In the introduction, a deep, sorrowful, heartfelt prayer of a soul in the keen agony 4

5 of a fresh grief gradually emerges. The full orchestra is like an overflowing

6 heart, a pulse of superhuman power. I was entranced. After the introduction,

7 Christ sings (upon the Mount of Olives):

8

$9 \quad$ Jehovah, you my Father, $\mathrm{O}$ send -

10 Comfort, power, and strength to me! 10

11 It approaches now, the hour of my sufferings, 11

12 Chosen by me already, before the world 12

13 At your behest, from Chaos did emerge, and so on. 13

$14 \quad 14$

15 The underlined words, skillfully connected by tremendous artistry, emerge as 15

16 strong picturesque motifs - something like an exercise in drawing, when between 16

17 five or more given points chosen at random a beautiful form, or group, has to be 17

18 limned by the hand of a master. The nonsense contained in the words vanishes, 18

19 familiar tones appear as if they had never been heard before - it is captivating. 19

20 No. 4. The soldiers, who are to seize Jesus, march like regular troops to the 20

21 attack, and sing, first softly and then louder: 21

$22 \quad 22$

23 We have seen Him 23

$24 \quad$ Going to the mountain, $\quad 24$

25 He cannot escape, $\quad 25$

26 He awaits Judgement. 26

$27 \quad 27$

28 The music for the march cannot be commended too highly, and if the Russians 28

29 have anything like it, God have mercy on their enemies! At last the disciples are 29

30 aroused, and sing, still half asleep: $\quad 30$

$31 \quad 31$

$32 \quad$ What means the noise? $\quad 32$

33 How will it fare with us? and so on. 33

$34 \quad 34$

35 And so a trio begins: Peter wants to attack, Jesus calms him, and a Seraph, who 35

36 at an early stage sounded like Saul among the prophets, now joins them, each 36

$38-697$ The libretto for Beethoven's oratorio, by Franz Xaver Huber, was possibly 38

39 The libretto for Beethoven's oratorio, by Franz Xaver Huber, was possibly 39

40 influenced by Beethoven and was heavily criticized from the start - a opinion which

40 Beethoven himself later endorsed. The fragmentary nature Zelter notices is probably due to

41 the incomplete presentation in the biblical text. Through the absence of an evangelist, the

42 action was portrayed through the eyes of a sentimentalized Christ-figure; the epic form -

43 on which the whole tradition of oratorio is based - was replaced in favour of the operatic 44 scene. 
1 retaining their own distinct style. Meanwhile, the soldiers, not idle and rather 1

2 coarse, [sing]: $\quad 2$

Up! Seize the betrayer

Drag him swiftly to judgement!' And so on.

8 At that point a concluding chorus of angels resounds, 'Worlds shall sing thanks 8

9 and praise', and so on.

10 Even if the work has no style as a whole, everything is dissolved into the most 10

11 pleasing forms, with such a humane and ethereal effect, that it is like a pleasant 11

12 summer night's dream. Viewed critically, the work is a fragment, parts of which 12

13 are missing, and one could dispense with the text. Still one must have it close at 13

14 hand, if only to convince oneself with surprise of the truth of what Ramler tells me 14

15 about Graun, connected with Der Tod Jesu: 698 ' 'Only words, my dear Ramler! Only 15

16 give me words, I will do the rest.' The rest! - isn't that great? [...]

$23[\ldots]$ I have received a very charming handwritten letter from Madame Mara ${ }^{699}$ to 23

24 the effect that the poet deserves all the praise for the beautiful clear way in which 24

25 he perceived and clearly expressed a connection which spun its invisible threads 25

26 through many years ${ }^{700}[\ldots]$

27 A passage in one of your earlier letters, which I came across when rereading 27

28 them, cast my mind back to the minor third; your last explanation has completely 28

29 satisfied me, for what exists in nature must after all one day be avowedly taken up 29

30 in theory and practice.

698 The libretto for Graun's Passion Der Tod Jesu was written by Carl Wilhelm 35 and marvellously crowned by your friendly acclamation (...) May you, my honoured 39 friend, please accept from me the blessed greetings which you sent and which I so happily 40 received' (GSA 28/598). 41 
1 Your friend Ramler, ${ }^{701}$ who only requires words in order to make music, 1 2 reminds me of Telemann with his playbill. ${ }^{702}$ Those good people respect neither 2 3 the value of words, nor the powerful possibilities of their art. Bad thoughts, bad 3 4 verses they can make use of, and perhaps they prefer these because it enables them 4 5 to take poetic licence. You have even an admirable sketch of the opportunities, 5 6 which significant words, even in an absurd connection, afford the musician. [...] 6

7 The Vampyr ${ }^{703}$ has been repeated here; the subject is detestable, but, from 7 8 what I am told, the piece is very well received as an opera. There we have it: 8 9 significant situations arranged in an artful succession, and the musician can win 9 10 great applause. Words, in a coherent, balanced relationship, offer the same result, 10 11 as you have so often proved in the case of my poems. 11

18 Our Königliches Theater now approaches its so-called 'sour-gherkin time'. Not less 18 19 than nine important individuals are sick and have left. Madame Milder appeared 19 20 as Armide and Alceste again; ${ }^{704}$ on the day of repentance Spontini performed 20 21 Handel's Alexanderfest ${ }^{705}$ and I saw or heard not one of them. [...] 21 22 According to his father Felix has arrived in Naples; ${ }^{706}$ he has not yet written 22 23 to me.

24 I suppose you would like to have my setting of 'Campanella', ${ }^{707}$ which I enclose 24

25 for you in score. The solo singer must set the tempo according to how he feels it 25 26

28702 Georg Philipp Telemann; this anecdote runs through the correspondence; see ZG

296 April to 7 May 1808; GZ 15 January 1813; ZG 10 to 23 February 1828.

30703 Romantic opera by Heinrich August Marschner (1795-1861), composer, Director 30 31 of Music in Dresden, Kapellmeister in Hanover. The opera (libretto freely adapted from 31

32 Byron's tale by Wilhelm August Wohlbrück) was performed in Weimar on 23 April 1831

33 (see Goethe's diary, WA III/13, pp. 66-7).

34704 The performance of Gluck's opera Armide (libretto by Philippe Quinault after

35 Torquato Tasso's La Gierulsalemme liberata) was reviewed in AMZ 33 (1831), no. 23,

368 June, column 376. Gluck's opera Alceste was performed in the Königliches Oper on 1

36 May 1831 with Anna Milder in the title role; MA 20.3, p. 1196.

705 For reviews of the performance; see the Spenersche Zeitung on 26 April 1831 and AMZ 33 (1831), no. 23, 8 June, column 378f.; MA 20.3, p. 1196.

39706 Felix Mendelssohn had left Rome in April 1831 with the painters Bendemann,

40 Hildebrandt and Karl Sohn, and travelled south to Naples and Pompeii; see the letters from

41 Naples to his sister Rebecca of 13 April, to his family on 20 and 27 April and 17 May, and

42 to his sisters on 28 May 1831. 32

43707 Goethe had asked Zelter to send his setting of Förster's 'Die Campanelle' for 43 44 publication in Chaos. Zelter, who, as usual, had wanted to play through the work before 44 
1 and the movement must then be retained to the end. I hate the chronomètre $e^{708}$ and 1

2 even more the man who is dependent on it. The theorists would drive me wild; 2

3 they even misled Beethoven into scoring his works with metronome markings, 3

4 which do not suit the music at all. ${ }^{709}$ What can't exist on its own two feet can go 4

5 to hell. [...]

6

7

Old Körner ${ }^{710}$ died last Friday, and yesterday evening his body was taken to 12

14 the house of mourners, tributes were made and sung; he was an active member of 14

15 the Sing-Akademie. ${ }^{712}$ I was not present, and at my time of life I must avoid such 15

16 emotions. We shall follow soon enough if not via Wöbbelin. [...]

17 Our opera is rather unhealthy; they are obliged to re-engage retired members 17

18 and consent to their rather arrogant demands. In addition to her pension Madame 18

19 Milder is paid 150 thalers for every opera, and for an opera by Spontini she 19

20 demands 50 Louis d'or because he is responsible for her being pensioned off. ${ }^{713} 20$

21 Spontini himself told me this. 21 the autograph setting is in Zelter's bequest. Zelter's setting of Förster's poem was published 24 in the second year of Chaos, as a supplement to no. 1 . 25

708 Chronomètre; metronome invented by Johann Nepomuk Mälzel of Vienna in 26 1816.

28709 Beethoven had begun to give metronome markings for his works from 1817. In 28

29 the $A M Z 19$ (1817), no. 51, 17 December, column 873f, he published additional metronome 29

30 markings for 'the movements of all Ludwig van Beethoven's symphonies, by the author 30

31 himself, using Mälzel's metronome markings'. Although Zelter's remarks are typical of 31 attitudes to metronome markings of nineteenth-century composers, later Rudolph Kolisch 32 campaigned to have Beethoven's metronome markings taken seriously.

710 Christian Gottfried Körner, father of the poet Theodor Körner, died in Berlin on 34 13 May 1831.

711 Körner's son, Theodor, died in Rosenow near Gadebusch in Meckenburg on 26 August 1813 and was buried in Wöbbelin (near Gadebusch); Körner's daughter, the 36 painter Emma Körner, died in 1815. 
1 Demoiselle Schechner of Munich ${ }^{714}$ demands 5,000 thalers per annum, 2,500

2 as a pension for life and three month's leave every year; in addition she also insists 3 on her own choice of parts and full pay on sick leave. So claims Count Redern, ${ }^{715}$ 4 our present Director [...]

5 Friday. At Prince Radziwill's Quartet yesterday evening and afterwards 6 pleasant conversation. Count Redern and Spontini were also there. They like to 7 talk in this house and I listen. I am much more at home with music. [...]

14 Do not fail, my dear friend, to continue sending me from time time a few sheafs 14

15 from the rich harvest of the outer world to which you are sent, ${ }^{716}$ unlike myself 15

16 who am completely confined to the inner life of my garden hermitage. ${ }^{717}$ Let me 16

17 tell you in one word that I submit to this in order to finish the second part of 17

18 my Faust. ${ }^{718}$ It is not easy in the eighty-second year of one's life to represent 18

19 objectively that which was conceived at the age of $20^{719}$ and to furnish a living 19

20 skeleton like this with sinews, flesh and skin and cast over the finished work some 20

21

part, consists of people who are unwell and how absolutely desirable an early replacement

for Milder is'; he recommended touring Germany in order to hear singers who had been 23

24 recommended to him 'who would be able to replace Milder when she was pensioned off'.

25714 Nanette Schechner (1806-60), singer at the Munich Court Theatre; Zelter had

26 heard her when she was in Berlin giving guest performances in 1827.

27715 Count Wilhelm von Redern (1802-83), theatre manager and artistic director of the

28 Königliche Schauspiele in Berlin as successor to Count von Brühl.

29716 Reference to the biblical words of the great harvest, Matthew 9, v. 37-38; Luke

3010 , v. 2.

$31 \quad 717$ In his late years Goethe often uses the image of a hermitage with reference to his 31

32 own walled garden; see his letters to Reinhard on 28 January 1828 (WA IV/43, pp. 265-9) 32

33 and to Willemer of 2 March 1831 (WA IV/48, pp.136-7), to Zelter on 26-29 January 183033

34 (WA IV/46, pp. 221-6) and to Wilhelm von Humboldt on 1 December 1831 (WA IV/49, 34

35 p. 164-7). Mostly this image stands for Goethe's loneliness and seclusion from the world; 35

36 here it refers to Goethe's endeavour to bring Faust II to completion.

$37 \quad 718$ Act 5 was 'as good as finished' at the beginning of May and was passed on to

38 Eckermann to read. Work on Act 4 was resumed on 26 June and the fair copy was already

38 complete by 20 July, as reported in a letter to Heinrich Meyer and in his diary on 21 and

3922 July.

40719 When Goethe had sketched a plan for Faust II cannot be ascertained with any 41 certainty. In Dichtung und Wahrheit, Part 2, Book 10, he himself places it in his Strasbourg

42 years: 'I took great care to conceal from him [Herder] my interest in certain subjects which

43 had rooted themselves in me and seemed to be developing gradually. These were Götz von

44 Berlichingen and Faust.' 
1 additional folds of drapery, so that the whole may be an open riddle to delight 1

2 mankind forevermore and also to give them something to think about. 2

3 Bless you in your musical life, rich in sound. Lately I have had some thoughts 3

4 about the Cantilena ${ }^{720}$ which are very fruitful for me. Perhaps they would be of no 4

5 use to others; they have had a really beneficial effect on me since they occured 5

6 to me. I won't say anything to you about it because you have it, have used it and 6

7 enjoyed it.

143 June: A former student, Teschner of Mageburg, wrote to me from Milan ${ }^{721}$ a very 14

15 satisfactory report about the opera and the ballet and hears the things like a native. 15 That is so comforting as so many don't know what they should be looking for if 16

17 they are not to be lost in admiration in a country which is so rich in music.

5 June: In Paris a female composer has set Faust to music and to complete 18 applause. ${ }^{722}$ There's no denying it: the Germans are cruel but compared with the 19

The little pages of drawings to your folksongs, ${ }^{723}$ which I still have on my wall 21

22 before me, are as delightful and fresh as if they lived and moved.

23 If you can let out some of your thoughts about the Cantilena, then share them 23

24 with me. They would be well preserved because they, too, belong to the illustrative 24

25 arts which demand a skilful hand. Théâtre Italien on 7 March 1831; the libretto, which had been written in Italian verse in 39 1830, was performed in French translation without any acknowledgement of the author's 40 name; see Andreas Maier, Faustlibretti. Geschichte des Fauststoffs auf der europäischen 41 Musikbühne nebst einer lexikalischen Bibliographie der Faustverordnungen (Frankfurt am 42 
5 [...] In the Revue de Paris, No. 1, 1 May, in the third issue, there is an extraordinary 6 article on Paganini. ${ }^{724}$ It is written by a doctor who knew and treated him for many 7 years; he argues, in a very convincing manner, that the musical talent of that unique 8 man was assisted by the conformation of his body, and by the proportions of his 9 limbs, which helped and even required him to perform what seemed incredible 10 - almost impossible. This leads the rest of us back to our conviction that organic 10 11 functions bring about the peculiar manifestations of living beings.

18 Have you seen the lithograph of my portrait by Begas in the Leipzig Musikalische 18

19 Zeitung of $1830 ?^{725}$ Chance gave a hint of sorrow to the left corner of the mouth, 19 20 which I don't acknowledge [as mine]. On this occasion the editors expressed fine 20 21 praise of my achievements, which I am glad to hear, and they express the wish that 21 22 I would erect for the world a worthy memorial to myself through a selection of my 22 23 best songs. They could have had that long ago, but I could have been looking for 23 24 it for a long time. I have never been criticized for destroying myself by working 24 25 on your poems. What they like they can keep and what can't be saved can rest in 25 26 the bosom of Abraham.

27 The main topic of conversation is now: cholera morbus. [...] I must escape in 27 28 my own way. ${ }^{726}$ There is no other way. I would need a substantial amount of time 28 29 before I dared to say whether Sargines is a good opera or not. ${ }^{727} \mathrm{Up}$ to this point I had 29 30 heard it without knowing the libretto and could not enter into it. Paer, productive 30 31 and instructive as he is, has for a long time been a favourite of singers. He himself 31 32 is said to have sung his own songs with so much grace that Napoleon, for instance, 32 33 whom I consider very frank, as he was not in the habit of restraining himself, was 33 34 delighted with the performance; this kind of thing can often surprise me. So now I 34 35 have got my hands on the text and am beginning to get some insight. 35

37724 Francesco Bennati, 'Notice physiologique sur Paganini', Revue de Paris 26 38 (1831): 52-60.

$39{ }_{725}$ Lithograph by Friedrich Krätzschmer with the subtitle 'Dr C.F. Zelter' after the 40 painting by Carl Begas (1830); it was published as the title page of $A M Z 32$ (1830). 40

41726 Here Zelter means to escape through art. 41

42727 Zelter's negative appraisal of the opera Sargines, oder Der Zögling der Liebe by 42

43 the Italian composer Ferdinando Paer (1771-1839) was already expressed in his letter of 43

4428 to 30 July from Prague. $\quad 44$ 
15 June: Yesterday when I returned from Potsdam your two letters of 9 June 1

2 arrived at the same time [...] My Potsdam expedition ${ }^{728}$ did not go off too badly 2

3 and even received more applause than is usual. The mess was execrable. First, in 3

4 the rehearsal I let them stand where they were used to. Nothing was in its place; 4

5 everything was muddled up: geese, hens, cows, pigs as they came from pasture 5

6 in the evening. The best stood apart at the back, the upper-class amateurs in the 6

7 front. I had a couple from Berlin with me who had to be fitted in. Faces were made 7

8 at that. The overture had to be repeated three times. 'And there was evening and 8

9 morning one day'. ${ }^{729}$ Then everything went much more smoothly and in the end 9

10 they were all delighted with themselves. The following day the performance was 10

11 as sleek as possible, at least without mistakes, and I should not forget to praise the 11

12 docility and good humour. As many asked whether I was pleased with them, the 12

13 question followed as to whether they were happy with me. The whole thing was, 13

14 nevertheless, mysterious. Here and in Potsdam there are perhaps a dozen directors 14

15 who seldom forget to refer to themselves as such and they are all younger, more 15

16 skilful and more powerful that I who never bore that title. And people, who are 16

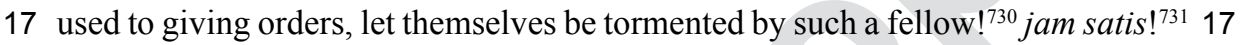

$18[\ldots]$

19 I enclose a passage of a letter from Felix, ${ }^{732}$ who I imagine is back in Rome 19

20 right now. His father would not allow him to see Sicily. He may have his reasons, 20

21 but the father of an obedient son should recognize the limitations of his power. I 21

22 have gently pointed this out to the old gentleman. 22

24 Enclosure

28 'Sterne has become a great favourite with me. I remembered that Goethe, when 28

29 talking about $A$ Sentimental Journey, once said that the defiance and despondency 29

30 of the human heart could not possibly be better expressed, and when I chanced 30

31 upon the volume accidentally, I thought I should like to make myself acquainted 31

32 with it. I was delighted the way everything is so clearly and finely observed and 32

33 expressed. Here I get very little German to read, so I am limited to Goethe's poems 33

34 which Hauser presented me with, and, by Heaven, there is enough food there for 34

35 reflection; they are always new. The poems that specially interest me here are 35

36 those which he evidently wrote in or near Naples, for example 'Alexis and Dora', 36

37 for I see almost daily before my window how that marvellous poem came into 37

43732 Enclosed excerpt (in an unknown hand) from Felix Mendelssohn's letter of 7 May 43

441831 from Naples to his father in Berlin (GSA 28/1026, no. 470). 
1 being; as happens with all masterpieces, I often think involuntarily and suddenly 1

2 that it is as if the same thing must have struck me, too, under similar circumstances

3 and that it was only an accident that he expressed it. I maintain that I have actually

4 found the locality of the poem 'Gott segne Dich, junge Frau'. ${ }^{733}$ I maintain that I

5 have actually dined with the woman, though naturally she must by this time have

6 become quite an old woman, and the babe at her breast a lusty vine-dresser; there

7 they were both of them. Between Pozzuoli and Bajae lies her house, 'the ruins of a

8 temple', and to Cumæ it is a good three miles. So you can imagine how the poems

9 are renewed for one and how differently and freshly they affect one [on closer

10 acquintance]. I really cannot speak of Mignon's Song. But seeing that Goethe and 10

11 Thorwaldsten are alive and Beethoven died only a few years ago - what madness 11

12 for H to maintain that German art is as dead as a doornail. Quod non ...'

19 I could support your conviction about the effect of the organism upon man's 19 20 intellectual nature with an example of my own. Morally, too, it is confirmed by the 20

21 most remarkable individuals of my personal acquaintance. One might say of old 21

22 Bach that the pedal was the basic element of the development of his unfathomable 22

23 intellect, and that without feet he would never have fully reached those intellectual 23

24 heights. So I fail to understand the strange question which Lessing makes his 24

25 painter ask, whether Raphael would have been just as great a genius if he had been 25

26 born without hands? ${ }^{734}$ Here is a man (our painter Begas) who can sniff a pinch of 26

27 tobacco with his arm stretched round the back of his neck. Perhaps such elasticity 27

28 belongs to a painter; but had I been so endowed, my talent, eagerness, and industry 28

29 would have made me the best of violin players, for all my instincts drove me 29

30 to that instrument which I practised unremittingly - and by so doing, brought 30

31 about the gout in my hand. In spite of that, in earlier days I performed significant 31

32 music on the violin, both in drawing rooms and churches, and I was able to give 32

33 successful public performances of Tartini, Benda, Celli, and Corelli's concerti. ${ }^{735} 33$

34 In a word, in the human organism there dwells a soul which seeks its companion, 34

35 as you long ago expressed it: to one talent belongs another. 35

40733 Goethe's poem 'Der Wanderer'.

41734 Lessing, Emilia Galotti, dialogue between the Prince Hettore Gonzaga and the 41

42 painter, Conti, Act 1, scene 4.

43735 Violin and viola concerti by Giuseppe Tartini, probably Franz Benda, Antonio 43

44 Lolli and Arcangelo Corelli. $\quad 44$ 
Finally, after the twentieth performance in the Königsstadtisches Theater, I 1

2 survived the highly acclaimed magic opera Lindane (by Bäuerle). ${ }^{736}$ Again, 2

3 typically Viennese: fantastic, good, even very decent enough to put a serious man 3

4 in good humour. A slipper-maker celebrated his engagement among close relatives. 4

5 Before the marriage the bridegroom has to make a journey to a dying relative, who 5

6 decided to make a bequest to him only in person. The journey passes through an 6

7 enchanted forest which is governed by a fairy in love and so the bride is worried 7

8 about the fidelity of her beloved (Spizeder) who in respectable naievity is subjected 8

9 to all kinds of temptations by the fairies. The charm of the story is genuinely 9

10 bourgeois, with delightful puns and innocent meetings of a coincidental nature. 10

11 The music is also good. It is a pastiche of tirades from the best-known operas 11

12 which are so well unified so as to put many genuine operas to shame. Technical 12

13 equipment and transformations surpass the expensive Königliche Kapelle by far. 13

14 What I referred to as decent above is that in this fairy tale the philistinism of the 14

15 slippered Christian, who consciously remains true to his honour, contains nothing 15

16 humiliating for his trade. The company work so well together that the comedy 16

17 is also well played, just as when I saw, with pleasure, your Die Mitschuldigen 17

18 performed here. ${ }^{737}$ The director of all this was a Jew and a typical Jew in every 18

19 way. And that was good! [...]

26 Yesterday your letter of the 18th of this month arrived and found me in the best 26

27 of form. It was the weekly big assembly of the Sing-Akademie. ${ }^{738}$ Around half 27

28 past six the $\mathrm{King}^{739}$ was announced unexpectedly, not to hear us but rather to see 28

29 the exhibition of flowers in our big hall. It was not easy to rearrange the society 29

30 immediately. They positioned themselves in the small hall behind the orangery 30

31 trees fairly invisibly so that the large hall could appear completely free in the 31

32 evening sunlight and the King and his wife ${ }^{740}$ - surrounded by groups of flowers -32 Zauberspiel in two acts by Adolf Bäuerle, adapted for the Berlin stage by Leopold Bartsch 35 with music arranged by Vinzenz Kugler, premiered on 20 April 1831. Zelter would have 36 presumably attended the performance on 15 June; for reviews see $A M Z 33$ (1831), no. 23, 37 8 June, column $377 f$.

40738 On Tuesday 21 June; at that time all members of the Sing-Akademie gathered to 40

41 rehearse on Tuesdays.

42739 Friedrich Wilhelm III of Prussia.

43740 Countess Auguste von Harrach, since 1824 Princess Liegnitz, morganatic marriage 43 
1 found themselves alone in a 200-foot circle, to cast a glance over the very rich 1

2 collection of flowers. The King, who as a rule does not show his favour to social 2

3 clubs and our Sing-Akademie, couldn't help noticing that our society had vacated 3

4 the room for him. I mentioned that today was our usual day of gathering and, if 4

5 he would care to command it, every member of the Sing-Akademie would be 5

6 prepared to offer him a pleasant performance which would not last more than ten 6

7 minutes. He was in a hurry as he still wanted to go to Schönhausen ${ }^{741}$ in order 7

8 to wish happy birthday to one of the princesses, the daughter-in-law of Prince 8

9 Albrecht $^{742}$ today, but he wanted to stay to hear it. So I presented the text of a 9

10 "Hymnus auf die Sonne" 743 to him and to his wife. At the nod I let the invisible 10

11 choir be heard which - including soft solo passages - lasted nine minutes. After 11

12 that I paid my respects, the King rose up, thanked, praised, enquired about the 12

13 soloists who were outstanding and took leave calmly as if he had time to stay on 13

14 longer with us.

15 The thing was so successful for this occassion that I would have to praise the 15

16 music itself if it had not by chance been mine, because everything was a decision 16

17 of the moment which turned out well. The King must have felt that I arranged it 17

18 for him alone, but in truth everything was unprepared - like a gift from God. The 18

19 members gathered didn't know what happened to them; obedient to a nod without 19

20 one asking how? why? and the effect brought about general good humour. The 20

21 King had hardly gone when your letter was brought to me letting me know you 21

22 are alive and well.

29 Your Postdam expedition ${ }^{744}$ gives the rest of us reflective people a good opportunity 29 30 to focus on egoistical anarchy which allows a person to force his way in, where he 30 31 has no business, to some agreeable post which he cannot properly fill. But after all, 31 32 this much can be said in praise of anarchy, that once it has a fixed goal in mind, it 32 33 looks about it for a dictator, and then sees that things are in order.

34 The advantage that you musicians have over all other artists is that a general 34

35 universally accepted basis exists for the whole, as well as for the parts, so that 35

$37 \quad 741$ Village near Berlin, summer residence of the royal family. 37

38742 Marianne of Prussia (1810-83), wife of King Friedrich Wilhelm III's son Albrecht,

39 gave birth to a daughter, Charlotte, on 21 June 1831.

$40{ }^{743}$ Presumably Zelter's setting of 'Hymnus an die Sonne' by Christoph August 41 Tiedge.

42744 Zelter had been summoned to Potsdam to take the place of a conductor who was

43 too ill to lead a performance of Haydn's oratorio The Creation; see ZG 10 to 15 June 441830 . 
1 anyone can write a score with the full certainty of getting it performed, whatever 1

2 it may be. You have your field, your laws, your symbolic language, which 2

3 everybody must understand. Every musician, even if he had to perform the work 3

4 of his deadly enemy, would necessarily, on this occasion, give a good rendition. 4

5 There is no art, scarcely any handicraft even, that can claim it does the same. You 5

6 can continually celebrate the oldest masters without pedantry, you can delight in 6

7 the latest composition without heresy and obstruction and even if an individual 7

8 of your circle produces something avant-garde, ultimately it must relate to the 8

9 orchestral forces.

10 And now a word or two about the worthy Felix. Papa was wrong not to allow 10

11 him to travel to Sicily; the young man will feel dissatisfied and that could have 11

12 been avoided. In my last letters from Sicily, or the following ones from Naples, 12

13 there must be some traces of the unpleasant impression I had of that idolized 13

14 island; I don't wish to dwell on the subject by repeating myself. 14

15 The second thing I must tell you, which you must not betray me on, is that the 15

16 poem 'Der Wanderer' was written in the year 1771, many years before my Italian 16

17 journey. ${ }^{745}$ But this is the advantage of the poet, that he can feel beforehand the 17

18 value of a thing, which the person who seeks it out in reality loves and enjoys 18

19 twice as much when he discovers and recognizes it in real life. 19

26 Your lovely dear letter of 28 June, which I had started to answer, reminds me of a 26

27 joke during the Potsdam expedition. They had started the only day's rehearsal so 27

28 late that dusk fell and no one could read anymore. I, too, could no longer make out 28

29 the score and really we should have stopped. They all pulled themselves together 29

30 and persevered until the work was finished. On the way out of the church one of 30

31 them said of me, 'The old fellow must have cat's eyes because I couldn't see a 31

41745 Goethe's reference to his poem 'Der Wanderer', which had already been written 41

42 before his Italian journey, namely in 1772. He picks up on a passage in Felix Mendelssohn's 42

43 letter from Naples on 7 May 1831, passed on by Zelter, where Felix had written that he 43

44 believed the poem originated 'between Pozzuoli and Bajae'. 
5 [...] Today, 29 June, I have received a letter from Felix, written in Rome on the 6 16th of this month; ${ }^{746}$ I expect it is the last one from there. ${ }^{747}$ It contains an account 7 of the Easter ceremonies in the Sistine Chapel during Holy Week. The lad did not

8 let a single note escape him; he looks at the whole historically, without betraying

9 the foreigner and the heretic. It says something for him, that he can grasp the 10 whole in its original form which is now in tatters, and that he can recognize the 10 11 empty body behind the outward pomp and ceremony.

12 Your annoyance about idyllic Sicily can only be right; also, nothing is to be 12

13 garnered there for the musician and I myself would not give up the opportunity to 13

14 be in Naples and to have seen Palermo [...]

15 In setting your poems to music, I have been inspired to seek out how and 15

16 where they arose, and as many of my melodies have pleased you, the apple cannot 16

17 have fallen so very far from the tree. I have had similar good fortune with many 17

18 different poets. Schiller, Voß, Matthisson, Tieck, Tiedge, and even Klopstock 18

19 have praised my melodies. When Naumaun's eldest son was born, Countess Eliza 19

20 commissioned settings, from Himmel, myself and others, of a cradle-song she had 20

21 written. ${ }^{748}$ Naumaun, the child's father, was to choose the song that pleased him 21

22 most without knowing who had composed it. He said that in the melody that he 22

23 liked best, he recognized Himmel, ${ }^{749}$ his favourite pupil - but that melody was in 23

24 fact mine. $\quad 24$

$25 \quad 25$

$26-26$

$27 \quad 27$

$28+28$

$29-29$

$30-30$

$31+31$

$32 \quad 32$

$33-33$

$34-34$

35746 The long letter from Felix Mendelssohn Bartholdy to Zelter is published in 35

$36{ }^{746}$ The long letter from Felix Mendelssohn Bartholdy to Zelter is published in 36

37 Reisebriefe (1862), pp. 171-88.

38747 Felix left Rome on 19 June 1831; he travelled through Florence, Genoa, Milan,

38 Switzerland, Munich, Stuttgart, Heidelberg, Frankfurt, Bonn, Liège to Paris, where he 39 remained until April 1832.

40748 The poem 'Wiegenlied für Mutter Naumann' by Elisa von der Recke, composed

41 to mark the birth of Johann Gottlieb Naumann's son, Carl Friedrich (1797); Zelter's setting

42 appeared in volume one of the Musikalisches Museum (1800).

43749 The composer Friedrich Heinrich Himmel (1765-1814), composer and pianist, 43

44 Court Kapellmeister in Berlin. $\quad 44$ 
557. Zelter 1

5 [...] Prince Radziwill has just buried his second grown-up son. ${ }^{750}$ I have just 5

6 come from the Catholic church where Mozart's Requiem was sung for him. That 6

7 [work] does not allow itself to be buried, neither by a bad review ${ }^{751}$ nor a moderate 7

8 performance. What moved me so deeply (besides this Requiem) was the old unison 8

9 singing of the 'Libera me de morte aeterna' sung by priests around the coffin. I 9

10 had to kneel down to conceal bitter tears and was afraid to stand up. What is man! 10

11 What strength does he have! 11

558. Zelter

18 My good students, who have still not got over Riemer's applause and discovered 18

19 from him that you still have not heard a song powerfully sung from the Divan, had 19

20 made a pact to use the holidays and to serenade you in your garden, until I had 20

21 to confide in them that you are not in Weimar for your birthday and, in general, 21

22 would not want to be met anywhere. They wanted to seek you out since they travel 22

23 and some have to go away. However, I think they should be sensible enough from 23

24 now on to be satisfied with their signs of good will. [...]

[...] A 72-year-old pious (unbaptized) Jewess ${ }^{752}$ has just sent me a bottle of Rhine 31 wine from 1873 with the task of consuming it in honour of your well-being. I 32 immediately discovered the effect it had on devout activity because I had just 33 read my morning prayer: as the grey, rising phoenix warns his pupil Achilles to 34 be lenient towards his fellow people and to show forgiveness towards the hated 35

750 Friedrich Wilhelm Ferdinand August Heinrich Anton Wladislaus Radziwill (1811- 39 $31)$.

751 Zelter is alluding to Gottfried Weber's two published articles in which he contested 41 the authenticity of Mozart's Requiem and which were published in Cäcilia in 1825 and 42 1826. 
1 Atreids. $^{753}$ I found myself suitably moved by it and, after I revived, a canon 1

2 occurred to me and one gets back into one's stride: 2

20 Nulla dies sine linea ${ }^{754}$ Given the day it is, it had to be so. The little work could 20

21 disappear into the new Chaos. ${ }^{755}$ I couldn't find any other words. If you don't like 21

22 them, you might like to write new ones to it.

$23[\ldots]$ At the Sing-Akademie yesterday evening we began with Fasch's 23

24 grand 'Gloria in Excelsis Deo', followed by the chorus in 16 parts, 'Laudamus 24

$25 \mathrm{Te}$, benedicimus Te, adoramus', ${ }^{756}$ and so on. Afterwards, as a secret tribute to 25

26 you, ${ }^{757}$ we had old Bach's melodious Motet, 'Singet dem Herrn ein neues Lied, 26

27 die Gemeine der Heiligen soll Ihn loben'. ${ }^{758}$ I knew by the performance that they 27

28 knew what I meant, and they asked for that great masterpiece over again, and sang 28

29 it with such reverential joy, in accordance with my previous instruction that old 29

30 Bach (who was still living when you were born) must have stirred in his grave 30

$31[\ldots]$

42756 Presumably from Fasch's Missa a 16 voci in quattro Cori (1783-88). 42

4375728 August is Goethe's birthday.

44758 Motet by J.S. Bach, BWV 225. 
5 For six days, and the best days of the entire summer, I was away from Weimar, ${ }^{759} 5$

6 having taken the road to Illmenau, where in former years I had worked a $\operatorname{lot}^{760}$ and 6

7 hadn't visited for a long time. ${ }^{761}$ On a lonely little wooden summer-house, ${ }^{762}$ at the 7

8 highest point of the pine forest, I recognized the inscription of that song, written on 8

97 September $1783,{ }^{763}$ which you have so tenderly and peacefully sent forth to the 9

10 world upon the wings of song, 'Über allen Gipfeln ist Ruh' ${ }^{764}$ After so many years 10

11 I could recognize what remains and what has vanished. Success stood out in relief 11

12 and was cheering, misfortune was forgotten and its sorrow overcome. The people 12

13 lived on as before in their own way, from the charcoal-burner to the porcelain 13

14 manufacturer. Iron was being smelted, and brown coal was brought up from the 14

15 mines, though it is not in as much demand as before. They were boiling pitch, 15

16 and collecting soot in small containers that were most artistically and elaborately 16

17 finished. Hard toilers were bringing up coals to the pit's mouth. Gigantic, primæval 17

18 trunks of trees had been discovered in the pit, whilst the men were at work; one of 18

19 these I forgot to show you - it stands in the garden house. [...] 19 Illmenau.

759 From 26 to 31 August 1831; see Goethe's notes to his diary for his sojourn in 31

760 For an account of Goethe's work in Illmenau; see Kurt Steenbuck: Silber und Kupfer 32 aus Illmenau. Ein Bergwerk unter Goethes Leitung, Schriften der Goethe-Gesellschaft 6534 (1995). Hereafter referred to as $S c h r G G$. an excursion to the Gickelhahn.

761 Goethe's previous visit to Weimar was from 26 August to 2 September 1813, with 35 is published in: Wolf Segebrecht, Johann Wolfgang Goethes Gedicht 'Über allen Gipfeln 38 ist Ruh' (Munich and Vienna: Carl Hanser Verlag, 1978), p. 192. 
1 The Försters ${ }^{765}$ have probably told you of the celebration in Weimar on my 2 birthday; ${ }^{766}$ it went off very successfully. The pretty little person ${ }^{767}$ whom I was 3 so glad to see at my table made a considerable effect. The ladies declared that her 4 exquisitely tasteful bonnet had much to do with it. [...]

5 You inquire about Faust; Part Two is now complete in itself. ${ }^{768}$ For many years 6 I have known perfectly well what I wanted, but only worked out those particular 7 passages that interested me at that time. As a result gaps became evident and these 8 had to be filled in. I firmly resolved to do this before my birthday and so I did. The 9 whole work now lies before me and I only have to correct a few little things. So 10 I shall put a seal on it and then it can add to the weight of the volumes that are to 11 follow, whatever might come of it. ${ }^{769}$

12 You have seen a wonderful scene or much more a wonderful part of the whole 12

13 work. Whatever you will have assigned for yourself will appear more entertaining 13

14 in the context.

15 Now that these demands are satisfied, new ones immediately press forward 15

16 from behind à la queue as in a baker's shop. I know well what is needed; the 16

17 future will show what can be done. I have planned far too many projects and in the 17

18 end I have neither means nor strength to finish them. I dare not even think of Die 18

19 Natürliche Tochter: how could I call to mind the enormity of the task there? 19

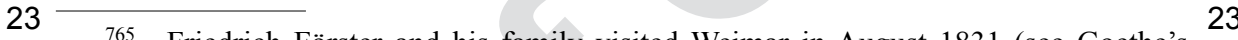

24765 Friedrich Förster and his family visited Weimar in August 1831 (see Goethe's

25 diary on 25 August $1831, W A \mathrm{III} / 3$, p. 128) and had apparently taken part in the festivities 25 for Goethe's birthday on 28 August 1831.

26766 The Weimar festivities, organized by the citizens of Weimar on 28 August 1831,

27 commenced with the unveiling of David d'Anger's colossal marble bust of Goethe in the

28 Duke's library, the celebrations were framed by the performance of a cantata to a text by

29 Chancellor von Müller, set to music by Hummel, and an address by Riemer. Over two

30 hundred people attended the meal in the town hall held afterwards where Ottilie von Goethe

31 received the various good wishes and honours on behalf of her father-in-law. Though 30

32 Goethe had escaped from the Weimar festivities, the people of Illmenau would not let his

33 birthday pass unnoticed. Early in the morning they assembled in front of the Lion Inn where

34 he was staying and sang the chorale Nun danket alle Gott! In the evening, they performed 35 the miners' comedy mentioned in Wilhelm Meisters Lehrjahre.

767 Laura Förster, who had already visited Goethe in Jena on 27 September 1820;

36 at that time Goethe had described her as 'very pretty' and later described her as Zelter's

37 'beautiful student' in a letter written on 14 October 1821.

768 See Goethe's diary on 22 July 1831, where he notes 'Managed to complete the main

39 part. Final draft. Everything filed for fair copy'; it was the same day on which Zelter arrived

40 unexpectedly in Weimar. Any final work on the manuscript must have been completed

41 after Zelter's visit. On 7 September 1831 Goethe wrote to Reinhard, 'I must confirm - but

42 confidentially - that I have succeeded in finishing Faust. Part Two'.

43769 Published by Riemer and Eckermann after Goethe's death as Ausgabe letzter

44 Hand. Nachlaßbände (final edition. Posthumous volumes). 
$5[\ldots]$ Förster tells me that you were in Illmenau on the day of your birthday. ${ }^{770} 5$

6 One embarrasses people and afterwards one will still always be grateful. Someone 6

7 asked me why I didn't go to Weimar for the celebration. I answered, because 7

8 I would not have wanted to travel any further. You know I am living on good 8

9 terms with many people. Many have what suits me and what doesn't suit me, and 9

10 I myself don't exactly make it my profession to please. What I find repulsive I 10

11 cast aside; what I find attractive I treasure. [...] With you it is very different. The 11

12 friendship is ingrained in me and comfortable and I like everything about you. [...] 12

13 To me you are the one who will live on after his death and if I saw you in person, 13

14 I would then consider myself departed.

21 Yesterday evening I saw a couple of acts of Götz von Berlichingen which were 21 22 chosen for your birthday. ${ }^{771}$ The play remains the same: there isn't a wrong word 22 23 in it. [...] I also know through music: the nearer to perfection, the more painful the 23 24 wrong note. A young girl with a magnificent voice brazenly carried off the role of 24 25 George and pleased me most of all. [...] 25

26 Your experience of the lovely autumn days in Illmenau ${ }^{772}$ compensated you 26 27 sufficiently for the celebration that you were happy for everyone else to enjoy ${ }^{773} 27$ 28 and Förster gave me a good account of it.

29 What I had imagined, however, to my relief came true. I thought that your 29 30 contentment with a completed work ${ }^{774}$ would bring back the cheerfulness of 30 31 earlier times for you and inspire you to new production. Your letter is like a garden 31 32 in blossom through which I frequently wander since yesterday and never have 32 33 enough. Since I have never seen your wooden hut on the heights of Illmenau, I 33 34 must be happy to have entered so surely into your loneliness and like a born minor 34 35 to see the quiet words brought to light from the devices in the rock where they 35

770 Zelter had not yet received Goethe's letter describing his time in Illmenau; it 37 arrived in Berlin on 7 September.

771 Goethe's Götz von Berlichingen was performed in the Königliches Opernhaus 39

40 in Berlin on 6 September 1831. The new production was performed for the first time on 40

41 Goethe's birthday on 28 August 1831.

42772 GZ 4 September 1831.

$43 \quad 773$ The Weimar festivities for Goethe's birthday. 43

$44 \quad 774$ Goethe's completion of Faust II. $\quad 44$ 
1 finally rested. Your recognition gives the few notes a value which time cannot 1

2 take away again, because they recapture the unfathomable - time, place, heart and 2

3 mind - after so many years. Should I not feel praised when you praise me because, 3

4 from my anti-polar circumstances ${ }^{775}$ to your mountain heights, I am capable of 4

5 casting a glance in your depths like a miner's light? How fortunate we are that we 5

6 are doing things of our own when so many thousands, out of sheer boredom, are 6

7 very busy breaking one another's necks while at the same time talking of peace. 7

8

9

563. Zelter

14 [...] The days rush by towards shorter [days], which should also have their good 14

15 points. Our Sing-Akademie have had to survive two consecutive Requiems in their 15

16 own ranks. Two members died suddenly; ${ }^{776}$ the last of them, Minister of Justice 16

17 Wollank, diagnosed with Asian cholera, died very suddenly in a few hours. No 17

18 one within these walls has fallen ill. Public buidings are being fumigated until one 18

19 is nauseous and weary of it. Here in the house we are just taking care that there is 19

20 fresh healthy air. Some sensible people follow suit.

21 [...] One of my young students, Otto Nicolai ${ }^{777}$ - this time no relation to that 21

22 average $\operatorname{man}^{778}$ - has trained himself to be a very cultivated singer and has set 22

23 several of your poems to music. ${ }^{779} \mathrm{I}$ have given him a recommendation to our 23

24 dear Ottilie, ${ }^{780}$ begging her to introduce the little fellow to you. Out of gratitude to 24

25 me he performs my bagatelles. I acknowledge his efforts because they show me 25

26 it is not my fault if the songs are not to everyone's taste. Now, if you could find a 26

27 leisure hour in which to listen to this youth, it would give him joy for rest of his 27

28 life. [...] 28

775 In his account of Illmenau, Goethe had written he wished 'for nothing more than

to see you appreciating the enormous contrast between your external circumstances and this'.

776 On 27 June 1831 the bass soloist Otto Grell had died and on 5 September Friedrich

36 Wollank, a member of the Sing-Akademie since 1799, died.

$37 \quad 777$ Karl Otto Ehrenfried Nicolai (1810-49), composer, who studied with Zelter and

37 at the Königliches Institute für Kirchenmusik from 1828 to 1830, later Kapellmeister in

38 Vienna and Berlin. As a member of the Sing-Akademie he sang the part of Jesus in the

39 revival of the St Matthew Passion on 27 March 1831.

$40 \quad 778$ The Berlin publisher and writer Friedrich Nicolai.

41779 There are very few settings of Goethe's poems by Nicolai before 1831: the four-

42 part choral setting of Goethe's 'Mailied' from the op. 6 Lieder; the duet setting of Goethe's

43 'Rastlose Liebe', op. 23 and a vocal quartet, op. 9, 'respectfully dedicated to the poet'.

44780 See Ottilie von Goethe's letter to Zelter on 13 September 1831 (GSA 95/I, 8, 5). 
5 [...] The fools of the day ${ }^{781}$ would like to see the nobility abolished, as though it 5

6 were possible for a man of worth to lose anything by possessing worthy ancestors! 6

7 Why, I suppose next they will be taking your great-uncle away from you and your 7

8 descendants. Instead of that they ought to ask God daily and hourly to let all that 8

9 has stood the test of time be recognized as being legitimate, and that from time to 9

10 time a creature may be born who shall stamp entire centuries with his name. 10

11 One quiet evening I remembered that Cicero had left us a little work called $D e 11$

12 Senectute. For the first time I felt inclined to take it up myself ${ }^{782}$ and I found it most 12

13 charming. As these ancient authors, for the most part, write discursively, it is as if 13

14 what one understands as a matter of course were rattled off in conversation. ${ }^{783} \mathrm{He} 14$

15 makes the elder Cato speak, ${ }^{784}$ and he - if you look into it closely - only gives a list 15

16 of the excellent people in history 'who have grown old', and describes how well 16

17 old age worked to their advantage. Then comes, as an example, how unreasonable 17

18 it is to want to recall anything - even the immediate past. Much else that does not 18

19 concern me I leave aside, but I must mention how highly he esteems the value, the 19 brought about the abolition of nobility by birth.

782 Possibly Goethe is referring to works 23 with Riemer on 12 Fon 24 (iber, 25 Marcus Aurelius, among others, Goethe had already borrowed from the Weimar library 26 Cicero's philosophical work Cato maior de senectute liber in the German translation by 27 Friedrich Samuel Gottfried Sack (Elise von Keudell, Goethe als Benutzer der Weimarer 27 Bibliothek. Ein Verzeichnis der von ihm entliehenen Werke (Weimar: H. Böhlau, 1931, 28 reprint 1982), no. 1597. Hereafter referred to as Keudell.). On the other hand Goethe had 29 as late as 1826 refused to read the treatise, 'About Old Age and its Condition': 'I have 30 read nothing from this treatise (...) because I was of a mind to experience and to know an 31 inevitable human fate when it affected me'. who (following Plato's model) presented their themes in fictional conversations, wherby the 34 popular moral philosophy (of Epictetus, Seneca etc.) made use of the discussion through 35 an individual who dealt with a fictitious opponent or, as Cicero preferred (in the manner of 36 Aristotle), the juxtapostition of different opinions in related speeches of the participants; the 37 strict method and abstract language of the tract was consciously avoided and the interests 38 of a wider public was kept alive by way of rhetorical means, quotations, examples and 38 anecdotes.

784 The main person in the conversation is Marcus Porcius Cato the Elder with the 40 epithet 'Censorius', whom Cicero had presented as an 84-year old. His rigorous stoicism, 41 his strictness and obduracy is tempered in the dialogues; his younger partners in the 42 conversation are Publius Cornelius Scipio Aemilianus 'Africanus' the Younger (185- 43 $129 \mathrm{BC}$ ) and Gaius Laelius (c.190 to $129 \mathrm{BC}$ ). 
1 respect, the honour that are bestowed on old age after a life's achievement. This 1

2 comes freely out of the mouth of a first-rate Roman, who both thinks and speaks 2

3 so admirably about his ancestors that we cannot amount to much if we remain 3

4 unaffected by it. [...]

5 I have decided to bring Felix's most charming letter ${ }^{785}$ to light through the 5

6 Chaos when a fitting opportunity presents itself.

7 Your protégé shall be kindly received. ${ }^{786}$ Ottilie knows how to handle the

8 situation so that a stranger, who may not happen to interest me at a particular time,

9 is brought to me in a happy hour. I must take this opportunity to tell [you] that

10 she and the children behave most charmingly; I could elaborate but really there is 10

11 nothing to report, because something so tender cannot be expressed in words. 11

12 I myself have been renewing my friendship with the 24-year-old manuscript ${ }^{787} 12$

13 from which you have read some passages. ${ }^{788}$ I hope one day it will give you a 13

14 cheerful, and even at your advanced age, an informative hour. In this I am confirmed 14

15 by the words of the ancient sage, the truth of which I have recently discovered: 'I 15

16 am ever learning; and only thus do I notice my increasing years. ${ }^{789}[\ldots]$

17

18

19

19

25785 Felix Mendelssohn Bartholdy's letter to Goethe from Lucerne on 28 August 1831,

26 in which he described his arrival in Switzerland following his Italian journey, a storm in the

27 Bernese Oberland, his visit to a monatery in Engelberg, a performance of Schiller's Wilhelm

$28 \mathrm{Tell}$ and the completion of his choral setting of Goethe's 'Die erste Walpurgisnacht'; $G J b$

2912 (1891): 93-8.

$30 \quad 786$ Zelter's student, Otto Nicolai. Nicolai's planned visit to Goethe never took place. 30

31 In his diary on 18 May 1832, after Zelter's burial, Nicolai writes about his last meeting with 31

32 his teacher: 'He spoke of Goethe and still said to me, "You see what a stupid thing you did 32

33 by not going to Weimar in the summer!" (At the time he had given me a letter of introduction 33

34 to Goethe's daughter-in-law, through which I would have made the acquaintance of the

35 prince among poets). "But the young always believe they have plenty of time." How gladly

36 I would have gone to Weimar in the summer, but money, which had completely run out in

36 Leipzig, did not allow it. I explained to Zelter that it caused me unspeakable regret but I

37 had had no more money for the journey. In keeping with his usual bluntness, he replied,

38 "Alright, then you should have begged!"'; B. Schröder (ed.) Otto Nicholais Tagebücher

39 (Leipzig, 1892), p.6.

40787 Goethe alludes to the beginning of the fourth part of his autobiography, Dichtung 41 und Wahrheit.

42788 On 23 July 1831, during Zelter's visit to Weimar. 42

43789 Plutarch, Solon, 31, 7; Goethe was familiar with this through Cicero's Cato 43

44 maior. $\quad 44$ 
565. Goethe 1

$5[\ldots]$ Music, which is your life, is almost completely vanishing from my unpractised 5

6 senses. [...]

14 to Paris brought to me his pianist daughter, who performed contemporary Parisian 14

15 compositions; the type [of music] was new to me; it demanded great skill of the 15 performer, but is always entertaining; it is a pleasure to follow it and you accept. 16

790 Friedrich Wieck and his 12-year-old daughter Clara, later wife of Robert Schumann. 29 Of her visit, Goethe wrote in his diary on 1 October 1831: 'A very dexterous little lady, 30 playing piano, led by her father, played for me. They were new Parisian compositions, 31 demanding great skill of the performer, but always entertaining, so you gladly followed [the 32 music]'; WA III/13, pp. 148-9. Friedrich Wieck wrote of the visit in his diary, 'On 1 October 33 at 12 noon we had an audience with his Excellency, the 83-year-old Minister Goethe. We 34 found him reading and the servant led us in without further announcement because the day 35 before he had asked us to come and see him at this time. He gave us a friendly reception; 36 Clara had to sit on the sofa next to him. Soon after, his daughter-in-law arrived with her two 37 very precocious-looking children, ages 10 to 12 . Clara was then called upon to play, and 38 since the piano stool was too low, Goethe himself fetched a cushion from the anteroom and 39 put it in place for her. She played La Violetta by Herz. During her performace, more visitors 40 came and she then played Herz's Bravour-Variationen, op. 20. Goethe pronounced very 40 accurately on the compositions and on Clara's playing; he considered the pieces entertaining 41 and piquant in the French manner, and he praised Clara's [ability to] capture this character'; 42

Berthold Litzmann, Clara Schumann. Ein Künstlerleben. Nach Tagebüchern und Briefen (3 43 vols, Leipzig: Breitkopf \& Härtel, 1902-08), vol. 1, p. 28 f. 
5 [...] After the destruction of Troy - I mean the conquest of Paris ${ }^{791}$ - the victorious

6 Blücher was received by us at the Sing-Akademie with this song, ${ }^{792}$ and he 6

7 complimented me as a good general, whereby he admitted that he never yet 7

8 ventured an action with such a mass of attractive women, and that he doubted 8

9 whether he would succeed; at which point I replied that his good sword was at 9

10 home everywhere and that he should be certain of his victory over our hearts. 10

$11[\ldots]$ We are far advanced in the perfection of our pianofortes. ${ }^{793}$ When 11

12 comparing our fortepiano with the first made by Silbermann of Strasbourg, we 12

13 should be convinced that he laid the foundation of a Babylonian building that is 13

14 the confusion of tongues, the despair of musical sages, who fight like dogs to take 14

15 it all into their theory. French music may be compared to their politics: it is such 15

16 a mixture of feminine rambling; their best writers cannot shake themselves free 16

17 of it. A short time ago I heard Der Wasserträger ${ }^{794}$ again, a reputable work which 17

18 I would not criticize. And yet the music in itself, in those parts where it aims at 18

19 personifying the real earnestness of the libretto, is about as good as a drum covered 19

20 with human skin - and this is the best work by one of their best composers. I 20

21 will say nothing about this composer's setting of Medea. ${ }^{795}$ Punching the air and 21

22 fights with the mirror; all too much to amount to anything. Whoever finds the 22

23 confusion of sensations uninspiring should clearly stay away. Grétry ${ }^{796}$ is forgotten 23

24 too quickly; he does not overreach himself but his strength is growing. He lets 24

25 himself down gently and keeps his wings moving so that he can raise himself 25

26 again immediately.

792 Goethe's 'Vorwärts', from Epimenides. It will be remembered that Blücher was

$37^{793}$ Reflections in connection with Goethe's report of Clara Wieck's virtuoso 38 performance on his Streicher piano.

39794 Opera by Luigi Cherubini performed in Berlin in an adaptation by Gottlieb

40 Heinrich Schmieder after the libretto by Jean Nicholas Bouilly, Les deux journées, ou le 41 porteur d'eau (Paris, 1800).

42795 Opera by Luigi Cherubini; libretto by Carl Herklots after François Benoit 42

43 Hoffmann's Médée (Paris 1797).

$44 \quad 796$ The French composer André Ernest Modeste Grétry (1741-1813). 44 
5 Our Liedertafel is suspended ${ }^{797}$ and the money we would have spent is to be 5

6 given to widows and orphans. The Sing-Akademie also wants to put on a public 6

7 performance for such a cause in its hall on the $23 \mathrm{rd}$ of the month. ${ }^{798}$ The cost of 7

8 official measures [to cope with the cholera outbreak] should amount to 12 million. 8

9 The King is supposed to have indignantly rejected the suggestion of fencing off 9

10 the courts in Sansousi and Charlottenburg with the words: you want to turn me into 10

11 a wren king. You may be more respectful than the cholera, but you are expensive 11

12 enough.

The Hamburg Bach ${ }^{799}$ had allowed a fugue to be published. Agricola asked him, 19 'Have you read Marpurg's criticism ${ }^{800}$ of your new fugue? He has criticized you 20

798 A subscription concert 'for the local poor who have been placed in misery and in 23 desperate straits by the cholera epidemic'. The concert, which included works by Fasch, 24 J.S. Bach, C.P.E Bach, Spohr and Zelter, was held 'at 12 noon so that whole amount without 26 deduction of costs could be used for the intended purpose (...) without hereby wanting to 26 set a limit to the well-known generosity of the Berlin public, the price of an entrance ticket 27 will be fixed at 20 Sgr.'; Announcement in the Spenersche Zeitung on 1 October 1831; 28 the $A M Z$ reported on the concert, which was not terribly well attended, $A M Z(1831)$, no. 46, 29 16 November, column 762.

800 In a fragmentary essay about a letter of C.P.E. Bach's and the polemics between 32 Kirnberger on the one hand and Reichardt and Marpurg on the other side, Zelter wrote: 33 'Since Bach was both industrious and liked to have his excellent pieces printed, then 34 the broadcasting and recommendation by recognized artists pleased him more that the 35 criticism, which could be no more help to him. Marpurg had strongly criticized Bach's 36 two-part fugue in D minor, at which Bach had said to his former student, 'Shame! Shame! 37 Why hadn't Marpurg written his lovely review before I had finished my fugue? Now I know 38 what it is lacking. As long as I live I intend to write fugues, but none better than I can'; 39 quoted by Heinrich Bellermann, 'Nachtrag zu Kirnbergers Briefen'. In: $A M Z 7$ (1872), 40 pp. 441-4, quote page 443. Bach's only two-part fugue in D minor (H 99) is published in 40 Friedrich Wilhelm Marpurgs Fugensammlung (Berlin, 1758), but without criticism. Also in 41

43 a Duos in A minor ( $(\mathrm{H} 76$ ). Possibly the the criticism arose from Marpurg's fugal war with 43

44 Kirnberger, in his Kritischen Briefen zur Tonkunst. 
1 very severely.' 'No', said Bach; 'had he told me of his criticism beforehand, I 1

2 might perhaps have been directed by him; but if he likes his own fugues so much, 2

3 I cannot see how one of mine could please him.' $[\ldots]$

4 A new opera by Scribe and Auber, Die Liebestrank, ${ }^{801}$ is so desperately weak 4

5 and empty that the house, on the occasion of the second performance, seemed like 5

6 a morgue.

7 On the other hand, the people at the Königstädter Theater have staged another 7

8 new opera by Rossini, Das Fräulein am See, ${ }^{802}$ La donna del lago, and very nicely 8

9 too; it is certain to be a success. A Scottish knight named Douglas has promised his 9

10 beautiful daughter to a Herr Roderick; James V, King of Scotland, is also interested 10

11 in her, but she, no matter what, is determined to marry a Herr Malcolm Grame. 11

12 And that could happen anywhere. The text is a wonderful medley of continually 12

13 repeated, worn-out, recognizable Italian operatic conventions, ${ }^{803}$ yet the whole 13

14 thing is as feasible and agreeable as willing girls. So there you have the opera. 14

15 What drew me to it immediately was that you didn't miss having a long, broad, 15

16 pathetic overture. ${ }^{804}$ The opera commences with the action; it has all the distinctive 16

17 characteristics that enable us immediately to recognize the well-known composer, 17

18 while at the same time there are very clear signs that he is still developing as a 18

19 composer. The singers have more that enough to do, and yet they are assisted by 19

20 the orchestra which Rossini handles as easily as if he were holding a bell in his 20

21 hand - weaving his instrumentation in as ingeniously as if it were a natural growth. 21

22 There is much to find fault with too, but he who concentrates on that is in danger 22

23 of missing the most daring and delicate passages, as they fly by very quickly. The 23

24 chorus often enters with such brilliance and force that for a moment one feels older 24

25 by a few thousand years. The scene is, as I said before, in Scotland, and at times it 25

26 felt as if I was transported from the King's Bridge in Berlin to a solemn Highland 26

27 region, although the composer has not bothered to search out a single national 27

28 Scottish song. $\quad 28$

29 I mentioned to you before that I had taken another turn at the Schiller 29

30 correspondence. Two letters, numbered 389 and $390,{ }^{805}$ have set me thinking again. 30

31

32

33801 Opera by Daniel François Espirit Auber (libretto by Eugène Scribe, La philtre,

34 German adaptation by Karl August von Lichtenstein), premiered in Berlin on 15 October

351831 in the Königliches Opernhaus; see $A M Z 33$ (1831), no. 46, 16 November, column

$36 \quad 760$.

$37 \quad$ Goethe lightly edited Zelter's remarks on Rossini's opera Das Fräulein am See

37 and on the Königstädtisches Theater and had them published in Ottilie von Goethe's journal

38 Chaos.

39803 Gems from the text of this opera are to be found in a very humorous article, 'With

40 Some Librettists' in the Cornhill Magazine for November 1885.

41804 Like all his Neapolitan operas, Rossini begins La donna del lago without an 42 overture.

43805 Schiller's letter to Goethe on 12 December 1797, in which he, prompted by work 
1 Schiller writes, 'Can it really be that tragedy doesn't suit your nature because of its 1

2 pathetic force?' And later, 'A certain reckoning on the spectators is a hindrance to 2

3 you and perhaps for that very reason you are less suited to being a writer of tragedy 3

4 because you are completely created to be a poet in the generic sense. Anyhow 4

5 I see in you all the poetic specialities of a writer of tragedy in fullest measure 5

6 and if, bearing this in mind, you are really unable to write a perfectly genuine 6

7 tragedy, ${ }^{806}$ the reason must lie in the non-poetical requirements.' For my part, I 7

8 do not understand this chiaroscuro even though I know quite well what writing a 8

9 tragedy means and whether such things can be written, since poetry bears about 9

10 the same relation to writing as music does to the notes. 10

570. Goethe

17 I am glad to hear you sometimes go back to the Schiller correspondence. There 17

18 you find two men of serious intent at a fairly high level, you are inspired to the 18

19 same intellectual activity, you strive to place yourself beside them and if possible 19

20 above them; that is all to the benefit of the next generation. [...] As regards tragedy, 20

21 that is more difficult. ${ }^{807}$ I was not born to be a tragic poet because my nature is 21

22 conciliatory. As a result a purely tragic tale cannot interest me for it has to be, by 22

23 its nature, irreconcilable and to me, in the exceeding flatness of this world, the 23

24 irreconcilable seems an utter absurdity. I must not continue for in the course of 24

25 conversation one can go off the point - something I would prefer to avoid. 25

The cholera creeps through the streets like the dragon which a priest of Apollo had 32

33 prayed for and needs to eat more or less from one day to the next. People have also 33

34 got used to it: it is discussed in pulpits, cathedrals, over a drink and a smoke.

3 November: Yesterday I was at Molière's Médecin malgré lui in the French 35 36 theatre. ${ }^{808}$ The three acts unfolded all right and even with musical intermezzi the 36

37 whole thing was over within an hour.

39806 Reference to Schiller's words in the above letter to Goethe: 'if you really are unable 39

40 to write a real tragedy, then the reason must lie in the unpoetical demands [of tragedy].' 40

41807 Reference to Zelter's remarks on Goethe as a tragic poet; ZG 27 October 1831. 41

$42 \quad 808$ The Berlin premiere of Molière's three-act comedy took place in the Königliches 42

43 Schauspielhaus on 2 November 1831, performed by French actors and followed by Scribe's 43

44 Une Faunt. 
16 November: You know already that I relate everything to music and so I think 2 tragedy relates to the tragic like the fugue to fugal counterpoint. [If] the poet wants 3 to rise high up, lay a hand on the unfathomable, he becomes like the Titans and he 4 can consider himself lucky if he has to turn back unhumiliated.

$11[\ldots]$ You see that things are the same with me as always. Among the hundred things 11

12 that interest me one always asserts itself the central planet and the remainder of 12

13 the quodlibet of my life revolves around it variously, like the many shapes of the 13

14 moon, until one or other of the satellites succeeds in moving to the centre. 14

15 Next I should like to hear what news you have of our excellent Felix. I had a 15

16 highly interesting letter from Switzerland, ${ }^{809}$ part of which I reported in the Chaos; 16

17 I wrote to him in Munich but have not heard from him since then. [...] 17

$24[\ldots]$ The youngest daughter of Moses Mendelssohn was buried yesterday. ${ }^{810}$ Of 24

25 all the family, she was most like her father, petite and not well formed - a woman 25

26 of a refined, sharp intelligence, and above all very amiable. She inherited only a 26

27 small sum of money from her father and travelled to Paris, where she made the 27

28 acquaintance of General Sebastiani and became governess to his only daughter. 28

29 She educated this child up to the time of her marriage and received a pension of 29 30 nearly 3,000 francs for the rest of her life, which allowed her to return to live in 30 31 her native Berlin. It was a remarkable thing, to find no difference in language, 31 32 manners, or way of life in the Jewish maiden of Berlin, who, without the aid of 32 33 an imposing presence, had become a lady in one of the foremost Parisian houses. 33 34 Since she came back to Berlin ten years ago, though I have seen her frequently (and 34 35 always with pleasure), I have hardly heard her utter a word of French, English, or 35 36 Italian; on the contrary, she spoke the most transparent, flowing German with a 36 37 liveliness which reminded me of your schöne Seele. Her vocation as a governess 37 38 in Paris had made her convert to Roman Catholicism, but apart from her daily 38 39 attendance at Mass, no appearance of positive religiosity was discernible. Felix 39 40 was her particular favourite; she liked to have my letters to him and transcribe 40

$43 \quad 809$ Goethe had already written to Zelter about this letter on 17 September 1831. 43

44810 Henriette Mendelssohn (1775-1831) died on 9 November 1831. 
1 them for herself. She was at my house very recently and now all that remains with 1

2 me is a very pleasant memory of her. 2

9 A Madame Fischer, who had appeared as a guest here as surrogate for the leading 9

10 lady in the Königliche Oper, did not perform again. ${ }^{811}$ No one will say what [...] 10

11 is wrong with her. Young, pretty, flexible, healthy, a reliable voice but immature. If 11

12 they let the dear woman play 20 times, they could make a judgement. I only heard 12

13 her once and she was very good in places, though admittedly she appeared to me to 13

14 be much too good to be drowning 30 violins in the new large-scale operas. ${ }^{812}$ They 14

15 want one false thing after another and in the meantime I am trying to calm down 15

16 and I have not tried to get to know her personally. I really liked her. 16

Your dear present, ${ }^{813}$ so well prepared for me from a distance, which reached me 23 on the 11th of this month, more than marked my birthday in the most pleasant and 24

811 Beatrix Fischer-Schwarzböck from Karlsruhe appeared in Berlin from 7 October 27 1831. Her first guest role was as Donna Anna in Mozart's Don Giovanni with the Königliche 28 Oper. Further roles included: Agathe in Weber's Der Freischütz on 9 October; Emeline in 29 Weigl's Die Schweizerfamilie; the title role in Fidelio on 21 October; Julia in Spontini's Die 30

Vestalin on 4, 13 and 16 November, and Donna Anna again on 8 November. Although her 31 guest appearances should have ended on 18 November with a further appearance in Weigl's 32

Die Schweizerfamilie on 18 November, she sang the title role in Fidelio on 25 November 33 and the part of Julia in Spontini's Die Vestalin on 11 and 18 December - which Zelter could 34 not have known when writing this letter.

812 On his return journey from Berlin, the Weimar flautist Johann Christian Lobe wrote, 35 'But the numerical strength of the Berlin orchestra, coupled with the excellent performance 37 under Spontini, who conducted his work himself, really inspired me. The orchestra was 38 made up of 30 violins, 10 cellos, 7 double basses, 6 clarinets etc.'; Johann Christian Lobe, 38
Aus dem Leben eines Musikers, quoted in Gespräche, vol. III/1, p. 183 .

39
40 813 Goethe's poem 'Ein Füllhorn von Blüten', written for Zelter's birthday on 40 11 December. The turn of phrase 'in der Entfernung so wohl bereitetes' (what is prepared 41 from afar) refers to its content: the desire to bring the present, the cornucopia, to the 42 celebration was prevented by the wild snow storm; the symbolic images on the medal - and 43 4 in the poem itself - are the gifts prepared from afar. 
1 enduring way. [...] On that morning 40 of my students ${ }^{814}$ were the first to arrive 1

2 with some poems, specially written and set to music, which they had rehearsed 2

3 completely by themselves although I only began my colloquium this month. 3

4 Then 24 trumpet players of the Guards Uhlan regiment arrived with completely 4

5 new works by them, well prepared, and blasted out the house as if to bend it and 5

6 were not a little delighted when I stepped among them in order to grate my ears 6

7 and test my nerves. The fellows blew as if [it were] the Day of Judgement. 7

8 Then a choir of young women, youths, men and matrons of the Sing-Akademie 8

9 [arrived] who were also not shy in letting themselves be heard. 9

10 At twelve noon the violinists arrived and so it was lunchtime and children and 10

11 grandchildren, friends and companions enjoyed a prepared table $\mathrm{e}^{815}$ and greeted the 11

12 wine cellar. That was a day which, 73 years ago, created for my mother painful 12

13 joy. ${ }^{816}[\ldots] \quad 13$

14

15

16

576. Goethe

20 [...] The correspondence from 1830 is revised as

21 concerned. I leave it to Riemer's judgement regarding which passages are to be 21

22 left out and which modified. Hopefully, given the torrent of words that comes with 22

23 the all-powerful freedom of the press, he won't be too meticulous and succinct. 23

24 Leave this to future generations! [...]

31 I had hardly put down the pen when a new Opus operandum appears published 31

32 by Oels in Schlesien. Lindau, Vice Chancillor of the Gymnasium there, sends his 32

33 German translation of Pindar's first Pythian Song of Victory ${ }^{817}$ with the innocent 33

34 instructions to set it to music, Greek in style. The good man doesn't consider that 34

817 On 6 September 1831 August Ferdinand Lindau sent Zelter his translation of the

40 first ode from Pindar's Pythischen Epinikia; in the extensive accompanying writings he explained his discoveries on verse metre and music in Pindar's odes and asked Zelter for a

42 setting of translation in the style of Greek music. He believed 'that the totality would have

43 a lovely effect and would be a suitable piece for the Sing-Akademie, which is flourishing 44 under your direction'. 
1 we have fitted our own 'Heil dir im Siegerkranz' ${ }^{818}$ to the old English national 1

2 anthem (God save the King) and that half of our poets have worn themselves 2

3 out paraphrasing and setting the Lutheran Lord's prayer without anyone paying 3

4 attention to the melody. Now I am embarrassed about answering the man who 4

5 praises me highly and almost calls me his godfather. Or should I wait until the 5

6 honourable Pindar beyond the Styx should let music sound around my ears? I 6

7 enclose the correspondence to give our friend Riemer something to mull over, 7

8 because it's not the kind of thing I do. Please return it to me sometime. 8

9 [Doris] is bringing you your letters from last year ${ }^{819}$ which I don't have time 9

10 to read beforehand. The total is 32 . Let me know how many of mine are in your 10

11 possession from this year. [...] 11

12 Next Thursday, 12 January, is [the performance of] our second oratorio, Judas 12

13 Maccabaeus $^{820}$ by Handel, which is causing me concern. My first violinist ${ }^{821}$ with 13

14 the orchestra, a reliable (finally) attentive violinist, is coughing up blood and so I 14

15 have to break in another [first violinist] in three days who, admittedly, is good and 15

16 from the Königliche Kapelle [..] 16

17

18

$23[\ldots]$ For the sake of convenience I enclose the text for our next oratorio, ${ }^{822}$ which 23

24 we performed three years ago. ${ }^{823}$ One of our directors of music and royal court 24

25 organist $^{824}$ (from my school) has had a piano reduction of this oratorio published ${ }^{825} 25$

26 with a preface to which he has signed his own name ${ }^{826}$ and sent me a copy. Wouldn't 26

27 it be amazing if I liked this introduction? [...]

818 Prussian hymn, sung to the melody of 'God save the King'. 29 819 Doris travelled with Angelika Facius to Weimar, where she was a guest in Goethe's $\begin{array}{r}30 \\ 31\end{array}$ home from 10 January to 18 February.

820 For reviews see $A M Z 34$ (1832), no. 10, 7 March, column 156; MA 20.3, p. 1281, 32

821 Eduard Rietz died on 22 January 1832.

822 Ed Goth's 34

in Musik gesetzt von Georg Friedrich Händel (Berlin: Dieterici, 1828), with a two-page 35

unsigned preface.

823 It was performed four years earlier on 17 January and 6 February; Handel's Judas 37

Maccabaeus was in the Sing-Akademie's repertoire from 1811.

824 Karl Friedrich Ludwig Hellwig (1773-1838). 39

825 Händel's Oratorium Judas Maccabäus nach Mozarts Bearbeitung im Clavier- 40 Auszuge von Ludwig Hellwig, Musikdirektor und Hoforganist in Berlin (Hamburg: Johann 41

August Böhme o.J, 1832).

44 little alteration, the wording of the unsigned preface (by Zelter) in the libretti, which had 44 
1 Spontini wanted to send the manuscript of his new opera Les Athéniennes ${ }^{827} 1$

2 [with the letter] today; but nothing has arrived yet. According to him, you promised 2

3 him some comments on the text. ${ }^{828}$ When returning it, you might let it pass through 3

4 my hands. Since I am at the moment reading Greek, ${ }^{829}$ it will be doubly interesting. 4

$5[\ldots] \quad 5$

626

$\begin{array}{ll}7 & 7 \\ 8 & 8\end{array}$

$8 \quad$ 579. Zelter 8

929

$10 \quad$ Berlin, 9 to 10 January 183210

$11 \quad 11$

12 Sunday evening after the children set off ${ }^{830}$ and everyone with them, the whole 12

13 house was like an empty bird's nest. So I decided to see and listen to a brand new 13

14 opera: Der Orakelspruch by Contessa, with music by Baron von Lauer. ${ }^{831}$

15 A magic fairy, who was unlucky in love, decided upon raging hatred of the male 15

16 sex. At the same time she enclosed herself in a solitary area with a high wall (as 16

17 one now says). In order to bring up a tender delightful daughter with an abhorance 17

18 of love, she turned her male servants into hunchbacks. But an oracle spoke out 18

19 against it: if a dumb man could win the love of the girl, the spell would be broken. 19

20 A young prince, who, during the hunt, strayed across the wall mentioned, was 20

21 struck dumb and there you have the whole story, which apart from not unpleasant 21

22 verses has no lack of evenness and breadth. The music appeared to please friends 22

23 of the composer more than other people and after the second or third performance 23

24 had to be laid to rest. The opera has only one act, which I find bearable since I have 24

25 still encountered no one who can do it better than he can. [...] 25

$26 \quad 26$

$27 \quad 27$

28

29 been published by the Sing-Akademie for the performances of the oratorio (Dieterici 1814, 29

30 1820, 1828).

31827 Referring to his announcement of the opera on 31 March 1831, Spontini gave 31

32 Doris Zelter the libretto by Etienne Jouy for the planned opera Les Athéniennes as well as a 32

33 politely written letter to Goethe. Shortly afterwards Goethe praised Jouy's text in a letter to 33

34 Zelter and equally in his letter to Spontini on 19 January 1832; WA IV/49, p. 208.

$35 \quad 828$ See Spontini's letter to Goethe, where he writes, 'You also deigned to promise 35

36 me to write commentary in your own hand on the empty page of the manuscript or beside

37 the text'; perhaps here the desire for a highly valuable document in Goethe's own hand

37 was more important that his literary judgement. On 19 September 1832 Goethe thanked

38 Spontini for the manuscript and with full appreciation gave him his impressions based on a

39 first reading and asked for some time for a more thorough reading.

$40 \quad 829$ Reading the dramas of Euripides and Socrates. $\quad 40$

41830 Departure of Doris Zelter and Angelika Facius for Weimar. 41

42831 One-act opera by Adolf Lauer von Münchhofen (1795/96-1874), libretto by 42

43 Wilhelm Contessa, first performed on 8 January 1832 in the Königliches Opernhaus, 43

44 Berlin. 44 
1 Tuesday, 10 January: Yesterday evening was my first rehearsal of the oratorio ${ }^{832} 1$

2 mentioned and my new first violinist ${ }^{833}$ conducted himself courageously and 2

3 attentively. In the second rehearsal this evening I hope to see everything go off 3

4 smoothly. The soloists, Madame Milder, Madame Türschmidt, ${ }^{834}$ Mantius and 4

5 Riese, are superb and the choruses are rehearsed in the usual way. What is still 5

6 missing for me now is that you and Handel are those I would gladly learn from, 6

7 even if the various kinds of quacking of the female soloists are driving me to 7

8 despair. Even that can be dealt with, since it results in two hours of happiness. 8

$9[\ldots]$

10 Spontini sent me a letter for you with the manuscript of his opera ${ }^{835}$ very late 10

11 and strongly sealed. Doris dutifully removed the seal and hopefully read nothing. 11

12 Would you allow Doris to copy his letter to you and send it to me as well? ${ }^{836} 12$

13 I would in fact be very interested in what it might contain. Let me look through the 13

14 libretto ${ }^{837}$ with your remarks on it; I can vouch for the most discrete use. 14

21 A word from you or from our friend, Riemer, about Pindar's Song of Victory ${ }^{838} 21$

22 would be very helpful to me since I really want to answer the good Lindau, 22

23 although I have to guard against translating his translation into music. He points 23

24 me to our linguist, Wilhelm von Humboldt. He might as well have directed me to 24

25 his brother Alexander, because neither are in Berlin and I won't be going either to 25

26 Tegel $^{839}$ or Paris. ${ }^{840}[\ldots]$

27 The day before yesterday our second oratorio ${ }^{841}$ finally went off not too badly. 27

28 Choirs and orchestras [performed] smoothly and decently; one can guarantee that 28

832 Handel's Judas Maccabaeus.

833 Hubert Ries (1802-86), violinist and music educationalist, brother of the composer $\begin{aligned} & 31 \\ & 32\end{aligned}$

834 Anna Milder (soprano) and Auguste Türrschmidt (alto). 33

835 See ZG 8 January 1832 . 34

836 Goethe could no more accede to this request than to Zelter's request to have a look $\begin{aligned} & 35 \\ & 36\end{aligned}$ at the libretto.

837 The libretto for Les Athéniennes by Etienne Jouy. 37

838 ZG 4 to 7 January 1832; in Goethe's letters to Zelter Lindau's translation is no 38

$\begin{array}{ll}\text { longer mentioned. } & 39\end{array}$

839 Wilhelm von Humboldt lived in the Tegel residence. 40

840 Alexander von Humboldt was on a diplomatic mission in Paris from January 183141 to April 1832. ${ }^{841}$ Handel's Judas Maccabaeus was performed by the Sing-Akademie on 12 January 43 1832. 
1 at any rate and be acknowledged. The bass arias were excellent and powerful, all 1

2 sung by a superb student. ${ }^{842}$ The female singers of higher social rank are of the 2

3 opinion that they have been given everything by nature and if they are not happy 3

4 with themselves, the fault lies with the composer, or at least not with them. Since 4

5 they don't ask, I keep my opinion and my wine to myself. The whole thing was 5

6 marvellous, however, and great, and gave that impression. What more could one 6

7 want! [...]

8 I must listen. My students ${ }^{843}$ want to rehearse some night music for their 8

9 Professor Neander ${ }^{844}$ with me today, and I am glad to encourage them since they are 9

10 usually so good that I envy them their youth and the opportunities I give them. 10

17 Through the arrival of the good Doris we are really drawn so much closer to you. ${ }^{845}$

$18[\ldots]$ She brought so many things with her that I cannot understand how they put such 18

19 luggage in the express carriage. First and foremost my letters, which have already 19

20 been inserted between yours. ${ }^{846}$ The sum of the latter amounts to 41 , compared to 20

2132 of mine. You are that many steps ahead of me. Don't neglect to outdo me again 21

22 this year. In all honesty, my circumstances were pieced together from so many 22

23 little parts that one would almost fear the whole thing would crumble. With you 23

24 there are still large undertakings, from which you derive intense joy through which 24

25 the inevitable annoyances are compensated for and cancelled out. [...] 25

26 The libretto of Judas Maccabaeus looks good. ${ }^{847}$ The old tale: the conquered, 26

27 the oppressed, first patient, then rebellious after varying success, finally achieved 27

28 liberation - this is a good theme especially suited to music. [...] 28

29 Jouy's libretto for Spontini's opera Les Athéniennes is truly admirable. ${ }^{848} 29$

30 I have read it through once; there is great understanding of dramatic effects, an 30

31 assured and fresh treatment of such situations from which there is no escape; there 31

32 are pleasant resting places which interrupt the movement, which is partly solemn, 32

33 partly passionate, where unsophisticated arias can be introduced; the finales are 33

34 lively, well grouped and full of movement. Let anyone who has to sit through Act 34

$36 \quad 842$ Friedrich Riese (d.1859), a member of the Sing-Akademie since 1828, appeared as 36

37 bass soloist from 1829 to 1851 .

$38 \quad 843 \quad$ Zelter's Sing Collegium.

39844 August Neander, Professor of Theology at Berlin University. 39

$40 \quad 845$ Doris Zelter and Angelika Facius arrived in Weimar on 10 January 1832.

41846 Goethe's letters to Zelter from 1831.

$42 \quad 847 \quad$ ZG 8 January 1832.

$43 \quad 848$ See Goethe's letter to Spontini on 20 February 1832 and Spontini's reply on 2943

44 February (GSA 28/872). $\quad 44$ 
1 Three have something to strengthen the heart and senses. Still, I do not know of 1

2 any passage that I would cut or alter, I can only praise, and give sound reasons for 2

3 my favourable opinion [...] 3

$4 \quad$ I hear about the particular aspects of your world of music more precisely 4

5 through your good Doris. How many have an idea of the power of understanding 5

6 which is required in order to hold together such a body! 6

7

8

Yesterday, Sunday, after I had already worked with my students, ${ }^{849}$ like the King 13 of France with his Ministers, ${ }^{850}$ the musical entertainment took place according to 14 the instructions on the enclosure, which is intended for a quartet. Since there is no 15 joy without variations, new art forms have to be invented like No. 1 double quartet 16 17 for which eight people are required. ${ }^{851}$ Then No. 2 in the morning before breakfast 17 one is served up a serenade. Also the different feelings all in one place with 50018 people are more than different enough. Finally a military septet could belong to 19 such designations. The military aspect is a single trumpet which tries to get along 20 with six other players in the best possible way and which for that reason gave me 21 the most pleasure, since all of Hummel's works of this nature are the best that our 22 time has to offer. Wit, lightness, perfection, calm singability and flow: superb! It 23 always does me good.

Apart from that, the four-part vocal quartet with grand piano was the most 25 delightful thing. I would have gladly listened to a repeat; our people are happiest 26 when they omit them. [...] The effect of the serenade for four cellos, ${ }^{852}$ towards 27 evening on the lawn - only not today and before dinner - would certainly have 28 been very pleasant. My own feeling was not very clear. It was mythological, a 29 conversation amongst Ovid figures, at the same time Indian, bajaderian, gentle, 30 delighted without being delightful, and so on.

Someone who plays the double bass found the combination of four cellos very 32 ingenious and wondered whether it would also work four double basses in their 33 own way? I was of the same opinion since a group of four bulls in harmony would 34 
$5[\ldots]$ You need not trouble yourself about Jouy's operatic text; ${ }^{853}$ you only have 6 to send it back to Spontini, who will certainly lay it before me with whatever 7 comments you make. I, too, will let him know your enthusiasm for the text. I am 8 on good artistic terms with him, and he understands this very well for we both 9 make no pretences. We have often conducted important concerts back to back 10 and on such occasions I have found myself between two forces. The last time 11 this happened, in our largest church, ${ }^{854}$ and in the presence of the whole of the 12 court orchesta and chorus, he launched out very loudly in my praises; while I, in 13 my turn, could only admire his potential discretion in letting that with which he 14 was basically unfamiliar take its own course. The most agreeable part of it was 15 the universal acknowledgement; I had not moved but everybody knew what was 16 meant. [...]

17 I enclose another programme. ${ }^{855}$ Until recently the Italian composer Bellini 17 18 was unknown to me; God only knows whether I know him now. A duke has 18 19 forcibly stolen the count's beloved and made her his wife. The count returns six 19 20 years later as a pirate, kills the duke and thereby destroys himself; the wife goes 20 $21 \mathrm{mad}$, and all that is left is a little five-year-old boy. The score is a musical melange 21 22 which deliberately contradicts everything that happens on stage. One is tossed 22 23 and turned between eye and ear, feeling and reason, all of which clash with each 23 24 other. Having said all this, the fellow has talent and audacity, and lords it over the 24 25 orchestra and singers in the most impertinent fashion. Such stuff is now being 25 26 performed with a kind of virtuosity at the Königsstädter Theater. Now and then 26 27 I was in such despair that I was on the point of running away, but before I could 27 28 quite get up from my chair, something always caught my attention again. In the 28 29 end I was exhausted by it. [...]

3022 January: My excellent leader, Rietz, ${ }^{856}$ died the day before yesterday. 30 31 It's all very sad - and we'll cope with it. Now I shall have to roll the new stone 31

853 Out of consideration for Spontini, Goethe could not grant Zelter's wish to see

36 Jouy's unpublished libretto for their new opera.

$37 \quad 854 \quad$ Zelter is referring to the performance of Haydn's Creation by the Sing-Akademie

38 and the Königliche Kapelle directed by Spontini on 28 April 1830 in the Garisonkirche,

38 Berlin, attended by over 4,000 people

$39{ }_{855}$ A theatre programme for a performance of Vincenzo Bellini's opera Der Pirat

40 (libretto by Felici Romani, Il Pirata) on 20 January 1832 in the Königstädter Theater. 40

41856 Eduard Theodor Ludwig Rietz (1802-32) violin virtuoso and Kapellmeister, who in

421826 founded a Philharmonische Gesellschaft, an amateur orchestra that participated in the

43 Sing-Akademie concerts. His early death deeply affected his intimate friend Mendelssohn, 43

44 who inscribed the Andante in the String Quintet, op. 18, with the words 'In memory of 44 
1 uphill again. ${ }^{857}$ There are some left to pick from still; they are all keen to have the 1

2 position; expertise and strength will come in time. Rietz had all those qualities and 2

3 was also dutiful. 3

4

5

584. Goethe

7

8

$10[\ldots]$ The excellent Doris seems to be quite happy and at home here; she has 10

11 come just at the right time, when everything is in full swing and things are a little 11

12 crazy even in my house. A few days ago they performed a quodlibet of dramatic 12

13 fragments $^{858}$ at a private home ${ }^{859}$ under the direction of Ottilie, who understands 13

14 that sort of thing very well and is, therefore, in great demand and is listened to. 14

$15[\ldots]$

16 Inwardly and outwardly one lives in a perpetual state of conflict because of 16 17 the young people whose ways and activities one cannot sanction and at the same 17

18 time cannot completely avoid. I often pity them for having made their appearance 18

19 in times that are so out of joint, when a rigid unyielding egotism hardens itself in 19

20 ways that are partly or completely false and presents the true self from working 20

21 out its own development. The result is that when a free spirit perceives and 21

22 expresses what can allow itself to be clearly seen and expressed, everyone falls 22

23 into despair. Then they lead one another by the hand into the old, conventional 23

24 labyrinths, without noticing what they will encounter on the way. I shall guard 24

25 against expressing myself more concretely, but I know best what it is that keeps 25

26 me young in old age, and more especially in the practical and productive sense of 26

27 the word, which, after all, is what matters. 27

$28 \quad 28$

$29-29$

$30-30$

$31 \longrightarrow 31$

$32 \longrightarrow 32$

$33-33$

$34-\quad 34$

35 E. Rietz'. The autograph is dated 'Jan. 23,1832 ,' and entitled 'Obituary'. An obituary is 35 published in the $A M Z 34$ (1832), no. 10, 7 March, column 158.

857 Zelter compares training up a new first violinist to the work of Sisyphus. 36

858 Goethe's diary on 24 January 1832 states: 'At Schwendlers. Large-scale 37 entertainment under Ottilie's direction until midnight.' As detailed in Goethe's diary entry of 38 8 January, these 'living tableaux', representing the 12 months of the year, were performed: ${ }^{39}$ 'Later Ottilie (...) She explained to me the presentation of the 12 months of the year at 40 Schwendlers as being more sensible than in the form of charades. The result was rather 41

43859 In the house of the Weimar government official Friedrich Christian August von 43 
5 The Royal Academy of Science had announced an official gathering in celebration 6 of the birthday of Friedrich II, ${ }^{860}$ and Moeser, the music director, likewise arranged 7 a similar celebration for Mozart's birthday ${ }^{861}$ with music and a meal. So I was 8 between two tempters and didn't know whether I should put myself in bad humour 9 or give myself an upset stomach. Rosamunde ${ }^{862}$ must have noticed this as she had 10 prepared a small evening meal in our home among friends, so we let the dead rest 10 11 and the living live. [...] 1

18 I will not be able to write much this week and next because I have an official 18 19 production $^{863}$ ahead of me a week from now. [...] A couple of new operas ${ }^{864}$ invite 19 20 little comment. Everything endeavours to cultivate barren deserts and shifting 20 21 sands and there is a rich harvest of dead grass and chaff. At the market there are 21 22 buyers for everything and one enjoys criticizing: everything will be discussed, 22 23 written, read up and down, and so one wiles away tedious hours. 23

24 [...] Felix is now in Paris, ${ }^{865}$ and is causing a sensation both as composer and 24 25 performer. I enclose a short extract from his letter, ${ }^{866}$ from which you can see for 25 26 yourself what else he is occupying himself with. 26

$27 \quad 27$

$28+28$

29860 On 24 January. 29

$30 \quad 861$ One the evening before Mozart's birthday, a concert of Mozart's vocal and 30 31 instrumental works under the direction of Carl Moeser took place in the Jagor Hall on 2631 32 January 1832.

$33 \quad 862$ Zelter's daughter. 33

$34 \quad 863$ The third subscription concert took place on 9 February; apart from an aria and a 35 motet by J.S. Bach, the programme consisted of Mozart's Requiem. The performance was 36 dedicated to the memory of the deceased leader of the orchestra, Eduard Rietz; see $A M Z 34$ 36 (1832), no. 13, 28 March, column 218

37864 Wilhelm Taubert's Singspiel Die Kirmes, libretto by Eduard Devrient, premiered on

38 23 January 1832 at the Königliches Schauspielhaus (with further performances at the oper

39 house on 25 and 29 January, and 1 February). Also the opera Zampa oder die Marmorbraut

40 by Louis Joseph Ferdinand Hérold, libretto by Carl Ludwig Blum after Mélesville's Zampa,

41 ou La fiancée de marbre, premiered at the opera house on 31 January 1832; see AMZ 34 42 (1832), no. 9, 29 February, column 140ff.

$43 \quad 865$ Felix Mendelssohn was in Paris from December 1831 until the end of April 1832. 43

44866 Felix to Abraham Mendelssohn, 21 January 1832 (GSA 28/1027, no. 503). 44 
$5[\ldots]$ Right now I am reading Italian and happen to be looking up a passage in 5

6 Benvenuto Cellini. ${ }^{867}[\ldots]$ I still remember the first impression it made on me 306

7 years ago when you first brought the book to my study. I have now started it from 7

8 the beginning again and one chapter leads to another. The naivety with which that 8

9 young fellow describes his justified hatred of that accursed music attracted me 9

10 very powerfully, as I myself had experienced the same thing except the other way 10

11 round. How often have I, with tears and faithful prayers, ${ }^{868}$ called out to God to 11

12 change that dreadful taste of mine for the beloved music that I loved into a talent 12

13 more suitable to my condition and more rewarding to my father. All that was so 13

14 vividly present to me as if the former agony of my soul at that time was for the first 14

15 time brought before my eyes in a vision. I dare say I have written to you about this 15

16 ten times already, but the effect is always the same.

17 [...] I mentioned to you that I was reading Italian, which reminds me that the 17

18 Italian Spontini has just been dissolving your little Mignon $^{869}$ like a pearl in the 18

19 river of German instrumentation. The little piece is pretty and effective and Mignon 19

20 plays there like a child among children; if it continued in this way to the end, it 20

21 would be fine. However, the main focus is placed on very long-drawn, everlasting 21

22 repetitions of 'Kennst du es wohl?' ${ }^{870}$ and I should like to see the man who would 22

23 say, 'I suppose that means Italy'. It was performed at yesterday's concert with 23

24 full orchestra (drums excepted) to great applause. As the people were going out, 24

25 someone called out quite clearly, 'Away. Be gone and leave us unscathed. ${ }^{, 871} 25$

867 Goethe's translation of Cellini's autobiography, Leben des Benvenuto Cellini, 31 Florentinischen Goldschmieds und Bildhauers, von ihm selbst geschrieben (1803, reprinted, 32 Frankfurt: Insel, 2004). Frankfurt: Insel, 2004). In Cellini's account of his father's wish to educate his son in music and Cellini's 35 own determination to become a goldsmith, Zelter recognizes the converse of his own 36 youthful years: namely the conflict between his father's desire for Zelter to become a builder $\begin{aligned} & 36 \\ & 37\end{aligned}$ and his own musical inclinations.

869 On 6 February 1832 a concert was given in the hall of the Königliches 38 Schauspielhaus; the programme included Spontini's setting of 'Mignons Gesang', which 39 $\begin{array}{ll}\text { was performed with orchestral accompaniment. } & 40\end{array}$ ${ }_{870}$ Refrain from Mignon's song 'Kennst du das Land?' 
5 Yesterday's public performance went off smoothly enough and with a single 5

6 rehearsal of one and a half hours for a performance of two and a half hours. Two

7 rehearsals were arranged but on the day of the second rehearsal a grand opera was

8 performed, the court orchestra were not to be had, and so we had to do what we

9 could. Even this one rehearsal was raced through because the musicians still had

10 to play a public concert.

11 I must recognize it as a particular grace of God that, with my orchestra consisting 11

12 for the most part of voluntary amateurs, there has never been a scandal such as I 12

13 have seen with other orchestras. A hearty [impromptu] address to my people (who 13

14 are 300 strong) produced the effect once again [...] All ran and came and stood 14

15 like the walls and joyfully got down to it. They appreciated my encouraging glance 15

16 and were delighted like children over a couple of mistakes that I made. They don't 16

17 know how to play down such things. My new concert master ${ }^{872}$ is a good boy and 17

18 concentrates like a snipe shooter. 18

19 I also have a couple of new complicated operas behind me again: [...] Die 19

20 Marmorbraut $^{873}$ and [...] Der Templer und die Jüdin ${ }^{874}$ [...] The two composers 20

21 are of the same breed more or less. They bombard people's ears with their music 21

22 as if they were tanning leather! A rogue gives more than he has! Now the time has 22

23 come to refute the adage. God knows how it comes about that I can't say anything 23

24 from deep down within me that you haven't said better. So I think I should be able 24

25 to withhold my wisdom and refer to what you expressed at length under the title 25

26 'Music' in the appendix to Rameus Neffe. ${ }^{875} \mathrm{Be}$ it confirmation of a true belief and 26

27 of a similar feeling or fruit of a healthy seed. It is there and wants to remain. 27

873 Zampa, oder die Marmorbraut; ZG 1 to 2 February 1832.

874 Opera by Heinrich Marschner (libretto after Walter Scott's novel, Ivanhoe, freely

39 adapted by Wilhelm August Wohlbrück) premiered in Berlin on 3 August 1831; Zelter 40 attended the performance in the opera house on 10 February 1832.

41 attended the performance in the opera house on 10 February 1832.

42 Diderot's Le Neveu de Rameau, 'something general about the art' is said, 'so that every

43 reader will be able to form some sort of opinion about the ideas which are often enough 44 strangely expressed.' 
5 16 February: I have written to you about Auber's opera Der Gott und die Bajadere. ${ }^{876} 5$

6 Yesterday's performance ${ }^{877}$ was so remarkable in every respect that I really quite 6

7 revelled in the music. There is something Indian about it, quite different from 7

8 anything we have had before. Wit, novelty, easy flow - and our guest performer, 8

9 Mdlle Elßner, ${ }^{878}$ (the Bajadere) not only dances but acts more perfectly than anyone 9

10 I have seen since Vigano. ${ }^{879}$ The whole theatre was delighted with her. [...] Every 10

11 part of her face is a keyboard of colour played upon with marvellous charm [...] 11

12 The vocal parts are admirably cast. Mantius ${ }^{880}$ (the God) is a beginner, and rather 12

13 undersized, but his tenor voice is of great beauty and even throughout. He has 13

14 made excellent progress in a very short time. [...] 14

15 The day before yesterday we commemorated, with a Requiem mass, the memory 15

16 of a 21-year-old charming girl of obvious talent, who died of nerve fever. When I 16

17 took her on she sang high soprano arias and handled them with all the power of a 17

18 youthful physique. I advised her not to strain her lovely mezzo-soprano voice. But 18

19 her friends and whatever such vermin are called knew better and I cannot get rid 19

20 of the impression that my dear Ulrike Peters ${ }^{881}$ sang herself to death. 20

27 I will slot in here what I had occasion to jot down a few days ago: natural talent lives in us as one of our finest feelings, but presently it is of greater value that before when every beginner still believed in schooling, rules and mastery, and modestly subjected himself to the fundamentals of his particular $\quad 32$ subject about which most young people of today don't want to know.

For the last 30 years German plastic artists have been under the delusion that $\quad 34$

877 On 15 February 1832 in the Königliches Opernhaus together with Johanna 39 
1 hear an artist boast that he owes everything to himself! I generally listen to this 1

2 patiently, but sometimes I reply in annoyance, 'It looks like it too!' 2

3 For what is man in and through himself? When he opens his eyes and ears he 3

4 cannot avoid objectivity, example, tradition; he educates himself through these 4

5 for a while as well as he can, according to what is enjoyable and comfortable. 5

6 But just when he reaches the highest point, he finds this fragmentary existence is 6

7 not enough; the malaise which is the particular problem of the [purely] practical 7

8 man sets in. Happy is he who is quick to grasp what art means! 8

9 9 9

10 Much as I have accomplished in general and much as I have set in motion, I 10 11 can still only name one man who has cultivated himself from beginning to end 11 12 in accordance with my ideas. This was the actor Wolff, who is still honourably 12 13 remembered in Berlin. ${ }^{882} 13$

30 It takes a man like Auber (whose talent the critics are not agreed upon) to compose 30

31 music to three such acts, which will prevent anyone dying of ennui, and for this 31

32 an orchestra as good as the Parisian orchestra is required, and not worse than ours; 32

33 for the difficult passages given to singers and orchestra are the best thing about it, 33

34 if it all goes off well. $\quad 34$

$36-882$ Pius Alexa 36

$37 \quad 882$ Pius Alexander Wolff, for whom Goethe had made the notes that form the basis of 37

38 Regeln für Schauspieler, was acknowledged by Goethe to be his most faithful disciple in

39 artistic matters. Wolff was in Weimar from 1803 to 1816; it was a blow for Goethe and the

40 Berlin in 1816, but he took the Weimar [acting] style with him.

41883 Fra Diavolo oder Das Gasthaus bei Terracina, comic opera in three acts by

42 Daniel François Espirit Auber (libretto by Carl Blum after Eugène Scribe's Fra Diavolo, ou

43 l'Hôntellerie de Terracine) in the repertoire of the Königliches Theater from 3 August 1830. 43

44 Zelter attended the performance on 24 February 1824 in the Königliches Opernhaus. 44 
1 I have received from Paris a letter from Felix, dated the 15th of this month. ${ }^{884} 1$

2 As he has often been there, new acquaintances have been made continually, and 2

3 apparently, the political, no less than the artistic life there rekindles his love for 3

4 Germany. In respect of his artistic life, his experience is as I expected - though I 4

5 have never been to Paris - and businessmen or merchants, with whom he has been 5

6 acquainted from childhood, direct him to the best opportunities [...] 6

7

8

\section{Zelter}

Berlin, 4 to 6 March 183211

Yesterday at noon Prince Radziwill finally performed new and old passages from 13 Faust, ${ }^{885}$ for which I provided some 40 accomplices. The noble composer has 14 gone very deeply into the text, one could say fallen into it. One can notice the 15 effect the libretto had on him rather than how the music responds to the text. An 16 oyster-like clinging to the situations is paralysing, since no art is more transient 17 than music. The Dies irae seems unsuccessful to me because to clothe matters 18 related to the conscience in music is a task which contains an evil spirit in itself. 19 In the libretto it is placed perfectly through the words: Cathedral. Mass, Organ 20 and Song. ${ }^{886}$ That makes everything very clear. Gretchen says, 'That's not right. 21 You must believe in it ${ }^{\prime 87}$ - and you can't. You hit the nail on the head through the 22 simple title as if the organ had tackled you itself. To me it has always been a strong 23 confessor; it contains something accusatory, something satanic in itself. Against 24 that the stroll through Martha's Garden is very charming: like the scornful irony 25 which weighs itself against genuine love and prevails. We only had a grand piano 26 without orchestra and an audience of nobility: our Crown Prince, ${ }^{888}$ Duke Carl of 27 Mecklenburg (Mephisto), ${ }^{889}$ the Grand Duke Strelitz, ${ }^{890}$ [who] was delighted as 28

${ }^{884}$ After his return from Italy Felix Mendelssohn reported in his letter to Zelter on 31 15 February 1832 his musical experiences and impressions on his travels from Munich to 32 Düsseldorf via Stuttgart and Frankfurt. After that he writes a detailed criticism of Parisian 33 musical life.

885 Prince Radziwill was preoccupied with the setting of individual scences from 34 Goethe's Faust from 1808; Zelter had often reported on the progress of the work, which 35 was always interrupted by work, and on the performances in Prince Radziwill's home, 36 most recently in March 1831. In March 1830 three more scenes had been completed: 37 'Spaziergang mit Wagner'; 'Marthens Garten' and the cathedral scene. 38 886 Title of the cathedral scene in Goethe's Faust. 39 887 Gretchen's reaction to Faust's evasive answer to her questions about his religion 40 in the scene 'Marthens Garten'. 888 Friedrich Wilhelm, later King Friedrich Wilhelm IV. 42 889 Duke Carl von Mecklenburg-Strelitz, in the role of Mephisto from the beginning. 43 890 The Grand Duke Georg von Mecklenburg-Strelitz. 
1 always and whether he would have been if he could hear better, I don't want to 1

2 know! A spark ignites some receptive places here and there. Quietly the libretto 2

3 has borne fruit, amazing but frightening. You could see a different expression on 3

4 everyone's face in the audience and no one can conceal the devil. They read it the 4

5 way Catholics read the Bible.

6 I hardly know what to say about the performance of our Messiah last Thursday. ${ }^{891}$

7 Whoever stands on the sun doesn't see it and the tongue doesn't hear the bell. The

8 reviewers are sympathetic, touched on things of an accidental nature, ${ }^{892}$ and prefer

9 to remain popular among the young folk who also consist of reviewers and visibly

10 show a genuine seriousness. So we deal with one another best when I know how 10

11 things stand. But we must earn interest on 60,000 thaler per year ${ }^{893}$ and be happy 11

12 if musical professionals and popular virtuosi do not begrudge us the thalers which 12

13 we try to earn for them. Our hall was full this time and the professionals and 13

14 judges also had to pay.

15

16

21 A music director from Stettin, ${ }^{894}$ whom I helped to be promoted there ten years 21

22 ago, came here a week ago, announced a concert ${ }^{895}$ in which he would have his 22

23 own compositions performed, rented our hall, hired a large orchestra and since he 23

24 was certain of his stuff and didn't want to wait for a more suitable day, the concert 24

25 took place yesterday after I had removed some major obstacles.

$28 \quad{ }^{8}$ Handel's Messiah was performed in the context of the fourth subscription concert

29 by the Sing-Akademie on 1 March 1832.

$30 \quad 892$ Ludwig Rellstab wrote in the Vossische Zeitung on 3 March 1832: 'As far as the 30

31 whole thing is concerned, we can't remember such a successful performance of the work 31

32 as this: details such the incorrect tempo form the aria 'Das Volk das in Dunkeln wandelt'

33 and prominence of the string instruments, which were too loud for the unusually delicate

34 colours which Mozart added in the wind instruments, furthermore the wavering of the beat

35 in some places, for example in the introduction to part two, and other minor matters, hardly

36 come into consideration against the magnificent, noble conception of the entire work, which was specially expressed by the performance of the choir.'

893 The building cost of 60,000 thalers was three times the original cost estimated by Ottmer for the construction of the Sing-Akademie. The subscription concerts were

39 established as a means of repaying the debt.

$40 \quad 894$ Thanks to Zelter's recommendation and references, Carl Loewe had been music

41 director in Stettin since 1821.

$42 \quad 895$ For Loewe's account; see C.H. Bitter (ed.) Dr Carl Loewes Selbstbibliographie

43 (Berlin: Müller, 1870, reprint Hildesheim: Germanistische Texte und Studien vol. 20, 44 1976), p. 124f.

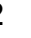
4

9

9

11

3

9

(1)

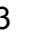

(1)

(2)

8


1 An overture and a piano concerto were really very good. In between he sang 1

2 ballads by Uhland and Herder ${ }^{896}$ and called upon me to give him a poem by Goethe 2

3 to improvise at the piano, which I modestly declined. Prince Radziwill set him 3

4 the challenge of 'Der Zauberlehrling ${ }^{897}$ and the improvisor didn't come out of the 4

5 wager badly, since it is no small feat even to read the poem publically without any 5

6 preparation.

7 After the concert the virtuoso stayed back for a glass of wine and [to eat] fish 7

8 with us in order to digest the applause of the grateful public, which unfortunately 8

9 consisted of connoisseurs (free tickets). Since one didn't let the reverberations die 9

10 off over the meal, he found the opportunity to lament the meagre takings, which 10

11 for him hardly covered a third of the outlay. I then said, my dear man, you have 11

12 discovered 'Der Zauberlehrling', now learn what it means. One doesn't sweep in 12

13 a paying audience with the broom and one will not get rid of the philistines. Your 13

14 concert is worth a thousand thalers; 300 cover the costs, the sum of 700 thalers 14

15 worth of fame and glory are left over for you. Take these with you to Stettin; 15

16 they will bear interest. That's how people with ability start. For only the master 16

17 conjures up the spirits; but Berliners are not Stettiners. This cleared the air. But he 17

18 left and is off today to invest his capital. And am I the better for it? The waters are 18

19 rising over my head and I would drown if I didn't take an occasional glass of wine. 19

20 The day before yesterday I listened to no less than 11 hours of music, one after the 20

21 other, and hardly had any time to eat. A bell will crack if it is struck long enough. 21

22 Tuesday 13 March: And you would have to ponder how priests and sextons, 22

23 goldsmiths and blacksmiths - each lives for his work and is supposed to be happy 23

24 in the fullness of his work. So it should be reported that along with essential daily 24

25 rehearsals over three days, four three- and four-hour rehearsals were dedicated to 25

26 the worthy Doctor Faust. Yesterday evening was the fourth, in the Prince's hotel ${ }^{898} 26$

27 in the presence of the court. The very best members of the Königliche Kapelle under 27

28 their Kapellmeister ${ }^{899}$ and a specially chosen vocal choir with my accompaniment 28

29 were, of course, not yet able to satisfy the princely master. The strictest obedience 29

30 and goodwill towards an honourable general is at the same time not everything. I 30

31 have already reported to you once on the matter from Darmstadt, ${ }^{900}$ I believe. You, 31

32 too, witnessed something similar in $1806 .{ }^{901}$ But everything could still be enjoyed 32

33

34

896 See the review in the $A M Z 34$ (1832), no. 19, 9 May, column 318f.; MA 20.3, 34 p. 1303.

897 Ibid.

898 Rehearsals for Prince Radizwill's setting of scenes from Faust, in his palace at 37 Wilhelmstraße, 77.

899 Georg Abraham Schneider (1770-1839), horn player, cellist, conductor and 39 composer.

900 ZG 20 August 1816.

901 Perhaps Zelter is thinking of the episode with Colonel von Massenbach described 42 in the Tag und Jahres-Heften of 1806, where Goethe wrote, 'Also the inclintion to [be a ] 43 writer of political acumen and military activity got in his way.' 
1 (since under such hands a complete failure is hardly imaginable) if the failure 1

2 consists in external details which could go wrong even for the best of people, where

3 the audience notices nothing unless it is expressly pointed out to them. If they are

4 fortunately brought off and recognized, they don't appear as an improper rendition.

5 For years the noble composer ${ }^{902}$ has spun himself into that work of the poet

6 like a silkworm: every thread holds him firmly. He has wedded the modernity of

7 the text which dwells in antiquity (eternal truth) with contemporary music which

8 sways back and forth in itself. What can be born naturally of this is jealousy of the

9 highest kind. One kills the other like the moor kills his beautiful white wife and

10 himself. $^{903}$ The music in itself is good and so well thought-out that a basic opinion 10

11 of it is perhaps impossible; especially since we all don't understand what we sing 11

12 and play with enjoyment. So you, too, may construct your gods, men and beasts, ${ }^{904} 12$

13 their duties and desires as suits you. 13

20 That's right! After having built and established your citadel through dedication 20

21 of your whole life, and not being without a trustworthy bodyguard and war- 21

22 like federation, you are manfully taking steps to preserve what you have won, 22

23 to promote your chief aim, and to lessen the burdens which must necessarily 23

24 accompany a position like yours. ${ }^{905}$

25 Here all kinds of examples from ancient history pass through my mind. I 25

26 cast these aside, however, for as a general rule one does not find any comfort in 26

27 the thought that the greatest of our ancestors must have fared much worse than 27

28 ourselves.

29 Fortunately, your individual gift is bound up with sound, namely with the 29

30 moment. Now, as a series of consecutive moments is always a kind of eternity in 30

31 itself, you have been allowed to remain constant in the midst of what is transitory 31

32 and so to satisfy fully both me and Hegel's spirit, in so far as I understand it.

33 Look at me on the other hand - living mainly in the past, less in the future and 33

34 for the time being in the distance - and remember that in my own way I am quite 34

35 content.

36 I have received from Naples a very pleasant communication from Zahn, that 36

37 good, energetic young fellow whom I dare say you still remember. I am really 37

$3 9 \longdiv { 9 0 2 }$ Radziwill. 39

$40 \quad 903$ Shakespeare's Othello. $\quad 40$

41904 A reference to Goethe's Götter, Helden und Wieland. 41

42905 Here Goethe uses the word 'citadel to refer to the building of the new Sing- 42

43 Akademie (the institution as well as the building); by 'efficient guards' he refers the student 43

44 Sing Collegium which was under Zelter's direction and which was always praised by him. 44 
1 pleased to discover that they have given my name to that house ${ }^{906}$ which has been 1

2 recently discovered, though they have not completely unearthed it. I am happy 2

3 with this. This is an echo from the past meant to temper the loss of my son. ${ }^{907} 3$

4 The house is considered to be one of the most beautiful discovered so far and 4

5 remarkable for a mosaic such as we have not yet met with from antiquity. ${ }^{908}$ This 5

6 was all announced in the newspapers long ago, so perhaps you have already heard 6

7 something about it.

8 They are sending me a detailed drawing of the vast enclosed space, columns 8

9 and all, ${ }^{909}$ as well as a miniature copy of the famous painting. ${ }^{910}$ We must be careful 9

10 that we don't behave like Wieland, ${ }^{911}$ who, with his delicate flexibility, allowed 10

11 what he last read to wipe out all that went before, for we might be quite tempted to 11

12 say that nothing has as yet come down to us from antiquity which matches this in 12

13 beauty of compositon and execution.

14 What would you say were they to lay before you an intelligible page of a 14

15 musical score belonging to a time in which you were forced to recognize a master 15

16 of the fugue, by its inner and outer criteria? I refer to a time suggestive of earlier 16

17 Grecian models.

18 The few but really serious connoisseurs you know ${ }^{912}$ will find ample material 18

19 for conversation and edification in this subject for some days to come. Besides 19

20 this, some perfectly different, yet equally interesting things have found their way 20

21 to me - namely, several specimens of an organic world that disappeared before 21

22 all historic times. Fossils of animals and plants ${ }^{913}$ are gathering around me, but it 22

23 is essential to refrain from thinking of anything but the origin and position of the 23

24 place of discovery, because to absorb oneself further in the contemplation of the 24

25 ages could only lead to madness. I should really like one day, as a joke, when you, 25

906 'Casa di Goethe' in memory of August von Goethe who had been present at the 29 excavation of the house in Pompeii. Today it is called 'Casa del Fauno'.

907 August von Goethe had died in Rome on the night of 26/27 October 1830.

908 Floor mosic after the Hellenic painting from $300 \mathrm{BC}$; it shows Alexe 31 Floor mosaic after the Hellenic painting from $300 \mathrm{BC}$; it shows Alexander the 32 Great's victory over Darius III. Wilhelm Zahn, under whose direction the mosaic was 33 uncovered, describes the mosaic in a letter to Goethe on 18 February 1832; $H A$, Briefe an 34 Goethe, vol. 2, p. 612. See also Bernard Andreae, 'Goethes Interpretation des Alexander- $\begin{aligned} & 34 \\ & 35\end{aligned}$ Mosaiks', JbSK 3 (1974): 41-9. 909 Ground plan of the 'Casa di Goethe in Pompeii by Wilhelm Zahn', MA 20.2, 36 p. 1676.

910 Drawing of the Alexander Mosaic by Wilhelm Zahn.

912 Riemer (see Goethe's diary on 6, 8 and 9 March) and Coudray (see Goethe's diary 42 on 11 and 12 March; WA III/13, pp. 232-3). 
1 with your lively disciples ${ }^{914}$ are rehearsing live choruses, to place before you a 1

2 primeval elephant's molar dug out of our gravel pits; you would feel the vivid and 2

3 charming contrast. ${ }^{915} 3$

So be it, then! 4

595. Zelter to Privy Councillor und Chancellor von Müller at Weimar 8

$1832 \quad 10$

12 I could not thank you until today, honourable sir, for your most friendly 12 13 consideration notwithstanding the present occasion. ${ }^{917} \quad 13$

14 What was to be expected, what was to be feared, inevitably came. The hour 14

15 has struck. The hand of the clock stands still like the sun at Gideon; for behold, the 15

16 man who bestrode the universe on pillars of Hercules lies overthrown, while under 16

17 him the powers of the earth contended for the dust beneath their feet.

18 What can I say of myself - to you, to all there? And everywhere? As he is gone 18

19 before me, so daily do I draw nearer to him, and I shall catch up with him again 19

20 and perpetuate that lovely peace which for so many successive years cheered and 20

21 enlivened the space of 36 [German] miles ${ }^{918}$ that lay between us. 21

22 Now I have a request: continue to honour me with your kindly letters. You will 22

23 be able to judge how far I can be trusted, as the undisturbed relations between two 23

24 close friends who were always one - though judged by their capacities, far apart - 24

25 are well known to you. I am like a widow who has lost her husband, her lord and 25

26 provider, and yet I should not grieve. I am astonished at the riches he brought me. 26

27 It is my duty to preserve that treasure, and to turn the interest into capital. 27

28 Pardon me, noble friend! I should not complain and yet my old eyes don't want 28

29 to obey and they let me down. But once I saw him weep - and that must justify 29

30 my tears.

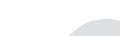

$$
914 \text { Zelter's Sing Collegium. }
$$

39915 Reference to Luke 21, v. 22.

40916 This is Goethe's last letter. Zelter wrote to Goethe for the last time, on the day of 40

41 the poet's death, 22 March 1832; the letter reached Weimar on the day of the funeral. 41

42917 This letter is from JbSK (1927/28). 42

$43 \quad 918$ The German mile was much longer than a western European mile. It was 24,000 43

44 German feet as opposed to the English statute mile of 5,280 feet. 44 


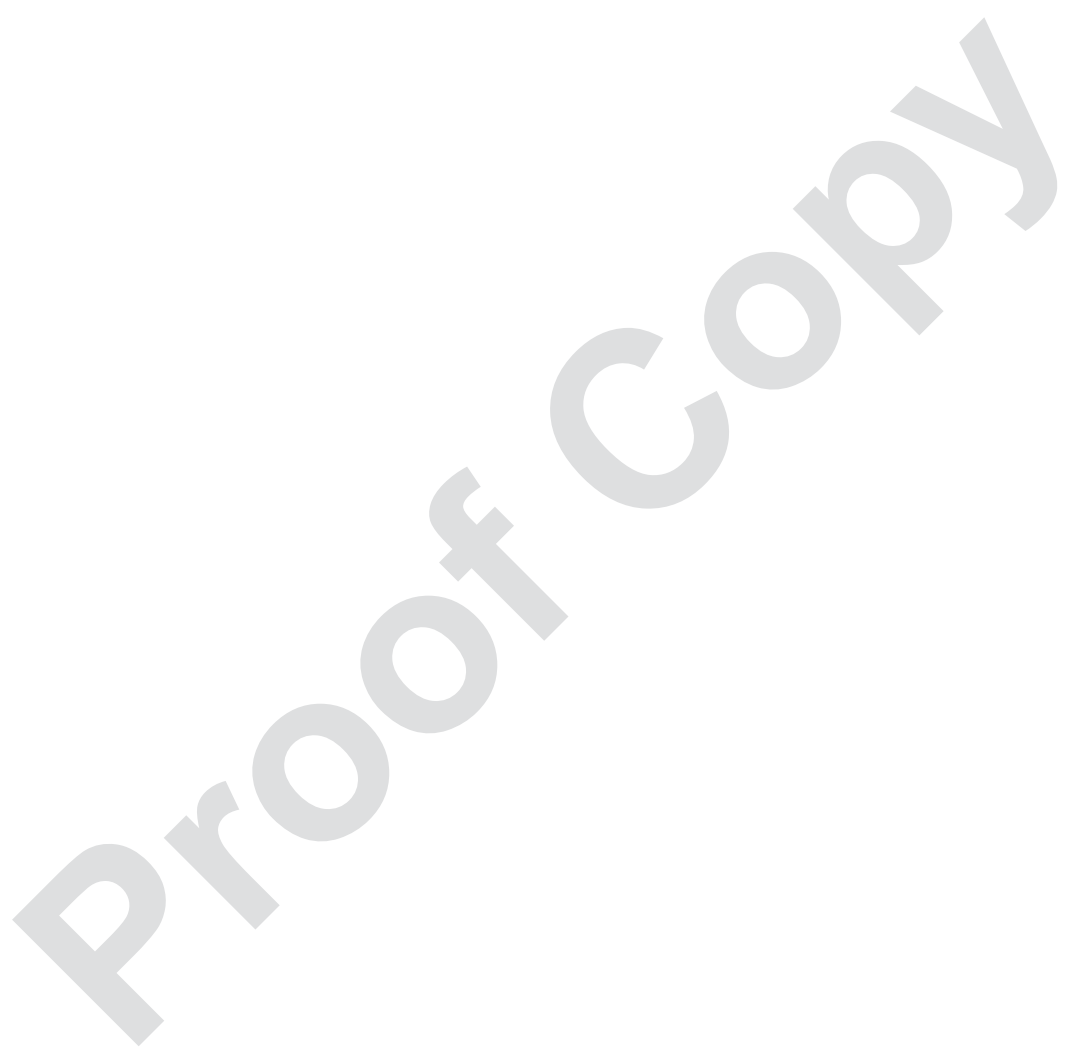


7 Goethe and Zelter: Encounters

\begin{tabular}{|c|c|c|}
\hline Year & Dates & Place \\
\hline 1802 & 24 to 28 February & Weimar \\
\hline 1803 & Early Summer (End of May to 11 June?) & Weimar \\
\hline 1805 & 9 to (presumably) 12 August & Lauchstädt \\
\hline \multirow[t]{2}{*}{1810} & 15 to 20 July & Carlsbad \\
\hline & 7 to 23 August & Teplitz \\
\hline \multirow[t]{4}{*}{1814} & 24 to 28 June & Berka \\
\hline & 28 June to 7 July & Weimar \\
\hline & 29 July to 31 August & Wiesbaden \\
\hline & 1 September & Winkel \\
\hline \multirow{2}{*}{1816} & 5 to 8 July & Weimar \\
\hline & 28 September to 2 October & Weimar \\
\hline 1818 & 25 October to 1 November & Weimar \\
\hline \multirow[t]{3}{*}{1819} & 22 to 25 June & Weimar \\
\hline & 26 to 27 June & Jena \\
\hline & & Dornburg \\
\hline \multirow[t]{2}{*}{1821} & 4 to 12 November & Weimar \\
\hline & 15 to 19 November & Weimar \\
\hline 1823 & 24 November to 13 December & Weimar \\
\hline 1826 & 7 to 19 July & Weimar \\
\hline 1827 & 12 to 18 October & Weimar \\
\hline \multirow[t]{4}{*}{1829} & \multirow[t]{3}{*}{14 to 17 September } & Weimar \\
\hline & & Dornburg \\
\hline & & Jena \\
\hline & 19 to 21 September & Weimar \\
\hline 1831 & 22 to 26 July & Weimar \\
\hline
\end{tabular}




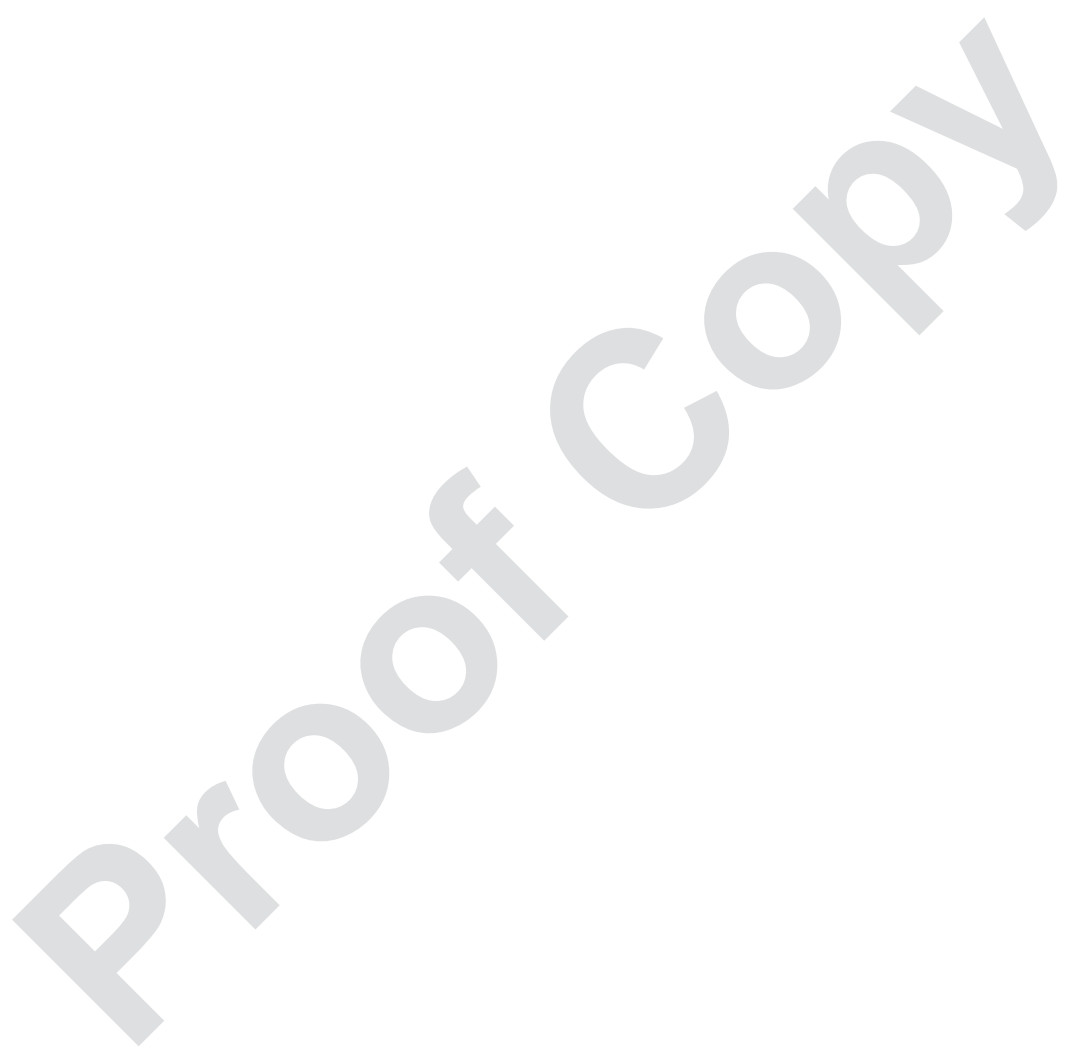


10 Berlinische Musikalische Zeitung, (ed.) Johann Friedrich Reichardt, vol. 1 (1805) 10 11 and vol. 2 (1806).

12 Eckermann, Johann Peter, Gespräche mit Goethe in den letzten Jahren seines 12

13 Lebens, (ed.) Heinrich Hubert Houben, 26th edn (Wiesbaden: Insel Verlag, 13 14 1975).

15 Goethe, Johann Wolfgang von, Werke. Weimarer Ausgabe, (eds) Gustav von 15

16 Loeper, Erich Schmidt, Hermann Grimm et al. on the instructions of the Grand 16

17 Duchess Sophie von Sachsen-Weimar-Eisenach (143 vols, Weimar: Hermann 17

18 Böhlau, 1887-1919; reprint Munich, 1987). 18

19 Goethes Werke Hamburger Ausgabe, (ed.) Erich Trunz (14 vols, Hamburg: 19

20 C.H. Beck, reprint 1994). 20

$21-J . W . V$. Goethe. Sämtliche Werke nach Epochen seines Schaffens. Münchner 21

22 Ausgabe, (eds) Karl Richter et al. (21 vols, Munich: Carl Hanser Verlag, 1985- 22

23 98).

24 Briefwechsel zwischen Goethe und Zelter in den Jahren 1796 bis 1832, (ed.) 24

25 Friedrich Wilhelm Riemer (6 vols, Berlin: Hermann Böhlau, 1833-34). 25

26 Briefwechsel zwischen Goethe und Zelter in den Jahren 1799 bis 1832, (ed.) 26

27 Ludwig Geiger (3 vols, Leipzig: Reclam, o.J.). 27

28 Briefwechsel zwischen Goethe und Zelter, (ed.) Max Hecker (Frankfurt am Main: 28

29 Insel Verlag, reprint 1987).

30 Briefwechsel mit Zelter, (eds) Hans-Günter Ottenberg, Sabine Schäfer and Edith 30

31 Zehm in Karl Richter (ed.) Goethe Sämtliche Werke nach Epochen seines 31

32 Schaffens. Münchner Ausgabe, vols 20.1, 20.2 and 20.3 (Munich: Hanser 32

33 Verlag, 1985-98).

34 Goethe-Zelter Briefwechsel, (ed.) Werner Pfister (Zurich and Munich: Artemis, 34

35 1987).

36 Briefwechsel zwischen Goethe und Zelter. Eine Auswahl, (ed.) Hans-Günter 36

37 Ottenberg. (Leipzig: Reclam, 1987). 37

38 Goethe Handbuch, (eds) Bernd Witte, Theo Buck, Hans-Dietrich Dahnke, Regine 38

39 Otto and Peter Schmidt (4 vols, Stuttgart and Weimar: Metzler Verlag, 1996- 39

40 99). 40

41 Goethe im Urteil seiner Kritiker. Dokumente zur Wirkungsgeschichte Goethes 41

42 in Deutschland, (ed.) Karl Robert Mandelkow (4 vols, Munich: C. H. Beck, 42

43 1975ff). $\quad 43$

44 
1 Goethe über seine Dichtungen. Versuch einer Sammlung aller Äußerungen des 1

2 Dichters über seine poetischen Werke, (ed.) Hans Gerhard Gräf $(9$ vols, 2

3 Frankfurt am Main: Literarische Anstalt Rütten \& Loening, 1901-14). 3

4 Goethe und die Romantik. Briefe mit Erläuterungen, (eds) Carl Schüddekopf and 4

5 Oskar Walzel, SchGG 13 (1898) and SchGG 14 (1899). 5

6 Mendelssohn-Bartholdy, Felix, Briefe aus den Jahren 1830-1847, (eds) Paul and Karl 6

$7 \quad$ Mendelssohn Bartholdy (2 vols, Leipzig: Hermann Mendelssohn, 1861-63). 7

8 Reisebriefe von Felix Mendelssohn Bartholdy aus den Jahren 180 bis 1832, 8

9 (ed.) Paul Mendelssohn Bartholdy, 3rd edn (Leipzig: Hermann Mendelssohn 9

10 1862, reprint 1947). 10

11 Mendelssohn Bartholdy, Karl, Goethe und Mendelssohn (Leipzig: Hirzel Verlag, 11

12 1872). 12

13 Reichardt, Johann Friedrich, Lyceum der schönen Künste 1 (Berlin: F.J. Unger, 13

14 1797). 14

15 Schiller, Friedrich von, Schillers Werke. Nationalausgabe, edited in collaboration 15

16 with the Goethe and Schiller Archive, Weimar, and the Schiller National 16

17 Museum, Marbach (46 vols, Weimar: Verlag Hermann Böhlaus Nachfolger 17

18 Weimar GmbH \& Co., 1943ff). 18

19 Zelter, Carl Friedrich, Die Liedertafel (Berlin: Zelter's Manuscript Copy GMD 19

20 Catalogue no. 1931, 1818). 20

21 Karl Friedrich Christian Fasch (Berlin: J. F. Unger, 1801). 21

22 Carl Friedrich Zelter. Eine Lebensbeschreibung. Nach autobiographischen 22

$23 \quad$ Manuscripten bearbeitet von Wilhelm Rintel (Berlin: Otto Janke, 1861). 23

24 Lieder. Faksimile der wichtigsten gedruckten Sammlungen nebst Kritischem 24

25 Bericht, (eds) Reinhold Kubrik and Andreas Meier, Das Erbe deutscher Musik, 25

26 vol. 106 (Munich: C. Henle Verlag, 1995). 26

$27 \quad 27$

$28 \quad 28$

29 Secondary Literature $\quad 29$

$30 \quad 30$

31 Abert, Hermann, Goethe und die Musik (Stuttgart: J. Engelhorns, 1922). 31

32 Adrio, Adam, 'Wirkungen Goethes im Berliner Musikleben seiner Zeit' in Fritz 32

33 Moser (ed.) Goethe in Berlin (Berlin: Wedding-Verlag 1949). 33

34 Albertsen, Leif Ludwig, 'Kritik an Schuberts Umgang mit Goethe-Texten mit 34

35 einem Anhang über Zelter', GJb 102 (1985): 226-37. 35

36 Anonymous, 'Rezension des Briefwechsels zwischen Goethe und Zelter', The 36

$37 \quad$ Foreign Quarterly Review 32 (1836): 328-60. 37

38 Anonymous, 'Der Zeltersche Briefwechsel und die preußische Censur', GJb 2238

39 (1901): 107-109. 39

40 Arnheim, Amalie, 'Zur Geschichte der Liebhaberkonzerte in Berlin im 18. 40

41 Jahrhundert', Mitteilungen des Vereins für die Geschichte Berlins 30 (1913): 41

42166.

$43 \quad 43$

$44 \quad 44$ 
1 Auerbach-Schröder, Cornelia, 'Frauen in der Geschichte der Sing-Akademie' in 1

2 Werner Bollert (ed.) Sing-Akademie zu Berlin. Festschrift zum 175jährigen 2

3 Bestehen (Berlin: Rembrandt Verlag, 1966), pp. 97-105. 3

4 Bandtz, Hans-Joachim, Die Beziehungen Zelters zu Potsdam und zur Potsdamer 4

$5 \quad$ Liedertafel. Typescript (Potsdam, 1934). 5

6 Barr, R.A., Carl Friedrich Zelter. The Study of the 'Lied' in Berlin (Wisconsin: 6

$7 \quad$ Unpublished Doctoral Dissertation, 1968). 7

8 Baser, Friedrich, 'Goethes Freund in Heidelberg', Alt-Heidelberg. Wochenbeilage 8

9 zum Heidelberger Tageblatt 42 (1931), 17 October. 9

10 -Der Liedkomponist Zelter in Heidelberg', Die Heimat. Beilage der 10

11 Heidelberger Nachrichten/ Heidelberger Anzeiger 21 (1932), 21 May. 11

12 Bauman, Thomas, North German Opera in the Age of Goethe (Cambridge, New 12

13 York: Cambridge University Press, 1985). 13

14 Baumberg, E. von and Weizsäcker, P., 'Zum Goethe-Zelterschen Briefwechsel ed. 14

$15 \quad$ Ludwig Geiger', GJb 22 (1901): 91-109. 15

16 Becker-Cantarino, Barbara, 'Leben als Text. Brief als Ausdrucks- und 16

17 Verständigungsmittel in der Briefkultur und Literatur des 18 Jahrhunderts' 17

18 in Hiltrud Gnüg and Renate Möhrmann (eds), Frauen. Literatur. Geschichte. 18

19 (Stuttgart: Metzler Verlag, 1985), pp. 83-103 and 515-17. 19

20 Béringuier, R., 'Carl Friedrich Zelter', Vermischte Schriften im Anschlusse an die 20

21 Berlinische Chronik und an das Urkundenbuch 1 (1888): 1-8. 21

22 Birnbaum, Max, 'Zum Briefwechsel zwischen Goethe und Zelter', GJb 27 (1906): 22

$23245 \mathrm{f} . \quad 23$

24 Blum, Lothar und Andreas Meier (eds), Der Brief in Klassik und Romantik. 24

25 Aktuelle Probleme der Briefedition (Würzburg: Königshausen und Neumann, 25

26 1993). 26

27 Blumenthal, Marie Luise, 'Die Freundschaft zwischen Goethe und Zelter', Die 27

$28 \quad$ Sammlung 12 (1957): 345-63. 28

29 Blumner, Martin, Geschichte der Sing-Akademie zu Berlin (Berlin: Horn \& 29

$30 \quad$ Raasch, 1891). 30

31 Bode, Wilhelm, Die Tonkunst in Goethes Leben (2 vols Berlin: E.G. Mittler \& 31

32 Sohn, 1912). 32

33 Goethes Schauspieler und Musiker (Berlin: E.G. Mittler \& Sohn, 1912). 33

34 Boerner, Peter, 'Goethes Briefwechsel mit Zelter', Wissenschaftskolleg - Institute 34

35 für Advanced Studies - zu Berlin (1986/87): 27-9. 35

36 Böhme, Erdmann Werner, 'Zelter beschreibt Goethe Vorpommern, Rügen und 36

37 eine Segelbootfahrt über die pommersche Ostsee', Unser Pommerland 1737

38 (1932): 1-33. 38

39 Bohnenkamp, Anne, '...das Hauptgeschäft nicht außer Augen lassend'. Die 39

40 Paralipomena zu Goethes 'Faust' (Frankfurt am Main and Leipzig: Insel 40

41 Verlag, 1994). 41

42 Bohrer, Karl Heinz, Der Romantische Brief. Die Entstehung ästhetischer 42

43 Subjektivität (Frankfurt am Main: Suhrkamp, 1989). 43

$44 \quad 44$ 
1 Bollert, Werner (ed.), Sing-Akakademie zu Berlin. Festschrift zum 175jährigen 1

2 Bestehen (Berlin: Rembrandt Verlag, 1966). 2

3 Bollert, Werner, 'Die Händel-Pflege der Berliner Sing-Akademie unter Zelter und 3

4 Rungenhagen' in Werner Bollert (ed.), Sing-Akakademie zu Berlin. Festschrift 4

5 zum 175jährigen Bestehen. (Berlin: Rembrandt Verlag, 1966), pp. 69-79. 5

6 Bornemann, Wilhelm, Die Zeltersche Liedertafel in Berlin, ihre Entstehung, 6

$7 \quad$ Stiftung und Fortgang (Berlin: Decker, 1851). 7

8 Brachvogel, Albert Emil, Geschichte des Königlichen Theaters zu Berlin. Nach 8

9 Archivalien des Königl. Geh. Staats-Archivs und des Königl. Theaters (Berlin: 9

10 O. Janke, 1877). 10

11 Brodtbeck, Felix, 'Carl Friedrich Zelter 1758-1832', Tiroler Volkskultur 3411

13 Bülow, Paul, 'Carl Friedrich Zelter', Türmer 34 (1932/33): 319f.

14 Büngel, Werner, Der Brief. Ein Kulturgeschichtliches Dokument (Berlin: Mann, 14

15 1938).

16 Bürck, August, 'Briefwechsel zwischen Goethe und Zelter in den Jahren 1796 bis 16

171832 ' in Neue Leipziger Zeitschrift für Musik 1 (1834), p. 2f; vol. 4, p. 13f; 17

18 vol. 6, p. 21f; vol. 7, pp. 25-7; vol. 8, p. 29f; vol. 9, p. 39f; 2 (1835), vol. 29, 18

20 Bürgel, Peter, 'Der Privatbrief. Entwurf eines heuristischen Modells', Deutsche 20

22 Brusniak, Friedrich 'Ein unbekannter Brief Zelters an Schiller aus dem Jahre 22

24 Dahlhaus, Carl, Studien zur Musikgeschichte Berlins im frühen 19. Jahrhundert, 24 Studien zur Musikgeschichte des 19. Jahrhunderts, vol. 56 (Regensburg: 25

26 Bosse, 1980).

27 Deetjen, Werner, 'Immermann über den Briefwechsel zwischen Goethe und 27

28 Zelter', GJb 2 (1915): 246-9.

29 Eberle, Gottfried, 200 Jahre Sing-Akademie zu Berlin. 'Ein Kunstverein für die 29

30 heilige Musik' (Berlin: Nicolai, 1991).

31 Eberwein, Karl, 'Goethes Hausmusik' in Wilhelm Bode, Stunden mit Goethe 31

32 (Berlin: Mittler \& Sohn, 1911): 70-290.

33 Ebrecht, Angelika, Regina Nörtemann und Herta Schwarz (eds), Brieftheorie des 33

35 Eitner, Robert, 'Karl Friedrich Zelter', $A D B 45$ (1898): 46-52.

36 Elvers, Rudolf, 'Ein nicht abgesandter Brief Zelters an Haydn', Musik und Verlag 36

37 (1968): 243-5.

38 - 'Musikdrucker, Musikalienhändler und Musikverleger in Berlin 1750 bis 38 1850. Eine Übersicht' in Georg von Holschneider and Andreas Dadelsen (eds), 39

41 Fairley, Barker, 'Inspiration and Letter Writing. A Note on Goethe's Beginnings as 41

42 a Poet', GR 24 (1949):161-7.

43 _ 'Goethe's Last Letter' in University of Toronto Quarterly 27 (1957/58): 1-9. 43 
1 Fischer, Lysander, 'Zwischen Beruf und Berufung. Ein Erinnerungsblatt für Carl 1

2 Friedrich Zelter, den Mauer und Musiker, den Freund Goethes. Zu Zelters 200. 2

3 Geburtstag', Gewerbeschule 49 (1958): 66-72 and 88-93. 3

4 Fischer-Dieskau, Dietrich, Carl Friedrich Zelter und das Berliner Musikleben 4

5 seiner Zeit. Eine Biographie (Berlin: Nicolai, 1997). 5

6 Friedländer, Max, Gedichte von Goethe in Compositionen seiner Zeitgenossen, 6

72 vols $S c h G G 11$ (1896) and SchGG 31 (1916). 7

8 - Das deutsche Lied im 18. Jahrhundert. Quellen und Studien, 2 vols (Stuttgart 8

9 and Berlin: Cotta, 1902; reprint, Hildesheim: Georg Olms Verlag, 1962). 9

10 _Goethe und die Musik' in GJb 3 (1916): 275-340. 10

11 _Musikerbriefe an Goethe', GJb 12 (1891). 11

12 Gappenach, Hans, 'Aus der Geschichte des Liedes "Es war einmal ein König in 12

13 Thule". Zum Gedenken an den 200. Geburtstag von Carl Friedrich Zelter, 13

14 Der Chor 10 (1958): 187f. 14

15 Geiger, Ludwig (ed.), 'Aus Berliner Briefen Augusts von Goethe (19-26 Mai 15

16 1819), Ein Brief der Ottilie (undatiert)', GJb 28 (1907): 26-56. 16

17 _Einleitung' in Der Briefwechsel zwischen Goethe und Zelter (Leipzig: 17

18 Reclam, o.J) vol.1, pp. 3-32. 18

19 Gerhard,Anselm,Musikund Ästhetikim BerlinMoses Mendelssohns, Wolfenbütteler 19

20 Studien zur Aufklärung, vol. 25 (Tübingen: M. Niemeyer, 1999). 20

21 Gilow, Hermann, 'Zur ersten Aufführung von Goethes Mahomet in Berlin 1810', 21

22 GJb 28 (1907): 218-24. 22

23 Goslich, Ilse, 'Zelter und seine Verleger', JbSK 8 (1929/30): 67-101. 23

24 Grupe, Walter, 'Neues über den Briefwechsel Goethe-Zelter', Neue deutsche 24

$25 \quad$ Literatur 7 (1959): 152-4. 25

26 Guttmann, Oskar, Johann Karl Friedrich Rellstab. Ein Beitrag zur Musikgeschichte 26

27 Berlins (Berlin: E. Ebering, 1910). 27

28 Hasselberg, Felix, 'Briefentwürfe Karl Friedrich Zelters. Ein kleiner Beitrag zu 28

29 seinem Briefwechsel mit Goethe' in Der Autographen-Sammler 5 (1941), 29

$30 \quad$ vol.9. 30

31 Hecker, Max (ed.), 'Die Briefe Johann Friedrich Reichardts an Goethe', GJb11 31

32 (1925): 197-252. 32

33 _ 'Goetheverehrung der Goethezeit', GJb 21 (1935): 152-99. 33

34 - 'Vater und Sohn. Briefe Carl Friedrich Zelters an seinen Stiefsohn Carl 34

35 Flöricke', Funde und Forschungen. Eine Festgabe für Julius Wahle (Leipzig: 35

36 1921): 17-36. 36

37 _Z 'Zelters Tod. Ungedrückte Briefe' JbSK 7 (1927/28), pp. 104-172. 37

38 Heinritz, Reinhard, 'Zur Theorie und Poetik des Briefwechsels im Umkreis von 38

39 Klassik und Romantik, Literatur im Wissenschaft und Unterricht 20 (1987): 39

$40 \quad 374-88 . \quad 40$

41 Henzel, Christoph, 'Die Musikalien der Sing-Akademie zu Berlin und die Berliner 41

42 Graun-Überlieferung', Jahrbuch des Staatlichen Instituts für Musikforschung - 42

$43 \quad$ Preußischer Kulturbesitz (2002): 60-106. 43

$44 \quad 44$ 
1 Hermann, Rudolf, 'Goethes und Zelters Plan einer Reformationskantate' in 1

2 Zeitschrift für systematische Theologie 18 (1941): 213-23. 2

3 - Die Bedeutung der Bibel in Goethes Briefen an Zelter (Berlin, 1948). 3

4 Herzfeld, Friedrich, 'Sing-Akademischer Alltag' in Werner Bollert (ed.), Sing- 4

$5 \quad$ Akademie zu Berlin. Festschrift (Berlin: Rembrandt Verlag, 1966), pp. 11-20. 5

6 Heuss, Alfred, 'Goethe-Zelters Lied "Um Mitternacht”, Zeitschrift für Musik 916

7 (1924): 685-92. 7

8 Hey'l, Bettina, Der Briefwechsel zwischen Goethe und Zelter. Lebenskunst und 8

9 literarisches Projekt. (Tübingen: Niemeyer, 1996). 9

10 'Goethe und Zelters Reflexionen über die menschliche Stimme in JbDSG 4010

11 (1996):181-209. 11

12 Hillebrand, Karl, 'Die Berliner Gesellschaft in den Jahren 1789 bis 1815' (1870) 12

13 in Hermann Uhde-Bernays (ed.), Unbekannte Essays (Bern: Francke, 1955), 13

14 pp. 11-81. 14

15 Holtzmann, Sigrid (ed.), Zelters im Spiegel seines Briefwechsels mit Goethe 15

16 (Weimar: Gustav Kiepenheuer Verlag, 1957). 16

17 Jacobi,E.R., 'C.F.Zelters kritische Beleuchtung von J.N. Forkels Buchüber J.S.Bach 17

18 aufgrund neu aufgefundener Manuskripte', International Musicological 18

19 Society Congress Report 11 (Kopenhagen: Hanson, 1972): 462-6. 19

20 Jappe, Georg, 'Vom Briefwechsel zum Schriftwechsel', Merkur 23 (1969): 20

21 351-62. 21

22 Kalischer, Alfred Christian, 'Beethoven und Zelter' in Beethoven und Berlin 22

23 (Leipzig: Schuster and Loeffler, 1908), pp. 211ff. 23

24 Kania, Hans, 'Ein neuentdecktes Zelter-Bild in Potsdam', Potsdamer 24

25 Männergesangsverein Monatliche Mittelungen, 5 Juni 1929, 77f. 25

26 Kettig, Konrad, 'Goetheverehrung in Berlin. Ein Besuch von August und Ottilie 26

27 von Goethe in der preußischen Residenz 1819', Schriften des Vereins für die 27

28 Geschichte Berlins 61 (1977): 87-132. 28

29 Knudsen, Jans, 'Goethes Werke auf den Berliner Bühnen' in Fritz Moser (ed.), 29

$30 \quad$ Goethe in Berlin (Berlin: Wedding-Verlag, 1949): 95-127. 30

31 Koskenniemi, Heikki, Studien zur Idee und Phraseologie des griechischen Briefes 31

32 bis 400 n.Chr. (Helsinki: Suomalaien Tiedeakatemie, 1956). 32

33 Kossmann, E.F., 'Der Chor in Zelters Auferstehungskantate', Zeitschrift für 33

$34 \quad$ Musikwissenschaft 11 (1928/29). $\quad 34$

35 Kräupl, Irmgard, 'Die Zelter-Bildnisse im Goethe-Museum Düsseldorf. Mit einem 35

36 Verzeichnis aller übrigen nachweisbaren Porträts', JbSK 1 (1963): 70-100. 36

37 Kruse, Georg Richard, 'Goethe, Zelter und Otto Nicolai' in GJb 31 (1910): 37

$38 \quad 163-68 . \quad 38$

39 Carl Friedrich Zelter (Leipzig: Reclam, 1915). 39

40 Kuhlo, Hermann, Geschichte der Zelterschen Liedertafel von 1809 bis 190940

41 (Berlin: Horn und Raasch, 1909). 41

42 Kühne, Gustav, [Rez. Der Teile 4-6 des Goethe-Zelterschen Briefwechsels] in 42

43 Jahrbücher für wissenschaftliche Kritik 1 (1835): 953-65; 969-72. 43 
1 Kühnlenz, Fritz, 'Carl Friedrich Zelter' in Fritz Kühnlenz, Weimarer Porträts. 1

2 Bedeutende Frauen und Männer um Goethe und Schiller (Rudolstadt: 2

3 Greifenverlag, 1993), pp. 65-135. 3

4 Ledebur, Carl, Tonkünstler-Lexikon Berlins von den Ältesten Zeiten bis auf die 4

5 Gegenwart (Berlin: L. Rauh, 1861). 5

6 Lichtenstein, Heinrich, Zur Geschichte der Sing-Akademie in Berlin (Berlin: 6

7 Trautwein 1843).

8 Liebe, Anneliese, 'Carl Freidrich Zelter 1758-1832' in Kulturelles Erbe. 8

9 Lebensbilder aus sechs Jahrhunderten (Bonn: Dümmler, 1985), vol. 2, p. $51 \mathrm{f} .9$

10 Lobe, Johann Christian, 'Gespräche mit Goethe und Zelter', Fliegende Blätter für 10

11 Musik (1857). 11

12 _ 'Gespräche mit Goethe und Zelter' in Johann Christian Lobe, Aus dem Leben 12

13 eines Musikers (Leipzig: J.J. Weber, 1859), pp. 81-141. 13

14 _Gespräch mit Zelter' in Wilhelm Bode, Stunden mit Goethe, (Berlin: E.G. 14

15 Mittler \& Sohn, 1912), vol. 8, pp. 187-202. 15

16 Maack, Rudolf, 'Zelters Goethelied. Geschichte einer Freundschaft', Der Kreis 16

1710 (1933): 21-32. 17

18 Mahling, Christoph Helmut, 'Zum Musikbetrieb Berlins und seinen Institutionen 18

19 in der ersten Hälfte des 19. Jahrhunderts' in Carl Dahlhaus (ed.), Studien zur 19

20 Musikgeschichte Berlins im frühen 19. Jahrhundert (Regensburg: Bosse, 20

21 1980), pp. 227-84. 21

22 Mann, Friedrich, 'Die Gunst des Augenblicks von Friedrich von Schiller; 22

23 vierstimmig in Musik gesetzt von Carl Freidrich Zelter (Berlin, 1805)', 23

24 Berlinische Musikalische Zeitung 1 (1805): 344-6. 24

25 _Feierliche Versammlungen der Berlinischen Sing-Akademie im Jahr 1805', 25

26 Berlinische Musikalische Zeitung 1 (1805), no. 19, column 73 and no. 27, 26

27 columns 105-108. 27

28 Marggraf, Hermann, 'Goethe und die Mittwochgesellschaft' in Blätter für 28

$29 \quad$ literarische Unterhaltung 34 (1858). 29

30 Meier, Andreas, 'Carl Freidrich Zelter: Ein literarischer Zeitgenosse' in Reinhold 30

31 Kubrik und Andreas Meier (eds), Zelter, Carl Friedrich. Lieder. Faksimile der 31

32 wichtigsten gedruckten Sammlungen nebst Kritischem Bericht (Munich: Das 32

33 Erbe deutscher Musik, 1995), pp. xiii-xxii 33

34 Meyer, Christoph, 'Goethe in seinen Briefen', Eckart 28 (1959): 62-6. 34

35 Mies, Paul, 'Zu Musikauffassung und Stil der Klassik. Eine Studie aus dem 35

36 Goethe-Zelter-Briefwechsel 1799-1832, Zeitschrift für Musikwissenschaft 1336

37 (1930/31): 432-43. 37

38 Milltitz, Karl Borromäus [Rezension des Briefwechsels zwischen Goethe und 38

39 Zelter], Allgemeine Musikalische Zeitung (1834), 9 Juli, column 458.

40 Milz, Friedemann, 'Zur Ästhetik der Berliner Sing-Akademie' in Werner Bollert 40

41 (ed.), Sing-Akademie zu Berlin. Festschrift (Berlin: Rembrandt Verlag, 1966), 41

42 pp. 50-60. 42

$43 \quad 43$

$44+44$ 
1 Morgenroth, Alfred, Carl Friedrich Zelter: Eine Musikgeschichtliche Studie 1. 1

2 Teil (Biographisches) (Berlin: unpublished Doctoral Dissertation, Friedrich- 2

3 Wilhelms-Universität, 1922). 3

4 - 'Carl. Freidrich Zelter. Eine musikalische Studie' in Jahrbuch der 4

5 Dissertationen der Philosophischen Fakultät der Friedrich-Wilhelms- 5

6 Universität zu Berlin. Dekanatsjahr 1921-1922 (1926): 276-80. 6

7 Mosel, J.G.F. von, [Rezension des Briefwechsels zwischen Goethe und Zelter] in 7

$8 \quad$ Wiener Jahrbücher der Literatur 74 (1836): 102-38. 8

9 Moser, Hans Joachim, 'Karl Friedrich Zelter und das Lied' in Jahrbuch der 9

$10 \quad$ Musikbibliothek Peters 39 (1932). 10

11 _Carl Friedrich Zelter und das Lied' in Goethe und die Musik (Leipzig: C.F. 11

12 Peters, 1949), pp. 78-91. 12

13 Müller, Joachim, 'Drei Briefe Goethes an Zelter. Taedium vitae und fortdauerndes 13

14 Leben. Eine Kommentierung im Kontext beider Briefwechsel', Zeitschrift für 14

15 Germanistik 1 (1980): 166-82. 15

16 Müller. Wolfgang G., 'Der Brief als Spiegel der Seele. Zur Geschichte eines Topos 16

17 der Epistolartheorie von der Antike bis zu Samuel Richardson' in Antike und 17

18 Abendland 26 (1980):138-57. 18

19 Müller, Wolfgang, 'Der Brief' in Klaus Weißenberger, Prosakunst ohne Erzählen. 19

20 (Tübingen: Max Niemeyer Verlag, 1985). 20

21 Müller, Fritz, 'Karl Friedrich Zelters Verdienste um die Wiedererweckung 21

22 Bachscher Tonwerke', Der Kirchenmusiker 10 (1959). 22

23 Müller-Blattau, Joseph, 'Goethe und die Kantate' in Jahrbücherder Musikbibliothek 23

$24 \quad$ Peters 38 (1931): 49-68. 24

25 _ 'Karl Friedrich Zelters Königsberger Briefe (1809)', Altpreußische 25

$26 \quad$ Forschungen 12 (1935): 256-76. 26

27 -Zelters Rede auf Friedrich den Großen', Deutsche Musikkultur 127

28 (1936/37). 28

29 _Karl Friedrich Zelter, Mauermeister und Musiker' in Deutsches Jahrbuch 29

30 der Musikwissenschaft 2 (1957). 30

31 Neumann, Wilhelm, 'Briefwechsel zwischen Goethe und Zelter in den Jahren 179631

32 bis 1832, ed. Dr. Friedrich Wilhelm Riemer, Großherzoglich Sächsischem 32

33 Hofrathe und Bibliothekar. Erster bis dritter Theil. Berlin 1833', Berliner 33

34 Jahrbücher für Wissenschaft und Kritik, 8 \& 9 (1834) and in Wilhelm Neumann, 34

$35 \quad$ Schriften 2 (1835):10-20. 35

36 Nickisch, Reinhard M.G., Brief (Stuttgart: Metzler, 1991). 36

37 Nitsche, Peter, 'Die Liedertafel in System der Zelterschen Gründung' in Carl 37

38 Dahlhaus (ed.), Studien zur Musikgeschichte Berlins im frühen 19 Jahrhundert 38

39 (Regensburg: Bosse, 1980), pp. 11-26. 39

40 Ottenberg, Hans-Günter, "MMöge Dich dieses Lied ... zu einer heitern 40 41 Kompositionaufregen”. Marginalien zu Zelters Vertonung eines Goethe- 41

42 Gedichts' in Peter Bloch, (ed) Denkmal Albrecht Thaers: Theodor Fontane, 42

43 Johann Wolfgang von Goethe, Hugo Hagen, Christian Daniel Rauch, Karl 43

44 Friedrich Zelter (Berlin: Domäne Dahlem, 1992), pp. 109-12. 
1 Petsch, 'Zelters Geburtsort und Geburtshaus', Brandenburgia, Monatsblatt der 1

2 Gesellschaft für Heimatkunde der Provinz Brandenburg 5 (1896/97): 194.

3 Pfister, Werner, Vorwort in Briefwechsel zwischen Goethe und Zelter (Zurich: 3

4 Artemis, 1987), pp. v-xxxi. 4

5 Pniower, Otto, 'Von Zelter bis Fontane. Berliner Briefe' in Beiträge zur Literatur- 5

6 und Theatergeschichte. Festschrift für Ludwig Geiger zum 70. Geburtstag 6

7 (Berlin: Behr, 1918), pp. 163-81. 7

8 Porter, Abbot H., 'Letters to the Self. The Clostered Writer in Nonretrospective 8

9 Fiction', PMLA 95 (1980): 23-41. 9

10 Pröper, Rolf, Die Bühnenwerke Johann Friedrich Reichardts: 1752-1814 (Bonn: 10

11 H. Bouvier, 1965). 11

12 Pulver, Jeffrey, 'Beethoven in the Goethe-Zelter Correspondence', $M L 17$ (1936): 12

13 124-30. 13

14 Rehberg, Karl, 'Ausstrahlungen der Sing-Akademie auf die Musikerziehung' in 14

15 Werner Bollert (ed.) Sing-Akademie zu Berlin. Festschrift (Berlin: Rembrandt 15

16 Verlag, 1966), pp. 106-16. 16

17 Reich, Willi (ed.), Karl Friedrich Zelter. Selbstdarstellung (Zürich: Manesse 17

18 Verlag 1955). 18

19 Reichardt, Johann Friedrich, 'Die Berlinische Sing-Akademie', Berlinische 19

$20 \quad$ Musikalische Zeitung 1 (1805): 29-31. 20

21 Rellstab, Ludwig [Rezension des Briefwechsels zwischen Goethe und Zelter] in 21

22 Vossische Zeitung 299 (1833), 21. December. 22

23 Reuter, Hans-Heinrich, 'Die Weihe der Kraft. Ein Dialog zwischen Goethe und 23

24 Zelter und seine Wiederaufnahme bei Fontane' in Wilhelm Heinse, Helmut 24

25 Holtzhauer and Bernhard Zeller (eds), Studien zur Goethezeit. Festschrift für 25

26 Lieselotte Blumenthal (Weimar: Böhlau, 1968) pp. 357-75. 26

27 Ribbeck, August Friedrich, 'Rede am 25jährigen Stiftungsfeste der Zelterschen 27

28 Liedertafel, den 28 Jan. 1834' (Manuscript, DLA Marbach). 28

29 Richter, Thomas, 'Bibliotheca Zelteriana'. Rekonstruktion der Bibliothek Carl 29

30 Friedrich Zelters. Alphabetischer Katalog (Stuttgart: Metzler Verlag, 1999). 30

31 Die Dialoge über Literatur im Briefwechsel zwischen Goethe und Zelter 31

32 (Stuttgart: Metzler Verlag, 1999). 32

33 __ 'Doris Zelters Briefe nach Weimar, 1818-1834, Part 1, Die Briefe an Goethe', 33

34 GJb 113 (1996):291-307. 34

35 _ ' Doris Zelters Briefe nach Weimar, 1818-1834, Part 2, Die Briefe an Goethes 35

36 Umkreis (1819-1832) Goethe-Jahrbuch 115 (1998): 245-80. 36

37 'Ein Brief Doris Zelters über den Besuch mit ihrem Vater bei Goethe im Juli 37

$38 \quad 1826$ ', GJb 112 (1995): 365-73. 38

39 _ 'Projekt einer Edition von Carl Friedrich Zelters Gesammelter Korrspondenz. 39

40 Als Ergänzung zu seinem Briefwechsel mit Goethe. Bericht und Suchanzeige', 40

41 Jahrbuch für Volksliedforschung 40 (1995):135. 41

42 Riemer, Friedrich Wilhelm, Vorbericht des Herausgebers in Briefwechsel zwischen 42

43 Goethe und Zelter in den Jahren 1796 bis 1832 (6 vols Berlin: Hermann 43

44 Böhlau, 1833-34), vol. 1, pp. v-xxxviii. 44 
1 Rintel, Wilhelm, 'Die erste Aufführung der Jahreszeiten von Haydn in Leipzig und 1

2 Berlin und ein eigenhändiger Brief Haydns an Zelter nebst dessen Antwort', 2

$3 \quad$ Vossische Zeitung 247/31 (1891): Sonntagsbeilage 22. 3

4 Rochlitz, Friedrich, Für Freunde der Tonkunst (4 vols, Leipzig: Carl Cnobloch, 4

5 1824-32). 5

6 _Über Zeltern. 1832', Allgemeine Musikalische Zeitung 24 (1832), 13 and vi. 6

7 [Rezension des Briefwechsels zwischen Goethe und Zelter] in Allgemeine 7

$8 \quad$ Musikalische Zeitung 37 (1835), 18 February, column 101ff. 8

9 Roentz, Wilhelm, 'C.F. Zelter und die Zeit seines akademischen Singkollegiums 9

10 1830-1832', Deutsche Sängerbundeszeitung 22/4 (1930), no.3, p. 3f. 10

11 Runze, Maximilian, 'Randglossen zu Breifen Zelters an Goethe. Auf Grund neu 11

12 erschlossener Quellen', Der Schatzgräber 6 (1926/27):15-19. 12

13 Schaeffer, Albrecht, 'Goethes Zelter', Kunst Welt Wissen 1 (1931): 17. GSA 13

14 151/195. 14

15 Schleiermacher, Friedrich, 'Rede am Sarge Zelters' in Wilhelm Rintel, Carl 15

16 Friedrich Zelter. Eine Lebensbeschreibung (Berlin: Janke Verlag, 1861), 16

17 pp. 300-304 and in Blumner, Martin, Geschichte der Sing-Akademie zu Berlin 17

18 (Berlin: Horn und Raasch, 1891), pp. 193-5. 18

19 Schmidt, Franz, 'Goethes letzter Brief', GJb 28 (1966): 284-8. 19

20 Schmidt, Jürgen, Goethes Briefstil in den Jahren 1805-1814. Beiträge zum 20

21 Verständnis von Goethes Entwicklung un der Zwischenepoche nach Schillers 21

22 Tod. (Hamburg, unpublished Doctoral Dissertation, 1957). 22

23 Schneider, Max, F., 'Eine Trauermusik der Sing-Akademie für Prinz Louis 23

24 Ferdinand. Drei bisher unveröffentlichte Briefe der Mutter des Prinezen an Carl 24

25 Friedrich Zelter' in Werner Bollert (ed.), Sing-Akademie zu Berlin. Festschrift. 25

26 (Berlin: Rembrandt Verlag, 1966), pp. 90-96. 26

27 Schottländer, Johann-Wolfgang (ed.), Carl Friedrich Zelters Darstellungen seines 27

28 Lebens. Zum ersten Male vollständig nach den Handschriften SchGG 4428

29 (1931). 29

30 _Die Reise nach Königsberg', Vossische Zeitung (1932) 6. August: 30

$31 \quad$ Unterhaltungsblatt. 31

32 _Einleitung' in Carl Freidrich Zelters Darstellung seines Lebens SchGG 4432

33 (1931): xi-xxvii. 33

34 -Zelters Beziehungen zu den Komponisten seiner Zeit', JbSK 8 (1929/30): 34

$35 \quad 134-248 . \quad 35$

36 — 'Zelters Beziehungen zu Breitkopf und Härtel' in Zeitschrift für 36

37 Musikwissenschaft 15 (1932): 97f. 37

38 _Zelters "Johanna Sebus"', JbSK 9 (1931). 38

39 Schrenk, Oswald, Berlin und die Musik. 200 Jahre Musikleben einer Stadt. 1740- 39

401940 (Berlin: Bote und Bock, 1940). 40

41 Schröder, Cornelia, (ed.), Carl Friedrich Zelter und die Akademie. Dokumente 41

42 und Briefe zur Entstehung der Musik-Sektion in der Preußischen Akademie 42

43 der Künste. (Berlin: Akademie der Künste Monographien und Biographien 3, 43

44 1959). 44 
1 Schünemann, Georg, 'Die Bachpflege der Berliner Sing-Akademie, Bach-Jahrbuch 1

225 (1928): 138-71. 2

3 Die Singakademie zu Berlin (Regensburg: G. Bosse, 1941). 3

4 Carl Friedrich Zelter, der Begründer der preußischen Musikpflege (Berlin: 4

5 Max Hesse, 1932). 5

6 - Carl Friedrich Zelter. Der Mensch und sein Werk (Berlin: Berliner 6

$7 \quad$ Bibliophilen-Abend, 1937).

8 - Die Sing-Akademie zu Berlin 1791-1941 (Regensburg: G. Bosse, 1941). 8

9 Schwab, Heinrich W., Sangbarkeit, Popularität und Kunstlied. Studien zu Lied 9

10 und Liedästethetik der mittleren Goethezeit 1770-1814 (Regensburg: G. 10

11 Bosse, 1965). 11

12 Schwartz, Rudolf, 'Zu Characteristik Zelters', Jahrbuch der Musikbibliothek 12

13 Peters, 22 (1929/30). 13

14 Schwartz, Herta, 'Brieftheorie in der Romantik' in Herta Schwartz, Angelika 14

15 Ebrecht And Regina Nörtemann (eds), Brieftheorie des 18.Jahrhunderts 15

16 (Stuttgart: Metzler, 1990), pp. 225-38. 16

17 Sieber, Ludwig, Karl Friedrich Zelter und der deutsche Männergesang (Basel, 17

18 1862). 18

19 Taubert, Karl Heinz, Carl Friedrich Zelter (1758-1832). Ein Leben durch das 19

20 Handwerk für die Musik (Berlin: Ries \& Erler, 1958). 20

21 Unseld, Siegfried, 'Das Briefgespräch zwischen Goethe und Zelter in Siegfried 21

22 Unseld, Goethe und seine Verleger (Frankfurt am Main/ Leipzig: Insel Verlag, 22

23 1991), pp. 600-615. 23

24 Valentin, Erich, 'C.F. Zelters Beziehungen zu Magdeburg. Ein Kapitel aus der 24

25 Musikgeschichte Magdeburgs zu Beginn des 19. Jahrhunderts', Montagsblatt. 25

26 Wissenschaftliche Beilage der Magdeburgischen Zeitung 74 (1932), 16 May. 26

27 _Goethes einziger Duzfreund. Ein Wort für Carl Freidrich Zelter', Neue 27

28 Zeitschrift für Musik 119 (1958). 28

29 _ 'Goethe-Jahre ist auch Zelter-Jahr' in Lied und Chor 74 (1982):103f. 29

30 Varnhagen von Ense, Karl August, Goethe in den Zeugnißen der Mitlebenden. 30

$31 \quad$ Erste Sammlung (Berlin: Dümmler, 1823). 31

32 Vesper, Will, 'Vorwort' in Will Vesper (ed.), Goethes Briefwechsel mit Zelter 32

33 (Berlin: Deutsche Bibliothek, o.J), pp. v-vii. 33

34 Victor, Walther, Goethe in Berlin (Berlin: Aufbau-Verlag, 1955). 34

35 _ Carl Friedrich Zelter. Über die Volksverbundenheit Goethes und eine 35

36 Männerfreundschaft am Beginn des bürgerlichen Zeitalters' in Walther Victor, 36

37 Verachtet mir die Meister nicht. Reden und Schriften zu den Klassikern 37

38 der deutschen Literatur und des Marxismus (Weimar: Volksverlag, 1960), 38

39 pp. 239-60. 39

40 Carl Friedrich Zelter und seine Freundschaft mit Goethe (Berlin: Das Neue 40

41 Berlin, 1960). 41

42 Wachsmuth, Bruno, 'Goethes Verhältnis zu Berlin' in Fritz Moser (ed.) Goethe in 42

43 Berlin (Berlin: Wedding-Verlag, 1949), pp. 17-37. 43

$44 \quad 44$ 
1 Wahle, Julius, 'Drei Briefe Goethes an die Familie Mendelssohn-Bartholdy', GJb 1

19 (1898): 48-52.

3 Wätzold, Paul, Carl Friedrich Zelter als Chordirigent (Pritzwalk: Koch, 1932). 3

4 - 'Zelters Lebensbild'in Nachrichtenblatt des Berliner Lehrer-Gesang-Vereins 4

59 (1932), 1, $2 \& 5$. 5

6 Wahl, Dora, 'Goethe und Zelter "damals in Wiesbaden"', JbSK 1 (1963): 101-38. 6

7 Weissmann, Adolf, Berlin als Musikstadt. Geschichte der Oper und des Konzerts 7

8 von 1740 bis 1911 (Berlin, Leipzig: Schuster und Loeffler, 1911). 8

9 Weizsächer, Paul, 'Zelters Bild', Goethe-Jahrbuch 22 (1901): 107.

10 Wellek, Albert, 'Zur Phänomenologie des Briefes, Die Sammlung 15 (1960): 10

11 339-55 and in Albert Wellek, Witz, Lyrik, Sprache. Beiträge zur Literatur- 11

12 und Sprachtheorie mit einem Anhang über den Fortschritt der Wissenschaften 12

13 (Bern/Munich: Francke, 1970), pp. 43-67. 13

14 Welter, Friedrich, 'Die Musikbibliothek der Sing-Akademie zu Berlin. 14

15 Versuch eines Nachweises ihrer früheren Bestände in Sing-Akademie zu 15

16 Berlin'. Festschrift, (ed.) Werner Bollert (Berlin: Rembrandt Verlag, 1966), 16

17 pp. 33-47. 17

18 Wigand, Otto, 'Zelter, der Berliner Mauermeister und Musikmeister' in Jahrbücher 18

19 für Wissenschaft und Kunst 4 (1855): 2.

20 Wittmann, Gertraud, Das klavierbegleitete Sololied Karl Friedrich Zelters (Berlin: 20

21 Triltsch \& Huther, 1936). 21

22 Wulf, Berthold, 'Karl Friedrich Zelter, der Freund Goethes' in Christengemeinschaft 22

2330 (1958):116-19. 23

24 Zehm, Edith, 'Briefwechsel mit Carl Friedrich Zelter' in Bernd Witte, Theo Buck, 24

25 Hans-Dietrich Dahnke, Regine Otto and Peter Schmidt (eds), Goethe-Handbuch 25

26 (4 vols, Stuttgart: Metzler Verlag 1997/98), vol. 4, pp. 484 and 496.

27 Zelter, Carl Friedrich, Karl Friedrich Fasch (Berlin: J.F. Unger, 1801). 27

$28 \quad 28$

$29-29$

$30 \quad 30$

$31 \quad 31$

$32 \quad 32$

$33-33$

$34-34$

$35 \quad 35$

$36 \quad 36$

$\begin{array}{ll}37 & 37\end{array}$

$38 \quad 38$

$39-39$

$40 \quad 40$

$41+41$

$42 \quad 42$

$43 \quad 43$

$\begin{array}{ll}44 & 44\end{array}$ 


\section{Index}

The German definite article (der, die, das) is ignored in the alphabetical order.

First names in italics indicate names by which a person is usually known.

Abschatz, Hans Aßmann von (16461699) 45

Aeschylus

Eumenides 51

Seven against Thebes 51

Supplices 51

Akademie der Künste 27, 125, 165, 245, 265,404

Alfieri, Vittorio Graf (1749-1803)

Saul 155

Allegri, Gregorio (1582-1652) 15

Almonde, Marianne Angelika von (18041866) 299,300

Anatole, Auguste 202

Anatole, Constance Hippolyte 202

André, Johann Anton (1775-1842) 215

André, Johann Christian (1741-1799) 210

Arnim, Achim (Ludwig Joachim) von (1781-1831) 120, 145

Des Knaben Wunderhorn 82, 138

Arnold, Ignaz Ferdinand, Mozarts Geist (1774-1812) 48, 52

Auber, Daniel François Esprit (1782-1871)

Fra Diavolo oder Das Gasthaus bei Terracina 547

Der Gott und die Bajadere 504, 546

La fiancée (Die Braut) 451

La Muette de Portici (Die Stumme von Portici) 420, 450

Die Liebestrank 531

Aumur, Jean Pierre (1774/76-1833) 487

Aline, Königin von Golkonda 291

Bach, Carl Philipp Emanuel (1714-1788)

14, 172, 205, 290, 530

Heilig for double choir (Wq 217) 402

Sonata in A minor 183
Bach, Johann Sebastian (1685-1750) 315

The Art of Fugue 9

Cantata (BWV 22) 39, 103, 110

Cantata (BWV 39) 376

Cantata (BWV 103) 376

Cantata (BWV 110) 376

Chorales 248

Das Wohltemperirte Clavier (BWV 846-93) 248, 250, 252

Mass in B minor (BWV 232) 26, 402, 459, 494

Overture in D Major 13

revival $13,18,34,423,525$

St John Passion 13, 371

St Matthew Passion (BWV 244) 18, 22, 34, 309, 422, 423, 424, 426, $429,463,504,525$

Singet dem Herrn eine neues Lied, die Gemeine der Heiligen soll Ihn loben (BWV 225) 521

Bach, Wilhelm Friedemann (1710-1784) 428, 429

Bacon, Francis (1561-1626) 416

Bader, Carl Adam (1789-1870) 392, 423, 426, 427, 465

Bagge, Charles Ernst von (1722-1791) 278-9, 431

Bavaria, Ludwig I of (1786-1868) 386, 410

Bavaria, Therese Charlotte Luise Friederkike Amalie of (1792-1854) 386

Beethoven, Ludwig van (1770-1827)

Christus am Ölberge 159, 506-8

Coriolan Overture, (op. 62) 402

Egmont 69, 166, 167

Fidelio 493, 504 
Goethe on 156-7, 159

Mass in D Major (op. 123) 402

Symphony no. 3 in E flat major, the

Eroica Symphony (op. 55) 267

Symphony no. 5 in C minor (op. 67)

$$
14,402
$$

Symphony no. 6 in F, the Pastoral Symphony (op. 68) 267

Wellington's Victory (op. 91) 207-8, 267

Zelter on 259, 261-2

Bellini, Vincenzo (1801-1835)

Der Pirat 541

Benda, Franz (František) (1709-1786) 515

Benda, Georg Anton (Jirí Antonín)

(1722-1795)

Ariadne auf Naxos 147

Medea 147

Bendavid (Ben David), Lazarus (17621832) 428

Berger, Ludwig (1777-1839) 281, 319, $356,411,459,477,478$

Berlin Hymnbook 460, 476

Berliner Allgemeine Musikalische Zeitung (ed. A.B. Marx, 1824-1830) 339, 343

Berliner Künstlerverein 249, 251, 265, 340

Berlinische Musikalische Zeitung ed. Reichardt 74, 312

Berlioz, Louis Hector (1803-1869)

Huit Scènes de Faust 23, 24, 430, 438, 446

La Damnation de Faust 24

Bertuch, Friedrich Justin, Journal des

Luxus und der Moden 7

Biedenfeld, Eugenie von (née Bonasegla) (1788-1862) 320

Biedrzynski, Effi, Goethes Weimar 7

Birch-Pfeiffer, Charlotte (1799/1800-1868) 485

Blum, Karl Heinrich (c.1786-1844) 291, 449, 465

Bodenschatz, Erhard (c.1576-1636) 236

Bohn, Friedrich (1775-1872) 350

Boisserée, Johann Sulpiz (1783-1854) 216, 242, 461

Boucher, Alexandre Jean (1778-1861) 277, 278, 280, 281, 282, 284, 286
Boucher, Céleste (née Gallyot) (d.1841)

277, 278, 280, 281, 282

Brandt, Caroline (1794-1852) 220

Breßlau Friedrich Julius von (1776-1860) 201

Breidenstein, Heinrich Carl (1796-1876) 395

Breitkopf und Härtel, publishers 9, 98, 167, $205,307,347,379,395,425,505$, 528

Brentano, Clemens (1778-1842) 120

Des Knaben Wunderhorn 82, 138

Brentano, Elizabeth Bettine (1785-1859) 145

Brizzi, Antonio Giovanni Maria (17701854) 143, 150, 212

Brühl, Carl Friedrich Moritz Paul von (1772-1837) 17, 180, 279, 283, $289,333,342,427,474$

Buchholz, Carl August 231

Buchholz, Johann Simon 231

Burg Theatre, Vienna 256

Busolt, J.E. 423

Byron, Lord (1788-1824) 496

Cäcelia, eine Zeitschrift für die musikalische Welt 320, 377

Calderón de la Barca, Pedro (1600-1681), Der standhafte Prinz, Don

Fernando von Portugal 145

Campi, Antonia (née Miklaszewicz) (1773-1822) 255, 284

Caracci, Annibale (1560-1609) 501

Carpani, Giuseppe Antonio (1751/52-1825)

Le Haydine 140, 255

Le Rossiniane 255

Catalani, Angelica (1780-1849) 201, 209 , 213, 214, 215, 216, 234, 286, 372

Cellini, Benvenuto (1500-1571) 544

Chaos (Journal) 475, 477, 509-10, 531

Chélard, Hippolyte André Jean Baptiste (1789-1861) 409

Macbeth 410, 454

Cherubini, Luigi (1760-1842) 121

Mass in A major for three-part choir and orchestra 338

Medea 529

Requiem 258

Der Wasserträger 529 
Chladni, Ernst Florens Friedrich (1756-

1827) 42, 196, 199, 211, 326, 366, $372,373,434$

Die Akustik 9, 365

chronometer, see metronome

Cibbini, Katharina (1785-1858) 259, 260

Cimarosa, Domenico

Il matrimonio segreto (Die heimliche Ehe) 218, 239, 302, 384, 481

Claudius, Matthias (1740-1815)

'An die Freude' 138

Der Mensch lebt und bestehet 74, 75

Coleridge, A.D., Goethe's Letters to Zelter 2

Corelli, Arcangelo (1653-1713) 515

Cotta, Elizabeth von (1789-1859) 413

Cotta, Johann Friedrich von (1764-1832) 92, 106

Couperin, François (1668-1733) 23, 373, 375

L'art de toucher le clavecin 374

Cramer, Franz (1772-1848) 414

Crelinger, Sophie Auguste Friederike (née Düring) (1795-1865) 268, 270, 426, 427

Descartes, René (1596-1650) 416

Devrient, Philipp Eduard (1801-1877) 21, 418, 423, 465

Diderot, Denis

Essai sur la peinture, Goethe's translation 8

Le Neveu de Rameau, Goethe's translation 8, 296, 545

Drechsler, Joseph (1782-1852), Der verlorne Sohn 255

Dryden, John (1631-1700) 99, 102, 278, 369

Dürer, Albrecht (1471-1528) 400

Dussek, Johann Ludwig (1760-1812) 248

Eberwein, Franz Carl Adalbert (17861868) 106

'Am Neujahrstage' 108-9

Der Graf von Gleichen 108, 319

'Ich denke dein' 109

Eberwein, Regina Henriette (née Haßler) (1790-1849) 104, 272
Eckermann, Johann Peter (1792-1854) 307, 472, 496, 497

Ehlers, Johann Wilhelm (1774-1845) 72, 102,483

Elßler, Franziska (Fanny) (1810-1884) 485, 546

Elßler, Theresia (Therese) (1808-1884) 485

Emerson, Ralph Waldo (1803-1882) 15

Engel, Johann Jacob (1741-1802) 482

Eunike, Katharina Friederike Dorothea Bernadine (1804-1842) 320

Euripedes

Helena 51

Iphigenie in Tauris 51

Fasch, Carl Friedrich Christian (17361800) $34,238,294,334,404,457$

Missa a 16 voci in quarto Cori 34,521

Versetto a 5 Voci Soli (Meine Seele hanget Dir an) 174

Fichte, Johann Gottlieb (1762-1814) 64, 84

Fichte, Maria Johanna (née Rahn (17551819) 64

Fischer-Schwarzböck, Beatrix 534

Fjodorowna, Maria, Empress of Russia

(1759-1828) 245, 291, 434

Flemming, Friedrich Ferdinand (17781813) 173

Flöricke, Carl (1784-1812) 27, 47, 90, $159,370,425$

Flöricke, Henriette (1780-1849) 89

Forkel, Johann Nikolaus (1749-1818) 243, 339-40, 370, 376

Förster, Friedrich Christoph (1791-1868), 'Die Campanelle' 475, 509

Frantzke, Thomas 6

Friedrich-Wilhelm University 27

Frisch, Johann Christoph (1738-1815) 86, 185

Froberger, Johann Jakob (1616-1667) 315

Fux, Johann Josef (1660-1741)

Gradus ad Parnassum 9, 408

Singfundament 406

Galilei, Galileo (1564-1642) 416

Gerber, Ernst Ludwig (1746-1819) 313 
Gerbert, Martin

\section{De Cantu 112}

Gerhardt, Paul (1607-1676) 45

Gern, Johann Georg (1757/59-1830) 460

Gesellschaft der Musikfreunde 396

Gherardini, Giovanni (1778-1861) 254

Gluck, Christoph Willibald (1714-1787)

Alceste 484, 509

Armide 191, 509

Iphigenie in Aulis 130, 158

Iphigenie in Tauris 479

Goethe, Christiane (née Vulpius) (17651816) 79, 195, 209

Goethe, Johann Wolfgang von (1749-1832)

'Ach! Um deine feuchten Schwingen' 194, 263

'Alle Menschen gross und klein' 269

'Äolsharfe' ('Ich dacht ich habe keinen Schmerz') 295, 303

on art, purpose of 9

as Augenmensch 13

'Aus wie vielen Elementen' 185, 251, 292, 412

on Beethoven 156-7, 159

on Beethoven's Fifth 14

Bei Allerhöchstet Anwesenheit Ihre Majestät der Kaiserin Mutter

Maria Fjodorowna in Weimar Maskenzug 247

'Blumengruß' 336

'Das Blümlein Wunderschön' 30, 32, 44, 461

'Clärchens Lied' ('Freudvoll und Leidvoll') 69, 70

Clavigo 201

and contemporary music theory 11-12

Die Danaiden 35

'Derb und Tüchtig' 282

Dichtung und Wahrheit 168, 217, 483, 511, 527

'Donnerstag nach Belvedere' ('Die

Lustigen von Weimar') 172

'Dreistigkeit' 282, 292

Egmont 69, 166

Eigentum ('Ich weiß, daß mir nichts angehört') 169, 170

'Ein Füllhorn von Blüten' 534

'Elemente' 185, 268, 292, 412
Elpenor 96

'Ephiphaniasfest' ('Die heil'gen drei König') 157, 231, 289

Epimenides 177, 179, 180, 181, 182, $183,186,187,189,191,197,529$ performance 202

'Die Erinnerung' 30, 31, 45, 46

'Die erste Walpurgisnacht' 26, 30, 31, $40,161,162,163,527$

'Es ist ein Schuß gefallen' 143

Essai sur la peinture, translation 8

'Euphrosyne' 131

Farbenlehre 11, 86, 92, 124, 357, 364

Faust I 18, 24, 96, 108, 117, 143, 144, 196, 199-201, 208, 253, 267-8, 269, 271, 446

Faust II 23, 24, 511, 523, 524

'Finnisches Lied' 144

'Flieh, Täubchen flieh' 229, 230

Frühzeitiger Frühling 35, 41

'Das Gastmahl' ('Offne Tafel') 172

'Gegenseitig' 229

'Die Geheimnisse' 150

'Generalbeichte' 102, 134, 138, 236, 349, 460, 477

'Genialisch Treiben' ('So wälz ich Unterlaß') 142

'Georgs Lied' 65, 66, 67

'Gleich und Gleich' 262

'Der Gott und die Bajadere' 194, 293, $369,435,461,504,546$

'Das Göttliche' 490

Götz von Berlichingen 62, 63, 64, 65, 67 performance 70-71, 524

on the Greek Chorus 51

'Herein, o du Guter' 230, 247

'Herr Ego' 204

'Hochzeitlied' 38, 39, 41, 42, 46

'In tausand Formen magst du dich verstecken' 269

'In te Domine speravi' (rhythmic setting) $170,171,172$

Iphigenie auf Tauris 33, 60, 281

'Johanna Sebus' 124, 126, 143, 195, 196

'Der Junggesell und der Mühlbach' 30,44

'Kennst du das Land'? 242, 315-6 
'Klaggesang. Irisch' ('So singet laut den Pillalu') 249, 250, 251, 252

'Der König in Thule' 293, 461

'Kriegsglück'('Verwünschter weiß ich nichts im Krieg') 356, 358

'Künstlerlied' 231

'Künstlers Apotheose' 149

'Laßt fahren hin das Allzuflüchtige!' 337, 356, 418

Leben des Benvenuto Cellini, Florentinischen Goldschmieds und Bildhauers, von ihm selbst geschrieben 544

'Legende' 216, 461

Die Leiden des jungen Werthers 23, 161, 162, 198

on Leonardo's Last Supper 14

on lied/lieder 12, 15-16, 29, 30, 129, $134,164,235,363$

on listening to music 12-13

'Lustrum ist ein fremdes Wort' 236, 237, 243

on Lutheranism 222

'Mag der Grieche seinen Ton' 296

'Mailied' ('Wie herrlich leutet') 153, 525

on the minor tonality $110-11,113-14$

Die Mitschuldigen 321, 323, 516

'Der Müllerin Reue' 40, 41, 130

'Musen und Grazien in der Mark' 467 music theatre 6

music theory, engagement with 11-12

on music and visual arts 9

and musical modernity 3-4

musical reality, representation 13-15

musicality $15-16$

musicological studies 8-11

mythologization 6-7

'Nachtgesang' 62, 64

'Nähe des Geliebten' 29, 109

Die natürliche Tochter 52, 54, 523

'Der neue Amadis' 41, 42

'Neue Liebe, Neues Leben' 153

Neveu de Rameau, translation 8

Pandora 117, 143, 144, 148, 276

Prolog zu Eröffnung des Berliner

Theaters im May, 1821281

Die Propyläen 94
Prosperpina 179, 185, 187, 188

'Das Publikum' 204

Rameaus Neffe. Ein Dialog von Diderot aus dem Manuscript bersetzt und mit Anmerkungen begleitet von Goethe 8, 75, 76, 196, 296, 545

'Rastlose Liebe' 25, 153, 525

'Rechenschaft' (aka 'Ächzlied' and 'Pflicht und Frohsinn') 132, 134

Reformation cantata, plan 220, 226

Rinaldo 152, 153, 154, 162, 430, 431, 437, 439

'Sagt es niemand, nur den Weisen' 268

'Sänge sind des Lebens Bild' 242, 243

'Der Sänger' 44, 461

'Sängers Ermutigung' ('Sänge sind des Lebens Bild', also 'Apotheose') 242

'Sankt Nepomuks Vorabend' ('Lichtlein schwimmen auf dem Strome') 274

'Schäfers Klagelied' 35, 41, 461

Scherz, List und Rache 176

'Schneidercourage' ('Es ist ein Schuß gefallen') 142, 143, 150

and Schubert 4-5

'Schweizerlied' 144

'Sehnsucht' ('Was zieht mir das Herz so'?) 44

'Sicilianlied' 144

'Soldatentrost' ('Nein! Hier hat es keine Not') 289

'Stirbt der Fuchs, so gilt der Balg' 95

'Das Sträußchen. Alt böhmisch' 295

Tonlehre 10-11, 13, 14, 357, 358, $364,365,366,377,381,384,385$, 432-3, 436

'Totentanz' 216

'Trost in Tränen' 122

Über die Nachteile der Stimmung 9

Über Kunst und Altertum 194, 195 , 210, 264, 296, 328, 355, 407, 426

'Um Mitternacht' 25, 240, 241, 242, 266

'Vanitas! Vanitatum vanitas!' 94, 95, 122

'Verschwiegenheit' 221 
'Versus memorials' ('Invocavit') 157, 162

'Von Gott dem Vater stammt Natur' 354

Die Wahlverwandtschaften 159, 321

'Die wandelnde Glocke' 171

'Der Wanderer' 515, 518

'Wanderlied' 351, 353

'Die Weisen und die Leute' 178, 186, 276

'Weltseele' ('Herr Urian') 130, 346

'Wenn die Liebste zum Erwiedern' 221, 225

'Wer kauft Liebesgötter!' 40, 41, 195

'Wer nie sein Brot' 215

'Wiederfinden' 268, 466

Wilhelm Meisters Lehrjahre 44, 175, $215,242,436,437,523$

'Worauf kommt es überall an' 282, 292

Die Zauberflöte Zweiter Teil 33, 35, 53, 169,174

'Der Zauberlehrling' 30, 31, 40, 550

Zelter

encounters, list of 555

relationship 26-7

'Zu erfinden, zu beschließen' 230, 231

'Zum vierzehnten Mai 1824' 307, 316

Der Zwerg 46

'Zwischen Weizen und Korn' 142, 153

'Zwischengesang' 355, 356, 418

Goethe, Julius August von (1789-1830) $79,240,450,464,496-8$

death 498,552

travel diary 472, 498-9

Goethe, Ottilie von (1796-1872) 355, 475, 489, 496, 525

Goethe, Walther Wolfgang von (18181825) 240

Gotter, Friedrich Wilhelm (1746-1797) Medea 36

Graun, Carl Heinrich (1703/4-1759) 84

Die Auferstehung und Himmelfahrt Jesu 138

Der Tod Jesu 138, 181, 185, 206, 233 , 235, 264, 279, 297, 309, 317, 326, $344,463,506,508$

Fetonte 368

Greek Chorus, Goethe on 51
Grell, August Eduard (1800-1886) 172, 446, 473

Grétry, André Ernest Modeste (1741-1813) 529

Grillparzer, Franz Seraphicus (1791-1872) 263

Grünbaum, Therese (née Müller) (17911876) 141,322

Grüner, Karl Franz (?1780-1845) 213

Haase, Johann Michael (d.1854) 444

Hackert, Georg Abraham (1755-1805) 261

Hackert, Jakob Phillipp (1837-1807) 261

Hallische Allgemeine Literatur-Zeitung 66

Handel, George Friedrich (1685-1759)

Alexanderfest (Alexander's Feast) 99, 102, 228, 278, 287, 319, 369, 372, 411, 480, 488, 509

Judas Maccabeus 394, 395, 457, 536, 538, 539

Messiah 214, 222, 291, 297, 309, 312, $313,316,318,373,414,417,418$, $419,484,491,549$

Samson 414, 451

Te Deum (HWV 283) 356, 489-90, 491

Hardenberg, Carl August von (1750-1822) 59,231

Harmonichord 139, 140

Hartknoch, Karl Edward (1796-1834) 285

Hartmann, Tina, Goethes Musiktheater 6

Hasse, Faustina (née Bordoni) (17001781) 165

Hasse, Johann Adolph (1699-1793) 165, 395

Piramo e Tisbo 499

Santa Elena al Calvario 492, 495, 501

Hauser, Franz (1794-1870) 332

Haydn, Franz Joseph (1732-1809)

The Creation 267, 344, 398, 465-7, 468, 514, 517, 541

The Seasons (Die Jahreszeiten) 267, 398, 486, 487, 488, 494

Heaney, Seamus (b.1939) 3

Hegel, Georg Wilhelm Friedrich (1770-

1831) 18, 283, 424

Heine, Heinrich (1797-1856) 18, 318

Heinefetter, Sabine (1809-1872) 475 
Hellwig, Karl Friedrich Ludwig (1773-

$$
\text { 1838) } 536
$$

Henning, Karl Wilhelm (1784-1867) 320, 449

Hensel, Wilhelm (1794-1861) 300, 301-2, 441

Hentschel, Ernst Julius (1804-1875) 304

Herder, Johann Gottfried (1744-1803) 44, 45

Volkslieder 46

Hérold, Louis Joseph Ferdinand (1791-1833), Zampa oder die Marmorbraut 543, 545

Herz, Henriette (1764-1847) 41, 528

Hessen-Darmstadt, Ludwig I von (17531830) $213,244,444$

Heygendorff, Henriette Caroline (née Jagemann) (1777-1848) 81, 141

Hey'l, Bettina 2

Hientzsch, Johann Gottfried (1787-1856) 434

Himmel, Friedrich Heinrich (1765-1814) 107, 108, 137, 148, 149, 519

Die Sylphen 89

Hirt, Aloys 241

Hoffmann, Ernst Theodor Amadeus (1776-1822) 271, 281

Hofmannsthal, Hugo von (1874-1927) 6

Holtbernd, Benedikt 6

Horace 73, 173, 341, 347, 380

Hufeland, Christoph Wilhelm (1762-1836) 64

Hufeland, Conradine Louise Wilhelmine (1776-1823) 35

Hufeland, Juliane Wilhelmine Friederike (née Amelung) (1771-1845) 64

Humboldt, Caroline Friederike von (née Dacheroeden) (1766-1829) 200

Humboldt, Friedrich Wilhelm von (17671835) $27,127,130,352,425,538$

Hummel, Johann Nepomuk (1778-1837) 5, 19, 279, 301, 345, 428, 494

Concerto in E major 346

Piano Concerto in A Major 399

Rondo brillant (op. 98) 346

Huschka, Juliane (née Zelter) (1791-1862) 230
Iffland, August Wilhelm (1759-1814) 37, 48,67

Institut für die Ausbildung von Organisten und Musiklehrern 26

Jacobi, Friedrich Heinrich (1743-1819) 76

Jagemann, see Heygendorff, Henriette Caroline

Jenaische Allgemeine Literatur-Zeitung 54, 55, 56, 58, 59, 66

John, Johann August Friedrich (17941854) 264,454

Josephstõdter Theater, Vienna 481

Jüngere Liedertafel 477-8, 480

Jungius, Joachim (1587-1657) 406, 409, 416

Kainz, Marianne Katharina Theresia (1800-1866) 284

Kanne, Friedrich August (1778-1833) 214

Kärnthnerthortheater 255, 256

Kaufmann, Johann Friedrich (1785-1866) 139

Kayser, Philipp Christoph (1755-1823) 176

Kerll, Kaspar (1627-1693) 315

Kestner, Georg August Christian (17771853) 495, 498

Kiesewetter, Johann Gottfried Karl Christian (1766-1819) 173, 174

Kirms, Franz (1750-1826) 69

Kirnberger, Johann Philipp (1721-1783) 253, 530

Die Kunst des reinen Satzes in der Musik 9, 183

Kittel, Johann Christian (1732-1809) 205

Klein, Bernhard Joseph (1793-1832) 242, 281, 301, 319, 356, 411, 459, 477

'Gott segne den König' 339

Klein, Elizabeth (Lili) (née Parthey) 301

Klingemann, Karl (1798-1862) 440

Klopstock, Friedrich Gottlieb (1724-1803), 'Die Auferstehung' 389

Knebel, Karl Ludwig von (1744-1834) 47, 236, 243

Königliche Bibliothek 387, 452, 468

Königliche Kapelle 291, 292, 298, 465, $516,536,550$

Königliche Schauspiele 511 
Königliches Institute für Kirchenmusik 525

Königliches Opernhaus 17, 130, 420

Königliches Orchester 458

Königliches Schauspielhaus 426, 485, 532, 544

Königliches Theater 415, 509

Königstädter Theater 326, 335, 481, 531

Königstädtisches Theater 320, 327, 449, 463, 516

Körner, Carl Theodor (1791-1813) 243, 510

Alfred der Große, König von England 486, 487

Körner, Christian Gottfried (1796-1831) 293, 510

Kotzebue, August Friedrich Ferdinand von (1761-1819)

Die deutschen Kleinstädter 321

Oktavia 147

La Roche, Johann Carl August (1794-1884) 384

Lachner, Franz Paul (1803-1890), Serenade in $\mathrm{G}$ major for four cellos (op. 29) 540

Laffert, Friedrich von (1769-1841) 211

Langermann, Johann Gottfied (1768-1832) 156

Lauchery (1779-1853), Albert 56

Lauchstädt theatre 38, 50, 74

Lemm, Friedrich Wilhelm (1782-1837) 199, 203

Lessing, Gotthold Ephraim (1729-1781), Emilia Galotti 515

Levetzow, Theodore Ulrike Sophie von (1804-1899) 300, 302

Levin, Liepmann (1778-1832) (aka Ernst Friedrich Ludwig Robert, RobertTornow, Ludwig Robert) 68, 89

Die Tochter Jephthas 155

Liebich, Johann Karl (1773-1816) 263

lied/lieder

Eberwein's 266, 271

Goethe on 12, 15-16, 29, 30, 129, 134, $135,164,170,235,363,522$

Goethe's 535

Nicolai's (Otto) 525

Paer's 513
Reichardt's 62, 167, 397-8

Schubertian 3-5

Zelter on 24-5, 69, 109, 133, 138, 272, 350,435

Zelter's 34, 36, 39, 40, 41, 42, 44, 50, $54,62,63-5,72,73,95,104,150$, 151, 174, 177, 194, 199, 207, 210, 215, 229, 237, 242, 263, 293, 295, $346,369,522$

Lobe, Johann Elias Christian (1797-1881) 12, 273, 534

Loewe, Johann Carl Gottfried (1796-1869) 305, 328, 549

Lolli, Antonio (c.1730-1802) 515

Lortzing, Johann Friedrich (1782-1841) 280

Lotti, Antonio (1666-1740)

Crucifixus 444

Ludwig, Johann Walter (1496-1570) 314

Ludwig, Robert, Die Tochter Jephthas 155

major triad 11, 110, 505; see also minor triad

major-minor tonalities debate 11, 110-12, 113-14, 432-3; see also major triad; minor triad

Mandelstam, Osip (1891-1938) 28

Mantius, Jakob Edward (1806-1874) 457, 546

Mara, Gertrud Elizabeth (née Schmeling) (1794-1833) 43, 46, 47, 48, 50, 54, $87-8,214,220,292,312,349,492$, 493, 494, 495, 499-500, 508

Marinelli (Casperl) Theatre 254, 256

Marpurg, Friedrich Wilhelm (1718-1795) 248, 253

Abhandlung von der Fuge 9, 530

Marschner, Heinrich August (1795-1861)

Der Templer und die Jüdin 545

The Vampyr 509

Marx, Adolph Bernhard (?1795-1866) 21, 343, 348, 402, 421

Berliner Allgemeine Musikalische Zeitung (editor 1824-1830) 339, 343

Die Kunst des Gesanges, theoretischpraktisch 476 
Mattheson, Johann (1681-1764)

Der vollkommene Capellmeister 9, 248, 250, 318

Matthisson, Friedrich von (1761-1831) 105,346

Mauer, August Wilhelm 231

May, Johann Christoph (1757-1828) 274

Mayr, Johann Simon (Giovanni Simone) (1763-1845)

Elena 238, 239, 262

Ginevra 150

Mecklenburg-Strelitz, Carl Friedrich August (1785-1837) 197, 199, 268, 270,548

Mecklenburg-Strelitz, Georg Friedrich Karl Joseph (1779-1860) 200, 289, 548

Mecklenburg-Strelitz, Marie Wilhelmine

Meisl, Carl Friederike von (1796-1880) 289

Die Damenhüte im Theater 254

Das Donnerwetter 254

Der lustige Fritz. Ein Märchen aus neuer Zeit 254

Mendelssohn, Abraham Ernst (1776-1835) 21, 55, 202, 204, 230, 288, 318, $328,329,332,340,422,461,464$, $503,519,543,548$

Mendelssohn, Fanny (1805-1847) 24, 202, 441

'Begräbnislied' 350

Mendelssohn, Felix (1809-1847) 297, 329, 382, 440, 461, 469-72, 480

Die beiden Neffen (Der Onkel aus Boston) 20, 305

Die beiden Pädagogen 283

Concerto in A major for two pianos and orchestra 324

Concerto in A minor for piano and string orchestra 290

Dürer Cantata 402

Gloria in E flat 290

Die Hochzeit des Camacho 335, 368, 373

Das Mädchen aus Andros 338, 364

Magnificat in D minor 290

A Midsummer Night's Dream (op. 21), overture 367,422
Octet in E flat major (op. 20) 20, 338

Piano Quartet in B minor (op. 3) 22, 328

Sextet in D for piano and strings (op. 110) 20

Soldatenliebschaft 283

String Quintet no. 1 in A major (op. 18) 349,541

Symphony no. 1 in C minor (op. 11) 422

Die wandernden Komödianten 283, 290

Mendelssohn, Felizia Pauline Lea (née Salomon) (1777/78-1842) 5, 16-17, 19

Mendelssohn, Maria Henriette (17751831) 533

metronome (chronomètre) 18, 435, 510

Metternich, Klemens Wenzel, Prince von (1773-1859) 5, 286

Meyer, Ernst 9

Meyer, Johanna Henriette (née Schüler) (1772-1849) 48, 55

Meyerbeer, Giacomo (1791-1864)

Romilda e Costanza 240

Mickiewicz, Adam Bernard (1798-1855) 438, 441

Milder-Hauptmann, (Pauline) Anna (17851838) $18,158,322,418,423,465$, $479,484,509,510,538$

Milton, John

Paradise Lost 397

Samson Agonistes 451, 453

minor triad 107, 503

Zelter on 110-11, 115-16, 504-5

see also major triad

Mizler, Lorenz Christoph von Kolof (1711-1778) 408

Moeser, Carl Heinrich Ludwig Joachim Wilhelm (1774-1851) 19, 286, 336, 445, 448-9, 454, 506, 543

Moltke, Carl Melchior Jakob (1783-1831) 175, 211-12, 244

Morales, Cristóbal de (c.1500-1553) 15

Mortimer, Peter (1750-1828) 293-4

Moscheles, Ignaz (Isaac) (1794-1870) 19, $21,322,422$ 
Mozart, Anna Maria Walpurga (née Pertl) (1720-1778) 425

Mozart, Johann Georg Leopold (17191787) 425

Mozart, Maria Anna ('Nannerl') (17491829) 425

Mozart, Wolfgang Amadeus (1756-1791)

Don Giovanni (Don Juan) 302, 322, 352, 469, 479

Die Hochzeit des Figaro 391, 463, 469

La Clemenza di Tito 255, 284

Misericordias Domini. Offertorium de tempore 222

Requiem 18, 185, 187, 458, 543 composition 378-80

Die Zauberflöte 158, 352, 381, 392

Müller, August Eberhard (1767-1817) 52, 146, 236

Müller, Franz Ferdinand Georg (18081855) 426

Müller, Johannes von (1752-1809) 64, 94

Müller, Karl Friedrich (1797-1873) 427

Müller, Minna (née Gerson) (c.1804-1847) 426

Müller, Robert (c.1804-1855) 494, 501, 504

Müller, Wenzel (1767-1835) 141, 322

Müller, Wilhelm Christian (1752-1831) 506

Münchhofen, Adolf Lauer von (1795/961874), Der Orakelspruch 537

Nägeli, Hans Georg (1773-1836) 506

Naue, Johann Friedrich (1787-1858) 304, 439,442

Naumann, Johann Gottlieb (1741-1801) $221,391,519$

'Die Ideale' 435, 482

I pellegrini al sepolcro di N.S. Gesù Christo 325

Neureuther, Eugen Napoleon (1806-1849), lithographs 413, 461

Nicolai, Christoph Friedrich (1733-1811) $165,482,525$

Nicolai, Karl Otto Ehrenfried (1810-1849) 525,527

Niemeyer, August Hermann (1754-1828) 223
Nissen, Georg Nikolaus (1761-1826)

Biographie W.A. Mozarts nach Originalbriefen 425

Oehlenschläger, Adam Gottlob (17991850) 120

Axel und Walburg 234

Ordentliche Singschule 26

Ottenberg, Hans-Günter 2

Ottmer, Carl Theodor (1800-1843) 327, 334

Pachelbel, Johann (1653-1706) 306, 309, 314,315

Paer, Ferdinando

Achilles 143, 157

Der lustige Schuster oder die verwandelten Weiber 141

Sargines oder der Triumph der Liebe (Sargines oder Der Zögling der Liebe) 141, 322, 386, 513

Paginini, Niccolò (1782-1840) 429-30, $434,436,445,446-7$

violin technique 431

Palestrina, Giovanni Pierluigi da (1525/261594) 408

Pavlovich, Alexander I of Russia, Aleksandr (1777-1825) 246

Perti, Giacomo Antonio (1661-1756) Adoramus te Christe 173

Pindar (Pindaros) 535, 536, 538

Pleyel, Ignaz Joseph (1757-1831) 385

Plotinus

Platoni, Platonicorum coryphaei, opera quae extant omnia 79

Ennead 79

Plutarch 451, 527

Pogwisch, Ulrike Henriette Adele Eleonore von (1798-1875) 288, 364, 397 , 438, 444, 469

Poiß1, Johann Nepomuk von (1783-1865)

Athalia 232, 233

Die Prinzessin von Provence 387

Poiß1, Maria Walpurga von (1778-1826) 387

Pollet, Marie Nicole (née Simonin) (1787-1864) 152

Praun (Braun), Sigismund Otto von (1811-1830) 431 
Printz, Wolfgang Caspar (1641-1717) 315

Prussia, Elizabeth Ludovike of (18011873) 316

Prussia, Frederick II of, 'the Great' (1712-1786) 34, 166, 187, 312, $313,316,543$

Prussia, Friedrich Heinrich Ludwig of (1726-1802) 312

Prussia, Friedrich Wilhelm III of (17701840) 473,516

Prussia, Friedrich Wilhelm IV of (17951861) $316,366,548$

Prussia, Maria Luise Alexandrine of (1808-1877) 382, 458

Prussia, Maria Luise Augusta of (18111890) 458

Pulver, Jeffrey 2-3

Pythagoras 163

Radziwill, Antoni Heinrich (1775-1833), Faust 135, 197, 267-8, 272, 484, 502, 548, 550

Radziwill, Friederike Dorothea Luise Philippine (1770-1836) 199, 289

Radziwill, Friedrich Wilhelm Ferdinand August Heinrich Anton Wladislaus (1811-31) 199, 520

Rainer, Rudolph Johann Joseph (17881831) 262

Rameau, Jean-Philippe (1683-1764), Samson 154, 155

Ramler, Carl Wilhelm (1725-1798) 298, 508, 509

Raphael (1483-1520) 265, 273

Recke, Charlotte Elizabeth (Elisa), von der (née von Medem) (1756-1833) 106,200

'Wiegenlied für Mutter Naumann' 519

Redern, Wilhelm Friedrich von (18021883) $17,461,462,511$

Reichardt, Gustav (1797-1884), 'Bundeslied' 478

Reichardt, Johann Friedrich (1752-1814)

Berlinische Musikalische Zeitung 74

'Clärchens Lied' ('Freudvoll und Leidvoll') 69, 70

'Heidenröslein' 95, 461

'Miltons Morgengesang' 283, 397
'Schneidercourage' ('Es ist ein Schuß gefallen' and 'Der junge Jäger') $142,143,150$

'Der Taucher' 147

Der Tod des Herkules 36 reception 37

'Der untreue Knabe' 95, 461

'Das Veilchen' 95

Rellstab, Heinrich Friedrich Ludwig (1799-1860) 280, 281, 319, 396, 411, 459, 487, 549

Rellstab, Johann Carl Friedrich (17591813) 280

Riemer, Friedrich Wilhelm (1774-1845) $1,108,142,143,151,186,490$

Ries, Ferdinand (1784-1838) 538

Die Räuberbraut 493

Ries, Hubert (1802-1886) 538, 545

Riese, Friedrich (d.1859) 539

Rietz, Eduard Theodor Ludwig (18021832) $423,536,541-2,543$

Righini, Vincenzo (1756-1812) 137, 158, 159

Ripienschule (Ripieno school) 27, 98, 115, 324

Robinson, Henry Crabb (1755-1867) 441, 452

Rochlitz, Johann Friedrich (1769-1842) 285, 306, 479

Für Freunde der Tonkunst 414, 491, 492

Rosenmüller, Johann (c.1619-1684) 315

Rossini, Gioacchino Antonio (1792-1868) 462-3

Die Belagerung von Corinth (The Siege of Corinth) 400, 455, 469

Das Fräulein am See (La donna del lago) 531

Il barbiere di Siviglia (Der Barbier von Sevilla) 284, 322, 323, 469

La Gazza Ladra 254

Othello 254, 463, 464, 469, 475

Semiramis/Semiramide 469, 479

Tancredi 235, 244, 323, 325, 400

William Tell (Guillaume Tell/Andreas Hofer) 478, 479-80, 485

Zelter on 261 
Rousseau, Jean-Jacques (1712-1778)

musical tastes 212

Royal Academy of Religious Music, Berlin 26

Rungenhagen, Carl Friedrich (1778-1851) 405, 411, 415, 490

Rupsch, Conrad (1475-1530) 314

Russia, Alexander I Pawlowitsch of (1777-1825) 245

Russia, Alexandra Fjodorowna of (17981860) 434

Sachsen-Weimar-Eisenach, Anna Amalie von (1739-1807) 59, 95, 96, 435, 502

Sachsen-Weimar-Eisenach, Maria Pawlowna von (1786-1859) 107, 245, 397

Salieri, Antonio (1750-1825) 158-9, 255, 458

Missa capella 259

Salieri, Therese, (née von Helfersdorfer) (1755-1807) 259

Salis-Seewis, Johann Gaudenz von (1762-1834) 105

Santini, Fortunato (1778-1861) 488

Sartori, Anton (1767-1821)

Die Werber oder Die belohnt Treue 254

Saxony, Friedrich August I, King of (1750-1827) 175, 415

Saxony, Marie Amalie Auguste, Queen of (1752-1828) 175

Scarlatti, Alessandro (1660-1725) 315

Schadow, Johann Gottfried (1764-1850) 197, 230, 241, 400

Schäfer, Sabine 2

Schale, Christian Friedrich (1713-1800) 505

Schätzel, Pauline von (1811-1882) 423, 455, 457, 486

Schechner, Nanette (1806-1860) 511

Scheidt, Samuel (1587-1654) 315

Schein, Johann Hermann (1586-1630) 315

Schick, Friedrich (1794-c.1858) 276

Schick, Margarete Luise (née Hamel) (1768/73-1809) 276

Schiller, Johann Christoph Friedrich (1759-1805)
'Der Alpenjäger' 61

'An die Freude' ('Liebe Freunde, es gab bess're Zeiten') 105, 138

'Berglied' 60, 62

'Die Braut von Messina' 48-9, 52

'Dithyrambe' ('Niemals erscheinen die Götter allein') 105

Don Carlos 160

'Die Gunst des Augenblicks' 72, 73, 129

'Hero und Leander' 44

'Die Ideale' 435

'Kabale und Liebe' 481

'Der Kampf mit dem Drachen' 36, 44

'Das Lied von der Glocke' ('Glocke') $26,73,77,78,80,81,82,83,85$

Macbeth (translation) 130, 371

Musenalmanach (also Almanach and Musen-Almanach) 29, 30, 31, 36, 40, 194, 435, 436

'Die Piccolomini' 31, 482

'Punschlied. Im Norden zu singen' ('Auf der Berge freien Höhen') 37, 104, 129, 195

'Punschlied' ('Vier Elemente, innig gesellt') 37, 104, 129, 195

Die Räuber 481

'Reiterlied' 43, 46, 71

'Die Sänger der Vorwelt' 44

Tafellieder 37

'Der Taucher' 36, 435, 483

'Die Verschwörung des Fiesco zu Genua' 482

'Die vier Weltalter' 36

Wallensteins Lager 81, 482

Wallensteins Tod 482

Wilhelm Tell 58, 527

'Die Worte des Glaubens' 44

Schinkel, Karl Friedrich (1781-1841) 231, 232, 278, 280, 283

Schlegel, August Wilhelm 343

Gesang und Kuss 32

Schleiermacher, Friedrich Daniel Ernst (1755-1844) 18, 460

Schmidt, Johann Philipp Samuel (17791853) 91, 92, 460, 487

Schneider, Caroline (née Portmann) (1774/75-1850) 128 
Schneider, Georg Abraham (1770-1839) $128,401,420,449,550$

Schneider, Georg Laurenz (1766-1855) 389

Schöpke, Adalbert (1793-1844) 237, 238

Schröder, Antoine Luise Sophie (née Bürger) (1781-1868) 345

Schröder-Devrient, Wilhelmine 18, 493-4

Schubart, Christian Friedrich Daniel 483

Schubert, Franz (1797-1828)

Erlkönig 16

and Goethe 4-5

Gretchen am Spinnrade 25

Lieder (op. 19) 5

Wandrers Nachtlied 25, 169, 175

Schultz, Christoph Ludwig Friedrich (1781-1834) 178, 184, 209, 234, 241

Schulz, Johann Abraham Peter (17471800) 36,350

Schulze, Josephine (née Kilitzschky) (c. 1790-1880) 325

Schütz, Heinrich (1585-1672) 315

Schütz, Henriette (née Schüler) (17721849) 147

Schütz, Johann Heinrich Friedrich (17791829) $12,13,205,248,252,375$

Schwendler, Friedrich Christian August von (c.1772-1844) 403, 542

Schwendler, Henriette August Sophie (née Mützschefahl) (1773-1853) 403

Seckendorff-Gudent Veit, Bernhard Emil von (1804-1890) 474

Seidel, Friedrich Ludwig (1765-1831) 449

Seidler, Caroline née Wranitzsky (1790/94-1872) 219

Senfl, Ludwig (1486-1542/3) 314

Sessi, Maria Theresia 234, 284

Shakespeare, William (1564-1616)

Macbeth 130

Othello 551

Sibbern, Frederik Christian (1785-1872) $151,152,167$

Siboni, Giuseppe (1785-1839) 157

Silbermann, Andreas (1678-1734) 216, 218

Silbermann, Johann Andreas (1712-1783) 216

Simonin-Pollet, Marie Nicole 152
Sing Collegium 535, 539, 540, 551, 553

Sing-Akademie 18, 26-7, 34, 39, 40, 57, $58,77,84,86,91,98,99$

Sistine Chapel 164, 488, 519

Socrates 537

song/songs, see lied/lieder

sonnet, Zelter on 31-2

Sontag, Gertrud Walpurgis Henriette (1806-1854) 18, 352, 353, 355, $358,391,392,393,463,464,465$, 469,481

Sophocles 36, 51

Spenersche Zeitung 322, 340

Spitzeder, Elizabeth (Betty) (née Vio) (1806/8-1872) 481

Spitzeder, Henriette (née Schüler) (18001828) 320

Spitzeder, Joseph (1795/96-1832) 320, 384

Spohr, Ludewig (Louis) (1784-1859)

Double Quartet in D minor (op. 65) 540

Faust 18, 448

Macbeth 341

Spontini, Gaspare Luigi Pacifico (17741851)

Agnes von Hohenstaufen 374, 420, 455

Alcidor 330, 333, 335

Ferdinand Cortez 145, 244, 274, 322

'Lalla Rookh' 291

Les Athéniennes 503, 537, 538, 539

Olympia 270, 271, 283, 322, 401, 458

Die Vestalin (La Vestale) 145, 270, 322, 388, 489

Stein zum Altstein, Carl von (1770-1840) 293, 460

Sterling, Charles (1804-1880) 496

Stieler, Joseph Karl (1791-1858) 472

Struve, Carl Ludwig (1785-1838) 343

Stümer, Anna Christina Henriette (née Weltz) 398

Stümer, Johann Daniel Heinrich (17891856) $398,418,423,424$

Süßmeyer, Franz Xaver 378, 379, 380

Sulzer, Johann Georg (1720-1779) 467

Allgemeiner Theorie der schönen Kunste 
Szymanowska, Maria Agata (née Wolowska) (1789-1831) 301, 304-5, 438, 439

Tartini, Giuseppe (1692-1770) 515

Taubert, Karl Gottfried Wilhelm (18111891), Die Kirmes 543

Telemachus 203

Telemann, Georg Philipp (1681-1767) $108,315,509$

Teplitz 10, 137, 138, 139, 140, 142, 143, 148, 156, 167, 170, 171, 172, 181, 255, 276, 278, 411, 555

Teschner, Gustav Wilhelm (1800-1883) 512

Teutschen Merkur 474

Thaer, Albrecht Daniel (1752-1828) 307, 308, 318

Theater an der Wien 254, 256

Theile, Johann (1646-1724) 315

Thibaut, Anton Friedrich Justus (17721840) 195,244

Thomson, John (1805-1841) 397-8, 441, 487

Tiedge, Christoph August (1752-1842) 105

'Hymnus an die Sonne' ('In flammen nähet Gott') 106, 134, 517

Tilly, Karoline Auguste (1800-1828) 224, 226, 228

Todd, Larry

Mendelssohn's Musical Education 20

Tralles, Johann Georg (1763-1822) 64

Türk, Daniel Gottlob (1750-1813) 223, 304, 365

Türrschmidt, Auguste (née Braun) (18001866) $423,438,457,538$

Unger, Friederike Helene (née Gothenburg) (1754?-1813) 12, 29

Unger, Johann Friedrich Gottlieb (17531804) 30,33

Unzelmann, Wilhelmine (1802-1871) 69, $140-41$

Valle, Pietro della (Il Pellegrino) (15861652) 407
Varnhagen von Ense, Antoine Friederike (Rahel) (née Rahel Levin) (17711833) 18, 68, 396

Veni Creator Spiritus 264, 271, 276, 277

Vetter, Daniel (1657/58-1721) 315

Viganó, Maria (?1756-1833) 546

Vivaldi, Antonio

Concerto in D minor for two violins and orchestra 428

The Four Seasons 488

Voß, Johann Heinrich (1779-1822) 73, 112

'Begräbnislied' (poem) 350

Trommellied 132, 134, 136, 138

Vogler, (Georg Joseph) Abbé (1749-1814) 176, 217

Voltaire (François Marie Arouet) (16941778)

Samson 154, 155

Vossische Zeitung 90, 118, 139, 147, 157 , 158, 166, 181

Vulpius, Christian August (1762-1827) 255

Waldura, Markus 6

Weber, Bernhard Anselm 177, 180, 194, 197, 207, 270

Weber, Carl Maria von (1796-1826)

Der Freischütz 18, 283, 342

Euryanthe 319, 342, 389

'Lützows wilde Jagd' 243

Oberon, Königin der Elfen 400, 401, 405, 486

Weber, Friedrich Dionys (1766-1842) 506

Weber, Jacob Gottfried (1779-1839) 506

Weigl, Joseph (1766-1846)

Die Schweizerfamilie 141, 155, 158, 191, 194, 256, 322, 534

Weil, Simone, Gravity and Grace 3

Weitsch, Friedrich Georg (1758-1828) 265, 404

Wendt, Amadeus (1783-1836) 120, 216

Werneburg, Johann Friedrich Christian (1777-1851) 163, 165, 166

Werner, Zacharias (1768-1823) 181

Wessely, Carl Berhard (1768-1826)

Wieck, Johann Gottlob Friedrich (17851873) 528

Wieck, Josephine Clara (1819-1896) 528, 529 
Wieland, Christoph Martin (1733-1813)

Oberon 405

Wild, Franz (1792-1860) 219, 232

Winter, Peter von (1754-1825) 152, 430

Das Labyrinth, oder Der Kampf mit den Elementen 53

Das unterbrochene Opferfest 391, 392

Zaïra 219

Wolf, Christian Wilhelm Friedrich August

(1759-1824) 61, 74, 76, 79, 98, $129,139,140,277$

Prolegomena ad Homerum 241, 299, 317

Wolff, Anna Amalie (1780/3-1851) 147, 148, 179, 201, 205, 318, 427

Wolff, Pius Alexander (1782-1828) 56, 199, 201, 205, 213, 268, 270, 300, $318,412,547$

Woltmann, Carl Ludwig (1770-1817) 64

Wolzogen, Baron Wilhelm Ernst Friedrich Franz August von (1762-1809) 47, $50,52,84$

Wranitzky-Seidler, Caroline 322

Yeats, William Butler (1865-1939) 26

Zehm, Edith 2

Zeitung für die elegante Welt 466

Zelter, Adolph Raphael (1799-1816) 87, 90, 198, 370

Zelter, Carl Friedrich (1758-1832)

'Alle Menschen gross und klein' 269

'An die Freude' ('Liebe Freunde, es gab beßre Zeiten') 105, 138

'Aus wie vielen Elementen 292

on Beethoven 259, 261-2

'Berglied' 60, 62, 195

'Blumengruß' 336

'Das Blümlein Wunderschön' 30, 32

'Die Braut von Corinth' 30, 32, 343

'Bundeslied' ('In allen guten Stunden') 30, 33, 138

'Die Campanelle' 475, 509

character, contradictions 16-17

'Derb und Tüchtig' 282

'Dithyrambe' ('Niemals erscheinen die Götter allein') 105

'Dreistigkeit' 292
'Eigentum' ('Ich weiß, daß mir nichts angehört') 169,170

'Elemente' 268, 412

'Der Entfernte' ('Im Fernen') 229

Ephiphaniasfest (Ephiphanias) 157, 231, 289, 350

'Die Erinnerung' 30, 31, 45

'Erschaffen und Beleben' 268

'Frisch! der Wein soll reichlich fließen' 132, 134, 135

Der Fromme geht dahin 85, 87

'Frühlingsmusikanten' ('Es wollt einmal in Königreich') 319

'Frühzeitiger Frühling' 35, 41

'Das Gastmahl' 172

'Die Geheimnisse' 150

'Generalbeichte' ('Lasset heut im edeln Kreis') 102, 134, 138, 477

'Genialisch Treiben' ('So wälz ich Unterlaß') ('Diogenes') 142

'Georgs Lied' 65, 66, 67

'Gleich und Gleich' 262

Gloria Für den Künstlerverein Saul und David am H. drei K. Feste 1817249

Goethe encounters, list 555 relationship 26-7

'Der Gott und die Bajadere' 194, 293, 369

'Die Gunst des Augenblicks' 134, 143

'Die heiligen drei Könige' 157, 289

'Das Herbstlied' 32

'Hero und Leander' 44

'Herr Urian', see 'Weltseele'

'Hymnus an die Sonne' ('In flammen nähet Gott') 106, 134, 517

'Ich denke Dein' 29, 109

'In Flammen nähet Gott' 134

'In tausand Formen magst du dich verstecken' 269

on individualism 18-19

'Invocavit' ('Versus memorials') 156, 157,162

'Johanna Sebus' 1, 9, 129, 131, 133, $135,143,146,170,266$

'Der Junggesell und der Mühlbach' 30,32 
'Der Kampf mit dem Drachen' 36, 43, 44

Kirchenmusik zum Reformationsfeste für 4 Stimmen mit Orgel und Bleichinstrumenten 232

'Klaggesang. Irisch' ('So singet laut den Pillalu') 249, 250, 251, 252, 381

'Der König in Thule' 293

'Kriegsglück' ('Verünschter weiß ich nichts im Krieg') 356, 358

'Laßt fahren hin das allzu Flüchtige!' 337,418

on lied/lieder 24-5, 69, 109, 133, 138, 272, 350, 397, 435

'Die Lustigen von Weimar' 168, 172

'Lustrum ist ein fremdes Wort' 236, 237, 243

'Mädchens Held' ('Flieh, Täubchen flieh') 229

'Mailied' ('Wie herrlich leutet') 153

'Männerkreis' ('Mauerlied') ('Wenn die Liebste zum Erwiedern') 221, 225, 226

'Der Mensch lebt und besteht' 74, 75, 76,454

on the minor triad $110-11,115-16$, 504-5

'Der Müllerin Reue' 40, 41, 130

musical achievements 26-7

'Der neue Amadis' 41, 42

'Neue Liebe, Neues Leben' 153

'Nur wer die Sehnsucht kennt' 245

'O Roma nobilis' 394

'Punschlied. Im Norden zu singen' ('Auf der Berge freien Höhlen') 37,104

'Punschlied' ('Vier Elemente, innig gesellt') 104

'Rastlose Liebe' 25, 153

'Rechenschaft' (aka 'Ächzlied' \& 'Pflicht und Frohsinn') 132, 134

Reformation Cantata 188, 226

Reisebriefe aus Wien 264

'Reiterlied' 43, 46

Requiem 74, 75, 76, 186, 265

Ripienschule (Ripieno school), foundation 27, 324 on Rossini 261

'Sagt es niemand, nur den Weisen' 268

'Der Sänger' 44, 461

'Die Sänger der Vorwelt' 44

'Sängers Ermutigung' ('Sänge sind des Lebens Bild') (aka 'Apotheose') 242, 243

'Sankt Nepomuks Vorabend' ('Lichtlein schwimmen auf dem Strome') 269, 274

'Schäfers Klagelied' 35, 41, 461

'Der Schneider' ('Es ist ein Schuß gefallen') 143

'Schneidercourage' ('Es ist ein Schuß gefallen') 142, 143, 150

'Der Schütze sang mit Freuden' 442

'Sehnsucht' ('Was zieht mir das Herz so'?) 44

'Selige Sehnsucht' 268

'So lang man nüchter[n] ist' 268

'So wälz' Ich Unterlaß' 142

'Soldatentrost' ('Nein! Hier hat es keine Not...') 289

on the sonnet 31-2

Stabat Mater 100, 105

'Das Sträußchen. Alt böhmisch'. 295

'Suleika' ('Ach! Um deine feuchten Schwingen') 263, 268

Te Deum 57

Thekla 31

'Der Totentanz' 174, 216, 461

travel diaries 491

'Um Mitternacht' 25, 242, 266

'Das Vaterland' 134

'Die wandelnde Glocke' 171

'Wanderers Nachtlied' ('Über allen Gipfeln ist Ruh') 25, 169, 175, 266, 522

'Weltseele' ('Herr Urian') 130, 134, $138,346,347$

'Wer kauft Liebesgötter!' 40, 41

'Wer nie sein Brot' 215

'Wiederfinden' 268, 466

'Wiegenlied für Mutter Naumann' 519

'Willkommensgedicht'

'Worauf kommt es überall an' 292

'Der Zauberlehrling' 30, 31, 40

'Die Zauberlehrling' 343, 550 
'Zu erfinden, zu beschließen' ('Dem edlen Künstler-Verein zu Berlin') 230, 231

'Der Zwerg' 46

'Zwischengesang' 355, 356, 418

Zelter, Clara Antigone (1800-1816) 218

Zelter, Dorothea (Doris) Auguste Cäcilie

(1792-1852) 288, 300
Zelter, Georg (1723-1787) 159, 482

Zelter, Georg Friedrich (1789-1827) 90, 230, 370

Zelter, Juliane Karoline Auguste (17671806) 99,300

Zinkgref, Julius Wilhelm (1591-1635) 45 